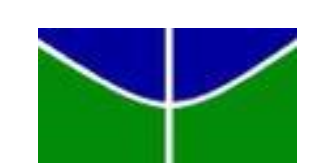

Universidade de Brasília - UnB

Faculdade de Economia, Administração, Contabilidade e Gestão de Políticas Públicas FACE

Programa de Pós-Graduação em Economia - PPGECO

Mestrado Profissional em Economia

\title{
A RELAÇÃO ENTRE O PERFIL EDUCACIONAL \\ E A GERAÇÃO DE EMPREGO E RENDA \\ NA ECONOMIA DO DISTRITO FEDERAL
}

Nara Cristina Ferreira Mendes

Brasília 
NARA CRISTINA FERREIRA MENDES

\section{A RELAÇÃO ENTRE O PERFIL EDUCACIONAL E A GERAÇÃO DE EMPREGO E RENDA NA ECONOMIA DO DISTRITO FEDERAL}

Dissertação apresentada ao Departamento de Economia da Faculdade de Economia, Administração, Contabilidade e Gestão de Políticas Públicas da Universidade de Brasília como requisito parcial para obtenção do título de Mestre em Economia, área de concentração: Finanças Públicas.

Orientadora: Profa. Dra. Milene Takasago 
Universidade de Brasília - UnB

Faculdade de Economia, Administração e Contabilidade e Gestão de Políticas Públicas FACE

Programa de Pós-Graduação em Economia - PPGECO

Mestrado Profissional em Economia

NARA CRISTINA FERREIRA MENDES

\section{A RELAÇÃO ENTRE O PERFIL EDUCACIONAL E A GERAÇÃO DE EMPREGO E RENDA NA ECONOMIA DO DISTRITO FEDERAL}

Dissertação apresentada ao Departamento de Economia da Faculdade de Economia, Administração, Contabilidade e Gestão de Políticas Públicas da Universidade de Brasília como requisito parcial para obtenção do título de Mestre em Economia, área de concentração: Finanças Públicas.

Orientadora: Profa. Dra. Milene Takasago

Banca Examinadora:

Profa. Dra. Milene Takasago - Orientadora

PPGECO/FACE/UnB

Prof. Dr. Pedro Henrique Zuchi da Conceição - Membro

PPGECO/FACE/UnB

Prof. Dr. Carlos Wagner de Albuquerque - Membro

IPEA

Aprovado em 03 de julho de 2015. 
Dedico este trabalho ao Deus altíssimo, sem o qual nada seria possível, aos meus pais e ao meu marido que me deram forças para concluir mais esta grande etapa de minha vida acadêmica. 


\section{AGRADECIMENTOS}

A Deus, que me deu forças para concluir mais uma etapa de minha vida acadêmica.

Aos meus pais Edna Cristina Vicente Ferreira de Sousa e Célio Pereira de Sousa, que sempre me apoiaram e incentivaram nos estudos.

Ao meu marido Valdeni de Sousa Mendes, pela compreensão constante e amor incondicional.

A minha colega de turma Luciana Alves de Azevedo, pelo companheirismo.

A minha orientadora, Professora Doutora Milene Takasago, pela paciência e pelos ensinamentos. Ao longo deste trabalho compartilhei desta pesquisa sobre a matriz de Leontief, que tanto tem a contribuir para a economia mundial. Hoje tenho a honra de ter participado e contribuído para o avanço deste estudo.

Aos meus colegas de trabalho: Professora Doutora Josivânia Farias, Mirlene da Silva Ananias, Augusto Maia, Emelle Cruz, Elizânia, que acompanharam fases deste trabalho compartilhando experiências acadêmicas.

E a todos que, de alguma forma, contribuíram para a realização deste trabalho. 
"Sabemos que todas as coisas cooperam para o bem daqueles que amam a Deus."

Romanos 2:28 


\section{RESUMO}

Este trabalho tem por objetivo estudar o perfil educacional do Distrito Federal e avaliar, para a economia desta Unidade da Federação, impactos diretos e indiretos em relação a geração de empregos e salários, por grau de instrução, a partir de mudanças decorrentes do aumento da demanda final $(Y)$. Os níveis de instrução foram divididos em dez classes para possibilitar a avaliação dos efeitos da política pública sobre o sistema produtivo. O trabalho utilizou o modelo insumo-produto, conhecido como Modelo de Leontief. Quanto ao tema, Silva (2008) efetuou análise semelhante na econômica baiana, assim, este estudo visa aplicar esta metodologia para o Distrito Federal. Ao longo do estudo, serão abordados aspectos da política educacional no Distrito Federal, apresentando as metas e estratégias estabelecidas pelo Plano Nacional da Educação, bem como sua relação com o capital humano. A metodologia abordou matrizes de relações intersetoriais, tabelas de produção e consumo, bem como o instrumental amplamente utilizado, o modelo insumo-produto. A partir deste instrumental apresenta-se analises dos impactos da educação sobre a geração de emprego e renda. Os resultados demonstraram que trabalhadores com o Ensino Médio completo possuem maior possibilidade de conseguir emprego nos setores da economia local, contudo, os maiores salários são destinados a trabalhadores mais qualificados, que possuem nível de instrução a partir do ensino superior completo.

Palavras-chave: Matriz de insumo-produto. Educação. Setores da economia do Distrito Federal. Capital humano. Geração de emprego e renda. 


\begin{abstract}
This work aims to study the educational profile of the Federal District and assess, in the DF economy, direct and indirect impacts with regard to job creation and wages by level of education, from changes resulting from increased final demand $(\mathrm{Y})$. The education levels were divided into ten classes to enable the assessment of the effects public policy on the production system. The study used the input-output model, known as Leontief model. On the subject, Silva (2008) made similar analysis in bahian economy, so this study is to apply this methodology for the Federal District. Throughout the study, they will be addressed aspects of education policy in the state of DF, with the goals and strategies established by the National Education Plan and its relation to human capital. The methodology addressed arrays of intersectoral relations, production and consumption tables as well as the widely used instrument, the input-output model. From this instrumental presents analysis of education impacts on the generation of employment and income. The results showed that workers with completed secondary education have a greater chance of getting jobs in the sectors of the local economy, however, the highest salaries are for the most skilled workers, which have educated from the university degree.
\end{abstract}

Keywords: Input-Output table. Education. Sectors of the Federal District economy. Human capital. Generate employment and income. 


\section{LISTA DE QUADROS}

Quadro 1 - $\quad$ Plano Nacional de Educação: principais metas......................................... 20

Quadro 2 - Meta 1 - Principais estratégias............................................................ 29

Quadro 3 - Meta 2 - Principais estratégias.......................................................... 30

Quadro 4 - $\quad$ Meta 5 - Principais estratégias........................................................... 31

Quadro 5 - Meta 3 - Principais estratégias.......................................................... 33

Quadro 6 - Meta 12 - Principais estratégias....................................................... 35

Quadro 7 - $\quad$ Meta 13 - Principais estratégias............................................................ 36

Quadro 8 - $\quad$ Meta 14 - Principais estratégias......................................................... 36

Quadro 9 - $\quad$ Setores das tabelas de recursos e usos.................................................. 48

Quadro 10 - Setores das contas regionais................................................................... 49

Quadro 11 - Setores da Economia do Distrito Federal................................................. 50 


\section{LISTA DE TABELAS}

Tabela 1 - $\quad$ Ranking IDHM 2010, por Unidade da Federação....................................... 21

Tabela 2 - Ranking IDHM 2010, por Município.......................................................... 22

Tabela 3 - Taxa de escolarização por idade - Brasil - 1992-2007 (\%).......................... 23

Tabela 4 - $\quad$ Taxa de escolarização - Brasil: Região Centro-Oeste - 1992-2007 (\%)...... 24

Tabela 5 - Escolaridade por grupos de anos de estudo - Distrito Federal - 2001-2011 $(\%)$

Tabela 6 - Taxa de analfabetismo das pessoas de 15 anos e mais de idade - Brasil 2002-2008 (\%).

Tabela 7 - Taxa de analfabetismo por faixa etária - Distrito Federal - 2001-2011 (\%). 26

Tabela 8 - Taxa de aprovação, reprovação e abandono - 2007-2010 (\%)...................... 27

Tabela 9 - IDEB Observados 2005, 2007, 2009, 2011, 2013 e Metas - Distrito Federal

Tabela 10 - Evolução da matrícula na educação infantil por dependência administrativa - Distrito Federal - 2007-2012.

Tabela 11 - Evolução da matrícula no Ensino Fundamental por dependência administrativa - Distrito Federal - 2007-2012

Tabela 12 - Evolução da matrícula no Ensino Médio por dependência administrativa Distrito Federal - 2007-2012

Tabela 13 - Evolução da matrícula no Ensino Superior por dependência administrativa - Distrito Federal - 2009-2012

Tabela 14 - Concluintes do Ensino Superior - Distrito Federal - 2009-2012 ................. 37

Tabela 15 - Taxa de conclusão do Ensino Superior - Distrito Federal - 2009-2012 ....... 38

Tabela 16 - Número de estabelecimentos e quantidade de trabalhadores formais por setor - Distrito Federal - 2008.

Tabela 17 - Número de estabelecimentos, após agregação, e quantidade de trabalhadores formais por setor - Distrito Federal - 2008

Tabela 18 - Pessoal ocupado por setor por grupo de instrução - Distrito Federal - 2008

Tabela 19 - Distribuição percentual de pessoal ocupado por setor por grau de instrução - Distrito Federal - 2008 
Tabela 20 - Distribuição percentual de pessoal ocupado por grau de instrução por setor - Distrito Federal - 2008.

Tabela 21 - Salário médio anual do pessoal ocupado por setor por grupo de instrução Distrito Federal - 2008 (em R\$ 1,00).

Tabela 22 - Distribuição do salário médio anual por setor por grau de instrução Distrito Federal - 2008 (\%)

Tabela 23 - Distribuição do salário médio anual por pessoal ocupado por grau de instrução por setor - Distrito Federal - 2008 (\%)

Tabela 24 - Emprego direto e indireto gerados por grau de instrução pela variação da demanda final de 10 milhões de reais - Distrito Federal - 2008.

Tabela 25 - Distribuição setorial do emprego direto e indireto gerados por grau de instrução pela variação da demanda final de 10 milhões de reais - Distrito Federal - $2008(\%)$

Tabela 26 - Distribuição por grau de instrução do emprego direto e indireto gerados por setor pela variação da demanda final de 10 milhões de reais - Distrito Federal - $2008(\%)$

Tabela 27 - Renda salarial direta e indireta geradas por grau de instrução pela variação da demanda final de 10 milhões de reais - Distrito Federal - 2008 (em R\$ $1,00)$........

Tabela 28 - Distribuição setorial da renda salarial direta e indireta geradas por grau de instrução pela variação da demanda final de 10 milhões de reais - Distrito Federal - 2008.

Tabela 29 - Distribuição por grau de instrução da renda salarial direta e indireta geradas por setor pela variação da demanda final de 10 milhões de reais Distrito Federal - 2008.

Tabela 30 - Massa salarial anual por grau de instrução por setor - Distrito Federal 2008 (em R\$). 


\section{LISTA DE ABREVIATURAS E SIGLAS}
APU
- Administração, Saúde e Educação Públicas
CAPES
- Coordenação de Aperfeiçoamento de Pessoal de Nível Superior
$\mathrm{CF}$
- Constituição Federal
CI
- Consumo Intermediário
CLT
- Consolidação das Leis do Trabalho
CNAE
- Classificação Nacional de Atividades
$\mathrm{CNE}$
- Conselho Nacional de Educação
CONAES
- Comissão Nacional de Avaliação da Educação Superior
DCNEI
- Diretrizes Curriculares Nacionais da Educação Infantil
$\mathrm{DF}$
- Distrito Federal
ENADE - Exame Nacional de Desempenho de Estudantes
ENEM
- Exame Nacional do Ensino Médio
FIES
- Fundo de Financiamento Estudantil
$\mathrm{G}(0)$
- Trabalhador Analfabeto
$\mathrm{G}(1)$
- Trabalhador com Instrução até o $5^{\mathrm{a}}$ ano Incompleto do Ensino Fundamental
G(2) - Trabalhador com Instrução Igual ao $5^{\mathrm{a}}$ ano Completo do Ensino Fundamental
G(3) - Trabalhador com Instrução do $6^{\mathrm{a}}$ ao $9^{\mathrm{a}}$ ano Incompleto do Ensino Fundamental
G(4) - - Trabalhador com Ensino Fundamental Completo
G(5) - - Trabalhador com Ensino Médio Incompleto
G(6) - Trabalhador com Ensino Médio Completo
G(7) - Trabalhador com Educação Superior Incompleta
G(8) - - Trabalhador com Educação Superior Completa
G(9) - - Trabalhador com Mestrado
G(10) - - Trabalhador com Doutorado
IBGE - Instituto Brasileiro de Geografia e Estatística
ICTs - Instituições Científicas e Tecnológicas
IDEB - Índice de Desenvolvimento da Educação Básica
IDH - Índice de Desenvolvimento Humano 
IDHM - Índice de Desenvolvimento Humano Municipal

IES - Instituições de Educação Superior

LRF - Lei de Responsabilidade Fiscal

MIP — Matriz Insumo-Produto

OCDE - Organização para a Cooperação e Desenvolvimento Econômico

PIB $\quad$ - Produto Interno Bruto

PNE $\quad$ - Plano Nacional de Educação

PNUD - Programa das Nações Unidas para o Desenvolvimento

PROUNI - Programa Universidade para Todos

RAIS - Relação Anual de Informações Sociais

REUNI - Programa de Reestruturação e Expansão das Universidades Federais

RNB $\quad$ - Renda Nacional Bruta

SAEB - - Sistema Nacional de Avaliação da Educação Básica

SINAES - Sistema Nacional de Avaliação da Educação Superior

SIUP - Produção e Distribuição de Eletricidade e Gás, Água, Esgoto e Limpeza Urbana

TRU $\quad-$ Tabelas de Recursos e Usos

UF - Unidade da Federação

VA $\quad-$ Valor Adicionado

VBP $\quad$ - Valor Bruto da Produção 


\section{SUMÁRIO}

1 INTRODUÇÃO ............................................................................................................................. 14

2 REFERENCIAL TEÓRICO: ANÁLISE DA EDUCAÇÃO ............................................17

2.1 EDUCAÇÃO NO BRASIL...................................................................................................17

2.2 ASPECTOS GERAIS SOBRE A EDUCAÇÃo NO DISTRITO FEDERAL .....................................20

2.3 ALGUNS ASPECTOS DA EDUCAÇÃO BÁSICA.......................................................................23

2.4 ALGUNS ASPECTOS DA EDUCAÇÃO INFANTIL .....................................................................28

2.5 ALGUNS ASPECTOS DO ENSINO FUNDAMENTAL .............................................................30

2.6 ALGUNS ASPECTOS DO ENSINO MÉDIO ..............................................................................32

2.7 ALGUNS ASPECTOS DO ENSINO SUPERIOR ....................................................................34

2.8 VinculaÇão da EduCaÇão ao TrabalHo ......................................................................38

2.9 QUALIFICAÇÃO DA MÃO DE OBRA DOS TRABALHADORES FORMAIS NO DISTRITO

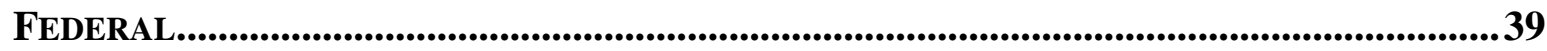

2.10 FINANCIAMENTO DA EDUCAÇÃO ........................................................................... 42

2.11 ABORDAGEM DA EDUCAÇÃo NA PERSPECTIVA DA ECONOMIA ........................................44

3 METODOLOGIA DE PESQUISA .............................................................................. 46

3.1 MATRIZES DE RELAÇÕES INTERSETORIAIS .....................................................................46

3.2 DADOS UTILIZADOS NA CONSTRUÇÃO DA MIP DF - 2008................................................47

3.3 METODOLOGIA BÁSICA DE INSUMO-PRODUTO..................................................................50

4 ANÁLISE DE DADOS: MULTIPLICADORES DE EMPREGO E RENDA

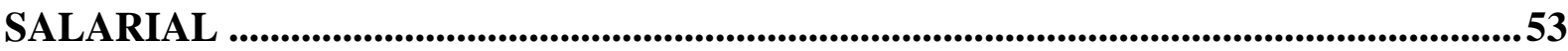

4.1 ESCOLARIDADE E ALOCAÇÃO DO EMPREGO NOS SETORES DA ECONOMIA ....................57

4.2 ESCOLARIDADE E ALOCAÇÃO DA RENDA SALARIAL NOS SETORES DA ECONOMIA DO

DISTRITO FEDERAL......................................................................................................63

4.3 ANÁLISE DOS RESULTADOS DOS IMPACTOS DA EDUCAÇÃo..............................................69

4.3.1 Multiplicadores de emprego o...................................................................................... 69

4.3.2 Multiplicadores de renda ........................................................................................ 77

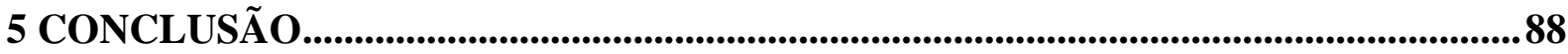

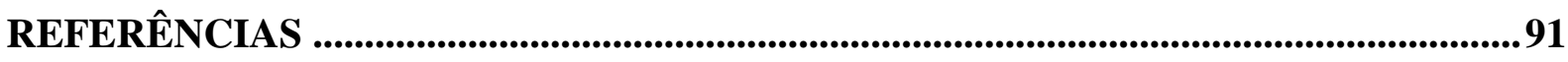

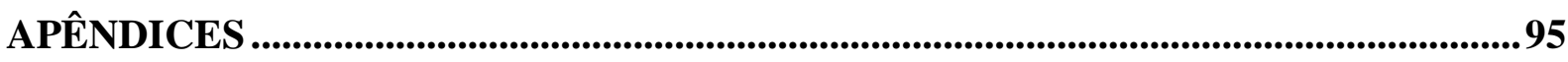

APÊNDICE "A" - SETORES AGREGADOS ..................................................................96

APÊNDICE "B” - MATRIZES DE GERAÇÃO DE EMPREGO ....................................102

APÊNDICE “C” - MATRIZES DE GERAÇÃO DE RENDA ............................................146 


\title{
1 INTRODUÇÃO
}

Atualmente, o setor de Educação vem ganhando atenção na economia brasileira. Tal afirmativa possui respaldo em documento divulgado pela Organização para a Cooperação e Desenvolvimento Econômico (OCDE) (2011, p. 2), conforme segue:

\begin{abstract}
Os gastos públicos em educação em relação ao percentual do gasto público total indicam em que proporção os governos priorizam a educação em relação a outras áreas de investimento. Embora o gasto público total seja responsável por uma parcela relativamente pequena do PIB per capita no Brasil, o maior aumento percentual em gastos no orçamento público total foi com gastos educacionais. Os gastos em educação em relação ao total dos gastos públicos cresceu de 10,5\%, em 2000, para 17,4\%, em 2008 - a terceira maior proporção entre os países.
\end{abstract}

No intuito de demonstrar a afirmação supracitada, a OCDE (2011) divulgou que, após o México e a Nova Zelândia, o Brasil é o terceiro país que mais investe em Educação, apresentando forte aumento desse investimento, a partir do ano de 1995, em relação aos demais países analisados.

Tal nível de investimento está fortemente ligado às vinculações constitucionais para que o governo realize a aplicação de seus recursos financeiros nesta área de atuação. Cabe destacar, que atualmente a União deve aplicar pelo menos $18 \%$ de seus recursos em Educação, para Estados e Municípios, o percentual corresponde a 25\% conforme estabelecido pela Constituição Federal de 1988. Estes percentuais vieram se alterando ao longo dos anos, o que pode ser claramente identificado, visto que o aumento da aplicação de recursos na área de Educação coincide com o Gráfico 1, disposto a seguir, apresentado pela OCDE. 


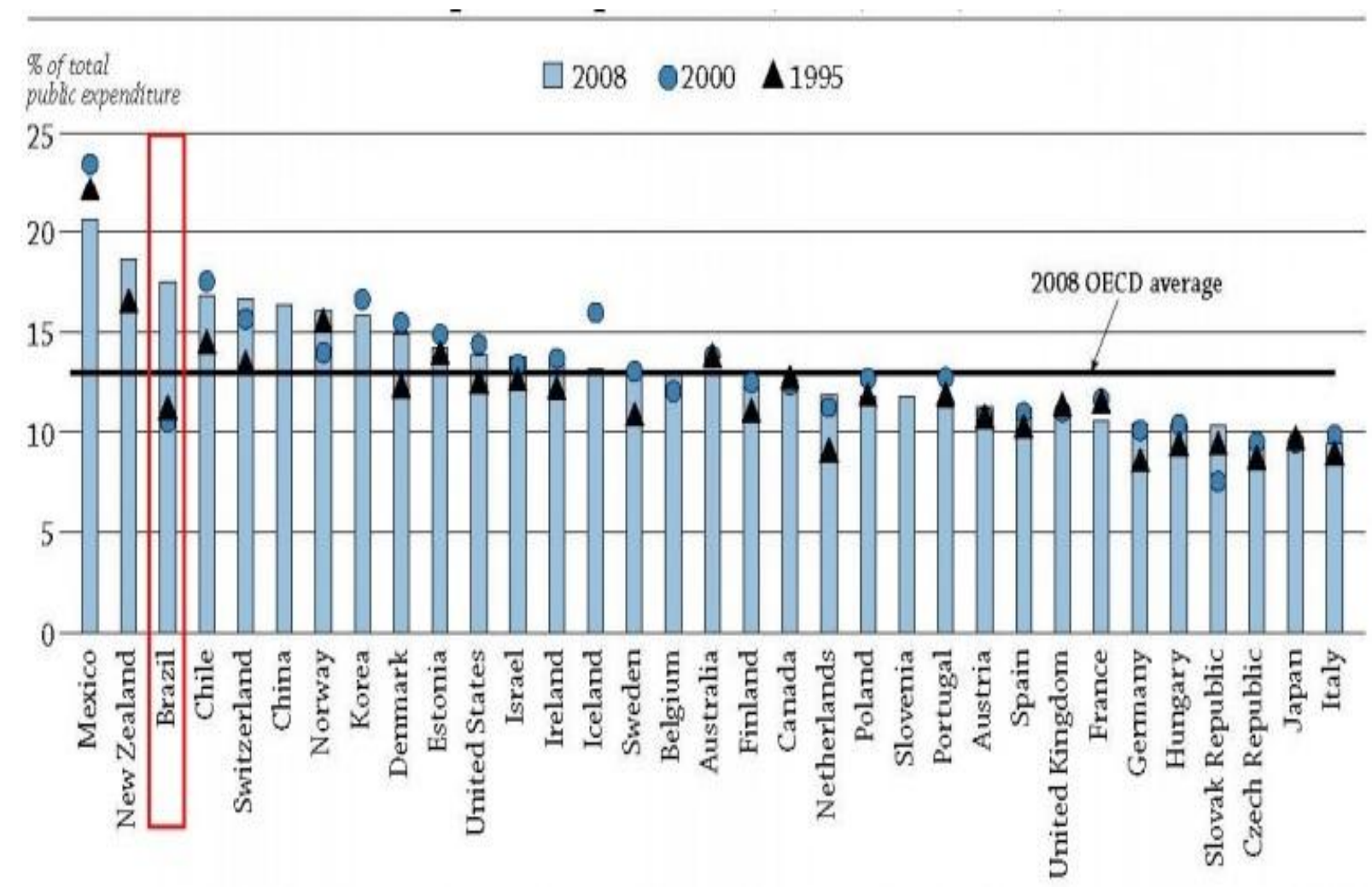

Gráfico 1 - Despesa pública total em educação em percentagem da despesa pública total (1995, 2000, 2008).

Fonte: OCDE (2011).

Diante do cenário apresentado acerca da educação brasileira, surge a dúvida quanto à relação existente entre o nível de instrução do indivíduo e o emprego e renda na sociedade.

Atualmente, as famílias brasileiras estão investindo em Educação com o intuito de auferir retornos financeiros por meio de empregos que lhes proporcionem maior remuneração, visto que um indivíduo qualificado e capacitado tem maiores chances de conquistar empregos com remunerações que lhe proporcione melhor qualidade de vida.

Sabe-se que distribuição de renda é fator crucial da determinação no nível de instrução do cidadão, corroborando esse pensamento Moreira (2007, p. 12) afirma que:

Um dos principais fatores que se deve levar em conta quando se analisa o desenvolvimento de um país é a distribuição de sua renda, ou seja, a forma como os benefícios do crescimento econômico são distribuídos entre as famílias da nação, determinando assim o nível de bem-estar dessa sociedade.

Atualmente, existem indicadores que visam medir os resultados da educação, avaliando essa política educacional com foco na gestão de políticas públicas. Contudo, conforme abordado por Silva (2008) tais indicadores não avaliam os resultados com foco nos 
aspectos econômicos, o que torna necessária a realização de análises dos possíveis impactos da educação na economia.

O uso da tecnologia disponível aliada ao capital intelectual, em prol do desenvolvimento de uma atividade produtiva, demonstra a importância da Educação na economia, visto que a formação e a utilização do conhecimento geram impactos significativos no resultado da produção econômica, bem como em todas as atividades envolvidas no processo de produção.

No sentido de contemplar a área de Educação na distribuição de renda, há previsão constitucional que estabelece percentuais mínimos de aplicação de recursos públicos nessa área de atuação para proporcionar qualificação à população e diminuir a extratificação social, consequentemente, gerando retorno econômico para o país. Sendo assim, este trabalho pretende responder a seguinte questão: Em que medida o nível de instrução do indivíduo influencia na geração de emprego e renda da economia do Distrito Federal?

Nesse contexto, o objetivo deste trabalho é avaliar impactos diretos e indiretos em relação a geração de empregos e salários, por grau de instrução, a partir de mudanças decorrentes do aumento da demanda final $(Y)$.

Ademais, considerando a importância do tema e a relevância para a economia regional, este trabalho pretende aplicar e estimular estudos nesta área de conhecimento incentivando a continuidade destas pesquisas em outros Estados brasileiros. 


\title{
2 REFERENCIAL TEÓRICO: ANÁLISE DA EDUCAÇÃO
}

Este capítulo visa apresentar aspectos sobre o tema em análise, de forma a contextualizar a situação da educação brasileira, abordando temas relacionados a educação no Brasil, aspectos gerais sobre a educação no Distrito Federal, alguns aspectos da educação básica, educação infantil, ensino fundamental, ensino médio e da educação superior, além de abordar a vinculação da educação ao trabalho, o financiamento da educação, bem como a educação na perspectiva da economia.

\subsection{Educação no Brasil}

Sabe-se que a Educação é um fator determinante na formação do indivíduo. A Educação gera impactos, tanto na personalidade, quanto na vida profissional dos cidadãos. Sendo assim, cidadãos bem educados tendem a ser adultos cultos e bem empregados.

Atualmente, o quantitativo de estudantes frequentando a educação superior é considerado reduzido, frente à densidade populacional do país. Conforme Corbucci (2007, p. 28):

\begin{abstract}
O reduzido percentual da população brasileira de 18 a 24 anos que freqüenta a educação superior decorre, em grande medida, da distorção idade-série que tem início no ensino fundamental. Cerca de $2 / 3$ dos estudantes dessa faixa etária encontram-se defasados em relação ao nível de ensino freqüentado. Para transformar esse efetivo de estudantes em potenciais demandantes de educação superior, há que se investir na qualidade da educação básica, sobre a qual incidem variáveis internas à escola e condicionantes de natureza socioeconômica. Paralelamente a essa melhoria de qualidade da educação básica, que faça crescer o número de diplomados do ensino médio a demandar a formação em nível superior, há também que se ampliar a oferta de vagas públicas ou subsidiadas, uma vez que se encontram fora do sistema educacional justamente os que dispõem de condições econômicas desfavoráveis.
\end{abstract}

Dessa forma, se pode afirmar que para aumentar o quantitativo de alunos da educação superior é necessário que haja investimento na educação básica, para que estes possuam condições intelectuais suficientes para frequentar aulas de nível superior, com temas específicos e complexos. O aumento de vagas públicas ou subsidiadas pelo governo também contribui para a expansão do ensino, tendo em vista que os indivíduos que não possuem acesso ao ensino superior são aqueles que pertencem a classe de mais baixa renda do país. 
Outro aspecto relevante é o preparo dos profissionais na área da Educação. Estes necessitam possuir competências para identificar alunos defasados para o nível escolar que estão frequentando, pois tal defasagem poderá impossibilitar que o aluno conclua seus estudos.

Além do preparo do aluno, para que se promova efetivamente o ensino há que se considerar alguns fatores: qualidade do ensino, sustentabilidade financeira das instituições e capacidade de pagamento dos estudantes.

Dessa forma, cabe a educação disseminar o conhecimento, formando profissionais qualificados e aptos à ingressar no mercado de trabalho. Conforme Corbucci (2007, p. 9), além dessas competências, "não se trata apenas de formar profissionais em número suficiente e tecnicamente habilitados para o desempenho de funções específicas, mas também preparados para atuar em contextos sociais extremamente adversos."

Corroborando este entendimento CEPAL (2014, p. 1) afirma que:

\begin{abstract}
As limitações da qualidade da educação também se refletem na escassez de competência, criando assim uma incompatibilidade no mercado de trabalho entre mão de obra disponível e sua demanda. Isso afeta gravemente a competitividade das empresas latino-americanas, que enfrentam maiores dificuldades para encontrar funcionários devidamente qualificados do que as empresas localizadas em qualquer outra região do mundo.
\end{abstract}

Sendo assim, fica evidente que o papel do governo na educação é um desafio a ser alcançado por meio da realização de políticas públicas que possibilitem diminuir o nível de desigualdade entre os estudantes, oferecendo mecanismos e programas de suporte à área da educação no Brasil.

Na mesma linha do pensamento de Corbucci, sobre a competência das universidades, Kureski (2010, p. 2) afirma que:

\footnotetext{
O papel das universidades no desenvolvimento regional vem recebendo uma atenção crescente nos últimos anos e está sendo considerado como um elemento chave do processo. Nas últimas décadas com o crescimento da compreensão de que as inovações têm papel relevante no processo de desenvolvimento econômico houve uma preocupação crescente com os condicionantes dessas inovações. Veio daí a motivação para uma extensa literatura sobre o que é chamado de Sistema Nacional de Inovações, Economia do Conhecimento, etc. Por outro lado, também ocorre um debate renovador sobre o desenvolvimento das regiões. A moderna concepção considera que as regiões com maior possibilidade de desenvolvimento são aquelas que conseguem estabelecer um projeto político de desenvolvimento congregando os seus diferentes atores.
} 
Dessa forma, a inovação é fator crucial na educação para a obtenção de avanços em médio e longo prazo. Tais avanços já podem ser observados, como é o caso do aumento de cursos à distância, possibilitando a disseminação do conhecimento independente de barreiras demográficas. A oferta do ensino à distância possui menos custos do que o curso presencial, resultando na redução do valor das mensalidades e possibilitando que indivíduos com baixa renda possuam acesso ao ensino, o que poderá contribuir para qualificação de mão de obra da região e melhores condições de vida.

Outro fator a se observar é que não basta a criação de normativos legais que vinculem o governo a aplicação de recursos mínimos na área de educação, se não houver o comprometimento dos gestores na aplicação eficiente desses recursos na educação.

O Plano Nacional de Educação - PNE está previsto no art. 214 da Constituição Federal, possuindo o objetivo de:

Art. 214 [...] articular o sistema nacional de educação em regime de colaboração e definir diretrizes, objetivos, metas e estratégias de implementação para assegurar a manutenção e desenvolvimento do ensino em seus diversos níveis, etapas e modalidades por meio de ações integradas dos poderes públicos das diferentes esferas federativas que conduzam a:

I - erradicação do analfabetismo;

II - universalização do atendimento escolar;

III - melhoria da qualidade do ensino;

IV - formação para o trabalho;

V - promoção humanística, científica e tecnológica do País;

VI - estabelecimento de meta de aplicação de recursos públicos em educação como proporção do produto interno bruto.

O PNE em vigor está regido pela Lei n. 13.005/2014, de 25 de junho de 2014, com vigência de 10 (dez) anos, e estabelece 20 (vinte) metas para o ensino, dentre as quais destacam-se a descritas no Quadro 1 a seguir: 
Quadro 1 - Plano Nacional de Educação: principais metas.

\begin{tabular}{|c|c|}
\hline Meta & Contexto \\
\hline Meta 1 & $\begin{array}{l}\text { Universalizar, até 2016, a educação infantil na pré-escola para as crianças de } 4 \text { (quatro) a } 5 \text { (cinco) } \\
\text { anos de idade e ampliar a oferta de educação infantil em creches de forma a atender, no mínimo, } \\
50 \% \text { (cinquenta por cento) das crianças de até } 3 \text { (três) anos até o final da vigência deste PNE. }\end{array}$ \\
\hline Meta 2 & $\begin{array}{l}\text { Universalizar o ensino fundamental de } 9 \text { (nove) anos para toda a população de } 6 \text { (seis) a } 14 \\
\text { (quatorze) anos e garantir que pelo menos } 95 \% \text { (noventa e cinco por cento) dos alunos concluam } \\
\text { essa etapa na idade recomendada, até o último ano de vigência deste PNE. }\end{array}$ \\
\hline Meta 3 & $\begin{array}{l}\text { Universalizar, até } 2016 \text {, o atendimento escolar para toda a população de } 15 \text { (quinze) a } 17 \\
\text { (dezessete) anos e elevar, até o final do período de vigência deste PNE, a taxa líquida de matrículas } \\
\text { no ensino médio para } 85 \% \text { (oitenta e cinco por cento). }\end{array}$ \\
\hline Meta 5 & Alfabetizar todas as crianças, no máximo, até o final do $3^{\circ}$ (terceiro) ano do ensino fundamental. \\
\hline Meta 12 & $\begin{array}{l}\text { Elevar a taxa bruta de matrícula na educação superior para } 50 \% \text { (cinquenta por cento) e a taxa } \\
\text { líquida para } 33 \% \text { (trinta e três por cento) da população de } 18 \text { (dezoito) a } 24 \text { (vinte e quatro) anos, } \\
\text { assegurada a qualidade da oferta e expansão para, pelo menos, } 40 \% \text { (quarenta por cento) das novas } \\
\text { matrículas, no segmento público. }\end{array}$ \\
\hline Meta 13 & $\begin{array}{l}\text { Elevar a qualidade da educação superior e ampliar a proporção de mestres e doutores do corpo } \\
\text { docente em efetivo exercício no conjunto do sistema de educação superior para } 75 \% \text { (setenta e } \\
\text { cinco por cento), sendo, do total, no mínimo, } 35 \% \text { (trinta e cinco por cento) doutores. }\end{array}$ \\
\hline Meta 14 & $\begin{array}{l}\text { Elevar gradualmente o número de matrículas na pós-graduação stricto sensu, de modo a atingir a } \\
\text { titulação anual de } 60.000 \text { (sessenta mil) mestres e } 25.000 \text { (vinte e cinco mil) doutores. }\end{array}$ \\
\hline
\end{tabular}

Fonte: Elaborado pelo autor.

Para cada meta mencionada em Lei, o PNE estabelece estratégias que visam materializar e viabilizar o atendimento das metas previstas.

\subsection{Aspectos gerais sobre a Educação no Distrito Federal}

O IDH é o índice de desenvolvimento humano proposto pelo PNUD (Programa das Nações Unidas para o Desenvolvimento) que visa auferir o grau do desenvolvimento da população. O IDH é constituído por 3 (três) pilares - saúde, educação e renda - que são medidos a partir dos seguintes parâmetros:

- Renda: medido pela Renda Nacional Bruta (RNB) per capita, expressa em poder de paridade de compra;

- Saúde: medida a partir da expectativa de vida da população (longevidade); e

- Educação: é considerado o acesso ao conhecimento, mensurado a partir da média dos anos de estudo dos indivíduos e pela expectativa de anos de escolarização que as crianças podem receber se mantido os padrões existentes. 
$\mathrm{O}$ índice varia de 0 a 1 , sendo que quanto mais próximo de 1 , maior o desenvolvimento humano. O nível de desenvolvimento é considerado baixo quando o IDH estiver abaixo de 0,499, entre 0,500 e 0,799 é considerado nível médio e acima de 0,800 o nível de desenvolvimento humano é considerado alto. O IDHM - Índice de Desenvolvimento Humano Municipal segue os mesmos parâmetros (longevidade, educação e renda) do IDH Global adequando a metodologia ao contexto brasileiro, mensurando de forma mais adequada o desenvolvimento dos municípios brasileiros.

A partir da identificação do Ranking do IDHM 2010, por unidade da federação, conforme demonstrado na Tabela 1, percebe-se que o Distrito Federal lidera o ranking, seguido de São Paulo, Santa Catarina e Rio de Janeiro. Tais posições possuem forte ligação com o crescimento econômico regional existente nestas localidades. Observa-se ainda que dentre os 10 (dez) maiores IDHM's não consta Unidade da Federação - UF pertencente às regiões Norte e Nordeste, o que confirma a existência de desigualdades regionais em território brasileiro.

Tabela 1 - Ranking IDHM 2010, por Unidade da Federação.

\begin{tabular}{clcccc}
\hline $\begin{array}{c}\text { Ranking } \\
\text { IDHM }\end{array}$ & $\begin{array}{c}\text { Unidade da } \\
\text { Federação }\end{array}$ & IDHM 2010 & IDHM Renda & $\begin{array}{c}\text { IDHM } \\
\text { Longevidade }\end{array}$ & $\begin{array}{c}\text { IDHM } \\
\text { Educação }\end{array}$ \\
\hline $1^{\circ}$ & Distrito Federal & 0,824 & 0,863 & 0,873 & 0,742 \\
$2^{\circ}$ & São Paulo & 0,783 & 0,789 & 0,845 & 0,719 \\
$3^{\circ}$ & Santa Catarina & 0,774 & 0,773 & 0,860 & 0,697 \\
$4^{\circ}$ & Rio de Janeiro & 0,761 & 0,782 & 0,835 & 0,675 \\
$5^{\circ}$ & Paraná & 0,749 & 0,757 & 0,830 & 0,668 \\
$6^{\circ}$ & Rio Grande do Sul & 0,746 & 0,769 & 0,840 & 0,642 \\
$7^{\circ}$ & Espírito Santo & 0,740 & 0,743 & 0,835 & 0,653 \\
$8^{\circ}$ & Goiás & 0,735 & 0,742 & 0,827 & 0,646 \\
$9^{\circ}$ & Minas Gerais & 0,731 & 0,730 & 0,838 & 0,638 \\
$1^{\circ}$ & Mato Grosso do Sul & 0,729 & 0,740 & 0,833 & 0,629 \\
\hline
\end{tabular}

Fonte: PNUD.

A partir dos indicadores apresentados apenas o Distrito Federal apresenta nível de desenvolvimento alto, estando as demais UF dispondo nível de desenvolvimento médio. Contudo, ao analisar o IDHM pelas óticas da renda, longevidade e educação pode-se afirmar que o Distrito Federal apresenta nível de desenvolvimento médio quanto ao índice relacionado à Educação, apresentando resultado elevado, quanto a renda e longevidade. 
Quanto ao IDHM-Educação observa-se que este índice apresenta desenvolvimento inferior aos demais, contudo ações advindas da Política Nacional para a Educação podem contribuir para a melhoria dos resultados apresentados.

Ao analisar IDHM por Municípios, observa-se que Brasília, pertencente ao Distrito Federal (UF), se encontra em 9a lugar no ranking, conforme demonstrado na Tabela 2.

Tabela 2 - Ranking IDHM 2010, por Município.

\begin{tabular}{|c|c|c|c|c|c|}
\hline $\begin{array}{l}\text { Ranking } \\
\text { IDHM }\end{array}$ & Município & IDHM 2010 & IDHM Renda & $\begin{array}{c}\text { IDHM } \\
\text { Longevidade }\end{array}$ & $\begin{array}{l}\text { IDHM } \\
\text { Educação }\end{array}$ \\
\hline $1^{o}$ & $\begin{array}{l}\text { São Caetano do Sul } \\
\text { (SP) }\end{array}$ & 0,862 & 0,891 & 0,887 & 0,811 \\
\hline $2^{o}$ & $\begin{array}{l}\text { Águas de São Pedro } \\
\text { (SP) }\end{array}$ & 0,854 & 0,849 & 0,890 & 0,825 \\
\hline $3^{\circ}$ & Florianópolis (SC) & 0,847 & 0,870 & 0,873 & 0,800 \\
\hline $4^{\circ}$ & $\begin{array}{l}\text { Balneário Camboriú } \\
\text { (SC) }\end{array}$ & 0,845 & 0,854 & 0,894 & 0,789 \\
\hline $5^{\circ}$ & Vitória (ES) & 0,845 & 0,876 & 0,855 & 0,805 \\
\hline $6^{\circ}$ & Santos (SP) & 0,840 & 0,861 & 0,852 & 0,807 \\
\hline $7^{\circ}$ & Niterói (RJ) & 0,837 & 0,887 & 0,854 & 0,773 \\
\hline $8^{\circ}$ & Joaçaba (SC) & 0,827 & 0,823 & 0,891 & 0,771 \\
\hline $9^{\circ}$ & Brasília (DF) & 0,824 & 0,863 & 0,873 & 0,742 \\
\hline $10^{\circ}$ & Curitiba (PR) & 0,823 & 0,850 & 0,855 & 0,768 \\
\hline
\end{tabular}

Fonte: PNUD.

Na tabela acima destaca-se o Estado de São Paulo, ocupante do $1^{\circ}$ e $2^{\circ}$ lugar no ranking pelos Municípios de São Caetano do Sul e Águas de São Pedro, respectivamente. Das 10 (dez) primeiras posições, há 3 (três) municípios pertencentes ao Estado de São Paulo e outros 3 (três) pertencentes a Santa Catarina, fato que demonstra que estes Estados possuem municípios com desenvolvimento maior que certas regiões do Distrito Federal. Quanto ao IDHM-Educação observa-se que este índice também apresentou resultado inferior aos demais, contudo, ao analisar o IDHM, em termos gerais, destaca-se que todos os índices apresentaram valor superior a 0,800, dado que representa alto nível de desenvolvimento. Cabe destacar que o mesmo ocorreu para o IDHM-Renda e IDHM-Longevidade. 


\subsection{Alguns aspectos da Educação Básica}

Dados da Educação brasileira nos permite averiguar a evolução do ensino em nosso país. A Tabela 3 visa apresentar a taxa de escolarização ${ }^{1}$, por idade, desde 1992 até o ano de 2007.

Tabela 3 - Taxa de escolarização por idade - Brasil - 1992-2007 (\%).

\begin{tabular}{cccc}
\hline Ano & $\begin{array}{c}\text { 05 ou 06 anos } \\
\text { Ensino Infantil }\end{array}$ & $\begin{array}{c}\text { 07 a 14 anos } \\
\text { Ensino Fundamental }\end{array}$ & $\begin{array}{c}\mathbf{1 5} \text { a 17 anos } \\
\text { Ensino Médio }\end{array}$ \\
\hline 1992 & 53,91 & 86,59 & 59,67 \\
1993 & 57,70 & 88,60 & 61,92 \\
1995 & 63,79 & 90,22 & 66,59 \\
1996 & 63,77 & 91,26 & 69,47 \\
1997 & 66,59 & 92,99 & 73,27 \\
1998 & 69,09 & 94,70 & 76,46 \\
1999 & 70,96 & 95,69 & 78,51 \\
2001 & 76,23 & 96,46 & 81,09 \\
2002 & 77,17 & 96,94 & 81,47 \\
2003 & 78,69 & 97,19 & 82,36 \\
2004 & 81,83 & 97,19 & 82,18 \\
2005 & 82,20 & 97,43 & 81,98 \\
2006 & 85,29 & 97,73 & 82,50 \\
2007 & 86,41 & 97,67 & 82,35 \\
\hline
\end{tabular}

Fonte: IBGE/PNAD.

Diante dos dados apresentados, pode-se afirmar que desde 1992 a taxa de escolarização no ensino fundamental vem se mostrando elevada, mantendo-se na faixa de $86,59 \%$ a $97,73 \%$. Quanto ao ensino infantil e médio o percentual que era baixo apresentou considerável crescimento ao longo dos anos, alcançando 86,41\% e 82,50\% respectivamente.

Delimitando a análise a região Centro-Oeste, conforme Tabela 4, observa-se pouca variação no ensino fundamental, de $89,24 \%$ a $98,07 \%$ e aumento na taxa do ensino médio de $61,64 \%$ a 83,02\% demonstrando uma tendência crescente. Dessa forma, pode-se considerar que as taxas do ensino fundamental e médio tendem a se igualar nos próximos anos.

\footnotetext{
${ }^{1}$ Taxa de escolarização: Percentual de pessoas de uma determinada faixa etária que frequentam escola em relação ao total de pessoas da mesma faixa etária. Ou: o percentual de estudantes de um grupo etário em relação ao total de pessoas do mesmo grupo etário.
} 
Tabela 4 - Taxa de escolarização - Brasil: Região Centro-Oeste - 1992-2007 (\%).

\begin{tabular}{ccc}
\hline Ano & Ensino Fundamental & Ensino Médio \\
\hline 1992 & 89,24 & 61,64 \\
1993 & 89,44 & 61,98 \\
1995 & 91,74 & 66,21 \\
1996 & 92,97 & 71,47 \\
1997 & 93,18 & 71,07 \\
1998 & 95,73 & 74,84 \\
1999 & 96,01 & 77,77 \\
2001 & 97,10 & 80,18 \\
2002 & 97,11 & 80,32 \\
2003 & 97,03 & 82,89 \\
2004 & 97,20 & 79,87 \\
2005 & 97,56 & 81,94 \\
2006 & 98,07 & 83,02 \\
2007 & 97,68 & 81,67 \\
\hline
\end{tabular}

Fonte: IBGE/PNAD.

Os dados sobre escolaridade, apresentados pela Tabela 5, por grupos de anos de ensino, demonstram que, no que tange à população do Distrito Federal, os grupos não apresentaram percentuais constantes durante o período analisado, com exceção do grupo de 15 anos ou mais, que apresentou crescimento constante, evidenciando queda apenas no ano de 2004, contudo com aumentos constantes nos anos seguintes, variando de 9,99\% a 18,57\%.

Tabela 5 - Escolaridade por grupos de anos de estudo - Distrito Federal - 2001-2011 (\%).

\begin{tabular}{lrrrrrrrrrr}
\hline $\begin{array}{c}\text { Grupos de Anos de } \\
\text { Estudo }\end{array}$ & $\mathbf{2 0 0 1}$ & $\mathbf{2 0 0 2}$ & $\mathbf{2 0 0 3}$ & $\mathbf{2 0 0 4}$ & $\mathbf{2 0 0 5}$ & $\mathbf{2 0 0 6}$ & $\mathbf{2 0 0 7}$ & $\mathbf{2 0 0 8}$ & $\mathbf{2 0 0 9}$ & $\mathbf{2 0 1 1}$ \\
\hline $\begin{array}{l}\text { Sem instrução e menos } \\
\text { de 1 ano de estudo }\end{array}$ & 7,21 & 5,74 & 6,06 & 5,46 & 5,32 & 4,62 & 5,39 & 5,31 & 3,69 & 6,53 \\
1 a 3 anos & 9,68 & 8,76 & 7,88 & 8,60 & 8,06 & 8,81 & 7,83 & 7,80 & 7,95 & 5,77 \\
4 a 7 anos & 29,06 & 27,84 & 26,92 & 26,78 & 25,02 & 24,27 & 21,96 & 22,00 & 22,69 & 19,3 \\
8 a 10 anos & 18,65 & 19,83 & 19,30 & 18,65 & 18,21 & 17,21 & 17,70 & 17,84 & 16,00 & 16,14 \\
11 a 14 anos & 24,60 & 26,81 & 28,30 & 28,42 & 30,33 & 31,26 & 31,63 & 32,65 & 32,61 & 33,62 \\
15 anos ou mais & 9,99 & 10,52 & 11,20 & 11,66 & 12,68 & 13,60 & 15,34 & 14,24 & 16,93 & 18,57 \\
\hline
\end{tabular}

Fonte: IBGE/PNAD. 
Quanto à taxa de analfabetismo, em termos gerais, a região Centro-Oeste apresentou queda, contudo, de 2007 a 2008 houve aumento de $0,13 \%$, conforme demonstrado na Tabela 6. Em análise ao comportamento ocorrido nos Estados desta região, pode-se observar que o Estado de Goiás também apresentou queda constante com aumento apenas de 2007 a 2008. Quanto aos demais Estados não houve comportamento constante nos dados apresentados, resultando em oscilações ao longo do período analisado.

Tabela 6 - Taxa de analfabetismo das pessoas de 15 anos e mais de idade - Brasil - 2002-2008 (\%).

\begin{tabular}{lcccccccc}
\hline \multirow{2}{*}{ Unidade da Federação } & \multicolumn{7}{c}{ Ano } \\
\cline { 2 - 8 } & $\mathbf{2 0 0 2}$ & $\mathbf{2 0 0 3}$ & $\mathbf{2 0 0 4}$ & $\mathbf{2 0 0 5}$ & $\mathbf{2 0 0 6}$ & $\mathbf{2 0 0 7}$ & $\mathbf{2 0 0 8}$ \\
\hline Centro-Oeste & 9,64 & 9,46 & 9,18 & 8,90 & 8,25 & 8,05 & 8,18 \\
Mato Grosso do Sul & 8,99 & 9,60 & 9,52 & 9,06 & 8,46 & 8,34 & 8,12 \\
Mato Grosso & 10,20 & 10,70 & 10,10 & 9,75 & 9,23 & 10,06 & 9,55 \\
Goiás & 11,28 & 10,90 & 10,69 & 10,22 & 9,60 & 8,80 & 9,31 \\
Distrito Federal & 5,67 & 4,48 & 4,20 & 4,68 & 3,77 & 3,73 & 4,02 \\
\hline
\end{tabular}

Fonte: IBGE/PNAD.

Ao aprofundar a análise na taxa de analfabetismo existente no Distrito Federal segue a Tabela 7 discriminada por faixa etária, com dados de 2001 a 2011. Assim, pode-se observar taxa de analfabetismo inferior a $1 \%$ na população do DF, de 7 a 59 anos. Para a faixa de indivíduos acima de 60 anos essa taxa aumenta, contudo, não alcança sequer 1,5\%. O analfabetismo está concentrado na faixa etária de 5 e 6 anos de idade, que apresenta as maiores taxas, chegando ao máximo de $3,11 \%$, logo, o índice é considerado baixo se comparado com outros estados brasileiros. 
Tabela 7 - Taxa de analfabetismo por faixa etária - Distrito Federal - 2001-2011 (\%).

\begin{tabular}{|c|c|c|c|c|c|c|c|c|c|c|}
\hline \multirow{2}{*}{ Faixa Etária } & \multicolumn{10}{|c|}{ Anos } \\
\hline & 2001 & 2002 & 2003 & 2004 & 2005 & 2006 & 2007 & 2008 & 2009 & 2011 \\
\hline 05 e 06 anos & 2,89 & 3,11 & 2,70 & 2,65 & 2,50 & 2,29 & 2,11 & 1,89 & 2,10 & 1,58 \\
\hline 07 anos & 0,42 & 0,64 & 0,31 & 0,32 & 0,33 & 0,38 & 0,39 & 0,19 & 0,32 & 0,17 \\
\hline 08 e 09 anos & 0,18 & 0,28 & 0,23 & 0,16 & 0,13 & 0,17 & 0,14 & 0,15 & 0,04 & 0,07 \\
\hline 10 a 14 anos & 0,15 & 0,09 & 0,03 & 0,04 & 0,15 & 0,06 & 0,06 & 0,12 & 0,07 & 0,01 \\
\hline 10 e 11 anos & 0,08 & 0,05 & 0,01 & 0,03 & 0,08 & 0,04 & 0,04 & 0,07 & 0,05 & 0,01 \\
\hline 12 anos & 0,01 & 0,02 & 0,02 & 0,01 & 0,02 & - & 0,02 & 0,02 & - & - \\
\hline 13 e 14 anos & 0,05 & 0,02 & - & - & 0,05 & 0,03 & - & 0,04 & 0,02 & - \\
\hline 15 a 19 anos & 0,08 & 0,07 & 0,07 & 0,07 & 0,04 & 0,06 & 0,07 & 0,11 & 0,02 & 0,04 \\
\hline 15 a 17 anos & 0,05 & 0,06 & 0,04 & 0,06 & 0,01 & 0,04 & 0,04 & 0,06 & - & 0,02 \\
\hline 18 a 19 anos & 0,03 & 0,01 & 0,03 & 0,01 & 0,03 & 0,03 & 0,03 & 0,05 & 0,02 & 0,01 \\
\hline 20 a 24 anos & 0,27 & 0,24 & 0,15 & 0,13 & 0,20 & 0,10 & 0,06 & 0,07 & 0,06 & 0,02 \\
\hline 25 a 29 anos & 0,36 & 0,30 & 0,18 & 0,17 & 0,20 & 0,11 & 0,14 & 0,19 & 0,18 & 0,04 \\
\hline 30 a 39 anos & 0,74 & 0,69 & 0,52 & 0,55 & 0,46 & 0,45 & 0,41 & 0,39 & 0,33 & 0,22 \\
\hline 40 a 49 anos & 0,80 & 0,84 & 0,75 & 0,52 & 0,60 & 0,55 & 0,53 & 0,54 & 0,52 & 0,47 \\
\hline 50 a 59 anos & 0,88 & 0,88 & 0,66 & 0,76 & 0,78 & 0,59 & 0,58 & 0,61 & 0,53 & 0,56 \\
\hline 60 anos ou mais & 1,23 & 1,47 & 1,24 & 1,15 & 1,46 & 1,15 & 1,25 & 1,35 & 1,21 & 1,27 \\
\hline Idade ignorada & 0,02 & - & 0,03 & - & 0,02 & - & - & - & - & - \\
\hline
\end{tabular}

Fonte: IBGE/PNAD.

Assim, pode-se afirmar que o Distrito Federal possui uma população com baixo nível de analfabetismo. O que leva a inferir que a população valoriza o ensino, visto que em todas as faixas etárias houve queda na taxa de analfabetismo de 2001 a 2011.

Na Tabela 8 estão demonstradas as taxas de aprovação, reprovação e abandono referentes ao ensino fundamental e médio, para o período de 2007 a 2010. Diante dos dados apresentados pode-se observar que houve queda nas taxas de abandono e reprovação e aumento na taxa de aprovação. Comparando-se o ensino fundamental e médio identificamos que o comportamento das taxas se assemelham, em ambos os níveis de ensino. 
Tabela 8 - Taxa de aprovação, reprovação e abandono - 2007-2010 (\%).

\begin{tabular}{ccccccc}
\hline \multirow{2}{*}{ Ano } & \multicolumn{3}{c}{ Ensino Fundamental } & \multicolumn{3}{c}{ Ensino Médio } \\
\cline { 2 - 7 } & Aprovação & Reprovação & Abandono & Aprovação & Reprovação & Abandono \\
\hline 2007 & 83,80 & 14,40 & 1,80 & 71,10 & 20,90 & 8,00 \\
2008 & 89,20 & 8,90 & 1,90 & 82,00 & 13,00 & 5,00 \\
2009 & 88,70 & 9,70 & 1,60 & 76,60 & 16,10 & 7,30 \\
2010 & 88,70 & 10,10 & 1,20 & 74,80 & 18,60 & 6,60 \\
\hline
\end{tabular}

Fonte: MEC/INEP.

O Índice de Desenvolvimento da Educação Básica (IDEB) foi instituído em 2007 pelo INEP no intuito de se obter, em apenas um indicador, o fluxo escolar e as médias de desempenho nas avaliações com fins de medir a qualidade da educação. Tal indicador viabiliza a elaboração de diagnóstico da situação da educação, bem como a projeção de metas que visem melhorias na qualidade do ensino.

O IDEB além de ser ferramenta de gestão de Políticas Públicas é utilizado no acompanhamento das metas de qualidade do Plano Nacional de Educação (PNE).

Tabela 9 - IDEB Observados 2005, 2007, 2009, 2011, 2013 e Metas - Distrito Federal.

\begin{tabular}{lccccccccccc}
\hline \multirow{2}{*}{ Fases de Ensino } & \multicolumn{4}{c}{ IDEB Observado } & \multicolumn{5}{c}{ Metas Projetadas } \\
\cline { 2 - 10 } & $\mathbf{2 0 0 5}$ & $\mathbf{2 0 0 7}$ & $\mathbf{2 0 0 9}$ & $\mathbf{2 0 1 1}$ & $\mathbf{2 0 1 3}$ & $\mathbf{2 0 1 3}$ & $\mathbf{2 0 1 5}$ & $\mathbf{2 0 1 7}$ & $\mathbf{2 0 1 9}$ & $\mathbf{2 0 2 1}$ \\
\hline Anos Iniciais do Ensino Fundamental & 4,8 & 5,0 & 5,6 & 5,7 & 5,9 & 5,8 & 6,1 & 6,3 & 6,6 & 6,8 \\
Anos Finais do Ensino Fundamental & 3,8 & 4,0 & 4,4 & 4,4 & 4,4 & 4,7 & 5,1 & 5,3 & 5,6 & 5,8 \\
Ensino Médio & 3,6 & 4,0 & 3,8 & 3,8 & 4,0 & 4,1 & 4,5 & 4,9 & 5,2 & 5,4 \\
\hline
\end{tabular}

Fonte: MEC/INEP.

A Tabela 9 dispõe de dados do IDEB, referente ao Distrito Federal, dos anos de 2005, 2007, 2009, 2011, 2013 e metas projetadas para os anos de 2013, 2015, 2017, 2019 e 2021. Cumpre informar que o IDEB é medido de zero a dez e corresponde ao nível educacional existente nos países da OCDE, ou seja, a um sistema educacional de qualidade. Assim, podese observar que o IDEB do DF demonstra crescimento moderado para o período analisado. 


\subsection{Alguns aspectos da Educação Infantil}

No que tange a Educação Infantil, cabe citar a definição apresentada pelo art. $5^{\circ}$, da Resolução n. 5, de 17 de dezembro de 2009, que fixa as Diretrizes Curriculares Nacionais da Educação Infantil (DCNEI), que dispõe:

Art. $5^{\circ}$ A Educação Infantil, primeira etapa da Educação Básica, é oferecida em creches e pré-escolas, as quais se caracterizam como espaços institucionais não domésticos que constituem estabelecimentos educacionais públicos ou privados que educam e cuidam de crianças de 0 a 5 anos de idade no período diurno, em jornada integral ou parcial, regulados e supervisionados por órgão competente do sistema de ensino e submetidos a controle social.

A Constituição Federal, em seu art. 208, dispõe que o dever do Estado com a Educação Infantil será efetivado garantindo creches e pré-escola para crianças de até 05 (cinco) anos de idade. O Plano Nacional de Educação (PNE) define metas cabendo mencionar como principal meta voltada ao ensino infantil:

Meta 1: universalizar, até 2016, a educação infantil na pré-escola para as crianças de 4 (quatro) a 5 (cinco) anos de idade e ampliar a oferta de educação infantil em creches de forma a atender, no mínimo, $50 \%$ (cinquenta por cento) das crianças de até 3 (três) anos até o final da vigência deste PNE.

Para cumprimento desta meta o PNE estabelece 17 estratégias, dentre as quais se destacam as seguintes: 
Quadro 2 - Meta 1 - Principais estratégias.

\begin{tabular}{|c|c|}
\hline 1.1 & $\begin{array}{l}\text { efinir, em regime de colaboração entre a União, os Estados, o Distrito Federal e os Municípios, metas } \\
\text { expansão das respectivas redes públicas de educação infantil segundo padrão nacional de qualidade, } \\
\text { nsiderando as peculiaridades locais; }\end{array}$ \\
\hline 1.6 & $\begin{array}{l}\text { plantar, até o segundo ano de vigência deste PNE, avaliação da educação infantil, a ser realizada a } \\
\text { da } 2 \text { (dois) anos, com base em parâmetros nacionais de qualidade, a fim de aferir a infraestrutura } \\
\text { ica, o quadro de pessoal, as condições de gestão, os recursos pedagógicos, a situação de } \\
\text { essibilidade, entre outros indicadores relevantes; }\end{array}$ \\
\hline 1.9 & $\begin{array}{l}\text { timular a articulação entre pós-graduação, núcleos de pesquisa e cursos de formação para } \\
\text { ofissionais da educação, de modo a garantir a elaboração de currículos e propostas pedagógicas que } \\
\text { corporem os avanços de pesquisas ligadas ao processo de ensino-aprendizagem e às teorias } \\
\text { ucacionais no atendimento da população de } 0 \text { (zero) a } 5 \text { (cinco) anos; }\end{array}$ \\
\hline 1.10 & $\begin{array}{l}\text { omentar o atendimento das populações do campo e das comunidades indígenas e quilombolas na } \\
\text { ducação infantil nas respectivas comunidades, por meio do redimensionamento da distribuição } \\
\text { rritorial da oferta, limitando a nucleação de escolas e o deslocamento de crianças, de forma a atender } \\
\text { s especificidades dessas comunidades, garantido consulta prévia e informada; }\end{array}$ \\
\hline 1.11 & $\begin{array}{l}\text { Priorizar o acesso à educação infantil e fomentar a oferta do atendimento educacional especializado } \\
\text { complementar e suplementar aos (às) alunos (as) com deficiência, transtornos globais do } \\
\text { desenvolvimento e altas habilidades ou superdotação, assegurando a educação bilíngue para crianças } \\
\text { surdas e a transversalidade da educação especial nessa etapa da educação básica; }\end{array}$ \\
\hline 1.14 & $\begin{array}{l}\text { Fortalecer o acompanhamento e o monitoramento do acesso e da permanência das crianças na educação } \\
\text { infantil, em especial dos beneficiários de programas de transferência de renda, em colaboração com as } \\
\text { famílias e com os órgãos públicos de assistência social, saúde e proteção à infância; }\end{array}$ \\
\hline 1.16 & $\begin{array}{l}\text { O Distrito Federal e os Municípios, com a colaboração da União e dos Estados, realizarão e publicarão, } \\
\text { a cada ano, levantamento da demanda manifesta por educação infantil em creches e pré-escolas, como } \\
\text { forma de planejar e verificar o atendimento; }\end{array}$ \\
\hline 1.17 & $\begin{array}{l}\text { à educação infantil em tempo integral, para todas as crianças de } 0 \text { (zero) a } 5 \text { (cinco) } \\
\text { abelecido nas Diretrizes Curriculares Nacionais para a Educação Infantil. }\end{array}$ \\
\hline
\end{tabular}

Fonte: Elaborado pelo autor.

Assim, a Tabela 10 demonstra a evolução da matrícula no ensino infantil por dependência administrativa (Federal, Estadual e Privada), no período de 2007 a 2012.

Tabela 10 - Evolução da matrícula na educação infantil por dependência administrativa - Distrito Federal 2007-2012.

\begin{tabular}{ccccc}
\hline Ano & Total & Federal & Estadual & Privada \\
\hline 2007 & 77.922 & 37 & 48.402 & 29.483 \\
2008 & 72.072 & 33 & 33.664 & 38.375 \\
2009 & 76.691 & 26 & 35.446 & 41.219 \\
2010 & 81.833 & 37 & 37.970 & 43.826 \\
2011 & 81.712 & 24 & 34.943 & 46.745 \\
2012 & 79.462 & 28 & 31.643 & 47.791 \\
\hline
\end{tabular}

Fonte: MEC/InepData. 
Conforme demonstrado na tabela acima, neste nível de ensino observa-se que a participação do Governo Federal e Estadual vem apresentando queda em oposição à participação privada, a qual demonstrou constante aumento, ao longo do período analisado. Em termos gerais, as matrículas na educação infantil não têm apresentado comportamento constante, oscilando ao longo do período em análise.

\subsection{Alguns aspectos do Ensino Fundamental}

Conforme previsto pela $\mathrm{CF} / 88$, artigo 208, o ensino fundamental deve ser gratuito e obrigatório, garantida sua oferta aos que não tiveram acesso na idade própria. Dentre as metas estabelecidas pelo PNE, as voltadas ao ensino fundamental que se destacam são:

Meta 2: universalizar o ensino fundamental de 9 (nove) anos para toda a população de 6 (seis) a 14 (quatorze) anos e garantir que pelo menos 95\% (noventa e cinco por cento) dos alunos concluam essa etapa na idade recomendada, até o último ano de vigência deste PNE.

Meta 5: alfabetizar todas as crianças, no máximo, até o final do $3^{\circ}$ (terceiro) ano do ensino fundamental.

Para cumprimento das metas supracitadas o PNE estabelece 20 (vinte) estratégias, dentre as quais destacam-se as seguintes:

Das 13 estratégias estabelecidas pela Meta 2, destacam-se as descritas no Quadro 3, a seguir.

Quadro 3 - Meta 2 - Principais estratégias.

\begin{tabular}{|l|l|}
\hline 2.2 & $\begin{array}{l}\text { Pactuar entre União, Estados, Distrito Federal e Municípios, no âmbito da instância permanente de que } \\
\text { trata o } \$ 5^{\circ} \text { do art. } 7^{\circ} \text { desta Lei, a implantação dos direitos e objetivos de aprendizagem e } \\
\text { desenvolvimento que configurarão a base nacional comum curricular do ensino fundamental; }\end{array}$ \\
\hline 2.4 & $\begin{array}{l}\text { Fortalecer o acompanhamento e o monitoramento do acesso, da permanência e do aproveitamento } \\
\text { escolar dos beneficiários de programas de transferência de renda, bem como das situações de } \\
\text { discriminação, preconceitos e violências na escola, visando ao estabelecimento de condições adequadas } \\
\text { para o sucesso escolar dos (as) alunos (as), em colaboração com as famílias e com órgãos públicos de } \\
\text { assistência social, saúde e proteção à infância, adolescência e juventude; }\end{array}$ \\
\hline 2.5 & $\begin{array}{l}\text { Promover a busca ativa de crianças e adolescentes fora da escola, em parceria com órgãos públicos de } \\
\text { assistência social, saúde e proteção à infância, adolescência e juventude; }\end{array}$ \\
\hline 2.9 & $\begin{array}{l}\text { Incentivar a participação dos pais ou responsáveis no acompanhamento das atividades escolares dos } \\
\text { filhos por meio do estreitamento das relações entre as escolas e as famílias; }\end{array}$ \\
\hline 2.10 & $\begin{array}{l}\text { Estimular a oferta do ensino fundamental, em especial dos anos iniciais, para as populações do campo, } \\
\text { indígenas e quilombolas, nas próprias comunidades; }\end{array}$ \\
\hline
\end{tabular}

Fonte: Elaborado pelo autor. 
Das 07 (sete) estratégias estabelecidas pela Meta 5, destacam-se as descritas no Quadro 4, a seguir.

Quadro 4 - Meta 5 - Principais estratégias.

\begin{tabular}{|l|l|}
\hline 5.2 & $\begin{array}{l}\text { Instituir instrumentos de avaliação nacional periódicos e específicos para aferir a alfabetização das } \\
\text { crianças, aplicados a cada ano, bem como estimular os sistemas de ensino e as escolas a criarem os } \\
\text { respectivos instrumentos de avaliação e monitoramento, implementando medidas pedagógicas para } \\
\text { alfabetizar todos os alunos e alunas até o final do terceiro ano do ensino fundamental; }\end{array}$ \\
\hline 5.4 & $\begin{array}{l}\text { Fomentar o desenvolvimento de tecnologias educacionais e de práticas pedagógicas inovadoras que } \\
\text { assegurem a alfabetização e favoreçam a melhoria do fluxo escolar e a aprendizagem dos (as) alunos } \\
\text { (as), consideradas as diversas abordagens metodológicas e sua efetividade; }\end{array}$ \\
\hline 5.5 & $\begin{array}{l}\text { Apoiar a alfabetização de crianças do campo, indígenas, quilombolas e de populaçães itinerantes, com a } \\
\text { produção de materiais didáticos específicos, e desenvolver instrumentos de acompanhamento que } \\
\text { considerem o uso da língua materna pelas comunidades indígenas e a identidade cultural das } \\
\text { comunidades quilombolas; }\end{array}$ \\
\hline 5.7 & $\begin{array}{l}\text { Apoiar a alfabetização das pessoas com deficiência, considerando as suas especificidades, inclusive a } \\
\text { alfabetização bilíngue de pessoas surdas, sem estabelecimento de terminalidade temporal. }\end{array}$ \\
\hline
\end{tabular}

Fonte: Elaborado pelo autor.

Diante da Tabela 11, que trata da evolução da matrícula no ensino fundamental, por dependência administrativa nos anos de 2007 a 2012, observa-se queda nos níveis Federal e Estadual, com aumento no nível Privado. Logo, pode-se afirmar que as famílias estão preferindo matricular seus filhos em escolas privadas e estão possuindo condições financeiras para isso. Tal fato pode estar relacionado com a qualidade do ensino nas redes analisadas, onde o nível Privado se destaca.

Tabela 11 - Evolução da matrícula no Ensino Fundamental por dependência administrativa - Distrito Federal 2007-2012.

\begin{tabular}{ccccc}
\hline Ano & Total & Federal & Estadual & Privada \\
\hline 2007 & 385.299 & 1.839 & 310.314 & 73.146 \\
2008 & 424.434 & 1.815 & 330.733 & 91.886 \\
2009 & 418.913 & 1.662 & 320.699 & 96.552 \\
2010 & 417.969 & 1.502 & 318.004 & 98.463 \\
2011 & 416.240 & 1.393 & 312.787 & 102.060 \\
2012 & 409.586 & 1.401 & 303.788 & 104.397 \\
\hline
\end{tabular}

Fonte: MEC/InepData. 
Sobre a qualidade da educação no Ensino Fundamental, Franco et al. (2007, p. 1007) ressaltam que:

[...] não restam dúvidas de que a questão da qualidade da educação ainda é um grande desafio para o Brasil. O desempenho do aluno mediano das escolas públicas fica aquém de habilidades em matemática e em leitura, consideradas como fundamentais ao término do primeiro segmento do ensino fundamental. Essas habilidades situam-se, na escala do SAEB, pelo menos 50 pontos à frente, o que corresponde aproximadamente a aumento de um desvio padrão da distribuição nacional de proficiência. As políticas educacionais avaliadas mostram magnitude modesta no aumento do desempenho dos alunos. Isso indica que nenhuma dessas medidas educacionais é capaz de oferecer incremento da qualidade na magnitude necessária.

\subsection{Alguns aspectos do Ensino Médio}

Em relação ao ensino médio, dentre as metas estabelecidas pelo PNE, cabe citar a Meta 3, que dispõe o que segue:

Meta 3: universalizar, até 2016, o atendimento escolar para toda a população de 15 (quinze) a 17 (dezessete) anos e elevar, até o final do período de vigência deste PNE, a taxa líquida de matrículas no ensino médio para $85 \%$ (oitenta e cinco por cento).

Das 14 estratégias estabelecidas pela Meta 3, destacam-se as descritas no Quadro 5, a seguir. 
Quadro 5 - Meta 3 - Principais estratégias.

\begin{tabular}{|c|c|}
\hline 3.1 & $\begin{array}{l}\text { stitucionalizar programa nacional de renovação do ensino médio, a fim de incentivar práticas } \\
\text { edagógicas com abordagens interdisciplinares estruturadas pela relação entre teoria e prática, por meio } \\
\text { currículos escolares que organizem, de maneira flexível e diversificada, conteúdos obrigatórios e } \\
\text { etivos articulados em dimensões como ciência, trabalho, linguagens, tecnologia, cultura e esporte, } \\
\text { arantindo-se a aquisição de equipamentos e laboratórios, a produção de material didático específico, a } \\
\text { rmação continuada de professores e a articulação com instituições acadêmicas, esportivas e culturais; }\end{array}$ \\
\hline 3.3 & $\begin{array}{l}\text { ctuar entre União, Estados, Distrito Federal e Municípios, no âmbito da instância permanente de que } \\
\text { ta o } \$ 5^{\circ} \text { do art. } 7^{\circ} \text { desta Lei, a implantação dos direitos e objetivos de aprendizagem e } \\
\text { senvolvimento que configurarão a base nacional comum curricular do ensino médio; }\end{array}$ \\
\hline 3.5 & $\begin{array}{l}\text { anter e ampliar programas e ações de correção de fluxo do ensino fundamental, por meio do } \\
\text { ompanhamento individualizado do (a) aluno (a) com rendimento escolar defasado e pela adoção de } \\
\text { áticas como aulas de reforço no turno complementar, estudos de recuperação e progressão parcial, de } \\
\text { rma a reposicioná-lo no ciclo escolar de maneira compatível com sua idade; }\end{array}$ \\
\hline 3.6 & $\begin{array}{l}\text { Universalizar o Exame Nacional do Ensino Médio - ENEM, fundamentado em matriz de referência do } \\
\text { conteúdo curricular do ensino médio e em técnicas estatísticas e psicométricas que permitam } \\
\text { comparabilidade de resultados, articulando-o com o Sistema Nacional de Avaliação da Educação Básica } \\
\text { - SAEB, e promover sua utilização como instrumento de avaliação sistêmica, para subsidiar políticas } \\
\text { públicas para a educação básica, de avaliação certificadora, possibilitando aferição de conhecimentos e } \\
\text { habilidades adquiridos dentro e fora da escola, e de avaliação classificatória, como critério de acesso à } \\
\text { educação superior; }\end{array}$ \\
\hline 3.7 & $\begin{array}{l}\text { mentar a expansão das matrículas gratuitas de ensino médio integrado à educação profissional, } \\
\text { servando-se as peculiaridades das populações do campo, das comunidades indígenas e quilombolas e } \\
\text { s pessoas com deficiência; }\end{array}$ \\
\hline 3.8 & $\begin{array}{l}\text { truturar e fortalecer o acompanhamento e o monitoramento do acesso e da permanência dos e das } \\
\text { vens beneficiários (as) de programas de transferência de renda, no ensino médio, quanto à frequência, } \\
\text { aproveitamento escolar e à interação com o coletivo, bem como das situações de discriminação, } \\
\text { econceitos e violências, práticas irregulares de exploração do trabalho, consumo de drogas, gravidez } \\
\text { ecoce, em colaboração com as famílias e com órgãos públicos de assistência social, saúde e proteção à } \\
\text { olescência e juventude; }\end{array}$ \\
\hline 3.13 & $\begin{array}{l}\text { Implementar políticas de prevenção à evasão motivada por preconceito ou quaisquer formas de } \\
\text { discriminação, criando rede de proteção contra formas associadas de exclusão; }\end{array}$ \\
\hline & \\
\hline
\end{tabular}

Fonte: Elaborado pelo autor.

Assim, segue a Tabela 12 que trata da evolução da matrícula no ensino médio, por dependência administrativa do DF, para o período de 2007 a 2012. 
Tabela 12 - Evolução da matrícula no Ensino Médio por dependência administrativa - Distrito Federal - 2007 2012.

\begin{tabular}{ccccc}
\hline Ano & Total & Federal & Estadual & Privada \\
\hline 2007 & 98.351 & 1.235 & 75.743 & 21.373 \\
2008 & 91.277 & 1.620 & 65.196 & 24.461 \\
2009 & 104.949 & 1.594 & 78.213 & 25.142 \\
2010 & 107.852 & 1.707 & 80.219 & 25.926 \\
2011 & 109.587 & 1.646 & 80.705 & 27.236 \\
2012 & 111.774 & 1.769 & 81.525 & 28.480 \\
\hline
\end{tabular}

Fonte: MEC/InepData.

Diante dos dados demonstrados pode-se observar oscilação na participação Federal neste nível de ensino, contudo, no nível Estadual e Privado a participação se mantem crescente ao longo do período analisado. Em termos gerais, houve aumento de aproximadamente $12 \%$ nas matrículas referente ao ensino médio.

\subsection{Alguns aspectos do Ensino Superior}

Quanto à Educação Superior, o PNE prevê as metas 12, 13 e 14, quais sejam:

\footnotetext{
Meta 12: elevar a taxa bruta de matrícula na educação superior para 50\% (cinquenta por cento) e a taxa líquida para 33\% (trinta e três por cento) da população de 18 (dezoito) a 24 (vinte e quatro) anos, assegurada a qualidade da oferta e expansão para, pelo menos, $40 \%$ (quarenta por cento) das novas matrículas, no segmento público.

Meta 13: elevar a qualidade da educação superior e ampliar a proporção de mestres e doutores do corpo docente em efetivo exercício no conjunto do sistema de educação superior para $75 \%$ (setenta e cinco por cento), sendo, do total, no mínimo, 35\% (trinta e cinco por cento) doutores.

Meta 14: elevar gradualmente o número de matrículas na pós-graduação stricto sensu, de modo a atingir a titulação anual de 60.000 (sessenta mil) mestres e 25.000 (vinte e cinco mil) doutores.
}

Diante das metas citadas, pode-se destacar que todas visam a expansão da Educação Superior resguardando a qualidade do ensino, visto que a expansão na oferta deste nível de ensino tende a comprometer a qualidade existente, de modo que apenas ganhos quantitativos não atenderão as metas estabelecidas no PNE.

Para viabilizar o alcance dessas metas, faz-se importante a apresentação de algumas estratégias previstas pelo PNE. Assim, das 21 estratégias estabelecidas pela Meta 12, destacam-se as descritas no Quadro 6, a seguir. 
Quadro 6-Meta 12 - Principais estratégias.

\begin{tabular}{|c|c|}
\hline 12.1 & $\begin{array}{l}\text { timizar a capacidade instalada da estrutura física e de recursos humanos das instituições públicas de } \\
\text { ducação superior, mediante ações planejadas e coordenadas, de forma a ampliar e interiorizar o } \\
\text { cesso à graduação; }\end{array}$ \\
\hline 12.2 & $\begin{array}{l}\text { Ampliar a oferta de vagas, por meio da expansão e interiorização da rede federal de educação superior, } \\
\text { da Rede Federal de Educação Profissional, Científica e Tecnológica e do sistema Universidade Aberta } \\
\text { do Brasil, considerando a densidade populacional, a oferta de vagas públicas em relação à população } \\
\text { na idade de referência e observadas as características regionais das micro e mesorregiões definidas } \\
\text { pela Fundação Instituto Brasileiro de Geografia e Estatística - IBGE, uniformizando a expansão no } \\
\text { território nacional; }\end{array}$ \\
\hline 12.3 & $\begin{array}{l}\text { Elevar gradualmente a taxa de conclusão média dos cursos de graduação presenciais nas universidades } \\
\text { públicas para } 90 \% \text { (noventa por cento), ofertar, no mínimo, um terço das vagas em cursos noturnos e } \\
\text { elevar a relação de estudantes por professor (a) para } 18 \text { (dezoito), mediante estratégias de } \\
\text { aproveitamento de créditos e inovações acadêmicas que valorizem a aquisição de competências de } \\
\text { nível superior; }\end{array}$ \\
\hline 12.5 & $\begin{array}{l}\text { Ampliar as políticas de inclusão e de assistência estudantil dirigidas aos (às) estudantes de instituições } \\
\text { públicas, bolsistas de instituições privadas de educação superior e beneficiários do Fundo de } \\
\text { Financiamento Estudantil - FIES, de que trata a Lei no } 10.260 \text {, de } 12 \text { de julho de } 2001 \text {, na educação } \\
\text { superior, de modo a reduzir as desigualdades étnico-raciais e ampliar as taxas de acesso e permanência } \\
\text { na educação superior de estudantes egressos da escola pública, afrodescendentes e indígenas e de } \\
\text { estudantes com deficiência, transtornos globais do desenvolvimento e altas habilidades ou } \\
\text { superdotação, de forma a apoiar seu sucesso acadêmico; }\end{array}$ \\
\hline 12.8 & ção na educação superior; \\
\hline 12.9 & $\begin{array}{l}\text { Ampliar a participação proporcional de grupos historicamente desfavorecidos na educação superior, } \\
\text { inclusive mediante a adoção de políticas afirmativas, na forma da lei; }\end{array}$ \\
\hline 12.10 & Assegurar condições de acessibilidade nas instituições de educação superior, na forma da legislação; \\
\hline 12.12 & $\begin{array}{l}\text { Consolidar e ampliar programas e ações de incentivo à mobilidade estudantil e docente em cursos de } \\
\text { graduação e pós-graduação, em âmbito nacional e internacional, tendo em vista o enriquecimento da } \\
\text { formação de nível superior; }\end{array}$ \\
\hline 12.13 & $\begin{array}{l}\text { Expandir atendimento específico a populações do campo e comunidades indígenas e quilombolas, em } \\
\text { relação a acesso, permanência, conclusão e formação de profissionais para atuação nessas populações; }\end{array}$ \\
\hline 12.14 & $\begin{array}{l}\text { Mapear a demanda e fomentar a oferta de formação de pessoal de nível superior, destacadamente a que } \\
\text { se refere à formação nas áreas de ciências e matemática, considerando as necessidades do } \\
\text { desenvolvimento do País, a inovação tecnológica e a melhoria da qualidade da educação básica; }\end{array}$ \\
\hline 12.15 & $\begin{array}{l}\text { Institucionalizar programa de composição de acervo digital de referências bibliográficas e audiovisuais } \\
\text { para os cursos de graduação, assegurada a acessibilidade às pessoas com deficiência; }\end{array}$ \\
\hline 12.17 & $\begin{array}{l}\text { Estimular mecanismos para ocupar as vagas ociosas em cada período letivo na educação superior } \\
\text { pública; }\end{array}$ \\
\hline 12.19 & $\begin{array}{l}\text { Reestruturar com ênfase na melhoria de prazos e qualidade da decisão, no prazo de } 2 \text { (dois) anos, os } \\
\text { procedimentos adotados na área de avaliação, regulação e supervisão, em relação aos processos de } \\
\text { autorização de cursos e instituições, de reconhecimento ou renovação de reconhecimento de cursos } \\
\text { superiores e de credenciamento ou recredenciamento de instituições, no âmbito do sistema federal de } \\
\text { ensino. }\end{array}$ \\
\hline
\end{tabular}

Fonte: Elaborado pelo autor.

Das 09 (nove) estratégias estabelecidas pela Meta 13, destacam-se as descritas no

Quadro 7, a seguir. 
Quadro 7 - Meta 13 - Principais estratégias.

\begin{tabular}{|l|l|}
\hline 13.1 & $\begin{array}{l}\text { Aperfeiçoar o Sistema Nacional de Avaliação da Educação Superior - SINAES, de que trata a Lei no } \\
10.861, \text { de } 14 \text { de abril de 2004, fortalecendo as ações de avaliação, regulação e supervisão; }\end{array}$ \\
\hline 13.2 & $\begin{array}{l}\text { Ampliar a cobertura do Exame Nacional de Desempenho de Estudantes - ENADE, de modo a ampliar } \\
\text { o quantitativo de estudantes e de áreas avaliadas no que diz respeito à aprendizagem resultante da } \\
\text { graduação; }\end{array}$ \\
\hline 13.3 & $\begin{array}{l}\text { Induzir processo contínuo de autoavaliação das instituições de educação superior, fortalecendo a } \\
\text { participação das comissões próprias de avaliação, bem como a aplicação de instrumentos de avaliação } \\
\text { que orientem as dimensões a serem fortalecidas, destacando-se a qualificação e a dedicação do corpo } \\
\text { docente; }\end{array}$ \\
\hline 13.8 & $\begin{array}{l}\text { Elevar gradualmente a taxa de conclusão média dos cursos de graduação presenciais nas universidades } \\
\text { públicas, de modo a atingir 90\% (noventa por cento) e, nas instituições privadas, 75\% (setenta e cinco } \\
\text { por cento), em 2020, e fomentar a melhoria dos resultados de aprendizagem, de modo que, em } 5 \\
\text { (cinco) anos, pelo menos } 60 \% \text { (sessenta por cento) dos estudantes apresentem desempenho positivo } \\
\text { igual ou superior a 60\% (sessenta por cento) no Exame Nacional de Desempenho de Estudantes - } \\
\text { ENADE e, no último ano de vigência, pelo menos 75\% (setenta e cinco por cento) dos estudantes } \\
\text { obtenham desempenho positivo igual ou superior a 75\% (setenta e cinco por cento) nesse exame, em } \\
\text { cada área de formação profissional; }\end{array}$ \\
\hline 13.9 & $\begin{array}{l}\text { Promover a formação inicial e continuada dos (as) profissionais técnico-administrativos da educação } \\
\text { superior. }\end{array}$ \\
\hline
\end{tabular}

Fonte: Elaborado pelo autor.

Das 15 estratégias estabelecidas pela Meta 14, destacam-se as descritas no Quadro 8, a seguir.

Quadro 8 - Meta 14 - Principais estratégias.

\begin{tabular}{|l|l|}
\hline 14.1 & Expandir o financiamento da pós-graduação stricto sensu por meio das agências oficiais de fomento; \\
\hline 14.2 & $\begin{array}{l}\text { Estimular a integração e a atuação articulada entre a Coordenação de Aperfeiçoamento de Pessoal de } \\
\text { Nível Superior - CAPES e as agências estaduais de fomento à pesquisa; }\end{array}$ \\
\hline 14.3 & Expandir o financiamento estudantil por meio do Fies à pós-graduação stricto sensu; \\
\hline 14.4 & $\begin{array}{l}\text { Expandir a oferta de cursos de pós-graduação stricto sensu, utilizando inclusive metodologias, } \\
\text { recursos e tecnologias de educação a distância; }\end{array}$ \\
\hline 14.5 & $\begin{array}{l}\text { Implementar ações para reduzir as desigualdades étnico-raciais e regionais e para favorecer o acesso } \\
\text { das populações do campo e das comunidades indígenas e quilombolas a programas de mestrado e } \\
\text { doutorado; }\end{array}$ \\
\hline 14.7 & $\begin{array}{l}\text { Manter e expandir programa de acervo digital de referências bibliográficas para os cursos de pós- } \\
\text { graduação, assegurada a acessibilidade às pessoas com deficiência; }\end{array}$ \\
\hline 14.8 & $\begin{array}{l}\text { Estimular a participação das mulheres nos cursos de pós-graduação stricto sensu, em particular aqueles } \\
\text { ligados às áreas de Engenharia, Matemática, Física, Química, Informática e outros no campo das } \\
\text { ciências; }\end{array}$ \\
\hline 14.10 & $\begin{array}{l}\text { Promover o intercâmbio científico e tecnológico, nacional e internacional, entre as instituições de } \\
\text { ensino, pesquisa e extensão; }\end{array}$ \\
\hline 14.12 & $\begin{array}{l}\text { Ampliar o investimento na formação de doutores de modo a atingir a proporção de } 4 \text { (quatro) doutores } \\
\text { por 1.000 (mil) habitantes; }\end{array}$ \\
\hline 14.14 & $\begin{array}{l}\text { Estimular a pesquisa científica e de inovação e promover a formação de recursos humanos que } \\
\text { valorize a diversidade regional e a biodiversidade da região amazônica e do cerrado, bem como a } \\
\text { gestão de recursos hídricos no semiárido para mitigação dos efeitos da seca e geração de emprego e } \\
\text { renda na região. }\end{array}$ \\
\hline
\end{tabular}


Fonte: Elaborado pelo autor.

No intuito de demonstrar a evolução da matrícula no ensino superior, por dependência administrativa do DF, para o período de 2009 a 2012, segue a Tabela 13.

Tabela 13 - Evolução da matrícula no Ensino Superior por dependência administrativa - Distrito Federal 2009-2012.

\begin{tabular}{ccccc}
\hline Ano & Total & Federal & Estadual & Privada \\
\hline 2009 & 167.956 & 22.731 & 2.894 & 142.331 \\
2010 & 177.825 & 25.038 & 1.438 & 151.349 \\
2011 & 187.442 & 27.958 & 633 & 158.851 \\
2012 & 191.077 & 28.885 & 1.845 & 160.347 \\
\hline
\end{tabular}

Fonte: MEC/InepData.

Diante dos dados apresentados, pode-se observar aumento no número de matrículas. Tal aumento evidenciou-se a nível Federal e Privado. Na esfera Federal, tal aumento pode estar associado à adoção de políticas de expansão, a exemplo do Programa de Reestruturação e Expansão das Universidades Federais - REUNI que contribuiu para o crescimento das universidades. Para o nível Privado, o crescimento foi substancial, apresentando crescimento de aproximadamente 11,23\% para o período em análise.

Contudo, o quantitativo de concluintes no ensino superior é consideravelmente inferior ao quantitativo de matrículas efetuadas, conforme a Tabela 14, a seguir.

Tabela 14 - Concluintes do Ensino Superior - Distrito Federal - 2009-2012.

\begin{tabular}{llc}
\hline Ano & Ensino Superior \\
\hline 2009 & 24.268 \\
2010 & 29.085 \\
2011 & 31.660 \\
2012 & 31.040 \\
\hline
\end{tabular}

Fonte: MEC/InepData.

Diante dos dados acima, segue Tabela 15 que visa demonstrar a taxa de conclusão existente no Distrito Federal para o ensino superior. 
Tabela 15 - Taxa de conclusão do Ensino Superior - Distrito Federal - 2009-2012.

\begin{tabular}{cccc}
\hline Ano & Matrículas & Conclusões & $\begin{array}{c}\text { Conclusão do Ensino } \\
\text { Superior (\%) }\end{array}$ \\
\hline 2009 & 167.956 & 24.268 & $14,45 \%$ \\
2010 & 177.825 & 29.085 & $16,36 \%$ \\
2011 & 187.442 & 31.660 & $16,89 \%$ \\
2012 & 191.077 & 31.040 & $16,24 \%$ \\
\hline
\end{tabular}

Fonte: Elaborado pelo autor.

Assim, pode-se observar que a taxa média de conclusão do ensino superior gira em torno de $15,98 \%$ restando clara a necessidade de implantação de políticas que incentivem a retenção dos alunos do ensino superior.

\subsection{Vinculação da Educação ao Trabalho}

Em relação à vinculação existente entre Educação e Trabalho, conforme afirma Crespo (2006, p. 29):

[...] graus de educação tem efeitos significativos sobre os rendimentos. Portanto, não apenas cada ano a mais de escolaridade gera um determinado aumento percentual nos rendimentos, como esse ganho pode ser bastante significativo se o ano adicional de educação está associado a um grau completo.

[...] o impacto da educação sobre os rendimentos se torna cada vez mais acentuado à medida que mais anos de escolaridade são acumulados pelo indivíduo. Com isso, a relação entre o logaritmo dos rendimentos e a educação é extremamente convexa no Brasil, ampliando ainda mais o papel dos diferenciais educacionais como determinante da desigualdade de renda.

A partir desta afirmação evidencia-se a relação existente entre educação e renda dos indivíduos, visto que quanto maior o nível de escolaridade, maior tende ser a renda.

Em relação às principais características que afetam o salário dos indivíduos se destacam a escolaridade e a experiência, conforme afirma Moreira (2007, p. 27):

[...] sendo que esta última pode ser desagregada em experiência no emprego atual ou experiência de trabalho (qualquer que seja a atividade desenvolvida), ao passo que a primeira também pode abranger tanto escolaridade como qualquer tipo de treinamento.

Dessa forma, pode-se afirmar que a escolaridade produz impactos positivos, sendo ela tanto no nível de capacitação, quanto no nível de qualificação, visto que o conhecimento por si gera retorno ao indivíduo de acordo com seu nível de instrução. 
Tal afirmativa é corroborada por Silva (2008, p. 110), ao defender que:

[...] o trabalhador com ensino médio tem maiores chances de ser alocados nos diversos setores da economia. No entanto, a renda salarial mais alta está concentrada nos trabalhadores com grau de instrução a partir do superior incompleto. Desta forma, as evidências empíricas demonstradas no modelo de geração de emprego e renda reforçam a tese da teoria do capital humano que considera a educação como investimento que produz retornos mais elevados no futuro. Do mesmo modo, demonstra que maior nível de escolaridade proporciona maiores chances de alocação no mercado de trabalho com acesso aos maiores níveis de salários.

Diante dos trabalhos apresentados, conclui-se que a busca pela educação está diretamente ligada à renda auferida pelo indivíduo, pois quanto maior o nível de instrução deste, maiores serão as chances na obtenção de melhores salários e inserção no mercado de trabalho.

\subsection{Qualificação da mão de obra dos trabalhadores formais no Distrito Federal}

Para identificar o cenário da mão de obra existente no Distrito Federal, segue a Tabela 16 que apresenta o número de estabelecimentos que compõem a economia local, bem como a quantidade de trabalhadores formais.

Tabela 16 - Número de estabelecimentos e quantidade de trabalhadores formais por setor - Distrito Federal 2008 (continua).

\begin{tabular}{|c|c|c|}
\hline Setores & Número de Estabelecimentos & Trabalhadores Formais \\
\hline Agricultura & 630 & 3.248 \\
\hline Pecuária & 601 & 2.817 \\
\hline Extrativa & 35 & 461 \\
\hline Alimentos & 723 & 12.193 \\
\hline Fumageiro & 1 & 66 \\
\hline Têxteis & 34 & 187 \\
\hline Vestuário & 227 & 1.172 \\
\hline Calçados & 18 & 82 \\
\hline Madeira & 46 & 583 \\
\hline Celulose & 19 & 298 \\
\hline Revistas & 467 & 3.948 \\
\hline Petróleo & 4 & 104 \\
\hline Químicos & 52 & 1.280 \\
\hline
\end{tabular}


Tabela 16 - Número de estabelecimentos e quantidade de trabalhadores formais por setor - Distrito Federal 2008 (conclusão).

\begin{tabular}{|c|c|c|}
\hline Setores & Número de Estabelecimentos & Trabalhadores Formais \\
\hline Borracha & 58 & 634 \\
\hline Cimento & 104 & 1.893 \\
\hline Aço & 26 & 306 \\
\hline Metal & 258 & 1.794 \\
\hline Eletrodomésticos & 75 & 621 \\
\hline Informática & 5 & 86 \\
\hline Máquinas & 24 & 461 \\
\hline Eletrônicos & 5 & 227 \\
\hline Instrumento hospitalar & 61 & 482 \\
\hline Veículos & 26 & 160 \\
\hline Equipamento de Transporte & 11 & 126 \\
\hline Indústria Diversa & 259 & 2.788 \\
\hline SIUP & 58 & 7.546 \\
\hline Construção & 2.450 & 47.105 \\
\hline Comércio & 21.185 & 144.232 \\
\hline Transportes & 1.801 & 38.839 \\
\hline Informação & 244 & 10.048 \\
\hline Financeiro & 941 & 35.732 \\
\hline Imobiliário & 1.386 & 21.981 \\
\hline Alojamento & 3.914 & 36.666 \\
\hline Serviços às Empresas & 3.924 & 110.240 \\
\hline Educação e Saúde mercantis & 4.818 & 57.816 \\
\hline Outros Serviços & 7.055 & 50.927 \\
\hline APU & 226 & 403.934 \\
\hline Total & 51.771 & 1.001 .083 \\
\hline
\end{tabular}

Fonte: Adaptado da RAIS.

Assim, observa-se que alguns setores possuem pouca representatividade na economia do DF, para estes casos uma variação na demanda final poderá enviesar o resultado a ser analisado ao longo deste estudo pois estes setores respondem com crescimentos elevados, justamente pelo pequeno porte, enquanto setores com maior representatividade não alcançam avanços em igual proporção, devido ao tamanho do setor na economia. 
Assim, houve a necessidade de agregação de alguns setores, resultando em 32 setores econômicos. Desse modo o setor fumageiro foi agregado ao setor alimentos, os setores têxteis e calçados foram agregados ao setor vestuário, o setor petróleo ao setor químico e o setor equipamento de transporte ao setor veículos, resultando na Tabela 17 que segue.

Tabela 17 - Número de estabelecimentos, após agregação, e quantidade de trabalhadores formais por setor Distrito Federal - 2008 (continua).

\begin{tabular}{|c|c|c|}
\hline Setores & Número de Estabelecimentos & Trabalhadores Formais \\
\hline Agricultura & 630 & 3.248 \\
\hline Pecuária & 601 & 2.817 \\
\hline Extrativa & 35 & 461 \\
\hline Alimentos & 724 & 12.259 \\
\hline Vestuário & 279 & 1.441 \\
\hline Madeira & 46 & 583 \\
\hline Celulose & 19 & 298 \\
\hline Revistas & 467 & 3.948 \\
\hline Químicos & 56 & 1.384 \\
\hline Borracha & 58 & 634 \\
\hline Cimento & 104 & 1.893 \\
\hline Aço & 26 & 306 \\
\hline Metal & 258 & 1.794 \\
\hline Eletrodomésticos & 75 & 621 \\
\hline Informática & 5 & 86 \\
\hline Máquinas & 24 & 461 \\
\hline Eletrônicos & 5 & 227 \\
\hline Instrumento hospitalar & 61 & 482 \\
\hline Veículos & 37 & 286 \\
\hline Indústria Diversa & 259 & 2.788 \\
\hline SIUP & 58 & 7.546 \\
\hline Construção & 2.450 & 47.105 \\
\hline Comércio & 21.185 & 144.232 \\
\hline Transportes & 1.801 & 38.839 \\
\hline Informação & 244 & 10.048 \\
\hline Financeiro & 941 & 35.732 \\
\hline Imobiliário & 1.386 & 21.981 \\
\hline Alojamento & 3.914 & 36.666 \\
\hline
\end{tabular}


Tabela 17 - Número de estabelecimentos, após agregação, e quantidade de trabalhadores formais por setor Distrito Federal - 2008 (conclusão).

\begin{tabular}{lcc}
\hline \multicolumn{1}{c}{ Setores } & Número de Estabelecimentos & Trabalhadores Formais \\
\hline Serviços às Empresas & 3.924 & 110.240 \\
Educação e Saúde mercantis & 4.809 & 57.816 \\
Outros Serviços & 7.055 & 50.927 \\
APU & 235 & 403.934 \\
Total & 51.771 & 1.001 .083 \\
\hline
\end{tabular}

Fonte: Adaptado da RAIS.

Diante dos dados apresentados na Tabela 17, tem-se que, em 2008, a economia do DF contava com 51.771 (cinquenta e um mil, setecentos e setenta e um) estabelecimento formalmente ativos empregando 1.001 .083 (um milhão, um mil e oitenta e três) de empregados formais.

Os setores com menos estabelecimentos na economia são informática, eletrônicos e celulose, enquanto que os que apresentam maior representatividade são os setores educação e saúde mercantis, outros serviços e comércio, este último apresentando 21.185 estabelecimentos na economia.

Apesar do setor APU não se destacar em relação a quantidade de estabelecimentos, este setor é o que mais emprega trabalhadores formais (403.934), alcançando cerca de 40,35\% do total de trabalhadores da região.

Cabe citar que diante de uma variação na demanda final de uma economia, setores com baixa produção tendem demandar um maior número de mão de obra, pois para que suas produções alcancem o aumento de demanda, no curto prazo, serão necessários um maior número de trabalhadores.

\subsection{Financiamento da Educação}

Em relação ao financiamento da Educação, Davies (2012, p. 40) afirma que “o financiamento da educação estatal numa perspectiva democrática não deveria depender da riqueza da região, estado ou município onde o indivíduo reside, mas sim dos recursos totais do país."

Contudo, atualmente, o financiamento educacional é determinado pela Constituição Federal de 1988. Adicionalmente a estes recursos vinculados, o Governo possui discricionariedade para aumentar o nível de gasto com Educação, observando os limites da 
Lei de Responsabilidade Fiscal - LRF. Cabe destacar que esse financiamento sofreu variações nos últimos anos.

A vinculação de investimento voltado para a área da Educação surgiu pela primeira vez na Constituição de 1934, que obrigava a União e os Municípios a utilizarem $10 \%$ da receita arrecadada com impostos na educação, na ocasião, aos Estados e ao Distrito Federal ficou estabelecido o percentual de $20 \%$.

Logo em seguida, no governo de Getúlio Vargas, na Constituição do "Estado Novo" essa vinculação foi suprimida voltando a aparecer na Constituição de 1946, nos mesmos percentuais anteriormente determinados na Constituição de 1934, com alteração no percentual dos Municípios que passou a ser de $20 \%$.

Nova alteração só ocorreu em 1961, com a Lei de Diretrizes e Bases da Educação Nacional que aumentou o percentual da União, passando para 12\%. Contudo, a Constituição de 1967, influenciada pelo período da ditadura suprimiu, novamente, esta obrigatoriedade.

Em 1969, a Emenda Constitucional n ${ }^{\circ}$ 1, retornou a vinculação de $20 \%$ para que os Municípios apliquem a receita tributária arrecadada no ensino primário. Para as demais esferas não houve vinculação mínima, o que prejudicou o investimento nesta área até o ano de 1983, com a Emenda Constitucional n ${ }^{\circ} 24$, que estabeleceu percentual mínimo de $13 \%$ para a União e $25 \%$ para as demais esferas de governo.

A atual Constituição Federal de 1988 manteve os percentuais, com exceção da União que aumentou para 18\% seu percentual mínimo. Posteriormente, as Constituições Estaduais de 1989 e as Leis Orgânicas dos Municípios de 1990, ou mantiveram ou ampliaram estes percentuais.

Durante os anos 90, muitos percentuais foram reduzidos para $25 \%$ conforme Constituições Estaduais e Leis Orgânicas. Cabe destacar que, em alguns casos, esta redução de percentual foi concedida mediante liminar judicial movida por governantes.

Cabe citar o governador do Rio de Janeiro, que em 1993 ganhou liminar judicial desobrigando-o de aplicar 35\% dos recursos estabelecidos pela Constituição Estadual na educação. No mesmo Estado, em 1999 o então Prefeito também conseguiu liminar o desobrigando a aplicar o percentual mínimo estipulado à educação, conforme determinação da Lei Orgânica do referido Estado.

Após a descrição do cenário evolutivo da educação na economia brasileira, observa-se que em períodos considerados democráticos foi dada prioridade aos gastos na área da educação. Contudo, em períodos de autoritarismo houveram retrocessos que representaram prejuízos significativos para a evolução da educação no cenário econômico brasileiro. 
Em contraponto a esta afirmação, nos anos 90, governantes denominados "democráticos" conseguiram meios de se desobrigarem a cumprir o percentual mínimo estabelecido por normativo legal de seu respectivo ente federativo, ou até mesmo reduzi-los ao percentual mínimo de $25 \%$ estabelecido pela Constitucional Federal.

Dessa forma, apesar de estarmos em período de democracia, a Educação continua em momento de fragilidade, visto que suas garantias de fortalecimento dependem do comprometimento dos atuais governantes.

\subsection{Abordagem da Educação na perspectiva da Economia}

A Educação, analisada pelo enfoque econômico, é considerada um investimento. Assim, políticas públicas buscam fomentar a Educação de modo a resultar em crescimento econômico para o país. Nesse sentido, conforme Schultz (1969, p. 79):

Embora a educação seja, em certa medida, uma atividade de consumo que oferece satisfações às pessoas no momento em que obtêm um tipo de educação, é predominantemente uma atividade de investimento realizado para o fim de aquisição de capacitações que oferece satisfações futuras ou que incrementa rendimentos futuros da pessoa como agente produtivo.

Ainda nesta linha de raciocínio, Frigotto (1984, p. 27) reforça que:

[...] o progresso técnico não só gera novos empregos, mas exige uma qualificação cada vez mais apurada. [...] a aquisição de capital humano, via escolarização e acesso aos graus mais elevados de ensino, se constitui em garantia de ascensão a um trabalho qualificado e, consequentemente, a níveis de renda cada vez mais elevados.

Contudo, existem estudiosos de outras áreas do conhecimento que estudam a Educação por outra perspectiva, sendo imprescindível que haja uma troca de conhecimento entre estes pesquisadores, com fins de obter avanços para a Educação do país, com maior celeridade. Corroborando esta linha de raciocínio, Pires (2005, p. 30) afirma:

Há, claramente, necessidade de se estabelecer um diálogo dos economistas com os pesquisadores não-economistas do campo da educação para que a economia possa também vir a contribuir mais consistentemente para o avanço dos fundamentos teóricos da política educacional. Esse diálogo não se tornará possível sem que haja algum tipo de defesa da validade do instrumental teórico e analítico da ciência econômica para a explicação do fenômeno educacional, mesmo admitindo-se suas limitações e vieses, coisas que, aliás, estão presentes também no interior de todas as ciências sociais e não apenas na economia. 
Definir o papel da Educação não é tarefa fácil, pois o processo educativo sofre constantes mudanças principalmente diante da tecnologia e constituição de novas instituições de ensino.

Os governos, por sua vez, incentivam a educação formal para que a sociedade alcance o bem-estar social, visto que a educação contribui para a ascensão social. Segundo Frieman (1962, p. 84):

Uma sociedade democrática e estável é impossível sem um grau mínimo de alfabetização e conhecimento por parte da maioria dos cidadãos e sem a ampla aceitação de algum conjunto de valores. Em consequência, o ganho com a educação de uma criança não é desfrutado apenas pela criança ou por seus pais mas também pelos outros membros da sociedade.

Assim, considerando as externalidades positivas que a educação propõe para a sociedade, visto que o resultado proveniente da educação vai além do internalizado pelo indivíduo, o Estado possui o compromisso de intervir e ofertar o ensino, por se tratar de um bem meritório, ou semipúblico, pois suas características impedem que este bem seja ofertado no mercado, mesmo em condições de perfeita concorrência.

\footnotetext{
Nos anos recentes, a teoria econômica tornou mais explícito o seu reconhecimento da educação como ingrediente indispensável ao crescimento econômico. A teoria do capital humano, desenvolvida ao longo dos anos 1960, a partir dos trabalhos pioneiro de Theodore W. Schultz (Prêmio Nobel de Economia em 1978) e Gary Becker, identifica os investimentos em educação como fator que explica o crescimento econômico que não pode ser atribuído às variáveis econômicas tradicionais, como o investimento em capital fixo. (PIRES, 2005, p. 44)
}

A política educacional define-se pelo conjunto de diretrizes e ações do ente estatal, com fins de proporcionar a educação formal, ofertada por instituições reconhecidas pela sociedade e que fornecem certificação, mediante a conclusão de um processo educativo. A política educacional em muito se assemelha à gestão educacional, posto que esta busca meios de materializar as diretrizes estabelecidas pela política educacional.

Nos países capitalistas, a política educacional é uma política pública, social e econômica. Política pública por ser instrumentalizada mediante ações governamentais, de modo a adotar medidas que a sociedade não teria condições de operacionalizar, havendo a necessidade de intervenção estatal. Política social, pois pretende atingir diversas classes sociais, melhorando o bem-estar e as condições de vida da sociedade, a partir da oferta do ensino. E política econômica por incentivar o ensino na busca de aumento na produtividade e na renda dos indivíduos aquecendo a economia do país. 


\title{
3 METODOLOGIA DE PESQUISA
}

\subsection{Matrizes de relações intersetoriais}

Esta seção abordará uma síntese da teoria de insumo-produto. Ressalta-se que um dos objetivo desta dissertação é avaliar impactos diretos e indiretos em relação a geração de empregos e salários, por grau de instrução, a partir de mudanças decorrentes do aumento da demanda final $(Y)$. Uma das aplicações do modelo de Leontief é a averiguação dos impactos diretos e indiretos sobre dada economia, diante da variação de sua demanda final. Para Leontief (1987, p. 860):

\begin{abstract}
A análise de Insumo-Produto é uma extensão prática da teoria clássica de interdependência geral que vê a economia total de uma região, país, ou mesmo do mundo todo, como um sistema simples, e parte para descrever e para interpretar a sua operação em termos de relações estruturais básicas observáveis.
\end{abstract}

Nesse diapasão, Guilhoto (2011, p. 11) afirma que:

\begin{abstract}
As relações fundamentais de insumo-produto mostram que as vendas dos setores podem ser utilizadas dentro do processo produtivo pelos diversos setores compradores da economia ou podem ser consumidas pelos diversos componentes da demanda final (família, governo, investimento, exportação). Por outro lado, para se produzir são necessários insumos, impostos são pagos, importam-se produtos e gerase valor adicionado (pagamento de salários, remuneração do capital, e da terra agrícola), além, é claro, de se gerar emprego.
\end{abstract}

A matriz insumo-produto MIP, utilizada neste trabalho, foi elaborada pelos pesquisadores Joaquim José Martins Guilhoto e Milene Takasago, construída para economia do Distrito Federal, para o ano de 2008. Com o objetivo de viabilizar a presente análise considerando os graus de instrução por setor produtivo, desagregou-se o número de pessoas ocupadas setorialmente por dez níveis de escolaridade.

Inspirado no trabalho de Silva (2008), que estudou a análise dos impactos da economia na geração de emprego e renda na economia baiana, no ano de 2005, a partir da matriz insumo-produto para esta região, este trabalho pretende realizar estudo similar em relação à geração de emprego e renda na economia do Distrito Federal.

Segundo Leontief, a economia poderia ser representada por um sistema integrado de fluxos de insumos e produtos entre seus setores (ARAUJO, 1998). Esse modelo analisa as relações produtivas existentes na economia de uma região, com diversas atividades interligadas. 
Ou seja, uma atividade dentro da economia, contribui na geração de emprego e renda, impactando na economia de sua própria atividade, bem como nas demais. Sendo assim, a atividade de agricultura, por exemplo, gera impactos financeiros, tanto na agricultura, quanto na pecuária e nas demais atividades, em proporções distintas.

\subsection{Dados utilizados na construção da MIP DF - 2008}

O Instituto Brasileiro de Geografia e Estatística - IBGE apresenta a Tabela de Recursos, que demonstra a produção, e a Tabela de Usos, que demonstra os usos de insumos.

Conforme Grijó (2006) o Sistema de Contas Nacionais, desde a revisão de 1968 do manual da ONU, já contemplava as tabelas de recursos e usos dos bens e serviços, substância básica para a construção da Matriz de Insumo-Produto. Essas tabelas se fundamentam na própria natureza estatística dos dados, ao passo que a Matriz de Insumo-Produto se constrói sobre modificações feitas a partir delas e da assunção de certos supostos analíticos.

As Tabelas de Recursos e Usos - TRU evidenciam as condições da oferta e da demanda, buscando representar o equilíbrio de cada produto, de modo a demonstrar o equilíbrio geral da economia.

Os setores econômicos das TRU acompanham a Classificação Nacional de Atividades - CNAE, do IBGE. Na construção da MIP DF considerou-se incialmente os setores descritos no Quadro 9, a seguir. 
Quadro 9 - Setores das tabelas de recursos e usos.

\begin{tabular}{|c|c|c|c|}
\hline Código & Setor & Código & Setor \\
\hline 0101 & $\begin{array}{l}\text { Agricultura, silvicultura, exploração } \\
\text { florestal }\end{array}$ & 0324 & $\begin{array}{l}\text { Máquinas e equipamentos, inclusive } \\
\text { manutenção e reparos }\end{array}$ \\
\hline 0102 & Pecuária e pesca & 0325 & Eletrodomésticos \\
\hline 0201 & Petróleo e gás natural & 0326 & $\begin{array}{l}\text { Máquinas para escritório e equipamentos de } \\
\text { informática }\end{array}$ \\
\hline 0202 & Minério de ferro & 0327 & Máquinas, aparelhos e materiais elétricos \\
\hline 0203 & Outros da indústria extrativa & 0328 & $\begin{array}{l}\text { Material eletrônico e equipamentos de } \\
\text { comunicações }\end{array}$ \\
\hline 0301 & Alimentos e Bebidas & 0329 & $\begin{array}{l}\text { Aparelhos/instrumentos médico-hospitalar, } \\
\text { medida e óptico }\end{array}$ \\
\hline 0302 & Produtos do fumo & 0330 & Automóveis, camionetas e utilitários \\
\hline 0303 & Têxteis & 0331 & Caminhões e ônibus \\
\hline 0304 & Artigos do vestuário e acessórios & 0332 & Peças e acessórios para veículos automotores \\
\hline 0305 & Artefatos de couro e calçados & 0333 & Outros equipamentos de transporte \\
\hline 0306 & Produtos de madeira - exclusive móveis & 0334 & Móveis e produtos das indústrias diversas \\
\hline 0307 & Celulose e produtos de papel & 0401 & $\begin{array}{l}\text { Eletricidade e gás, agua, esgoto e limpeza } \\
\text { urbana }\end{array}$ \\
\hline 0308 & Jornais, revistas, discos & 0501 & Construção Civil \\
\hline 0309 & Refino de petróleo e coque & 0601 & Comércio \\
\hline 0310 & Álcool & 0701 & Transporte, armazenagem e correio \\
\hline 0311 & Produtos químicos & 0801 & Serviços de informação \\
\hline 0312 & Fabricação de resina e elastômeros & 0901 & Intermediação financeira e seguros \\
\hline 0313 & Produtos farmacêuticos & 1001 & Serviços imobiliários e aluguel \\
\hline 0314 & Defensivos agrícolas & 1101 & Serviços de manutenção e reparação \\
\hline 0315 & Perfumaria, higiene e limpeza & 1102 & Serviços de alojamento e alimentação \\
\hline 0316 & Tintas, vernizes, esmaltes e lacas & 1103 & Serviços prestados às empresas \\
\hline 0317 & Produtos e preparados químicos diversos & 1104 & Educação Mercantil \\
\hline 0318 & Artigos de borracha e plástico & 1105 & Saúde Mercantil \\
\hline 0319 & Cimento & 1106 & Outros serviços \\
\hline 0320 & Outros produtos de minerais não-metálicos & 1201 & Educação Pública \\
\hline 0321 & Fabricação de aço e derivados & 1202 & Saúde Pública \\
\hline 0322 & Metalurgia de metais não-ferrosos & 1203 & Administração pública e seguridade social. \\
\hline 0323 & $\begin{array}{l}\text { Produtos de metal - exclusive máquinas e } \\
\text { equipamentos }\end{array}$ & & \\
\hline
\end{tabular}

Fonte: Elaborado pelo autor. 
As TRU são apresentadas em nível nacional, para obter a MIP DF considerou-se inicialmente os dados das Contas Regionais as quais demonstram o valor bruto da produção VBP, o consumo intermediário - CI e o valor adicionado - VA, para os setores descritos no Quadro 10, a seguir. Estes valores são utilizados como uma forma de calcular os equilíbrios após os ajustes em cada setor.

Quadro 10 - Setores das contas regionais.

\begin{tabular}{|c|c|}
\hline Ordem & Setores \\
\hline 1 & Agricultura, silvicultura, exploração florestal \\
\hline 2 & Pecuária e pesca \\
\hline 3 & Indústria extrativa mineral \\
\hline 4 & Indústria de transformação \\
\hline 5 & Construção Civil \\
\hline 6 & $\begin{array}{l}\text { Produção e distribuição de eletricidade e gás, água, esgoto e limpeza } \\
\text { urbana }\end{array}$ \\
\hline 7 & Comércio e serviços de manutenção e reparação \\
\hline 8 & Serviços de alojamento e alimentação \\
\hline 9 & Transportes, armazenagem e correio \\
\hline 10 & Serviços de informação \\
\hline 11 & Intermediação financeira, seguros e previdência complementar \\
\hline 12 & Serviços prestados às famílias e associativos \\
\hline 13 & Serviços prestados às empresas \\
\hline 14 & Atividades imobiliárias e aluguel \\
\hline 15 & Administração, saúde e educação públicas \\
\hline 16 & Saúde e educação mercantis \\
\hline 17 & Serviços domésticos \\
\hline
\end{tabular}

Fonte: IBGE apud Silva (2008, p. 46).

Considerando as diferentes classificações apresentadas pelas TRU e pelas Contas Regionais, Silva (2008) apresentou tabela de agregação e desagregação, com fins de obter 37 37 setores para a economia baiana, conforme detalhado no Quadro A1, apêndice deste trabalho, apresentando a correspondência entre os setores decorrentes da agregação e os novos setores renomeados. Este trabalho se baseou nesta agregação e desagregação, de modo a replicar a metodologia utilizada com fins de viabilizar comparações econômicas, entre o Estado da Bahia e o Distrito Federal, em algumas análises. Cabe destacar que, para a economia do Distrito Federal, houve a necessidade de agregação de alguns setores, resultando 
em 32 setores econômicos. Desse modo o setor fumageiro foi agregado ao setor alimentos, os setores têxteis e calçados foram agregados ao setor vestuário, o setor petróleo ao setor químico e o setor equipamento de transporte ao setor veículos, tendo em vista a ausência destes na economia do DF, resultado no Quadro 11, a seguir.

Quadro 11 - Setores da Economia do Distrito Federal.

\begin{tabular}{|c|l|c|l|c|l|}
\hline Ordem & \multicolumn{1}{|c|}{ Setores } & Ordem & \multicolumn{1}{|c|}{ Setores } & Ordem & \multicolumn{2}{|c|}{ Setores } \\
\hline 1 & Agricultura & 12 & Aço & 23 & Comércio \\
\hline 2 & Pecuária & 13 & Metal & 24 & Transportes \\
\hline 3 & Extrativa & 14 & Eletrodomésticos & 25 & Informação \\
\hline 4 & Alimentos & 15 & Informática & 26 & Financeiro \\
\hline 5 & Vestuário & 16 & Máquinas & 27 & Imobiliário \\
\hline 6 & Madeira & 17 & Eletrônicos & 28 & Alojamento \\
\hline 7 & Celulose & 18 & Instrumento hospitalar & 29 & Serviços às Empresas \\
\hline 8 & Revistas & 19 & Veículos & 30 & Educação e Saúde mercantis \\
\hline 9 & Químicos & 20 & Indústria Diversa & 31 & Outros serviços \\
\hline 10 & Borracha & 21 & SIUP & 32 & APU \\
\hline 11 & Cimento & 22 & Construção Civil & & \\
\hline
\end{tabular}

Fonte: IBGE apud Silva (2008, p. 47).

\subsection{Metodologia básica de insumo-produto}

Segundo Miller e Blair (1985, apud ANEFALOS, 2004, p. 34), os $n$ setores da economia possuem relações fundamentais com a teoria de insumo-produto, o que pode ser demonstrado a partir da equação (1) a seguir:

$$
\sum_{\mathrm{j}=1}^{n} z_{i j}+C_{i}+G_{i}+I_{i}+E_{i}=X_{i}
$$

Onde:

- $\quad \mathrm{z}_{\mathrm{ij}}$ é a produção do setor $i$ utilizada como insumo intermediário pelo setor $j$;

- $\quad C_{\mathrm{i}}$ é a produção do setor $i$ comprada pelas famílias;

- $G_{\mathrm{i}}$ é a produção do setor $i$ comprada pelo governo;

- $\quad I_{\mathrm{i}}$ é a produção do setor $i$ destinada ao investimento; 
- $E_{\mathrm{i}}$ é a produção do setor $i$ destinada à exportação;

- $X_{\mathrm{i}}$ é a produção doméstica total do setor $i$ (demanda final e insumos intermediários); $\mathrm{e}$

- $C_{i}+G_{i}+I_{i}$ é a demanda final doméstica;

A demanda final da produção do setor $i$ é alcançada quando da soma de todas as produções do setor $i$, compradas pelas famílias, pelo governo, investimento e exportação, conforme expresso pela equação 2 :

$Y_{i}=C_{i}+G_{i}+I_{i}+E_{i}$

Segundo Silva (2008) a teoria insumo-produto possui como principais pressupostos:

- Equilíbrio geral na economia, a determinado nível de preços;

- Ausência de ilusão monetária, por parte dos agentes econômicos;

- Preços constantes;

- Retornos constantes a escala.

Sendo que os retornos constantes a escala significam que:

- As funções de produção são lineares e homogêneas; e

- O conjunto de coeficientes técnicos são diretos $a_{\mathrm{ij}}\left(a_{\mathrm{ij}}=z_{\mathrm{ij}} / X_{\mathrm{j}}\right)$ é fixo e resulta na matriz A (de dimensão $n \times n$ ). Onde $a_{\mathrm{ij}}$ representa a quantidade de insumo do setor $i$ que é necessária para a produção de uma unidade de produto total do setor $j$, e $X_{\mathrm{j}}$ representa a produção total do setor $j$.

Os elementos da representação da matriz inversa de Leontief representam a proporção dos insumos por unidade do produto final fixa, demonstrada na equação (3), a seguir, sendo $X$ e $Y$ vetores coluna de ordem $(n x l)$ :

$A X+Y=X$ 
Ao considerar mudanças na demanda final, determinada de forma exógena, pode-se demonstrar a produção total final para atendimento da demanda estabelecida, da forma que segue na equação (4). Sendo o termo $(I-A)^{-1}$ a matriz de coeficientes técnicos de insumos diretos e indiretos, também denominada de matriz inversa de Leontief.

$$
X=(I-A)^{-1} Y
$$

O modelo insumo-produto é um instrumental amplamente utilizado, podendo ser efetuado diante de 04 (quatro) enfoques, quais sejam: setor $\mathrm{x}$ setor; setor $\mathrm{x}$ produto; produto $\mathrm{x}$ setor; e produto x produto. Destes, o mais utilizado é o setor $\mathrm{x}$ setor, pois este defende a abordagem da tecnologia baseada na indústria, que adota a hipótese da existência de participação constante de cada setor no mercado, viabilizando analisar a interação entre os setores de determinada economia, visto que uma variação na demanda final implicará em impactos nos setores da economia, de forma proporcional. 


\section{ANÁLISE DE DADOS: MULTIPLICADORES DE EMPREGO E RENDA SALARIAL}

A mensuração das potencialidades da educação sobre a economia do Distrito Federal foi realizada utilizando o modelo de insumo-produto. Os dados analisados demonstram a influência do grau de instrução sobre o emprego e a renda dos trabalhadores do DF, por atividade econômica.

Os dados necessários para a desagregação do número de pessoas ocupadas e da renda salarial, por setor foram extraídos da Relação Anual de Informações Sociais - RAIS. Assim, considerando que a matriz insumo-produto foi elaborada utilizando o ano de 2008 como referência, os dados da RAIS foram extraídos do mesmo período, viabilizando o cálculo dos multiplicadores de emprego e renda salarial.

No que tange ao grau de instrução em análise, os dados foram coletados da forma que segue:

- $\mathrm{G}(0)$ - analfabeto;

- $\mathrm{G}(1)$ - até o $5^{\circ}$ ano incompleto do ensino fundamental;

- $\mathrm{G}(2)-5^{\circ}$ ano completo do ensino fundamental;

- $\mathrm{G}(3)$ - do $6^{\circ}$ ao $9^{\circ}$ ano incompleto do ensino fundamental;

- $\mathrm{G}(4)$ - ensino fundamental completo;

- $\mathrm{G}(5)$ - ensino médio incompleto;

- $\mathrm{G}(6)$ - ensino médio completo;

- $\mathrm{G}(7)$ - educação superior incompleta;

- $\mathrm{G}(8)$ - educação superior completa;

- $\mathrm{G}(9)$ - mestrado; e

- $\mathrm{G}(10)$ - doutorado.

Quanto às quantidades de empregos e salários formais, a RAIS demonstra os vínculos dos trabalhadores contratados pelo regime da Consolidação das Leis do Trabalho - CLT e entidades governamentais.

Ao longo da análise do modelo insumo-produto será possível avaliar impactos diretos e indiretos em relação a geração de empregos e salários, por grau de instrução, a partir de mudanças decorrentes do aumento da demanda final $(Y)$. 
O modelo básico de Leontief, é uma metodologia que possibilita a mensuração dos impactos ocorridos diante de mudanças na demanda final $(Y)$, demonstrado a partir da seguinte expressão:

$X=[I-A]^{-1} Y$

Conforme Guilhoto (2011, p. 37), a partir deste modelo:

[...] pode-se mensurar o impacto que as mudanças ocorridas na demanda final $(Y)$, ou em cada um de seus componentes (consumo das famílias, gastos do governo, investimentos e exportações), teriam sobre a produção total, emprego, importações, impostos, salários, valor adicionado, entre outros.

Tal análise de impacto calcula-se da forma a seguir:

$$
\begin{aligned}
& \Delta X=(I-A)^{-1} \Delta Y \\
& \Delta V=\hat{v} \Delta X
\end{aligned}
$$

Dada a equação acima, tem-se que $\Delta X$ e $\Delta Y$ são vetores $(n x l)$ que demonstram o volume da produção, representado por $\Delta X$, e a estratégia setorial, por meio de $\Delta Y$. Por conseguinte, $\Delta V$ é um vetor $(n x l)$ que apresenta o impacto as variáveis, quais sejam: emprego, importações, impostos, salários, valor adicionado, dentre outros. Neste estudo serão abordadas as variáveis de emprego e salários.

O elemento $\hat{v}$ representa uma matriz diagonal (nxn) que apresenta os coeficientes de determinadas variáveis, quais sejam: emprego, importações, impostos, salários, valor adicionado, dentre outros, que resultam, para cada setor em análise, da razão entre o valor utilizado destas variáveis na produção total e a produção total do setor correspondente, representando pela expressão (8), a seguir:

$$
v_{i}=\frac{V_{i}}{X_{i}}
$$

Para o cálculo dos multiplicadores de emprego deve-se estimar os coeficientes de mão de obra por unidade de produção, em relação a cada setor econômico em análise e multiplicar o vetor formado pelos coeficientes encontrados pela matriz inversa de Leontief, expressão (4) 
demonstrada neste trabalho. O resultado será os indicadores diretos e indiretos, por setor econômico, por unidade de demanda final.

De modo similar, o multiplicador de renda salarial decorrente de variação na demanda final a partir da determinação de coeficientes de salários, informa a participação do salário $i$ na produção de $j$.

Conforme Chahad et al. (2003) a especificação da qualificação do emprego, por nível de instrução é obtida a partir da determinação dos coeficientes de emprego, por grau de instrução. Desse modo, determina-se os vetores de coeficientes de emprego, por grau de instrução para cada setor econômico. Para cada qualificação q, cada elemento de um vetor poderá ser representado pela expressão (9), a seguir:

$e_{i q}=\frac{E_{i q}}{V B P_{i q}}$

Tem-se $e_{i q}$ como a razão entre a quantidade de empregados $\mathrm{E}$ e a escolaridade $q=1 \ldots 11$, correspondente aos níveis de ensino $\mathrm{G}(0)$ a $\mathrm{G}(10)$, compreendendo trabalhadores de analfabetos a doutores, do setor $i$ e o valor bruto da produção (VBP) deste setor.

Após tais medidas tem-se a matriz de geração de emprego, por nível de escolaridade. Assim, será possível identificar quais setores da economia local geram empregos e em qual proporção, se comparado com os demais, bem como especificar a geração de emprego por perfil educacional. Esta matriz deriva da matriz inversa de Leontief, onde cada setor da economia é ponderado pelo coeficiente de emprego correspondente ao setor $e_{i q}$, resultando em onze matrizes de impacto de emprego, cada matriz referente a cada nível de instrução em análise, conforme demonstrado na expressão (10):

$$
E(G)_{q}=\hat{e}[I-A]^{-1}
$$

Sendo $\hat{e}$ o vetor diagonalizado gerado a partir do vetor de coeficiente de emprego, por nível de instrução, por atividade econômica. Desse modo, cada matriz $E(G)_{q}$ demonstra a capacidade intersetorial de geração de emprego, para cada qualificação $q$, considerando a variação da demanda final. 
Os multiplicadores de salários, por sua vez, são calculados a partir da determinação dos coeficientes de salários por nível de escolaridade. Os salários médios por nível de instrução e por setor econômico foram utilizados para demonstrar quanto ganha cada trabalhador na economia do DF, dependendo do setor em que se encontra e do grau de instrução que possui. A partir de tais informações, definiu-se os vetores de coeficientes de salário, por nível de ensino para cada atividade econômica, sendo que cada elemento de uma vetor relativo ao salário, por grau de instrução $q$ pode ser demonstrado conforme expressão (11), a seguir:

$s_{i q}=\frac{S^{*}{ }_{i q}}{V B P_{i}}$

Sendo que $S_{i q}^{*}$ representa a média salarial, por grau de ensino $q$ no setor $i$. O vetor $s_{i q}$ resulta da razão entre a média salarial $S_{i q}^{*}$, por nível de instrução $q=1 \ldots 11$, do setor $i$ e o valor bruto da produção (VBP) deste setor.

Semelhante a matriz de emprego, após estes procedimentos obtém-se a matriz de geração de renda salarial, por nível de instrução. Assim, será possível demonstrar em que medida os setores da economia local geram rendas salariais, especificando pelo perfil educacional. Esta matriz deriva da matriz inversa de Leontief, onde cada setor da economia é ponderado pelo coeficiente de salário correspondente ao setor $s_{i q}$, resultando em onze matrizes de impacto de renda salarial, cada matriz referente a cada nível de instrução em análise, conforme demonstrado na expressão (12), a seguir:

$$
S(G)_{q}=\hat{s}[I-A]^{-1}
$$

Sendo $\hat{s}$ o vetor diagonalizado gerado a partir do vetor de coeficiente de salários, por nível de instrução, por atividade econômica. Desse modo, cada matriz $S(G)_{q}$ demonstra a capacidade intersetorial de geração de renda salarial, para cada qualificação $q$, considerando a variação da demanda final. 
As matrizes de multiplicadores de emprego e renda, $E(G)_{q}$ e $S(G)_{q}$, respectivamente, são semelhantes a matriz inversa de Leontief. Para cada setor $i$ da economia, o somatório dos elementos da coluna correspondente $\operatorname{em} E(G)_{q}$ e em $S(G)_{q}$ resulta no multiplicador de emprego e renda, respectivamente, para cada nível de escolaridade $q$ do referido setor $i$.

\subsection{Escolaridade e alocação do emprego nos setores da economia}

As informações apresentadas nesta seção visam proporcionar a análise de impacto da educação sobre a economia do Distrito Federal. Assim, a Tabela 18 apresenta o perfil ocupacional da economia do DF distribuindo a mão de obra nos setores desta economia.

Tabela 18 - Pessoal ocupado por setor por grupo de instrução - Distrito Federal - 2008 (continua).

\begin{tabular}{|c|c|c|c|c|c|c|c|c|c|c|c|c|}
\hline Setores & $\mathbf{G}(\mathbf{0})$ & G(1) & $G(2)$ & G(3) & G(4) & G(5) & $\mathbf{G}(\mathbf{6})$ & $\mathbf{G}(7)$ & $\mathbf{G}(\mathbf{8})$ & $\mathbf{G}(\mathbf{9})$ & $\mathbf{G}(10)$ & Total \\
\hline Agricultura & 85 & 674 & 531 & 630 & 797 & 348 & 823 & 87 & 175 & 8 & 3 & 4.161 \\
\hline Pecuária & 48 & 207 & 284 & 439 & 338 & 130 & 380 & 24 & 54 & 0 & 0 & 1.904 \\
\hline Extrativa & 4 & 13 & 32 & 40 & 89 & 35 & 137 & 19 & 91 & 1 & 0 & 461 \\
\hline Alimentos & 57 & 425 & 355 & 1.251 & 2.458 & 2.022 & 4.974 & 338 & 377 & 2 & 0 & 12.259 \\
\hline Vestuário & 6 & 16 & 28 & 127 & 314 & 201 & 679 & 34 & 35 & 0 & 1 & 1441 \\
\hline Madeira & 6 & 21 & 59 & 95 & 164 & 93 & 127 & 10 & 8 & 0 & 0 & 583 \\
\hline Celulose & 0 & 2 & 8 & 31 & 58 & 45 & 123 & 12 & 19 & 0 & 0 & 298 \\
\hline Revistas & 1 & 39 & 32 & 207 & 476 & 423 & 1.699 & 263 & 808 & 0 & 0 & 3.948 \\
\hline Químicos & 3 & 21 & 16 & 73 & 129 & 79 & 482 & 181 & 392 & 7 & 1 & 1.384 \\
\hline Borracha & 5 & 26 & 45 & 86 & 183 & 60 & 210 & 12 & 7 & 0 & 0 & 634 \\
\hline Cimento & 23 & 87 & 74 & 192 & 329 & 242 & 748 & 66 & 130 & 0 & 2 & 1.893 \\
\hline Aço & 0 & 5 & 7 & 52 & 42 & 39 & 134 & 10 & 17 & 0 & 0 & 306 \\
\hline Metal & 9 & 95 & 52 & 177 & 465 & 282 & 633 & 36 & 45 & 0 & 0 & 1.794 \\
\hline Eletrodomésticos & 0 & 10 & 14 & 47 & 84 & 59 & 313 & 41 & 49 & 0 & 4 & 621 \\
\hline Informática & 0 & 0 & 0 & 4 & 4 & 3 & 39 & 22 & 14 & 0 & 0 & 86 \\
\hline Máquinas & 0 & 5 & 8 & 68 & 83 & 70 & 189 & 21 & 17 & 0 & 0 & 461 \\
\hline Eletrônicos & 0 & 0 & 1 & 3 & 2 & 5 & 185 & 6 & 25 & 0 & 0 & 227 \\
\hline $\begin{array}{l}\text { Instrumento } \\
\text { hospitalar }\end{array}$ & 0 & 4 & 11 & 14 & 43 & 38 & 244 & 29 & 97 & 1 & 1 & 482 \\
\hline Veículos & 3 & 6 & 5 & 9 & 54 & 21 & 78 & 11 & 92 & 7 & 0 & 286 \\
\hline Indústria Diversa & 21 & 681 & 180 & 411 & 455 & 270 & 714 & 26 & 30 & 0 & 0 & 2.788 \\
\hline SIUP & 30 & 711 & 1.183 & 397 & 592 & 244 & 2.119 & 222 & 1.953 & 88 & 7 & 7.546 \\
\hline Construção Civil & 465 & 5.754 & 4.019 & 8.110 & 9.322 & 4.078 & 11.922 & 863 & 2.523 & 23 & 26 & 47.105 \\
\hline Comércio & 233 & 1.349 & 2.166 & 7.470 & 23.198 & 17.718 & 81.424 & 5.363 & 5.260 & 33 & 18 & 144.232 \\
\hline
\end{tabular}


Tabela 18 - Pessoal ocupado por setor por grupo de instrução - Distrito Federal - 2008 (conclusão).

\begin{tabular}{lrrrrrrrrrrrr}
\hline \multicolumn{1}{c}{ Setores } & $\mathbf{G}(\mathbf{0})$ & $\mathbf{G}(\mathbf{1})$ & $\mathbf{G}(\mathbf{2})$ & $\mathbf{G}(\mathbf{3})$ & $\mathbf{G}(\mathbf{4})$ & $\mathbf{G}(\mathbf{5})$ & $\mathbf{G}(\mathbf{6})$ & $\mathbf{G}(\mathbf{7})$ & $\mathbf{G}(\mathbf{8})$ & $\mathbf{G}(\mathbf{9})$ & $\mathbf{G}(\mathbf{1 0})$ & Total \\
\hline Transportes & 97 & 638 & 1.238 & 3.831 & 6.791 & 4.059 & 15.460 & 1.394 & 5.308 & 17 & 6 & 38.839 \\
Informação & 3 & 44 & 94 & 232 & 1.092 & 745 & 8.493 & 3.954 & 9.596 & 131 & 13 & 24.397 \\
Financeiro & 1 & 23 & 22 & 115 & 286 & 287 & 6.767 & 4.982 & 22.802 & 378 & 69 & 35.732 \\
Imobiliário & 57 & 849 & 518 & 1.159 & 1.938 & 858 & 3.279 & 439 & 600 & 12 & 0 & 9.709 \\
Alojamento & 184 & 561 & 956 & 3.346 & 9.145 & 6.366 & 15.060 & 445 & 600 & 2 & 1 & 36.666 \\
Serviços às & & & & & & & & & & & & \\
Empresas & 415 & 2.221 & 4.683 & 9.458 & 21.672 & 9.858 & 43.433 & 7.584 & 9.892 & 580 & 444 & 110.240 \\
Educação e & & & & & & & & & & & & \\
Saúde mercantis & 74 & 484 & 554 & 1.821 & 3.187 & 2.766 & 24.880 & 3.523 & 18.744 & 1.363 & 420 & 57.816 \\
Outros Serviços & 375 & 2.091 & 2.251 & 4.619 & 6.983 & 5.625 & 15.480 & 2.845 & 8.457 & 102 & 22 & 48.850 \\
APU & 27 & 5.581 & 1.445 & 6.751 & 58.050 & 2.827 & 152.981 & 11.601 & 162.026 & 2.348 & 297 & 403.934 \\
Total & 2.232 & 22.643 & 20.871 & 51.265 & 148.823 & 59.896 & 394.209 & 44.463 & 250.243 & 5.103 & 1.335 & 1.001 .083 \\
\hline
\end{tabular}

Onde: Analfabeto - G(0); Até o $5^{\circ}$ ano incompleto do ensino fundamental - $\mathrm{G}(1) ; 5^{\circ}$ ano completo do ensino fundamental - G(2); Do $6^{\circ}$ ao $9^{\circ}$ ano incompleto do ensino fundamental - G(3); Ensino fundamental completo G(4); Ensino médio incompleto - G(5); Ensino médio completo - G(6); Educação superior incompleta - G(7); Educação superior completa - G(8); Mestrado - G(9); Doutorado - G(10).

Fonte: Adaptado da RAIS 2008.

Diante da Tabela acima, observa-se que, em 2008, o Distrito Federal empregava aproximadamente 1 milhão de trabalhadores com empregos formais. Destes, cerca de 400 mil estão alocados no grau de instrução G(6), ou seja, possuem o ensino médio completo. Mesmo comportamento, ocorreu na economia da baiana, conforme demonstrado por Silva (2008), onde a maioria dos trabalhadores se concentraram no grau $\mathrm{G}(6)$.

Os setores da economia que mais empregaram foram: APU (403.934); comércio (144.232); serviços às empresas (110.240); e educação e saúde mercantis (57.816). Tal comportamento da economia também ocorreu em relação à economia baiana, conforme Silva (2008). O setor educação e saúde mercantis possuem representatividade na economia do Distrito Federal e Bahia, fato que reforça os resultados positivos apresentados ao longo deste estudo.

A Tabela 19 demonstra a distribuição percentual de pessoal ocupado, por setor e por grau de instrução. Os dados apresentados evidenciam que o setor APU empregava 40,34\% do total de trabalhadores formalmente registrados na economia do DF; o comércio gerava 14,41\% de empregos formais; o setor de serviços às empresas 11,02\% e Educação e saúde mercantis 5,78\%. Novamente, o comportamento apresentado na economia do DF se assemelhou a economia baiana, onde os setores da economia: APU, comércio, serviços às empresas e educação e saúde mercantis apresentaram percentuais de 32,29\%, 16,89\%, 
$8,661 \%$ e 6,38\%, respectivamente. Ressalta-se os setores comércio e educação e saúde mercantis, maiores setores da economia local.

Tabela 19 - Distribuição percentual de pessoal ocupado por setor por grau de instrução - Distrito Federal - 2008 (continua).

\begin{tabular}{|c|c|c|c|c|c|c|c|c|c|c|c|c|}
\hline Setores & $\mathbf{G}(\mathbf{0})$ & $\mathbf{G}(\mathbf{1})$ & $\mathbf{G}(2)$ & G(3) & G(4) & G(5) & $G(6)$ & $\mathbf{G}(7)$ & $\mathbf{G}(\mathbf{8})$ & $\mathbf{G}(9)$ & G(10) & Total \\
\hline Agricultura & 3,81 & 2,98 & 2,54 & 1,23 & 0,54 & 0,58 & 0,21 & 0,20 & 0,07 & 0,16 & 0,22 & 0,42 \\
\hline Pecuária & 2,15 & 0,91 & 1,36 & 0,86 & 0,23 & 0,22 & 0,10 & 0,05 & 0,02 & 0,00 & 0,00 & 0,19 \\
\hline Extrativa & 0,18 & 0,06 & 0,15 & 0,08 & 0,06 & 0,06 & 0,03 & 0,04 & 0,04 & 0,02 & 0,00 & 0,05 \\
\hline Alimentos & 2,55 & 1,88 & 1,70 & 2,44 & 1,65 & 3,38 & 1,26 & 0,76 & 0,15 & 0,04 & 0,00 & 1,22 \\
\hline Vestuário & 0,27 & 0,07 & 0,13 & 0,25 & 0,21 & 0,34 & 0,17 & 0,08 & 0,01 & 0,00 & 0,07 & 0,14 \\
\hline Madeira & 0,27 & 0,09 & 0,28 & 0,19 & 0,11 & 0,16 & 0,03 & 0,02 & 0,00 & 0,00 & 0,00 & 0,06 \\
\hline Celulose & 0,00 & 0,01 & 0,04 & 0,06 & 0,04 & 0,08 & 0,03 & 0,03 & 0,01 & 0,00 & 0,00 & 0,03 \\
\hline Revistas & 0,04 & 0,17 & 0,15 & 0,40 & 0,32 & 0,71 & 0,43 & 0,59 & 0,32 & 0,00 & 0,00 & 0,39 \\
\hline Químicos & 0,13 & 0,09 & 0,08 & 0,14 & 0,09 & 0,13 & 0,12 & 0,41 & 0,16 & 0,14 & 0,07 & 0,14 \\
\hline Borracha & 0,22 & 0,11 & 0,22 & 0,17 & 0,12 & 0,10 & 0,05 & 0,03 & 0,00 & 0,00 & 0,00 & 0,06 \\
\hline Cimento & 1,03 & 0,38 & 0,35 & 0,37 & 0,22 & 0,40 & 0,19 & 0,15 & 0,05 & 0,00 & 0,15 & 0,19 \\
\hline Aço & 0,00 & 0,02 & 0,03 & 0,10 & 0,03 & 0,07 & 0,03 & 0,02 & 0,01 & 0,00 & 0,00 & 0,03 \\
\hline Metal & 0,40 & 0,42 & 0,25 & 0,35 & 0,31 & 0,47 & 0,16 & 0,08 & 0,02 & 0,00 & 0,00 & 0,18 \\
\hline Eletrodomésticos & 0,00 & 0,04 & 0,07 & 0,09 & 0,06 & 0,10 & 0,08 & 0,09 & 0,02 & 0,00 & 0,30 & 0,06 \\
\hline Informática & 0,00 & 0,00 & 0,00 & 0,01 & 0,00 & 0,01 & 0,01 & 0,05 & 0,01 & 0,00 & 0,00 & 0,01 \\
\hline Máquinas & 0,00 & 0,02 & 0,04 & 0,13 & 0,06 & 0,12 & 0,05 & 0,05 & 0,01 & 0,00 & 0,00 & 0,05 \\
\hline Eletrônicos & 0,00 & 0,00 & 0,00 & 0,01 & 0,00 & 0,01 & 0,05 & 0,01 & 0,01 & 0,00 & 0,00 & 0,02 \\
\hline Instrumento hospitalar & 0,00 & 0,02 & 0,05 & 0,03 & 0,03 & 0,06 & 0,06 & 0,07 & 0,04 & 0,02 & 0,07 & 0,05 \\
\hline Veículos & 0,13 & 0,03 & 0,02 & 0,02 & 0,04 & 0,04 & 0,02 & 0,02 & 0,04 & 0,14 & 0,00 & 0,03 \\
\hline Indústria Diversa & 0,94 & 3,01 & 0,86 & 0,80 & 0,31 & 0,45 & 0,18 & 0,06 & 0,01 & 0,00 & 0,00 & 0,28 \\
\hline SIUP & 1,34 & 3,14 & 5,67 & 0,77 & 0,40 & 0,41 & 0,54 & 0,50 & 0,78 & 1,72 & 0,52 & 0,75 \\
\hline Construção Civil & 20,83 & 25,41 & 19,26 & 15,82 & 6,26 & 6,81 & 3,02 & 1,94 & 1,01 & 0,45 & 1,95 & 4,71 \\
\hline Comércio & 10,44 & 5,96 & 10,38 & 14,57 & 15,59 & 29,58 & 20,66 & 12,06 & 2,10 & 0,65 & 1,35 & 14,41 \\
\hline Transportes & 4,35 & 2,82 & 5,93 & 7,47 & 4,56 & 6,78 & 3,92 & 3,14 & 2,12 & 0,33 & 0,45 & 3,88 \\
\hline Informação & 0,13 & 0,19 & 0,45 & 0,45 & 0,73 & 1,24 & 2,15 & 8,89 & 3,83 & 2,57 & 0,97 & 2,44 \\
\hline Financeiro & 0,04 & 0,10 & 0,11 & 0,22 & 0,19 & 0,48 & 1,72 & 11,20 & 9,11 & 7,41 & 5,17 & 3,57 \\
\hline Imobiliário & 2,55 & 3,75 & 2,48 & 2,26 & 1,30 & 1,43 & 0,83 & 0,99 & 0,24 & 0,24 & 0,00 & 0,97 \\
\hline Alojamento & 8,24 & 2,48 & 4,58 & 6,53 & 6,14 & 10,63 & 3,82 & 1,00 & 0,24 & 0,04 & 0,07 & 3,66 \\
\hline Serviços às Empresas & 18,59 & 9,81 & 22,44 & 18,45 & 14,56 & 16,46 & 11,02 & 17,06 & 3,95 & 11,37 & 33,26 & 11,02 \\
\hline Educação e Saúde mercantis & 3,32 & 2,14 & 2,65 & 3,55 & 2,14 & 4,62 & 6,31 & 7,92 & 7,49 & 26,71 & 31,46 & 5,78 \\
\hline Outros Serviços & 16,80 & 9,23 & 10,79 & 9,01 & 4,69 & 9,39 & 3,93 & 6,40 & 3,38 & 2,00 & 1,65 & 4,88 \\
\hline
\end{tabular}


Tabela 19 - Distribuição percentual de pessoal ocupado por setor por grau de instrução - Distrito Federal - 2008 (conclusão).

\begin{tabular}{|c|c|c|c|c|c|c|c|c|c|c|c|c|}
\hline Setores & $\mathbf{G}(\mathbf{0})$ & $\mathbf{G}(\mathbf{1})$ & $\mathbf{G}(2)$ & G(3) & G(4) & G(5) & $\mathbf{G}(\mathbf{6})$ & $\mathbf{G}(7)$ & $\mathbf{G}(\mathbf{8})$ & $\mathbf{G}(\mathbf{9})$ & $\mathbf{G}(\mathbf{1 0})$ & Total \\
\hline APU & 1,21 & 24,65 & 6,92 & 13,17 & 39,01 & 4,72 & 38,81 & 26,09 & 64,75 & 46,01 & 22,25 & 40,34 \\
\hline Total & 100 & 100 & 100 & 100 & 100 & 100 & 100 & 100 & 100 & 100 & 100 & 100 \\
\hline
\end{tabular}

Onde: Analfabeto - $\mathrm{G}(0)$; Até o $5^{\circ}$ ano incompleto do ensino fundamental - $\mathrm{G}(1)$; $5^{\circ}$ ano completo do ensino fundamental - G(2); Do $6^{\circ}$ ao $9^{\circ}$ ano incompleto do ensino fundamental - G(3); Ensino fundamental completo G(4); Ensino médio incompleto - G(5); Ensino médio completo - G(6); Educação superior incompleta - G(7); Educação superior completa - G(8); Mestrado - G(9); Doutorado - G(10).

Fonte: Adaptado da RAIS 2008.

Ainda em análise a Tabela 19, no que tange a concentração de mão de obra devido ao grau de instrução dos trabalhadores, resta evidenciado que o setor de Construção civil concentra os trabalhadores com grau de instrução $G(0)$ e $G(1)$. Nas faixas $G(2)$ e $G(3)$, a maioria dos indivíduos estão no setor de Serviço às empresas. Para os graus de instrução a partir do G(4), com exceção do G(5) e G(10) os trabalhadores estão concentrados no setor de APU que visivelmente, proporciona quantidade considerável de empregos formais para a economia do DF.

Os trabalhadores pertencentes ao grau de instrução $\mathrm{G}(5)$ concentram-se no setor de comércio, enquanto os $\mathrm{G}(10)$, trabalhadores que possuem doutorado, se dedicam as atividades do setor de serviço às empresas com 33,26\% e ao setor de educação e saúde mercantil, com $31,46 \%$. Tal resultado deve-se ao fato que estes trabalhadores possuem alto capital intelectual, de modo a estarem concentrados em áreas econômicas que exigem conhecimento específico e aprofundado para o desempenho de suas atividades.

Quanto ao setor de educação e saúde mercantis, os trabalhadores estão concentrados nos graus de instrução $\mathrm{G}(9)$ e $\mathrm{G}(10)$, ou seja, possuem mestrado e doutorado.

A Tabela 20 demonstra a distribuição de pessoal ocupado, por grau de instrução, por setor de atividade econômica. Em termos gerais, dos trabalhadores formais da economia do DF 39,38\% possuem o ensino médio completo, o que corresponde ao grau de instrução $G(6)$. Dos 32 setores da economia analisados, 27 possuem a grande parte de seus empregados com o ensino médio completo, destacando-se os setores de eletrônicos, comércio e instrumento hospitalar, com $81,50 \%, 56,45 \%$ e 50,62\%, respectivamente.

O setor eletrônicos apresenta resultados positivos, tendo em vista que, conforme ora demonstrado na Tabela 16, este setor possui baixa representatividade na economia do DF, correspondendo sensivelmente, quando na aplicação de recursos na economia local. Comportamento semelhante ocorre em relação ao setor comércio, contudo, por se tratar de 
setor que possui grande representatividade, o que possibilita crescimentos econômicos diante de variações na demanda final.

Assim como no trabalho de Silva (2008) o setor pecuária apresentou o maior percentual demonstrado para o grau de instrução $G(0)$, reforçando que este setor é o que mais absorve trabalhadores com este perfil. Contudo, neste setor a maioria da força de trabalho, $23,06 \%$, é composta por trabalhadores com grau de instrução G(3).

Tabela 20 - Distribuição percentual de pessoal ocupado por grau de instrução por setor - Distrito Federal - 2008 (continua).

\begin{tabular}{|c|c|c|c|c|c|c|c|c|c|c|c|c|}
\hline Setores & $\mathbf{G}(\mathbf{0})$ & G(1) & G(2) & G(3) & G(4) & G(5) & $G(6)$ & G(7) & $\mathbf{G}(\mathbf{8})$ & G(9) & $\mathbf{G}(10)$ & Total \\
\hline Agricultura & 2,04 & 16,20 & 12,76 & 15,14 & 19,15 & 8,36 & 19,78 & 2,09 & 4,21 & 0,19 & 0,07 & 100 \\
\hline Pecuária & 2,52 & 10,87 & 14,92 & 23,06 & 17,75 & 6,83 & 19,96 & 1,26 & 2,84 & 0,00 & 0,00 & 100 \\
\hline Extrativa & 0,87 & 2,82 & 6,94 & 8,68 & 19,31 & 7,59 & 29,72 & 4,12 & 19,74 & 0,22 & 0,00 & 100 \\
\hline Alimentos & 0,47 & 3,44 & 2,91 & 10,25 & 20,16 & 16,53 & 40,49 & 2,72 & 3,02 & 0,01 & 0,00 & 100 \\
\hline Vestuário & 0,42 & 1,11 & 1,94 & 8,81 & 21,79 & 13,95 & 47,12 & 2,36 & 2,43 & 0,00 & 0,07 & 100 \\
\hline Madeira & 1,03 & 3,60 & 10,12 & 16,30 & 28,13 & 15,95 & 21,78 & 1,72 & 1,37 & 0,00 & 0,00 & 100 \\
\hline Celulose & 0,00 & 0,67 & 2,68 & 10,40 & 19,46 & 15,10 & 41,28 & 4,03 & 6,38 & 0,00 & 0,00 & 100 \\
\hline Revistas & 0,03 & 0,99 & 0,81 & 5,24 & 12,06 & 10,71 & 43,03 & 6,66 & 20,47 & 0,00 & 0,00 & 100 \\
\hline Químicos & 0,22 & 1,52 & 1,15 & 5,27 & 9,32 & 5,71 & 34,83 & 13,08 & 28,32 & 0,50 & 0,07 & 100 \\
\hline Borracha & 0,79 & 4,10 & 7,10 & 13,56 & 28,86 & 9,46 & 33,12 & 1,89 & 1,10 & 0,00 & 0,00 & 100 \\
\hline Cimento & 1,22 & 4,60 & 3,91 & 10,14 & 17,38 & 12,78 & 39,51 & 3,49 & 6,87 & 0,00 & 0,11 & 100 \\
\hline Aço & 0,00 & 1,63 & 2,29 & 16,99 & 13,73 & 12,75 & 43,79 & 3,27 & 5,56 & 0,00 & 0,00 & 100 \\
\hline Metal & 0,50 & 5,30 & 2,90 & 9,87 & 25,92 & 15,72 & 35,28 & 2,01 & 2,51 & 0,00 & 0,00 & 100 \\
\hline Eletrodomésticos & 0,00 & 1,61 & 2,25 & 7,57 & 13,53 & 9,50 & 50,40 & 6,60 & 7,89 & 0,00 & 0,64 & 100 \\
\hline Informática & 0,00 & 0,00 & 0,00 & 4,65 & 4,65 & 3,49 & 45,35 & 25,58 & 16,28 & 0,00 & 0,00 & 100 \\
\hline Máquinas & 0,00 & 1,08 & 1,74 & 14,75 & 18,00 & 15,18 & 41,00 & 4,56 & 3,69 & 0,00 & 0,00 & 100 \\
\hline Eletrônicos & 0,00 & 0,00 & 0,44 & 1,32 & 0,88 & 2,20 & 81,50 & 2,64 & 11,01 & 0,00 & 0,00 & 100 \\
\hline Instrumento hospitalar & 0,00 & 0,83 & 2,28 & 2,90 & 8,92 & 7,88 & 50,62 & 6,02 & 20,12 & 0,21 & 0,21 & 100 \\
\hline Veículos & 1,05 & 2,10 & 1,75 & 3,15 & 18,88 & 7,34 & 27,27 & 3,85 & 32,17 & 2,45 & 0,00 & 100 \\
\hline Indústria Diversa & 0,75 & 24,43 & 6,46 & 14,74 & 16,32 & 9,68 & 25,61 & 0,93 & 1,08 & 0,00 & 0,00 & 100 \\
\hline SIUP & 0,40 & 9,42 & 15,68 & 5,26 & 7,85 & 3,23 & 28,08 & 2,94 & 25,88 & 1,17 & 0,09 & 100 \\
\hline Construção Civil & 0,99 & 12,22 & 8,53 & 17,22 & 19,79 & 8,66 & 25,31 & 1,83 & 5,36 & 0,05 & 0,06 & 100 \\
\hline Comércio & 0,16 & 0,94 & 1,50 & 5,18 & 16,08 & 12,28 & 56,45 & 3,72 & 3,65 & 0,02 & 0,01 & 100 \\
\hline Transportes & 0,25 & 1,64 & 3,19 & 9,86 & 17,49 & 10,45 & 39,81 & 3,59 & 13,67 & 0,04 & 0,02 & 100 \\
\hline Informação & 0,01 & 0,18 & 0,39 & 0,95 & 4,48 & 3,05 & 34,81 & 16,21 & 39,33 & 0,54 & 0,05 & 100 \\
\hline Financeiro & 0,00 & 0,06 & 0,06 & 0,32 & 0,80 & 0,80 & 18,94 & 13,94 & 63,81 & 1,06 & 0,19 & 100 \\
\hline Imobiliário & 0,59 & 8,74 & 5,34 & 11,94 & 19,96 & 8,84 & 33,77 & 4,52 & 6,18 & 0,12 & 0,00 & 100 \\
\hline Alojamento & 0,50 & 1,53 & 2,61 & 9,13 & 24,94 & 17,36 & 41,07 & 1,21 & 1,64 & 0,01 & 0,00 & 100 \\
\hline
\end{tabular}


Tabela 20 - Distribuição percentual de pessoal ocupado por grau de instrução por setor - Distrito Federal - 2008 (conclusão).

\begin{tabular}{lcccccccccccc}
\hline \multicolumn{1}{c}{ Setores } & $\mathbf{G ( 0 )}$ & $\mathbf{G ( 1 )}$ & $\mathbf{G ( 2 )}$ & $\mathbf{G ( 3 )}$ & $\mathbf{G ( 4 )}$ & $\mathbf{G ( 5 )}$ & $\mathbf{G ( 6 )}$ & $\mathbf{G ( 7 )}$ & $\mathbf{G ( 8 )}$ & $\mathbf{G ( 9 )}$ & $\mathbf{G ( 1 0 )}$ & Total \\
\hline Serviços às Empresas & 0,38 & 2,01 & 4,25 & 8,58 & 19,66 & 8,94 & 39,40 & 6,88 & 8,97 & 0,53 & 0,40 & 100 \\
Educação e Saúde mercantis & 0,13 & 0,84 & 0,96 & 3,15 & 5,51 & 4,78 & 43,03 & 6,09 & 32,42 & 2,36 & 0,73 & 100 \\
Outros Serviços & 0,77 & 4,28 & 4,61 & 9,46 & 14,29 & 11,51 & 31,69 & 5,82 & 17,31 & 0,21 & 0,05 & 100 \\
APU & 0,01 & 1,38 & 0,36 & 1,67 & 14,37 & 0,70 & 37,87 & 2,87 & 40,11 & 0,58 & 0,07 & 100 \\
Total & 0,22 & 2,26 & 2,08 & 5,12 & 14,87 & 5,98 & 39,38 & 4,44 & 25,00 & 0,51 & 0,13 & 100 \\
\hline
\end{tabular}

Onde: Analfabeto - G(0); Até o $5^{\circ}$ ano incompleto do ensino fundamental - $\mathrm{G}(1) ; 5^{\circ}$ ano completo do ensino fundamental - G(2); Do $6^{\circ}$ ao $9^{\circ}$ ano incompleto do ensino fundamental - G(3); Ensino fundamental completo G(4); Ensino médio incompleto - G(5); Ensino médio completo - G(6); Educação superior incompleta - G(7); Educação superior completa - G(8); Mestrado - G(9); Doutorado - G(10).

Fonte: Adaptado da RAIS 2008.

Quanto às demais atividades econômicas do DF, cabe citar os setores de veículos, informação, financeiro e APU, com percentuais de 35\%, 39,33\%, 63,81\% e 40,11, respectivamente. Tais setores apresentaram força de trabalho com predominância no grau de instrução $G(8)$, correspondente ao ensino superior completo.

Outro dado que merece destaque é o percentual de trabalhadores com graus de instrução $G(9)$ e $G(10)$, representando apenas $0,51 \%$ e $0,13 \%$, respectivamente, de toda a força de trabalho formal.

Quanto ao setor educação e saúde mercantis, os graus de instrução G(9) e $G(10)$, apresentaram os percentuais $2,36 \%$ e $0,73 \%$, respectivamente. Tais percentuais estão abaixo do esperado, contudo, o resultado pode decorrer do fato de que este setor possui trabalhadores com diversos perfis, sendo sua maioria pertencente aos graus de instrução G(6), com 43,03\% e G(8) com 32,42\%. Assim, observa-se que a maioria da mão de obra deste setor é composta por trabalhadores pertencentes ao ensino $\mathrm{G}(6)$ e $\mathrm{G}(8)$, sendo os trabalhadores com nível de mestrado e doutorado minoria dentre o total dos trabalhadores nesta área de atuação. Este cenário pode comprometer o ensino, conforme Tabela 8 que demonstra taxas de aprovação, reprovação e abandono. Sendo que os ensinos fundamental e médio apresentaram taxas de reprovação de $8,9 \%$ a $20,9 \%$ e taxas de abandono de $1,2 \%$ a $8 \%$. Para o ensino superior, a Tabela 15 apresentou baixos percentuais de conclusão, variando de $14,45 \%$ a $16,89 \%$. 


\subsection{Escolaridade e alocação da renda salarial nos setores da Economia do Distrito} Federal

A Tabela 21 demonstra o salário médio anual auferido pela população do DF, por grau de instrução. Em análise da tabela, pode-se afirmar, que a partir do grau $G(6)$ há maior concentração salarial, por pessoal ocupado, replicando o comportamento identificado por Silva (2008).

O setor APU destaca-se pagando maiores salários aos indivíduos pertencentes ao grau $\mathrm{G}(8)$, referente ao ensino superior completo. Para o grau $\mathrm{G}(10)$, os setores que ofertam maiores salários, respectivamente, são: cimento, agricultura, comércio e financeiro. Já no grau G(9) tem-se os setores: veículos, SIUP, imobiliário e financeiro, respectivamente.

Para os indivíduos com ensino superior completo - G(8), os setores que fornecem maiores salários são: veículos, SIUP, extrativa e eletrodomésticos. Coexistindo destaque para os setores de veículos e extrativa, quando comparadas as economias do DF e da Bahia. 
Tabela 21 - Salário médio anual do pessoal ocupado por setor por grupo de instrução - Distrito Federal - 2008 (em R\$1,00).

\begin{tabular}{|c|c|c|c|c|c|c|c|c|c|c|c|c|}
\hline Setores & $G(0)$ & $\mathrm{G}(1)$ & $G(2)$ & $G(3)$ & $\mathrm{G}(4)$ & $G(5)$ & $\mathrm{G}(6)$ & $\mathrm{G}(7)$ & $\mathrm{G}(8)$ & $G(9)$ & $\mathrm{G}(10)$ & Média Total \\
\hline Agricultura & $6.519,38$ & $20.865,19$ & $14.747,30$ & $13.601,72$ & $11.088,33$ & $18.070,31$ & $18.305,25$ & $36.132,63$ & $59.827,99$ & $81.001,16$ & $172.465,56$ & $18.654,24$ \\
\hline Pecuária & $6.676,39$ & $7.144,97$ & $7.023,33$ & $7.434,01$ & $7.292,52$ & $7.461,62$ & $10.647,97$ & $17.457,93$ & $39.979,90$ & 0,00 & 0,00 & $8.672,24$ \\
\hline Extrativa & $7.940,43$ & $11.732,68$ & $14.413,10$ & $15.377,57$ & $10.262,69$ & $20.901,63$ & $21.085,60$ & $57.815,82$ & $112.118,61$ & $70.342,92$ & 0,00 & $37.430,90$ \\
\hline Alimentos & $8.004,04$ & $9.846,52$ & $8.341,59$ & $8.703,49$ & $7.719,80$ & $7.691,82$ & $9.835,06$ & $21.744,92$ & $46.556,34$ & $69.867,78$ & 0,00 & $10.372,30$ \\
\hline Vestuário & $6.436,24$ & $8.921,65$ & $7.538,78$ & $7.133,11$ & $7.250,93$ & $6.777,01$ & $8.292,43$ & $13.191,29$ & $16.555,80$ & 0,00 & $110.195,04$ & $8.123,41$ \\
\hline Madeira & 184,56 & $11.250,58$ & $9.457,82$ & $9.185,32$ & $10.031,85$ & $8.668,15$ & $9.149,88$ & $7.063,04$ & $38.919,14$ & 0,00 & 0,00 & $9.782,53$ \\
\hline Celulose & 0,00 & $9.725,46$ & $15.141,81$ & $10.607,32$ & $13.267,37$ & $12.269,23$ & $21.683,91$ & $36.201,00$ & $51.077,58$ & 0,00 & 0,00 & $19.674,64$ \\
\hline Revistas & $6.631,80$ & $12.485,40$ & $13.104,44$ & $14.044,05$ & $12.819,16$ & $11.662,77$ & $15.227,10$ & $26.170,03$ & $62.872,44$ & 0,00 & 0,00 & 25.005 \\
\hline Químicos & $10.973,84$ & $14.111,95$ & $11.313,50$ & $11.238,72$ & $10.334,28$ & $12.605,19$ & $23.894,29$ & $44.200,77$ & $71.910,32$ & $94.523,40$ & $94.170,00$ & $37.880,94$ \\
\hline Borracha & $8.338,05$ & $9.117,36$ & $8.878,70$ & $10.295,84$ & $9.087,27$ & $8.687,03$ & $9.489,60$ & $19.532,67$ & $49.249,10$ & 0,00 & 0,00 & $9.981,26$ \\
\hline Cimento & $6.735,16$ & $10.403,05$ & $9.701,89$ & $10.795,37$ & $11.379,94$ & $11.543,82$ & $16.962,48$ & $23.428,28$ & $73.292,22$ & 0,00 & $226.044,06$ & $18.296,93$ \\
\hline Aço & 0,00 & $12.072,70$ & $8.224,94$ & $17.254,79$ & 10.3 & $10.744,14$ & $12.204,45$ & $13.549,51$ & 1,88 & 0,00 & 0,00 & \\
\hline Metal & $7.581,01$ & $11.782,35$ & $9.574,46$ & &, 64 & $10.140,06$ & 13.65 & 0,52 & & 0,00 & 0,00 & \\
\hline Eletrodomésticos & 0,00 & $19.797,22$ & $17.807,75$ & $14.912,33$ & $10.495,64$ & $14.877,97$ & $16.070,07$ & $22.684,74$ & $80.772,59$ & 0,00 & 0,00 &, 65 \\
\hline Informática & 0,00 & 0,00 & 0,00 & $11.411,22$ & $7.219,89$ & $2.660,88$ & $14.794,86$ & $18.417,15$ & $36.449,79$ & 0,00 & 0,00 & $18.355,13$ \\
\hline Máquinas & 0,00 & $7.050,05$ & $14.100,48$ & $9.342,85$ & $8.236,06$ & $9.875,47$ & $10.887,11$ & $24.245,15$ & $20.552,28$ & 0,00 & 0,00 & $11.007,47$ \\
\hline Eletrônicos & 0,00 & 0,00 & $6.525,12$ & $8.303,44$ & $9.646,56$ & $6.749,47$ & $6.695,23$ & $16.419,24$ & $61.738,93$ & 0,00 & 0,00 & $13.077,15$ \\
\hline Instrumento hospitalar & 0,00 & $6.269,49$ & $5.800,12$ & $7.364,95$ & $9.549,85$ & $6.442,18$ & $12.125,66$ & $14.905,14$ & $31.196,30$ & $44.820,00$ & $32.727,36$ & $15.257,01$ \\
\hline Veic & 247,32 & 23,94 & $6.953,66$ & & 4,21 & 10.49 & & 5,55 & 188. & $195.479,91$ & 0,00 & $91.617,40$ \\
\hline Indústria Diversa &, 00 & $7.830,52$ & $9.868,01$ & 7,81 & $8.606,81$ & $8.417,92$ & 58 & $18.551,95$ & $22.178,10$ & 0,00 & 0,00 & 321,32 \\
\hline SIUP & $6.619,64$ & $9.242,46$ & $9.290,62$ & $27.159,08$ & $26.552,69$ & $22.702,15$ & $47.043,35$ & $48.234,20$ & $112.840,16$ & $145.610,07$ & $107.036,83$ & $44.332,50$ \\
\hline Construg & $9.069,58$ & $10.298,99$ & $11.556,20$ & $11.279,72$ & $11.980,65$ & $11.207,16$ & $14.479,78$ & $21.075,67$ & $67.177,40$ & $62.806,11$ & $19.197,60$ & $15.354,95$ \\
\hline Comércio & $7.027,64$ & $9.169,44$ & $8.973,81$ & $8.804,82$ & $8.594,19$ & $8.739,06$ & $10.044,25$ & $17.829,33$ & $31.767,87$ & $44.399,00$ & $135.684,81$ & $10.667,11$ \\
\hline Transportes & $8.764,27$ & $11.875,32$ & $12.120,65$ & $11.521,96$ & $10.931,87$ & $9.948,92$ & $14.591,94$ & $22.366,06$ & $62.320,65$ & $68.388,12$ & $65.345,28$ & $19.999,18$ \\
\hline Informação & $8.627,64$ & $12.660,10$ & $11.606,21$ & $12.266,22$ & $11.786,95$ & $13.285,42$ & $17.486,40$ & $23.713,60$ & $58.472,77$ & $106.991,90$ & $91.927,80$ & $34.714,62$ \\
\hline Financeiro & $5.174,64$ & $13.919,61$ & $15.640,33$ & $35.453,61$ & $35.759,02$ & $29.956,61$ & $36.352,82$ & $34.205,25$ & $78.507,77$ & $111.668,68$ & $129.517,01$ & $63.901,49$ \\
\hline Imobiliário & 633,42 & $12.868,28$ & & $12.312,38$ & $10.976,64$ & $11.654,76$ & $15.538,14$ & $25.044,32$ & $9.512,36$ & $126.859,41$ & 0,00 & $17.853,64$ \\
\hline Alojamento & 553,30 & $8.387,28$ & 105,76 & $8.090,79$ & & $7.064,43$ & $7.835,82$ & $12.504,18$ & $25.403,49$ & $63.089,04$ & $19.969,44$ & $8.016,10$ \\
\hline Serviços às $\mathrm{E}$ & $7.216,66$ & $8.242,10$ & $9.272,43$ & $8.549,81$ & $9.607,97$ & $9.061,14$ & $12.342,04$ & $16.162,42$ & $39.793,01$ & $76.506,92$ & $124.470,06$ & $14.487,31$ \\
\hline Educação e Saúde mercantis & $8.450,34$ & $11.158,38$ & $10.972,15$ & $10.496,95$ & $9.475,57$ & $9.201,54$ & $10.839,34$ & $15.474,50$ & $33.199,39$ & $43.274,30$ & $74.899,34$ & $19.294,76$ \\
\hline Outros Serviços & $8.206,24$ & $9.157,82$ & $9.282,16$ & $9.016,81$ & $9.527,11$ & $7.846,59$ & $12.225,24$ & $19.634,84$ & $42.578,90$ & $86.642,46$ & $91.423,06$ & $16.627,63$ \\
\hline APU & 236,61 & $28.223,52$ & $9.106,40$ & $23.970,74$ & $21.588,80$ & $17.164,40$ & $36.764,59$ & $26.047,90$ & $79.396,53$ & $6.888,66$ & 471,33 & $56.354,85$ \\
\hline Total & $1.969,91$ & $19.883,61$ & $12.064,51$ & $13.910,70$ & $15.125,38$ & $10.855,42$ & $22.580,95$ & $27.363,07$ & $77.040,15$ & $92.312,83$ & $100.330,83$ & $34.333,63$ \\
\hline
\end{tabular}

Onde: Analfabeto - G(0); Até o $5^{\circ}$ ano incompleto do ensino fundamental - G(1); $5^{\circ}$ ano completo do ensino fundamental - G(2); Do $6^{\circ}$ ao $9^{\circ}$ ano incompleto do ensino fundamental - G(3); Ensino fundamental completo - G(4); Ensino médio incompleto - G(5); Ensino médio completo - G(6); Educação superior incompleta - G(7); Educação superior completa - G(8); Mestrado - G(9); Doutorado - G(10).

Fonte: Adaptado da RAIS 2008. 
Ainda sobre a Tabela 21, tem-se como média salarial anual da economia do DF o valor de $\mathrm{R} \$ 34,333,63$ (trinta e quatro mil, trezentos e trinta e três reais e sessenta e três centavos). Diante de tal informação observa-se que trabalhadores com baixo grau de instrução não alcançam a média salarial da região, de modo a evidenciar relação direta entre o grau de ensino e a renda salarial auferida.

Em termos gerais, observa-se que os trabalhadores com maiores níveis de escolarização tendem a auferir maiores remunerações. Tais percentuais reforçam que a população do DF se preocupa com a instrução do indivíduo, buscando manter seus filhos em instituições de ensino, fato que se estende ao crescimento das matrículas ao longo dos anos, nos níveis de ensino (infantil, fundamental, médio e superior), conforme detalhado nas Tabelas 10 a 13 já citadas neste trabalho.

A Tabela 22 a seguir, demonstra a razão entre o salário médio de cada atividade, por grau de instrução, e a média salarial total dos trabalhadores com aquele grau de instrução, de modo a demonstrar a aderência de atuação na economia, por nível de ensino. Nesta linha de raciocínio, a coluna referente a Média Total, representa a razão entre a média salarial, de cada setor, pela média salarial da economia, como um todo. Assim, quando apresentado valor maior que 1, pode-se afirmar que a remuneração paga pelo referido setor está acima da média, para o mesmo grau de ensino, ou acima da média da economia.

Tabela 22 - Distribuição do salário médio anual por setor por grau de instrução - Distrito Federal - $2008(\%)$ (continua).

\begin{tabular}{lccccccccccccc}
\hline & Setores & $\mathbf{G}(\mathbf{0})$ & $\mathbf{G}(\mathbf{1})$ & $\mathbf{G}(\mathbf{2})$ & $\mathbf{G}(\mathbf{3})$ & $\mathbf{G}(\mathbf{4})$ & $\mathbf{G}(\mathbf{5})$ & $\mathbf{G}(\mathbf{6})$ & $\mathbf{G}(\mathbf{7})$ & $\mathbf{G}(\mathbf{8})$ & $\mathbf{G}(\mathbf{9})$ & $\mathbf{G}(\mathbf{1 0})$ & Média Total \\
Agricultura & 3,31 & 1,05 & 1,22 & 0,98 & 0,73 & 1,66 & 0,81 & 1,32 & 0,78 & 0,88 & 1,72 & 0,54 \\
Pecuária & 3,39 & 0,36 & 0,58 & 0,53 & 0,48 & 0,69 & 0,47 & 0,64 & 0,52 & 0,00 & 0,00 & 0,25 \\
Extrativa & 4,03 & 0,59 & 1,19 & 1,11 & 0,68 & 1,93 & 0,93 & 2,11 & 1,46 & 0,76 & 0,00 & 1,09 \\
Alimentos & 4,06 & 0,50 & 0,69 & 0,63 & 0,51 & 0,71 & 0,44 & 0,79 & 0,60 & 0,76 & 0,00 & 0,30 \\
Vestuário & 3,27 & 0,45 & 0,62 & 0,51 & 0,48 & 0,62 & 0,37 & 0,48 & 0,21 & 0,00 & 1,10 & 0,24 \\
Madeira & 3,14 & 0,57 & 0,78 & 0,66 & 0,66 & 0,80 & 0,41 & 0,26 & 0,51 & 0,00 & 0,00 & 0,28 \\
Celulose & 0,00 & 0,49 & 1,26 & 0,76 & 0,88 & 1,13 & 0,96 & 1,32 & 0,66 & 0,00 & 0,00 & 0,57 \\
Revistas & 3,37 & 0,63 & 1,09 & 1,01 & 0,85 & 1,07 & 0,67 & 0,96 & 0,82 & 0,00 & 0,00 & 0,73 \\
Químicos & 5,57 & 0,71 & 0,94 & 0,81 & 0,68 & 1,16 & 1,06 & 1,62 & 0,93 & 1,02 & 0,94 & 1,10 \\
Borracha & 4,23 & 0,46 & 0,74 & 0,74 & 0,60 & 0,80 & 0,42 & 0,71 & 0,64 & 0,00 & 0,00 & 0,29 \\
Cimento & 3,43 & 0,52 & 0,80 & 0,78 & 0,75 & 1,06 & 0,75 & 0,86 & 0,95 & 0,00 & 2,25 & 0,53 \\
Aço & 0,00 & 0,61 & 0,68 & 1,24 & 0,68 & 0,99 & 0,54 & 0,50 & 0,75 & 0,00 & 0,00 & 0,44 \\
Metal & 3,85 & 0,59 & 0,79 & 0,67 & 0,71 & 0,93 & 0,60 & 0,72 & 0,45 & 0,00 & 0,00 & 0,36 \\
Eletrodomésticos & 0,00 & 1,00 & 1,48 & 1,07 & 0,69 & 1,37 & 0,71 & 0,83 & 1,05 & 0,00 & 0,00 & 0,52 \\
\hline
\end{tabular}


Tabela 22 - Distribuição do salário médio anual por setor por grau de instrução - Distrito Federal - 2008 (\%) (conclusão).

\begin{tabular}{lccccccccccccc}
\hline \multicolumn{1}{c}{ Setores } & $\mathbf{G}(\mathbf{0})$ & $\mathbf{G}(\mathbf{1})$ & $\mathbf{G}(\mathbf{2})$ & $\mathbf{G}(\mathbf{3})$ & $\mathbf{G}(\mathbf{4})$ & $\mathbf{G}(\mathbf{5})$ & $\mathbf{G}(\mathbf{6})$ & $\mathbf{G}(\mathbf{7})$ & $\mathbf{G}(\mathbf{8})$ & $\mathbf{G}(\mathbf{9})$ & $\mathbf{G}(\mathbf{1 0})$ & Média Total \\
\hline Informática & 0,00 & 0,00 & 0,00 & 0,82 & 0,48 & 0,25 & 0,66 & 0,67 & 0,47 & 0,00 & 0,00 & 0,53 \\
Máquinas & 0,00 & 0,35 & 1,17 & 0,67 & 0,54 & 0,91 & 0,48 & 0,89 & 0,27 & 0,00 & 0,00 & 0,32 \\
Eletrônicos & 0,00 & 0,00 & 0,54 & 0,60 & 0,64 & 0,62 & 0,30 & 0,60 & 0,80 & 0,00 & 0,00 & 0,38 \\
Instrumento hospitalar & 0,00 & 0,32 & 0,48 & 0,53 & 0,63 & 0,59 & 0,54 & 0,54 & 0,40 & 0,49 & 0,33 & 0,44 \\
Veículos & 3,68 & 0,48 & 0,58 & 0,72 & 0,82 & 0,97 & 0,90 & 2,74 & 2,45 & 2,12 & 0,00 & 2,67 \\
Indústria Diversa & 4,40 & 0,39 & 0,82 & 0,59 & 0,57 & 0,78 & 0,41 & 0,68 & 0,29 & 0,00 & 0,00 & 0,26 \\
SIUP & 3,36 & 0,46 & 0,77 & 1,95 & 1,76 & 2,09 & 2,08 & 1,76 & 1,46 & 1,58 & 1,07 & 1,29 \\
Construção Civil & 4,60 & 0,52 & 0,96 & 0,81 & 0,79 & 1,03 & 0,64 & 0,77 & 0,87 & 0,68 & 0,19 & 0,45 \\
Comércio & 3,57 & 0,46 & 0,74 & 0,63 & 0,57 & 0,81 & 0,44 & 0,65 & 0,41 & 0,48 & 1,35 & 0,31 \\
Transportes & 4,45 & 0,60 & 1,00 & 0,83 & 0,72 & 0,92 & 0,65 & 0,82 & 0,81 & 0,74 & 0,65 & 0,58 \\
Informação & 4,38 & 0,64 & 0,96 & 0,88 & 0,78 & 1,22 & 0,77 & 0,87 & 0,76 & 1,16 & 0,92 & 1,01 \\
Financeiro & 2,63 & 0,70 & 1,30 & 2,55 & 2,36 & 2,76 & 1,61 & 1,25 & 1,02 & 1,21 & 1,29 & 1,86 \\
Imobiliário & 3,88 & 0,65 & 0,75 & 0,89 & 0,73 & 1,07 & 0,69 & 0,92 & 1,03 & 1,37 & 0,00 & 0,52 \\
Alojamento & 3,33 & 0,42 & 0,67 & 0,58 & 0,50 & 0,65 & 0,35 & 0,46 & 0,33 & 0,68 & 0,20 & 0,23 \\
Serviços às Empresas & 3,66 & 0,41 & 0,77 & 0,61 & 0,64 & 0,83 & 0,55 & 0,59 & 0,52 & 0,83 & 1,24 & 0,42 \\
Educação e Saúde mercantis & 4,29 & 0,56 & 0,91 & 0,75 & 0,63 & 0,85 & 0,48 & 0,57 & 0,43 & 0,47 & 0,75 & 0,56 \\
Outros Serviços & 4,17 & 0,46 & 0,77 & 0,65 & 0,63 & 0,72 & 0,54 & 0,72 & 0,55 & 0,94 & 0,91 & 0,48 \\
APU & 0,12 & 1,42 & 0,75 & 1,72 & 1,43 & 1,58 & 1,63 & 0,95 & 1,03 & 0,07 & 0,00 & 1,64 \\
\hline Onde: Analfaberny
\end{tabular}

Onde: Analfabeto - $\mathrm{G}(0)$; Até o $5^{\circ}$ ano incompleto do ensino fundamental - $\mathrm{G}(1) ; 5^{\circ}$ ano completo do ensino fundamental - G(2); Do $6^{\circ}$ ao $9^{\circ}$ ano incompleto do ensino fundamental - G(3); Ensino fundamental completo G(4); Ensino médio incompleto - G(5); Ensino médio completo - G(6); Educação superior incompleta - G(7); Educação superior completa - G(8); Mestrado - G(9); Doutorado - G(10).

Fonte: Adaptado da RAIS 2008.

Diante dos dados supracitados, destaca-se que a população de grau $G(0)$ apresentou salários acima da média, em 24 dos 32 setores em análise. Para o grau $\mathrm{G}(1)$, os setores agricultura, eletrodomésticos e APU ofertaram remunerações acima da média. Para a população pertencente ao grau $\mathrm{G}(2)$, os setores agricultura, extrativa, celulose, revistas, eletrodomésticos, máquinas, transporte e financeiro pagam acima da média. Do mesmo modo, para o grau G(3) destacam-se os setores: extrativa, revistas, aço, eletrodomésticos, SIUP, financeiro e APU. Já para o grau G(4) apenas os setores SIUP, financeiro e APU, oferecem salários acima da média.

Quanto ao grau G(5), 13 dos 32 setores apresentaram valor acima de 1. Para o grau G(6) apenas os setores químicos, SIUP, financeiro e APU apresentaram representatividade. No grau G(7) merecem destacaram-se os setores: agricultura, extrativa, celulose, químicos, veículos, SIUP e financeiro. Para a população pertencente ao grau $\mathrm{G}(8)$, as possibilidades com 
melhores remunerações estão nos setores: extrativa, eletrodomésticos, veículos, SIUP, financeiro, imobiliário e APU.

Para o grau G(9) destacam-se os setores: químicos, veículos, SIUP, informação, financeiro e imobiliário. Em seguida, para o nível $\mathrm{G}(10)$ os setores que ofertam maiores salários para o citado grau de instrução são: agricultura, vestuário, cimento, SIUP, comércio, financeiro e serviço às empresas.

Em termos gerais, segundo a média total, para todos os níveis de instrução, as melhores ofertas para a população do DF estão nos seguintes setores da economia regional: extrativa, químicos, SIUP, informação, financeiro e APU. Sendo que os setores SIUP e financeiro foram os que ofertaram melhores médias salariais para toda a população, envolvendo quase a totalidade dos graus de instrução.

A Tabela 23, demonstra a razão entre cada grau de instrução e a remuneração salarial média do setor. Desse modo, pode-se afirmar que se demonstrado valor maior que 1, para o referido grau de instrução ocorre remuneração da força de trabalho acima da média.

Da análise da tabela 23, observa-se que o grau $\mathrm{G}(8)$ remunera acima da média em todos os setores da economia do DF, destacando-se os setores borracha e eletrônicos. Para o grau G(7) oferecem maiores remunerações os setores têxteis e máquinas, sendo que para a maioria dos setores há oferta de remunerações acima da média, com exceção dos setores: madeira, aço, instrumento hospitalar, informação, financeiro, educação e saúde mercantis e APU.

O setor eletrônicos novamente apresenta destaque, tendo em vista a baixa representatividade na economia do DF, conforme já abordado ao longo deste estudo. Por outro lado, o setor educação e saúde mercantis, grande setor da economia, também demonstra resultados positivos.

Tais resultados positivos, em relação aos graus $\mathrm{G}(7)$ e $\mathrm{G}(8)$ se assemelham a situação existente na economia baiana, conforme apresentado por Silva (2008). 
Tabela 23 - Distribuição do salário médio anual por pessoal ocupado por grau de instrução por setor - Distrito Federal - $2008(\%)$.

\begin{tabular}{|c|c|c|c|c|c|c|c|c|c|c|c|}
\hline Setores & G(0) & G(1) & G(2) & G(3) & G(4) & G(5) & G(6) & G(7) & G(8) & G(9) & G(10) \\
\hline Agricultura & 0,35 & 1,12 & 0,79 & 0,73 & 0,59 & 0,97 & 0,98 & 1,94 & 3,21 & 4,34 & 9,25 \\
\hline Pecuária & 0,77 & 0,82 & 0,81 & 0,86 & 0,84 & 0,86 & 1,23 & 2,01 & 4,61 & 0,00 & 0,00 \\
\hline Extrativa & 0,21 & 0,31 & 0,39 & 0,41 & 0,27 & 0,56 & 0,56 & 1,54 & 3,00 & 1,88 & 0,00 \\
\hline Alimentos & 0,77 & 0,95 & 0,80 & 0,84 & 0,74 & 0,74 & 0,95 & 2,10 & 4,49 & 6,74 & 0,00 \\
\hline Vestuário & 0,79 & 1,10 & 0,93 & 0,88 & 0,89 & 0,83 & 1,02 & 1,62 & 2,04 & 0,00 & 13,57 \\
\hline Madeira & 0,63 & 1,15 & 0,97 & 0,94 & 1,03 & 0,89 & 0,94 & 0,72 & 3,98 & 0,00 & 0,00 \\
\hline Celulose & 0,00 & 0,49 & 0,77 & 0,54 & 0,67 & 0,62 & 1,10 & 1,84 & 2,60 & 0,00 & 0,00 \\
\hline Revistas & 0,27 & 0,50 & 0,52 & 0,56 & 0,51 & 0,47 & 0,61 & 1,05 & 2,51 & 0,00 & 0,00 \\
\hline Químicos & 0,29 & 0,37 & 0,30 & 0,30 & 0,27 & 0,33 & 0,63 & 1,17 & 1,90 & 2,50 & 2,49 \\
\hline Borracha & 0,84 & 0,91 & 0,89 & 1,03 & 0,91 & 0,87 & 0,95 & 1,96 & 4,93 & 0,00 & 0,00 \\
\hline Cimento & 0,37 & 0,57 & 0,53 & 0,59 & 0,62 & 0,63 & 0,93 & 1,28 & 4,01 & 0,00 & 12,35 \\
\hline Aço & 0,00 & 0,80 & 0,54 & 1,14 & 0,68 & 0,71 & 0,80 & 0,89 & 3,82 & 0,00 & 0,00 \\
\hline Metal & 0,61 & 0,95 & 0,78 & 0,76 & 0,87 & 0,82 & 1,11 & 1,60 & 2,80 & 0,00 & 0,00 \\
\hline Eletrodomésticos & 0,00 & 1,10 & 0,99 & 0,83 & 0,58 & 0,83 & 0,89 & 1,26 & 4,50 & 0,00 & 0,00 \\
\hline Informática & 0,00 & 0,00 & 0,00 & 0,62 & 0,39 & 0,14 & 0,81 & 1,00 & 1,99 & 0,00 & 0,00 \\
\hline Máquinas & 0,00 & 0,64 & 1,28 & 0,85 & 0,75 & 0,90 & 0,99 & 2,20 & 1,87 & 0,00 & 0,00 \\
\hline Eletrônicos & 0,00 & 0,00 & 0,50 & 0,63 & 0,74 & 0,52 & 0,51 & 1,26 & 4,72 & 0,00 & 0,00 \\
\hline Instrumento hospitalar & 0,00 & 0,41 & 0,38 & 0,48 & 0,63 & 0,42 & 0,79 & 0,98 & 2,04 & 2,94 & 2,15 \\
\hline Veículos & 0,08 & 0,11 & 0,08 & 0,11 & 0,13 & 0,11 & 0,22 & 0,82 & 2,06 & 2,13 & 0,00 \\
\hline Indústria Diversa & 0,98 & 0,89 & 1,12 & 0,94 & 0,98 & 0,95 & 1,04 & 2,10 & 2,51 & 0,00 & 0,00 \\
\hline SIUP & 0,15 & 0,21 & 0,21 & 0,61 & 0,60 & 0,51 & 1,06 & 1,09 & 2,55 & 3,28 & 2,41 \\
\hline Construção Civil & 0,59 & 0,67 & 0,75 & 0,73 & 0,78 & 0,73 & 0,94 & 1,37 & 4,37 & 4,09 & 1,25 \\
\hline Comércio & 0,66 & 0,86 & 0,84 & 0,83 & 0,81 & 0,82 & 0,94 & 1,67 & 2,98 & 4,16 & 12,72 \\
\hline Transportes & 0,44 & 0,59 & 0,61 & 0,58 & 0,55 & 0,50 & 0,73 & 1,12 & 3,12 & 3,42 & 3,27 \\
\hline Informação & 0,25 & 0,36 & 0,33 & 0,35 & 0,34 & 0,38 & 0,50 & 0,68 & 1,68 & 3,08 & 2,65 \\
\hline Financeiro & 0,08 & 0,22 & 0,24 & 0,55 & 0,56 & 0,47 & 0,57 & 0,54 & 1,23 & 1,75 & 2,03 \\
\hline Imobiliário & 0,43 & 0,72 & 0,51 & 0,69 & 0,61 & 0,65 & 0,87 & 1,40 & 4,45 & 7,11 & 0,00 \\
\hline Alojamento & 0,82 & 1,05 & 1,01 & 1,01 & 0,95 & 0,88 & 0,98 & 1,56 & 3,17 & 7,87 & 2,49 \\
\hline Serviços às Empresas & 0,50 & 0,57 & 0,64 & 0,59 & 0,66 & 0,63 & 0,85 & 1,12 & 2,75 & 5,28 & 8,59 \\
\hline Educação e Saúde mercantis & 0,44 & 0,58 & 0,57 & 0,54 & 0,49 & 0,48 & 0,56 & 0,80 & 1,72 & 2,24 & 3,88 \\
\hline Outros Serviços & 0,49 & 0,55 & 0,56 & 0,54 & 0,57 & 0,47 & 0,74 & 1,18 & 2,56 & 5,21 & 5,50 \\
\hline APU & 0,00 & 0,50 & 0,16 & 0,43 & 0,38 & 0,30 & 0,65 & 0,46 & 1,41 & 0,12 & 0,01 \\
\hline Média Total & 0,06 & 0,58 & 0,35 & 0,41 & 0,44 & 0,32 & 0,66 & 0,80 & 2,24 & 2,69 & 2,92 \\
\hline
\end{tabular}

Onde: Analfabeto - $\mathrm{G}(0)$; Até o $5^{\circ}$ ano incompleto do ensino fundamental - $\mathrm{G}(1) ; 5^{\circ}$ ano completo do ensino fundamental - G(2); Do $6^{\circ}$ ao $9^{\circ}$ ano incompleto do ensino fundamental - G(3); Ensino fundamental completo G(4); Ensino médio incompleto - G(5); Ensino médio completo - G(6); Educação superior incompleta - G(7); Educação superior completa - G(8); Mestrado - G(9); Doutorado - G(10).

Fonte: Adaptado da RAIS 2008. 
Quanto aos graus $\mathrm{G}(0)$ e $\mathrm{G}(5)$, não há oferta de remunerações acima da média. Para o grau G(1), apenas os setores agricultura, vestuário, madeira, eletrodoméstico e alojamento apresentaram remunerações acima da média. No grau G(2), há remuneração acima da média nos setores: máquinas, indústria diversa e alojamento. No grau G(3), tal comportamento se repete nos setores borracha, aço e alojamento. Contudo, para a população pertencente ao grau de instrução $G(4)$, apenas o setor madeira demonstra oferta de remuneração acima da média.

Quanto aos graus $\mathrm{G}(9)$ e $\mathrm{G}(10)$, relativos a população detentora do título de mestrado e doutorado, respectivamente, observa-se que a distribuição concentra-se em determinados setores da economia, apresentando valores consideravelmente acima dos apresentados em graus de instrução inferiores.

Assim, para o grau G(9), esta categoria se distribui em 17 dos 32 setores analisados, auferindo maiores salários nos setores de alojamento e imobiliário, respectivamente. Para o grau $\mathrm{G}(10)$, os profissionais se concentram em 15 dos 32 setores analisados, galgando maiores salários nos setores de vestuário e comércio, respectivamente.

\subsection{Análise dos resultados dos impactos da Educação}

Os dados sobre quantidade populacional, perfil educacional, emprego e renda salarial foram extraídos da RAIS. Considerando um aumento de R \$ 10.000.000,00 (dez milhões de reais) de demanda final, para cada setor de atividade econômica do DF, elaborou-se os multiplicadores de emprego e renda utilizando a matriz inversa de Leontief, identificando a quantidade direta e indireta relativa a geração de emprego e renda salarial.

\subsubsection{Multiplicadores de emprego}

A Tabela 24 demonstra a quantidade de empregos diretos e indiretos que devem ser gerados na economia do DF a partir da variação de R \$ 10.000.000,00 (dez milhões de reais) na demanda final de cada setor analisado. Ao analisar a tabela observa-se que os setores que mais contribuem na geração de empregos são: madeira, eletrodomésticos e vestuário, gerando 504, 228 e 212 novos empregos, respectivamente. Vale ressaltar que a justificativa para que estes setores com baixa produção gerem o maior número de empregos é por causa do tamanho do setor no DF. Os setores listados como maiores geradores de emprego possuem baixa produção, assim qualquer aumento de demanda vai exigir um aumento de produção no setor, 
e para alcançar a variação de produção, dado o tamanho do setor, haverá um aumento maior de mão de obra.

Tabela 24 - Emprego direto e indireto gerados por grau de instrução pela variação da demanda final de 10 milhões de reais - Distrito Federal - 2008 (continua).

\begin{tabular}{|c|c|c|c|c|c|c|c|c|c|c|c|c|}
\hline Setores & $\mathbf{G}(\mathbf{0})$ & $\mathbf{G}(\mathbf{1})$ & $\mathbf{G}(2)$ & $\mathbf{G}(\mathbf{3})$ & $\mathbf{G}(4)$ & G(5) & $\mathbf{G}(\mathbf{6})$ & G(7) & $\mathbf{G}(\mathbf{8})$ & $\mathbf{G}(9)$ & $\mathbf{G}(\mathbf{1 0})$ & Total \\
\hline Agricultura & 1 & 9 & 7 & 9 & 12 & 6 & 17 & 2 & 4 & 0 & 0 & 67 \\
\hline Pecuária & 2 & 9 & 12 & 20 & 19 & 9 & 28 & 2 & 4 & 0 & 0 & 104 \\
\hline Extrativa & 1 & 4 & 11 & 14 & 31 & 13 & 51 & 7 & 31 & 0 & 0 & 163 \\
\hline Alimentos & 1 & 4 & 4 & 10 & 19 & 14 & 40 & 3 & 4 & 0 & 0 & 98 \\
\hline Vestuário & 1 & 3 & 4 & 18 & 45 & 29 & 100 & 5 & 6 & 0 & 0 & 212 \\
\hline Madeira & 5 & 18 & 50 & 81 & 140 & 80 & 112 & 9 & 8 & 0 & 0 & 504 \\
\hline Celulose & 0 & 2 & 6 & 21 & 39 & 30 & 83 & 8 & 14 & 0 & 0 & 203 \\
\hline Revistas & 0 & 1 & 1 & 7 & 16 & 13 & 53 & 8 & 24 & 0 & 0 & 123 \\
\hline Químicos & 0 & 1 & 1 & 4 & 8 & 5 & 26 & 7 & 15 & 0 & 0 & 67 \\
\hline Borracha & 1 & 4 & 7 & 15 & 31 & 11 & 40 & 3 & 3 & 0 & 0 & 115 \\
\hline Cimento & 0 & 1 & 1 & 3 & 7 & 5 & 18 & 2 & 4 & 0 & 0 & 42 \\
\hline Aço & 0 & 1 & 2 & 8 & 8 & 7 & 24 & 2 & 5 & 0 & 0 & 57 \\
\hline Metal & 0 & 3 & 2 & 6 & 16 & 10 & 24 & 2 & 3 & 0 & 0 & 66 \\
\hline Eletrodomésticos & 0 & 4 & 5 & 18 & 32 & 22 & 112 & 14 & 19 & 0 & 1 & 228 \\
\hline Informática & 0 & 1 & 1 & 9 & 13 & 9 & 93 & 31 & 25 & 0 & 0 & 183 \\
\hline Máquinas & 0 & 1 & 2 & 12 & 16 & 13 & 38 & 4 & 5 & 0 & 0 & 91 \\
\hline Eletrônicos & 0 & 1 & 2 & 6 & 10 & 8 & 132 & 6 & 20 & 0 & 0 & 185 \\
\hline Instrumento hospitalar & 0 & 1 & 2 & 3 & 9 & 8 & 45 & 5 & 16 & 0 & 0 & 90 \\
\hline Veículos & 2 & 4 & 3 & 7 & 31 & 14 & 52 & 7 & 46 & 3 & 0 & 168 \\
\hline Indústria Diversa & 1 & 36 & 10 & 23 & 27 & 16 & 45 & 2 & 3 & 0 & 0 & 161 \\
\hline SIUP & 0 & 5 & 8 & 3 & 6 & 3 & 18 & 2 & 14 & 1 & 0 & 60 \\
\hline Construção Civil & 1 & 9 & 6 & 13 & 16 & 8 & 24 & 2 & 5 & 0 & 0 & 84 \\
\hline Comércio & 0 & 2 & 3 & 9 & 26 & 20 & 89 & 6 & 7 & 0 & 0 & 163 \\
\hline Transportes & 0 & 2 & 3 & 9 & 16 & 10 & 38 & 4 & 13 & 0 & 0 & 95 \\
\hline Informação & 0 & 0 & 1 & 2 & 5 & 3 & 21 & 7 & 18 & 0 & 0 & 58 \\
\hline Financeiro & 0 & 0 & 1 & 1 & 3 & 1 & 11 & 5 & 19 & 0 & 0 & 40 \\
\hline Imobiliário & 0 & 1 & 1 & 2 & 3 & 2 & 6 & 1 & 1 & 0 & 0 & 17 \\
\hline Alojamento & 1 & 2 & 4 & 12 & 32 & 22 & 58 & 2 & 4 & 0 & 0 & 136 \\
\hline Serviços às Empresas & 1 & 3 & 6 & 12 & 28 & 13 & 58 & 10 & 15 & 1 & 1 & 147 \\
\hline Educação e Saúde mercantis & 0 & 1 & 2 & 5 & 10 & 8 & 61 & 9 & 41 & 3 & 1 & 142 \\
\hline Outros Serviços & 1 & 4 & 5 & 10 & 16 & 12 & 37 & 6 & 18 & 0 & 0 & 109 \\
\hline
\end{tabular}


Tabela 24 - Emprego direto e indireto gerados por grau de instrução pela variação da demanda final de 10 milhões de reais - Distrito Federal - 2008 (conclusão).

\begin{tabular}{|c|c|c|c|c|c|c|c|c|c|c|c|c|}
\hline Setores & $\mathbf{G}(\mathbf{0})$ & $\mathbf{G}(\mathbf{1})$ & $\mathbf{G}(2)$ & $\mathbf{G}(\mathbf{3})$ & G(4) & $\mathbf{G}(5)$ & $G(6)$ & $\mathbf{G}(7)$ & $\mathbf{G}(\mathbf{8})$ & G(9) & $\mathbf{G}(10)$ & Total \\
\hline APU & 0 & 1 & 1 & 2 & 9 & 2 & 23 & 3 & 21 & 0 & 0 & 61 \\
\hline Total & 20 & 139 & 174 & 372 & 700 & 423 & 1578 & 187 & 432 & 11 & 4 & 4039 \\
\hline
\end{tabular}

Onde: Analfabeto - $\mathrm{G}(0)$; Até o $5^{\circ}$ ano incompleto do ensino fundamental - $\mathrm{G}(1)$; $5^{\circ}$ ano completo do ensino fundamental - G(2); Do $6^{\circ}$ ao $9^{\circ}$ ano incompleto do ensino fundamental - G(3); Ensino fundamental completo G(4); Ensino médio incompleto - G(5); Ensino médio completo - G(6); Educação superior incompleta - G(7); Educação superior completa - G(8); Mestrado - G(9); Doutorado - G(10).

Fonte: Adaptado da RAIS 2008.

De modo geral, pode-se afirmar que são gerados 4.039 novos empregos no DF. Para a economia baiana, a mesma variação de demanda final gerou a criação de 7.278 novos empregos, conforme apresentado por Silva (2008).

Do total de empregos gerados, sua maioria é composta por indivíduos pertencentes aos níveis $\mathrm{G}(4)$ a $\mathrm{G}(6)$, o que representa 2.278 novos empregos, de modo a demonstrar que a maioria da população do DF possui nível de instrução do ensino fundamental completo ao ensino médio completo. Para Silva (2008), na economia baiana, a maioria da população possuía a partir do $6^{\circ}$ ano incompleto do ensino fundamental ao ensino médio completo.

Para o grau $\mathrm{G}(0)$ são gerados apenas 20 novos postos de trabalho, quantitativo baixo, se comparado aos demais graus de escolarização, tal fato, evidencia que a economia do DF possui baixo nível de analfabetismo, conforme já identificado na Tabela 6, que apresentou taxa de 4,02\% de analfabetismo no DF, no ano de 2008. Para os graus a partir do G(7) criouse 187 novos empregos a trabalhadores com nível de ensino a partir do nível superior incompleto. Tal quantitativo é considerado baixo, principalmente se comparado montante de postos de trabalho criados (1.578) para o grau $\mathrm{G}(6)$, relativo ao ensino médio.

Nos graus $\mathrm{G}(9)$ e $\mathrm{G}(10)$ foram criados apenas 15 novos empregos, sendo 11 para indivíduos com mestrado e 4 com doutorado. Para o grau G(8) o quantitativo subiu para 432 novos empregos, destacando-se os setores: veículos (46), educação e saúde mercantis (41) e extrativa (31). Em contraponto, para o $\mathrm{G}(0)$, os setores que mais geraram empregos foram: madeira (5), pecuária (2) e veículos (2).

Para o grau G(1) destacam-se os setores indústria diversa (36), madeira (18), agricultura (9) e pecuária (9). Para o $G(2)$ os setores madeira (50), pecuária (12), extrativa (11) e indústria diversa (10). Quanto ao grau G(3) apresentam maiores gerações de novos empregos os setores: madeira (81), celulose (21) e pecuária (20). Os setores que se destacam no grau G(4) são madeira (140), vestuário (45) e celulose (39). No grau G(5) tem-se madeira, 
celulose e eletrodomésticos proporcionando 80, 30 e 22 novos empregos. Em relação ao grau G(6) destacam-se os setores eletrônicos (132), eletrodomésticos (112), madeira (112) e vestuário (100).

Em termos gerais, observa-se que os setores madeira, eletrodoméstico e vestuário ofertaram mais empregos que os demais setores da economia do DF.

A Tabela 25 apresenta, em percentual, a distribuição dos novos empregos diretos e indiretos, de forma setorial e por grau de instrução, diante da variação da demanda final em $\mathrm{R} \$ 10.000 .000,00$ (dez milhões de reais).

Do total de empregos gerados para os trabalhadores pertencentes ao grau $\mathrm{G}(0)$, destacam-se os setores madeira (25\%), pecuária (10\%) e veículos (10\%). Por outro lado, 19 dos 32 setores não contribuíram na geração de empregos para o grau $\mathrm{G}(0)$. Para o grau $\mathrm{G}(1)$, os setores que mais absorveram pessoal foram indústria diversa $(24,08 \%)$ e madeira $(12,06 \%)$. Para o grau G(3) os setores que mais geraram empregos foram madeira $(21,77 \%)$, indústria diversa $(6,18 \%)$ e celulose $(5,65 \%)$.

Dos maiores percentuais alcançados nos graus G(4) e G(5) tem-se madeira com $20 \%$ e $18,91 \%$, respectivamente, e celulose, com 5,57\% e 7,09\%, respectivamente. No caso do grau G(6) os destaques são os setores madeira $(7,10 \%)$ e vestuário $(6,34 \%)$. No grau $G(7)$ os setores que mais colaboraram na geração de empregos foram informática e serviços às empresas, com $16,58 \%$ e $5,35 \%$, respectivamente.

Os setores celulose e informática apresentaram resultados positivos, tendo em vista que, conforme ora demonstrado na Tabela 16, estes setores possuem baixa representatividade na economia do DF, correspondendo sensivelmente, quando na aplicação de recursos na economia local.

Para os graus $\mathrm{G}(8)$ e $\mathrm{G}(9)$ os setores que mais geraram novos postos de trabalho foram veículos com $10,65 \%$ e $27,27 \%$, respectivamente, e educação e saúde mercantis com 9,49\% no grau $\mathrm{G}(9)$ e $27,27 \%$ no grau $\mathrm{G}(10)$. Já no grau $\mathrm{G}(10)$, os únicos setores que geraram empregos foram eletrodomésticos, serviços às empresas e educação e saúde mercantis, ambos $\operatorname{com} 25 \%$. 
Tabela 25 - Distribuição setorial do emprego direto e indireto gerados por grau de instrução pela variação da demanda final de 10 milhões de reais - Distrito Federal - 2008 (\%) (continua).

\begin{tabular}{|c|c|c|c|c|c|c|c|c|c|c|c|c|}
\hline Setores & $\mathbf{G}(\mathbf{0})$ & $\mathbf{G}(\mathbf{1})$ & $\mathbf{G}(2)$ & G(3) & $\mathbf{G}(4)$ & G(5) & $\mathbf{G}(\mathbf{6})$ & G(7) & $\mathbf{G}(\mathbf{8})$ & G(9) & G(10) & Total \\
\hline Agricultura & 5,00 & 6,47 & 4,02 & 2,42 & 1,71 & 1,42 & 1,08 & 1,07 & 0,93 & 0,00 & 0,00 & 1,66 \\
\hline Pecuária & 10,00 & 6,47 & 6,90 & 5,38 & 2,71 & 2,13 & 1,77 & 1,07 & 0,93 & 0,00 & 0,00 & 2,57 \\
\hline Extrativa & 5,00 & 2,88 & 6,32 & 3,76 & 4,43 & 3,07 & 3,23 & 3,74 & 7,18 & 0,00 & 0,00 & 4,04 \\
\hline Alimentos & 5,00 & 2,88 & 2,30 & 2,69 & 2,71 & 3,31 & 2,53 & 1,60 & 0,93 & 0,00 & 0,00 & 2,43 \\
\hline Vestuário & 5,00 & 2,16 & 2,30 & 4,84 & 6,43 & 6,86 & 6,34 & 2,67 & 1,39 & 0,00 & 0,00 & 5,25 \\
\hline Madeira & 25,00 & 12,95 & 28,74 & 21,77 & 20,00 & 18,91 & 7,10 & 4,81 & 1,85 & 0,00 & 0,00 & 12,48 \\
\hline Celulose & 0,00 & 1,44 & 3,45 & 5,65 & 5,57 & 7,09 & 5,26 & 4,28 & 3,24 & 0,00 & 0,00 & 5,03 \\
\hline Revistas & 0,00 & 0,72 & 0,57 & 1,88 & 2,29 & 3,07 & 3,36 & 4,28 & 5,56 & 0,00 & 0,00 & 3,05 \\
\hline Químicos & 0,00 & 0,72 & 0,57 & 1,08 & 1,14 & 1,18 & 1,65 & 3,74 & 3,47 & 0,00 & 0,00 & 1,66 \\
\hline Borracha & 5,00 & 2,88 & 4,02 & 4,03 & 4,43 & 2,60 & 2,53 & 1,60 & 0,69 & 0,00 & 0,00 & 2,85 \\
\hline Cimento & 0,00 & 0,72 & 0,57 & 0,81 & 1,00 & 1,18 & 1,14 & 1,07 & 0,93 & 0,00 & 0,00 & 1,04 \\
\hline Aço & 0,00 & 0,72 & 1,15 & 2,15 & 1,14 & 1,65 & 1,52 & 1,07 & 1,16 & 0,00 & 0,00 & 1,41 \\
\hline Metal & 0,00 & 2,16 & 1,15 & 1,61 & 2,29 & 2,36 & 1,52 & 1,07 & 0,69 & 0,00 & 0,00 & 1,63 \\
\hline Eletrodomésticos & 0,00 & 2,88 & 2,87 & 4,84 & 4,57 & 5,20 & 7,10 & 7,49 & 4,40 & 0,00 & 25,00 & 5,64 \\
\hline Informática & 0,00 & 0,72 & 0,57 & 2,42 & 1,86 & 2,13 & 5,89 & 16,58 & 5,79 & 0,00 & 0,00 & 4,53 \\
\hline Máquinas & 0,00 & 0,72 & 1,15 & 3,23 & 2,29 & 3,07 & 2,41 & 2,14 & 1,16 & 0,00 & 0,00 & 2,25 \\
\hline Eletrônicos & 0,00 & 0,72 & 1,15 & 1,61 & 1,43 & 1,89 & 8,37 & 3,21 & 4,63 & 0,00 & 0,00 & 4,58 \\
\hline $\begin{array}{l}\text { Instrumento } \\
\text { hospitalar }\end{array}$ & 0,00 & 0,72 & 1,15 & 0,81 & 1,29 & 1,89 & 2,85 & 2,67 & 3,70 & 0,00 & 0,00 & 2,23 \\
\hline Veículos & 10,00 & 2,88 & 1,72 & 1,88 & 4,43 & 3,31 & 3,30 & 3,74 & 10,65 & 27,27 & 0,00 & 4,16 \\
\hline Indústria Diversa & 5,00 & 25,90 & 5,75 & 6,18 & 3,86 & 3,78 & 2,85 & 1,07 & 0,69 & 0,00 & 0,00 & 3,99 \\
\hline SIUP & 0,00 & 3,60 & 4,60 & 0,81 & 0,86 & 0,71 & 1,14 & 1,07 & 3,24 & 9,09 & 0,00 & 1,49 \\
\hline Construção Civil & 5,00 & 6,47 & 3,45 & 3,49 & 2,29 & 1,89 & 1,52 & 1,07 & 1,16 & 0,00 & 0,00 & 2,08 \\
\hline Comércio & 0,00 & 1,44 & 1,72 & 2,42 & 3,71 & 4,73 & 5,64 & 3,21 & 1,62 & 0,00 & 0,00 & 4,04 \\
\hline Transportes & 0,00 & 1,44 & 1,72 & 2,42 & 2,29 & 2,36 & 2,41 & 2,14 & 3,01 & 0,00 & 0,00 & 2,35 \\
\hline Informação & 0,00 & 0,00 & 0,57 & 0,54 & 0,71 & 0,71 & 1,33 & 3,74 & 4,17 & 0,00 & 0,00 & 1,44 \\
\hline Financeiro & 0,00 & 0,00 & 0,57 & 0,27 & 0,43 & 0,24 & 0,70 & 2,67 & 4,40 & 0,00 & 0,00 & 0,99 \\
\hline Imobiliário & 0,00 & 0,72 & 0,57 & 0,54 & 0,43 & 0,47 & 0,38 & 0,53 & 0,23 & 0,00 & 0,00 & 0,42 \\
\hline Alojamento & 5,00 & 1,44 & 2,30 & 3,23 & 4,57 & 5,20 & 3,68 & 1,07 & 0,93 & 0,00 & 0,00 & 3,37 \\
\hline $\begin{array}{l}\text { Serviços às } \\
\text { Empresas }\end{array}$ & 5,00 & 2,16 & 3,45 & 3,23 & 4,00 & 3,07 & 3,68 & 5,35 & 3,47 & 9,09 & 25,00 & 3,64 \\
\hline $\begin{array}{l}\text { Educação e Saúde } \\
\text { mercantis }\end{array}$ & 0,00 & 0,72 & 1,15 & 1,34 & 1,43 & 1,89 & 3,87 & 4,81 & 9,49 & 27,27 & 25,00 & 3,52 \\
\hline Outros Serviços & 5,00 & 2,88 & 2,87 & 2,69 & 2,29 & 2,84 & 2,34 & 3,21 & 4,17 & 0,00 & 0,00 & 2,70 \\
\hline
\end{tabular}


Tabela 25 - Distribuição setorial do emprego direto e indireto gerados por grau de instrução pela variação da demanda final de 10 milhões de reais - Distrito Federal - 2008 (\%) (conclusão).

\begin{tabular}{lrrrrrrrrrrrr}
\hline \multicolumn{1}{c}{ Setores } & $\mathbf{G ( 0 )}$ & $\mathbf{G ( 1 )}$ & $\mathbf{G}(\mathbf{2})$ & $\mathbf{G ( 3 )}$ & $\mathbf{G}(\mathbf{4})$ & $\mathbf{G}(\mathbf{5})$ & $\mathbf{G}(\mathbf{6})$ & $\mathbf{G ( 7 )}$ & $\mathbf{G}(\mathbf{8})$ & $\mathbf{G}(\mathbf{9})$ & $\mathbf{G ( 1 0 )}$ & Total \\
\hline APU & 0,00 & 0,72 & 0,57 & 0,54 & 1,29 & 0,47 & 1,46 & 1,60 & 4,86 & 0,00 & 0,00 & 1,51 \\
Total & 100 & 100 & 100 & 100 & 100 & 100 & 100 & 100 & 100 & 100 & 100 & 100 \\
\hline
\end{tabular}

Onde: Analfabeto - $\mathrm{G}(0)$; Até o $5^{\circ}$ ano incompleto do ensino fundamental - $\mathrm{G}(1) ; 5^{\circ}$ ano completo do ensino fundamental - G(2); Do $6^{\circ}$ ao $9^{\circ}$ ano incompleto do ensino fundamental - G(3); Ensino fundamental completo G(4); Ensino médio incompleto - G(5); Ensino médio completo - G(6); Educação superior incompleta - G(7); Educação superior completa - G(8); Mestrado - G(9); Doutorado - G(10).

Fonte: Adaptado da RAIS 2008.

Ainda em análise a Tabela 25, cabe citar que, para os trabalhos pertencentes as classes de $\mathrm{G}(0)$ a $\mathrm{G}(6)$ o setor madeira se destacou contribuindo significativamente para o crescimento deste setor econômico, no DF. Porém este setor não é predominante no DF, mas vale ressaltar a importância deste setor na captação de mão de obra pouco qualificada. Este mesmo resultado foi observado na economia baiana, o que nos permite concluir que o setor de madeira, uma vez estimulado, poderá ser estratégico para geração de renda nas classes com baixa instrução.

A Tabela 26 demonstra a distribuição dos novos empregos diretos e indiretos gerados a partir da variação da demanda final em $\mathrm{R} \$$ 10.000.000,00 (dez milhões de reais), por grau de instrução, para cada atividade econômica. Inicialmente, pode-se constatar que dos novos empregos 39,07\% foram alocados para trabalhadores com o ensino médio completo. Este percentual também foi identificado por Silva (2008), onde foram criados 39,02\% de novos empregos para o mesmo grau de instrução, reforçando que este perfil de trabalhador possui maiores chances de empregabilidade quando da injeção de recursos financeiros na econômica de uma região. Outros $37,01 \%$ dos novos empregos são para trabalhadores do $6^{\circ}$ ano do ensino fundamental ao nível médio incompleto. No estudo realizado por Silva (2008) este percentual foi de $33,67 \%$ para trabalhadores com mesmo perfil, demonstrando, novamente, comportamentos similares entre os perfis da educação da Bahia e do DF.

Outro destaque é o percentual de novos empregos que foram gerados para trabalhadores a partir da educação superior incompleta, que alcançou 15,70\%, sendo que destes, apenas $0,37 \%$ representam trabalhadores em nível de mestrado ou doutorado. Por outro lado $0,50 \%$ dos novos postos são destinados a trabalhadores que não possuem instrução formal e $7,75 \%$ aos indivíduos com até o $5^{\circ}$ ano completo do ensino fundamental. 
Tabela 26 - Distribuição por grau de instrução do emprego direto e indireto gerados por setor pela variação da demanda final de 10 milhões de reais - Distrito Federal - $2008(\%)$.

\begin{tabular}{|c|c|c|c|c|c|c|c|c|c|c|c|c|}
\hline Setores & $\mathbf{G}(\mathbf{0})$ & $\mathbf{G}(\mathbf{1})$ & $\mathbf{G}(2)$ & G(3) & G(4) & G(5) & $G(6)$ & G(7) & $\mathbf{G}(\mathbf{8})$ & G(9) & G(10) & Total \\
\hline Agricultura & 1,49 & 13,43 & 10,45 & 13,43 & 17,91 & 8,96 & 25,37 & 2,99 & 5,97 & 0,00 & 0,00 & 100 \\
\hline Pecuária & 1,92 & 8,65 & 11,54 & 19,23 & 18,27 & 8,65 & 26,92 & 1,92 & 3,85 & 0,00 & 0,00 & 100 \\
\hline Extrativa & 0,61 & 2,45 & 6,75 & 8,59 & 19,02 & 7,98 & 31,29 & 4,29 & 19,02 & 0,00 & 0,00 & 100 \\
\hline Alimentos & 1,02 & 4,08 & 4,08 & 10,20 & 19,39 & 14,29 & 40,82 & 3,06 & 4,08 & 0,00 & 0,00 & 100 \\
\hline Vestuário & 0,47 & 1,42 & 1,89 & 8,49 & 21,23 & 13,68 & 47,17 & 2,36 & 2,83 & 0,00 & 0,00 & 100 \\
\hline Madeira & 0,99 & 3,57 & 9,92 & 16,07 & 27,78 & 15,87 & 22,22 & 1,79 & 1,59 & 0,00 & 0,00 & 100 \\
\hline Celulose & 0,00 & 0,99 & 2,96 & 10,34 & 19,21 & 14,78 & 40,89 & 3,94 & 6,90 & 0,00 & 0,00 & 100 \\
\hline Revistas & 0,00 & 0,81 & 0,81 & 5,69 & 13,01 & 10,57 & 43,09 & 6,50 & 19,51 & 0,00 & 0,00 & 100 \\
\hline Químicos & 0,00 & 1,49 & 1,49 & 5,97 & 11,94 & 7,46 & 38,81 & 10,45 & 22,39 & 0,00 & 0,00 & 100 \\
\hline Borracha & 0,87 & 3,48 & 6,09 & 13,04 & 26,96 & 9,57 & 34,78 & 2,61 & 2,61 & 0,00 & 0,00 & 100 \\
\hline Cimento & 0,00 & 2,38 & 2,38 & 7,14 & 16,67 & 11,90 & 42,86 & 4,76 & 9,52 & 0,00 & 0,00 & 100 \\
\hline Aço & 0,00 & 1,75 & 3,51 & 14,04 & 14,04 & 12,28 & 42,11 & 3,51 & 8,77 & 0,00 & 0,00 & 100 \\
\hline Metal & 0,00 & 4,55 & 3,03 & 9,09 & 24,24 & 15,15 & 36,36 & 3,03 & 4,55 & 0,00 & 0,00 & 100 \\
\hline Eletrodomésticos & 0,00 & 1,75 & 2,19 & 7,89 & 14,04 & 9,65 & 49,12 & 6,14 & 8,33 & 0,00 & 0,44 & 100 \\
\hline Informática & 0,00 & 0,55 & 0,55 & 4,92 & 7,10 & 4,92 & 50,82 & 16,94 & 13,66 & 0,00 & 0,00 & 100 \\
\hline Máquinas & 0,00 & 1,10 & 2,20 & 13,19 & 17,58 & 14,29 & 41,76 & 4,40 & 5,49 & 0,00 & 0,00 & 100 \\
\hline Eletrônicos & 0,00 & 0,54 & 1,08 & 3,24 & 5,41 & 4,32 & 71,35 & 3,24 & 10,81 & 0,00 & 0,00 & 100 \\
\hline Instrumento hospitalar & 0,00 & 1,11 & 2,22 & 3,33 & 10,00 & 8,89 & 50,00 & 5,56 & 17,78 & 0,00 & 0,00 & 100 \\
\hline Veículos & 1,19 & 2,38 & 1,79 & 4,17 & 18,45 & 8,33 & 30,95 & 4,17 & 27,38 & 1,79 & 0,00 & 100 \\
\hline Indústria Diversa & 0,62 & 22,36 & 6,21 & 14,29 & 16,77 & 9,94 & 27,95 & 1,24 & 1,86 & 0,00 & 0,00 & 100 \\
\hline SIUP & 0,00 & 8,33 & 13,33 & 5,00 & 10,00 & 5,00 & 30,00 & 3,33 & 23,33 & 1,67 & 0,00 & 100 \\
\hline Construção Civil & 1,19 & 10,71 & 7,14 & 15,48 & 19,05 & 9,52 & 28,57 & 2,38 & 5,95 & 0,00 & 0,00 & 100 \\
\hline Comércio & 0,00 & 1,23 & 1,84 & 5,52 & 15,95 & 12,27 & 54,60 & 3,68 & 4,29 & 0,00 & 0,00 & 100 \\
\hline Transportes & 0,00 & 2,11 & 3,16 & 9,47 & 16,84 & 10,53 & 40,00 & 4,21 & 13,68 & 0,00 & 0,00 & 100 \\
\hline Informação & 0,00 & 0,00 & 1,72 & 3,45 & 8,62 & 5,17 & 36,21 & 12,07 & 31,03 & 0,00 & 0,00 & 100 \\
\hline Financeiro & 0,00 & 0,00 & 2,50 & 2,50 & 7,50 & 2,50 & 27,50 & 12,50 & 47,50 & 0,00 & 0,00 & 100 \\
\hline Imobiliário & 0,00 & 5,88 & 5,88 & 11,76 & 17,65 & 11,76 & 35,29 & 5,88 & 5,88 & 0,00 & 0,00 & 100 \\
\hline Alojamento & 0,74 & 1,47 & 2,94 & 8,82 & 23,53 & 16,18 & 42,65 & 1,47 & 2,94 & 0,00 & 0,00 & 100 \\
\hline Serviços às Empresas & 0,68 & 2,04 & 4,08 & 8,16 & 19,05 & 8,84 & 39,46 & 6,80 & 10,20 & 0,68 & 0,68 & 100 \\
\hline $\begin{array}{l}\text { Educação e Saúde } \\
\text { mercantis }\end{array}$ & 0,00 & 0,70 & 1,41 & 3,52 & 7,04 & 5,63 & 42,96 & 6,34 & 28,87 & 2,11 & 0,70 & 100 \\
\hline Outros Serviços & 0,92 & 3,67 & 4,59 & 9,17 & 14,68 & 11,01 & 33,94 & 5,50 & 16,51 & 0,00 & 0,00 & 100 \\
\hline APU & 0,00 & 1,64 & 1,64 & 3,28 & 14,75 & 3,28 & 37,70 & 4,92 & 34,43 & 0,00 & 0,00 & 100 \\
\hline Total & 0,50 & 3,44 & 4,31 & 9,21 & 17,33 & 10,47 & 39,07 & 4,63 & 10,70 & 0,27 & 0,10 & 100 \\
\hline
\end{tabular}

Fonte: Adaptado da RAIS 2008 e da matriz inversa de Leontief (2008).

Onde: Analfabeto - $\mathrm{G}(0)$; Até o $5^{\circ}$ ano incompleto do ensino fundamental - $\mathrm{G}(1)$; $5^{\circ}$ ano completo do ensino fundamental - G(2); Do $6^{\circ}$ ao $9^{\circ}$ ano incompleto do ensino fundamental - G(3); Ensino fundamental completo G(4); Ensino médio incompleto - G(5); Ensino médio completo - G(6); Educação superior incompleta - G(7); Educação superior completa - G(8); Mestrado - G(9); Doutorado - G(10). 
Em continuidade a análise da Tabela 26 observa-se que os setores que mais contribuem na geração de empregos são pecuária, madeira, celulose, metal, veículos, indústria diversa, construção civil e alojamento.

Nos setores pecuária e construção civil, os graus de instrução que mais geraram empregos foram G(3), com 19,23\% e 15,48\%, G(4), com 18,27\% e 19,05\% e G(6), com $26,92 \%$ e $28,57 \%$.

No setor de madeira, a concentração dos postos de trabalhos gerados são destinadas a indivíduos dos graus $\mathrm{G}(3)$ ao $\mathrm{G}(6)$, representando $16,07 \%, 27,78 \%, 15,87 \%$, e 22,22\%, respectivamente. No setor veículos, os graus de instrução que mais geram novos postos de trabalho são $\mathrm{G}(4), \mathrm{G}(6)$ e $\mathrm{G}(8)$, com $18,45 \%$, 30,95\% e 27,38\%, respectivamente. No setor indústria diversa a maior concentração deu-se nos graus $\mathrm{G}(1), \mathrm{G}(4)$ e no $\mathrm{G}(6)$, apresentando $22,36 \%, 16,77 \%$ e $27,95 \%$, respectivamente.

Nos setores celulose, metal e alojamento, destacaram-se os graus G(4) a G(6). Para o grau $\mathrm{G}(4)$ os percentuais resultaram em $19,21 \%, 24,24 \%$ e $23,53 \%$, respectivamente. Quanto ao grau $\mathrm{G}(5)$ temos $14,78 \%, 15,15 \%$ e $16,18 \%$. E o grau $\mathrm{G}(6) 40,89 \%, 36,36 \%$ e $42,65 \%$.

Já os setores informática, eletrônicos, instrumento hospitalar e comércio ofertaram a maioria de seus novos empregos a trabalhadores pertencentes ao grau G(8), com educação superior completa. Em termos gerais, dos postos de trabalho gerados, em todas as atividades econômicas analisadas a oportunidade de emprego alcançou os trabalhadores que possuem o ensino médio completo.

Comparando o comportamento do grau $\mathrm{G}(0)$, analfabetos, em relação aos graus $\mathrm{G}(9)$, mestrado, e G(10), doutorado, observa-se que quanto aos analfabetos apenas os setores agricultura (1,49\%), pecuária (1,92\%), veículos (1,19\%) e construção civil $(1,19 \%)$, apresentaram percentual acima de $1 \%$. Para o grau G(9), tal comportamento só foi identificado nos setores veículos, SIUP e educação e saúde mercantis, com 1,79\%, 1,67\% e $2,11 \%$. Para os demais setores, os percentuais apresentados não alcançaram sequer $1 \%$, sendo que para o grau $\mathrm{G}(10)$ tal comportamento foi generalizado, visto que nenhum setor apresentou percentual acima de $1 \%$. Assim, pode-se afirmar que poucos empregos são gerados para trabalhadores sem instrução formal, bem como para trabalhadores com título de mestrado e doutorado. 


\subsubsection{Multiplicadores de renda}

A Tabela 27 demonstra a renda salarial direta e indireta gerada na economia do DF a partir da variação de $\mathrm{R} \$ 10.000 .000,00$ (dez milhões de reais) na demanda final de cada setor econômico analisado. De modo geral, pode-se afirmar que a geração de renda salarial alcançará R\$ 1.027.692,00 (um milhão, vinte e sete mil, seiscentos e noventa e dois reais). Para a economia baiana, a mesma variação de 10 milhões gerou renda salarial de $\mathrm{R} \$$ 96.201,03 (noventa e seis mil, duzentos e um reais e três centavos), conforme apresentado por Silva (2008), representando apenas 9,36\% da renda alcançada no DF.

Ao analisar a tabela observa-se que os trabalhadores pertencentes aos graus de $\mathrm{G}(7)$ a G(9) absorveram maior parte da renda salarial, sendo $\mathrm{R} \$ 154.922,00 ; \mathrm{R} \$ 379.387,00$ e $\mathrm{R} \$$ $91.013,00$, respectivamente.

Os trabalhadores pertencentes aos graus $\mathrm{G}(2)$ a $\mathrm{G}(6)$ estão em faixa intermediária, alcançando renda salarial de $\mathrm{R} \$ 47.108,00 ; \mathrm{R} \$ 65.533,00 ; \mathrm{R} \$ 61.056,00 ; \mathrm{R} \$ 54.567,00$ e $\mathrm{R} \$$ 85.356,00, respectivamente. Logo abaixo, aparecem os graus $\mathrm{G}(0), \mathrm{G}(1)$ e $\mathrm{G}(10)$ com $\mathrm{R} \$$ $16.728,00 ; \mathrm{R} \$ 41.374,00$ e $\mathrm{R} \$ 30.648,00$, respectivamente.

Durante sua análise, Silva (2008, p. 97) afirmou que "observa-se que os trabalhadores com menores níveis de instrução ficam com menores rendas”. Em termos gerais, a constatação de Silva (2008) também ocorre na economia do DF, com ressalva ao ocorrido no grau $\mathrm{G}(10)$, pois neste caso, apesar de $\mathrm{G}(10)$ ser o maior nível de instrução em análise, o trabalho de Silva não efetuou a segregação para os graus de mestrado e doutorado, não sendo possível realizar tal tipo de comparação, quanto a estes níveis de ensino.

Ademais, os setores que mais contribuem na geração de renda são: veículos ( $R$ \$ 253.830,00), informática ( $\mathrm{R} \$ 132.168,00)$, extrativa ( $\mathrm{R} \$ 108.101,00)$ e celulose (R\$ 105.036,00). Ressalta-se o setor celulose, que possui pequeno porte na economia do DF, o que resulta em alavancagem para o setor diante de variação na demanda final da economia reginal 
Tabela 27 - Renda salarial direta e indireta geradas por grau de instrução pela variação da demanda final de 10 milhões de reais - Distrito Federal - 2008 (em R\$1,00).

\begin{tabular}{|c|c|c|c|c|c|c|c|c|c|c|c|c|}
\hline Setores & $\mathrm{G}(0)$ & $\mathrm{G}(1)$ & $\mathrm{G}(2)$ & $\mathrm{G}(3)$ & $\mathrm{G}(4)$ & $\mathrm{G}(5)$ & $\mathrm{G}(6)$ & $G(7)$ & $\mathrm{G}(8)$ & $G(9)$ & $\mathrm{G}(10)$ & Média Total \\
\hline Agricultura & 103,00 & 316,00 & 234,00 & 218,00 & 179,00 & 275,00 & 299,00 & 571,00 & 933,00 & $1.179,00$ & $2.348,00$ & $6.656,00$ \\
\hline Pecuária & 283,00 & 342,00 & 322,00 & 344,00 & 323,00 & 355,00 & 497,00 & 830,00 & $1.831,00$ & 300,00 & 245,00 & $5.673,00$ \\
\hline Extrativa & $2.509,00$ & $3.736,00$ & $4.578,00$ & $4.883,00$ & $3.274,00$ & $6.607,00$ & $6.683,00$ & $18.241,00$ & $35.426,00$ & $22.096,00$ & 67,00 & $108.101,00$ \\
\hline Alimentos & 72,00 & 154,00 & 89,00 & 141,00 & 83,00 & 183,00 & 221,00 & 423,00 & 981,00 & 929,00 & 225,00 & $3.502,00$ \\
\hline Vestuário & $1.819,00$ & $2.011,00$ & $1.979,00$ & $2.884,00$ & $2.864,00$ & $2.712,00$ & $3.220,00$ & $4.763,00$ & $8.116,00$ & 36,00 & $14.843,00$ & $45.247,00$ \\
\hline Madeira & $5.244,00$ & $9.561,00$ & $8.050,00$ & $7.816,00$ & $8.531,00$ & $7.378,00$ & $7.806,00$ & $6.085,00$ & $33.134,00$ & 38,00 & 34,00 & $93.677,00$ \\
\hline Celulose & 66,00 & $6.047,00$ & $9.315,00$ & $6.569,00$ & $8.171,00$ & $7.568,00$ & $13.302,00$ & $22.164,00$ & $31.582,00$ & 127,00 & 124,00 & $105.036,00$ \\
\hline evistas & 182,00 & 342,00 & 359,00 & 385,00 & 352,00 & 321,00 & 419,00 & 719,00 & $1.725,00$ & 23,00 & 26,00 & $4.853,00$ \\
\hline uímicos & 355,00 & 990,00 & 949,00 & 869,00 & 720,00 & 856,00 & $1.343,00$ & $2.218,00$ & $2.946,00$ & $2.990,00$ & $2.978,00$ & $17.214,00$ \\
\hline Borracha & $1.317,00$ & $1.473,00$ & $1.438,00$ & $1.662,00$ & $1.467,00$ & $1.407,00$ & $1.552,00$ & $3.168,00$ & $7.921,00$ & 80,00 & 74,00 & $21.560,00$ \\
\hline Cimento & 65,00 & 102,00 & 97,00 & 110,00 & 114,00 & 116,00 & 170,00 & 239,00 & 714,00 & 64,00 & $2.029,00$ & $3.822,00$ \\
\hline Aço & 70,00 & $1.509,00$ & $1.079,00$ & $2.122,00$ & $1.295,00$ & $1.403,00$ & $1.593,00$ & $1.999,00$ & $7.552,00$ & 478,00 & 89,00 & $19.187,00$ \\
\hline Metal & 237,00 & 380,00 & 311,00 & 316,00 & 351,00 & 334,00 & 447,00 & 663,00 & $1.225,00$ & 70,00 & 34,00 & $4.368,00$ \\
\hline Eletrodomésticos & 68,00 & $6.590,00$ & $5.932,00$ & $5.169,00$ & $3.661,00$ & $5.052,00$ & $5.510,00$ & $7.867,00$ & $27.421,00$ & 301,00 & 92,00 & $67.663,00$ \\
\hline Informática & 43,00 & 163,00 & $1.017,00$ & $15.670,00$ & $10.506,00$ & $4.386,00$ & $19.797,00$ & $25.806,00$ & $54.570,00$ & 151,00 & 58,00 & $132.168,00$ \\
\hline has & 35,00 & $1.135,00$ & $2.159,00$ & 504,00 & 21,00 & $1.559,00$ & $1.740,00$ & 3.820 & $3.758,00$ & & 66,00 & $17.286,00$ \\
\hline Eletrônicos & 79,00 & 9,00 & $4.333,00$ & $5.371,00$ & $6.150,00$ & $4.416,00$ & $4.465,00$ & $10.723,00$ & $38.738,00$ & 249,00 & 69,00 & $74.892,00$ \\
\hline Instrumento hospitalar & 18,00 & 976,00 & 910,00 & $1.145,00$ & $1.467,00$ & $1.005,00$ & $1.864,00$ & $2.328,00$ & $4.870,00$ & $6.732,00$ & $4.913,00$ & $26.228,00$ \\
\hline Veículos & $3.462,00$ & $4.462,00$ & $3.078,00$ & $7.400,00$ & $9.277,00$ & $7.718,00$ & $13.213,00$ & $40.364,00$ & $112.465,00$ & $52.314,00$ & 77,00 & $253.830,00$ \\
\hline Indústria Diversa & 477,00 & 457,00 & 560,00 & 481,00 & 497,00 & 486,00 & 537,00 & $1.058,00$ & $1.401,00$ & 48,00 & 60,00 & $6.061,00$ \\
\hline SIUP & 45,00 & 5,00 & 68,00 & 182,00 & 177,00 & 153,00 & 311,00 & 327,00 & 755,00 & 952,00 & 705,00 & $3.739,00$ \\
\hline Construção &, 00 & 4,00 & 26,00 & 27,00 & 28,00 & 27,00 & 35,00 & 53,00 & 154,00 & 109,00 & 117,00 & 619,00 \\
\hline Comércio & 10,00 & 15,00 & 15,00 & 16,00 & 15,00 & 15,00 & 20,00 & 32,00 & 65,00 & 75,00 & 166,00 & 444,00 \\
\hline Transportes &, 00 & 29,00 & 29,00 & 30,00 & 8,00 & 26,00 & & 57,00 & 153,00 & & 157,00 & 731,00 \\
\hline Inform & 18 & 7,00 & 26,00 & 28,00 & 27,00 & 29,00 & 39,00 & 56,00 & 134,00 & & 174,00 & 758,00 \\
\hline Finan & 7,00 & 00 & 16,00 & 31,00 & 31,00 & 26,00 & 33,00 & 34,00 & 79,00 & 104,00 & 118,00 & 492,00 \\
\hline Imobil & 11,00 &, 00 & 14,00 & 19,00 & 17,00 & 18,00 & 24,00 & 38,00 & 119,00 & 182,00 & 5,00 & 467,00 \\
\hline Alojamento & 30,00 & 48,00 & 39,00 & 46,00 & 37,00 & 48,00 & 57,00 & 99,00 & 217,00 & 320,00 & 122,00 & $1.064,00$ \\
\hline Serviç & 15,00 & 21,00 & 23,00 & 24,00 & 24,00 & 23,00 & 32,00 & 46,00 & 110,00 & 132,00 & 185,00 & 636,00 \\
\hline Educação e S: & 23,00 & 31,00 & 31,00 & 32,00 & 29,00 & 28,00 & 36,00 & 52,00 & 114,00 & 132,00 & 197,00 & 705,00 \\
\hline Outros Serviços & 20,00 & 25,00 & 26,00 & 28,00 & 29,00 & 26,00 & 39,00 & 60,00 & 132,00 & 208,00 & 213,00 & 807,00 \\
\hline APU & 4,00 & 9,00 & 7,00 & 11,00 & 11,00 & 10,00 & 15,00 & 18,00 & 45,00 & 40,00 & 37,00 & 207,00 \\
\hline Total & $16.728,00$ & $41.374,00$ & $47.108,00$ & $65.533,00$ & $61.056,00$ & $54.567,00$ & $85.356,00$ & $154.922,00$ & $379.387,00$ & $91.013,00$ & $30.648,00$ & $1.027 .692,00$ \\
\hline
\end{tabular}

Onde: Analfabeto - G(0); Até o $5^{\circ}$ ano incompleto do ensino fundamental - G(1); $5^{\circ}$ ano completo do ensino fundamental - G(2); Do $6^{\circ}$ ao $9^{\circ}$ ano incompleto do ensino fundamental - G(3); Ensino fundamental completo - G(4); Ensino médio incompleto - G(5); Ensino médio completo - G(6); Educação superior incompleta - G(7); Educação superior completa - G(8); Mestrado G(9); Doutorado - G(10).

Fonte: Adaptado da RAIS 2008 e da matriz Inversa de Leontief (2008). 
Em comparação entre os graus $\mathrm{G}(0)$ e $\mathrm{G}(1), 31$ dos 32 setores analisados geraram maiores rendas salariais em $\mathrm{G}(1)$ do que em $\mathrm{G}(0)$, sendo que este comportamento também ocorreu em análise ao grau $\mathrm{G}(8)$, em relação a $\mathrm{G}(7)$ e no grau $\mathrm{G}(7)$ em relação a $\mathrm{G}(6)$. Se analisado $G(1)$ e $G(2)$, em 11 dos casos os trabalhadores pertencentes ao grau $G(2)$ auferiram rendas maiores que $\mathrm{g}(1)$, tal comportamento ocorre também quando da análise do grau $\mathrm{G}(10)$ em relação a $G(9)$. Ao observar $G(3)$ em relação a $G(2)$ este quantitativo sobre para 25 . Quando analisado G(4) em relação a G(3) o quantitativo cai para 10 setores. Se comparado G(5) com G(4) 12 dos 32 setores ofereceram rendas maiores em G(5) do que em G(4), sendo que o mesmo ocorre ao analisar $\mathrm{G}(9)$ em relação a $\mathrm{G}(8)$. Contudo, no graus $\mathrm{G}(6)$ todos os 32 setores ofertaram rendas maiores que no grau $\mathrm{G}(5)$.

Por fim, na economia baiana observou-se que para os trabalhadores com grau de instrução acima do $\mathrm{G}(6)$ possuem rendas salariais maiores que os demais. Assim, em termos gerais pode-se afirmar que para o mesmo período analisado o comportamento se replica na economia do DF, contudo, destaca-se a queda apresentada para os graus $G(9)$ e $G(10)$, onde o estudo anterior não efetuou a análise. Ademais, pode-se afirmar que os valores apresentados nos graus $G(9)$ e $G(10)$ são relativamente menores tendo em vista que a população que alcança altos níveis de instrução representa apenas $0,64 \%$ da população do DF, que em 2008 se aproximou a um milhão de habitantes, conforme já exposto na Tabela 18.

A Tabela 28 apresenta, em percentual, a distribuição renda salarial direta e indireta, de forma setorial e por grau de instrução, diante da variação da demanda final em $\mathrm{R}$ \$ 10.000.000,00 (dez milhões de reais), demonstrando a renda gerada por atividade econômica para cada grau de instrução.

Ao analisar a tabela observa-se que o setor têxteis apresentou percentuais elevados para os graus $\mathrm{G}(0)$ a $\mathrm{G}(1)$. O setor celulose apresenta altos percentuais para o grau $\mathrm{G}(2)$, já o setor informática demonstrou destaque nos níveis $\mathrm{G}(3), \mathrm{G}(4)$ e $\mathrm{G}(6)$. O setor veículos, por sua vez, concentrou a distribuição de renda nos graus $G(5)$ e $G(7)$ a $G(9)$. Para o grau $G(10)$ a concentração de renda ocorreu no setor vestuário. Contudo, o setor que menos gerou renda foi APU. 
Tabela 28 - Distribuição setorial da renda salarial direta e indireta geradas por grau de instrução pela variação da demanda final de 10 milhões de reais - Distrito Federal - 2008.

\begin{tabular}{|c|c|c|c|c|c|c|c|c|c|c|c|c|}
\hline Setores & $\mathbf{G}(\mathbf{0})$ & $\mathbf{G}(\mathbf{1})$ & $\mathbf{G}(2)$ & $\mathbf{G}(\mathbf{3})$ & G(4) & G(5) & G(6) & G(7) & $\mathbf{G}(\mathbf{8})$ & $\mathbf{G}(\mathbf{9})$ & G(10) & Total \\
\hline Agricultura & 0,62 & 0,76 & 0,50 & 0,33 & 0,29 & 0,50 & 0,35 & 0,37 & 0,25 & 1,30 & 7,66 & 0,65 \\
\hline Pecuária & 1,69 & 0,83 & 0,68 & 0,52 & 0,53 & 0,65 & 0,58 & 0,54 & 0,48 & 0,33 & 0,80 & 0,55 \\
\hline Extrativa & 15,00 & 9,03 & 9,72 & 7,45 & 5,36 & 12,11 & 7,83 & 11,77 & 9,34 & 24,28 & 0,22 & 10,52 \\
\hline Alimentos & 0,43 & 0,37 & 0,19 & 0,22 & 0,14 & 0,34 & 0,26 & 0,27 & 0,26 & 1,02 & 0,73 & 0,34 \\
\hline Vestuário & 10,87 & 4,86 & 4,20 & 4,40 & 4,69 & 4,97 & 3,77 & 3,07 & 2,14 & 0,04 & 48,43 & 4,40 \\
\hline Madeira & 31,35 & 23,11 & 17,09 & 11,93 & 13,97 & 13,52 & 9,15 & 3,93 & 8,73 & 0,04 & 0,11 & 9,12 \\
\hline Celulose & 0,39 & 14,62 & 19,77 & 10,02 & 13,38 & 13,87 & 15,58 & 14,31 & 8,32 & 0,14 & 0,40 & 10,22 \\
\hline Revistas & 1,09 & 0,83 & 0,76 & 0,59 & 0,58 & 0,59 & 0,49 & 0,46 & 0,45 & 0,03 & 0,08 & 0,47 \\
\hline Químicos & 2,12 & 2,39 & 2,01 & 1,33 & 1,18 & 1,57 & 1,57 & 1,43 & 0,78 & 3,29 & 9,72 & 1,68 \\
\hline Borracha & 7,87 & 3,56 & 3,05 & 2,54 & 2,40 & 2,58 & 1,82 & 2,04 & 2,09 & 0,09 & 0,24 & 2,10 \\
\hline Cimento & 0,39 & 0,25 & 0,21 & 0,17 & 0,19 & 0,21 & 0,20 & 0,15 & 0,19 & 0,07 & 6,62 & 0,37 \\
\hline Aço & 0,42 & 3,65 & 2,29 & 3,24 & 2,12 & 2,57 & 1,87 & 1,29 & 1,99 & 0,53 & 0,29 & 1,87 \\
\hline Metal & 1,42 & 0,92 & 0,66 & 0,48 & 0,57 & 0,61 & 0,52 & 0,43 & 0,32 & 0,08 & 0,11 & 0,43 \\
\hline Eletrodomésticos & 0,41 & 15,93 & 12,59 & 7,89 & 6,00 & 9,26 & 6,46 & 5,08 & 7,23 & 0,33 & 0,30 & 6,58 \\
\hline Informática & 0,26 & 0,39 & 2,16 & 23,91 & 17,21 & 8,04 & 23,19 & 16,66 & 14,38 & 0,17 & 0,19 & 12,86 \\
\hline Máquinas & 0,21 & 2,74 & 4,58 & 2,30 & 2,16 & 2,86 & 2,04 & 2,47 & 0,99 & 0,21 & 0,22 & 1,68 \\
\hline Eletrônicos & 0,47 & 0,72 & 9,20 & 8,20 & 10,07 & 8,09 & 5,23 & 6,92 & 10,21 & 0,27 & 0,23 & 7,29 \\
\hline Instrumento hospitalar & 0,11 & 2,36 & 1,93 & 1,75 & 2,40 & 1,84 & 2,18 & 1,50 & 1,28 & 7,40 & 16,03 & 2,55 \\
\hline Veículos & 20,70 & 10,78 & 6,53 & 11,29 & 15,19 & 14,14 & 15,48 & 26,05 & 29,64 & 57,48 & 0,25 & 24,70 \\
\hline Indústria Diversa & 2,85 & 1,10 & 1,19 & 0,73 & 0,81 & 0,89 & 0,63 & 0,68 & 0,37 & 0,05 & 0,20 & 0,59 \\
\hline SIUP & 0,27 & 0,16 & 0,14 & 0,28 & 0,29 & 0,28 & 0,36 & 0,21 & 0,20 & 1,05 & 2,30 & 0,36 \\
\hline Construção Civil & 0,11 & 0,06 & 0,06 & 0,04 & 0,05 & 0,05 & 0,04 & 0,03 & 0,04 & 0,12 & 0,38 & 0,06 \\
\hline Comércio & 0,06 & 0,04 & 0,03 & 0,02 & 0,02 & 0,03 & 0,02 & 0,02 & 0,02 & 0,08 & 0,54 & 0,04 \\
\hline Transportes & 0,12 & 0,07 & 0,06 & 0,05 & 0,05 & 0,05 & 0,04 & 0,04 & 0,04 & 0,18 & 0,51 & 0,07 \\
\hline Informação & 0,11 & 0,07 & 0,06 & 0,04 & 0,04 & 0,05 & 0,05 & 0,04 & 0,04 & 0,22 & 0,57 & 0,07 \\
\hline Financeiro & 0,04 & 0,03 & 0,03 & 0,05 & 0,05 & 0,05 & 0,04 & 0,02 & 0,02 & 0,11 & 0,39 & 0,05 \\
\hline Imobiliário & 0,07 & 0,05 & 0,03 & 0,03 & 0,03 & 0,03 & 0,03 & 0,02 & 0,03 & 0,20 & 0,02 & 0,05 \\
\hline Alojamento & 0,18 & 0,12 & 0,08 & 0,07 & 0,06 & 0,09 & 0,07 & 0,06 & 0,06 & 0,35 & 0,40 & 0,10 \\
\hline Serviços às Empresas & 0,09 & 0,05 & 0,05 & 0,04 & 0,04 & 0,04 & 0,04 & 0,03 & 0,03 & 0,15 & 0,60 & 0,06 \\
\hline $\begin{array}{l}\text { Educação e Saúde } \\
\text { mercantis }\end{array}$ & 0,14 & 0,07 & 0,07 & 0,05 & 0,05 & 0,05 & 0,04 & 0,03 & 0,03 & 0,15 & 0,64 & 0,07 \\
\hline Outros Serviços & 0,12 & 0,06 & 0,06 & 0,04 & 0,05 & 0,05 & 0,05 & 0,04 & 0,03 & 0,23 & 0,69 & 0,08 \\
\hline APU & 0,02 & 0,02 & 0,01 & 0,02 & 0,02 & 0,02 & 0,02 & 0,01 & 0,01 & 0,04 & 0,12 & 0,02 \\
\hline Total & 100 & 100 & 100 & 100 & 100 & 100 & 100 & 100 & 100 & 100 & 100 & 100 \\
\hline
\end{tabular}

Onde: Analfabeto - G(0); Até o $5^{\circ}$ ano incompleto do ensino fundamental - G(1); $5^{\circ}$ ano completo do ensino fundamental $\mathrm{G}(2)$; Do $6^{\circ}$ ao $9^{\circ}$ ano incompleto do ensino fundamental - G(3); Ensino fundamental completo - G(4); Ensino médio incompleto - G(5); Ensino médio completo - G(6); Educação superior incompleta - G(7); Educação superior completa - G(8); Mestrado - G(9); Doutorado - G(10).

Fonte: Adaptado da RAIS 2008 e da matriz Inversa de Leontief (2008). 
A Tabela 29 demonstra a distribuição da renda salarial direta e indireta gerada a partir da variação da demanda final em $\mathrm{R} \$ 10.000 .000,00$ (dez milhões de reais), por grau de instrução, para cada atividade econômica. Inicialmente, pode-se constatar que 36,92\% da renda salarial concentrou-se nos trabalhadores com o ensino superior completo, ou seja, $G(8)$. Percentual semelhante também foi identificado por Silva (2008), onde a mesma faixa de instrução concentrou 37,52\% da renda salarial, para o mesmo grau de instrução, reforçando que este perfil de trabalhador possui maiores perspectivas de aumentos salariais quando da injeção de recursos financeiros na econômica de uma região.

Continuando com a análise, evidencia-se que $48,75 \%$ da renda salarial foi alocada para os indivíduos com instrução a partir de $\mathrm{G}(8)$. Restando para o grau $\mathrm{G}(7), 15,07 \%$ e para os trabalhadores pertencentes ao grau G(6) apenas 8,31\%. Para os demais graus de instrução identificou-se percentuais abaixo de 6,5\%, alcançando 1,63\% para indivíduos sem instrução formal, grau $\mathrm{G}(0)$.

Ademais os setores cimento (53,09\%), eletrônicos $(51,73 \%)$ e informática $(41,29 \%)$ foram os que mais concentraram renda para os trabalhadores com grau de instrução $G(8)$ e G(10), demonstrando que estes perfis de trabalhadores são os que mais concentram renda salarial, frente aos demais.

Novamente o setor eletrônicos apresenta resultados positivos, respondendo a variações na demanda final da economia local, por se tratar de setor com pouca representatividade na economia local. 
Tabela 29 - Distribuição por grau de instrução da renda salarial direta e indireta geradas por setor pela variação da demanda final de 10 milhões de reais - Distrito Federal - 2008.

\begin{tabular}{|c|c|c|c|c|c|c|c|c|c|c|c|c|}
\hline Setores & G(0) & $\mathbf{G}(\mathbf{1})$ & $\mathbf{G}(2)$ & G(3) & $\mathbf{G}(4)$ & G(5) & G(6) & $\mathbf{G}(7)$ & $\mathbf{G}(\mathbf{8})$ & G(9) & $\mathbf{G}(10)$ & Total \\
\hline Agricultura & 1,55 & 4,75 & 3,52 & 3,28 & 2,69 & 4,13 & 4,49 & 8,58 & 14,02 & 17,71 & 35,28 & 100 \\
\hline Pecuária & 4,99 & 6,03 & 5,68 & 6,06 & 5,69 & 6,26 & 8,76 & 14,63 & 32,28 & 5,29 & 4,32 & 100 \\
\hline Extrativa & 2,32 & 3,46 & 4,23 & 4,52 & 3,03 & 6,11 & 6,18 & 16,87 & 32,77 & 20,44 & 0,06 & 100 \\
\hline Alimentos & 2,06 & 4,40 & 2,54 & 4,03 & 2,37 & 5,23 & 6,31 & 12,08 & 28,01 & 26,53 & 6,42 & 100 \\
\hline Vestuário & 4,02 & 4,44 & 4,37 & 6,37 & 6,33 & 5,99 & 7,12 & 10,53 & 17,94 & 0,08 & 32,80 & 100 \\
\hline Madeira & 5,60 & 10,21 & 8,59 & 8,34 & 9,11 & 7,88 & 8,33 & 6,50 & 35,37 & 0,04 & 0,04 & 100 \\
\hline Celulose & 0,06 & 5,76 & 8,87 & 6,25 & 7,78 & 7,21 & 12,66 & 21,10 & 30,07 & 0,12 & 0,12 & 100 \\
\hline Revistas & 3,75 & 7,05 & 7,40 & 7,93 & 7,25 & 6,61 & 8,63 & 14,82 & 35,55 & 0,47 & 0,54 & 100 \\
\hline Químicos & 2,06 & 5,75 & 5,51 & 5,05 & 4,18 & 4,97 & 7,80 & 12,88 & 17,11 & 17,37 & 17,30 & 100 \\
\hline Borracha & 6,11 & 6,83 & 6,67 & 7,71 & 6,80 & 6,53 & 7,20 & 14,69 & 36,74 & 0,37 & 0,34 & 100 \\
\hline Cimento & 1,70 & 2,67 & 2,54 & 2,88 & 2,98 & 3,04 & 4,45 & 6,25 & 18,68 & 1,67 & 53,09 & 100 \\
\hline Aço & 0,36 & 7,86 & 5,62 & 11,06 & 6,75 & 7,31 & 8,30 & 10,42 & 39,36 & 2,49 & 0,46 & 100 \\
\hline Metal & 5,43 & 8,70 & 7,12 & 7,23 & 8,04 & 7,65 & 10,23 & 15,18 & 28,04 & 1,60 & 0,78 & 100 \\
\hline Eletrodomésticos & 0,10 & 9,74 & 8,77 & 7,64 & 5,41 & 7,47 & 8,14 & 11,63 & 40,53 & 0,44 & 0,14 & 100 \\
\hline Informática & 0,03 & 0,12 & 0,77 & 11,86 & 7,95 & 3,32 & 14,98 & 19,53 & 41,29 & 0,11 & 0,04 & 100 \\
\hline Máquinas & 0,20 & 6,57 & 12,49 & 8,70 & 7,64 & 9,02 & 10,07 & 22,10 & 21,74 & 1,10 & 0,38 & 100 \\
\hline Eletrônicos & 0,11 & 0,40 & 5,79 & 7,17 & 8,21 & 5,90 & 5,96 & 14,32 & 51,73 & 0,33 & 0,09 & 100 \\
\hline Instrumento hospitalar & 0,07 & 3,72 & 3,47 & 4,37 & 5,59 & 3,83 & 7,11 & 8,88 & 18,57 & 25,67 & 18,73 & 100 \\
\hline Veículos & 1,36 & 1,76 & 1,21 & 2,92 & 3,65 & 3,04 & 5,21 & 15,90 & 44,31 & 20,61 & 0,03 & 100 \\
\hline Indústria Diversa & 7,87 & 7,54 & 9,24 & 7,94 & 8,20 & 8,02 & 8,86 & 17,46 & 23,11 & 0,79 & 0,99 & 100 \\
\hline SIUP & 1,20 & 1,74 & 1,82 & 4,87 & 4,73 & 4,09 & 8,32 & 8,75 & 20,19 & 25,46 & 18,86 & 100 \\
\hline Construção Civil & 3,07 & 3,88 & 4,20 & 4,36 & 4,52 & 4,36 & 5,65 & 8,56 & 24,88 & 17,61 & 18,90 & 100 \\
\hline Comércio & 2,25 & 3,38 & 3,38 & 3,60 & 3,38 & 3,38 & 4,50 & 7,21 & 14,64 & 16,89 & 37,39 & 100 \\
\hline Transportes & 2,74 & 3,97 & 3,97 & 4,10 & 3,83 & 3,56 & 5,20 & 7,80 & 20,93 & 22,44 & 21,48 & 100 \\
\hline Informação & 2,37 & 3,56 & 3,43 & 3,69 & 3,56 & 3,83 & 5,15 & 7,39 & 17,68 & 26,39 & 22,96 & 100 \\
\hline Financeiro & 1,42 & 2,85 & 3,25 & 6,30 & 6,30 & 5,28 & 6,71 & 6,91 & 16,06 & 21,14 & 23,98 & 100 \\
\hline Imobiliário & 2,36 & 4,07 & 3,00 & 4,07 & 3,64 & 3,85 & 5,14 & 8,14 & 25,48 & 38,97 & 1,07 & 100 \\
\hline Alojamento & 2,82 & 4,51 & 3,67 & 4,32 & 3,48 & 4,51 & 5,36 & 9,30 & 20,39 & 30,08 & 11,47 & 100 \\
\hline Serviços às Empresas & 2,36 & 3,30 & 3,62 & 3,77 & 3,77 & 3,62 & 5,03 & 7,23 & 17,30 & 20,75 & 29,09 & 100 \\
\hline $\begin{array}{l}\text { Educação e Saúde } \\
\text { mercantis }\end{array}$ & 3,26 & 4,40 & 4,40 & 4,54 & 4,11 & 3,97 & 5,11 & 7,38 & 16,17 & 18,72 & 27,94 & 100 \\
\hline Outros Serviços & 2,48 & 3,10 & 3,22 & 3,47 & 3,59 & 3,22 & 4,83 & 7,43 & 16,36 & 25,77 & 26,39 & 100 \\
\hline APU & 1,93 & 4,35 & 3,38 & 5,31 & 5,31 & 4,83 & 7,25 & 8,70 & 21,74 & 19,32 & 17,87 & 100 \\
\hline Total & 1,63 & 4,03 & 4,58 & 6,38 & 5,94 & 5,31 & 8,31 & 15,07 & 36,92 & 8,86 & 2,98 & 100 \\
\hline
\end{tabular}

Onde: Analfabeto - G(0); Até o $5^{\circ}$ ano incompleto do ensino fundamental - G(1); $5^{\circ}$ ano completo do ensino fundamental $\mathrm{G}(2)$; Do $6^{\circ}$ ao $9^{\circ}$ ano incompleto do ensino fundamental - G(3); Ensino fundamental completo - G(4); Ensino médio incompleto - G(5); Ensino médio completo - G(6); Educação superior incompleta - G(7); Educação superior completa - $G(8)$; Mestrado - G(9); Doutorado - G(10).

Fonte: Adaptado da RAIS 2008 e da matriz Inversa de Leontief (2008). 
Ao comparar as Tabelas 26 e 29, observa-se que o setor de eletrônicos, setor com baixa produção na economia do DF, gerou cerca de $71,35 \%$ de novos empregos, para o grau $\mathrm{G}(6)$, enquanto que o mesmo setor gerou apenas 5,96\% de renda salarial, para o mesmo grau de instrução. Contudo, para o grau $\mathrm{G}(10)$ a renda salarial alcançou 51,09\%, na atividade econômica cimento.

Do mesmo modo, para o setor de comércio, cerca de 54,60\% de novos empregos foram criados para o grau $\mathrm{G}(6)$, enquanto que o setor alocou apenas 4,50\% de renda salarial, para o mesmo grau de instrução. Contudo, a distribuição de renda salarial alcançou 37,02\% para o grau $\mathrm{G}(10)$. Este comportamento se repete nos setores eletrodoméstico, máquinas, instrumento hospitalar e comércio.

Silva (2008, p. 102) identificou este cenário na economia da Bahia, concluindo que:

[...] há uma tendência de concentração de renda salarial na economia baiana para os trabalhadores com graus de instrução mais elevados, desta forma, a educação do trabalhador voltada para o ensino médio aumenta as oportunidades de garantia de alocação nos novos postos de trabalho criados. Por outro lado, trabalhadores com nível educacional a partir do superior incompleto possuem mais chances de alocação nos maiores níveis salariais.

Assim, tal fenômeno também ocorre na economia do DF, o que reforça o constatado por Silva (2008).

A Tabela 30 demonstra a distribuição da massa salarial, bem como a relação intersetorial existente, por grau de instrução. Segundo a definição da RAIS, massa salarial é o somatório do produto entre a remuneração média pelo número de vínculos empregatícios ativos 
Tabela 30 - Massa salarial anual por grau de instrução por setor - Distrito Federal - 2008 (em R\$).

\begin{tabular}{|c|c|c|c|c|c|c|c|c|c|c|c|c|}
\hline Setores & $G(0)$ & $G(1)$ & $G(2)$ & $G(3)$ & $G(4)$ & $G(5)$ & $G(6)$ & $G(7)$ & $G(S)$ & $G(9)$ & $G(10)$ & Total \\
\hline Agricultura & 77,00 & 31,01 & 27,85 & 21,63 & 13,93 & 51,82 & 22,15 & 412,40 & 339,45 & $10.272,52$ & $58.271,19$ & $69.540,94$ \\
\hline Pecuánia & 139,19 & 34,66 & 24,82 & 16,95 & 21,33 & 56,23 & 27,32 & 703,38 & 720,88 & 0,00 & 0,00 & $1.744,75$ \\
\hline Extrativa & $2.089,89$ & 909,92 & 441,65 & 375,20 & 112,81 & 573,10 & 147,71 & $2.925,26$ & 1. 209,38 & $92.438,92$ & 0,00 & $101.223,83$ \\
\hline Alimentos & 139,24 & 23,31 & $23,4 \mathrm{~S}$ & 7,01 & 3,15 & 3,87 & 2,01 & 65,01 & 124,77 & $35.398,39$ & 0,00 & $35.790,24$ \\
\hline Vestuánio & $1.179,32$ & 575,40 & 297,43 & 69,08 & 28,18 & 41,26 & $14,7 \mathrm{~s}$ & 460,37 & 601,75 & 0,00 & $125.038,04$ & $128.305,60$ \\
\hline Madeira & $1.038,96$ & 533,63 & 160,62 & 96,60 & 61,06 & 92,75 & 70,95 & 692,00 & $4.503,32$ & 0,00 & 0,00 & $7.249,89$ \\
\hline Celulose & 0,00 & $3.943,12$ & $1.746,92$ & 330,31 & 221,01 & 264,50 & 169,83 & $2.918,25$ & $2.504,84$ & 0,00 & 0,00 & $12.098,77$ \\
\hline Revistas & $6.813,80$ & 320,69 & 407,98 & 67,43 & 26,77 & 27,49 & 8,93 & 99,22 & 77,64 & 0,00 & 0,00 & $7.849,94$ \\
\hline Químicos & $3.776,28$ & 686,45 & 721,32 & 157,24 & so, 69 & 160,25 & 49,68 & 246,91 & 183,92 & $13.930,49$ & $97.148,00$ & $117.141,24$ \\
\hline Borracha & 0,00 & 353,01 & 198,40 & 118,39 & 49,32 & 142,17 & 44,17 & $1.513,38$ & $5.717,01$ & 0,00 & 0,00 & $8.135,85$ \\
\hline Cimento & 295,66 & 119,38 & 130,65 & 55,92 & 34,21 & 47,21 & 22,37 & 348,05 & 552,29 & 0,00 & $114.036,53$ & $115.642,26$ \\
\hline Aspo & 0,00 & $2.263,62$ & $1.033,77$ & 322,95 & 232,14 & 264,07 & 87,33 & $1.295,71$ & $2.977,45$ & 0,00 & 0,00 & $8.477,03$ \\
\hline Metal & 0,00 & 124,11 & 183,06 & 52,70 & 23,16 & 35,87 & 21,47 & 538,25 & 744,82 & 0,00 & 0,00 & $1.723,44$ \\
\hline Eletrodomésticos & 0,00 & $1.884,80$ & $1.249,46$ & 308,94 & 122,04 & 246,05 & 50,78 & 555,49 & $1.591,08$ & 0,00 & 18,40 & $6.027,04$ \\
\hline Informmática & 0,00 & 0,00 & 0,00 & $2.083,17$ & $1.042,70$ & 587,24 & 262,06 & 834,40 & $2.333,84$ & 0,00 & 0,00 & $7.143,41$ \\
\hline Máquinas & 0,00 & $1.364,18$ & $1.625,95$ & 135,59 & 96,54 & 137,76 & 55,63 & $1.122,61$ & $1.105,01$ & 0,00 & 0,00 & $5.643,25$ \\
\hline Eletrônicos & 0,00 & 299,00 & $3.619,37$ & $1.519,38$ & $1.316,38$ & 858,88 & 35,21 & $2.261,85$ & $2.232,82$ & 0,00 & 0,00 & $12.142,90$ \\
\hline Instrumento hospitalax & 0,00 & $1.449,10$ & 516,16 & 500,59 & 211,86 & 161,90 & 48,41 & 506,86 & 319,17 & $51.552,00$ & $37.640,36$ & $92.906,40$ \\
\hline Veículos & $2.141,86$ & $1.408,59$ & $1.253,96$ & $1.092,27$ & 254,25 & 520,25 & 258,37 & $6.406,09$ & $2.179,97$ & 0,00 & 0,00 & $15.515,61$ \\
\hline Indústria Diversa & 415,55 & 11,56 & 54,88 & 20,16 & 18,89 & 31,13 & 12,83 & 700,36 & 714,52 & 0,00 & 0,00 & $1.979,87$ \\
\hline SIUP & 222,15 & 13,00 & 7,86 & 68,35 & 44,70 & 92,53 & 22,16 & 216,79 & 57,75 & $1.646,76$ & $15.391,69$ & $17.783,75$ \\
\hline Construção & 19,50 & 1,79 & $2,8 \mathrm{~s}$ & 1,39 & 1,29 & 2,75 & 1,22 & 24,43 & 26,63 & $2.735,44$ & 742,87 & $3.560,18$ \\
\hline Comércio & 30,20 & 6,80 & 4,14 & 1,18 & 0,37 & 0,49 & 0,12 & 3,33 & 6,04 & $1.347,70$ & $7.547,27$ & $8.947,65$ \\
\hline Transportes & 90,56 & 18,60 & 9,79 & 3,01 & 1,61 & 2,45 & 0,94 & 16,04 & 11,74 & $4.032,48$ & $10.917,05$ & $15.104,27$ \\
\hline Informação & $2.881,88$ & 288,34 & 122,44 & 52,54 & 10,77 & 17,80 & 2,06 & 6,00 & 6,10 & 818,26 & $7.084,75$ & $11.290,94$ \\
\hline Financeiro & $5.181,64$ & 605,81 & 680,71 & 305,90 & 123,84 & 104,11 & 5,37 & 6,87 & 3,44 & 295,69 & $1.878,77$ & $9.192,15$ \\
\hline Imobiliánio & 134,11 & 15,16 & 17,40 & 10,62 & 5,66 & 13,57 & 4,74 & 57,01 & 132,50 & $10.586,78$ & 0,00 & $10.977,56$ \\
\hline Alojamento & 35,59 & 14,98 & 8,48 & 2,42 & 0,83 & 1,11 & 0,52 & 28,20 & 42,42 & $31.704,52$ & $20.091,44$ & $51.930,51$ \\
\hline Servicos as Empresas & 17,38 & 3,72 & 1,98 & 0,91 & 0,44 & 0,92 & 0,28 & 2,13 & 4,03 & 131,91 & 280,12 & 443,83 \\
\hline Educação e Saúde mercantis & 114,50 & 23,07 & 19,79 & 5,77 & 2,97 & 3,33 & 0,44 & 4,40 & 1,77 & 31,78 & 178,38 & 386,19 \\
\hline Outros Serviços & 21,88 & 4,38 & 4,13 & 1,95 & 1,37 & 1,40 & 0,79 & 6,91 & 5,04 & 851,48 & $4.165,28$ & $5.064,59$ \\
\hline APU & 8,91 & 5,06 & 6,30 & 3,55 & 0,37 & 6,07 & 0,24 & 2,25 & 0,49 & 2,95 & 1,71 & 37,91 \\
\hline Total & $26.865,07$ & $17.336,24$ & $14.603,66$ & $7.809,10$ & $4.164,63$ & $4.550,33$ & $1.450,83$ & $24.980,17$ & $31.031,89$ & $257.778,06$ & $500.431,84$ & $891.001,80$ \\
\hline
\end{tabular}

Onde: Analfabeto - $\mathrm{G}(0)$; Até o $5^{\mathrm{o}}$ ano incompleto do ensino fundamental - $\mathrm{G}(1)$; $5^{\mathrm{o}}$ ano completo do ensino fundamental - $\mathrm{G}(2)$; Do $6^{\mathrm{o}}$ ao $9^{\mathrm{o}}$ ano incompleto do ensino fundamental - $\mathrm{G}(3)$; Ensino fundamental completo - G(4); Ensino médio incompleto - G(5); Ensino médio completo - G(6); Educação superior incompleta - G(7); Educação superior completa - G(8); Mestrado $\mathrm{G}(9)$; Doutorado - G(10).

Fonte: Adaptado da RAIS 2008 e da matriz Inversa de Leontief (2008). 
Assim, a Tabela 30 foi elaborada pelo resultado entre a soma da renda salarial média gerada a partir do aumento da demanda final e a renda salarial média existente no DF e a soma dos novos empregos gerados a partir do aumento de demanda final e os empregos existentes na economia.

Em termos gerais, a massa salarial anual auferida pela economia do DF no período analisado resultou em $\mathrm{R} \$ 891.001,80$ (oitocentos e noventa e um mil, um real e oitenta centavos).

Analisando o cenário do DF, em resgate ao demonstrado pela Tabela 19 que apresentou a quantidade de pessoal ocupado por setor por grupo de instrução, no ano de 2008, a economia contava com 1.001.083 trabalhadores formais, onde os setores econômicos que mais ofertavam empregos eram APU (403.934), comércio (144.232) e serviços às empresas (110.240). Em relação ao perfil educacional, a maioria da população possuía ensino médio, grau $\mathrm{G}(6)$, representando 394.209 dos trabalhadores formais e ensino superior completo, grau $\mathrm{G}(8)$, correspondendo a 250.243 trabalhadores formais.

A partir da variação de $\mathrm{R} \$ 10.000 .000,00$ (dez milhões de reais) na demanda final da economia os impactos foram apresentados na Tabela 24, onde observou-se que os setores que mais corresponderam contribuindo na geração de empregos foram: madeira, eletrodomésticos e vestuário, gerando 504, 228 e 212 novos empregos, respectivamente.

Iniciando a análise da Tabela 30, relativa a massa salarial destinada a cada setor da economia do DF, pode-se afirmar que os setores que mais concentraram massa salarial foram vestuário ( $R$ \$ 128.305,60), químicos $(R \$ 117.141,24)$ e cimento ( $R$ \$ 115.642,26). Dos trabalhadores, os que mais se beneficiaram foram os pertencentes aos graus $G(8), G(9)$ e $\mathrm{G}(10)$ alcançando $\mathrm{R} \$ 31.031,89, \mathrm{R} \$ 257.778,06$ e $\mathrm{R} \$ 500.431,84$, respectivamente, da massa salarial distribuída.

Contudo, na economia baiana a concentração da massa salarial deu-se no grau G(6), classe identificada como as que menos adquiriram massa salarial no DF com R $\$ 1.450,83$, acompanhada por $\mathrm{G}(4)$ com $\mathrm{R} \$ 4.164,63$. O que demonstra que a concentração de massa salarial dá-se, no DF, aos trabalhadores com maiores níveis de instrução, diferente do que ocorre na economia baiana, onde a concentração de massa salarial ocorre na classe de trabalhadores que detém ensino médio completo e ensino superior completo, respectivamente.

Ainda na Tabela 30, também pode-se afirmar que a maior parte da fatia salarial encontra-se nas extremidades dos níveis de instrução, de modo a concentrar-se nas faixas de $\mathrm{G}(0)$ a $\mathrm{G}(3)$ e de $\mathrm{G}(7)$ a $\mathrm{G}(10)$. Logo, os demais graus de instrução, $G(4)$ a $G(6)$, recebem as menores massas salariais. 
Quanto ao aspecto salarial, este trabalho demonstrou que a renda salarial anual da economia do DF é R \$34.333,63 (trinta e quatro mil, trezentos e trinta e três reais e sessenta e três centavos). A Tabela 19 evidenciou que os setores que alcançaram os maiores salários médios anuais foram veículos $(\mathrm{R} \$ 91.617,40)$, financeiro $(\mathrm{R} \$ 63.901,49)$ e APU (R\$ $56.354,85)$. Em relação ao perfil educacional, a maiores rendas salariais foram auferidas por trabalhadores com mestrado, grau $\mathrm{G}(9)$, auferindo $\mathrm{R} \$ 92.312,83$ e trabalhadores com doutorado, grau $\mathrm{G}(10)$, correspondendo a salário médio de $\mathrm{R} \$ 100.330,83$.

A partir da variação de $\mathrm{R} \$ 10.000 .000,00$ (dez milhões de reais) na demanda final da economia os impactos foram apresentados na Tabela 25, onde observou-se que os setores que mais corresponderam contribuindo na geração de renda salarial anual foram: veículos (R\$ 253.830,00), informática ( $\mathrm{R} \$ 132.168,00)$ e extrativa $(\mathrm{R} \$ 108.101,00)$.

Voltando a análise da Tabela 30, relativa a massa salarial, cabe relembrar que os setores que mais concentraram massa salarial foram vestuário ( $R$ \$ 128.305,60), químicos ( $R$ \$ 117.141,24) e cimento ( $\mathrm{R} \$ 115.642,26)$. Dos trabalhadores, os que mais se beneficiaram foram os pertencentes aos graus $\mathrm{G}(8), \mathrm{G}(9)$ e $\mathrm{G}(10)$ alcançando $\mathrm{R} \$ 31.031,89, \mathrm{R} \$ 257.778,06$ e R \$ 500.431,84, respectivamente, da massa salarial distribuída.

Logo, quanto aos impactos de geração de emprego e renda, na economia do DF ressalta-se que os salários médios eram maiores nos setores cimento (R $\$ 226.044,06$ ), agricultura $(\mathrm{R} \$ 172.465,56)$ e comércio $(\mathrm{R} \$ 135.684,81)$, para os trabalhadores com nível de instrução $G(10)$, correspondente a doutorado. Contudo, a concentração de empregos e de geração de novos empregos destes supracitados setores concentravam-se no grau de instrução G(6), referente a trabalhadores com ensino médio completo. Em análise a massa salarial concentrada para estes setores, os trabalhadores que mais se beneficiaram foram os pertencentes ao $\mathrm{G}(10)$. Tal comportamento, também ocorreu na economia baiana, conforme disposto por Silva (2008).

Assim, em termos gerais, quantos aos setores que mais empregavam setores do grau G(6), ensino médio completo, estes geraram mais empregos para este mesmo nível de instrução, contudo, os maiores salários ocorreram para os trabalhadores pertencentes ao maior grau de instrução em análise, o grau $\mathrm{G}(10)$ que corresponde ao nível de doutorado. Tal fenômeno, replicou o ocorrido na economia da Bahia, reforçando este comportamento da economia. 
Contudo, para Silva (2008), nestes casos a massa salarial estaria direcionada para o grau G(6), ensino médio completo, contudo, na economia do DF a massa salarial é alocada para os trabalhadores do grau $\mathrm{G}(10)$, com doutorado. 


\section{CONCLUSÃO}

Este trabalho teve por objetivo avaliar impactos diretos e indiretos em relação à geração de empregos e salários, por grau de instrução, a partir de mudanças decorrentes do aumento da demanda final $(Y)$. Ao longo do trabalho foi estudado o perfil da educação no Distrito Federal (DF) e ao simular um aumento de demanda, quais seriam os impactos no nível de instrução por setor produtivo na economia do DF. A utilização do instrumental insumo-produto permitiu demonstrar quais são os setores chaves da economia do DF com relação a geração de emprego e renda, por nível de instrução.

Os setores que mais apresentaram destaque na geração de empregos foram madeira, eletroeletrônicos e vestuário. Na geração de renda destacaram os setores veículos, informática e extrativa. Assim, observa-se que não há correlação dos setores que repercutem geração de emprego e de renda, pois um setor pode gerar muito emprego, mas ofertar baixa remuneração, em contrapartida, outros setores geram pouco emprego, porém com alta remuneração.

Da análise quanto ao perfil educacional dos trabalhadores formais do DF, tem-se que a maioria destes pertencem ao grau G(6), ensino médio. Dos empregos gerados 39,07\% pertencem ao grau $\mathrm{G}(6)$, aumentando para $54,77 \%$ se considerados os trabalhadores com instrução do ensino médio completo ao doutorado.

Quanto aos demais níveis de instrução, apenas 0,50\% de novos empregos são gerados para os trabalhadores sem instrução formal, grau $G(0)$, que representa $4,2 \%$ da população total do DF, conforme demonstrado na Tabela 6 quando da análise das taxas de analfabetismo. Para os demais níveis de ensino, G(1) a G(5), os percentuais de geração de novos postos de trabalho são 3,44\%, 4,31\%, 9,21\%, 17,33\% e 10,47\%, respectivamente. Assim, ao analisar a geração de empregos com o grau de instrução dos indivíduos percebe-se relação positiva entre níveis de instrução maiores e quantitativo maior de criação de empregos.

Para os trabalhadores que possuem o ensino fundamental completo G(4) e o ensino médio completo $\mathrm{G}(6)$, o fenômeno em analise gerou 56,40\% novos empregos e para os trabalhadores com nível de instrução a partir do superior incompleto este percentual correspondeu a 15,70\%. Reforçando a afirmação de Silva (2008, p. 110), a seguir: 
[...] Esses resultados dão sustentação às estratégias definidas na política pública educacional, que demonstram ter o ensino fundamental e médio como níveis de ensino principais de atuação. Os montantes de gastos e a quantidade de estudantes que ingressam e concluem nesses níveis de ensino confirma esta questão.

No que tange a geração de renda para a economia do DF conclui-se que $72,14 \%$ da geração de renda foi destinada a trabalhadores com o nível de instrução a partir do ensino médio, compreendendo os graus $\mathrm{G}(6)$ a $\mathrm{G}(10)$. Sendo que estes níveis de ensino apresentaram os percentuais $8,31 \%, 15,07 \%, 36,92 \% 8,86 \%$ e $2,98 \%$, respectivamente.

A distribuição da renda demonstrou que os setores que possuem destaque na geração de emprego aos trabalhadores com baixo grau de instrução remuneram mais aos trabalhadores pertencentes aos altos graus de instrução. Dessa forma, setores como a indústria diversa apresenta percentual de 13,43\% quanto a geração de novos empregos para trabalhadores com até o quinto ano do ensino fundamental, grau G(1), contudo, para este nível de instrução a geração de renda é de apenas 7,54\%, enquanto que para os trabalhadores com nível de ensino a partir do ensino superior completo, $\mathrm{G}(8)$ a $\mathrm{G}(10)$, a geração de renda chega a $24,89 \%$.

Comportamento similar ocorre no setor comércio que apresenta geração de emprego em $54,60 \%$ para o grau $\mathrm{G}(6)$, correspondente ao ensino médio completo, e somente $4,5 \%$ de geração de renda para o mesmo nível de instrução, enquanto trabalhadores com nível de ensino a partir do ensino superior completo absorvem 68,92\% da geração de renda da economia, para o setor em análise.

Diante do fenômeno ora detalhado, evidencia-se que a renda salarial cresce à medida que aumenta o grau de instrução do indivíduo, pois na economia do DF identificou comportamento igual ao ocorrido na economia baiana.

$\mathrm{O}$ estudo do modelo insumo-produto de Leontief demonstrou que trabalhadores com o ensino médio completo possuem maior possibilidade de conseguir emprego nos setores da economia local, contudo, os maiores salários são destinados a trabalhadores mais qualificados, que possuem nível superior completo, mestrado e/ou doutorado.

Consequentemente, a utilização deste instrumental na tomada de decisão dos gestores podem influenciar no alcance das metas estabelecidas pelo IDEB, ora referenciadas na Tabela 9 deste estudo, posto que quando o governo estimula a população pela busca por instrução na expectativa de auferir empregos bem remunerados, a sociedade tende a aumentar seu nível de bem-estar, o que tende a reduzir taxas de analfabetismo, aumentar o percentual de matrículas e conclusões nos níveis de escolarização, além de contribuir para o crescimento Índice de Desenvolvimento Humano (IDH) da região. 
Assim, a aplicação do instrumental insumo-produto comprovou que a Educação possui papel relevante sobre os setores de uma economia local, tanto na geração de empregos quanto na geração de renda salarial. Por fim, as evidências empíricas apresentadas ao longo deste trabalho fortalecem a tese do capital humano, onde a Educação é vista como um investimento, tendo em vista que, quanto mais o indivíduo investe em Educação mais chances este possui de auferir emprego que lhe ofereça maior renda salarial. 


\section{REFERÊNCIAS}

ANEFALOS, L. C. Modelo insumo-produto como instrumento de avaliação econômica da cadeia de suprimentos: o caso da exportação de flores de corte. $210 \mathrm{f}$. Tese (Doutorado em Ciências - Área de Concentração: Economia Aplicada) - Escola Superior de Agricultura Luiz Queiroz, Universidade de São Paulo, Piracicaba, SP, 2004. Disponível em:

<http://esalqlog.esalq.usp.br/files/biblioteca/arquivo357.pdf >. Acesso em: 10 abr 2015.

ARAUJO, J. P; SOUSA, N. J. Sistemas de Leontief. Teoria e Evidência Econômica, Passo Fundo, v. 6, n. 11, p. 123-142, nov. 1988.

BRASIL. Constituição dos Estados Unidos do Brasil de 1934. Disponível em: <http://www.planalto.gov.br/ccivil_03/constituicao/constituicao34.htm>. Acesso em: 21 abr. 2014.

Constituição dos Estados Unidos do Brasil de 1937. Disponível em:

<http://www.planalto.gov.br/ccivil_03/constituicao/constituicao37.htm>. Acesso em: 21 abr. 2014.

Constituição dos Estados Unidos do Brasil de 1946. Disponível em:

<http://www.planalto.gov.br/ccivil_03/constituicao/constituicao46.htm>. Acesso em: 21 abr. 2014.

Constituição da República Federativa do Brasil de 1988. Disponível em:

<http://www.planalto.gov.br/ccivil_03/constituicao/constituicao.htm>. Acesso em: 21 abr. 2014.

Emenda Constitucional $n^{0}$ 1, de 17 de outubro de 1969. Disponível em:

<http://www.planalto.gov.br/ccivil_03/constituicao/Emendas/Emc_anterior1988/emc0169.htm>. Acesso em: 21 abr. 2014.

Emenda Constitucional no 24, de 10 de dezembro de 1983. Disponível em: <http://www.planalto.gov.br/ccivil_03/constituicao/Emendas/Emc_anterior1988/emc2483.htm>. Acesso em: 21 abr. 2014.

Lei $\mathrm{n}^{\circ}$ 10.260, de 12 de julho 2001. Dispõe sobre o Fundo de Financiamento ao estudante do Ensino Superior e dá outras providências. Disponível em:

<http://www.planalto.gov.br/ccivil_03/Leis/LEIS_2001/L10260.htm>. Acesso em: 16 mar. 2015 . 
Lei no 10.172, de 09 de janeiro 2001. Aprova o Plano Nacional de Educação e dá outras providências. Disponível em:

<https://www.planalto.gov.br/ccivil_03/leis/leis_2001/110172.htm>. Acesso em: 16 mar. 2015.

Lei no 13.005, de 25 de junho 2014. Aprova o Plano Nacional de Educação e dá outras providências. Disponível em: <http://www.planalto.gov.br/ccivil_03/_Ato20112014/2014/Lei/L13005.htm>. Acesso em: 16 mar. 2015.

Resolução no 5, de 17 de dezembro 2009. Fixa as Diretrizes Curriculares Nacionais para a Educação Infantil. Disponível em:

<file:///C:/Users/Casa/Downloads/rceb005_09.pdf>. Acesso em: 28 fev. 2015.

CASIMIRO FILHO, F. Construções do Turismo à economia brasileira. $220 \mathrm{f}$. Tese (Doutorado em Ciências - Área de Concentração: Economia Aplicada). Escola Superior de Agricultura Luiz Queiroz, Universidade de São Paulo, Piracicaba, SP, 2002. Disponível em: $<$ http://fama2.us.es:8080/turismo/turismonet1/economia\%20del\%20turismo/economia\%20del $\% 20$ turismo/Contribuciones $\% 20 \mathrm{del} \% 20$ turismo $\% 20 \mathrm{en} \% 20 \mathrm{la} \% 20 \mathrm{economia} \% 20 \mathrm{brasileira} . \mathrm{pdf}$ >. Acesso em: 10 abr. 2015.

CEPAL. Educação e competências de melhor qualidade são a chave para dinamizar a economia. 2014. Disponível em: <http://www.cepal.org/pt-br/comunicados/educacao-ecompetencias-de-melhor-qualidade-sao-chave-para-dinamizar-economia $>$. Acesso em: 18 fev. 2015.

CHAHAD, J.P.Z; COMUNE, A. E; HADDAD, E. A. Interdependência espacial das exportações brasileiras: repercussões sobre o mercado de trabalho. São Paulo, 2003. TD Nereus, v. 6.

CORBUCCI, P. R. Desafios da Educação Superior e Desenvolvimento no Brasil. Brasília: IPEA, 2007. (Texto para discussão n. 1287). Disponível em: <http://repositorio.ipea.gov.br/bitstream/11058/1887/1/TD_1287.pdf>. Acesso em: 25 mar. 2014.

CRESPO, A; REIS, M. C. O Efeito-Diploma no Brasil. Notas Técnicas. Mercado de Trabalho, Brasília, out. 2006. Disponível em: <https://ipea.gov.br/agencia/images/stories/PDFs/mercadodetrabalho/08Nota2_Anna_Maurici o.pdf>. Acesso em: 25 mar. 2014.

DAVIES, N. O financiamento da educação estatal no Brasil: novos e velhos desafios? Revista Educação On-line PUC-Rio, Rio de Janeiro, n. 10, p. 31-63, 2012. 
FRANCO, C. et al. Qualidade do ensino fundamental: políticas, suas possibilidades, seus limites. Educação e Sociedade, Campinas, v. 28, n. 100 - especial, p. 989-1014, out. 2007. Disponível em: <http://www.scielo.br/pdf/es/v28n100/a1728100.pdf>. Acesso em: 17 jun. 2015.

FRIGOTTO, Gaudêncio. A produtividade da escola improdutiva. São Paulo: Cortez/Autores Associados, 1984.

FRIEDMAN, Milton (1962). Capitalismo e liberdade. São Paulo: Abril Cultural, 1984.

GRIJÓ, E; BÊRNI, D. A. Metodologia completa para a estimativa de matrizes de InsumoProduto. Teoria e Evidência Econômica, Passo Fundo, v. 14, n. 16, maio 2006. Disponível em:

<http://www.upf.br/cepeac/download/rev_n26_2006_art1.pdf?origin=publication_detail>. Acesso em: 18 out. 2014.

GUILHOTO, J. J. M. Análise de insumo-produto: teoria e fundamentos, 2011. Disponível em: <http://mpra.ub.uni-muenchen.de/32566/2/MPRA_paper_32566.pdf >. Acesso em: 13 maio 2014.

KURESKI, R; ROLIM, C. Impacto econômico de curto prazo das Universidades Federais na economia brasileira. Rio Grande do Sul, 2010. Disponível em:

<http://www.ppge.ufrgs.br/anpecsul2010/artigos/48.pdf>. Acesso em: 22 mar. 2014.

LEONTIEF, W. Input-output analysis. In: EATWELL, J.; MILGATE, M.; NEWMAN, P. (Eds.) The New Palgrave. A Dictionary of Economics. 1987. v. 2.

MOREIRA, G. R. C. Políticas sociais, desigualdades pessoais e regionais da renda no Brasil: uma análise de insumo-produto. 95 f. Dissertação (Mestrado em Ciências) - Escola Superior de Agricultura Luiz Queiroz, Universidade de São Paulo, Piracicaba, SP, 2007. Disponível em: <http://www.teses.usp.br/teses/disponiveis/11/11132/tde-15062007102435/pt-br.php>. Acesso em: 24 mar. 2014.

ORGANIZAÇÃO PARA A COOPERAÇÃO E DESENVOLVIMENTO ECONÔMICO OCDE. Relatório de País - Brasil. 2011. Disponível em: <http://www.oecd.org/edu/skillsbeyond-school/48670822.pdf>. Acesso em: 06 abr. 2014.

PIRES, Valdemir. Economia da Educação: para além do capital humano. São Paulo: Cortez, 2005. 
SILVA, A. M. B. Matriz de Insumo-Produto: Análise dos impactos da educação na geração de emprego e renda na economia baiana - 2005. 196 f. Dissertação (Mestrado em Economia) - Universidade Federal da Bahia, Salvador, 2008. Disponível em:

<file:///C:/Users/celio/Downloads/682009072025.pdf>. Acesso em: 10 mar. 2014.

SCHULTZ, Theodore W. (1969). O capital humano. Rio de Janeiro: Zahar, 1973. 
APÊNDICES 
APÊNDICE "A" - Setores Agregados

Quadro A1 - Agregação e Desagregação dos Setores das Tabelas de Recursos e Usos e da Conta Regional.

\begin{tabular}{|c|c|c|c|c|c|c|c|c|}
\hline Código & $\begin{array}{c}\text { Setores das TRU antes da } \\
\text { agregação }\end{array}$ & Código & $\begin{array}{c}\text { Setores após a Agregação da } \\
\text { TRU }\end{array}$ & $\begin{array}{c}\text { Renomeado } \\
\text { após } \\
\text { agregação e } \\
\text { desagregação }\end{array}$ & $\begin{array}{l}\text { Novo } \\
\text { Código }\end{array}$ & Código & $\begin{array}{l}\text { Setores das Contas Regionais } \\
\text { após desagregação }\end{array}$ & $\begin{array}{l}\text { Setores das Contas Regionais antes } \\
\text { da desagregação }\end{array}$ \\
\hline 101 & $\begin{array}{l}\text { Agricultura, silvicultura, exploração } \\
\text { florestal }\end{array}$ & 101 & $\begin{array}{l}\text { Agricultura, silvicultura, } \\
\text { exploração florestal }\end{array}$ & Agricultura & 1 & 101 & $\begin{array}{l}\text { Agricultura, silvicultura, } \\
\text { exploração florestal }\end{array}$ & $\begin{array}{l}\text { Agricultura, silvicultura, exploração } \\
\text { florestal }\end{array}$ \\
\hline 102 & Pecuária e pesca & 102 & Pecuária e pesca & Pecuária & 2 & 102 & Pecuária e pesca & Pecuária e pesca \\
\hline 201 & Petróleo e gás natural & 201 & Petróleo e gás natural & Extrativa & 3 & 201 & Petróleo e gás natural & Indústria extrativa mineral \\
\hline 202 & Minério de ferro & 202 & Minério de ferro & & & 202 & Minério de ferro & \\
\hline 203 & Outros da indústria extrativa & 203 & Outros da indústria extrativa & & & 203 & Outros da indústria extrativa & \\
\hline 301 & Alimentos e bebidas & 301 & Alimentos e bebidas & Alimentos & 4 & 301 & Alimentos e bebidas & Indústria de transformação \\
\hline 302 & Produtos do fumo & 302 & Produtos do fumo & & & 302 & Produtos do fumo & \\
\hline 303 & Têxteis & 303 & Têxteis & Vestuário & 5 & 303 & Têxteis & \\
\hline 304 & Artigos do vestuário e acessórios & 304 & Artigos do vestuário e acessórios & & & 304 & Artigos do vestuário e acessórios & \\
\hline 305 & Artefatos de couro e calçados & 305 & Artefatos de couro e calçados & & & 305 & Artefatos de couro e calçados & \\
\hline 306 & $\begin{array}{l}\text { Produtos de madeira - exclusive } \\
\text { móveis }\end{array}$ & 306 & $\begin{array}{l}\text { Produtos de madeira - exclusive } \\
\text { móveis }\end{array}$ & Madeira & 6 & 306 & $\begin{array}{l}\text { Produtos de madeira - exclusive } \\
\text { móveis }\end{array}$ & \\
\hline 307 & Celulose e produtos de papel & 307 & Celulose e produtos de papel & Celulose & 7 & 307 & Celulose e produtos de papel & \\
\hline 308 & Jornais, revistas, discos & 308 & Jornais, revistas, discos & Revistas & 8 & 308 & Jornais, revistas, discos & \\
\hline 309 & Refino de petróleo e coque & 309 & Refino de petróleo e coque & Químicos & 9 & 309 & Refino de petróleo e coque & \\
\hline 310 & Álcool & 310 & Álcool & & & 310 & Álcool & \\
\hline 311 & Produtos químicos & 311 & Produtos químicos & & & 311 & Produtos químicos & \\
\hline 312 & Fabricação de resina e elastômeros & 312 & $\begin{array}{l}\text { Fabricação de resina e } \\
\text { elastômeros }\end{array}$ & & & 312 & Fabricação de resina e elastômeros & \\
\hline 313 & Produtos farmacêuticos & 313 & Produtos farmacêuticos & & & 313 & Produtos farmacêuticos & \\
\hline 314 & Defensivos agrícolas & 314 & Defensivos agrícolas & & & 314 & Defensivos agrícolas & \\
\hline
\end{tabular}




\begin{tabular}{|c|c|c|c|c|c|c|c|c|}
\hline 315 & Perfumaria, higiene e limpeza & 315 & Perfumaria, higiene e limpeza & & & 315 & Perfumaria, higiene e limpeza & \\
\hline 316 & Tintas, vernizes, esmaltes e lacas & 316 & Tintas, vernizes, esmaltes e lacas & & & 316 & Tintas, vernizes, esmaltes e lacas & \\
\hline 317 & $\begin{array}{l}\text { Produtos e preparados químicos } \\
\text { diversos }\end{array}$ & 317 & $\begin{array}{l}\text { Produtos e preparados químicos } \\
\text { diversos }\end{array}$ & & & 317 & $\begin{array}{l}\text { Produtos e preparados químicos } \\
\text { diversos }\end{array}$ & \\
\hline 318 & Artigos de borracha e plástico & 318 & Artigos de borracha e plástico & Borracha & 10 & 318 & Artigos de borracha e plástico & \\
\hline 319 & Cimento & 319 & Cimento & Cimento & 11 & 319 & Cimento & \\
\hline 320 & $\begin{array}{l}\text { Outros produtos de minerais não- } \\
\text { metálicos }\end{array}$ & 320 & $\begin{array}{l}\text { Outros produtos de minerais } \\
\text { não-metálicos }\end{array}$ & & & 320 & $\begin{array}{l}\text { Outros produtos de minerais não- } \\
\text { metálicos }\end{array}$ & \\
\hline 321 & Fabricação de aço e derivados & 321 & Fabricação de aço e derivados & Aço & 12 & 321 & Fabricação de aço e derivados & \\
\hline 322 & Metalurgia de metais não-ferrosos & 322 & $\begin{array}{l}\text { Metalurgia de metais não- } \\
\text { ferrosos }\end{array}$ & & & 322 & Metalurgia de metais não-ferrosos & \\
\hline 323 & $\begin{array}{l}\text { Produtos de metal - exclusive } \\
\text { máquinas e equipamentos }\end{array}$ & 323 & $\begin{array}{l}\text { Produtos de metal - exclusive } \\
\text { máquinas e equipamentos }\end{array}$ & Metal & 13 & 323 & $\begin{array}{l}\text { Produtos de metal - exclusive } \\
\text { máquinas e equipamentos }\end{array}$ & \\
\hline 324 & $\begin{array}{l}\text { Máquinas e equipamentos, inclusive } \\
\text { manutenção e reparos }\end{array}$ & 324 & $\begin{array}{l}\text { Máquinas e equipamentos, } \\
\text { inclusive manutenção e reparos }\end{array}$ & $\begin{array}{l}\text { Eletrodoméstic } \\
\text { os }\end{array}$ & 14 & 324 & $\begin{array}{l}\text { Máquinas e equipamentos, } \\
\text { inclusive manutenção e reparos }\end{array}$ & \\
\hline 325 & Eletrodomésticos & 325 & Eletrodomésticos & & & 325 & Eletrodomésticos & \\
\hline 326 & $\begin{array}{l}\text { Máquinas para escritório e } \\
\text { equipamentos de informática }\end{array}$ & 326 & $\begin{array}{l}\text { Máquinas para escritório e } \\
\text { equipamentos de informática }\end{array}$ & Informática & 15 & 326 & $\begin{array}{l}\text { Máquinas para escritório e } \\
\text { equipamentos de informática }\end{array}$ & \\
\hline 327 & $\begin{array}{l}\text { Máquinas, aparelhos e materiais } \\
\text { elétricos }\end{array}$ & 327 & $\begin{array}{l}\text { Máquinas, aparelhos e materiais } \\
\text { elétricos }\end{array}$ & Máquinas & 16 & 327 & $\begin{array}{l}\text { Máquinas, aparelhos e materiais } \\
\text { elétricos }\end{array}$ & \\
\hline 328 & $\begin{array}{l}\text { Material eletrônico e equipamentos de } \\
\text { comunicações }\end{array}$ & 328 & $\begin{array}{l}\text { Material eletrônico e } \\
\text { equipamentos de comunicações }\end{array}$ & Eletrônicos & 17 & 328 & $\begin{array}{l}\text { Material eletrônico e equipamentos } \\
\text { de comunicações }\end{array}$ & \\
\hline 329 & $\begin{array}{l}\text { Aparelhos/instrumentos médico- } \\
\text { hospitalar, medida e óptico }\end{array}$ & 329 & $\begin{array}{l}\text { Aparelhos/instrumentos médico- } \\
\text { hospitalar, medida e óptico }\end{array}$ & $\begin{array}{l}\text { Instrumento } \\
\text { hospitalar }\end{array}$ & 18 & 329 & $\begin{array}{l}\text { Aparelhos/instrumentos médico- } \\
\text { hospitalar, medida e óptico }\end{array}$ & \\
\hline 330 & Automóveis, camionetas e utilitários & 330 & $\begin{array}{l}\text { Automóveis, camionetas e } \\
\text { utilitários }\end{array}$ & Veículos & 19 & 330 & $\begin{array}{l}\text { Automóveis, camionetas e } \\
\text { utilitários }\end{array}$ & \\
\hline 331 & Caminhões e ônibus & 331 & Caminhões e ônibus & & & 331 & Caminhões e ônibus & \\
\hline 332 & $\begin{array}{l}\text { Peças e acessórios para veículos } \\
\text { automotores }\end{array}$ & 332 & $\begin{array}{l}\text { Peças e acessórios para veículos } \\
\text { automotores }\end{array}$ & & & 332 & $\begin{array}{l}\text { Peças e acessórios para veículos } \\
\text { automotores }\end{array}$ & \\
\hline 333 & Outros equipamentos de transporte & 333 & $\begin{array}{l}\text { Outros equipamentos de } \\
\text { transporte }\end{array}$ & & & 333 & Outros equipamentos de transporte & \\
\hline 334 & $\begin{array}{l}\text { Móveis e produtos das indústrias } \\
\text { diversas }\end{array}$ & 334 & $\begin{array}{l}\text { Móveis e produtos das indústrias } \\
\text { diversas }\end{array}$ & $\begin{array}{l}\text { Indústria } \\
\text { Diversa }\end{array}$ & 20 & 334 & $\begin{array}{l}\text { Móveis e produtos das indústrias } \\
\text { diversas }\end{array}$ & \\
\hline
\end{tabular}




\begin{tabular}{|c|c|c|c|c|c|c|c|c|}
\hline 401 & $\begin{array}{l}\text { Eletricidade e gás, água, esgoto e } \\
\text { limpeza urbana }\end{array}$ & 401 & $\begin{array}{l}\text { Eletricidade e gás, água, esgoto e } \\
\text { limpeza urbana }\end{array}$ & SIUP & 21 & 401 & $\begin{array}{l}\text { Eletricidade e gás, água, esgoto e } \\
\text { limpeza urbana }\end{array}$ & $\begin{array}{l}\text { Produção e distribuição de } \\
\text { eletricidade e gás, água, esgoto e } \\
\text { limpeza urbana }\end{array}$ \\
\hline 501 & Construção & 501 & Construção & Construção & 22 & 501 & Construção & Construção civil \\
\hline 601 & Comércio & $\begin{array}{l}601 \mathrm{e} \\
1101\end{array}$ & $\begin{array}{l}\text { Comércio; Serviços de } \\
\text { manutenção e reparação }\end{array}$ & Comércio & 23 & $\begin{array}{l}601 \mathrm{e} \\
1101\end{array}$ & $\begin{array}{l}\text { Comércio; Serviços de } \\
\text { manutenção e reparação }\end{array}$ & $\begin{array}{l}\text { Comércio e Serviços de manutenção } \\
\text { e reparação }\end{array}$ \\
\hline 701 & Transporte, armazenagem e correio & 701 & $\begin{array}{l}\text { Transporte, armazenagem e } \\
\text { correio }\end{array}$ & Transportes & 24 & 701 & Transporte, armazenagem e correio & Transporte, armazenagem e correio \\
\hline 801 & Serviços de informação & 801 & Serviços de informação & Informação & 25 & 801 & Serviços de informação & Serviços de informação \\
\hline 901 & Intermediação financeira e seguros & 901 & $\begin{array}{l}\text { Intermediação financeira e } \\
\text { seguros }\end{array}$ & Financeiro & 26 & 901 & Intermediação financeira e seguros & $\begin{array}{l}\text { Intermediação financeira, seguros e } \\
\text { previdência complementar }\end{array}$ \\
\hline 1001 & Serviços imobiliários e aluguel & 1001 & Serviços imobiliários e aluguel & Imobiliário & 27 & 1001 & Serviços imobiliários e aluguel & Atividades imobiliárias e aluguel \\
\hline 1101 & Serviços de manutenção e reparação & & & & & 1101 & & \\
\hline 1102 & Serviços de alojamento e alimentação & 1102 & $\begin{array}{l}\text { Serviços de alojamento e } \\
\text { alimentação }\end{array}$ & Alojamento & 28 & 1102 & $\begin{array}{l}\text { Serviços de alojamento e } \\
\text { alimentação }\end{array}$ & $\begin{array}{l}\text { Serviços de alojamento e } \\
\text { alimentação }\end{array}$ \\
\hline 1103 & Serviços prestados às empresas & 1103 & Serviços prestados às empresas & $\begin{array}{l}\text { Serviços às } \\
\text { Empresas }\end{array}$ & 29 & 1103 & Serviços prestados às empresas & Serviços prestados às empresas \\
\hline 1104 & Educação mercantil & 1104 & Educação mercantil & $\begin{array}{l}\text { Educação e } \\
\text { Saúde } \\
\text { mercantis }\end{array}$ & 30 & 1104 & Educação mercantil & \\
\hline 1105 & Saúde mercantil & 1105 & Saúde mercantil & & & 1105 & Saúde mercantil & Saúde e educação mercantis \\
\hline 1106 & Outros serviços & 1106 & Outros serviços & $\begin{array}{l}\text { Outros } \\
\text { Serviços }\end{array}$ & 31 & 1106 & Outros serviços & $\begin{array}{l}\text { Serviços domésticos: Serviços } \\
\text { prestados às famílias e associativos }\end{array}$ \\
\hline 1201 & Educação pública & 1201 & Educação pública & APU & 32 & 1201 & Educação pública & \\
\hline 1202 & Saúde pública & 1202 & Saúde pública & & & 1202 & Saúde pública & $\begin{array}{l}\text { Administração, saúde e educação } \\
\text { públicas }\end{array}$ \\
\hline 1203 & $\begin{array}{l}\text { Administração pública e seguridade } \\
\text { social }\end{array}$ & 1203 & $\begin{array}{l}\text { Administração pública e } \\
\text { seguridade social }\end{array}$ & & & 1203 & $\begin{array}{l}\text { Administração pública e } \\
\text { seguridade social }\end{array}$ & \\
\hline
\end{tabular}

Fonte: Adaptado de Silva (2008). 
Quadro A2 - Dados de Atividades do Sistema de Contas Nacionais e Atividades após agregação e desagregação.

\begin{tabular}{|c|c|c|c|}
\hline Código da atividade nível 55 & Descrição da atividade nível 55 & Renomeado após agregação e desagregação & Grupo da CNAE 1.0 \\
\hline 101 & $\begin{array}{l}\text { Agricultura, silvicultura, exploração } \\
\text { florestal }\end{array}$ & Agricultura & $\begin{array}{l}0113+0115+0131+0132+0111+0112+0114+0119+0121+0122+0161+0133+0134+0139+ \\
021\end{array}$ \\
\hline 102 & Pecuária e pesca & Pecuária & $0141+0142+0143+0146+0162+0170+0144+0145+051+0150$ \\
\hline 201 & Petróleo e gás natural & \multirow[t]{3}{*}{ Extrativa } & $111+112$ \\
\hline 202 & Minério de ferro & & 131 \\
\hline 203 & Outros da indústria extrativa & & $100+132+141+142$ \\
\hline 301 & Alimentos e bebidas & \multirow[t]{2}{*}{ Alimentos } & $151+152+153+154+155+156+157+158+159+160$ \\
\hline 302 & Produtos do fumo & & 160 \\
\hline 303 & Têxteis & Têxteis & $171+172+173+174+175+176+177$ \\
\hline 304 & Artigos do vestuário e acessórios & Vestuário & $181+182$ \\
\hline 305 & Artefatos de couro e calçados & Calçados & $191+192+193$ \\
\hline 306 & $\begin{array}{l}\text { Produtos de madeira - exclusive } \\
\text { móveis }\end{array}$ & Madeira & $201+202$ \\
\hline 307 & Celulose e produtos de papel & Celulose & $211+212+213+214$ \\
\hline 308 & Jornais, revistas, discos & Revistas & $221+222+223$ \\
\hline 309 & Refino de petróleo e coque & \multirow[t]{2}{*}{ Petróleo } & $231+232+233$ \\
\hline 310 & Álcool & & 234 \\
\hline 311 & Produtos químicos & \multirow[t]{7}{*}{ Químicos } & $241+242$ \\
\hline 312 & Fabricação de resina e elastômeros & & $243+244$ \\
\hline 313 & Produtos farmacêuticos & & 245 \\
\hline 314 & Defensivos agrícolas & & 246 \\
\hline 315 & Perfumaria, higiene e limpeza & & 247 \\
\hline 316 & Tintas, vernizes, esmaltes e lacas & & 248 \\
\hline 317 & $\begin{array}{l}\text { Produtos e preparados químicos } \\
\text { diversos }\end{array}$ & & 249 \\
\hline 318 & Artigos de borracha e plástico & Borracha & $251+252$ \\
\hline
\end{tabular}




\begin{tabular}{|c|c|c|c|}
\hline 319 & Cimento & \multirow[t]{2}{*}{ Cimento } & 262 \\
\hline 320 & $\begin{array}{l}\text { Outros produtos de minerais não- } \\
\text { metálicos }\end{array}$ & & $261+263+264+269$ \\
\hline 321 & Fabricação de aço e derivados & Aço & $271+272+273$ \\
\hline 323 & $\begin{array}{l}\text { Produtos de metal - exclusive máquinas } \\
\text { e equipamentos }\end{array}$ & Metal & $281+282+288+283+284+289$ \\
\hline 324 & $\begin{array}{l}\text { Máquinas e equipamentos, inclusive } \\
\text { manutenção e reparos }\end{array}$ & Eletrodomésticos & $291+292+294+295+296+2991+2992+2994+2995+2996+293+2993+297$ \\
\hline 326 & $\begin{array}{l}\text { Máquinas para escritório e } \\
\text { equipamentos de informática }\end{array}$ & Informática & $301+302$ \\
\hline 327 & $\begin{array}{l}\text { Máquinas, aparelhos e materiais } \\
\text { elétricos }\end{array}$ & Máquinas & $311+312+3181+313+314+315+3182+316+319+3189$ \\
\hline 328 & $\begin{array}{l}\text { Material eletrônico e equipamentos de } \\
\text { comunicaçōes }\end{array}$ & Eletrônicos & $321+322+329+323$ \\
\hline 332 & $\begin{array}{l}\text { Peças e acessórios para veículos } \\
\text { automotores }\end{array}$ & Veículos & $343+345+344$ \\
\hline 333 & Outros equipamentos de transporte & Equipamento de Transporte & $351+352+353+359$ \\
\hline 334 & $\begin{array}{l}\text { Móveis e produtos das indústrias } \\
\text { diversas }\end{array}$ & Indústria Diversa & $361+369+371+372$ \\
\hline 401 & $\begin{array}{l}\text { Eletricidade e gás, água, esgoto e } \\
\text { limpeza urbana }\end{array}$ & SIUP & $401+402+403+410+900$ \\
\hline 501 & Construção & Construção & $451+452+453+454+455+456$ \\
\hline 601 & Comércio & Comércio & $\begin{array}{l}501+502+503+504+505+511+512+513+5146+5147+5149+515+516+519+521+522+523 \\
+5242+5243+5244+5245+5246+5247+5249+525+526+5145+5241+5262+527+725\end{array}$ \\
\hline
\end{tabular}




\begin{tabular}{|l|l|l|l|}
\hline 701 & Transporte, armazenagem e correio & Transportes & $\begin{array}{l}6010+6021+6022+6029+6023+6024+6025+6026+6027+6028+603+6111+6112+6121+6 \\
122+6123+6210+6220+6230+631+632+634+633+641\end{array}$ \\
\hline 801 & Serviços de informação & Informação & $642+721+722+723+724+729+921+922+924+921+923$ \\
\hline 901 & Intermediação financeira e seguros & Financeiro & $651+652+653+654+655+659+661+662+663+671+672$ \\
\hline 1001 & Serviços imobiliários e aluguel & Imobiliário & $701+702+$ estimado+703+711+712+713+714 \\
\hline 1101 & Serviços de manutenção e reparação & & $502+5042+527$ \\
\hline 1102 & Serviços de alojamento e alimentação & Alojamento & $551+552$ \\
\hline 1103 & Serviços prestados às empresas & Serviços às Empresas & $731+732+741+742+743+744+745+746+747+749$ \\
\hline 1104 & Educação mercantil & Educação e Saúde mercantis & $801+802+803+809$ \\
\hline 1105 & Saúde mercantil & Outros Serviços & $8511+8512+8513+8514+8515+8516+852+853$ \\
\hline 1106 & Outros serviços & APU & $704+911+912+919+925+926+930+950+990$ \\
\hline 1201 & Educação pública & & $801+802+803+809$ \\
\hline 1202 & Saúde pública & $851+852$ \\
\hline 1203 & $\begin{array}{l}\text { Administração pública e seguridade } \\
\text { social }\end{array}$ & & $751+752+753$ \\
\hline
\end{tabular}

Fonte: Adaptado de Silva (2008). 


\section{APÊNDICE "B" - Matrizes de Geração de Emprego}

Tabela B1 - Matriz Geração de Emprego para o Grau de Instrução G(0), Distrito Federal - 2008.

(1)

\begin{tabular}{|c|c|c|c|c|c|c|c|c|c|c|c|}
\hline Setores & Agricultura & Pecuária & Extrativa & Alimentos & Vestuário & Madeira & Celulose & Revistas & Químicos & Borracha & Cimento \\
\hline Agricultura & $1,09341 \mathrm{E}-07$ & 7,17373E-09 & $1,19317 \mathrm{E}-11$ & $8,80932 \mathrm{E}-09$ & $1,10201 \mathrm{E}-10$ & $1,7323 \mathrm{E}-10$ & $5,00281 \mathrm{E}-10$ & $4,88005 \mathrm{E}-12$ & $2,19692 \mathrm{E}-11$ & $3,72319 \mathrm{E}-10$ & $8,53982 \mathrm{E}-12$ \\
\hline Pecuária & $7,22172 \mathrm{E}-10$ & $1,84709 \mathrm{E}-07$ & $5,42943 \mathrm{E}-12$ & $7,30656 \mathrm{E}-09$ & $1,52542 \mathrm{E}-10$ & $1,28074 \mathrm{E}-11$ & $4,20792 \mathrm{E}-11$ & $2,05087 \mathrm{E}-12$ & $1,33199 \mathrm{E}-11$ & $6,21587 \mathrm{E}-11$ & $5,06854 \mathrm{E}-12$ \\
\hline Extrativa & $9,09059 \mathrm{E}-12$ & $2,15496 \mathrm{E}-11$ & $1,25242 \mathrm{E}-07$ & $5,12681 \mathrm{E}-12$ & $4,71156 \mathrm{E}-12$ & $6,48654 \mathrm{E}-12$ & $5,01659 \mathrm{E}-11$ & $1,20061 \mathrm{E}-12$ & $7,62462 \mathrm{E}-11$ & $1,62195 \mathrm{E}-11$ & $5,6665 \mathrm{E}-11$ \\
\hline Alimentos & $3,57471 \mathrm{E}-10$ & $5,42835 \mathrm{E}-09$ & $1,87515 \mathrm{E}-11$ & $3,27277 \mathrm{E}-08$ & $2,46939 \mathrm{E}-10$ & $2,55683 \mathrm{E}-11$ & $7,99253 \mathrm{E}-11$ & $6,93224 \mathrm{E}-12$ & $3,01971 \mathrm{E}-11$ & $1,01084 \mathrm{E}-11$ & $1,83374 \mathrm{E}-11$ \\
\hline Vestuário & $1,52323 \mathrm{E}-12$ & $1,34801 \mathrm{E}-12$ & $4,49438 \mathrm{E}-11$ & $1,96469 \mathrm{E}-12$ & $8,0634 \mathrm{E}-08$ & $1,82706 \mathrm{E}-12$ & $6,45349 \mathrm{E}-11$ & $2,06795 \mathrm{E}-12$ & $4,12112 \mathrm{E}-12$ & $1,20766 \mathrm{E}-11$ & $2,85623 \mathrm{E}-12$ \\
\hline Madeira & $3,02188 \mathrm{E}-11$ & $5,92368 \mathrm{E}-12$ & $1,64744 \mathrm{E}-11$ & $7,06898 \mathrm{E}-12$ & $2,94184 \mathrm{E}-11$ & $5,076 \mathrm{E}-07$ & $3,06246 \mathrm{E}-09$ & $5,07465 \mathrm{E}-12$ & $9,28236 \mathrm{E}-11$ & $2,5199 \mathrm{E}-11$ & $2,86342 \mathrm{E}-11$ \\
\hline Celulose & 0 & 0 & 0 & 0 & 0 & 0 & 0 & 0 & 0 & 0 & 0 \\
\hline Revistas & $1,11527 \mathrm{E}-12$ & $1,24341 \mathrm{E}-12$ & $2,87484 \mathrm{E}-12$ & $2,0521 \mathrm{E}-12$ & $1,0824 \mathrm{E}-12$ & $6,6645 \mathrm{E}-13$ & $1,23764 \mathrm{E}-11$ & 2,68795E-09 & $1,76416 \mathrm{E}-11$ & $6,93569 \mathrm{E}-12$ & $2,36264 \mathrm{E}-12$ \\
\hline Químicos & $3,60585 \mathrm{E}-10$ & $2,50799 \mathrm{E}-10$ & $8,37923 \mathrm{E}-11$ & $4,69195 \mathrm{E}-11$ & $2,57908 \mathrm{E}-11$ & $4,78085 \mathrm{E}-11$ & $2,17433 \mathrm{E}-10$ & $1,44971 \mathrm{E}-12$ & $9,33153 \mathrm{E}-09$ & $1,26736 \mathrm{E}-10$ & $1,18689 \mathrm{E}-11$ \\
\hline Borracha & $8,57714 \mathrm{E}-11$ & $5,49648 \mathrm{E}-11$ & $7,05881 \mathrm{E}-10$ & $1,52334 \mathrm{E}-10$ & $2,00476 \mathrm{E}-10$ & $3,73064 \mathrm{E}-10$ & $9,30378 \mathrm{E}-10$ & $1,17252 \mathrm{E}-10$ & $2,76208 \mathrm{E}-10$ & 7,83544E-08 & $9,38943 \mathrm{E}-12$ \\
\hline Cimento & $2,02196 \mathrm{E}-11$ & $1,03229 \mathrm{E}-11$ & $2,3854 \mathrm{E}-11$ & $3,45492 \mathrm{E}-11$ & $9,09247 \mathrm{E}-12$ & $3,94913 \mathrm{E}-12$ & $3,08942 \mathrm{E}-11$ & $3,23968 \mathrm{E}-12$ & $1,27091 \mathrm{E}-10$ & $9,46225 \mathrm{E}-12$ & $2,0106 \mathrm{E}-08$ \\
\hline Aço & 0 & 0 & 0 & 0 & 0 & 0 & 0 & 0 & 0 & 0 & 0 \\
\hline Metal & $1,30524 \mathrm{E}-10$ & $9,19721 \mathrm{E}-11$ & $4,22935 \mathrm{E}-10$ & $2,2703 \mathrm{E}-10$ & $3,64682 \mathrm{E}-11$ & $2,20481 \mathrm{E}-10$ & $3,94147 \mathrm{E}-10$ & $2,4461 \mathrm{E}-12$ & $1,91672 \mathrm{E}-10$ & $2,17815 \mathrm{E}-10$ & $3,44247 \mathrm{E}-11$ \\
\hline Eletrodomésticos & 0 & 0 & 0 & 0 & 0 & 0 & 0 & 0 & 0 & 0 & 0 \\
\hline Informática & 0 & 0 & 0 & 0 & 0 & 0 & 0 & 0 & 0 & 0 & 0 \\
\hline Máquinas & 0 & 0 & 0 & 0 & 0 & 0 & 0 & 0 & 0 & 0 & 0 \\
\hline Eletrônicos & 0 & 0 & 0 & 0 & 0 & 0 & 0 & 0 & 0 & 0 & 0 \\
\hline Instrumento hospitalar & 0 & 0 & 0 & 0 & 0 & 0 & 0 & 0 & 0 & 0 & 0 \\
\hline Veículos & $6,48193 \mathrm{E}-12$ & $5,3042 \mathrm{E}-12$ & $3,83879 \mathrm{E}-11$ & $1,23163 \mathrm{E}-11$ & $6,62014 \mathrm{E}-12$ & $1,59671 \mathrm{E}-11$ & $3,11557 \mathrm{E}-11$ & $2,03484 \mathrm{E}-12$ & $1,46814 \mathrm{E}-11$ & $3,22618 \mathrm{E}-11$ & $5,81956 \mathrm{E}-12$ \\
\hline Indústria Diversa & $3,42155 \mathrm{E}-12$ & $3,17167 \mathrm{E}-11$ & $9,236 \mathrm{E}-12$ & $2,14915 \mathrm{E}-11$ & $3,37621 \mathrm{E}-10$ & $9,95808 \mathrm{E}-12$ & $1,82934 \mathrm{E}-10$ & $3,98081 \mathrm{E}-12$ & $9,09324 \mathrm{E}-12$ & $6,4978 \mathrm{E}-11$ & $8,6899 \mathrm{E}-12$ \\
\hline SIUP & $5,85467 \mathrm{E}-11$ & $9,03639 \mathrm{E}-11$ & $2,34937 \mathrm{E}-10$ & $1,44716 \mathrm{E}-10$ & $1,18425 \mathrm{E}-10$ & $1,23023 \mathrm{E}-10$ & $3,63294 \mathrm{E}-10$ & $9,63852 \mathrm{E}-11$ & $1,75493 \mathrm{E}-10$ & $1,81475 \mathrm{E}-10$ & $4,78595 \mathrm{E}-10$ \\
\hline Construção & $1,27479 \mathrm{E}-11$ & $1,8109 \mathrm{E}-11$ & $3,27689 \mathrm{E}-11$ & $4,20479 \mathrm{E}-11$ & $3,77728 \mathrm{E}-11$ & $3,33665 \mathrm{E}-11$ & $6,00728 \mathrm{E}-11$ & $4,75516 \mathrm{E}-11$ & $6,73028 \mathrm{E}-11$ & $1,09305 \mathrm{E}-10$ & $1,49072 \mathrm{E}-10$ \\
\hline
\end{tabular}




\begin{tabular}{|c|c|c|c|c|c|c|c|c|c|c|c|}
\hline Comércio & $1,14578 \mathrm{E}-09$ & 1,69077E-09 & $1,00771 \mathrm{E}-09$ & $1,81295 \mathrm{E}-09$ & $1,90432 \mathrm{E}-09$ & $7,77715 \mathrm{E}-10$ & $9,94941 \mathrm{E}-10$ & $1,03034 \mathrm{E}-09$ & $1,4139 \mathrm{E}-09$ & $1,10194 \mathrm{E}-09$ & $1,76822 \mathrm{E}-09$ \\
\hline Transportes & $3,89683 \mathrm{E}-10$ & $3,54567 \mathrm{E}-10$ & $1,04162 \mathrm{E}-09$ & $6,64629 \mathrm{E}-10$ & $3,08911 \mathrm{E}-10$ & $3,34458 \mathrm{E}-10$ & $5,6659 \mathrm{E}-10$ & $3,25735 \mathrm{E}-10$ & $6,16119 \mathrm{E}-10$ & $4,02887 \mathrm{E}-10$ & $1,24876 \mathrm{E}-09$ \\
\hline Informação & $1,5483 \mathrm{E}-12$ & $2,40026 \mathrm{E}-12$ & $7,06351 \mathrm{E}-12$ & $3,01641 \mathrm{E}-12$ & $1,72843 \mathrm{E}-12$ & $1,27867 \mathrm{E}-12$ & $2,95204 \mathrm{E}-12$ & $7,10263 \mathrm{E}-12$ & $9,14554 \mathrm{E}-12$ & $4,07851 \mathrm{E}-12$ & $5,53479 \mathrm{E}-12$ \\
\hline Financeiro & $8,79953 \mathrm{E}-13$ & $9,75736 \mathrm{E}-13$ & $1,97176 \mathrm{E}-12$ & $1,67916 \mathrm{E}-12$ & $1,34266 \mathrm{E}-12$ & $1,24468 \mathrm{E}-12$ & $2,71478 \mathrm{E}-12$ & $1,53979 \mathrm{E}-12$ & $2,67331 \mathrm{E}-12$ & $1,94175 \mathrm{E}-12$ & $3,12244 \mathrm{E}-12$ \\
\hline Imobiliário & $2,32792 \mathrm{E}-11$ & $2,98128 \mathrm{E}-11$ & $7,0627 \mathrm{E}-11$ & $5,95784 \mathrm{E}-11$ & $6,63782 \mathrm{E}-11$ & $2,65662 \mathrm{E}-11$ & $5,86934 \mathrm{E}-11$ & $9,24806 \mathrm{E}-11$ & $7,91728 \mathrm{E}-11$ & $4,93636 \mathrm{E}-11$ & $8,60184 \mathrm{E}-11$ \\
\hline Alojamento & $1,16469 \mathrm{E}-11$ & $1,64278 \mathrm{E}-11$ & $1,06182 \mathrm{E}-10$ & $2,89005 \mathrm{E}-11$ & $1,6851 \mathrm{E}-11$ & $3,38022 \mathrm{E}-11$ & $3,44484 \mathrm{E}-11$ & $4,56658 \mathrm{E}-11$ & $3,82732 \mathrm{E}-11$ & 3,39973E-11 & $1,86871 \mathrm{E}-10$ \\
\hline Serviços às Empresas & $3,34517 \mathrm{E}-10$ & $4,80915 \mathrm{E}-10$ & $9,27266 \mathrm{E}-10$ & $1,13166 \mathrm{E}-09$ & $7,4248 \mathrm{E}-10$ & $3,94808 \mathrm{E}-10$ & $9,5749 \mathrm{E}-10$ & 2,60918E-09 & 2,95064E-09 & $7,98453 \mathrm{E}-10$ & $1,85339 \mathrm{E}-09$ \\
\hline Educação e Saúde mercantis & $6,30376 \mathrm{E}-12$ & $8,71566 \mathrm{E}-12$ & $1,28262 \mathrm{E}-11$ & $1,31374 \mathrm{E}-11$ & $1,60395 \mathrm{E}-11$ & $5,88983 \mathrm{E}-12$ & $1,15309 \mathrm{E}-11$ & $1,4059 \mathrm{E}-11$ & $1,4125 \mathrm{E}-11$ & $1,01093 \mathrm{E}-11$ & $1,45645 \mathrm{E}-11$ \\
\hline Outros Serviços & $1,32914 \mathrm{E}-10$ & $1,92622 \mathrm{E}-10$ & $2,00676 \mathrm{E}-10$ & $2,54107 \mathrm{E}-10$ & $2,73163 \mathrm{E}-10$ & $1,00708 \mathrm{E}-10$ & $1,66987 \mathrm{E}-10$ & $1,96295 \mathrm{E}-10$ & $2,7069 \mathrm{E}-10$ & $1,97652 \mathrm{E}-10$ & $3,15286 \mathrm{E}-10$ \\
\hline $\mathrm{APU}$ & $2,64846 \mathrm{E}-13$ & 3,15993E-13 & $6,34387 \mathrm{E}-13$ & $5,85839 \mathrm{E}-13$ & 3,69217E-13 & $2,49145 \mathrm{E}-13$ & $6,04881 \mathrm{E}-13$ & $1,11949 \mathrm{E}-12$ & $1,01265 \mathrm{E}-12$ & $4,29584 \mathrm{E}-13$ & $9,67376 \mathrm{E}-13$ \\
\hline
\end{tabular}

Tabela B1 - Matriz Geração de Emprego para o Grau de Instrução G(0), Distrito Federal - 2008.

(2)

\begin{tabular}{|c|c|c|c|c|c|c|c|c|c|c|}
\hline Setores & Aço & Metal & Eletrodomésticos & Informática & Máquinas & Eletrônicos & $\begin{array}{l}\text { Instrumento } \\
\text { hospitalar }\end{array}$ & Veículos & $\begin{array}{l}\text { Indústria } \\
\text { Diversa }\end{array}$ & SIUP \\
\hline Agricultura & $6,43378 \mathrm{E}-12$ & $3,54731 \mathrm{E}-12$ & $1,27369 \mathrm{E}-11$ & $1,21336 \mathrm{E}-11$ & $7,23629 \mathrm{E}-12$ & $1,65659 \mathrm{E}-11$ & $4,40158 \mathrm{E}-12$ & $2,52723 \mathrm{E}-11$ & $9,88893 \mathrm{E}-12$ & $1,79245 \mathrm{E}-12$ \\
\hline Pecuária & $2,7865 \mathrm{E}-12$ & $1,37647 \mathrm{E}-12$ & $3,40227 \mathrm{E}-12$ & $3,68012 \mathrm{E}-12$ & $2,91855 \mathrm{E}-12$ & $3,81864 \mathrm{E}-12$ & $1,57373 \mathrm{E}-12$ & $6,09143 \mathrm{E}-12$ & $3,26296 \mathrm{E}-11$ & $8,94974 \mathrm{E}-13$ \\
\hline Extrativa & 2,10991E-09 & $1,24654 \mathrm{E}-10$ & $3,95601 \mathrm{E}-10$ & $3,01525 \mathrm{E}-11$ & $1,19962 \mathrm{E}-10$ & $6,74168 \mathrm{E}-11$ & $1,12331 \mathrm{E}-11$ & $2,25651 \mathrm{E}-10$ & $6,91712 \mathrm{E}-11$ & $1,0589 \mathrm{E}-12$ \\
\hline Alimentos & $8,2177 \mathrm{E}-12$ & $3,86355 \mathrm{E}-12$ & $7,99809 \mathrm{E}-12$ & $8,94767 \mathrm{E}-12$ & $8,05817 \mathrm{E}-12$ & $8,7529 \mathrm{E}-12$ & $4,24337 \mathrm{E}-12$ & $1,08217 \mathrm{E}-11$ & $7,69844 \mathrm{E}-12$ & $2,57958 \mathrm{E}-12$ \\
\hline Vestuário & $3,79446 \mathrm{E}-12$ & $5,80663 \mathrm{E}-12$ & $3,187 \mathrm{E}-11$ & $4,43241 \mathrm{E}-12$ & $3,72269 \mathrm{E}-12$ & $5,04668 \mathrm{E}-12$ & $5,61774 \mathrm{E}-12$ & $2,73376 \mathrm{E}-11$ & $3,83726 \mathrm{E}-12$ & $3,84181 \mathrm{E}-12$ \\
\hline Madeira & $2,30381 \mathrm{E}-11$ & $3,40279 \mathrm{E}-11$ & $6,78933 \mathrm{E}-10$ & $6,24604 \mathrm{E}-10$ & $3,00238 \mathrm{E}-11$ & 2,77795E-09 & $8,21689 \mathrm{E}-12$ & $4,25571 \mathrm{E}-10$ & $9,17399 \mathrm{E}-10$ & $1,11198 \mathrm{E}-12$ \\
\hline Celulose & 0 & 0 & 0 & 0 & 0 & 0 & 0 & 0 & 0 & 0 \\
\hline Revistas & $3,38529 \mathrm{E}-12$ & $3,33132 \mathrm{E}-12$ & $2,04025 \mathrm{E}-12$ & $3,85067 \mathrm{E}-12$ & $1,73835 \mathrm{E}-12$ & $3,23303 \mathrm{E}-12$ & $1,59759 \mathrm{E}-11$ & $3,80082 \mathrm{E}-12$ & $1,1357 \mathrm{E}-12$ & $4,76209 \mathrm{E}-12$ \\
\hline Químicos & $1,1173 \mathrm{E}-10$ & $1,94782 \mathrm{E}-11$ & $1,03137 \mathrm{E}-10$ & $7,39976 \mathrm{E}-12$ & $3,24591 \mathrm{E}-11$ & $1,30476 \mathrm{E}-11$ & $2,46163 \mathrm{E}-11$ & $6,78986 \mathrm{E}-11$ & $1,208 \mathrm{E}-11$ & $8,16972 \mathrm{E}-12$ \\
\hline Borracha & $4,82097 \mathrm{E}-10$ & $2,76352 \mathrm{E}-10$ & $1,31825 \mathrm{E}-09$ & $1,17454 \mathrm{E}-09$ & $6,05918 \mathrm{E}-10$ & $1,36319 \mathrm{E}-09$ & $3,79833 \mathrm{E}-10$ & 3,15804E-09 & $4,9981 \mathrm{E}-10$ & $1,19578 \mathrm{E}-11$ \\
\hline Cimento & $1,77383 \mathrm{E}-10$ & $5,29396 \mathrm{E}-11$ & $6,88049 \mathrm{E}-11$ & $3,62331 \mathrm{E}-11$ & $1,70455 \mathrm{E}-10$ & $1,32832 \mathrm{E}-10$ & $6,24402 \mathrm{E}-11$ & $1,53449 \mathrm{E}-10$ & $3,56775 \mathrm{E}-10$ & $1,7189 \mathrm{E}-12$ \\
\hline Aço & 0 & 0 & 0 & 0 & 0 & 0 & 0 & 0 & 0 & 0 \\
\hline Metal & $1,04034 \mathrm{E}-09$ & $2,6707 \mathrm{E}-08$ & $1,67475 \mathrm{E}-09$ & $6,28199 \mathrm{E}-10$ & $1,16385 \mathrm{E}-09$ & $1,0364 \mathrm{E}-09$ & $7,1338 \mathrm{E}-10$ & $7,47211 \mathrm{E}-10$ & $5,74388 \mathrm{E}-10$ & $2,92044 \mathrm{E}-12$ \\
\hline
\end{tabular}




\begin{tabular}{|c|c|c|c|c|c|c|c|c|c|c|}
\hline Eletrodomésticos & 0 & 0 & 0 & 0 & 0 & 0 & 0 & 0 & 0 & 0 \\
\hline Informática & 0 & 0 & 0 & 0 & 0 & 0 & 0 & 0 & 0 & 0 \\
\hline Máquinas & 0 & 0 & 0 & 0 & 0 & 0 & 0 & 0 & 0 & 0 \\
\hline Eletrônicos & 0 & 0 & 0 & 0 & 0 & 0 & 0 & 0 & 0 & 0 \\
\hline Instrumento hospitalar & 0 & 0 & 0 & 0 & 0 & 0 & 0 & 0 & 0 & 0 \\
\hline Veículos & 8,79893E-11 & $5,55882 \mathrm{E}-11$ & $3,9688 \mathrm{E}-10$ & $2,80373 \mathrm{E}-10$ & $3,20301 \mathrm{E}-10$ & $5,08772 \mathrm{E}-10$ & $6,74281 \mathrm{E}-11$ & $1,4025 \mathrm{E}-07$ & $4,01232 \mathrm{E}-11$ & $8,55728 \mathrm{E}-12$ \\
\hline Indústria Diversa & $4,34311 \mathrm{E}-10$ & $3,20001 \mathrm{E}-11$ & $1,00942 \mathrm{E}-10$ & $1,91042 \mathrm{E}-11$ & $5,86116 \mathrm{E}-11$ & $3,10875 \mathrm{E}-11$ & $8,28293 \mathrm{E}-12$ & $5,21463 \mathrm{E}-11$ & $1,08827 \mathrm{E}-07$ & $2,71322 \mathrm{E}-12$ \\
\hline SIUP & $4,25235 \mathrm{E}-10$ & $2,07366 \mathrm{E}-10$ & $2,06414 \mathrm{E}-10$ & $1,38215 \mathrm{E}-10$ & $2,42332 \mathrm{E}-10$ & $1,68883 \mathrm{E}-10$ & $1,76617 \mathrm{E}-10$ & $1,80956 \mathrm{E}-10$ & $1,2885 \mathrm{E}-10$ & $1,92525 \mathrm{E}-08$ \\
\hline Construção & $4,64428 \mathrm{E}-11$ & $3,12087 \mathrm{E}-11$ & $6,31268 \mathrm{E}-11$ & $9,29308 \mathrm{E}-11$ & $1,28356 \mathrm{E}-10$ & $1,93954 \mathrm{E}-10$ & $2,94259 \mathrm{E}-11$ & $2,05697 \mathrm{E}-10$ & $3,77143 \mathrm{E}-11$ & $2,91529 \mathrm{E}-11$ \\
\hline Comércio & $9,42054 \mathrm{E}-10$ & $8,25085 \mathrm{E}-10$ & 1,38611E-09 & $3,12027 \mathrm{E}-09$ & $1,23575 \mathrm{E}-09$ & $2,33062 \mathrm{E}-09$ & $1,24474 \mathrm{E}-09$ & $1,77564 \mathrm{E}-09$ & 1,44153E-09 & $3,93448 \mathrm{E}-10$ \\
\hline Transportes & $8,37686 \mathrm{E}-10$ & $4,80696 \mathrm{E}-10$ & 6,61471E-10 & $7,41879 \mathrm{E}-10$ & $6,32851 \mathrm{E}-10$ & $9,20983 \mathrm{E}-10$ & $5,02528 \mathrm{E}-10$ & $5,79806 \mathrm{E}-10$ & $3,11445 \mathrm{E}-10$ & $2,54493 \mathrm{E}-10$ \\
\hline Informação & $7,2201 \mathrm{E}-12$ & $3,21114 \mathrm{E}-12$ & $8,07657 \mathrm{E}-12$ & $1,16108 \mathrm{E}-11$ & $9,90906 \mathrm{E}-12$ & $1,7083 \mathrm{E}-11$ & $5,2327 \mathrm{E}-12$ & $6,4588 \mathrm{E}-12$ & $1,75453 \mathrm{E}-12$ & $6,10972 \mathrm{E}-12$ \\
\hline Financeiro & $3,40157 \mathrm{E}-12$ & $2,00397 \mathrm{E}-12$ & $4,33364 \mathrm{E}-12$ & $3,02665 \mathrm{E}-12$ & $3,09614 \mathrm{E}-12$ & $5,33327 \mathrm{E}-12$ & $2,1524 \mathrm{E}-12$ & $2,9727 \mathrm{E}-12$ & $1,27386 \mathrm{E}-12$ & $1,1455 \mathrm{E}-12$ \\
\hline Imobiliário & $5,57766 \mathrm{E}-11$ & $4,73298 \mathrm{E}-11$ & $7,37505 \mathrm{E}-11$ & $7,90824 \mathrm{E}-11$ & $5,8508 \mathrm{E}-11$ & $7,8231 \mathrm{E}-11$ & $6,88219 \mathrm{E}-11$ & $5,14834 \mathrm{E}-11$ & $4,48868 \mathrm{E}-11$ & $4,03874 \mathrm{E}-11$ \\
\hline Alojamento & $4,94815 \mathrm{E}-11$ & $1,88599 \mathrm{E}-11$ & $2,72451 \mathrm{E}-11$ & $3,93987 \mathrm{E}-11$ & $5,84623 \mathrm{E}-11$ & $3,9365 \mathrm{E}-11$ & $1,69407 \mathrm{E}-11$ & $5,22692 \mathrm{E}-11$ & $3,52049 \mathrm{E}-11$ & $1,44695 \mathrm{E}-11$ \\
\hline Serviços às Empresas & $7,75824 \mathrm{E}-10$ & $7,56028 \mathrm{E}-10$ & $9,06099 \mathrm{E}-10$ & $4,0532 \mathrm{E}-09$ & $1,29203 \mathrm{E}-09$ & $2,85678 \mathrm{E}-09$ & $1,03758 \mathrm{E}-09$ & $1,73527 \mathrm{E}-09$ & $5,9696 \mathrm{E}-10$ & $2,20373 \mathrm{E}-09$ \\
\hline Educação e Saúde mercantis & $9,57238 \mathrm{E}-12$ & $9,67211 \mathrm{E}-12$ & $1,42029 \mathrm{E}-11$ & $1,97899 \mathrm{E}-11$ & $1,21676 \mathrm{E}-11$ & $1,81775 \mathrm{E}-11$ & $1,21011 \mathrm{E}-11$ & $1,22684 \mathrm{E}-11$ & $1,11052 \mathrm{E}-11$ & $7,61566 \mathrm{E}-12$ \\
\hline Outros Serviços & $1,8641 \mathrm{E}-10$ & $1,69617 \mathrm{E}-10$ & $2,49086 \mathrm{E}-10$ & $4,89309 \mathrm{E}-10$ & $3,55599 \mathrm{E}-10$ & $4,51212 \mathrm{E}-10$ & $2,02382 \mathrm{E}-10$ & $2,6349 \mathrm{E}-10$ & $2,07769 \mathrm{E}-10$ & $1,98211 \mathrm{E}-10$ \\
\hline APU & $6,15944 \mathrm{E}-13$ & $4,23491 \mathrm{E}-13$ & $4,98252 \mathrm{E}-13$ & $1,28039 \mathrm{E}-12$ & $5,5433 \mathrm{E}-13$ & $1,01719 \mathrm{E}-12$ & $4,93207 \mathrm{E}-13$ & $6,87547 \mathrm{E}-13$ & $3,18142 \mathrm{E}-13$ & $1,14288 \mathrm{E}-12$ \\
\hline
\end{tabular}

Tabela B1 - Matriz Geração de Emprego para o Grau de Instrução G(0), Distrito Federal - 2008.

(3)

\begin{tabular}{|c|c|c|c|c|c|c|c|c|c|c|c|}
\hline Setores & Construção & Comércio & Transportes & Informação & Financeiro & Imobiliário & Alojamento & $\begin{array}{c}\text { Serviços às } \\
\text { Empresas }\end{array}$ & $\begin{array}{l}\text { Educação e } \\
\text { Saúde } \\
\text { mercantis }\end{array}$ & $\begin{array}{c}\text { Outros } \\
\text { Serviços }\end{array}$ & APU \\
\hline Agricultura & $5,14308 \mathrm{E}-12$ & $1,59567 \mathrm{E}-11$ & $1,20702 \mathrm{E}-11$ & $7,32168 \mathrm{E}-12$ & $4,74095 \mathrm{E}-12$ & $1,00481 \mathrm{E}-12$ & $1,60527 \mathrm{E}-09$ & $7,26956 \mathrm{E}-12$ & $3,82702 \mathrm{E}-11$ & $1,65324 \mathrm{E}-10$ & $2,0432 \mathrm{E}-11$ \\
\hline Pecuária & $2,69057 \mathrm{E}-12$ & $7,90722 \mathrm{E}-12$ & $7,04019 \mathrm{E}-12$ & $3,48464 \mathrm{E}-12$ & $2,6677 \mathrm{E}-12$ & $4,5111 \mathrm{E}-13$ & $1,04136 \mathrm{E}-09$ & $3,48458 \mathrm{E}-12$ & $2,3177 \mathrm{E}-11$ & $1,13152 \mathrm{E}-10$ & $1,08546 \mathrm{E}-11$ \\
\hline Extrativa & $5,50691 \mathrm{E}-12$ & $2,87068 \mathrm{E}-12$ & $1,76913 \mathrm{E}-12$ & $3,32438 \mathrm{E}-12$ & $9,92124 \mathrm{E}-13$ & $5,49367 \mathrm{E}-13$ & $2,61021 \mathrm{E}-12$ & $2,6527 \mathrm{E}-12$ & $2,61007 \mathrm{E}-12$ & $2,46304 \mathrm{E}-12$ & $2,7046 \mathrm{E}-12$ \\
\hline
\end{tabular}




\begin{tabular}{|c|c|c|c|c|c|c|c|c|c|c|c|}
\hline Alimentos & $1,01094 \mathrm{E}-11$ & $3,14125 \mathrm{E}-11$ & $2,77459 \mathrm{E}-11$ & $1,0995 \mathrm{E}-11$ & $9,0399 \mathrm{E}-12$ & $1,52334 \mathrm{E}-12$ & 3,95727E-09 & $1,0546 \mathrm{E}-11$ & $6,42362 \mathrm{E}-11$ & $1,47183 \mathrm{E}-10$ & $2,93406 \mathrm{E}-11$ \\
\hline Vestuário & $2,38483 \mathrm{E}-12$ & $5,34454 \mathrm{E}-12$ & $1,12059 \mathrm{E}-11$ & $5,21821 \mathrm{E}-12$ & $4,27027 \mathrm{E}-12$ & $5,65043 \mathrm{E}-13$ & $6,20021 \mathrm{E}-12$ & $1,52806 \mathrm{E}-11$ & $9,85094 \mathrm{E}-12$ & $2,20313 \mathrm{E}-11$ & $4,29183 \mathrm{E}-12$ \\
\hline Madeira & $1,04275 \mathrm{E}-11$ & $3,69986 \mathrm{E}-12$ & $2,48173 \mathrm{E}-12$ & $4,91053 \mathrm{E}-12$ & $2,77632 \mathrm{E}-12$ & $3,62646 \mathrm{E}-12$ & $3,02776 \mathrm{E}-12$ & $4,08398 \mathrm{E}-12$ & $5,42276 \mathrm{E}-12$ & $5,72327 \mathrm{E}-12$ & $8,18603 \mathrm{E}-12$ \\
\hline Celulose & 0 & 0 & 0 & 0 & 0 & 0 & 0 & 0 & 0 & 0 & 0 \\
\hline Revistas & $1,26613 \mathrm{E}-12$ & $4,55805 \mathrm{E}-12$ & $3,84141 \mathrm{E}-12$ & $1,06452 \mathrm{E}-11$ & $5,51205 \mathrm{E}-12$ & $1,19803 \mathrm{E}-12$ & $1,26137 \mathrm{E}-12$ & $3,38361 \mathrm{E}-11$ & $5,52353 \mathrm{E}-12$ & $5,84772 \mathrm{E}-12$ & $3,214 \mathrm{E}-12$ \\
\hline Químicos & $1,10579 \mathrm{E}-12$ & $5,85329 \mathrm{E}-13$ & $4,13434 \mathrm{E}-13$ & $1,07704 \mathrm{E}-12$ & $2,46033 \mathrm{E}-13$ & $1,60325 \mathrm{E}-13$ & $8,03062 \mathrm{E}-12$ & 6,69437E-13 & $7,68973 \mathrm{E}-12$ & $1,50812 \mathrm{E}-12$ & $1,16266 \mathrm{E}-12$ \\
\hline Borracha & $4,95796 \mathrm{E}-11$ & 1,9767E-11 & $1,66305 \mathrm{E}-11$ & $4,0612 \mathrm{E}-11$ & $6,49644 \mathrm{E}-12$ & $3,70725 \mathrm{E}-12$ & $2,69735 \mathrm{E}-11$ & $5,88547 \mathrm{E}-11$ & $5,14043 \mathrm{E}-11$ & $1,64017 \mathrm{E}-11$ & $7,8063 \mathrm{E}-12$ \\
\hline Cimento & $7,23346 \mathrm{E}-10$ & $2,58923 \mathrm{E}-12$ & $1,11228 \mathrm{E}-12$ & $3,20457 \mathrm{E}-12$ & 2,99633E-12 & $6,39714 \mathrm{E}-12$ & $5,0475 \mathrm{E}-12$ & $2,40755 \mathrm{E}-12$ & $2,38772 \mathrm{E}-11$ & $1,25885 \mathrm{E}-11$ & $1,19524 \mathrm{E}-11$ \\
\hline Aço & 0 & 0 & 0 & 0 & 0 & 0 & 0 & 0 & 0 & 0 & 0 \\
\hline Metal & $7,17878 \mathrm{E}-11$ & $6,93056 \mathrm{E}-12$ & $1,6264 \mathrm{E}-12$ & $3,78157 \mathrm{E}-12$ & $1,109 \mathrm{E}-12$ & $2,7117 \mathrm{E}-12$ & $3,06652 \mathrm{E}-11$ & $1,92968 \mathrm{E}-12$ & $7,27095 \mathrm{E}-12$ & $4,62294 \mathrm{E}-12$ & $4,82473 \mathrm{E}-12$ \\
\hline Eletrodomésticos & 0 & 0 & 0 & 0 & 0 & 0 & 0 & 0 & 0 & 0 & 0 \\
\hline Informática & 0 & 0 & 0 & 0 & 0 & 0 & 0 & 0 & 0 & 0 & 0 \\
\hline Máquinas & 0 & 0 & 0 & 0 & 0 & 0 & 0 & 0 & 0 & 0 & 0 \\
\hline Eletrônicos & 0 & 0 & 0 & 0 & 0 & 0 & 0 & 0 & 0 & 0 & 0 \\
\hline Instrumento hospitalar & 0 & 0 & 0 & 0 & 0 & 0 & 0 & 0 & 0 & 0 & 0 \\
\hline Veículos & $6,84202 \mathrm{E}-12$ & $3,7919 \mathrm{E}-12$ & $3,32109 \mathrm{E}-12$ & $5,74763 \mathrm{E}-12$ & $1,50298 \mathrm{E}-12$ & $1,44397 \mathrm{E}-12$ & $3,55056 \mathrm{E}-12$ & $3,86473 \mathrm{E}-12$ & $3,75881 \mathrm{E}-12$ & $5,02446 \mathrm{E}-12$ & $3,76986 \mathrm{E}-12$ \\
\hline Indústria Diversa & $3,57963 \mathrm{E}-11$ & $4,8783 \mathrm{E}-12$ & $3,06785 \mathrm{E}-11$ & $6,01987 \mathrm{E}-12$ & $5,42164 \mathrm{E}-11$ & $1,35562 \mathrm{E}-11$ & $5,98833 \mathrm{E}-12$ & $1,98307 \mathrm{E}-11$ & $1,96485 \mathrm{E}-11$ & $9,91365 \mathrm{E}-11$ & $2,16583 \mathrm{E}-11$ \\
\hline SIUP & 4,20709E-11 & $1,44151 \mathrm{E}-10$ & $1,19536 \mathrm{E}-10$ & $1,12333 \mathrm{E}-10$ & $6,77879 \mathrm{E}-11$ & $1,42786 \mathrm{E}-11$ & $1,4572 \mathrm{E}-10$ & $1,26506 \mathrm{E}-10$ & $1,86264 \mathrm{E}-10$ & $4,19087 \mathrm{E}-10$ & $1,60433 \mathrm{E}-10$ \\
\hline Construção & $6,95357 \mathrm{E}-08$ & $7,95751 \mathrm{E}-11$ & $6,18577 \mathrm{E}-11$ & $2,53401 \mathrm{E}-10$ & $2,50709 \mathrm{E}-10$ & $5,99382 \mathrm{E}-10$ & $4,25884 \mathrm{E}-11$ & $1,78568 \mathrm{E}-10$ & $5,35252 \mathrm{E}-10$ & $4,62064 \mathrm{E}-10$ & $1,04524 \mathrm{E}-09$ \\
\hline Comércio & $1,29112 \mathrm{E}-09$ & $2,4251 \mathrm{E}-08$ & $1,07527 \mathrm{E}-09$ & $5,34292 \mathrm{E}-10$ & $3,19424 \mathrm{E}-10$ & $1,40971 \mathrm{E}-10$ & $2,47524 \mathrm{E}-09$ & $9,26242 \mathrm{E}-10$ & $8,24219 \mathrm{E}-10$ & $8,91185 \mathrm{E}-10$ & $4,72318 \mathrm{E}-10$ \\
\hline Transportes & $2,38302 \mathrm{E}-10$ & $6,2699 \mathrm{E}-10$ & $1,91503 \mathrm{E}-08$ & $4,25323 \mathrm{E}-10$ & $1,78847 \mathrm{E}-10$ & $3,18112 \mathrm{E}-11$ & $2,86995 \mathrm{E}-10$ & $3,37889 \mathrm{E}-10$ & $3,03621 \mathrm{E}-10$ & $4,4879 \mathrm{E}-10$ & $1,63007 \mathrm{E}-10$ \\
\hline Informação & $1,99972 \mathrm{E}-12$ & $6,30273 \mathrm{E}-12$ & $6,58946 \mathrm{E}-12$ & $4,71801 \mathrm{E}-10$ & $1,92249 \mathrm{E}-11$ & $1,2998 \mathrm{E}-12$ & $3,1485 \mathrm{E}-12$ & $5,11023 \mathrm{E}-11$ & $1,75735 \mathrm{E}-11$ & $1,1508 \mathrm{E}-11$ & $2,13065 \mathrm{E}-11$ \\
\hline Financeiro & $9,22368 \mathrm{E}-13$ & $1,83073 \mathrm{E}-12$ & $2,53146 \mathrm{E}-12$ & $2,57699 \mathrm{E}-12$ & $7,30965 \mathrm{E}-11$ & $3,72414 \mathrm{E}-13$ & $9,52155 \mathrm{E}-13$ & $2,43898 \mathrm{E}-12$ & $1,07683 \mathrm{E}-12$ & $5,99349 \mathrm{E}-13$ & $5,7037 \mathrm{E}-12$ \\
\hline Imobiliário & $3,3251 \mathrm{E}-11$ & $1,67392 \mathrm{E}-10$ & $2,98312 \mathrm{E}-10$ & $2,70255 \mathrm{E}-10$ & $8,57228 \mathrm{E}-11$ & 7,94788E-09 & $1,03004 \mathrm{E}-10$ & $1,95087 \mathrm{E}-10$ & $2,02937 \mathrm{E}-10$ & $1,45423 \mathrm{E}-10$ & $1,53491 \mathrm{E}-10$ \\
\hline Alojamento & $4,94341 \mathrm{E}-11$ & $6,86969 \mathrm{E}-11$ & $1,33757 \mathrm{E}-10$ & $9,02023 \mathrm{E}-11$ & $8,67517 \mathrm{E}-11$ & $9,57219 \mathrm{E}-12$ & $5,30637 \mathrm{E}-08$ & $7,78212 \mathrm{E}-11$ & $4,12549 \mathrm{E}-10$ & $4,70821 \mathrm{E}-10$ & $2,55006 \mathrm{E}-10$ \\
\hline Serviços às Empresas & $8,94688 \mathrm{E}-10$ & $2,49551 \mathrm{E}-09$ & $2,8676 \mathrm{E}-09$ & $4,08706 \mathrm{E}-09$ & 3,09115E-09 & $4,83075 \mathrm{E}-10$ & $7,90362 \mathrm{E}-10$ & $4,93231 \mathrm{E}-08$ & 4,11426E-09 & 2,61809E-09 & 2,90729E-09 \\
\hline Educação e Saúde mercantis & $8,5114 \mathrm{E}-12$ & $3,03288 \mathrm{E}-11$ & $2,00994 \mathrm{E}-11$ & $3,38655 \mathrm{E}-11$ & $3,49234 \mathrm{E}-11$ & $4,37381 \mathrm{E}-12$ & $2,41803 \mathrm{E}-11$ & $2,88299 \mathrm{E}-11$ & $1,52743 \mathrm{E}-08$ & $2,31089 \mathrm{E}-11$ & $4,76728 \mathrm{E}-11$ \\
\hline Outros Serviços & $1,85417 \mathrm{E}-10$ & $4,90223 \mathrm{E}-10$ & $3,06497 \mathrm{E}-10$ & $5,46305 \mathrm{E}-10$ & $2,80664 \mathrm{E}-10$ & $5,47353 \mathrm{E}-11$ & $5,3458 \mathrm{E}-10$ & $6,52706 \mathrm{E}-10$ & $4,83011 \mathrm{E}-10$ & $6,8747 \mathrm{E}-08$ & $3,46057 \mathrm{E}-10$ \\
\hline APU & $3,2668 \mathrm{E}-13$ & $8,78394 \mathrm{E}-13$ & $9,21496 \mathrm{E}-13$ & $1,18534 \mathrm{E}-12$ & $8,48535 \mathrm{E}-13$ & $1,4047 \mathrm{E}-13$ & $4,15834 \mathrm{E}-13$ & $1,05492 \mathrm{E}-12$ & $1,15782 \mathrm{E}-12$ & $8,9477 \mathrm{E}-13$ & $2,87468 \mathrm{E}-10$ \\
\hline
\end{tabular}


Tabela B2 - Matriz Geração de Emprego para o Grau de Instrução G(1), Distrito Federal - 2008.

(1)

\begin{tabular}{|c|c|c|c|c|c|c|c|c|c|c|c|}
\hline Setores & Agricultura & Pecuária & Extrativa & Alimentos & Vestuário & Madeira & Celulose & Revistas & Químicos & Borracha & Cimento \\
\hline Agricultura & $8,67012 \mathrm{E}-07$ & $5,68834 \mathrm{E}-08$ & $9,46114 \mathrm{E}-11$ & $6,98527 \mathrm{E}-08$ & $8,73833 \mathrm{E}-10$ & 1,37362E-09 & $3,96693 \mathrm{E}-09$ & $3,86959 \mathrm{E}-11$ & $1,74203 \mathrm{E}-10$ & 2,95227E-09 & $6,77157 \mathrm{E}-11$ \\
\hline Pecuária & $3,11437 \mathrm{E}-09$ & $7,96556 \mathrm{E}-07$ & $2,34144 \mathrm{E}-11$ & $3,15095 \mathrm{E}-08$ & $6,57839 \mathrm{E}-10$ & $5,52318 \mathrm{E}-11$ & $1,81466 \mathrm{E}-10$ & $8,84436 \mathrm{E}-12$ & $5,74422 \mathrm{E}-11$ & $2,68059 \mathrm{E}-10$ & $2,18581 \mathrm{E}-11$ \\
\hline Extrativa & $2,95444 \mathrm{E}-11$ & $7,00363 \mathrm{E}-11$ & $4,07035 \mathrm{E}-07$ & $1,66621 \mathrm{E}-11$ & $1,53126 \mathrm{E}-11$ & $2,10813 \mathrm{E}-11$ & $1,63039 \mathrm{E}-10$ & $3,90199 \mathrm{E}-12$ & $2,478 \mathrm{E}-10$ & $5,27133 \mathrm{E}-11$ & $1,84161 \mathrm{E}-10$ \\
\hline Alimentos & $2,66536 \mathrm{E}-09$ & 4,04746E-08 & $1,39813 \mathrm{E}-10$ & $2,44022 \mathrm{E}-07$ & $1,84121 \mathrm{E}-09$ & $1,9064 \mathrm{E}-10$ & $5,95934 \mathrm{E}-10$ & $5,16878 \mathrm{E}-11$ & $2,25154 \mathrm{E}-10$ & $7,53697 \mathrm{E}-11$ & $1,36726 \mathrm{E}-10$ \\
\hline Vestuário & $4,06194 \mathrm{E}-12$ & $3,5947 \mathrm{E}-12$ & $1,1985 \mathrm{E}-10$ & $5,23917 \mathrm{E}-12$ & $2,15024 \mathrm{E}-07$ & $4,87215 \mathrm{E}-12$ & $1,72093 \mathrm{E}-10$ & $5,51453 \mathrm{E}-12$ & $1,09897 \mathrm{E}-11$ & $3,22043 \mathrm{E}-11$ & $7,61661 \mathrm{E}-12$ \\
\hline Madeira & $1,05766 \mathrm{E}-10$ & $2,07329 \mathrm{E}-11$ & $5,76603 \mathrm{E}-11$ & $2,47414 \mathrm{E}-11$ & $1,02964 \mathrm{E}-10$ & $1,7766 \mathrm{E}-06$ & $1,07186 \mathrm{E}-08$ & $1,77613 \mathrm{E}-11$ & $3,24883 \mathrm{E}-10$ & $8,81965 \mathrm{E}-11$ & $1,0022 \mathrm{E}-10$ \\
\hline Celulose & $2,96753 \mathrm{E}-12$ & $3,24655 \mathrm{E}-12$ & $7,7651 \mathrm{E}-11$ & $3,79281 \mathrm{E}-12$ & $1,8046 \mathrm{E}-10$ & $2,97122 \mathrm{E}-10$ & $1,21267 \mathrm{E}-07$ & $1,89441 \mathrm{E}-11$ & $4,95114 \mathrm{E}-11$ & $1,43426 \mathrm{E}-10$ & $2,51941 \mathrm{E}-12$ \\
\hline Revistas & $4,34954 \mathrm{E}-11$ & $4,84929 \mathrm{E}-11$ & $1,12119 \mathrm{E}-10$ & $8,00317 \mathrm{E}-11$ & $4,22138 \mathrm{E}-11$ & $2,59916 \mathrm{E}-11$ & $4,8268 \mathrm{E}-10$ & $1,0483 \mathrm{E}-07$ & $6,88022 \mathrm{E}-10$ & $2,70492 \mathrm{E}-10$ & $9,21428 \mathrm{E}-11$ \\
\hline Químicos & $2,52409 \mathrm{E}-09$ & $1,7556 \mathrm{E}-09$ & $5,86546 \mathrm{E}-10$ & $3,28437 \mathrm{E}-10$ & $1,80536 \mathrm{E}-10$ & $3,3466 \mathrm{E}-10$ & $1,52203 \mathrm{E}-09$ & $1,0148 \mathrm{E}-11$ & $6,53207 \mathrm{E}-08$ & $8,87151 \mathrm{E}-10$ & $8,30826 \mathrm{E}-11$ \\
\hline Borracha & $4,46012 \mathrm{E}-10$ & $2,85817 \mathrm{E}-10$ & $3,67058 \mathrm{E}-09$ & $7,92139 \mathrm{E}-10$ & $1,04248 \mathrm{E}-09$ & 1,93993E-09 & 4,83796E-09 & $6,0971 \mathrm{E}-10$ & $1,43628 \mathrm{E}-09$ & $4,07443 \mathrm{E}-07$ & $4,8825 \mathrm{E}-11$ \\
\hline Cimento & $7,64827 \mathrm{E}-11$ & $3,90474 \mathrm{E}-11$ & $9,02303 \mathrm{E}-11$ & $1,30686 \mathrm{E}-10$ & $3,43932 \mathrm{E}-11$ & $1,4938 \mathrm{E}-11$ & $1,16861 \mathrm{E}-10$ & $1,22545 \mathrm{E}-11$ & $4,80734 \mathrm{E}-10$ & $3,5792 \mathrm{E}-11$ & $7,60532 \mathrm{E}-08$ \\
\hline Aço & $4,39489 \mathrm{E}-11$ & $2,118 \mathrm{E}-11$ & $2,29786 \mathrm{E}-10$ & $2,41679 \mathrm{E}-11$ & $1,33414 \mathrm{E}-11$ & $1,1729 \mathrm{E}-10$ & $2,32146 \mathrm{E}-10$ & $2,00476 \mathrm{E}-12$ & $6,10957 \mathrm{E}-11$ & $3,37266 \mathrm{E}-10$ & $2,35157 \mathrm{E}-11$ \\
\hline Metal & 1,37775E-09 & $9,70817 \mathrm{E}-10$ & $4,46431 \mathrm{E}-09$ & 2,39643E-09 & $3,84942 \mathrm{E}-10$ & 2,3273E-09 & $4,16044 \mathrm{E}-09$ & $2,58199 \mathrm{E}-11$ & $2,0232 \mathrm{E}-09$ & 2,29916E-09 & $3,63372 \mathrm{E}-10$ \\
\hline Eletrodomésticos & $1,97744 \mathrm{E}-11$ & $1,3493 \mathrm{E}-11$ & $8,04216 \mathrm{E}-10$ & $2,26833 \mathrm{E}-11$ & $2,07034 \mathrm{E}-10$ & $3,56776 \mathrm{E}-10$ & $1,5268 \mathrm{E}-09$ & $6,09347 \mathrm{E}-12$ & $1,13709 \mathrm{E}-10$ & $1,54002 \mathrm{E}-10$ & $1,19179 \mathrm{E}-11$ \\
\hline Informática & 0 & 0 & 0 & 0 & 0 & 0 & 0 & 0 & 0 & 0 & 0 \\
\hline Máquinas & $8,36873 \mathrm{E}-12$ & $1,52095 \mathrm{E}-11$ & $2,52295 \mathrm{E}-10$ & $2,82922 \mathrm{E}-11$ & $2,82208 \mathrm{E}-11$ & $5,91915 \mathrm{E}-11$ & $5,88028 \mathrm{E}-11$ & $3,67455 \mathrm{E}-12$ & $7,10282 \mathrm{E}-11$ & $2,13085 \mathrm{E}-10$ & $5,26609 \mathrm{E}-11$ \\
\hline Eletrônicos & 0 & 0 & 0 & 0 & 0 & 0 & 0 & 0 & 0 & 0 & 0 \\
\hline Instrumento hospitalar & $3,54824 \mathrm{E}-13$ & $3,90931 \mathrm{E}-13$ & $1,75232 \mathrm{E}-12$ & $5,168 \mathrm{E}-13$ & $6,87289 \mathrm{E}-13$ & $7,34781 \mathrm{E}-13$ & $4,03088 \mathrm{E}-12$ & $7,85783 \mathrm{E}-13$ & $4,26763 \mathrm{E}-12$ & $8,20908 \mathrm{E}-12$ & $6,31022 \mathrm{E}-13$ \\
\hline Veículos & $1,29639 \mathrm{E}-11$ & $1,06084 \mathrm{E}-11$ & $7,67757 \mathrm{E}-11$ & $2,46327 \mathrm{E}-11$ & $1,32403 \mathrm{E}-11$ & $3,19342 \mathrm{E}-11$ & $6,23114 \mathrm{E}-11$ & $4,06967 \mathrm{E}-12$ & $2,93628 \mathrm{E}-11$ & $6,45235 \mathrm{E}-11$ & $1,16391 \mathrm{E}-11$ \\
\hline Indústria Diversa & $1,10956 \mathrm{E}-10$ & $1,02853 \mathrm{E}-09$ & $2,9951 \mathrm{E}-10$ & $6,96937 \mathrm{E}-10$ & $1,09486 \mathrm{E}-08$ & $3,22926 \mathrm{E}-10$ & $5,93228 \mathrm{E}-09$ & $1,29092 \mathrm{E}-10$ & $2,94881 \mathrm{E}-10$ & 2,10714E-09 & $2,81801 \mathrm{E}-10$ \\
\hline SIUP & 1,38756E-09 & $2,14162 \mathrm{E}-09$ & $5,568 \mathrm{E}-09$ & $3,42978 \mathrm{E}-09$ & $2,80668 \mathrm{E}-09$ & 2,91564E-09 & $8,61007 \mathrm{E}-09$ & 2,28433E-09 & $4,15918 \mathrm{E}-09$ & $4,30095 \mathrm{E}-09$ & $1,13427 \mathrm{E}-08$ \\
\hline Construção & $1,57744 \mathrm{E}-10$ & $2,24085 \mathrm{E}-10$ & $4,05488 \mathrm{E}-10$ & $5,20309 \mathrm{E}-10$ & $4,67408 \mathrm{E}-10$ & $4,12883 \mathrm{E}-10$ & $7,43352 \mathrm{E}-10$ & $5,88412 \mathrm{E}-10$ & $8,32818 \mathrm{E}-10$ & $1,35256 \mathrm{E}-09$ & $1,84464 \mathrm{E}-09$ \\
\hline Comércio & 6,63373E-09 & 9,78904E-09 & 5,83431E-09 & $1,04965 \mathrm{E}-08$ & $1,10255 \mathrm{E}-08$ & 4,50274E-09 & $5,76041 \mathrm{E}-09$ & $5,96537 \mathrm{E}-09$ & $8,18607 \mathrm{E}-09$ & 6,37991E-09 & $1,02374 \mathrm{E}-08$ \\
\hline Transportes & $2,56307 \mathrm{E}-09$ & 2,3321E-09 & $6,85109 \mathrm{E}-09$ & $4,37148 \mathrm{E}-09$ & $2,0318 \mathrm{E}-09$ & 2,19984E-09 & $3,72664 \mathrm{E}-09$ & $2,14246 \mathrm{E}-09$ & $4,05241 \mathrm{E}-09$ & 2,64992E-09 & $8,21348 \mathrm{E}-09$ \\
\hline Informação & $2,27085 \mathrm{E}-11$ & $3,52038 \mathrm{E}-11$ & $1,03598 \mathrm{E}-10$ & 4,42407E-11 & $2,53503 \mathrm{E}-11$ & $1,87539 \mathrm{E}-11$ & 4,32966E-11 & $1,04172 \mathrm{E}-10$ & $1,34135 \mathrm{E}-10$ & $5,98181 \mathrm{E}-11$ & $8,11769 \mathrm{E}-11$ \\
\hline
\end{tabular}




\begin{tabular}{|c|c|c|c|c|c|c|c|c|c|c|c|}
\hline Financeiro & $2,02389 \mathrm{E}-11$ & $2,24419 \mathrm{E}-11$ & $4,53505 \mathrm{E}-11$ & $3,86207 \mathrm{E}-11$ & $3,08813 \mathrm{E}-11$ & $2,86276 \mathrm{E}-11$ & $6,24399 \mathrm{E}-11$ & $3,54151 \mathrm{E}-11$ & $6,14861 \mathrm{E}-11$ & $4,46603 \mathrm{E}-11$ & $7,18161 \mathrm{E}-11$ \\
\hline Imobiliário & 3,46737E-10 & $4,44054 \mathrm{E}-10$ & $1,05197 \mathrm{E}-09$ & $8,87405 \mathrm{E}-10$ & 9,88685E-10 & 3,95696E-10 & $8,74223 \mathrm{E}-10$ & 1,37747E-09 & $1,17926 \mathrm{E}-09$ & $7,35258 \mathrm{E}-10$ & $1,28122 \mathrm{E}-09$ \\
\hline Alojamento & $3,55104 \mathrm{E}-11$ & $5,00869 \mathrm{E}-11$ & $3,23739 \mathrm{E}-10$ & $8,81151 \mathrm{E}-11$ & $5,13774 \mathrm{E}-11$ & $1,0306 \mathrm{E}-10$ & $1,0503 \mathrm{E}-10$ & $1,39231 \mathrm{E}-10$ & $1,16692 \mathrm{E}-10$ & $1,03655 \mathrm{E}-10$ & $5,69753 \mathrm{E}-10$ \\
\hline Serviços às Empresas & 1,79027E-09 & 2,57376E-09 & 4,96255E-09 & $6,0564 \mathrm{E}-09$ & 3,97361E-09 & 2,11294E-09 & $5,1243 \mathrm{E}-09$ & $1,39638 \mathrm{E}-08$ & $1,57912 \mathrm{E}-08$ & 4,27317E-09 & 9,91897E-09 \\
\hline Educação e Saúde mercantis & $4,123 \mathrm{E}-11$ & $5,70051 \mathrm{E}-11$ & $8,38902 \mathrm{E}-11$ & $8,59259 \mathrm{E}-11$ & $1,04907 \mathrm{E}-10$ & $3,85227 \mathrm{E}-11$ & $7,54182 \mathrm{E}-11$ & $9,19536 \mathrm{E}-11$ & $9,23851 \mathrm{E}-11$ & $6,612 \mathrm{E}-11$ & $9,52597 \mathrm{E}-11$ \\
\hline Outros Serviços & $7,41127 \mathrm{E}-10$ & $1,07406 \mathrm{E}-09$ & 1,11897E-09 & $1,4169 \mathrm{E}-09$ & $1,52316 \mathrm{E}-09$ & $5,61547 \mathrm{E}-10$ & $9,31119 \mathrm{E}-10$ & $1,09454 \mathrm{E}-09$ & 1,50937E-09 & 1,10211E-09 & $1,75803 \mathrm{E}-09$ \\
\hline APU & $5,47447 \mathrm{E}-11$ & $6,53169 \mathrm{E}-11$ & $1,3113 \mathrm{E}-10$ & $1,21095 \mathrm{E}-10$ & 7,63185E-11 & $5,14993 \mathrm{E}-11$ & $1,25031 \mathrm{E}-10$ & $2,31402 \mathrm{E}-10$ & $2,09319 \mathrm{E}-10$ & $8,87965 \mathrm{E}-11$ & $1,9996 \mathrm{E}-10$ \\
\hline
\end{tabular}

Tabela B2 - Matriz Geração de Emprego para o Grau de Instrução G(1), Distrito Federal - 2008.

(2)

\begin{tabular}{|c|c|c|c|c|c|c|c|c|c|c|}
\hline Setores & Aço & Metal & Eletrodomésticos & Informática & Máquinas & Eletrônicos & $\begin{array}{l}\text { Instrumento } \\
\text { hospitalar }\end{array}$ & Veículos & $\begin{array}{l}\text { Indústria } \\
\text { Diversa }\end{array}$ & SIUP \\
\hline Agricultura & $5,10161 \mathrm{E}-11$ & $2,81281 \mathrm{E}-11$ & $1,00996 \mathrm{E}-10$ & $9,62122 \mathrm{E}-11$ & $5,73795 \mathrm{E}-11$ & $1,31358 \mathrm{E}-10$ & $3,49019 \mathrm{E}-11$ & $2,00394 \mathrm{E}-10$ & $7,84134 \mathrm{E}-11$ & $1,42131 \mathrm{E}-11$ \\
\hline Pecuária & $1,20168 \mathrm{E}-11$ & $5,93602 \mathrm{E}-12$ & $1,46723 \mathrm{E}-11$ & $1,58705 \mathrm{E}-11$ & $1,25863 \mathrm{E}-11$ & $1,64679 \mathrm{E}-11$ & $6,78671 \mathrm{E}-12$ & 2,62693E-11 & $1,40715 \mathrm{E}-10$ & $3,85957 \mathrm{E}-12$ \\
\hline Extrativa & 6,8572E-09 & $4,05125 \mathrm{E}-10$ & $1,2857 \mathrm{E}-09$ & $9,79958 \mathrm{E}-11$ & $3,89876 \mathrm{E}-10$ & $2,19105 \mathrm{E}-10$ & $3,65075 \mathrm{E}-11$ & $7,33365 \mathrm{E}-10$ & $2,24806 \mathrm{E}-10$ & $3,44141 \mathrm{E}-12$ \\
\hline Alimentos & $6,12724 \mathrm{E}-11$ & $2,88072 \mathrm{E}-11$ & $5,96349 \mathrm{E}-11$ & $6,67151 \mathrm{E}-11$ & $6,00829 \mathrm{E}-11$ & $6,52628 \mathrm{E}-11$ & $3,16391 \mathrm{E}-11$ & $8,06881 \mathrm{E}-11$ & $5,74007 \mathrm{E}-11$ & $1,92337 \mathrm{E}-11$ \\
\hline Vestuário & $1,01186 \mathrm{E}-11$ & $1,54843 \mathrm{E}-11$ & $8,49866 \mathrm{E}-11$ & $1,18197 \mathrm{E}-11$ & $9,92717 \mathrm{E}-12$ & $1,34578 \mathrm{E}-11$ & $1,49806 \mathrm{E}-11$ & $7,29002 \mathrm{E}-11$ & $1,02327 \mathrm{E}-11$ & $1,02448 \mathrm{E}-11$ \\
\hline Madeira & $8,06333 \mathrm{E}-11$ & $1,19098 \mathrm{E}-10$ & 2,37627E-09 & 2,18611E-09 & $1,05083 \mathrm{E}-10$ & $9,72283 \mathrm{E}-09$ & $2,87591 \mathrm{E}-11$ & $1,4895 \mathrm{E}-09$ & $3,21089 \mathrm{E}-09$ & $3,89194 \mathrm{E}-12$ \\
\hline Celulose & $2,0421 \mathrm{E}-11$ & $4,9344 \mathrm{E}-12$ & $3,76568 \mathrm{E}-10$ & $2,03613 \mathrm{E}-10$ & $3,67448 \mathrm{E}-11$ & $4,01996 \mathrm{E}-10$ & $8,59841 \mathrm{E}-12$ & $2,05939 \mathrm{E}-10$ & $1,98128 \mathrm{E}-11$ & $1,72909 \mathrm{E}-12$ \\
\hline Revistas & $1,32026 \mathrm{E}-10$ & $1,29922 \mathrm{E}-10$ & $7,95697 \mathrm{E}-11$ & $1,50176 \mathrm{E}-10$ & $6,77958 \mathrm{E}-11$ & $1,26088 \mathrm{E}-10$ & $6,2306 \mathrm{E}-10$ & $1,48232 \mathrm{E}-10$ & $4,42921 \mathrm{E}-11$ & $1,85722 \mathrm{E}-10$ \\
\hline Químicos & $7,82112 \mathrm{E}-10$ & $1,36347 \mathrm{E}-10$ & $7,21957 \mathrm{E}-10$ & $5,17983 \mathrm{E}-11$ & $2,27213 \mathrm{E}-10$ & $9,13334 \mathrm{E}-11$ & $1,72314 \mathrm{E}-10$ & $4,75291 \mathrm{E}-10$ & $8,45599 \mathrm{E}-11$ & $5,71881 \mathrm{E}-11$ \\
\hline Borracha & 2,50691E-09 & $1,43703 \mathrm{E}-09$ & $6,85489 \mathrm{E}-09$ & 6,10761E-09 & 3,15077E-09 & 7,0886E-09 & 1,97513E-09 & $1,64218 \mathrm{E}-08$ & 2,59901E-09 & $6,21803 \mathrm{E}-11$ \\
\hline Cimento & $6,70971 \mathrm{E}-10$ & $2,0025 \mathrm{E}-10$ & $2,60262 \mathrm{E}-10$ & $1,37056 \mathrm{E}-10$ & $6,44765 \mathrm{E}-10$ & $5,02452 \mathrm{E}-10$ & $2,36187 \mathrm{E}-10$ & $5,80436 \mathrm{E}-10$ & $1,34954 \mathrm{E}-09$ & $6,50192 \mathrm{E}-12$ \\
\hline Aço & $5,73617 \mathrm{E}-08$ & $4,68141 \mathrm{E}-10$ & $8,5728 \mathrm{E}-09$ & $6,20809 \mathrm{E}-10$ & 1,69003E-09 & 1,4933E-09 & $1,70775 \mathrm{E}-10$ & 4,7194E-09 & $1,74113 \mathrm{E}-10$ & $5,42749 \mathrm{E}-12$ \\
\hline Metal & $1,09813 \mathrm{E}-08$ & 2,81907E-07 & $1,76779 \mathrm{E}-08$ & 6,63099E-09 & $1,22851 \mathrm{E}-08$ & $1,09398 \mathrm{E}-08$ & 7,53013E-09 & 7,88723E-09 & $6,06298 \mathrm{E}-09$ & $3,08269 \mathrm{E}-11$ \\
\hline Eletrodomésticos & $8,19892 \mathrm{E}-10$ & $9,42176 \mathrm{E}-11$ & $3,15084 \mathrm{E}-07$ & $8,73466 \mathrm{E}-10$ & $4,0313 \mathrm{E}-10$ & $5,89398 \mathrm{E}-10$ & $1,75574 \mathrm{E}-10$ & $3,69258 \mathrm{E}-09$ & $6,11215 \mathrm{E}-11$ & $9,87874 \mathrm{E}-12$ \\
\hline Informática & 0 & 0 & 0 & 0 & 0 & 0 & 0 & 0 & 0 & 0 \\
\hline Máquinas & $9,08594 \mathrm{E}-11$ & $2,48425 \mathrm{E}-11$ & $1,87608 \mathrm{E}-09$ & 4,48973E-09 & $7,34287 \mathrm{E}-08$ & $8,25071 \mathrm{E}-09$ & $5,47262 \mathrm{E}-10$ & $1,22675 \mathrm{E}-09$ & $1,83305 \mathrm{E}-10$ & $1,39338 \mathrm{E}-10$ \\
\hline
\end{tabular}




\begin{tabular}{|c|c|c|c|c|c|c|c|c|c|c|}
\hline Eletrônicos & 0 & 0 & 0 & 0 & 0 & 0 & 0 & 0 & 0 & 0 \\
\hline Instrumento hospitalar & $1,25202 \mathrm{E}-12$ & $6,88296 \mathrm{E}-13$ & $1,89864 \mathrm{E}-10$ & $2,48229 \mathrm{E}-11$ & $7,37278 \mathrm{E}-11$ & $3,46342 \mathrm{E}-11$ & $5,95638 \mathrm{E}-08$ & $3,16922 \mathrm{E}-11$ & $3,25759 \mathrm{E}-12$ & 7,19633E-13 \\
\hline Veículos & $1,75979 \mathrm{E}-10$ & $1,11176 \mathrm{E}-10$ & 7,93761E-10 & $5,60745 \mathrm{E}-10$ & $6,40602 \mathrm{E}-10$ & $1,01754 \mathrm{E}-09$ & $1,34856 \mathrm{E}-10$ & $2,805 \mathrm{E}-07$ & $8,02464 \mathrm{E}-11$ & $1,71146 \mathrm{E}-11$ \\
\hline Indústria Diversa & $1,40841 \mathrm{E}-08$ & $1,03772 \mathrm{E}-09$ & $3,2734 \mathrm{E}-09$ & $6,19521 \mathrm{E}-10$ & $1,90069 \mathrm{E}-09$ & $1,00812 \mathrm{E}-09$ & $2,68604 \mathrm{E}-10$ & $1,69103 \mathrm{E}-09$ & 3,5291E-06 & $8,7986 \mathrm{E}-11$ \\
\hline SIUP & $1,00781 \mathrm{E}-08$ & 4,91457E-09 & 4,89201E-09 & $3,27569 \mathrm{E}-09$ & $5,74328 \mathrm{E}-09$ & 4,00253E-09 & $4,18582 \mathrm{E}-09$ & 4,28866E-09 & $3,05375 \mathrm{E}-09$ & $4,56285 \mathrm{E}-07$ \\
\hline Construção & $5,74693 \mathrm{E}-10$ & $3,86182 \mathrm{E}-10$ & 7,81143E-10 & $1,14994 \mathrm{E}-09$ & $1,5883 \mathrm{E}-09$ & 2,40002E-09 & $3,64122 \mathrm{E}-10$ & $2,54533 \mathrm{E}-09$ & $4,66684 \mathrm{E}-10$ & $3,60744 \mathrm{E}-10$ \\
\hline Comércio & $5,45421 \mathrm{E}-09$ & 4,777E-09 & $8,02514 \mathrm{E}-09$ & $1,80654 \mathrm{E}-08$ & 7,15461E-09 & $1,34936 \mathrm{E}-08$ & 7,20667E-09 & $1,02804 \mathrm{E}-08$ & $8,34603 \mathrm{E}-09$ & 2,27794E-09 \\
\hline Transportes & $5,50973 \mathrm{E}-09$ & 3,16169E-09 & 4,3507E-09 & 4,87957E-09 & 4,16247E-09 & $6,0576 \mathrm{E}-09$ & $3,30529 \mathrm{E}-09$ & $3,81357 \mathrm{E}-09$ & $2,04847 \mathrm{E}-09$ & $1,67388 \mathrm{E}-09$ \\
\hline Informação & $1,05895 \mathrm{E}-10$ & $4,70968 \mathrm{E}-11$ & $1,18456 \mathrm{E}-10$ & $1,70292 \mathrm{E}-10$ & $1,45333 \mathrm{E}-10$ & $2,50551 \mathrm{E}-10$ & $7,67463 \mathrm{E}-11$ & $9,4729 \mathrm{E}-11$ & $2,5733 \mathrm{E}-11$ & $8,96092 \mathrm{E}-11$ \\
\hline Financeiro & 7,82362E-11 & 4,60914E-11 & $9,96738 \mathrm{E}-11$ & $6,96129 \mathrm{E}-11$ & $7,12112 \mathrm{E}-11$ & $1,22665 \mathrm{E}-10$ & $4,95052 \mathrm{E}-11$ & $6,83722 \mathrm{E}-11$ & 2,92987E-11 & $2,63466 \mathrm{E}-11$ \\
\hline Imobiliário & $8,30777 \mathrm{E}-10$ & $7,04965 \mathrm{E}-10$ & 1,09849E-09 & $1,17791 \mathrm{E}-09$ & $8,71461 \mathrm{E}-10$ & $1,16523 \mathrm{E}-09$ & $1,02508 \mathrm{E}-09$ & $7,66832 \mathrm{E}-10$ & $6,68577 \mathrm{E}-10$ & $6,0156 \mathrm{E}-10$ \\
\hline Alojamento & $1,50865 \mathrm{E}-10$ & $5,75021 \mathrm{E}-11$ & $8,30678 \mathrm{E}-11$ & $1,20123 \mathrm{E}-10$ & $1,78246 \mathrm{E}-10$ & $1,2002 \mathrm{E}-10$ & $5,16508 \mathrm{E}-11$ & $1,59364 \mathrm{E}-10$ & $1,07337 \mathrm{E}-10$ & $4,41162 \mathrm{E}-11$ \\
\hline Serviços às Empresas & $4,15206 \mathrm{E}-09$ & $4,04612 \mathrm{E}-09$ & 4,84927E-09 & $2,16919 \mathrm{E}-08$ & 6,91472E-09 & $1,5289 \mathrm{E}-08$ & $5,55291 \mathrm{E}-09$ & $9,28682 \mathrm{E}-09$ & $3,19481 \mathrm{E}-09$ & $1,17939 \mathrm{E}-08$ \\
\hline Educação e Saúde mercantis & $6,26086 \mathrm{E}-11$ & $6,32609 \mathrm{E}-11$ & $9,28944 \mathrm{E}-11$ & $1,29437 \mathrm{E}-10$ & $7,95826 \mathrm{E}-11$ & $1,1889 \mathrm{E}-10$ & $7,9148 \mathrm{E}-11$ & $8,02417 \mathrm{E}-11$ & $7,26338 \mathrm{E}-11$ & $4,98105 \mathrm{E}-11$ \\
\hline Outros Serviços & $1,03942 \mathrm{E}-09$ & $9,45783 \mathrm{E}-10$ & 1,38891E-09 & $2,72839 \mathrm{E}-09$ & $1,98282 \mathrm{E}-09$ & 2,51596E-09 & $1,12848 \mathrm{E}-09$ & $1,46922 \mathrm{E}-09$ & $1,15852 \mathrm{E}-09$ & $1,10523 \mathrm{E}-09$ \\
\hline APU & $1,27318 \mathrm{E}-10$ & $8,75371 \mathrm{E}-11$ & $1,02991 \mathrm{E}-10$ & $2,6466 \mathrm{E}-10$ & $1,14582 \mathrm{E}-10$ & $2,10257 \mathrm{E}-10$ & $1,01948 \mathrm{E}-10$ & $1,42119 \mathrm{E}-10$ & $6,57611 \mathrm{E}-11$ & $2,36237 \mathrm{E}-10$ \\
\hline
\end{tabular}

Tabela B2 - Matriz Geração de Emprego para o Grau de Instrução G(1), Distrito Federal - 2008.

(3)

\begin{tabular}{|c|c|c|c|c|c|c|c|c|c|c|c|}
\hline Setores & Construção & Comércio & Transportes & Informação & Financeiro & Imobiliário & Alojamento & $\begin{array}{c}\text { Serviços às } \\
\text { Empresas }\end{array}$ & $\begin{array}{l}\text { Educação e } \\
\text { Saúde } \\
\text { mercantis }\end{array}$ & $\begin{array}{c}\text { Outros } \\
\text { Serviços }\end{array}$ & APU \\
\hline Agricultura & $4,07816 \mathrm{E}-11$ & $1,26527 \mathrm{E}-10$ & 9,57099E-11 & $5,80567 \mathrm{E}-11$ & $3,7593 \mathrm{E}-11$ & $7,96754 \mathrm{E}-12$ & $1,27288 \mathrm{E}-08$ & $5,76433 \mathrm{E}-11$ & $3,0346 \mathrm{E}-10$ & $1,31092 \mathrm{E}-09$ & $1,62013 \mathrm{E}-10$ \\
\hline Pecuária & $1,16031 \mathrm{E}-11$ & $3,40999 \mathrm{E}-11$ & $3,03608 \mathrm{E}-11$ & $1,50275 \mathrm{E}-11$ & $1,15044 \mathrm{E}-11$ & $1,94541 \mathrm{E}-12$ & 4,49085E-09 & $1,50272 \mathrm{E}-11$ & $9,9951 \mathrm{E}-11$ & $4,87968 \mathrm{E}-10$ & $4,68103 \mathrm{E}-11$ \\
\hline Extrativa & $1,78975 \mathrm{E}-11$ & $9,3297 \mathrm{E}-12$ & $5,74967 \mathrm{E}-12$ & $1,08042 \mathrm{E}-11$ & $3,2244 \mathrm{E}-12$ & $1,78544 \mathrm{E}-12$ & $8,48317 \mathrm{E}-12$ & $8,62128 \mathrm{E}-12$ & $8,48273 \mathrm{E}-12$ & $8,00488 \mathrm{E}-12$ & 8,78994E-12 \\
\hline Alimentos & 7,53772E-11 & $2,34216 \mathrm{E}-10$ & $2,06878 \mathrm{E}-10$ & $8,19801 \mathrm{E}-11$ & $6,74028 \mathrm{E}-11$ & $1,13582 \mathrm{E}-11$ & $2,9506 \mathrm{E}-08$ & $7,86321 \mathrm{E}-11$ & $4,78954 \mathrm{E}-10$ & $1,09742 \mathrm{E}-09$ & $2,18767 \mathrm{E}-10$ \\
\hline Vestuário & $6,35954 \mathrm{E}-12$ & $1,42521 \mathrm{E}-11$ & $2,98824 \mathrm{E}-11$ & $1,39152 \mathrm{E}-11$ & $1,13874 \mathrm{E}-11$ & $1,50678 \mathrm{E}-12$ & $1,65339 \mathrm{E}-11$ & $4,07483 \mathrm{E}-11$ & $2,62692 \mathrm{E}-11$ & $5,87502 \mathrm{E}-11$ & $1,14449 \mathrm{E}-11$ \\
\hline Madeira & 3,64964E-11 & $1,29495 \mathrm{E}-11$ & $8,68606 \mathrm{E}-12$ & $1,71869 \mathrm{E}-11$ & $9,71711 \mathrm{E}-12$ & $1,26926 \mathrm{E}-11$ & $1,05972 \mathrm{E}-11$ & $1,42939 \mathrm{E}-11$ & $1,89797 \mathrm{E}-11$ & $2,00314 \mathrm{E}-11$ & $2,86511 \mathrm{E}-11$ \\
\hline
\end{tabular}




\begin{tabular}{|c|c|c|c|c|c|c|c|c|c|c|c|}
\hline Celulose & $1,2522 \mathrm{E}-12$ & $5,02214 \mathrm{E}-12$ & $3,17464 \mathrm{E}-12$ & $6,39154 \mathrm{E}-12$ & $2,16449 \mathrm{E}-12$ & $8,42413 \mathrm{E}-13$ & $3,14516 \mathrm{E}-12$ & $8,35933 \mathrm{E}-12$ & $4,47434 \mathrm{E}-12$ & $4,22237 \mathrm{E}-12$ & 4,20659E-12 \\
\hline Revistas & $4,9379 \mathrm{E}-11$ & $1,77764 \mathrm{E}-10$ & $1,49815 \mathrm{E}-10$ & $4,15163 \mathrm{E}-10$ & $2,1497 \mathrm{E}-10$ & $4,6723 \mathrm{E}-11$ & $4,91935 \mathrm{E}-11$ & 1,31961E-09 & $2,15418 \mathrm{E}-10$ & $2,28061 \mathrm{E}-10$ & $1,25346 \mathrm{E}-10$ \\
\hline Químicos & $7,74053 \mathrm{E}-12$ & $4,0973 \mathrm{E}-12$ & $2,89404 \mathrm{E}-12$ & 7,53927E-12 & $1,72223 \mathrm{E}-12$ & $1,12228 \mathrm{E}-12$ & $5,62144 \mathrm{E}-11$ & $4,68606 \mathrm{E}-12$ & $5,38281 \mathrm{E}-11$ & $1,05569 \mathrm{E}-11$ & $8,13865 \mathrm{E}-12$ \\
\hline Borracha & $2,57814 \mathrm{E}-10$ & $1,02788 \mathrm{E}-10$ & $8,64786 \mathrm{E}-11$ & $2,11182 \mathrm{E}-10$ & $3,37815 \mathrm{E}-11$ & $1,92777 \mathrm{E}-11$ & $1,40262 \mathrm{E}-10$ & $3,06045 \mathrm{E}-10$ & $2,67302 \mathrm{E}-10$ & $8,5289 \mathrm{E}-11$ & $4,05928 \mathrm{E}-11$ \\
\hline Cimento & 2,73613E-09 & $9,79406 \mathrm{E}-12$ & $4,20732 \mathrm{E}-12$ & $1,21216 \mathrm{E}-11$ & $1,13339 \mathrm{E}-11$ & $2,41979 \mathrm{E}-11$ & $1,90927 \mathrm{E}-11$ & $9,1068 \mathrm{E}-12$ & $9,03182 \mathrm{E}-11$ & $4,76172 \mathrm{E}-11$ & $4,52113 \mathrm{E}-11$ \\
\hline Aço & $1,59553 \mathrm{E}-11$ & $2,33931 \mathrm{E}-12$ & $1,83256 \mathrm{E}-12$ & $3,2076 \mathrm{E}-12$ & $9,20031 \mathrm{E}-13$ & $8,61051 \mathrm{E}-13$ & $4,33102 \mathrm{E}-12$ & $2,24445 \mathrm{E}-12$ & $2,71073 \mathrm{E}-12$ & $3,03187 \mathrm{E}-12$ & $2,17059 \mathrm{E}-12$ \\
\hline Metal & $7,5776 \mathrm{E}-10$ & $7,31559 \mathrm{E}-11$ & $1,71675 \mathrm{E}-11$ & $3,99166 \mathrm{E}-11$ & $1,17061 \mathrm{E}-11$ & $2,86235 \mathrm{E}-11$ & $3,23688 \mathrm{E}-10$ & $2,03688 \mathrm{E}-11$ & $7,6749 \mathrm{E}-11$ & 4,87977E-11 & $5,09277 \mathrm{E}-11$ \\
\hline Eletrodomésticos & $1,22574 \mathrm{E}-11$ & $1,17352 \mathrm{E}-11$ & $7,98581 \mathrm{E}-12$ & $1,47933 \mathrm{E}-11$ & $4,11276 \mathrm{E}-12$ & $3,0891 \mathrm{E}-12$ & $9,42773 \mathrm{E}-12$ & $1,15726 \mathrm{E}-11$ & $1,09689 \mathrm{E}-11$ & $1,10937 \mathrm{E}-11$ & $1,1234 \mathrm{E}-11$ \\
\hline Informática & 0 & 0 & 0 & 0 & 0 & 0 & 0 & 0 & 0 & 0 & 0 \\
\hline Máquinas & $3,82496 \mathrm{E}-11$ & $8,06707 \mathrm{E}-12$ & $2,3742 \mathrm{E}-11$ & $3,46035 \mathrm{E}-11$ & $4,31768 \mathrm{E}-12$ & $9,38211 \mathrm{E}-12$ & $6,40281 \mathrm{E}-12$ & $1,20463 \mathrm{E}-11$ & $1,07216 \mathrm{E}-11$ & $3,81712 \mathrm{E}-11$ & 6,79667E-12 \\
\hline Eletrônicos & 0 & 0 & 0 & 0 & 0 & 0 & 0 & 0 & 0 & 0 & 0 \\
\hline Instrumento hospitalar & $4,0329 \mathrm{E}-12$ & $2,4372 \mathrm{E}-12$ & $7,72941 \mathrm{E}-13$ & $1,00495 \mathrm{E}-12$ & $5,66321 \mathrm{E}-13$ & $4,59421 \mathrm{E}-12$ & $4,91681 \mathrm{E}-13$ & $6,53976 \mathrm{E}-12$ & $6,78852 \mathrm{E}-12$ & $5,17196 \mathrm{E}-12$ & $1,40661 \mathrm{E}-12$ \\
\hline Veículos & $1,3684 \mathrm{E}-11$ & $7,5838 \mathrm{E}-12$ & $6,64217 \mathrm{E}-12$ & $1,14953 \mathrm{E}-11$ & $3,00596 \mathrm{E}-12$ & $2,88794 \mathrm{E}-12$ & $7,10112 \mathrm{E}-12$ & 7,72947E-12 & $7,51763 \mathrm{E}-12$ & $1,00489 \mathrm{E}-11$ & 7,53973E-12 \\
\hline Indústria Diversa & $1,16082 \mathrm{E}-09$ & $1,58196 \mathrm{E}-10$ & $9,9486 \mathrm{E}-10$ & $1,95216 \mathrm{E}-10$ & $1,75816 \mathrm{E}-09$ & $4,39609 \mathrm{E}-10$ & $1,94193 \mathrm{E}-10$ & $6,43081 \mathrm{E}-10$ & $6,37172 \mathrm{E}-10$ & $3,21486 \mathrm{E}-09$ & $7,02347 \mathrm{E}-10$ \\
\hline SIUP & $9,97081 \mathrm{E}-10$ & $3,41638 \mathrm{E}-09$ & 2,83301E-09 & $2,66229 \mathrm{E}-09$ & $1,60657 \mathrm{E}-09$ & $3,38402 \mathrm{E}-10$ & $3,45356 \mathrm{E}-09$ & 2,9982E-09 & 4,41446E-09 & $9,93235 \mathrm{E}-09$ & $3,80226 \mathrm{E}-09$ \\
\hline Construção & $8,60448 \mathrm{E}-07$ & $9,84678 \mathrm{E}-10$ & $7,65439 \mathrm{E}-10$ & $3,13564 \mathrm{E}-09$ & 3,10232E-09 & $7,41687 \mathrm{E}-09$ & $5,26997 \mathrm{E}-10$ & 2,20964E-09 & 6,62332E-09 & $5,71767 \mathrm{E}-09$ & $1,2934 \mathrm{E}-08$ \\
\hline Comércio & $7,47519 \mathrm{E}-09$ & $1,40406 \mathrm{E}-07$ & $6,22547 \mathrm{E}-09$ & $3,09339 \mathrm{E}-09$ & $1,84937 \mathrm{E}-09$ & $8,16177 \mathrm{E}-10$ & $1,43309 \mathrm{E}-08$ & $5,36266 \mathrm{E}-09$ & 4,77198E-09 & $5,15969 \mathrm{E}-09$ & $2,73458 \mathrm{E}-09$ \\
\hline Transportes & $1,56739 \mathrm{E}-09$ & 4,12391E-09 & $1,25958 \mathrm{E}-07$ & 2,79749E-09 & $1,17634 \mathrm{E}-09$ & $2,09233 \mathrm{E}-10$ & $1,88766 \mathrm{E}-09$ & 2,2224E-09 & $1,99701 \mathrm{E}-09$ & $2,95184 \mathrm{E}-09$ & $1,07215 \mathrm{E}-09$ \\
\hline Informação & $2,93292 \mathrm{E}-11$ & $9,24401 \mathrm{E}-11$ & $9,66454 \mathrm{E}-11$ & $6,91974 \mathrm{E}-09$ & $2,81965 \mathrm{E}-10$ & $1,90638 \mathrm{E}-11$ & $4,6178 \mathrm{E}-11$ & $7,495 \mathrm{E}-10$ & $2,57744 \mathrm{E}-10$ & $1,68784 \mathrm{E}-10$ & $3,12496 \mathrm{E}-10$ \\
\hline Financeiro & $2,12145 \mathrm{E}-11$ & $4,21067 \mathrm{E}-11$ & $5,82235 \mathrm{E}-11$ & $5,92707 \mathrm{E}-11$ & $1,68122 \mathrm{E}-09$ & $8,56552 \mathrm{E}-12$ & $2,18996 \mathrm{E}-11$ & $5,60965 \mathrm{E}-11$ & $2,47671 \mathrm{E}-11$ & $1,3785 \mathrm{E}-11$ & $1,31185 \mathrm{E}-10$ \\
\hline Imobiliário & $4,95266 \mathrm{E}-10$ & 2,49326E-09 & $4,44328 \mathrm{E}-09$ & $4,02538 \mathrm{E}-09$ & $1,27682 \mathrm{E}-09$ & $1,18382 \mathrm{E}-07$ & $1,53422 \mathrm{E}-09$ & 2,90577E-09 & $3,02269 \mathrm{E}-09$ & $2,16604 \mathrm{E}-09$ & $2,28621 \mathrm{E}-09$ \\
\hline Alojamento & $1,5072 \mathrm{E}-10$ & $2,09451 \mathrm{E}-10$ & $4,07813 \mathrm{E}-10$ & $2,75019 \mathrm{E}-10$ & $2,64498 \mathrm{E}-10$ & $2,91848 \mathrm{E}-11$ & $1,61787 \mathrm{E}-07$ & $2,3727 \mathrm{E}-10$ & $1,25783 \mathrm{E}-09$ & $1,43549 \mathrm{E}-09$ & $7,77492 \mathrm{E}-10$ \\
\hline Serviços às Empresas & 4,7882E-09 & $1,33555 \mathrm{E}-08$ & $1,53468 \mathrm{E}-08$ & $2,18731 \mathrm{E}-08$ & $1,65433 \mathrm{E}-08$ & $2,58532 \mathrm{E}-09$ & 4,22986E-09 & $2,63968 \mathrm{E}-07$ & $2,20187 \mathrm{E}-08$ & $1,40115 \mathrm{E}-08$ & $1,55592 \mathrm{E}-08$ \\
\hline Educação e Saúde mercantis & $5,56692 \mathrm{E}-11$ & $1,98367 \mathrm{E}-10$ & $1,31461 \mathrm{E}-10$ & $2,21499 \mathrm{E}-10$ & $2,28418 \mathrm{E}-10$ & $2,86071 \mathrm{E}-11$ & $1,58152 \mathrm{E}-10$ & $1,88563 \mathrm{E}-10$ & $9,99024 \mathrm{E}-08$ & $1,51145 \mathrm{E}-10$ & $3,11806 \mathrm{E}-10$ \\
\hline Outros Serviços & $1,03389 \mathrm{E}-09$ & $2,73348 \mathrm{E}-09$ & $1,70903 \mathrm{E}-09$ & $3,0462 \mathrm{E}-09$ & $1,56499 \mathrm{E}-09$ & $3,05204 \mathrm{E}-10$ & $2,98082 \mathrm{E}-09$ & 3,63949E-09 & $2,69327 \mathrm{E}-09$ & $3,83333 \mathrm{E}-07$ & $1,92961 \mathrm{E}-09$ \\
\hline APU & $6,75259 \mathrm{E}-11$ & $1,81567 \mathrm{E}-10$ & $1,90477 \mathrm{E}-10$ & $2,45014 \mathrm{E}-10$ & $1,75395 \mathrm{E}-10$ & $2,90357 \mathrm{E}-11$ & $8,59545 \mathrm{E}-11$ & $2,18055 \mathrm{E}-10$ & $2,39326 \mathrm{E}-10$ & $1,84952 \mathrm{E}-10$ & $5,94206 \mathrm{E}-08$ \\
\hline
\end{tabular}


Tabela B3 - Matriz Geração de Emprego para o Grau de Instrução G(2), Distrito Federal - 2008.

(1)

\begin{tabular}{|c|c|c|c|c|c|c|c|c|c|c|c|}
\hline Setores & Agricultura & Pecuária & Extrativa & Alimentos & Vestuário & Madeira & Celulose & Revistas & Químicos & Borracha & Cimento \\
\hline Agricultura & $6,83061 \mathrm{E}-07$ & 4,48147E-08 & $7,4538 \mathrm{E}-11$ & $5,50323 \mathrm{E}-08$ & $6,88435 \mathrm{E}-10$ & $1,08218 \mathrm{E}-09$ & $3,12528 \mathrm{E}-09$ & $3,04859 \mathrm{E}-11$ & $1,37243 \mathrm{E}-10$ & 2,3259E-09 & $5,33488 \mathrm{E}-11$ \\
\hline Pecuária & $4,27285 \mathrm{E}-09$ & $1,09286 \mathrm{E}-06$ & $3,21241 \mathrm{E}-11$ & 4,32305E-08 & $9,02542 \mathrm{E}-10$ & $7,57769 \mathrm{E}-11$ & $2,48968 \mathrm{E}-10$ & $1,21343 \mathrm{E}-11$ & 7,88096E-11 & $3,67772 \mathrm{E}-10$ & $2,99889 \mathrm{E}-11$ \\
\hline Extrativa & $7,27247 \mathrm{E}-11$ & $1,72397 \mathrm{E}-10$ & $1,00193 \mathrm{E}-06$ & $4,10145 \mathrm{E}-11$ & $3,76924 \mathrm{E}-11$ & $5,18923 \mathrm{E}-11$ & $4,01327 \mathrm{E}-10$ & $9,6049 \mathrm{E}-12$ & $6,0997 \mathrm{E}-10$ & $1,29756 \mathrm{E}-10$ & $4,5332 \mathrm{E}-10$ \\
\hline Alimentos & 2,22636E-09 & $3,38082 \mathrm{E}-08$ & $1,16785 \mathrm{E}-10$ & $2,0383 \mathrm{E}-07$ & $1,53795 \mathrm{E}-09$ & $1,59241 \mathrm{E}-10$ & $4,9778 \mathrm{E}-10$ & $4,31745 \mathrm{E}-11$ & $1,8807 \mathrm{E}-10$ & $6,29558 \mathrm{E}-11$ & $1,14206 \mathrm{E}-10$ \\
\hline Vestuário & $7,10839 \mathrm{E}-12$ & $6,29072 \mathrm{E}-12$ & $2,09738 \mathrm{E}-10$ & $9,16855 \mathrm{E}-12$ & $3,76292 \mathrm{E}-07$ & $8,52627 \mathrm{E}-12$ & $3,01163 \mathrm{E}-10$ & $9,65042 \mathrm{E}-12$ & $1,92319 \mathrm{E}-11$ & $5,63575 \mathrm{E}-11$ & $1,33291 \mathrm{E}-11$ \\
\hline Madeira & $2,97152 \mathrm{E}-10$ & $5,82495 \mathrm{E}-11$ & $1,61998 \mathrm{E}-10$ & $6,95116 \mathrm{E}-11$ & $2,89281 \mathrm{E}-10$ & 4,9914E-06 & $3,01142 \mathrm{E}-08$ & $4,99007 \mathrm{E}-11$ & $9,12765 \mathrm{E}-10$ & $2,4779 \mathrm{E}-10$ & $2,8157 \mathrm{E}-10$ \\
\hline Celulose & $1,18701 \mathrm{E}-11$ & $1,29862 \mathrm{E}-11$ & $3,10604 \mathrm{E}-10$ & $1,51712 \mathrm{E}-11$ & $7,21841 \mathrm{E}-10$ & $1,18849 \mathrm{E}-09$ & $4,85069 \mathrm{E}-07$ & $7,57765 \mathrm{E}-11$ & $1,98046 \mathrm{E}-10$ & $5,73703 \mathrm{E}-10$ & $1,00776 \mathrm{E}-11$ \\
\hline Revistas & $3,56886 \mathrm{E}-11$ & $3,97891 \mathrm{E}-11$ & $9,19949 \mathrm{E}-11$ & $6,56671 \mathrm{E}-11$ & $3,46369 \mathrm{E}-11$ & $2,13264 \mathrm{E}-11$ & $3,96045 \mathrm{E}-10$ & $8,60143 \mathrm{E}-08$ & $5,64531 \mathrm{E}-10$ & $2,21942 \mathrm{E}-10$ & $7,56044 \mathrm{E}-11$ \\
\hline Químicos & $1,92312 \mathrm{E}-09$ & 1,3376E-09 & $4,46893 \mathrm{E}-10$ & $2,50237 \mathrm{E}-10$ & $1,37551 \mathrm{E}-10$ & $2,54979 \mathrm{E}-10$ & $1,15964 \mathrm{E}-09$ & $7,73177 \mathrm{E}-12$ & $4,97682 \mathrm{E}-08$ & $6,75924 \mathrm{E}-10$ & $6,33011 \mathrm{E}-11$ \\
\hline Borracha & 7,71943E-10 & $4,94684 \mathrm{E}-10$ & 6,35293E-09 & $1,37101 \mathrm{E}-09$ & $1,80428 \mathrm{E}-09$ & $3,35758 \mathrm{E}-09$ & $8,3734 \mathrm{E}-09$ & $1,05527 \mathrm{E}-09$ & $2,48587 \mathrm{E}-09$ & $7,0519 \mathrm{E}-07$ & $8,45049 \mathrm{E}-11$ \\
\hline Cimento & $6,50543 \mathrm{E}-11$ & $3,32127 \mathrm{E}-11$ & $7,67476 \mathrm{E}-11$ & $1,11158 \mathrm{E}-10$ & $2,9254 \mathrm{E}-11$ & $1,27059 \mathrm{E}-11$ & $9,93987 \mathrm{E}-11$ & $1,04233 \mathrm{E}-11$ & $4,089 \mathrm{E}-10$ & $3,04438 \mathrm{E}-11$ & $6,46889 \mathrm{E}-08$ \\
\hline Aço & $6,15284 \mathrm{E}-11$ & $2,96519 \mathrm{E}-11$ & $3,217 \mathrm{E}-10$ & $3,3835 \mathrm{E}-11$ & $1,8678 \mathrm{E}-11$ & $1,64206 \mathrm{E}-10$ & $3,25005 \mathrm{E}-10$ & $2,80666 \mathrm{E}-12$ & $8,5534 \mathrm{E}-11$ & $4,72173 \mathrm{E}-10$ & $3,2922 \mathrm{E}-11$ \\
\hline Metal & $7,54136 \mathrm{E}-10$ & $5,31394 \mathrm{E}-10$ & $2,44362 \mathrm{E}-09$ & $1,31173 \mathrm{E}-09$ & $2,10705 \mathrm{E}-10$ & $1,27389 \mathrm{E}-09$ & $2,27729 \mathrm{E}-09$ & $1,4133 \mathrm{E}-11$ & 1,10744E-09 & $1,25849 \mathrm{E}-09$ & $1,98898 \mathrm{E}-10$ \\
\hline Eletrodomésticos & $2,76841 \mathrm{E}-11$ & $1,88902 \mathrm{E}-11$ & $1,1259 \mathrm{E}-09$ & $3,17567 \mathrm{E}-11$ & $2,89848 \mathrm{E}-10$ & $4,99486 \mathrm{E}-10$ & 2,13751E-09 & $8,53086 \mathrm{E}-12$ & $1,59192 \mathrm{E}-10$ & $2,15603 \mathrm{E}-10$ & $1,66851 \mathrm{E}-11$ \\
\hline Informática & 0 & 0 & 0 & 0 & 0 & 0 & 0 & 0 & 0 & 0 & 0 \\
\hline Máquinas & $1,339 \mathrm{E}-11$ & $2,43351 \mathrm{E}-11$ & $4,03672 \mathrm{E}-10$ & $4,52676 \mathrm{E}-11$ & $4,51533 \mathrm{E}-11$ & $9,47065 \mathrm{E}-11$ & $9,40845 \mathrm{E}-11$ & $5,87927 \mathrm{E}-12$ & $1,13645 \mathrm{E}-10$ & $3,40936 \mathrm{E}-10$ & $8,42574 \mathrm{E}-11$ \\
\hline Eletrônicos & $3,81844 \mathrm{E}-13$ & $4,33177 \mathrm{E}-13$ & $4,36271 \mathrm{E}-11$ & $8,6813 \mathrm{E}-13$ & $8,7432 \mathrm{E}-13$ & $1,42925 \mathrm{E}-12$ & $2,91224 \mathrm{E}-12$ & $5,01569 \mathrm{E}-13$ & $1,81538 \mathrm{E}-12$ & $3,56867 \mathrm{E}-12$ & $9,72266 \mathrm{E}-13$ \\
\hline Instrumento hospitalar & $9,75766 \mathrm{E}-13$ & $1,07506 \mathrm{E}-12$ & $4,81888 \mathrm{E}-12$ & $1,4212 \mathrm{E}-12$ & $1,89005 \mathrm{E}-12$ & $2,02065 \mathrm{E}-12$ & $1,10849 \mathrm{E}-11$ & $2,1609 \mathrm{E}-12$ & $1,1736 \mathrm{E}-11$ & $2,2575 \mathrm{E}-11$ & $1,73531 \mathrm{E}-12$ \\
\hline Veículos & $1,08032 \mathrm{E}-11$ & $8,84034 \mathrm{E}-12$ & $6,39798 \mathrm{E}-11$ & $2,05272 \mathrm{E}-11$ & $1,10336 \mathrm{E}-11$ & $2,66119 \mathrm{E}-11$ & $5,19262 \mathrm{E}-11$ & $3,39139 \mathrm{E}-12$ & $2,4469 \mathrm{E}-11$ & $5,37696 \mathrm{E}-11$ & $9,69926 \mathrm{E}-12$ \\
\hline Indústria Diversa & $2,93276 \mathrm{E}-11$ & $2,71858 \mathrm{E}-10$ & $7,91657 \mathrm{E}-11$ & $1,84212 \mathrm{E}-10$ & $2,89389 \mathrm{E}-09$ & $8,5355 \mathrm{E}-11$ & $1,568 \mathrm{E}-09$ & $3,41212 \mathrm{E}-11$ & $7,79421 \mathrm{E}-11$ & $5,56954 \mathrm{E}-10$ & $7,44849 \mathrm{E}-11$ \\
\hline SIUP & 2,30869E-09 & 3,56335E-09 & $9,26433 \mathrm{E}-09$ & $5,70665 \mathrm{E}-09$ & 4,6699E-09 & 4,85119E-09 & $1,43259 \mathrm{E}-08$ & 3,80079E-09 & $6,92026 \mathrm{E}-09$ & $7,15615 \mathrm{E}-09$ & $1,88726 \mathrm{E}-08$ \\
\hline Construção & $1,1018 \mathrm{E}-10$ & $1,56517 \mathrm{E}-10$ & $2,83222 \mathrm{E}-10$ & $3,63421 \mathrm{E}-10$ & $3,26471 \mathrm{E}-10$ & $2,88387 \mathrm{E}-10$ & $5,1921 \mathrm{E}-10$ & $4,10989 \mathrm{E}-10$ & $5,81699 \mathrm{E}-10$ & $9,44725 \mathrm{E}-10$ & $1,28843 \mathrm{E}-09$ \\
\hline Comércio & $1,06513 \mathrm{E}-08$ & $1,57176 \mathrm{E}-08$ & $9,36777 \mathrm{E}-09$ & $1,68535 \mathrm{E}-08$ & $1,77028 \mathrm{E}-08$ & 7,22974E-09 & $9,24911 \mathrm{E}-09$ & $9,5782 \mathrm{E}-09$ & $1,31438 \mathrm{E}-08$ & $1,02438 \mathrm{E}-08$ & $1,64376 \mathrm{E}-08$ \\
\hline Transportes & 4,97348E-09 & 4,5253E-09 & $1,32941 \mathrm{E}-08$ & $8,48258 \mathrm{E}-09$ & $3,94259 \mathrm{E}-09$ & $4,26865 \mathrm{E}-09$ & $7,23133 \mathrm{E}-09$ & 4,15732E-09 & 7,86346E-09 & $5,142 \mathrm{E}-09$ & $1,59377 \mathrm{E}-08$ \\
\hline Informação & $4,85135 \mathrm{E}-11$ & $7,5208 \mathrm{E}-11$ & $2,21323 \mathrm{E}-10$ & $9,45141 \mathrm{E}-11$ & $5,41575 \mathrm{E}-11$ & $4,00651 \mathrm{E}-11$ & $9,24973 \mathrm{E}-11$ & $2,22549 \mathrm{E}-10$ & $2,8656 \mathrm{E}-10$ & $1,27793 \mathrm{E}-10$ & $1,73423 \mathrm{E}-10$ \\
\hline
\end{tabular}




\begin{tabular}{|c|c|c|c|c|c|c|c|c|c|c|c|}
\hline Financeiro & $1,9359 \mathrm{E}-11$ & $2,14662 \mathrm{E}-11$ & $4,33788 \mathrm{E}-11$ & $3,69415 \mathrm{E}-11$ & $2,95386 \mathrm{E}-11$ & $2,73829 \mathrm{E}-11$ & $5,97251 \mathrm{E}-11$ & 3,38753E-11 & $5,88127 \mathrm{E}-11$ & $4,27186 \mathrm{E}-11$ & $6,86936 \mathrm{E}-11$ \\
\hline Imobiliário & $2,11555 \mathrm{E}-10$ & $2,70931 \mathrm{E}-10$ & $6,41838 \mathrm{E}-10$ & $5,41432 \mathrm{E}-10$ & $6,03226 \mathrm{E}-10$ & $2,41426 \mathrm{E}-10$ & $5,3339 \mathrm{E}-10$ & $8,40438 \mathrm{E}-10$ & $7,19501 \mathrm{E}-10$ & 4,48603E-10 & 7,81711E-10 \\
\hline Alojamento & $6,05133 \mathrm{E}-11$ & $8,5353 \mathrm{E}-11$ & $5,51684 \mathrm{E}-10$ & $1,50157 \mathrm{E}-10$ & $8,75522 \mathrm{E}-11$ & $1,75625 \mathrm{E}-10$ & $1,78982 \mathrm{E}-10$ & $2,37263 \mathrm{E}-10$ & $1,98854 \mathrm{E}-10$ & $1,76638 \mathrm{E}-10$ & $9,70916 \mathrm{E}-10$ \\
\hline Serviços às Empresas & 3,7748E-09 & $5,4268 \mathrm{E}-09$ & $1,04636 \mathrm{E}-08$ & $1,277 \mathrm{E}-08$ & 8,37839E-09 & 4,45515E-09 & $1,08046 \mathrm{E}-08$ & 2,94429E-08 & $3,3296 \mathrm{E}-08$ & $9,01001 \mathrm{E}-09$ & 2,09143E-08 \\
\hline Educação e Saúde mercantis & $4,7193 \mathrm{E}-11$ & $6,52497 \mathrm{E}-11$ & $9,6023 \mathrm{E}-11$ & $9,83532 \mathrm{E}-11$ & $1,2008 \mathrm{E}-10$ & $4,40942 \mathrm{E}-11$ & $8,63258 \mathrm{E}-11$ & $1,05253 \mathrm{E}-10$ & $1,05747 \mathrm{E}-10$ & $7,56828 \mathrm{E}-11$ & $1,09037 \mathrm{E}-10$ \\
\hline Outros Serviços & 7,97837E-10 & $1,15625 \mathrm{E}-09$ & $1,20459 \mathrm{E}-09$ & $1,52532 \mathrm{E}-09$ & $1,63971 \mathrm{E}-09$ & $6,04516 \mathrm{E}-10$ & $1,00237 \mathrm{E}-09$ & $1,1783 \mathrm{E}-09$ & $1,62486 \mathrm{E}-09$ & 1,18644E-09 & $1,89256 \mathrm{E}-09$ \\
\hline APU & $1,41742 \mathrm{E}-11$ & $1,69115 \mathrm{E}-11$ & 3,39515E-11 & $3,13532 \mathrm{E}-11$ & $1,97599 \mathrm{E}-11$ & $1,33339 \mathrm{E}-11$ & $3,23723 \mathrm{E}-11$ & $5,99132 \mathrm{E}-11$ & $5,41957 \mathrm{E}-11$ & 2,29907E-11 & $5,17726 \mathrm{E}-11$ \\
\hline
\end{tabular}

Tabela B3 - Matriz Geração de Emprego para o Grau de Instrução G(2), Distrito Federal - 2008.

(2)

\begin{tabular}{|c|c|c|c|c|c|c|c|c|c|c|}
\hline Setores & Aço & Metal & Eletrodomésticos & Informática & Máquinas & Eletrônicos & $\begin{array}{l}\text { Instrumento } \\
\text { hospitalar }\end{array}$ & Veículos & $\begin{array}{l}\text { Indústria } \\
\text { Diversa }\end{array}$ & SIUP \\
\hline Agricultura & $4,01922 \mathrm{E}-11$ & $2,21603 \mathrm{E}-11$ & $7,95682 \mathrm{E}-11$ & 7,57992E-11 & $4,52055 \mathrm{E}-11$ & $1,03488 \mathrm{E}-10$ & $2,74969 \mathrm{E}-11$ & $1,57877 \mathrm{E}-10$ & $6,17767 \mathrm{E}-11$ & $1,11976 \mathrm{E}-11$ \\
\hline Pecuária & $1,64868 \mathrm{E}-11$ & $8,14411 \mathrm{E}-12$ & $2,01301 \mathrm{E}-11$ & $2,17741 \mathrm{E}-11$ & $1,72681 \mathrm{E}-11$ & $2,25936 \mathrm{E}-11$ & $9,31123 \mathrm{E}-12$ & $3,6041 \mathrm{E}-11$ & $1,93058 \mathrm{E}-10$ & $5,29526 \mathrm{E}-12$ \\
\hline Extrativa & $1,68793 \mathrm{E}-08$ & $9,9723 \mathrm{E}-10$ & 3,16481E-09 & $2,4122 \mathrm{E}-10$ & $9,59694 \mathrm{E}-10$ & $5,39335 \mathrm{E}-10$ & $8,98645 \mathrm{E}-11$ & $1,80521 \mathrm{E}-09$ & $5,53369 \mathrm{E}-10$ & $8,47116 \mathrm{E}-12$ \\
\hline Alimentos & $5,11804 \mathrm{E}-11$ & $2,40625 \mathrm{E}-11$ & $4,98127 \mathrm{E}-11$ & $5,57267 \mathrm{E}-11$ & $5,01869 \mathrm{E}-11$ & $5,45136 \mathrm{E}-11$ & $2,6428 \mathrm{E}-11$ & $6,73983 \mathrm{E}-11$ & $4,79464 \mathrm{E}-11$ & $1,60658 \mathrm{E}-11$ \\
\hline Vestuário & $1,77075 \mathrm{E}-11$ & $2,70976 \mathrm{E}-11$ & $1,48726 \mathrm{E}-10$ & $2,06846 \mathrm{E}-11$ & $1,73725 \mathrm{E}-11$ & $2,35512 \mathrm{E}-11$ & $2,62161 \mathrm{E}-11$ & $1,27575 \mathrm{E}-10$ & $1,79072 \mathrm{E}-11$ & $1,79284 \mathrm{E}-11$ \\
\hline Madeira & $2,26541 \mathrm{E}-10$ & $3,34607 \mathrm{E}-10$ & $6,67618 \mathrm{E}-09$ & $6,14194 \mathrm{E}-09$ & $2,95235 \mathrm{E}-10$ & $2,73165 \mathrm{E}-08$ & $8,07994 \mathrm{E}-11$ & 4,18478E-09 & $9,02109 \mathrm{E}-09$ & $1,09345 \mathrm{E}-11$ \\
\hline Celulose & $8,16841 \mathrm{E}-11$ & $1,97376 \mathrm{E}-11$ & $1,50627 \mathrm{E}-09$ & $8,14452 \mathrm{E}-10$ & $1,46979 \mathrm{E}-10$ & $1,60799 \mathrm{E}-09$ & 3,43936E-11 & $8,23757 \mathrm{E}-10$ & $7,92514 \mathrm{E}-11$ & $6,91638 \mathrm{E}-12$ \\
\hline Revistas & $1,08329 \mathrm{E}-10$ & $1,06602 \mathrm{E}-10$ & $6,5288 \mathrm{E}-11$ & $1,23221 \mathrm{E}-10$ & $5,56273 \mathrm{E}-11$ & $1,03457 \mathrm{E}-10$ & $5,11229 \mathrm{E}-10$ & $1,21626 \mathrm{E}-10$ & $3,63423 \mathrm{E}-11$ & $1,52387 \mathrm{E}-10$ \\
\hline Químicos & $5,95895 \mathrm{E}-10$ & $1,03884 \mathrm{E}-10$ & $5,50063 \mathrm{E}-10$ & $3,94654 \mathrm{E}-11$ & $1,73115 \mathrm{E}-10$ & $6,95874 \mathrm{E}-11$ & $1,31287 \mathrm{E}-10$ & $3,62126 \mathrm{E}-10$ & $6,44266 \mathrm{E}-11$ & $4,35719 \mathrm{E}-11$ \\
\hline Borracha & 4,33888E-09 & 2,48717E-09 & $1,18642 \mathrm{E}-08$ & $1,05709 \mathrm{E}-08$ & $5,45326 \mathrm{E}-09$ & $1,22687 \mathrm{E}-08$ & $3,4185 \mathrm{E}-09$ & $2,84223 \mathrm{E}-08$ & 4,49829E-09 & $1,0762 \mathrm{E}-10$ \\
\hline Cimento & $5,70711 \mathrm{E}-10$ & $1,70328 \mathrm{E}-10$ & $2,21372 \mathrm{E}-10$ & $1,16576 \mathrm{E}-10$ & $5,48421 \mathrm{E}-10$ & $4,27373 \mathrm{E}-10$ & $2,00895 \mathrm{E}-10$ & $4,93705 \mathrm{E}-10$ & $1,14788 \mathrm{E}-09$ & $5,53037 \mathrm{E}-12$ \\
\hline Aço & $8,03064 \mathrm{E}-08$ & $6,55398 \mathrm{E}-10$ & $1,20019 \mathrm{E}-08$ & $8,69133 \mathrm{E}-10$ & $2,36604 \mathrm{E}-09$ & 2,09062E-09 & $2,39085 \mathrm{E}-10$ & $6,60716 \mathrm{E}-09$ & $2,43759 \mathrm{E}-10$ & $7,59848 \mathrm{E}-12$ \\
\hline Metal & 6,01083E-09 & $1,54307 \mathrm{E}-07$ & $9,6763 \mathrm{E}-09$ & $3,6296 \mathrm{E}-09$ & $6,72449 \mathrm{E}-09$ & $5,98808 \mathrm{E}-09$ & $4,12175 \mathrm{E}-09$ & $4,31722 \mathrm{E}-09$ & $3,31869 \mathrm{E}-09$ & $1,68737 \mathrm{E}-11$ \\
\hline Eletrodomésticos & $1,14785 \mathrm{E}-09$ & $1,31905 \mathrm{E}-10$ & 4,41117E-07 & $1,22285 \mathrm{E}-09$ & $5,64382 \mathrm{E}-10$ & $8,25158 \mathrm{E}-10$ & $2,45803 \mathrm{E}-10$ & 5,16961E-09 & $8,55701 \mathrm{E}-11$ & $1,38302 \mathrm{E}-11$ \\
\hline Informática & 0 & 0 & 0 & 0 & 0 & 0 & 0 & 0 & 0 & 0 \\
\hline Máquinas & $1,45375 \mathrm{E}-10$ & $3,97479 \mathrm{E}-11$ & 3,00173E-09 & 7,18356E-09 & $1,17486 \mathrm{E}-07$ & $1,32011 \mathrm{E}-08$ & $8,7562 \mathrm{E}-10$ & $1,96279 \mathrm{E}-09$ & $2,93289 \mathrm{E}-10$ & $2,2294 \mathrm{E}-10$ \\
\hline
\end{tabular}




\begin{tabular}{|c|c|c|c|c|c|c|c|c|c|c|}
\hline Eletrônicos & $4,14411 \mathrm{E}-12$ & $2,48514 \mathrm{E}-12$ & $1,046 \mathrm{E}-10$ & $1,22367 \mathrm{E}-08$ & $1,0202 \mathrm{E}-10$ & $6,03099 \mathrm{E}-08$ & $1,21024 \mathrm{E}-11$ & $9,72773 \mathrm{E}-11$ & $5,06738 \mathrm{E}-12$ & $1,96704 \mathrm{E}-12$ \\
\hline Instrumento hospitalar & $3,44306 \mathrm{E}-12$ & $1,89282 \mathrm{E}-12$ & $5,22125 \mathrm{E}-10$ & $6,82629 \mathrm{E}-11$ & $2,02751 \mathrm{E}-10$ & $9,5244 \mathrm{E}-11$ & $1,638 \mathrm{E}-07$ & $8,71535 \mathrm{E}-11$ & $8,95836 \mathrm{E}-12$ & $1,97899 \mathrm{E}-12$ \\
\hline Veículos & $1,46649 \mathrm{E}-10$ & $9,2647 \mathrm{E}-11$ & $6,61467 \mathrm{E}-10$ & $4,67288 \mathrm{E}-10$ & $5,33835 \mathrm{E}-10$ & $8,47953 \mathrm{E}-10$ & $1,1238 \mathrm{E}-10$ & $2,3375 \mathrm{E}-07$ & $6,6872 \mathrm{E}-11$ & $1,42621 \mathrm{E}-11$ \\
\hline Indústria Diversa & $3,72267 \mathrm{E}-09$ & $2,74287 \mathrm{E}-10$ & $8,65215 \mathrm{E}-10$ & $1,6375 \mathrm{E}-10$ & $5,02385 \mathrm{E}-10$ & $2,66464 \mathrm{E}-10$ & $7,09965 \mathrm{E}-11$ & $4,46969 \mathrm{E}-10$ & $9,32801 \mathrm{E}-07$ & $2,32562 \mathrm{E}-11$ \\
\hline SIUP & $1,67684 \mathrm{E}-08$ & 8,17713E-09 & $8,13959 \mathrm{E}-09$ & $5,45027 \mathrm{E}-09$ & $9,55598 \mathrm{E}-09$ & 6,65962E-09 & 6,96459E-09 & 7,13571E-09 & $5,08099 \mathrm{E}-09$ & 7,59191E-07 \\
\hline Construção & $4,01406 \mathrm{E}-10$ & $2,69737 \mathrm{E}-10$ & $5,45605 \mathrm{E}-10$ & $8,03202 \mathrm{E}-10$ & $1,10938 \mathrm{E}-09$ & $1,67634 \mathrm{E}-09$ & $2,54328 \mathrm{E}-10$ & $1,77784 \mathrm{E}-09$ & $3,25965 \mathrm{E}-10$ & $2,51969 \mathrm{E}-10$ \\
\hline Comércio & $8,75746 \mathrm{E}-09$ & 7,67011E-09 & $1,28854 \mathrm{E}-08$ & $2,90064 \mathrm{E}-08$ & $1,14877 \mathrm{E}-08$ & $2,16658 \mathrm{E}-08$ & $1,15713 \mathrm{E}-08$ & $1,65066 \mathrm{E}-08$ & $1,34007 \mathrm{E}-08$ & $3,65755 \mathrm{E}-09$ \\
\hline Informação & $2,2623 \mathrm{E}-10$ & $1,00616 \mathrm{E}-10$ & $2,53066 \mathrm{E}-10$ & $3,63806 \mathrm{E}-10$ & $3,10484 \mathrm{E}-10$ & $5,35267 \mathrm{E}-10$ & $1,63958 \mathrm{E}-10$ & $2,02376 \mathrm{E}-10$ & $5,49751 \mathrm{E}-11$ & $1,91438 \mathrm{E}-10$ \\
\hline Financeiro & $7,48346 \mathrm{E}-11$ & $4,40874 \mathrm{E}-11$ & $9,53401 \mathrm{E}-11$ & $6,65863 \mathrm{E}-11$ & $6,8115 \mathrm{E}-11$ & $1,17332 \mathrm{E}-10$ & $4,73528 \mathrm{E}-11$ & $6,53995 \mathrm{E}-11$ & $2,80249 \mathrm{E}-11$ & $2,52011 \mathrm{E}-11$ \\
\hline Imobiliário & $5,06882 \mathrm{E}-10$ & $4,3012 \mathrm{E}-10$ & $6,70224 \mathrm{E}-10$ & $7,18678 \mathrm{E}-10$ & $5,31704 \mathrm{E}-10$ & $7,10942 \mathrm{E}-10$ & $6,25434 \mathrm{E}-10$ & 4,67867E-10 & $4,07919 \mathrm{E}-10$ & $3,6703 \mathrm{E}-10$ \\
\hline Alojamento & $2,57089 \mathrm{E}-10$ & $9,79894 \mathrm{E}-11$ & $1,41556 \mathrm{E}-10$ & $2,04702 \mathrm{E}-10$ & $3,0375 \mathrm{E}-10$ & $2,04527 \mathrm{E}-10$ & $8,80181 \mathrm{E}-11$ & $2,71572 \mathrm{E}-10$ & $1,82912 \mathrm{E}-10$ & $7,51784 \mathrm{E}-11$ \\
\hline Serviços às Empresas & $8,75466 \mathrm{E}-09$ & $8,53127 \mathrm{E}-09$ & $1,02247 \mathrm{E}-08$ & $4,57376 \mathrm{E}-08$ & $1,45797 \mathrm{E}-08$ & $3,22369 \mathrm{E}-08$ & $1,17084 \mathrm{E}-08$ & $1,95814 \mathrm{E}-08$ & $6,7363 \mathrm{E}-09$ & $2,48676 \mathrm{E}-08$ \\
\hline Educação e Saúde mercantis & $7,16635 \mathrm{E}-11$ & $7,24102 \mathrm{E}-11$ & $1,0633 \mathrm{E}-10$ & $1,48157 \mathrm{E}-10$ & $9,10924 \mathrm{E}-11$ & $1,36085 \mathrm{E}-10$ & $9,0595 \mathrm{E}-11$ & $9,18469 \mathrm{E}-11$ & $8,31387 \mathrm{E}-11$ & $5,70145 \mathrm{E}-11$ \\
\hline $\mathrm{APU}$ & $3,29644 \mathrm{E}-11$ & $2,26646 \mathrm{E}-11$ & $2,66657 \mathrm{E}-11$ & $6,85243 \mathrm{E}-11$ & $2,96669 \mathrm{E}-11$ & $5,44386 \mathrm{E}-11$ & $2,63957 \mathrm{E}-11$ & $3,67965 \mathrm{E}-11$ & $1,70265 \mathrm{E}-11$ & $6,11652 \mathrm{E}-11$ \\
\hline
\end{tabular}

Tabela B3 - Matriz Geração de Emprego para o Grau de Instrução G(2), Distrito Federal - 2008.

(3)

\begin{tabular}{|c|c|c|c|c|c|c|c|c|c|c|c|}
\hline Setores & Construção & Comércio & Transportes & Informação & Financeiro & Imobiliário & Alojamento & $\begin{array}{l}\text { Serviços às } \\
\text { Empresas }\end{array}$ & $\begin{array}{l}\text { Educação e } \\
\text { Saúde } \\
\text { mercantis }\end{array}$ & $\begin{array}{c}\text { Outros } \\
\text { Serviços }\end{array}$ & APU \\
\hline Agricultura & $3,21291 \mathrm{E}-11$ & $9,96825 \mathrm{E}-11$ & $7,54035 \mathrm{E}-11$ & $4,5739 \mathrm{E}-11$ & $2,9617 \mathrm{E}-11$ & $6,2771 \mathrm{E}-12$ & $1,00282 \mathrm{E}-08$ & $4,54133 \mathrm{E}-11$ & $2,39076 \mathrm{E}-10$ & $1,03279 \mathrm{E}-09$ & $1,2764 \mathrm{E}-10$ \\
\hline Pecuária & $1,59192 \mathrm{E}-11$ & $4,67844 \mathrm{E}-11$ & $4,16545 \mathrm{E}-11$ & $2,06175 \mathrm{E}-11$ & $1,57839 \mathrm{E}-11$ & $2,66907 \mathrm{E}-12$ & $6,16136 \mathrm{E}-09$ & $2,06171 \mathrm{E}-11$ & $1,37131 \mathrm{E}-10$ & $6,69482 \mathrm{E}-10$ & $6,42228 \mathrm{E}-11$ \\
\hline Extrativa & $4,40553 \mathrm{E}-11$ & $2,29654 \mathrm{E}-11$ & $1,4153 \mathrm{E}-11$ & $2,65951 \mathrm{E}-11$ & $7,937 \mathrm{E}-12$ & 4,39493E-12 & $2,08816 \mathrm{E}-11$ & $2,12216 \mathrm{E}-11$ & $2,08806 \mathrm{E}-11$ & $1,97043 \mathrm{E}-11$ & $2,16368 \mathrm{E}-11$ \\
\hline Alimentos & $6,29622 \mathrm{E}-11$ & $1,9564 \mathrm{E}-10$ & $1,72804 \mathrm{E}-10$ & $6,84775 \mathrm{E}-11$ & $5,63012 \mathrm{E}-11$ & $9,48746 \mathrm{E}-12$ & $2,46462 \mathrm{E}-08$ & $6,56809 \mathrm{E}-11$ & $4,00068 \mathrm{E}-10$ & $9,16667 \mathrm{E}-10$ & $1,82735 \mathrm{E}-10$ \\
\hline Vestuário & $1,11292 \mathrm{E}-11$ & $2,49412 \mathrm{E}-11$ & $5,22942 \mathrm{E}-11$ & $2,43517 \mathrm{E}-11$ & $1,99279 \mathrm{E}-11$ & $2,63687 \mathrm{E}-12$ & $2,89343 \mathrm{E}-11$ & $7,13095 \mathrm{E}-11$ & 4,59711E-11 & $1,02813 \mathrm{E}-10$ & $2,00285 \mathrm{E}-11$ \\
\hline Madeira & $1,02538 \mathrm{E}-10$ & $3,6382 \mathrm{E}-11$ & $2,44037 \mathrm{E}-11$ & $4,82869 \mathrm{E}-11$ & $2,73004 \mathrm{E}-11$ & $3,56602 \mathrm{E}-11$ & $2,9773 \mathrm{E}-11$ & $4,01592 \mathrm{E}-11$ & $5,33238 \mathrm{E}-11$ & $5,62788 \mathrm{E}-11$ & $8,04959 \mathrm{E}-11$ \\
\hline
\end{tabular}




\begin{tabular}{|c|c|c|c|c|c|c|c|c|c|c|c|}
\hline Celulose & $5,00881 \mathrm{E}-12$ & $2,00886 \mathrm{E}-11$ & $1,26986 \mathrm{E}-11$ & $2,55661 \mathrm{E}-11$ & $8,65796 \mathrm{E}-12$ & $3,36965 \mathrm{E}-12$ & $1,25807 \mathrm{E}-11$ & $3,34373 \mathrm{E}-11$ & $1,78974 \mathrm{E}-11$ & $1,68895 \mathrm{E}-11$ & $1,68264 \mathrm{E}-11$ \\
\hline Revistas & $4,05161 \mathrm{E}-11$ & $1,45858 \mathrm{E}-10$ & $1,22925 \mathrm{E}-10$ & $3,40647 \mathrm{E}-10$ & $1,76386 \mathrm{E}-10$ & $3,83368 \mathrm{E}-11$ & $4,03639 \mathrm{E}-11$ & $1,08275 \mathrm{E}-09$ & $1,76753 \mathrm{E}-10$ & $1,87127 \mathrm{E}-10$ & $1,02848 \mathrm{E}-10$ \\
\hline Químicos & $5,89755 \mathrm{E}-12$ & $3,12175 \mathrm{E}-12$ & $2,20498 \mathrm{E}-12$ & $5,74421 \mathrm{E}-12$ & $1,31218 \mathrm{E}-12$ & $8,55068 \mathrm{E}-13$ & $4,283 \mathrm{E}-11$ & $3,57033 \mathrm{E}-12$ & $4,10119 \mathrm{E}-11$ & $8,04332 \mathrm{E}-12$ & $6,20087 \mathrm{E}-12$ \\
\hline Borracha & $4,46217 \mathrm{E}-10$ & $1,77903 \mathrm{E}-10$ & $1,49674 \mathrm{E}-10$ & $3,65508 \mathrm{E}-10$ & $5,8468 \mathrm{E}-11$ & $3,33653 \mathrm{E}-11$ & $2,42761 \mathrm{E}-10$ & $5,29693 \mathrm{E}-10$ & $4,62639 \mathrm{E}-10$ & $1,47616 \mathrm{E}-10$ & $7,02567 \mathrm{E}-11$ \\
\hline Cimento & 2,32729E-09 & $8,33058 \mathrm{E}-12$ & $3,57864 \mathrm{E}-12$ & $1,03103 \mathrm{E}-11$ & $9,64036 \mathrm{E}-12$ & $2,05821 \mathrm{E}-11$ & $1,62398 \mathrm{E}-11$ & $7,74602 \mathrm{E}-12$ & $7,68223 \mathrm{E}-11$ & $4,0502 \mathrm{E}-11$ & $3,84556 \mathrm{E}-11$ \\
\hline Aço & $2,23375 \mathrm{E}-11$ & $3,27504 \mathrm{E}-12$ & $2,56559 \mathrm{E}-12$ & 4,49064E-12 & $1,28804 \mathrm{E}-12$ & $1,20547 \mathrm{E}-12$ & $6,06343 \mathrm{E}-12$ & $3,14222 \mathrm{E}-12$ & $3,79502 \mathrm{E}-12$ & $4,24462 \mathrm{E}-12$ & $3,03882 \mathrm{E}-12$ \\
\hline Metal & $4,14774 \mathrm{E}-10$ & $4,00432 \mathrm{E}-11$ & $9,39696 \mathrm{E}-12$ & $2,18491 \mathrm{E}-11$ & $6,40754 \mathrm{E}-12$ & $1,56676 \mathrm{E}-11$ & $1,77177 \mathrm{E}-10$ & $1,11492 \mathrm{E}-11$ & $4,201 \mathrm{E}-11$ & $2,67103 \mathrm{E}-11$ & $2,78762 \mathrm{E}-11$ \\
\hline Eletrodomésticos & $1,71604 \mathrm{E}-11$ & $1,64293 \mathrm{E}-11$ & $1,11801 \mathrm{E}-11$ & $2,07106 \mathrm{E}-11$ & $5,75786 \mathrm{E}-12$ & $4,32475 \mathrm{E}-12$ & $1,31988 \mathrm{E}-11$ & $1,62017 \mathrm{E}-11$ & $1,53565 \mathrm{E}-11$ & $1,55312 \mathrm{E}-11$ & $1,57276 \mathrm{E}-11$ \\
\hline Informática & 0 & 0 & 0 & 0 & 0 & 0 & 0 & 0 & 0 & 0 & 0 \\
\hline Máquinas & $6,11993 \mathrm{E}-11$ & $1,29073 \mathrm{E}-11$ & $3,79873 \mathrm{E}-11$ & $5,53656 \mathrm{E}-11$ & $6,90829 \mathrm{E}-12$ & $1,50114 \mathrm{E}-11$ & $1,02445 \mathrm{E}-11$ & $1,9274 \mathrm{E}-11$ & $1,71546 \mathrm{E}-11$ & $6,10739 \mathrm{E}-11$ & $1,08747 \mathrm{E}-11$ \\
\hline Eletrônicos & $7,21442 \mathrm{E}-13$ & $4,77865 \mathrm{E}-13$ & $5,95037 \mathrm{E}-13$ & $1,01206 \mathrm{E}-12$ & $2,23684 \mathrm{E}-13$ & $2,77566 \mathrm{E}-13$ & $3,4767 \mathrm{E}-13$ & $6,79445 \mathrm{E}-13$ & $4,65978 \mathrm{E}-13$ & $8,49784 \mathrm{E}-13$ & $4,42441 \mathrm{E}-13$ \\
\hline Instrumento hospitalar & $1,10905 \mathrm{E}-11$ & $6,70231 \mathrm{E}-12$ & $2,12559 \mathrm{E}-12$ & $2,76362 \mathrm{E}-12$ & $1,55738 \mathrm{E}-12$ & $1,26341 \mathrm{E}-11$ & $1,35212 \mathrm{E}-12$ & $1,79843 \mathrm{E}-11$ & $1,86684 \mathrm{E}-11$ & $1,42229 \mathrm{E}-11$ & $3,86819 \mathrm{E}-12$ \\
\hline Veículos & $1,14034 \mathrm{E}-11$ & $6,31983 \mathrm{E}-12$ & $5,53515 \mathrm{E}-12$ & $9,57939 \mathrm{E}-12$ & $2,50497 \mathrm{E}-12$ & $2,40661 \mathrm{E}-12$ & $5,9176 \mathrm{E}-12$ & $6,44122 \mathrm{E}-12$ & $6,26469 \mathrm{E}-12$ & $8,37411 \mathrm{E}-12$ & $6,2831 \mathrm{E}-12$ \\
\hline Indústria Diversa & $3,06825 \mathrm{E}-10$ & $4,1814 \mathrm{E}-11$ & $2,62959 \mathrm{E}-10$ & $5,15989 \mathrm{E}-11$ & $4,64712 \mathrm{E}-10$ & $1,16196 \mathrm{E}-10$ & $5,13286 \mathrm{E}-11$ & $1,69977 \mathrm{E}-10$ & $1,68416 \mathrm{E}-10$ & $8,49742 \mathrm{E}-10$ & $1,85642 \mathrm{E}-10$ \\
\hline SIUP & 1,659E-09 & $5,68435 \mathrm{E}-09$ & 4,71371E-09 & 4,42967E-09 & 2,6731E-09 & $5,63052 \mathrm{E}-10$ & $5,74622 \mathrm{E}-09$ & 4,98857E-09 & 7,34502E-09 & $1,6526 \mathrm{E}-08$ & $6,3264 \mathrm{E}-09$ \\
\hline Construção & $6,00998 \mathrm{E}-07$ & $6,87769 \mathrm{E}-10$ & $5,34637 \mathrm{E}-10$ & 2,19015E-09 & $2,16688 \mathrm{E}-09$ & $5,18047 \mathrm{E}-09$ & $3,68092 \mathrm{E}-10$ & $1,54337 \mathrm{E}-09$ & 4,62619E-09 & $3,99362 \mathrm{E}-09$ & $9,03399 \mathrm{E}-09$ \\
\hline Comércio & $1,20024 \mathrm{E}-08$ & $2,25441 \mathrm{E}-07$ & $9,99583 \mathrm{E}-09$ & 4,96685E-09 & 2,96941E-09 & $1,31048 \mathrm{E}-09$ & $2,30101 \mathrm{E}-08$ & $8,61047 \mathrm{E}-09$ & 7,66206E-09 & $8,28458 \mathrm{E}-09$ & 4,39074E-09 \\
\hline Transportes & 3,04143E-09 & $8,0022 \mathrm{E}-09$ & $2,44413 \mathrm{E}-07$ & $5,42835 \mathrm{E}-09$ & 2,28261E-09 & $4,06003 \mathrm{E}-10$ & $3,66288 \mathrm{E}-09$ & $4,31243 \mathrm{E}-09$ & $3,87508 \mathrm{E}-09$ & $5,72786 \mathrm{E}-09$ & 2,08044E-09 \\
\hline Informação & $6,26579 \mathrm{E}-11$ & $1,97486 \mathrm{E}-10$ & $2,0647 \mathrm{E}-10$ & $1,47831 \mathrm{E}-08$ & $6,02381 \mathrm{E}-10$ & $4,07272 \mathrm{E}-11$ & $9,86531 \mathrm{E}-11$ & $1,6012 \mathrm{E}-09$ & $5,50636 \mathrm{E}-10$ & $3,60585 \mathrm{E}-10$ & $6,67605 \mathrm{E}-10$ \\
\hline Financeiro & $2,02921 \mathrm{E}-11$ & $4,0276 \mathrm{E}-11$ & $5,56921 \mathrm{E}-11$ & $5,66937 \mathrm{E}-11$ & $1,60812 \mathrm{E}-09$ & $8,19311 \mathrm{E}-12$ & $2,09474 \mathrm{E}-11$ & $5,36575 \mathrm{E}-11$ & $2,36903 \mathrm{E}-11$ & $1,31857 \mathrm{E}-11$ & $1,25481 \mathrm{E}-10$ \\
\hline Imobiliário & $3,02176 \mathrm{E}-10$ & $1,52121 \mathrm{E}-09$ & $2,71097 \mathrm{E}-09$ & $2,456 \mathrm{E}-09$ & $7,79024 \mathrm{E}-10$ & $7,22281 \mathrm{E}-08$ & $9,36075 \mathrm{E}-10$ & 1,7729E-09 & $1,84424 \mathrm{E}-09$ & $1,32157 \mathrm{E}-09$ & $1,39488 \mathrm{E}-09$ \\
\hline Alojamento & $2,56842 \mathrm{E}-10$ & $3,56925 \mathrm{E}-10$ & $6,94954 \mathrm{E}-10$ & $4,6866 \mathrm{E}-10$ & $4,50732 \mathrm{E}-10$ & $4,97338 \mathrm{E}-11$ & $2,757 \mathrm{E}-07$ & $4,04332 \mathrm{E}-10$ & $2,14346 \mathrm{E}-09$ & $2,44622 \mathrm{E}-09$ & $1,32492 \mathrm{E}-09$ \\
\hline Serviços às Empresas & $1,0096 \mathrm{E}-08$ & $2,81601 \mathrm{E}-08$ & $3,2359 \mathrm{E}-08$ & $4,61197 \mathrm{E}-08$ & $3,48816 \mathrm{E}-08$ & $5,45118 \mathrm{E}-09$ & $8,91871 \mathrm{E}-09$ & $5,56579 \mathrm{E}-07$ & $4,64267 \mathrm{E}-08$ & $2,95434 \mathrm{E}-08$ & $3,28068 \mathrm{E}-08$ \\
\hline Educação e Saúde mercantis & $6,37205 \mathrm{E}-11$ & $2,27056 \mathrm{E}-10$ & $1,50474 \mathrm{E}-10$ & $2,53534 \mathrm{E}-10$ & $2,61454 \mathrm{E}-10$ & $3,27445 \mathrm{E}-11$ & $1,81026 \mathrm{E}-10$ & $2,15835 \mathrm{E}-10$ & $1,14351 \mathrm{E}-07$ & $1,73004 \mathrm{E}-10$ & $3,56902 \mathrm{E}-10$ \\
\hline Outros Serviços & $1,113 \mathrm{E}-09$ & 2,94264E-09 & $1,8398 \mathrm{E}-09$ & $3,27929 \mathrm{E}-09$ & $1,68474 \mathrm{E}-09$ & $3,28558 \mathrm{E}-10$ & $3,2089 \mathrm{E}-09$ & 3,91797E-09 & 2,89936E-09 & $4,12665 \mathrm{E}-07$ & $2,07727 \mathrm{E}-09$ \\
\hline APU & $1,74834 \mathrm{E}-11$ & 4,70103E-11 & 4,93171E-11 & $6,34375 \mathrm{E}-11$ & 4,54123E-11 & $7,51774 \mathrm{E}-12$ & $2,22548 \mathrm{E}-11$ & $5,64575 \mathrm{E}-11$ & $6,1965 \mathrm{E}-11$ & 4,78867E-11 & $1,53848 \mathrm{E}-08$ \\
\hline
\end{tabular}


Tabela B4 - Matriz Geração de Emprego para o Grau de Instrução G(3), Distrito Federal - 2008.

(1)

\begin{tabular}{|c|c|c|c|c|c|c|c|c|c|c|c|}
\hline Setores & Agricultura & Pecuária & Extrativa & Alimentos & Vestuário & Madeira & Celulose & Revistas & Químicos & Borracha & Cimento \\
\hline Agricultura & $8,10412 \mathrm{E}-07$ & $5,317 \mathrm{E}-08$ & $8,8435 \mathrm{E}-11$ & $6,52926 \mathrm{E}-08$ & $8,16788 \mathrm{E}-10$ & $1,28394 \mathrm{E}-09$ & 3,70797E-09 & $3,61698 \mathrm{E}-11$ & $1,62831 \mathrm{E}-10$ & 2,75954E-09 & $6,32951 \mathrm{E}-11$ \\
\hline Pecuária & $6,60486 \mathrm{E}-09$ & $1,68931 \mathrm{E}-06$ & $4,96566 \mathrm{E}-11$ & $6,68245 \mathrm{E}-08$ & 1,39513E-09 & $1,17134 \mathrm{E}-10$ & $3,84849 \mathrm{E}-10$ & $1,87569 \mathrm{E}-11$ & $1,21822 \mathrm{E}-10$ & $5,68493 \mathrm{E}-10$ & $4,6356 \mathrm{E}-11$ \\
\hline Extrativa & $9,09059 \mathrm{E}-11$ & $2,15496 \mathrm{E}-10$ & $1,25242 \mathrm{E}-06$ & $5,12681 \mathrm{E}-11$ & $4,71156 \mathrm{E}-11$ & $6,48654 \mathrm{E}-11$ & $5,01659 \mathrm{E}-10$ & $1,20061 \mathrm{E}-11$ & $7,62462 \mathrm{E}-10$ & $1,62195 \mathrm{E}-10$ & $5,6665 \mathrm{E}-10$ \\
\hline Alimentos & $7,84555 \mathrm{E}-09$ & $1,19138 \mathrm{E}-07$ & $4,11545 \mathrm{E}-10$ & $7,18287 \mathrm{E}-07$ & 5,41965E-09 & $5,61156 \mathrm{E}-10$ & $1,75415 \mathrm{E}-09$ & $1,52144 \mathrm{E}-10$ & $6,62747 \mathrm{E}-10$ & $2,21853 \mathrm{E}-10$ & $4,02457 \mathrm{E}-10$ \\
\hline Vestuário & $3,22416 \mathrm{E}-11$ & $2,85329 \mathrm{E}-11$ & $9,5131 \mathrm{E}-10$ & $4,15859 \mathrm{E}-11$ & $1,70675 \mathrm{E}-06$ & $3,86727 \mathrm{E}-11$ & $1,36599 \mathrm{E}-09$ & $4,37716 \mathrm{E}-11$ & $8,72304 \mathrm{E}-11$ & $2,55621 \mathrm{E}-10$ & $6,04569 \mathrm{E}-11$ \\
\hline Madeira & $4,78465 \mathrm{E}-10$ & $9,37916 \mathrm{E}-11$ & $2,60844 \mathrm{E}-10$ & $1,11926 \mathrm{E}-10$ & 4,65791E-10 & 8,037E-06 & $4,8489 \mathrm{E}-08$ & $8,03487 \mathrm{E}-11$ & 1,46971E-09 & $3,98984 \mathrm{E}-10$ & $4,53375 \mathrm{E}-10$ \\
\hline Celulose & $4,59967 \mathrm{E}-11$ & $5,03216 \mathrm{E}-11$ & $1,20359 \mathrm{E}-09$ & $5,87886 \mathrm{E}-11$ & 2,79713E-09 & 4,60539E-09 & $1,87964 \mathrm{E}-06$ & $2,93634 \mathrm{E}-10$ & $7,67427 \mathrm{E}-10$ & 2,2231E-09 & $3,90509 \mathrm{E}-11$ \\
\hline Revistas & $2,3086 \mathrm{E}-10$ & $2,57386 \mathrm{E}-10$ & $5,95092 \mathrm{E}-10$ & $4,24784 \mathrm{E}-10$ & $2,24058 \mathrm{E}-10$ & $1,37955 \mathrm{E}-10$ & $2,56192 \mathrm{E}-09$ & $5,56405 \mathrm{E}-07$ & $3,65181 \mathrm{E}-09$ & $1,43569 \mathrm{E}-09$ & $4,89066 \mathrm{E}-10$ \\
\hline Químicos & $8,77423 \mathrm{E}-09$ & $6,10279 \mathrm{E}-09$ & $2,03895 \mathrm{E}-09$ & $1,14171 \mathrm{E}-09$ & $6,27577 \mathrm{E}-10$ & $1,16334 \mathrm{E}-09$ & $5,29086 \mathrm{E}-09$ & $3,52762 \mathrm{E}-11$ & $2,27067 \mathrm{E}-07$ & $3,0839 \mathrm{E}-09$ & $2,88811 \mathrm{E}-10$ \\
\hline Borracha & $1,47527 \mathrm{E}-09$ & $9,45395 \mathrm{E}-10$ & $1,21412 \mathrm{E}-08$ & $2,62015 \mathrm{E}-09$ & $3,44819 \mathrm{E}-09$ & $6,41671 \mathrm{E}-09$ & $1,60025 \mathrm{E}-08$ & 2,01673E-09 & 4,75077E-09 & 1,3477E-06 & $1,61498 \mathrm{E}-10$ \\
\hline Cimento & $1,68789 \mathrm{E}-10$ & $8,61736 \mathrm{E}-11$ & $1,99129 \mathrm{E}-10$ & $2,88411 \mathrm{E}-10$ & 7,59023E-11 & $3,29667 \mathrm{E}-11$ & $2,57899 \mathrm{E}-10$ & $2,70443 \mathrm{E}-11$ & $1,06093 \mathrm{E}-09$ & $7,89892 \mathrm{E}-11$ & $1,67842 \mathrm{E}-07$ \\
\hline Aço & $4,57068 \mathrm{E}-10$ & $2,20272 \mathrm{E}-10$ & 2,38977E-09 & $2,51346 \mathrm{E}-10$ & $1,3875 \mathrm{E}-10$ & $1,21982 \mathrm{E}-09$ & $2,41432 \mathrm{E}-09$ & $2,08495 \mathrm{E}-11$ & $6,35395 \mathrm{E}-10$ & 3,50757E-09 & $2,44564 \mathrm{E}-10$ \\
\hline Metal & $2,56696 \mathrm{E}-09$ & $1,80878 \mathrm{E}-09$ & $8,31772 \mathrm{E}-09$ & 4,46493E-09 & $7,17209 \mathrm{E}-10$ & $4,33612 \mathrm{E}-09$ & $7,75155 \mathrm{E}-09$ & $4,81066 \mathrm{E}-11$ & 3,76954E-09 & 4,2837E-09 & $6,77019 \mathrm{E}-10$ \\
\hline Eletrodomésticos & $9,29395 \mathrm{E}-11$ & $6,3417 \mathrm{E}-11$ & 3,77981E-09 & $1,06612 \mathrm{E}-10$ & $9,73061 \mathrm{E}-10$ & $1,67685 \mathrm{E}-09$ & $7,17594 \mathrm{E}-09$ & $2,86393 \mathrm{E}-11$ & $5,34431 \mathrm{E}-10$ & $7,2381 \mathrm{E}-10$ & $5,60144 \mathrm{E}-11$ \\
\hline Informática & $5,24841 \mathrm{E}-13$ & $4,17566 \mathrm{E}-13$ & $3,54118 \mathrm{E}-12$ & $5,74813 \mathrm{E}-13$ & $2,97547 \mathrm{E}-12$ & $1,56862 \mathrm{E}-12$ & $1,71883 \mathrm{E}-11$ & $2,15766 \mathrm{E}-12$ & $7,61847 \mathrm{E}-12$ & $8,08685 \mathrm{E}-12$ & $4,22898 \mathrm{E}-13$ \\
\hline Máquinas & $1,13815 \mathrm{E}-10$ & $2,06849 \mathrm{E}-10$ & $3,43121 \mathrm{E}-09$ & $3,84774 \mathrm{E}-10$ & $3,83803 \mathrm{E}-10$ & $8,05005 \mathrm{E}-10$ & $7,99718 \mathrm{E}-10$ & $4,99738 \mathrm{E}-11$ & $9,65983 \mathrm{E}-10$ & 2,89795E-09 & $7,16188 \mathrm{E}-10$ \\
\hline Eletrônicos & $1,14553 \mathrm{E}-12$ & $1,29953 \mathrm{E}-12$ & $1,30881 \mathrm{E}-10$ & $2,60439 \mathrm{E}-12$ & $2,62296 \mathrm{E}-12$ & $4,28775 \mathrm{E}-12$ & $8,73672 \mathrm{E}-12$ & $1,50471 \mathrm{E}-12$ & $5,44614 \mathrm{E}-12$ & $1,0706 \mathrm{E}-11$ & $2,9168 \mathrm{E}-12$ \\
\hline Instrumento hospitalar & $1,24188 \mathrm{E}-12$ & $1,36826 \mathrm{E}-12$ & $6,13312 \mathrm{E}-12$ & $1,8088 \mathrm{E}-12$ & $2,40551 \mathrm{E}-12$ & $2,57173 \mathrm{E}-12$ & $1,41081 \mathrm{E}-11$ & $2,75024 \mathrm{E}-12$ & $1,49367 \mathrm{E}-11$ & $2,87318 \mathrm{E}-11$ & $2,20858 \mathrm{E}-12$ \\
\hline Veículos & $1,94458 \mathrm{E}-11$ & $1,59126 \mathrm{E}-11$ & $1,15164 \mathrm{E}-10$ & $3,6949 \mathrm{E}-11$ & $1,98604 \mathrm{E}-11$ & $4,79013 \mathrm{E}-11$ & $9,34671 \mathrm{E}-11$ & $6,10451 \mathrm{E}-12$ & $4,40441 \mathrm{E}-11$ & $9,67853 \mathrm{E}-11$ & $1,74587 \mathrm{E}-11$ \\
\hline Indústria Diversa & $6,69646 \mathrm{E}-11$ & $6,20742 \mathrm{E}-10$ & $1,80762 \mathrm{E}-10$ & $4,20619 \mathrm{E}-10$ & 6,60772E-09 & $1,94894 \mathrm{E}-10$ & $3,58027 \mathrm{E}-09$ & 7,79102E-11 & $1,77968 \mathrm{E}-10$ & $1,27171 \mathrm{E}-09$ & $1,70074 \mathrm{E}-10$ \\
\hline SIUP & $7,74769 \mathrm{E}-10$ & 1,19582E-09 & 3,10899E-09 & $1,91508 \mathrm{E}-09$ & $1,56716 \mathrm{E}-09$ & $1,628 \mathrm{E}-09$ & 4,80759E-09 & $1,2755 \mathrm{E}-09$ & 2,32235E-09 & 2,40151E-09 & $6,3334 \mathrm{E}-09$ \\
\hline Construção & $2,22334 \mathrm{E}-10$ & $3,15837 \mathrm{E}-10$ & $5,71517 \mathrm{E}-10$ & $7,33352 \mathrm{E}-10$ & $6,5879 \mathrm{E}-10$ & $5,8194 \mathrm{E}-10$ & $1,04772 \mathrm{E}-09$ & $8,2934 \mathrm{E}-10$ & $1,17382 \mathrm{E}-09$ & $1,90637 \mathrm{E}-09$ & 2,59994E-09 \\
\hline Comércio & $3,67338 \mathrm{E}-08$ & $5,42062 \mathrm{E}-08$ & $3,23071 \mathrm{E}-08$ & $5,81235 \mathrm{E}-08$ & $6,10528 \mathrm{E}-08$ & $2,49336 \mathrm{E}-08$ & $3,18979 \mathrm{E}-08$ & $3,30329 \mathrm{E}-08$ & $4,53298 \mathrm{E}-08$ & $3,53283 \mathrm{E}-08$ & $5,66891 \mathrm{E}-08$ \\
\hline Transportes & $1,53905 \mathrm{E}-08$ & $1,40036 \mathrm{E}-08$ & 4,11387E-08 & 2,62494E-08 & $1,22004 \mathrm{E}-08$ & $1,32094 \mathrm{E}-08$ & $2,23774 \mathrm{E}-08$ & $1,28649 \mathrm{E}-08$ & 2,43335E-08 & $1,5912 \mathrm{E}-08$ & $4,93195 \mathrm{E}-08$ \\
\hline Informação & $1,19736 \mathrm{E}-10$ & $1,8562 \mathrm{E}-10$ & $5,46245 \mathrm{E}-10$ & $2,33269 \mathrm{E}-10$ & $1,33665 \mathrm{E}-10$ & $9,88841 \mathrm{E}-11$ & $2,28291 \mathrm{E}-10$ & $5,4927 \mathrm{E}-10$ & $7,07255 \mathrm{E}-10$ & $3,15405 \mathrm{E}-10$ & $4,28023 \mathrm{E}-10$ \\
\hline
\end{tabular}




\begin{tabular}{|c|c|c|c|c|c|c|c|c|c|c|c|}
\hline Financeiro & $1,01195 \mathrm{E}-10$ & $1,1221 \mathrm{E}-10$ & $2,26753 \mathrm{E}-10$ & $1,93103 \mathrm{E}-10$ & $1,54406 \mathrm{E}-10$ & $1,43138 \mathrm{E}-10$ & $3,12199 \mathrm{E}-10$ & $1,77076 \mathrm{E}-10$ & $3,0743 \mathrm{E}-10$ & $2,23302 \mathrm{E}-10$ & $3,5908 \mathrm{E}-10$ \\
\hline Imobiliário & $4,73344 \mathrm{E}-10$ & $6,06194 \mathrm{E}-10$ & $1,43608 \mathrm{E}-09$ & $1,21143 \mathrm{E}-09$ & $1,34969 \mathrm{E}-09$ & $5,40179 \mathrm{E}-10$ & 1,19343E-09 & $1,88044 \mathrm{E}-09$ & $1,60985 \mathrm{E}-09$ & $1,00373 \mathrm{E}-09$ & 1,74904E-09 \\
\hline Alojamento & $2,11796 \mathrm{E}-10$ & $2,98736 \mathrm{E}-10$ & $1,93089 \mathrm{E}-09$ & $5,25549 \mathrm{E}-10$ & $3,06433 \mathrm{E}-10$ & $6,14686 \mathrm{E}-10$ & $6,26436 \mathrm{E}-10$ & $8,30422 \mathrm{E}-10$ & 6,9599E-10 & $6,18234 \mathrm{E}-10$ & $3,39821 \mathrm{E}-09$ \\
\hline Serviços às Empresas & $7,62375 \mathrm{E}-09$ & $1,09602 \mathrm{E}-08$ & $2,11327 \mathrm{E}-08$ & $2,57908 \mathrm{E}-08$ & $1,69214 \mathrm{E}-08$ & $8,99782 \mathrm{E}-09$ & $2,18215 \mathrm{E}-08$ & $5,94641 \mathrm{E}-08$ & $6,72461 \mathrm{E}-08$ & $1,8197 \mathrm{E}-08$ & 4,22394E-08 \\
\hline Educação e Saúde mercantis & $1,55124 \mathrm{E}-10$ & $2,14476 \mathrm{E}-10$ & $3,15628 \mathrm{E}-10$ & $3,23287 \mathrm{E}-10$ & $3,94703 \mathrm{E}-10$ & $1,44938 \mathrm{E}-10$ & $2,83753 \mathrm{E}-10$ & $3,45966 \mathrm{E}-10$ & $3,47589 \mathrm{E}-10$ & $2,4877 \mathrm{E}-10$ & $3,58405 \mathrm{E}-10$ \\
\hline Outros Serviços & $1,63714 \mathrm{E}-09$ & 2,37259E-09 & 2,47179E-09 & $3,12992 \mathrm{E}-09$ & $3,36464 \mathrm{E}-09$ & $1,24045 \mathrm{E}-09$ & $2,05683 \mathrm{E}-09$ & $2,41784 \mathrm{E}-09$ & $3,33418 \mathrm{E}-09$ & $2,43455 \mathrm{E}-09$ & $3,88348 \mathrm{E}-09$ \\
\hline APU & $6,62213 \mathrm{E}-11$ & $7,901 \mathrm{E}-11$ & $1,5862 \mathrm{E}-10$ & $1,46481 \mathrm{E}-10$ & $9,23178 \mathrm{E}-11$ & $6,22956 \mathrm{E}-11$ & $1,51243 \mathrm{E}-10$ & $2,79913 \mathrm{E}-10$ & $2,53201 \mathrm{E}-10$ & $1,07412 \mathrm{E}-10$ & $2,4188 \mathrm{E}-10$ \\
\hline
\end{tabular}

Tabela B4 - Matriz Geração de Emprego para o Grau de Instrução G(3), Distrito Federal - 2008.

(2)

\begin{tabular}{|c|c|c|c|c|c|c|c|c|c|c|}
\hline Setores & Aço & Metal & Eletrodomésticos & Informática & Máquinas & Eletrônicos & $\begin{array}{l}\text { Instrumento } \\
\text { hospitalar }\end{array}$ & Veículos & $\begin{array}{l}\text { Indústria } \\
\text { Diversa }\end{array}$ & SIUP \\
\hline Agricultura & $4,76857 \mathrm{E}-11$ & $2,62919 \mathrm{E}-11$ & $9,44029 \mathrm{E}-11$ & $8,99313 \mathrm{E}-11$ & $5,36336 \mathrm{E}-11$ & $1,22783 \mathrm{E}-10$ & $3,26235 \mathrm{E}-11$ & $1,87312 \mathrm{E}-10$ & 7,32944E-11 & $1,32852 \mathrm{E}-11$ \\
\hline Pecuária & $2,54848 \mathrm{E}-11$ & $1,2589 \mathrm{E}-11$ & $3,11166 \mathrm{E}-11$ & $3,36578 \mathrm{E}-11$ & $2,66926 \mathrm{E}-11$ & $3,49246 \mathrm{E}-11$ & $1,43931 \mathrm{E}-11$ & $5,57112 \mathrm{E}-11$ & $2,98425 \mathrm{E}-10$ & $8,18528 \mathrm{E}-12$ \\
\hline Extrativa & 2,10991E-08 & $1,24654 \mathrm{E}-09$ & 3,95601E-09 & $3,01525 \mathrm{E}-10$ & $1,19962 \mathrm{E}-09$ & $6,74168 \mathrm{E}-10$ & $1,12331 \mathrm{E}-10$ & $2,25651 \mathrm{E}-09$ & $6,91712 \mathrm{E}-10$ & $1,0589 \mathrm{E}-11$ \\
\hline Alimentos & $1,80357 \mathrm{E}-10$ & $8,47948 \mathrm{E}-11$ & $1,75537 \mathrm{E}-10$ & $1,96378 \mathrm{E}-10$ & $1,76856 \mathrm{E}-10$ & $1,92103 \mathrm{E}-10$ & $9,31308 \mathrm{E}-11$ & $2,37508 \mathrm{E}-10$ & $1,68961 \mathrm{E}-10$ & $5,66149 \mathrm{E}-11$ \\
\hline Vestuário & $8,0316 \mathrm{E}-11$ & $1,22907 \mathrm{E}-10$ & $6,74581 \mathrm{E}-10$ & 9,38193E-11 & $7,87969 \mathrm{E}-11$ & $1,06821 \mathrm{E}-10$ & $1,18909 \mathrm{E}-10$ & $5,78646 \mathrm{E}-10$ & $8,12221 \mathrm{E}-11$ & $8,13183 \mathrm{E}-11$ \\
\hline Madeira & $3,6477 \mathrm{E}-10$ & $5,38775 \mathrm{E}-10$ & $1,07498 \mathrm{E}-08$ & $9,88956 \mathrm{E}-09$ & $4,75378 \mathrm{E}-10$ & $4,39842 \mathrm{E}-08$ & $1,30101 \mathrm{E}-10$ & 6,73821E-09 & $1,45255 \mathrm{E}-08$ & $1,76064 \mathrm{E}-11$ \\
\hline Celulose & $3,16526 \mathrm{E}-10$ & $7,64832 \mathrm{E}-11$ & $5,83681 \mathrm{E}-09$ & $3,156 \mathrm{E}-09$ & $5,69544 \mathrm{E}-10$ & 6,23094E-09 & $1,33275 \mathrm{E}-10$ & 3,19206E-09 & $3,07099 \mathrm{E}-10$ & $2,6801 \mathrm{E}-11$ \\
\hline Revistas & 7,00754E-10 & $6,89584 \mathrm{E}-10$ & $4,22332 \mathrm{E}-10$ & $7,97089 \mathrm{E}-10$ & $3,59839 \mathrm{E}-10$ & 6,69237E-10 & 3,30701E-09 & 7,86771E-10 & $2,35089 \mathrm{E}-10$ & $9,85753 \mathrm{E}-10$ \\
\hline Químicos & 2,71877E-09 & $4,73969 \mathrm{E}-10$ & 2,50966E-09 & $1,80061 \mathrm{E}-10$ & $7,89837 \mathrm{E}-10$ & $3,17492 \mathrm{E}-10$ & $5,98996 \mathrm{E}-10$ & $1,6522 \mathrm{E}-09$ & $2,93946 \mathrm{E}-10$ & $1,98797 \mathrm{E}-10$ \\
\hline Borracha & $8,29208 \mathrm{E}-09$ & $4,75325 \mathrm{E}-09$ & 2,26739E-08 & $2,02021 \mathrm{E}-08$ & $1,04218 \mathrm{E}-08$ & $2,34469 \mathrm{E}-08$ & 6,53313E-09 & $5,43182 \mathrm{E}-08$ & 8,59673E-09 & $2,05673 \mathrm{E}-10$ \\
\hline Cimento & 1,48076E-09 & $4,41931 \mathrm{E}-10$ & $5,74371 \mathrm{E}-10$ & $3,02468 \mathrm{E}-10$ & $1,42293 \mathrm{E}-09$ & $1,10886 \mathrm{E}-09$ & $5,2124 \mathrm{E}-10$ & $1,28096 \mathrm{E}-09$ & 2,97829E-09 & $1,43491 \mathrm{E}-11$ \\
\hline Aço & $5,96562 \mathrm{E}-07$ & 4,86867E-09 & $8,91572 \mathrm{E}-08$ & $6,45641 \mathrm{E}-09$ & $1,75763 \mathrm{E}-08$ & $1,55303 \mathrm{E}-08$ & 1,77606E-09 & $4,90818 \mathrm{E}-08$ & 1,81078E-09 & $5,64459 \mathrm{E}-11$ \\
\hline Metal & $2,04599 \mathrm{E}-08$ & $5,25238 \mathrm{E}-07$ & 3,29367E-08 & $1,23546 \mathrm{E}-08$ & 2,28891E-08 & $2,03825 \mathrm{E}-08$ & $1,40298 \mathrm{E}-08$ & $1,46951 \mathrm{E}-08$ & $1,12963 \mathrm{E}-08$ & $5,74353 \mathrm{E}-11$ \\
\hline Eletrodomésticos & 3,85349E-09 & $4,42823 \mathrm{E}-10$ & $1,48089 \mathrm{E}-06$ & 4,10529E-09 & $1,89471 \mathrm{E}-09$ & 2,77017E-09 & $8,25196 \mathrm{E}-10$ & $1,73551 \mathrm{E}-08$ & $2,87271 \mathrm{E}-10$ & 4,64301E-11 \\
\hline Informática & $2,31551 \mathrm{E}-12$ & $1,24809 \mathrm{E}-12$ & $1,19672 \mathrm{E}-11$ & $5,06915 \mathrm{E}-07$ & $7,4232 \mathrm{E}-12$ & $2,53909 \mathrm{E}-10$ & $1,61075 \mathrm{E}-12$ & $1,5642 \mathrm{E}-11$ & $1,26923 \mathrm{E}-12$ & $2,51963 \mathrm{E}-13$ \\
\hline Máquinas & $1,23569 \mathrm{E}-09$ & 3,37857E-10 & $2,55147 \mathrm{E}-08$ & $6,10603 \mathrm{E}-08$ & $9,98631 \mathrm{E}-07$ & $1,1221 \mathrm{E}-07$ & 7,44277E-09 & $1,66837 \mathrm{E}-08$ & 2,49295E-09 & $1,89499 \mathrm{E}-09$ \\
\hline
\end{tabular}




\begin{tabular}{|c|c|c|c|c|c|c|c|c|c|c|}
\hline Eletrônicos & $1,24323 \mathrm{E}-11$ & $7,45541 \mathrm{E}-12$ & $3,138 \mathrm{E}-10$ & $3,67101 \mathrm{E}-08$ & $3,06059 \mathrm{E}-10$ & $1,8093 \mathrm{E}-07$ & 3,63072E-11 & $2,91832 \mathrm{E}-10$ & $1,52021 \mathrm{E}-11$ & $5,90111 \mathrm{E}-12$ \\
\hline Instrumento hospitalar & $4,38208 \mathrm{E}-12$ & $2,40904 \mathrm{E}-12$ & $6,64522 \mathrm{E}-10$ & $8,688 \mathrm{E}-11$ & $2,58047 \mathrm{E}-10$ & $1,2122 \mathrm{E}-10$ & $2,08473 \mathrm{E}-07$ & $1,10923 \mathrm{E}-10$ & $1,14016 \mathrm{E}-11$ & $2,51872 \mathrm{E}-12$ \\
\hline Veículos & $2,63968 \mathrm{E}-10$ & $1,66765 \mathrm{E}-10$ & $1,19064 \mathrm{E}-09$ & $8,41118 \mathrm{E}-10$ & $9,60903 \mathrm{E}-10$ & $1,52632 \mathrm{E}-09$ & $2,02284 \mathrm{E}-10$ & $4,2075 \mathrm{E}-07$ & $1,2037 \mathrm{E}-10$ & $2,56718 \mathrm{E}-11$ \\
\hline Indústria Diversa & $8,50009 \mathrm{E}-09$ & $6,26288 \mathrm{E}-10$ & $1,97558 \mathrm{E}-09$ & $3,73896 \mathrm{E}-10$ & 1,14711E-09 & $6,08427 \mathrm{E}-10$ & $1,62109 \mathrm{E}-10$ & $1,02058 \mathrm{E}-09$ & $2,12989 \mathrm{E}-06$ & $5,31017 \mathrm{E}-11$ \\
\hline SIUP & $5,62728 \mathrm{E}-09$ & 2,74414E-09 & 2,73154E-09 & $1,82904 \mathrm{E}-09$ & 3,20687E-09 & $2,23489 \mathrm{E}-09$ & 2,33723E-09 & 2,39465E-09 & $1,70512 \mathrm{E}-09$ & $2,54775 \mathrm{E}-07$ \\
\hline Construção & $8,10003 \mathrm{E}-10$ & $5,44306 \mathrm{E}-10$ & 1,10099E-09 & $1,62079 \mathrm{E}-09$ & 2,23864E-09 & 3,38272E-09 & $5,13213 \mathrm{E}-10$ & $3,58753 \mathrm{E}-09$ & $6,5777 \mathrm{E}-10$ & $5,08452 \mathrm{E}-10$ \\
\hline Comércio & $3,02023 \mathrm{E}-08$ & $2,64523 \mathrm{E}-08$ & $4,44387 \mathrm{E}-08$ & $1,00036 \mathrm{E}-07$ & 3,96182E-08 & $7,472 \mathrm{E}-08$ & $3,99065 \mathrm{E}-08$ & $5,69271 \mathrm{E}-08$ & $4,62156 \mathrm{E}-08$ & $1,2614 \mathrm{E}-08$ \\
\hline Transportes & $3,30843 \mathrm{E}-08$ & $1,8985 \mathrm{E}-08$ & $2,61247 \mathrm{E}-08$ & 2,93004E-08 & 2,49944E-08 & $3,63741 \mathrm{E}-08$ & $1,98473 \mathrm{E}-08$ & 2,28994E-08 & $1,23005 \mathrm{E}-08$ & $1,00512 \mathrm{E}-08$ \\
\hline Informação & $5,58355 \mathrm{E}-10$ & $2,48329 \mathrm{E}-10$ & $6,24588 \mathrm{E}-10$ & $8,97905 \mathrm{E}-10$ & $7,66301 \mathrm{E}-10$ & $1,32109 \mathrm{E}-09$ & $4,04662 \mathrm{E}-10$ & $4,9948 \mathrm{E}-10$ & $1,35683 \mathrm{E}-10$ & $4,72485 \mathrm{E}-10$ \\
\hline Financeiro & $3,91181 \mathrm{E}-10$ & $2,30457 \mathrm{E}-10$ & $4,98369 \mathrm{E}-10$ & $3,48065 \mathrm{E}-10$ & $3,56056 \mathrm{E}-10$ & $6,13326 \mathrm{E}-10$ & $2,47526 \mathrm{E}-10$ & $3,41861 \mathrm{E}-10$ & $1,46494 \mathrm{E}-10$ & $1,31733 \mathrm{E}-10$ \\
\hline Imobiliário & $1,13412 \mathrm{E}-09$ & $9,62373 \mathrm{E}-10$ & 1,49959E-09 & $1,60801 \mathrm{E}-09$ & $1,18966 \mathrm{E}-09$ & $1,5907 \mathrm{E}-09$ & $1,39938 \mathrm{E}-09$ & $1,04683 \mathrm{E}-09$ & $9,12698 \mathrm{E}-10$ & $8,21211 \mathrm{E}-10$ \\
\hline Alojamento & $8,99811 \mathrm{E}-10$ & $3,42963 \mathrm{E}-10$ & $4,95446 \mathrm{E}-10$ & $7,16456 \mathrm{E}-10$ & $1,06312 \mathrm{E}-09$ & $7,15844 \mathrm{E}-10$ & $3,08063 \mathrm{E}-10$ & $9,50503 \mathrm{E}-10$ & $6,40193 \mathrm{E}-10$ & $2,63124 \mathrm{E}-10$ \\
\hline Serviços às Empresas & $1,76813 \mathrm{E}-08$ & $1,72301 \mathrm{E}-08$ & $2,06503 \mathrm{E}-08$ & $9,23738 \mathrm{E}-08$ & $2,94459 \mathrm{E}-08$ & $6,51072 \mathrm{E}-08$ & $2,36467 \mathrm{E}-08$ & 3,95474E-08 & $1,36049 \mathrm{E}-08$ & $5,02238 \mathrm{E}-08$ \\
\hline Educação e Saúde mercantis & $2,35558 \mathrm{E}-10$ & $2,38012 \mathrm{E}-10$ & $3,49506 \mathrm{E}-10$ & $4,86992 \mathrm{E}-10$ & $2,99421 \mathrm{E}-10$ & $4,47313 \mathrm{E}-10$ & $2,97786 \mathrm{E}-10$ & 3,01901E-10 & $2,73277 \mathrm{E}-10$ & $1,87407 \mathrm{E}-10$ \\
\hline Outros Serviços & 2,29607E-09 & 2,08923E-09 & $3,06808 \mathrm{E}-09$ & $6,02698 \mathrm{E}-09$ & 4,38003E-09 & $5,55773 \mathrm{E}-09$ & $2,4928 \mathrm{E}-09$ & $3,2455 \mathrm{E}-09$ & $2,55916 \mathrm{E}-09$ & $2,44143 \mathrm{E}-09$ \\
\hline APU & $1,54009 \mathrm{E}-10$ & $1,05888 \mathrm{E}-10$ & $1,24582 \mathrm{E}-10$ & $3,20144 \mathrm{E}-10$ & $1,38603 \mathrm{E}-10$ & $2,54336 \mathrm{E}-10$ & $1,2332 \mathrm{E}-10$ & $1,71912 \mathrm{E}-10$ & 7,95472E-11 & $2,85762 \mathrm{E}-10$ \\
\hline
\end{tabular}

Tabela B4 - Matriz Geração de Emprego para o Grau de Instrução G(3), Distrito Federal - 2008.

(3)

\begin{tabular}{|c|c|c|c|c|c|c|c|c|c|c|c|}
\hline Setores & Construção & Comércio & Transportes & Informação & Financeiro & Imobiliário & Alojamento & $\begin{array}{c}\text { Serviços às } \\
\text { Empresas }\end{array}$ & $\begin{array}{l}\text { Educação e } \\
\text { Saúde } \\
\text { mercantis }\end{array}$ & $\begin{array}{c}\text { Outros } \\
\text { Serviços }\end{array}$ & APU \\
\hline Agricultura & 3,81193E-11 & $1,18267 \mathrm{E}-10$ & $8,94618 \mathrm{E}-11$ & $5,42666 \mathrm{E}-11$ & $3,51388 \mathrm{E}-11$ & $7,4474 \mathrm{E}-12$ & $1,18979 \mathrm{E}-08$ & $5,38802 \mathrm{E}-11$ & $2,8365 \mathrm{E}-10$ & $1,22534 \mathrm{E}-09$ & $1,51437 \mathrm{E}-10$ \\
\hline Pecuária & $2,46075 \mathrm{E}-11$ & $7,23181 \mathrm{E}-11$ & $6,43884 \mathrm{E}-11$ & $3,187 \mathrm{E}-11$ & $2,43983 \mathrm{E}-11$ & $4,12578 \mathrm{E}-12$ & $9,52407 \mathrm{E}-09$ & $3,18694 \mathrm{E}-11$ & $2,11973 \mathrm{E}-10$ & $1,03487 \mathrm{E}-09$ & $9,9274 \mathrm{E}-11$ \\
\hline Extrativa & $5,50691 \mathrm{E}-11$ & $2,87068 \mathrm{E}-11$ & $1,76913 \mathrm{E}-11$ & $3,32438 \mathrm{E}-11$ & $9,92124 \mathrm{E}-12$ & $5,49367 \mathrm{E}-12$ & $2,61021 \mathrm{E}-11$ & $2,6527 \mathrm{E}-11$ & $2,61007 \mathrm{E}-11$ & $2,46304 \mathrm{E}-11$ & $2,7046 \mathrm{E}-11$ \\
\hline Alimentos & $2,21875 \mathrm{E}-10$ & $6,89423 \mathrm{E}-10$ & $6,0895 \mathrm{E}-10$ & $2,41311 \mathrm{E}-10$ & $1,98402 \mathrm{E}-10$ & $3,34333 \mathrm{E}-11$ & $8,68516 \mathrm{E}-08$ & $2,31456 \mathrm{E}-10$ & $1,40982 \mathrm{E}-09$ & $3,23028 \mathrm{E}-09$ & $6,43948 \mathrm{E}-10$ \\
\hline Vestuário & $5,04789 \mathrm{E}-11$ & $1,13126 \mathrm{E}-10$ & $2,37192 \mathrm{E}-10$ & $1,10452 \mathrm{E}-10$ & $9,03873 \mathrm{E}-11$ & $1,19601 \mathrm{E}-11$ & $1,31238 \mathrm{E}-10$ & $3,2344 \mathrm{E}-10$ & $2,08512 \mathrm{E}-10$ & $4,6633 \mathrm{E}-10$ & $9,08437 \mathrm{E}-11$ \\
\hline Madeira & $1,65103 \mathrm{E}-10$ & $5,85811 \mathrm{E}-11$ & $3,92941 \mathrm{E}-11$ & $7,77501 \mathrm{E}-11$ & $4,39583 \mathrm{E}-11$ & $5,74189 \mathrm{E}-11$ & 4,79396E-11 & $6,46631 \mathrm{E}-11$ & $8,58603 \mathrm{E}-11$ & $9,06184 \mathrm{E}-11$ & $1,29612 \mathrm{E}-10$ \\
\hline
\end{tabular}




\begin{tabular}{|c|c|c|c|c|c|c|c|c|c|c|c|}
\hline Celulose & $1,94091 \mathrm{E}-11$ & $7,78431 \mathrm{E}-11$ & 4,9207E-11 & $9,90688 \mathrm{E}-11$ & $3,35496 \mathrm{E}-11$ & $1,30574 \mathrm{E}-11$ & $4,875 \mathrm{E}-11$ & $1,2957 \mathrm{E}-10$ & $6,93523 \mathrm{E}-11$ & $6,54468 \mathrm{E}-11$ & $6,52022 \mathrm{E}-11$ \\
\hline Revistas & $2,62088 \mathrm{E}-10$ & $9,43517 \mathrm{E}-10$ & 7,95172E-10 & 2,20356E-09 & 1,14099E-09 & $2,47991 \mathrm{E}-10$ & $2,61104 \mathrm{E}-10$ & 7,00407E-09 & $1,14337 \mathrm{E}-09$ & $1,21048 \mathrm{E}-09$ & $6,65297 \mathrm{E}-10$ \\
\hline Químicos & $2,69076 \mathrm{E}-11$ & $1,4243 \mathrm{E}-11$ & $1,00602 \mathrm{E}-11$ & $2,6208 \mathrm{E}-11$ & $5,9868 \mathrm{E}-12$ & $3,90125 \mathrm{E}-12$ & $1,95412 \mathrm{E}-10$ & $1,62896 \mathrm{E}-11$ & $1,87117 \mathrm{E}-10$ & $3,66976 \mathrm{E}-11$ & $2,82915 \mathrm{E}-11$ \\
\hline Borracha & $8,5277 \mathrm{E}-10$ & $3,39992 \mathrm{E}-10$ & $2,86045 \mathrm{E}-10$ & $6,98527 \mathrm{E}-10$ & $1,11739 \mathrm{E}-10$ & $6,37647 \mathrm{E}-11$ & $4,63944 \mathrm{E}-10$ & $1,0123 \mathrm{E}-09$ & $8,84154 \mathrm{E}-10$ & $2,8211 \mathrm{E}-10$ & $1,34268 \mathrm{E}-10$ \\
\hline Cimento & 6,03836E-09 & $2,16145 \mathrm{E}-11$ & $9,28511 \mathrm{E}-12$ & $2,67512 \mathrm{E}-11$ & $2,50128 \mathrm{E}-11$ & $5,34022 \mathrm{E}-11$ & $4,21357 \mathrm{E}-11$ & $2,00978 \mathrm{E}-11$ & $1,99323 \mathrm{E}-10$ & $1,05086 \mathrm{E}-10$ & $9,97767 \mathrm{E}-11$ \\
\hline Aço & $1,65936 \mathrm{E}-10$ & $2,43289 \mathrm{E}-11$ & $1,90587 \mathrm{E}-11$ & $3,3359 \mathrm{E}-11$ & $9,56832 \mathrm{E}-12$ & $8,95494 \mathrm{E}-12$ & $4,50426 \mathrm{E}-11$ & $2,33422 \mathrm{E}-11$ & $2,81916 \mathrm{E}-11$ & $3,15315 \mathrm{E}-11$ & $2,25741 \mathrm{E}-11$ \\
\hline Metal & $1,41183 \mathrm{E}-09$ & $1,36301 \mathrm{E}-10$ & $3,19858 \mathrm{E}-11$ & $7,43709 \mathrm{E}-11$ & $2,18103 \mathrm{E}-11$ & $5,333 \mathrm{E}-11$ & $6,03082 \mathrm{E}-10$ & $3,79503 \mathrm{E}-11$ & $1,42995 \mathrm{E}-10$ & $9,09178 \mathrm{E}-11$ & $9,48863 \mathrm{E}-11$ \\
\hline Eletrodomésticos & $5,76099 \mathrm{E}-11$ & $5,51555 \mathrm{E}-11$ & $3,75333 \mathrm{E}-11$ & $6,95284 \mathrm{E}-11$ & $1,933 \mathrm{E}-11$ & $1,45188 \mathrm{E}-11$ & $4,43103 \mathrm{E}-11$ & $5,43914 \mathrm{E}-11$ & $5,15538 \mathrm{E}-11$ & $5,21406 \mathrm{E}-11$ & $5,27998 \mathrm{E}-11$ \\
\hline Informática & $1,01164 \mathrm{E}-12$ & $8,4083 \mathrm{E}-13$ & $4,3636 \mathrm{E}-13$ & $1,61494 \mathrm{E}-12$ & $5,43974 \mathrm{E}-13$ & $7,46761 \mathrm{E}-13$ & $4,46849 \mathrm{E}-13$ & $9,63469 \mathrm{E}-13$ & $1,18515 \mathrm{E}-12$ & $9,57727 \mathrm{E}-13$ & $1,66466 \mathrm{E}-12$ \\
\hline Máquinas & $5,20194 \mathrm{E}-10$ & $1,09712 \mathrm{E}-10$ & $3,22892 \mathrm{E}-10$ & $4,70608 \mathrm{E}-10$ & $5,87205 \mathrm{E}-11$ & $1,27597 \mathrm{E}-10$ & $8,70782 \mathrm{E}-11$ & $1,63829 \mathrm{E}-10$ & $1,45814 \mathrm{E}-10$ & $5,19128 \mathrm{E}-10$ & $9,24347 \mathrm{E}-11$ \\
\hline Eletrônicos & $2,16433 \mathrm{E}-12$ & $1,43359 \mathrm{E}-12$ & $1,78511 \mathrm{E}-12$ & $3,03617 \mathrm{E}-12$ & $6,71052 \mathrm{E}-13$ & $8,32697 \mathrm{E}-13$ & $1,04301 \mathrm{E}-12$ & $2,03834 \mathrm{E}-12$ & $1,39793 \mathrm{E}-12$ & $2,54935 \mathrm{E}-12$ & $1,32732 \mathrm{E}-12$ \\
\hline Instrumento hospitalar & $1,41151 \mathrm{E}-11$ & $8,53021 \mathrm{E}-12$ & $2,70529 \mathrm{E}-12$ & $3,51733 \mathrm{E}-12$ & $1,98212 \mathrm{E}-12$ & $1,60797 \mathrm{E}-11$ & $1,72089 \mathrm{E}-12$ & $2,28892 \mathrm{E}-11$ & $2,37598 \mathrm{E}-11$ & $1,81018 \mathrm{E}-11$ & $4,92315 \mathrm{E}-12$ \\
\hline Veículos & $2,05261 \mathrm{E}-11$ & $1,13757 \mathrm{E}-11$ & $9,96326 \mathrm{E}-12$ & $1,72429 \mathrm{E}-11$ & $4,50895 \mathrm{E}-12$ & $4,33191 \mathrm{E}-12$ & $1,06517 \mathrm{E}-11$ & $1,15942 \mathrm{E}-11$ & $1,12764 \mathrm{E}-11$ & $1,50734 \mathrm{E}-11$ & $1,13096 \mathrm{E}-11$ \\
\hline Indústria Diversa & $7,00585 \mathrm{E}-10$ & $9,54752 \mathrm{E}-11$ & $6,00422 \mathrm{E}-10$ & $1,17817 \mathrm{E}-10$ & $1,06109 \mathrm{E}-09$ & $2,65315 \mathrm{E}-10$ & $1,172 \mathrm{E}-10$ & $3,88115 \mathrm{E}-10$ & $3,84549 \mathrm{E}-10$ & $1,94024 \mathrm{E}-09$ & $4,23884 \mathrm{E}-10$ \\
\hline SIUP & $5,56739 \mathrm{E}-10$ & $1,9076 \mathrm{E}-09$ & $1,58186 \mathrm{E}-09$ & $1,48654 \mathrm{E}-09$ & $8,97059 \mathrm{E}-10$ & $1,88953 \mathrm{E}-10$ & $1,92836 \mathrm{E}-09$ & 1,6741E-09 & 2,4649E-09 & 5,54591E-09 & $2,12306 \mathrm{E}-09$ \\
\hline Construção & $1,21276 \mathrm{E}-06$ & $1,38786 \mathrm{E}-09$ & $1,07885 \mathrm{E}-09$ & 4,41954E-09 & $4,37258 \mathrm{E}-09$ & $1,04537 \mathrm{E}-08$ & $7,42778 \mathrm{E}-10$ & $3,11439 \mathrm{E}-09$ & $9,33526 \mathrm{E}-09$ & $8,05879 \mathrm{E}-09$ & $1,82298 \mathrm{E}-08$ \\
\hline Comércio & 4,13934E-08 & $7,77489 \mathrm{E}-07$ & $3,44732 \mathrm{E}-08$ & $1,71294 \mathrm{E}-08$ & $1,02407 \mathrm{E}-08$ & 4,51953E-09 & 7,93563E-08 & $2,96954 \mathrm{E}-08$ & $2,64245 \mathrm{E}-08$ & $2,85715 \mathrm{E}-08$ & $1,51426 \mathrm{E}-08$ \\
\hline Transportes & $9,41172 \mathrm{E}-09$ & $2,47629 \mathrm{E}-08$ & $7,56339 \mathrm{E}-07$ & $1,67981 \mathrm{E}-08$ & 7,06354E-09 & $1,25638 \mathrm{E}-09$ & $1,13348 \mathrm{E}-08$ & $1,33449 \mathrm{E}-08$ & $1,19915 \mathrm{E}-08$ & $1,77249 \mathrm{E}-08$ & 6,43792E-09 \\
\hline Informação & $1,54645 \mathrm{E}-10$ & $4,87411 \mathrm{E}-10$ & $5,09585 \mathrm{E}-10$ & $3,64859 \mathrm{E}-08$ & $1,48673 \mathrm{E}-09$ & $1,00518 \mathrm{E}-10$ & $2,43484 \mathrm{E}-10$ & $3,95191 \mathrm{E}-09$ & $1,35902 \mathrm{E}-09$ & $8,89954 \mathrm{E}-10$ & $1,64771 \mathrm{E}-09$ \\
\hline Financeiro & $1,06072 \mathrm{E}-10$ & $2,10533 \mathrm{E}-10$ & $2,91118 \mathrm{E}-10$ & $2,96354 \mathrm{E}-10$ & $8,4061 \mathrm{E}-09$ & $4,28276 \mathrm{E}-11$ & $1,09498 \mathrm{E}-10$ & $2,80482 \mathrm{E}-10$ & $1,23835 \mathrm{E}-10$ & $6,89252 \mathrm{E}-11$ & $6,55926 \mathrm{E}-10$ \\
\hline Imobiliário & $6,76105 \mathrm{E}-10$ & $3,40364 \mathrm{E}-09$ & $6,06567 \mathrm{E}-09$ & $5,49519 \mathrm{E}-09$ & $1,74303 \mathrm{E}-09$ & $1,61607 \mathrm{E}-07$ & 2,09442E-09 & $3,96678 \mathrm{E}-09$ & $4,12639 \mathrm{E}-09$ & $2,95694 \mathrm{E}-09$ & $3,12098 \mathrm{E}-09$ \\
\hline Alojamento & $8,98948 \mathrm{E}-10$ & $1,24924 \mathrm{E}-09$ & $2,43234 \mathrm{E}-09$ & $1,64031 \mathrm{E}-09$ & $1,57756 \mathrm{E}-09$ & $1,74068 \mathrm{E}-10$ & $9,64952 \mathrm{E}-07$ & $1,41516 \mathrm{E}-09$ & $7,50211 \mathrm{E}-09$ & $8,56178 \mathrm{E}-09$ & 4,63723E-09 \\
\hline Serviços às Empresas & $2,03903 \mathrm{E}-08$ & $5,68735 \mathrm{E}-08$ & $6,53537 \mathrm{E}-08$ & $9,31455 \mathrm{E}-08$ & $7,04485 \mathrm{E}-08$ & $1,10095 \mathrm{E}-08$ & $1,80126 \mathrm{E}-08$ & $1,12409 \mathrm{E}-06$ & $9,37654 \mathrm{E}-08$ & $5,96672 \mathrm{E}-08$ & $6,62582 \mathrm{E}-08$ \\
\hline Educação e Saúde mercantis & $2,0945 \mathrm{E}-10$ & $7,46335 \mathrm{E}-10$ & $4,94609 \mathrm{E}-10$ & $8,33367 \mathrm{E}-10$ & $8,59399 \mathrm{E}-10$ & $1,07631 \mathrm{E}-10$ & $5,95032 \mathrm{E}-10$ & $7,0945 \mathrm{E}-10$ & $3,75872 \mathrm{E}-07$ & $5,68666 \mathrm{E}-10$ & $1,17314 \mathrm{E}-09$ \\
\hline Outros Serviços & 2,28385E-09 & $6,03824 \mathrm{E}-09$ & $3,77522 \mathrm{E}-09$ & $6,72902 \mathrm{E}-09$ & $3,45704 \mathrm{E}-09$ & $6,74192 \mathrm{E}-10$ & $6,58459 \mathrm{E}-09$ & $8,03959 \mathrm{E}-09$ & $5,94941 \mathrm{E}-09$ & $8,46779 \mathrm{E}-07$ & $4,2625 \mathrm{E}-09$ \\
\hline APU & $8,1682 \mathrm{E}-11$ & 2,19631E-10 & $2,30408 \mathrm{E}-10$ & 2,96378E-10 & $2,12165 \mathrm{E}-10$ & 3,51227E-11 & $1,03974 \mathrm{E}-10$ & $2,63768 \mathrm{E}-10$ & $2,89499 \mathrm{E}-10$ & $2,23726 \mathrm{E}-10$ & $7,18775 \mathrm{E}-08$ \\
\hline
\end{tabular}


Tabela B5 - Matriz Geração de Emprego para o Grau de Instrução G(4), Distrito Federal - 2008.

(1)

\begin{tabular}{|c|c|c|c|c|c|c|c|c|c|c|c|}
\hline Setores & Agricultura & Pecuária & Extrativa & Alimentos & Vestuário & Madeira & Celulose & Revistas & Químicos & Borracha & Cimento \\
\hline Agricultura & $1,02524 \mathrm{E}-06$ & $6,72642 \mathrm{E}-08$ & $1,11877 \mathrm{E}-10$ & $8,26003 \mathrm{E}-08$ & $1,0333 \mathrm{E}-09$ & $1,62429 \mathrm{E}-09$ & 4,69087E-09 & $4,57576 \mathrm{E}-11$ & $2,05994 \mathrm{E}-10$ & 3,49104E-09 & $8,00734 \mathrm{E}-11$ \\
\hline Pecuária & $5,08529 \mathrm{E}-09$ & $1,30066 \mathrm{E}-06$ & $3,82322 \mathrm{E}-11$ & $5,14503 \mathrm{E}-08$ & $1,07415 \mathrm{E}-09$ & $9,01852 \mathrm{E}-11$ & $2,96307 \mathrm{E}-10$ & $1,44415 \mathrm{E}-11$ & $9,37946 \mathrm{E}-11$ & $4,37701 \mathrm{E}-10$ & $3,5691 \mathrm{E}-11$ \\
\hline Extrativa & $2,02266 \mathrm{E}-10$ & $4,79479 \mathrm{E}-10$ & 2,78662E-06 & $1,14072 \mathrm{E}-10$ & $1,04832 \mathrm{E}-10$ & $1,44326 \mathrm{E}-10$ & $1,11619 \mathrm{E}-09$ & $2,67136 \mathrm{E}-11$ & $1,69648 \mathrm{E}-09$ & $3,60883 \mathrm{E}-10$ & $1,2608 \mathrm{E}-09$ \\
\hline Alimentos & $1,54152 \mathrm{E}-08$ & $2,34086 \mathrm{E}-07$ & $8,08615 \mathrm{E}-10$ & $1,41131 \mathrm{E}-06$ & $1,06487 \mathrm{E}-08$ & $1,10257 \mathrm{E}-09$ & $3,4466 \mathrm{E}-09$ & $2,98938 \mathrm{E}-10$ & $1,30218 \mathrm{E}-09$ & $4,35903 \mathrm{E}-10$ & 7,90759E-10 \\
\hline Vestuário & $7,97155 \mathrm{E}-11$ & $7,0546 \mathrm{E}-11$ & $2,35206 \mathrm{E}-09$ & $1,02819 \mathrm{E}-10$ & 4,21984E-06 & $9,5616 \mathrm{E}-11$ & $3,37732 \mathrm{E}-09$ & $1,08223 \mathrm{E}-10$ & $2,15672 \mathrm{E}-10$ & $6,32009 \mathrm{E}-10$ & $1,49476 \mathrm{E}-10$ \\
\hline Madeira & $8,25981 \mathrm{E}-10$ & $1,61914 \mathrm{E}-10$ & $4,503 \mathrm{E}-10$ & $1,93219 \mathrm{E}-10$ & $8,04103 \mathrm{E}-10$ & $1,38744 \mathrm{E}-05$ & $8,37074 \mathrm{E}-08$ & $1,38707 \mathrm{E}-10$ & $2,53718 \mathrm{E}-09$ & $6,88773 \mathrm{E}-10$ & $7,82669 \mathrm{E}-10$ \\
\hline Celulose & $8,60583 \mathrm{E}-11$ & $9,415 \mathrm{E}-11$ & $2,25188 \mathrm{E}-09$ & $1,09992 \mathrm{E}-10$ & $5,23335 \mathrm{E}-09$ & $8,61654 \mathrm{E}-09$ & $3,51675 \mathrm{E}-06$ & $5,4938 \mathrm{E}-10$ & 1,43583E-09 & $4,15935 \mathrm{E}-09$ & $7,30629 \mathrm{E}-11$ \\
\hline Revistas & $5,30867 \mathrm{E}-10$ & $5,91863 \mathrm{E}-10$ & $1,36842 \mathrm{E}-09$ & $9,76798 \mathrm{E}-10$ & $5,15224 \mathrm{E}-10$ & $3,1723 \mathrm{E}-10$ & 5,89117E-09 & $1,27946 \mathrm{E}-06$ & $8,39739 \mathrm{E}-09$ & 3,30139E-09 & $1,12461 \mathrm{E}-09$ \\
\hline Químicos & $1,55052 \mathrm{E}-08$ & $1,07844 \mathrm{E}-08$ & $3,60307 \mathrm{E}-09$ & $2,01754 \mathrm{E}-09$ & 1,10901E-09 & $2,05577 \mathrm{E}-09$ & $9,3496 \mathrm{E}-09$ & $6,23374 \mathrm{E}-11$ & $4,01256 \mathrm{E}-07$ & $5,44964 \mathrm{E}-09$ & $5,10365 \mathrm{E}-10$ \\
\hline Borracha & $3,13923 \mathrm{E}-09$ & $2,01171 \mathrm{E}-09$ & $2,58353 \mathrm{E}-08$ & $5,57544 \mathrm{E}-09$ & 7,33742E-09 & $1,36542 \mathrm{E}-08$ & $3,40518 \mathrm{E}-08$ & 4,29142E-09 & $1,01092 \mathrm{E}-08$ & $2,86777 \mathrm{E}-06$ & $3,43653 \mathrm{E}-10$ \\
\hline Cimento & $2,89228 \mathrm{E}-10$ & $1,47662 \mathrm{E}-10$ & $3,41216 \mathrm{E}-10$ & $4,94204 \mathrm{E}-10$ & $1,30062 \mathrm{E}-10$ & $5,64898 \mathrm{E}-11$ & 4,41921E-10 & $4,63416 \mathrm{E}-11$ & 1,81795E-09 & $1,35351 \mathrm{E}-10$ & $2,87603 \mathrm{E}-07$ \\
\hline Aço & $3,69171 \mathrm{E}-10$ & $1,77912 \mathrm{E}-10$ & $1,9302 \mathrm{E}-09$ & $2,0301 \mathrm{E}-10$ & $1,12068 \mathrm{E}-10$ & $9,85236 \mathrm{E}-10$ & $1,95003 \mathrm{E}-09$ & $1,684 \mathrm{E}-11$ & $5,13204 \mathrm{E}-10$ & 2,83304E-09 & $1,97532 \mathrm{E}-10$ \\
\hline Metal & $6,74372 \mathrm{E}-09$ & $4,75189 \mathrm{E}-09$ & $2,18516 \mathrm{E}-08$ & $1,17299 \mathrm{E}-08$ & $1,88419 \mathrm{E}-09$ & $1,13915 \mathrm{E}-08$ & $2,03642 \mathrm{E}-08$ & $1,26382 \mathrm{E}-10$ & $9,90304 \mathrm{E}-09$ & $1,12538 \mathrm{E}-08$ & $1,77861 \mathrm{E}-09$ \\
\hline Eletrodomésticos & $1,66105 \mathrm{E}-10$ & $1,13341 \mathrm{E}-10$ & 6,75541E-09 & $1,9054 \mathrm{E}-10$ & 1,73909E-09 & 2,99692E-09 & $1,28251 \mathrm{E}-08$ & $5,11851 \mathrm{E}-11$ & $9,55153 \mathrm{E}-10$ & $1,29362 \mathrm{E}-09$ & $1,00111 \mathrm{E}-10$ \\
\hline Informática & $5,24841 \mathrm{E}-13$ & $4,17566 \mathrm{E}-13$ & $3,54118 \mathrm{E}-12$ & $5,74813 \mathrm{E}-13$ & $2,97547 \mathrm{E}-12$ & $1,56862 \mathrm{E}-12$ & $1,71883 \mathrm{E}-11$ & $2,15766 \mathrm{E}-12$ & $7,61847 \mathrm{E}-12$ & $8,08685 \mathrm{E}-12$ & $4,22898 \mathrm{E}-13$ \\
\hline Máquinas & $1,38921 \mathrm{E}-10$ & $2,52477 \mathrm{E}-10$ & $4,1881 \mathrm{E}-09$ & $4,69651 \mathrm{E}-10$ & $4,68465 \mathrm{E}-10$ & $9,8258 \mathrm{E}-10$ & $9,76127 \mathrm{E}-10$ & $6,09974 \mathrm{E}-11$ & 1,17907E-09 & $3,53721 \mathrm{E}-09$ & $8,7417 \mathrm{E}-10$ \\
\hline Eletrônicos & $7,63688 \mathrm{E}-13$ & $8,66355 \mathrm{E}-13$ & $8,72542 \mathrm{E}-11$ & $1,73626 \mathrm{E}-12$ & $1,74864 \mathrm{E}-12$ & $2,8585 \mathrm{E}-12$ & $5,82448 \mathrm{E}-12$ & $1,00314 \mathrm{E}-12$ & $3,63076 \mathrm{E}-12$ & $7,13734 \mathrm{E}-12$ & $1,94453 \mathrm{E}-12$ \\
\hline Instrumento hospitalar & $3,81436 \mathrm{E}-12$ & $4,2025 \mathrm{E}-12$ & $1,88374 \mathrm{E}-11$ & $5,5556 \mathrm{E}-12$ & $7,38836 \mathrm{E}-12$ & $7,89889 \mathrm{E}-12$ & 4,3332E-11 & $8,44716 \mathrm{E}-12$ & $4,5877 \mathrm{E}-11$ & $8,82476 \mathrm{E}-11$ & $6,78349 \mathrm{E}-12$ \\
\hline Veículos & $1,16675 \mathrm{E}-10$ & $9,54757 \mathrm{E}-11$ & $6,90981 \mathrm{E}-10$ & $2,21694 \mathrm{E}-10$ & $1,19162 \mathrm{E}-10$ & $2,87408 \mathrm{E}-10$ & $5,60803 \mathrm{E}-10$ & $3,66271 \mathrm{E}-11$ & $2,64265 \mathrm{E}-10$ & $5,80712 \mathrm{E}-10$ & $1,04752 \mathrm{E}-10$ \\
\hline Indústria Diversa & $7,41336 \mathrm{E}-11$ & $6,87196 \mathrm{E}-10$ & $2,00113 \mathrm{E}-10$ & $4,65648 \mathrm{E}-10$ & $7,31512 \mathrm{E}-09$ & $2,15758 \mathrm{E}-10$ & $3,96356 \mathrm{E}-09$ & $8,62509 \mathrm{E}-11$ & $1,9702 \mathrm{E}-10$ & $1,40786 \mathrm{E}-09$ & $1,88281 \mathrm{E}-10$ \\
\hline SIUP & $1,15532 \mathrm{E}-09$ & $1,78318 \mathrm{E}-09$ & $4,63608 \mathrm{E}-09$ & $2,85574 \mathrm{E}-09$ & 2,33692E-09 & $2,42765 \mathrm{E}-09$ & 7,169E-09 & $1,902 \mathrm{E}-09$ & $3,46306 \mathrm{E}-09$ & $3,5811 \mathrm{E}-09$ & $9,44427 \mathrm{E}-09$ \\
\hline Construção & $2,5556 \mathrm{E}-10$ & $3,63037 \mathrm{E}-10$ & $6,56928 \mathrm{E}-10$ & $8,42948 \mathrm{E}-10$ & $7,57243 \mathrm{E}-10$ & $6,68908 \mathrm{E}-10$ & $1,2043 \mathrm{E}-09$ & $9,53281 \mathrm{E}-10$ & $1,34924 \mathrm{E}-09$ & $2,19127 \mathrm{E}-09$ & $2,98849 \mathrm{E}-09$ \\
\hline Comércio & $1,14077 \mathrm{E}-07$ & $1,68337 \mathrm{E}-07$ & $1,00329 \mathrm{E}-07$ & $1,80502 \mathrm{E}-07$ & $1,89599 \mathrm{E}-07$ & $7,7431 \mathrm{E}-08$ & $9,90585 \mathrm{E}-08$ & $1,02583 \mathrm{E}-07$ & $1,40771 \mathrm{E}-07$ & $1,09712 \mathrm{E}-07$ & $1,76048 \mathrm{E}-07$ \\
\hline Transportes & $2,72818 \mathrm{E}-08$ & $2,48234 \mathrm{E}-08$ & $7,29243 \mathrm{E}-08$ & $4,65309 \mathrm{E}-08$ & $2,16269 \mathrm{E}-08$ & $2,34155 \mathrm{E}-08$ & $3,96672 \mathrm{E}-08$ & $2,28048 \mathrm{E}-08$ & $4,31347 \mathrm{E}-08$ & $2,82062 \mathrm{E}-08$ & $8,74259 \mathrm{E}-08$ \\
\hline Informação & $5,63583 \mathrm{E}-10$ & $8,73693 \mathrm{E}-10$ & $2,57112 \mathrm{E}-09$ & $1,09797 \mathrm{E}-09$ & $6,29149 \mathrm{E}-10$ & $4,65437 \mathrm{E}-10$ & $1,07454 \mathrm{E}-09$ & 2,58536E-09 & 3,32898E-09 & $1,48458 \mathrm{E}-09$ & $2,01466 \mathrm{E}-09$ \\
\hline
\end{tabular}




\begin{tabular}{|c|c|c|c|c|c|c|c|c|c|c|c|}
\hline Financeiro & $2,51666 \mathrm{E}-10$ & $2,79061 \mathrm{E}-10$ & $5,63924 \mathrm{E}-10$ & $4,80239 \mathrm{E}-10$ & $3,84002 \mathrm{E}-10$ & 3,55977E-10 & $7,76426 \mathrm{E}-10$ & $4,4038 \mathrm{E}-10$ & $7,64566 \mathrm{E}-10$ & $5,55342 \mathrm{E}-10$ & $8,93017 \mathrm{E}-10$ \\
\hline Imobiliário & $7,91493 \mathrm{E}-10$ & $1,01364 \mathrm{E}-09$ & 2,40132E-09 & $2,02567 \mathrm{E}-09$ & 2,25686E-09 & $9,0325 \mathrm{E}-10$ & 1,99558E-09 & $3,14434 \mathrm{E}-09$ & 2,69188E-09 & 1,67836E-09 & $2,92462 \mathrm{E}-09$ \\
\hline Alojamento & $5,78864 \mathrm{E}-10$ & $8,16478 \mathrm{E}-10$ & $5,27736 \mathrm{E}-09$ & 1,43639E-09 & $8,37515 \mathrm{E}-10$ & $1,68001 \mathrm{E}-09$ & $1,71212 \mathrm{E}-09$ & 2,26964E-09 & $1,90222 \mathrm{E}-09$ & 1,6897E-09 & $9,28769 \mathrm{E}-09$ \\
\hline Serviços às Empresas & $1,7469 \mathrm{E}-08$ & $2,51142 \mathrm{E}-08$ & $4,84234 \mathrm{E}-08$ & $5,9097 \mathrm{E}-08$ & $3,87735 \mathrm{E}-08$ & $2,06175 \mathrm{E}-08$ & $5,00018 \mathrm{E}-08$ & $1,36256 \mathrm{E}-07$ & $1,54087 \mathrm{E}-07$ & $4,16966 \mathrm{E}-08$ & $9,6787 \mathrm{E}-08$ \\
\hline Educação e Saúde mercantis & $2,71488 \mathrm{E}-10$ & $3,75362 \mathrm{E}-10$ & $5,52392 \mathrm{E}-10$ & $5,65797 \mathrm{E}-10$ & $6,90784 \mathrm{E}-10$ & $2,53661 \mathrm{E}-10$ & $4,96607 \mathrm{E}-10$ & $6,05488 \mathrm{E}-10$ & $6,08329 \mathrm{E}-10$ & $4,35381 \mathrm{E}-10$ & $6,27258 \mathrm{E}-10$ \\
\hline Outros Serviços & 2,47503E-09 & 3,58688E-09 & 3,73686E-09 & 4,73181E-09 & $5,08666 \mathrm{E}-09$ & $1,87531 \mathrm{E}-09$ & 3,10952E-09 & 3,65528E-09 & $5,04061 \mathrm{E}-09$ & 3,68055E-09 & $5,87104 \mathrm{E}-09$ \\
\hline APU & $5,69419 \mathrm{E}-10$ & $6,79385 \mathrm{E}-10$ & $1,36393 \mathrm{E}-09$ & $1,25955 \mathrm{E}-09$ & $7,93816 \mathrm{E}-10$ & $5,35662 \mathrm{E}-10$ & $1,30049 \mathrm{E}-09$ & 2,4069E-09 & 2,1772E-09 & $9,23605 \mathrm{E}-10$ & $2,07986 \mathrm{E}-09$ \\
\hline
\end{tabular}

Tabela B5 - Matriz Geração de Emprego para o Grau de Instrução G(4), Distrito Federal - 2008.

(2)

\begin{tabular}{|c|c|c|c|c|c|c|c|c|c|c|}
\hline Setores & Aço & Metal & Eletrodomésticos & Informática & Máquinas & Eletrônicos & $\begin{array}{l}\text { Instrumento } \\
\text { hospitalar }\end{array}$ & Veículos & $\begin{array}{l}\text { Indústria } \\
\text { Diversa }\end{array}$ & SIUP \\
\hline Agricultura & $6,03261 \mathrm{E}-11$ & $3,32613 \mathrm{E}-11$ & $1,19427 \mathrm{E}-10$ & $1,1377 \mathrm{E}-10$ & $6,78508 \mathrm{E}-11$ & $1,5533 \mathrm{E}-10$ & $4,12713 \mathrm{E}-11$ & 2,36965E-10 & $9,27232 \mathrm{E}-11$ & $1,68069 \mathrm{E}-11$ \\
\hline Pecuária & $1,96216 \mathrm{E}-11$ & $9,69263 \mathrm{E}-12$ & 2,39577E-11 & $2,59142 \mathrm{E}-11$ & $2,05515 \mathrm{E}-11$ & $2,68896 \mathrm{E}-11$ & $1,10817 \mathrm{E}-11$ & $4,28938 \mathrm{E}-11$ & 2,29767E-10 & $6,30211 \mathrm{E}-12$ \\
\hline Extrativa & 4,69454E-08 & 2,77355E-09 & $8,80213 \mathrm{E}-09$ & $6,70894 \mathrm{E}-10$ & 2,66915E-09 & $1,50002 \mathrm{E}-09$ & $2,49936 \mathrm{E}-10$ & $5,02073 \mathrm{E}-09$ & $1,53906 \mathrm{E}-09$ & 2,35604E-11 \\
\hline Alimentos & $3,5437 \mathrm{E}-10$ & $1,66607 \mathrm{E}-10$ & $3,449 \mathrm{E}-10$ & $3,85849 \mathrm{E}-10$ & $3,47491 \mathrm{E}-10$ & $3,77449 \mathrm{E}-10$ & $1,82986 \mathrm{E}-10$ & $4,66662 \mathrm{E}-10$ & $3,31978 \mathrm{E}-10$ & $1,11239 \mathrm{E}-10$ \\
\hline Vestuário & $1,98577 \mathrm{E}-10$ & $3,0388 \mathrm{E}-10$ & $1,66786 \mathrm{E}-09$ & 2,31963E-10 & $1,94821 \mathrm{E}-10$ & $2,6411 \mathrm{E}-10$ & $2,93995 \mathrm{E}-10$ & 1,43067E-09 & $2,00817 \mathrm{E}-10$ & $2,01055 \mathrm{E}-10$ \\
\hline Madeira & $6,29707 \mathrm{E}-10$ & $9,30095 \mathrm{E}-10$ & $1,85575 \mathrm{E}-08$ & $1,70725 \mathrm{E}-08$ & $8,20652 \mathrm{E}-10$ & 7,59307E-08 & $2,24595 \mathrm{E}-10$ & $1,16323 \mathrm{E}-08$ & $2,50756 \mathrm{E}-08$ & $3,03942 \mathrm{E}-11$ \\
\hline Celulose & $5,92209 \mathrm{E}-10$ & $1,43098 \mathrm{E}-10$ & $1,09205 \mathrm{E}-08$ & $5,90478 \mathrm{E}-09$ & $1,0656 \mathrm{E}-09$ & $1,16579 \mathrm{E}-08$ & $2,49354 \mathrm{E}-10$ & $5,97224 \mathrm{E}-09$ & $5,74573 \mathrm{E}-10$ & $5,01437 \mathrm{E}-11$ \\
\hline Revistas & 1,6114E-09 & $1,58571 \mathrm{E}-09$ & $9,71159 \mathrm{E}-10$ & $1,83292 \mathrm{E}-09$ & $8,27456 \mathrm{E}-10$ & $1,53892 \mathrm{E}-09$ & 7,60453E-09 & $1,80919 \mathrm{E}-09$ & $5,40591 \mathrm{E}-10$ & 2,26676E-09 \\
\hline Químicos & 4,8044E-09 & $8,37562 \mathrm{E}-10$ & $4,43488 \mathrm{E}-09$ & $3,18189 \mathrm{E}-10$ & 1,39574E-09 & $5,61048 \mathrm{E}-10$ & $1,0585 \mathrm{E}-09$ & 2,91964E-09 & $5,19439 \mathrm{E}-10$ & $3,51298 \mathrm{E}-10$ \\
\hline Borracha & $1,76448 \mathrm{E}-08$ & $1,01145 \mathrm{E}-08$ & 4,82479E-08 & 4,29882E-08 & 2,21766E-08 & $4,98929 \mathrm{E}-08$ & $1,39019 \mathrm{E}-08$ & $1,15584 \mathrm{E}-07$ & $1,8293 \mathrm{E}-08$ & $4,37654 \mathrm{E}-10$ \\
\hline Cimento & 2,53735E-09 & $7,57267 \mathrm{E}-10$ & $9,84209 \mathrm{E}-10$ & $5,18291 \mathrm{E}-10$ & 2,43825E-09 & $1,90008 \mathrm{E}-09$ & $8,93167 \mathrm{E}-10$ & 2,19498E-09 & $5,10343 \mathrm{E}-09$ & $2,45877 \mathrm{E}-11$ \\
\hline Aço & $4,81838 \mathrm{E}-07$ & $3,93239 \mathrm{E}-09$ & $7,20116 \mathrm{E}-08$ & $5,2148 \mathrm{E}-09$ & $1,41963 \mathrm{E}-08$ & $1,25437 \mathrm{E}-08$ & $1,43451 \mathrm{E}-09$ & $3,9643 \mathrm{E}-08$ & $1,46255 \mathrm{E}-09$ & $4,55909 \mathrm{E}-11$ \\
\hline Metal & $5,37507 \mathrm{E}-08$ & $1,37986 \mathrm{E}-06$ & $8,65285 \mathrm{E}-08$ & $3,2457 \mathrm{E}-08$ & $6,01325 \mathrm{E}-08$ & $5,35472 \mathrm{E}-08$ & $3,6858 \mathrm{E}-08$ & 3,86059E-08 & 2,96767E-08 & $1,50889 \mathrm{E}-10$ \\
\hline Eletrodomésticos & 6,88709E-09 & $7,91428 \mathrm{E}-10$ & $2,6467 \mathrm{E}-06$ & 7,33711E-09 & 3,38629E-09 & $4,95095 \mathrm{E}-09$ & 1,47482E-09 & 3,10177E-08 & $5,13421 \mathrm{E}-10$ & $8,29814 \mathrm{E}-11$ \\
\hline Informática & $2,31551 \mathrm{E}-12$ & $1,24809 \mathrm{E}-12$ & $1,19672 \mathrm{E}-11$ & $5,06915 \mathrm{E}-07$ & $7,4232 \mathrm{E}-12$ & $2,53909 \mathrm{E}-10$ & $1,61075 \mathrm{E}-12$ & $1,5642 \mathrm{E}-11$ & $1,26923 \mathrm{E}-12$ & 2,51963E-13 \\
\hline Máquinas & $1,50827 \mathrm{E}-09$ & $4,12385 \mathrm{E}-10$ & 3,1143E-08 & $7,45294 \mathrm{E}-08$ & $1,21892 \mathrm{E}-06$ & $1,36962 \mathrm{E}-07$ & $9,08455 \mathrm{E}-09$ & $2,0364 \mathrm{E}-08$ & $3,04287 \mathrm{E}-09$ & 2,313E-09 \\
\hline
\end{tabular}




\begin{tabular}{|c|c|c|c|c|c|c|c|c|c|c|}
\hline Eletrônicos & $8,28822 \mathrm{E}-12$ & $4,97027 \mathrm{E}-12$ & $2,092 \mathrm{E}-10$ & $2,44734 \mathrm{E}-08$ & $2,04039 \mathrm{E}-10$ & $1,2062 \mathrm{E}-07$ & $2,42048 \mathrm{E}-11$ & $1,94555 \mathrm{E}-10$ & $1,01348 \mathrm{E}-11$ & $3,93407 \mathrm{E}-12$ \\
\hline Instrumento hospitalar & $1,34592 \mathrm{E}-11$ & $7,39919 \mathrm{E}-12$ & $2,04103 \mathrm{E}-09$ & $2,66846 \mathrm{E}-10$ & $7,92574 \mathrm{E}-10$ & $3,72317 \mathrm{E}-10$ & $6,4031 \mathrm{E}-07$ & $3,40691 \mathrm{E}-10$ & $3,50191 \mathrm{E}-11$ & $7,73606 \mathrm{E}-12$ \\
\hline Veículos & $1,58381 \mathrm{E}-09$ & $1,00059 \mathrm{E}-09$ & $7,14385 \mathrm{E}-09$ & $5,04671 \mathrm{E}-09$ & $5,76542 \mathrm{E}-09$ & $9,1579 \mathrm{E}-09$ & $1,21371 \mathrm{E}-09$ & $2,5245 \mathrm{E}-06$ & $7,22218 \mathrm{E}-10$ & $1,54031 \mathrm{E}-10$ \\
\hline Indústria Diversa & $9,41008 \mathrm{E}-09$ & $6,93336 \mathrm{E}-10$ & $2,18707 \mathrm{E}-09$ & $4,13924 \mathrm{E}-10$ & $1,26992 \mathrm{E}-09$ & $6,73562 \mathrm{E}-10$ & $1,79463 \mathrm{E}-10$ & $1,12984 \mathrm{E}-09$ & 2,35791E-06 & $5,87865 \mathrm{E}-11$ \\
\hline SIUP & $8,39131 \mathrm{E}-09$ & 4,09202E-09 & 4,07323E-09 & $2,72744 \mathrm{E}-09$ & 4,78203E-09 & 3,33263E-09 & 3,48524E-09 & $3,57087 \mathrm{E}-09$ & 2,54264E-09 & 3,79916E-07 \\
\hline Construção & $9,31054 \mathrm{E}-10$ & $6,2565 \mathrm{E}-10$ & $1,26552 \mathrm{E}-09$ & $1,86301 \mathrm{E}-09$ & 2,57319E-09 & $3,88825 \mathrm{E}-09$ & $5,8991 \mathrm{E}-10$ & 4,12367E-09 & 7,56071E-10 & $5,84437 \mathrm{E}-10$ \\
\hline Comércio & $9,3793 \mathrm{E}-08$ & $8,21473 \mathrm{E}-08$ & $1,38004 \mathrm{E}-07$ & $3,10661 \mathrm{E}-07$ & $1,23034 \mathrm{E}-07$ & $2,32042 \mathrm{E}-07$ & $1,23929 \mathrm{E}-07$ & $1,76786 \mathrm{E}-07$ & $1,43522 \mathrm{E}-07$ & $3,91725 \mathrm{E}-08$ \\
\hline Transportes & $5,86467 \mathrm{E}-08$ & $3,36537 \mathrm{E}-08$ & 4,63098E-08 & $5,19391 \mathrm{E}-08$ & $4,43061 \mathrm{E}-08$ & $6,44783 \mathrm{E}-08$ & $3,51821 \mathrm{E}-08$ & $4,05924 \mathrm{E}-08$ & $2,18043 \mathrm{E}-08$ & $1,78171 \mathrm{E}-08$ \\
\hline Informação & $2,62812 \mathrm{E}-09$ & $1,16886 \mathrm{E}-09$ & 2,93987E-09 & 4,22634E-09 & $3,6069 \mathrm{E}-09$ & $6,21821 \mathrm{E}-09$ & $1,9047 \mathrm{E}-09$ & 2,351E-09 & $6,38647 \mathrm{E}-10$ & 2,22394E-09 \\
\hline Financeiro & $9,7285 \mathrm{E}-10$ & $5,73136 \mathrm{E}-10$ & $1,23942 \mathrm{E}-09$ & $8,65621 \mathrm{E}-10$ & $8,85495 \mathrm{E}-10$ & $1,52532 \mathrm{E}-09$ & $6,15587 \mathrm{E}-10$ & $8,50193 \mathrm{E}-10$ & $3,64323 \mathrm{E}-10$ & $3,27614 \mathrm{E}-10$ \\
\hline Imobiliário & $1,8964 \mathrm{E}-09$ & $1,60921 \mathrm{E}-09$ & $2,50752 \mathrm{E}-09$ & $2,6888 \mathrm{E}-09$ & $1,98927 \mathrm{E}-09$ & $2,65986 \mathrm{E}-09$ & 2,33994E-09 & $1,75044 \mathrm{E}-09$ & $1,52615 \mathrm{E}-09$ & $1,37317 \mathrm{E}-09$ \\
\hline Alojamento & $2,45929 \mathrm{E}-09$ & $9,37357 \mathrm{E}-10$ & $1,35411 \mathrm{E}-09$ & $1,95816 \mathrm{E}-09$ & $2,90564 \mathrm{E}-09$ & $1,95648 \mathrm{E}-09$ & $8,41973 \mathrm{E}-10$ & $2,59783 \mathrm{E}-09$ & $1,74972 \mathrm{E}-09$ & 7,19149E-10 \\
\hline Serviços às Empresas & $4,05148 \mathrm{E}-08$ & $3,94811 \mathrm{E}-08$ & $4,7318 \mathrm{E}-08$ & $2,11665 \mathrm{E}-07$ & $6,74722 \mathrm{E}-08$ & $1,49186 \mathrm{E}-07$ & $5,4184 \mathrm{E}-08$ & $9,06186 \mathrm{E}-08$ & $3,11742 \mathrm{E}-08$ & $1,15082 \mathrm{E}-07$ \\
\hline Educação e Saúde mercantis & $4,12259 \mathrm{E}-10$ & $4,16554 \mathrm{E}-10$ & $6,11683 \mathrm{E}-10$ & $8,52303 \mathrm{E}-10$ & $5,24028 \mathrm{E}-10$ & $7,82859 \mathrm{E}-10$ & $5,21167 \mathrm{E}-10$ & $5,28369 \mathrm{E}-10$ & $4,78273 \mathrm{E}-10$ & $3,27988 \mathrm{E}-10$ \\
\hline Outros Serviços & $3,4712 \mathrm{E}-09$ & 3,15849E-09 & 4,63832E-09 & $9,11158 \mathrm{E}-09$ & $6,62172 \mathrm{E}-09$ & $8,40217 \mathrm{E}-09$ & $3,76862 \mathrm{E}-09$ & 4,90654E-09 & 3,86894E-09 & 3,69096E-09 \\
\hline APU & $1,32428 \mathrm{E}-09$ & $9,10505 \mathrm{E}-10$ & $1,07124 \mathrm{E}-09$ & $2,75283 \mathrm{E}-09$ & 1,19181E-09 & 2,18696E-09 & $1,06039 \mathrm{E}-09$ & $1,47823 \mathrm{E}-09$ & $6,84005 \mathrm{E}-10$ & $2,45719 \mathrm{E}-09$ \\
\hline
\end{tabular}

Tabela B5 - Matriz Geração de Emprego para o Grau de Instrução G(4), Distrito Federal - 2008.

(3)

\begin{tabular}{|c|c|c|c|c|c|c|c|c|c|c|c|}
\hline Setores & Construção & Comércio & Transportes & Informação & Financeiro & Imobiliário & Alojamento & $\begin{array}{c}\text { Serviços às } \\
\text { Empresas }\end{array}$ & $\begin{array}{l}\text { Educação e } \\
\text { Saúde } \\
\text { mercantis }\end{array}$ & $\begin{array}{c}\text { Outros } \\
\text { Serviços }\end{array}$ & APU \\
\hline Agricultura & $4,82239 \mathrm{E}-11$ & $1,49618 \mathrm{E}-10$ & $1,13176 \mathrm{E}-10$ & $6,86516 \mathrm{E}-11$ & 4,44534E-11 & $9,42156 \mathrm{E}-12$ & $1,50518 \mathrm{E}-08$ & $6,81628 \mathrm{E}-11$ & $3,5884 \mathrm{E}-10$ & $1,55015 \mathrm{E}-09$ & $1,9158 \mathrm{E}-10$ \\
\hline Pecuária & $1,89461 \mathrm{E}-11$ & $5,568 \mathrm{E}-11$ & $4,95747 \mathrm{E}-11$ & $2,45377 \mathrm{E}-11$ & $1,8785 \mathrm{E}-11$ & $3,17657 \mathrm{E}-12$ & $7,33289 \mathrm{E}-09$ & $2,45372 \mathrm{E}-11$ & $1,63205 \mathrm{E}-10$ & $7,96778 \mathrm{E}-10$ & $7,64342 \mathrm{E}-11$ \\
\hline Extrativa & $1,22529 \mathrm{E}-10$ & $6,38725 \mathrm{E}-11$ & $3,93631 \mathrm{E}-11$ & $7,39675 \mathrm{E}-11$ & $2,20748 \mathrm{E}-11$ & $1,22234 \mathrm{E}-11$ & $5,80771 \mathrm{E}-11$ & $5,90226 \mathrm{E}-11$ & $5,80741 \mathrm{E}-11$ & $5,48027 \mathrm{E}-11$ & $6,01773 \mathrm{E}-11$ \\
\hline Alimentos & $4,35946 \mathrm{E}-10$ & $1,3546 \mathrm{E}-09$ & $1,19648 \mathrm{E}-09$ & $4,74135 \mathrm{E}-10$ & $3,89826 \mathrm{E}-10$ & $6,56906 \mathrm{E}-11$ & $1,70649 \mathrm{E}-07$ & $4,54771 \mathrm{E}-10$ & $2,77005 \mathrm{E}-09$ & $6,34695 \mathrm{E}-09$ & $1,26525 \mathrm{E}-09$ \\
\hline Vestuário & $1,24806 \mathrm{E}-10$ & $2,79698 \mathrm{E}-10$ & $5,86442 \mathrm{E}-10$ & $2,73086 \mathrm{E}-10$ & $2,23477 \mathrm{E}-10$ & $2,95706 \mathrm{E}-11$ & $3,24478 \mathrm{E}-10$ & $7,99685 \mathrm{E}-10$ & $5,15533 \mathrm{E}-10$ & $1,15297 \mathrm{E}-09$ & $2,24606 \mathrm{E}-10$ \\
\hline Madeira & $2,8502 \mathrm{E}-10$ & $1,0113 \mathrm{E}-10$ & 6,7834E-11 & $1,34221 \mathrm{E}-10$ & $7,5886 \mathrm{E}-11$ & $9,91232 \mathrm{E}-11$ & $8,27589 \mathrm{E}-11$ & $1,11629 \mathrm{E}-10$ & $1,48222 \mathrm{E}-10$ & $1,56436 \mathrm{E}-10$ & $2,23751 \mathrm{E}-10$ \\
\hline
\end{tabular}




\begin{tabular}{|c|c|c|c|c|c|c|c|c|c|c|c|}
\hline Celulose & $3,63138 \mathrm{E}-11$ & $1,45642 \mathrm{E}-10$ & $9,20647 \mathrm{E}-11$ & $1,85355 \mathrm{E}-10$ & $6,27702 \mathrm{E}-11$ & $2,443 \mathrm{E}-11$ & $9,12097 \mathrm{E}-11$ & $2,42421 \mathrm{E}-10$ & $1,29756 \mathrm{E}-10$ & $1,22449 \mathrm{E}-10$ & $1,21991 \mathrm{E}-10$ \\
\hline Revistas & $6,02677 \mathrm{E}-10$ & 2,16963E-09 & $1,82851 \mathrm{E}-09$ & $5,06712 \mathrm{E}-09$ & 2,62374E-09 & $5,7026 \mathrm{E}-10$ & $6,00413 \mathrm{E}-10$ & $1,6106 \mathrm{E}-08$ & 2,6292E-09 & 2,78352E-09 & $1,52986 \mathrm{E}-09$ \\
\hline Químicos & $4,7549 \mathrm{E}-11$ & $2,51691 \mathrm{E}-11$ & $1,77777 \mathrm{E}-11$ & $4,63127 \mathrm{E}-11$ & $1,05794 \mathrm{E}-11$ & $6,89398 \mathrm{E}-12$ & $3,45317 \mathrm{E}-10$ & $2,87858 \mathrm{E}-11$ & $3,30659 \mathrm{E}-10$ & $6,48492 \mathrm{E}-11$ & $4,99945 \mathrm{E}-11$ \\
\hline Borracha & $1,81461 \mathrm{E}-09$ & $7,23471 \mathrm{E}-10$ & $6,08676 \mathrm{E}-10$ & $1,4864 \mathrm{E}-09$ & $2,3777 \mathrm{E}-10$ & $1,35685 \mathrm{E}-10$ & $9,87229 \mathrm{E}-10$ & $2,15408 \mathrm{E}-09$ & $1,8814 \mathrm{E}-09$ & $6,00304 \mathrm{E}-10$ & $2,85711 \mathrm{E}-10$ \\
\hline Cimento & $1,0347 \mathrm{E}-08$ & $3,70373 \mathrm{E}-11$ & $1,59104 \mathrm{E}-11$ & $4,58392 \mathrm{E}-11$ & $4,28605 \mathrm{E}-11$ & $9,15069 \mathrm{E}-11$ & $7,22012 \mathrm{E}-11$ & $3,44384 \mathrm{E}-11$ & $3,41548 \mathrm{E}-10$ & $1,8007 \mathrm{E}-10$ & 1,70971E-10 \\
\hline Aço & $1,34025 \mathrm{E}-10$ & $1,96502 \mathrm{E}-11$ & $1,53935 \mathrm{E}-11$ & $2,69438 \mathrm{E}-11$ & $7,72826 \mathrm{E}-12$ & $7,23283 \mathrm{E}-12$ & $3,63806 \mathrm{E}-11$ & $1,88533 \mathrm{E}-11$ & $2,27701 \mathrm{E}-11$ & $2,54677 \mathrm{E}-11$ & $1,82329 \mathrm{E}-11$ \\
\hline Metal & 3,70904E-09 & $3,58079 \mathrm{E}-10$ & $8,40305 \mathrm{E}-11$ & $1,95381 \mathrm{E}-10$ & $5,72982 \mathrm{E}-11$ & $1,40104 \mathrm{E}-10$ & $1,58437 \mathrm{E}-09$ & $9,97 \mathrm{E}-11$ & $3,75666 \mathrm{E}-10$ & $2,38852 \mathrm{E}-10$ & $2,49278 \mathrm{E}-10$ \\
\hline Eletrodomésticos & $1,02962 \mathrm{E}-10$ & $9,85757 \mathrm{E}-11$ & $6,70808 \mathrm{E}-11$ & $1,24264 \mathrm{E}-10$ & $3,45472 \mathrm{E}-11$ & $2,59485 \mathrm{E}-11$ & $7,9193 \mathrm{E}-11$ & $9,72102 \mathrm{E}-11$ & $9,21388 \mathrm{E}-11$ & $9,31874 \mathrm{E}-11$ & $9,43655 \mathrm{E}-11$ \\
\hline Informática & $1,01164 \mathrm{E}-12$ & $8,4083 \mathrm{E}-13$ & $4,3636 \mathrm{E}-13$ & $1,61494 \mathrm{E}-12$ & $5,43974 \mathrm{E}-13$ & $7,46761 \mathrm{E}-13$ & $4,46849 \mathrm{E}-13$ & $9,63469 \mathrm{E}-13$ & $1,18515 \mathrm{E}-12$ & $9,57727 \mathrm{E}-13$ & $1,66466 \mathrm{E}-12$ \\
\hline Máquinas & $6,34943 \mathrm{E}-10$ & $1,33913 \mathrm{E}-10$ & $3,94118 \mathrm{E}-10$ & $5,74418 \mathrm{E}-10$ & $7,16735 \mathrm{E}-11$ & $1,55743 \mathrm{E}-10$ & $1,06287 \mathrm{E}-10$ & $1,99968 \mathrm{E}-10$ & $1,77979 \mathrm{E}-10$ & $6,33642 \mathrm{E}-10$ & $1,12825 \mathrm{E}-10$ \\
\hline Eletrônicos & $1,44288 \mathrm{E}-12$ & $9,55729 \mathrm{E}-13$ & $1,19007 \mathrm{E}-12$ & $2,02411 \mathrm{E}-12$ & $4,47368 \mathrm{E}-13$ & $5,55131 \mathrm{E}-13$ & $6,9534 \mathrm{E}-13$ & $1,35889 \mathrm{E}-12$ & $9,31956 \mathrm{E}-13$ & $1,69957 \mathrm{E}-12$ & $8,84883 \mathrm{E}-13$ \\
\hline Instrumento hospitalar & $4,33537 \mathrm{E}-11$ & $2,61999 \mathrm{E}-11$ & $8,30912 \mathrm{E}-12$ & $1,08032 \mathrm{E}-11$ & $6,08795 \mathrm{E}-12$ & $4,93878 \mathrm{E}-11$ & $5,28558 \mathrm{E}-12$ & $7,03024 \mathrm{E}-11$ & $7,29766 \mathrm{E}-11$ & $5,55985 \mathrm{E}-11$ & $1,51211 \mathrm{E}-11$ \\
\hline Veículos & $1,23156 \mathrm{E}-10$ & $6,82542 \mathrm{E}-11$ & $5,97796 \mathrm{E}-11$ & $1,03457 \mathrm{E}-10$ & $2,70537 \mathrm{E}-11$ & $2,59914 \mathrm{E}-11$ & $6,391 \mathrm{E}-11$ & $6,95652 \mathrm{E}-11$ & $6,76587 \mathrm{E}-11$ & $9,04404 \mathrm{E}-11$ & $6,78575 \mathrm{E}-11$ \\
\hline Indústria Diversa & $7,75587 \mathrm{E}-10$ & $1,05696 \mathrm{E}-10$ & $6,64701 \mathrm{E}-10$ & $1,30431 \mathrm{E}-10$ & $1,17469 \mathrm{E}-09$ & $2,93718 \mathrm{E}-10$ & $1,29747 \mathrm{E}-10$ & $4,29665 \mathrm{E}-10$ & $4,25717 \mathrm{E}-10$ & 2,14796E-09 & $4,69263 \mathrm{E}-10$ \\
\hline SIUP & $8,302 \mathrm{E}-10$ & $2,84458 \mathrm{E}-09$ & 2,35885E-09 & 2,21671E-09 & $1,33768 \mathrm{E}-09$ & $2,81764 \mathrm{E}-10$ & 2,87554E-09 & 2,49639E-09 & $3,67561 \mathrm{E}-09$ & $8,26998 \mathrm{E}-09$ & $3,16588 \mathrm{E}-09$ \\
\hline Construção & $1,394 \mathrm{E}-06$ & $1,59527 \mathrm{E}-09$ & $1,24008 \mathrm{E}-09$ & $5,08001 \mathrm{E}-09$ & $5,02604 \mathrm{E}-09$ & $1,2016 \mathrm{E}-08$ & $8,53782 \mathrm{E}-10$ & $3,57982 \mathrm{E}-09$ & $1,07304 \mathrm{E}-08$ & $9,26314 \mathrm{E}-09$ & $2,09542 \mathrm{E}-08$ \\
\hline Comércio & $1,28547 \mathrm{E}-07$ & $2,41448 \mathrm{E}-06$ & $1,07056 \mathrm{E}-07$ & $5,31953 \mathrm{E}-08$ & $3,18025 \mathrm{E}-08$ & $1,40353 \mathrm{E}-08$ & $2,4644 \mathrm{E}-07$ & $9,22187 \mathrm{E}-08$ & $8,20611 \mathrm{E}-08$ & $8,87284 \mathrm{E}-08$ & 4,70251E-08 \\
\hline Transportes & $1,66836 \mathrm{E}-08$ & $4,38958 \mathrm{E}-08$ & $1,34072 \mathrm{E}-06$ & $2,9777 \mathrm{E}-08$ & $1,25212 \mathrm{E}-08$ & 2,22711E-09 & $2,00926 \mathrm{E}-08$ & $2,36557 \mathrm{E}-08$ & $2,12566 \mathrm{E}-08$ & $3,142 \mathrm{E}-08$ & $1,14121 \mathrm{E}-08$ \\
\hline Informação & $7,27898 \mathrm{E}-10$ & 2,2942E-09 & $2,39856 \mathrm{E}-09$ & $1,71735 \mathrm{E}-07$ & 6,99787E-09 & $4,73129 \mathrm{E}-10$ & $1,14605 \mathrm{E}-09$ & $1,86012 \mathrm{E}-08$ & 6,39675E-09 & 4,18892E-09 & $7,75558 \mathrm{E}-09$ \\
\hline Financeiro & $2,63797 \mathrm{E}-10$ & $5,23588 \mathrm{E}-10$ & $7,23997 \mathrm{E}-10$ & $7,37019 \mathrm{E}-10$ & $2,09056 \mathrm{E}-08$ & $1,0651 \mathrm{E}-10$ & $2,72316 \mathrm{E}-10$ & $6,97548 \mathrm{E}-10$ & $3,07973 \mathrm{E}-10$ & $1,71414 \mathrm{E}-10$ & $1,63126 \mathrm{E}-09$ \\
\hline Imobiliário & $1,13054 \mathrm{E}-09$ & $5,69133 \mathrm{E}-09$ & $1,01426 \mathrm{E}-08$ & $9,18868 \mathrm{E}-09$ & 2,91457E-09 & $2,70228 \mathrm{E}-07$ & $3,50215 \mathrm{E}-09$ & $6,63297 \mathrm{E}-09$ & 6,89986E-09 & 4,94439E-09 & $5,21869 \mathrm{E}-09$ \\
\hline Alojamento & $2,45693 \mathrm{E}-09$ & $3,41431 \mathrm{E}-09$ & $6,64786 \mathrm{E}-09$ & $4,48315 \mathrm{E}-09$ & 4,31166E-09 & $4,75748 \mathrm{E}-10$ & $2,63732 \mathrm{E}-06$ & $3,8678 \mathrm{E}-09$ & $2,05041 \mathrm{E}-08$ & $2,34003 \mathrm{E}-08$ & $1,26741 \mathrm{E}-08$ \\
\hline Serviços às Empresas & 4,67221E-08 & $1,3032 \mathrm{E}-07$ & $1,49751 \mathrm{E}-07$ & $2,13433 \mathrm{E}-07$ & $1,61425 \mathrm{E}-07$ & $2,5227 \mathrm{E}-08$ & $4,1274 \mathrm{E}-08$ & $2,57574 \mathrm{E}-06$ & $2,14853 \mathrm{E}-07$ & $1,36721 \mathrm{E}-07$ & $1,51824 \mathrm{E}-07$ \\
\hline Educação e Saúde mercantis & $3,66565 \mathrm{E}-10$ & $1,30619 \mathrm{E}-09$ & $8,65634 \mathrm{E}-10$ & $1,45851 \mathrm{E}-09$ & $1,50407 \mathrm{E}-09$ & $1,88369 \mathrm{E}-10$ & $1,04139 \mathrm{E}-09$ & $1,24163 \mathrm{E}-09$ & $6,57828 \mathrm{E}-07$ & $9,95243 \mathrm{E}-10$ & $2,05315 \mathrm{E}-09$ \\
\hline Outros Serviços & $3,45272 \mathrm{E}-09$ & $9,1286 \mathrm{E}-09$ & $5,70738 \mathrm{E}-09$ & $1,01729 \mathrm{E}-08$ & $5,22635 \mathrm{E}-09$ & $1,01924 \mathrm{E}-09$ & $9,95458 \mathrm{E}-09$ & $1,21542 \mathrm{E}-08$ & $8,99431 \mathrm{E}-09$ & $1,28016 \mathrm{E}-06$ & $6,44405 \mathrm{E}-09$ \\
\hline APU & $7,02361 \mathrm{E}-10$ & $1,88855 \mathrm{E}-09$ & $1,98122 \mathrm{E}-09$ & $2,54848 \mathrm{E}-09$ & $1,82435 \mathrm{E}-09$ & $3,0201 \mathrm{E}-10$ & $8,94044 \mathrm{E}-10$ & $2,26807 \mathrm{E}-09$ & 2,48932E-09 & $1,92375 \mathrm{E}-09$ & $6,18055 \mathrm{E}-07$ \\
\hline
\end{tabular}


Tabela B6 - Matriz Geração de Emprego para o Grau de Instrução G(5), Distrito Federal - 2008.

(1)

\begin{tabular}{|c|c|c|c|c|c|c|c|c|c|c|c|}
\hline Setores & Agricultura & Pecuária & Extrativa & Alimentos & Vestuário & Madeira & Celulose & Revistas & Químicos & Borracha & Cimento \\
\hline Agricultura & $4,47656 \mathrm{E}-07$ & $2,93701 \mathrm{E}-08$ & $4,88498 \mathrm{E}-11$ & $3,60664 \mathrm{E}-08$ & $4,51178 \mathrm{E}-10$ & $7,09226 \mathrm{E}-10$ & $2,04821 \mathrm{E}-09$ & $1,99795 \mathrm{E}-11$ & $8,99446 \mathrm{E}-11$ & $1,52432 \mathrm{E}-09$ & $3,4963 \mathrm{E}-11$ \\
\hline Pecuária & $1,95588 \mathrm{E}-09$ & $5,00252 \mathrm{E}-07$ & $1,47047 \mathrm{E}-11$ & $1,97886 \mathrm{E}-08$ & $4,13135 \mathrm{E}-10$ & $3,46866 \mathrm{E}-11$ & $1,13964 \mathrm{E}-10$ & $5,55443 \mathrm{E}-12$ & $3,60748 \mathrm{E}-11$ & $1,68347 \mathrm{E}-10$ & $1,37273 \mathrm{E}-11$ \\
\hline Extrativa & $7,95427 \mathrm{E}-11$ & $1,88559 \mathrm{E}-10$ & $1,09586 \mathrm{E}-06$ & $4,48596 \mathrm{E}-11$ & $4,12261 \mathrm{E}-11$ & $5,67572 \mathrm{E}-11$ & $4,38951 \mathrm{E}-10$ & $1,05054 \mathrm{E}-11$ & $6,67154 \mathrm{E}-10$ & $1,4192 \mathrm{E}-10$ & $4,95819 \mathrm{E}-10$ \\
\hline Alimentos & $1,26808 \mathrm{E}-08$ & $1,92564 \mathrm{E}-07$ & $6,65183 \mathrm{E}-10$ & $1,16097 \mathrm{E}-06$ & 8,75983E-09 & $9,07 \mathrm{E}-10$ & 2,83524E-09 & $2,45912 \mathrm{E}-10$ & $1,0712 \mathrm{E}-09$ & $3,58582 \mathrm{E}-10$ & $6,50494 \mathrm{E}-10$ \\
\hline Vestuário & $5,10281 \mathrm{E}-11$ & $4,51584 \mathrm{E}-11$ & $1,50562 \mathrm{E}-09$ & $6,58171 \mathrm{E}-11$ & $2,70124 \mathrm{E}-06$ & $6,12064 \mathrm{E}-11$ & 2,16192E-09 & $6,92762 \mathrm{E}-11$ & $1,38058 \mathrm{E}-10$ & $4,04566 \mathrm{E}-10$ & 9,56837E-11 \\
\hline Madeira & $4,68392 \mathrm{E}-10$ & $9,1817 \mathrm{E}-11$ & $2,55353 \mathrm{E}-10$ & $1,09569 \mathrm{E}-10$ & $4,55985 \mathrm{E}-10$ & $7,8678 \mathrm{E}-06$ & $4,74682 \mathrm{E}-08$ & $7,86571 \mathrm{E}-11$ & $1,43877 \mathrm{E}-09$ & $3,90584 \mathrm{E}-10$ & $4,43831 \mathrm{E}-10$ \\
\hline Celulose & 6,67694E-11 & 7,30474E-11 & $1,74715 \mathrm{E}-09$ & $8,53383 \mathrm{E}-11$ & 4,06036E-09 & $6,68525 \mathrm{E}-09$ & $2,72851 \mathrm{E}-06$ & $4,26243 \mathrm{E}-10$ & 1,11401E-09 & $3,22708 \mathrm{E}-09$ & $5,66868 \mathrm{E}-11$ \\
\hline Revistas & $4,71758 \mathrm{E}-10$ & $5,25962 \mathrm{E}-10$ & $1,21606 \mathrm{E}-09$ & $8,68037 \mathrm{E}-10$ & $4,57857 \mathrm{E}-10$ & $2,81908 \mathrm{E}-10$ & $5,23522 \mathrm{E}-09$ & 1,137E-06 & $7,46239 \mathrm{E}-09$ & $2,9338 \mathrm{E}-09$ & $9,99395 \mathrm{E}-10$ \\
\hline Químicos & 9,4954E-09 & $6,60439 \mathrm{E}-09$ & $2,20653 \mathrm{E}-09$ & $1,23555 \mathrm{E}-09$ & $6,79159 \mathrm{E}-10$ & $1,25896 \mathrm{E}-09$ & $5,72573 \mathrm{E}-09$ & $3,81756 \mathrm{E}-11$ & $2,4573 \mathrm{E}-07$ & 3,33738E-09 & $3,12549 \mathrm{E}-10$ \\
\hline Borracha & $1,02926 \mathrm{E}-09$ & $6,59578 \mathrm{E}-10$ & $8,47057 \mathrm{E}-09$ & $1,82801 \mathrm{E}-09$ & 2,40571E-09 & 4,47677E-09 & $1,11645 \mathrm{E}-08$ & $1,40702 \mathrm{E}-09$ & 3,31449E-09 & $9,40253 \mathrm{E}-07$ & $1,12673 \mathrm{E}-10$ \\
\hline Cimento & $2,12745 \mathrm{E}-10$ & $1,08615 \mathrm{E}-10$ & $2,50985 \mathrm{E}-10$ & $3,63518 \mathrm{E}-10$ & $9,56686 \mathrm{E}-11$ & $4,15518 \mathrm{E}-11$ & $3,25061 \mathrm{E}-10$ & $3,40871 \mathrm{E}-11$ & $1,33721 \mathrm{E}-09$ & $9,95593 \mathrm{E}-11$ & $2,1155 \mathrm{E}-07$ \\
\hline Aço & $3,42801 \mathrm{E}-10$ & $1,65204 \mathrm{E}-10$ & $1,79233 \mathrm{E}-09$ & $1,88509 \mathrm{E}-10$ & $1,04063 \mathrm{E}-10$ & $9,14862 \mathrm{E}-10$ & $1,81074 \mathrm{E}-09$ & $1,56371 \mathrm{E}-11$ & $4,76547 \mathrm{E}-10$ & 2,63068E-09 & $1,83423 \mathrm{E}-10$ \\
\hline Metal & 4,08974E-09 & 2,88179E-09 & $1,3252 \mathrm{E}-08$ & $7,11361 \mathrm{E}-09$ & $1,14267 \mathrm{E}-09$ & $6,9084 \mathrm{E}-09$ & $1,23499 \mathrm{E}-08$ & $7,66443 \mathrm{E}-11$ & $6,00572 \mathrm{E}-09$ & $6,82487 \mathrm{E}-09$ & $1,07864 \mathrm{E}-09$ \\
\hline Eletrodomésticos & $1,16669 \mathrm{E}-10$ & $7,96086 \mathrm{E}-11$ & 4,74487E-09 & $1,33832 \mathrm{E}-10$ & $1,2215 \mathrm{E}-09$ & 2,10498E-09 & $9,0081 \mathrm{E}-09$ & $3,59515 \mathrm{E}-11$ & $6,70881 \mathrm{E}-10$ & $9,08613 \mathrm{E}-10$ & $7,03159 \mathrm{E}-11$ \\
\hline Informática & $3,93631 \mathrm{E}-13$ & $3,13174 \mathrm{E}-13$ & $2,65588 \mathrm{E}-12$ & $4,3111 \mathrm{E}-13$ & $2,2316 \mathrm{E}-12$ & $1,17647 \mathrm{E}-12$ & $1,28912 \mathrm{E}-11$ & $1,61824 \mathrm{E}-12$ & $5,71385 \mathrm{E}-12$ & $6,06514 \mathrm{E}-12$ & $3,17173 \mathrm{E}-13$ \\
\hline Máquinas & $1,17162 \mathrm{E}-10$ & $2,12932 \mathrm{E}-10$ & 3,53213E-09 & $3,96091 \mathrm{E}-10$ & $3,95091 \mathrm{E}-10$ & $8,28682 \mathrm{E}-10$ & $8,23239 \mathrm{E}-10$ & $5,14436 \mathrm{E}-11$ & $9,94395 \mathrm{E}-10$ & 2,98319E-09 & 7,37252E-10 \\
\hline Eletrônicos & $1,90922 \mathrm{E}-12$ & $2,16589 \mathrm{E}-12$ & $2,18135 \mathrm{E}-10$ & $4,34065 \mathrm{E}-12$ & $4,3716 \mathrm{E}-12$ & $7,14625 \mathrm{E}-12$ & $1,45612 \mathrm{E}-11$ & $2,50785 \mathrm{E}-12$ & $9,07691 \mathrm{E}-12$ & $1,78433 \mathrm{E}-11$ & $4,86133 \mathrm{E}-12$ \\
\hline Instrumento hospitalar & $3,37083 \mathrm{E}-12$ & $3,71384 \mathrm{E}-12$ & $1,6647 \mathrm{E}-11$ & $4,9096 \mathrm{E}-12$ & $6,52925 \mathrm{E}-12$ & $6,98042 \mathrm{E}-12$ & $3,82934 \mathrm{E}-11$ & $7,46494 \mathrm{E}-12$ & $4,05425 \mathrm{E}-11$ & 7,79863E-11 & $5,99471 \mathrm{E}-12$ \\
\hline Veículos & $4,53735 \mathrm{E}-11$ & $3,71294 \mathrm{E}-11$ & $2,68715 \mathrm{E}-10$ & $8,62144 \mathrm{E}-11$ & $4,6341 \mathrm{E}-11$ & $1,1177 \mathrm{E}-10$ & $2,1809 \mathrm{E}-10$ & $1,42439 \mathrm{E}-11$ & $1,0277 \mathrm{E}-10$ & $2,25832 \mathrm{E}-10$ & $4,07369 \mathrm{E}-11$ \\
\hline Indústria Diversa & 4,39914E-11 & $4,07787 \mathrm{E}-10$ & $1,18749 \mathrm{E}-10$ & $2,76319 \mathrm{E}-10$ & 4,34084E-09 & $1,28032 \mathrm{E}-10$ & $2,35201 \mathrm{E}-09$ & $5,11819 \mathrm{E}-11$ & $1,16913 \mathrm{E}-10$ & $8,35432 \mathrm{E}-10$ & $1,11727 \mathrm{E}-10$ \\
\hline SIUP & $4,7618 \mathrm{E}-10$ & $7,3496 \mathrm{E}-10$ & $1,91082 \mathrm{E}-09$ & $1,17703 \mathrm{E}-09$ & $9,63191 \mathrm{E}-10$ & $1,00058 \mathrm{E}-09$ & $2,95479 \mathrm{E}-09$ & $7,83933 \mathrm{E}-10$ & $1,42734 \mathrm{E}-09$ & $1,47599 \mathrm{E}-09$ & 3,89257E-09 \\
\hline Construção & $1,11797 \mathrm{E}-10$ & $1,58814 \mathrm{E}-10$ & $2,87379 \mathrm{E}-10$ & $3,68756 \mathrm{E}-10$ & $3,31263 \mathrm{E}-10$ & $2,9262 \mathrm{E}-10$ & $5,26832 \mathrm{E}-10$ & $4,17022 \mathrm{E}-10$ & $5,90239 \mathrm{E}-10$ & $9,58593 \mathrm{E}-10$ & $1,30734 \mathrm{E}-09$ \\
\hline Comércio & $8,71285 \mathrm{E}-08$ & $1,28571 \mathrm{E}-07$ & $7,66288 \mathrm{E}-08$ & $1,37862 \mathrm{E}-07$ & $1,4481 \mathrm{E}-07$ & $5,91397 \mathrm{E}-08$ & $7,56582 \mathrm{E}-08$ & $7,83502 \mathrm{E}-08$ & $1,07517 \mathrm{E}-07$ & $8,37949 \mathrm{E}-08$ & $1,3446 \mathrm{E}-07$ \\
\hline Transportes & $1,63064 \mathrm{E}-08$ & $1,4837 \mathrm{E}-08$ & $4,35871 \mathrm{E}-08$ & 2,78116E-08 & $1,29265 \mathrm{E}-08$ & $1,39955 \mathrm{E}-08$ & $2,37092 \mathrm{E}-08$ & $1,36305 \mathrm{E}-08$ & $2,57817 \mathrm{E}-08$ & $1,6859 \mathrm{E}-08$ & $5,22547 \mathrm{E}-08$ \\
\hline Informação & $3,84496 \mathrm{E}-10$ & $5,96064 \mathrm{E}-10$ & $1,75411 \mathrm{E}-09$ & $7,49075 \mathrm{E}-10$ & $4,29227 \mathrm{E}-10$ & $3,17537 \mathrm{E}-10$ & $7,3309 \mathrm{E}-10$ & $1,76382 \mathrm{E}-09$ & 2,27114E-09 & $1,01283 \mathrm{E}-09$ & $1,37447 \mathrm{E}-09$ \\
\hline
\end{tabular}




\begin{tabular}{|c|c|c|c|c|c|c|c|c|c|c|c|}
\hline Financeiro & $2,52546 \mathrm{E}-10$ & $2,80036 \mathrm{E}-10$ & $5,65896 \mathrm{E}-10$ & $4,81919 \mathrm{E}-10$ & $3,85345 \mathrm{E}-10$ & $3,57222 \mathrm{E}-10$ & 7,79141E-10 & $4,41919 \mathrm{E}-10$ & $7,67239 \mathrm{E}-10$ & $5,57283 \mathrm{E}-10$ & $8,96139 \mathrm{E}-10$ \\
\hline Imobiliário & $3,50413 \mathrm{E}-10$ & $4,48761 \mathrm{E}-10$ & $1,06312 \mathrm{E}-09$ & $8,96812 \mathrm{E}-10$ & $9,99166 \mathrm{E}-10$ & $3,99891 \mathrm{E}-10$ & $8,83491 \mathrm{E}-10$ & $1,39208 \mathrm{E}-09$ & $1,19176 \mathrm{E}-09$ & $7,43052 \mathrm{E}-10$ & $1,2948 \mathrm{E}-09$ \\
\hline Alojamento & $4,02957 \mathrm{E}-10$ & $5,68365 \mathrm{E}-10$ & 3,67366E-09 & $9,99894 \mathrm{E}-10$ & $5,8301 \mathrm{E}-10$ & $1,16948 \mathrm{E}-09$ & $1,19184 \mathrm{E}-09$ & $1,57994 \mathrm{E}-09$ & $1,32417 \mathrm{E}-09$ & $1,17623 \mathrm{E}-09$ & $6,46533 \mathrm{E}-09$ \\
\hline Serviços às Empresas & $7,94618 \mathrm{E}-09$ & $1,14238 \mathrm{E}-08$ & $2,20265 \mathrm{E}-08$ & $2,68816 \mathrm{E}-08$ & $1,7637 \mathrm{E}-08$ & $9,37836 \mathrm{E}-09$ & $2,27444 \mathrm{E}-08$ & $6,1979 \mathrm{E}-08$ & $7,00901 \mathrm{E}-08$ & $1,89666 \mathrm{E}-08$ & $4,40258 \mathrm{E}-08$ \\
\hline Educação e Saúde mercantis & $2,35624 \mathrm{E}-10$ & $3,25777 \mathrm{E}-10$ & $4,79422 \mathrm{E}-10$ & $4,91056 \mathrm{E}-10$ & $5,99532 \mathrm{E}-10$ & $2,20152 \mathrm{E}-10$ & $4,31006 \mathrm{E}-10$ & $5,25503 \mathrm{E}-10$ & $5,27969 \mathrm{E}-10$ & $3,77867 \mathrm{E}-10$ & $5,44397 \mathrm{E}-10$ \\
\hline Outros Serviços & $1,99371 \mathrm{E}-09$ & 2,88933E-09 & $3,01014 \mathrm{E}-09$ & $3,8116 \mathrm{E}-09$ & 4,09745E-09 & $1,51062 \mathrm{E}-09$ & $2,5048 \mathrm{E}-09$ & $2,94443 \mathrm{E}-09$ & $4,06035 \mathrm{E}-09$ & $2,96479 \mathrm{E}-09$ & 4,72929E-09 \\
\hline APU & $2,77304 \mathrm{E}-11$ & $3,30856 \mathrm{E}-11$ & $6,64227 \mathrm{E}-11$ & $6,13395 \mathrm{E}-11$ & $3,86584 \mathrm{E}-11$ & $2,60864 \mathrm{E}-11$ & $6,33332 \mathrm{E}-11$ & $1,17214 \mathrm{E}-10$ & $1,06028 \mathrm{E}-10$ & $4,4979 \mathrm{E}-11$ & $1,01288 \mathrm{E}-10$ \\
\hline
\end{tabular}

Tabela B6 - Matriz Geração de Emprego para o Grau de Instrução G(5), Distrito Federal - 2008.

(2)

\begin{tabular}{|c|c|c|c|c|c|c|c|c|c|c|}
\hline Setores & Aço & Metal & Eletrodomésticos & Informática & Máquinas & Eletrônicos & $\begin{array}{l}\text { Instrumento } \\
\text { hospitalar }\end{array}$ & Veículos & $\begin{array}{l}\text { Indústria } \\
\text { Diversa }\end{array}$ & SIUP \\
\hline Agricultura & $2,63406 \mathrm{E}-11$ & $1,45231 \mathrm{E}-11$ & $5,21464 \mathrm{E}-11$ & $4,96763 \mathrm{E}-11$ & $2,96262 \mathrm{E}-11$ & $6,78229 \mathrm{E}-11$ & $1,80206 \mathrm{E}-11$ & $1,03468 \mathrm{E}-10$ & $4,04864 \mathrm{E}-11$ & $7,33852 \mathrm{E}-12$ \\
\hline Pecuária & $7,54676 \mathrm{E}-12$ & $3,72794 \mathrm{E}-12$ & $9,21449 \mathrm{E}-12$ & $9,967 \mathrm{E}-12$ & $7,90442 \mathrm{E}-12$ & $1,03421 \mathrm{E}-11$ & $4,26218 \mathrm{E}-12$ & $1,64976 \mathrm{E}-11$ & $8,83718 \mathrm{E}-11$ & $2,42389 \mathrm{E}-12$ \\
\hline Extrativa & $1,84617 \mathrm{E}-08$ & 1,09072E-09 & 3,46151E-09 & $2,63835 \mathrm{E}-10$ & $1,04967 \mathrm{E}-09$ & $5,89897 \mathrm{E}-10$ & $9,82893 \mathrm{E}-11$ & $1,97445 \mathrm{E}-09$ & $6,05248 \mathrm{E}-10$ & $9,26534 \mathrm{E}-12$ \\
\hline Alimentos & $2,91512 \mathrm{E}-10$ & $1,37054 \mathrm{E}-10$ & $2,83722 \mathrm{E}-10$ & $3,17407 \mathrm{E}-10$ & $2,85853 \mathrm{E}-10$ & $3,10497 \mathrm{E}-10$ & $1,50528 \mathrm{E}-10$ & $3,83886 \mathrm{E}-10$ & $2,73092 \mathrm{E}-10$ & $9,15071 \mathrm{E}-11$ \\
\hline Vestuário & $1,27114 \mathrm{E}-10$ & $1,94522 \mathrm{E}-10$ & 1,06764E-09 & $1,48486 \mathrm{E}-10$ & $1,2471 \mathrm{E}-10$ & $1,69064 \mathrm{E}-10$ & $1,88194 \mathrm{E}-10$ & $9,15809 \mathrm{E}-10$ & $1,28548 \mathrm{E}-10$ & $1,28701 \mathrm{E}-10$ \\
\hline Madeira & $3,5709 \mathrm{E}-10$ & $5,27432 \mathrm{E}-10$ & $1,05235 \mathrm{E}-08$ & 9,68136E-09 & $4,6537 \mathrm{E}-10$ & $4,30583 \mathrm{E}-08$ & $1,27362 \mathrm{E}-10$ & $6,59635 \mathrm{E}-09$ & $1,42197 \mathrm{E}-08$ & $1,72357 \mathrm{E}-11$ \\
\hline Celulose & $4,59473 \mathrm{E}-10$ & $1,11024 \mathrm{E}-10$ & $8,47278 \mathrm{E}-09$ & 4,58129E-09 & $8,26758 \mathrm{E}-10$ & $9,04492 \mathrm{E}-09$ & $1,93464 \mathrm{E}-10$ & 4,63363E-09 & $4,45789 \mathrm{E}-10$ & $3,89046 \mathrm{E}-11$ \\
\hline Revistas & $1,43198 \mathrm{E}-09$ & 1,40915E-09 & $8,63025 \mathrm{E}-10$ & 1,62883E-09 & $7,35323 \mathrm{E}-10$ & $1,36757 \mathrm{E}-09$ & 6,75781E-09 & $1,60775 \mathrm{E}-09$ & $4,80399 \mathrm{E}-10$ & 2,01437E-09 \\
\hline Químicos & 2,94223E-09 & $5,12926 \mathrm{E}-10$ & 2,71593E-09 & $1,9486 \mathrm{E}-10$ & $8,54755 \mathrm{E}-10$ & $3,43588 \mathrm{E}-10$ & $6,48228 \mathrm{E}-10$ & $1,788 \mathrm{E}-09$ & $3,18106 \mathrm{E}-10$ & $2,15136 \mathrm{E}-10$ \\
\hline Borracha & 5,78517E-09 & $3,31622 \mathrm{E}-09$ & $1,5819 \mathrm{E}-08$ & $1,40945 \mathrm{E}-08$ & $7,27101 \mathrm{E}-09$ & $1,63583 \mathrm{E}-08$ & $4,558 \mathrm{E}-09$ & 3,78964E-08 & 5,99772E-09 & $1,43493 \mathrm{E}-10$ \\
\hline Cimento & $1,86638 \mathrm{E}-09$ & $5,57017 \mathrm{E}-10$ & 7,23947E-10 & $3,81235 \mathrm{E}-10$ & $1,79348 \mathrm{E}-09$ & $1,39762 \mathrm{E}-09$ & $6,5698 \mathrm{E}-10$ & $1,61455 \mathrm{E}-09$ & 3,75389E-09 & $1,80858 \mathrm{E}-11$ \\
\hline Aço & 4,47421E-07 & $3,6515 \mathrm{E}-09$ & 6,68679E-08 & 4,84231E-09 & $1,31822 \mathrm{E}-08$ & $1,16477 \mathrm{E}-08$ & $1,33205 \mathrm{E}-09$ & 3,68113E-08 & $1,35808 \mathrm{E}-09$ & $4,23344 \mathrm{E}-11$ \\
\hline Metal & 3,25972E-08 & $8,3682 \mathrm{E}-07$ & $5,24753 \mathrm{E}-08$ & $1,96836 \mathrm{E}-08$ & $3,64674 \mathrm{E}-08$ & $3,24738 \mathrm{E}-08$ & $2,23526 \mathrm{E}-08$ & $2,34126 \mathrm{E}-08$ & $1,79975 \mathrm{E}-08$ & $9,15072 \mathrm{E}-11$ \\
\hline Eletrodomésticos & 4,83736E-09 & $5,55884 \mathrm{E}-10$ & $1,85899 \mathrm{E}-06$ & $5,15345 \mathrm{E}-09$ & $2,37847 \mathrm{E}-09$ & $3,47745 \mathrm{E}-09$ & $1,03588 \mathrm{E}-09$ & $2,17862 \mathrm{E}-08$ & 3,60617E-10 & $5,82846 \mathrm{E}-11$ \\
\hline Informática & $1,73663 \mathrm{E}-12$ & $9,36069 \mathrm{E}-13$ & $8,97543 \mathrm{E}-12$ & 3,80186E-07 & $5,5674 \mathrm{E}-12$ & $1,90432 \mathrm{E}-10$ & $1,20806 \mathrm{E}-12$ & $1,17315 \mathrm{E}-11$ & $9,51925 \mathrm{E}-13$ & $1,88972 \mathrm{E}-13$ \\
\hline Máquinas & $1,27203 \mathrm{E}-09$ & 3,47794E-10 & 2,62652E-08 & $6,28562 \mathrm{E}-08$ & $1,028 \mathrm{E}-06$ & $1,1551 \mathrm{E}-07$ & 7,66167E-09 & $1,71744 \mathrm{E}-08$ & 2,56628E-09 & $1,95073 \mathrm{E}-09$ \\
\hline
\end{tabular}




\begin{tabular}{|c|c|c|c|c|c|c|c|c|c|c|}
\hline Eletrônicos & $2,07206 \mathrm{E}-11$ & $1,24257 \mathrm{E}-11$ & $5,23 \mathrm{E}-10$ & $6,11835 \mathrm{E}-08$ & $5,10098 \mathrm{E}-10$ & $3,0155 \mathrm{E}-07$ & $6,0512 \mathrm{E}-11$ & $4,86387 \mathrm{E}-10$ & $2,53369 \mathrm{E}-11$ & $9,83518 \mathrm{E}-12$ \\
\hline Instrumento hospitalar & $1,18942 \mathrm{E}-11$ & $6,53882 \mathrm{E}-12$ & $1,8037 \mathrm{E}-09$ & $2,35817 \mathrm{E}-10$ & $7,00414 \mathrm{E}-10$ & $3,29025 \mathrm{E}-10$ & $5,65856 \mathrm{E}-07$ & $3,01076 \mathrm{E}-10$ & $3,09471 \mathrm{E}-11$ & $6,83652 \mathrm{E}-12$ \\
\hline Veículos & $6,15925 \mathrm{E}-10$ & $3,89118 \mathrm{E}-10$ & 2,77816E-09 & $1,96261 \mathrm{E}-09$ & $2,24211 \mathrm{E}-09$ & $3,5614 \mathrm{E}-09$ & $4,71997 \mathrm{E}-10$ & $9,8175 \mathrm{E}-07$ & $2,80862 \mathrm{E}-10$ & $5,9901 \mathrm{E}-11$ \\
\hline Indústria Diversa & 5,584E-09 & $4,1143 \mathrm{E}-10$ & $1,29782 \mathrm{E}-09$ & $2,45625 \mathrm{E}-10$ & $7,53578 \mathrm{E}-10$ & $3,99696 \mathrm{E}-10$ & $1,06495 \mathrm{E}-10$ & $6,70453 \mathrm{E}-10$ & $1,3992 \mathrm{E}-06$ & $3,48843 \mathrm{E}-11$ \\
\hline SIUP & $3,45858 \mathrm{E}-09$ & $1,68658 \mathrm{E}-09$ & $1,67883 \mathrm{E}-09$ & $1,12415 \mathrm{E}-09$ & $1,97097 \mathrm{E}-09$ & $1,37358 \mathrm{E}-09$ & $1,43648 \mathrm{E}-09$ & $1,47178 \mathrm{E}-09$ & $1,04798 \mathrm{E}-09$ & $1,56587 \mathrm{E}-07$ \\
\hline Construção & $4,07299 \mathrm{E}-10$ & $2,73697 \mathrm{E}-10$ & $5,53615 \mathrm{E}-10$ & $8,14993 \mathrm{E}-10$ & $1,12567 \mathrm{E}-09$ & $1,70095 \mathrm{E}-09$ & $2,58062 \mathrm{E}-10$ & $1,80394 \mathrm{E}-09$ & $3,30751 \mathrm{E}-10$ & $2,55668 \mathrm{E}-10$ \\
\hline Comércio & $7,16365 \mathrm{E}-08$ & $6,27419 \mathrm{E}-08$ & $1,05404 \mathrm{E}-07$ & $2,37274 \mathrm{E}-07$ & $9,39699 \mathrm{E}-08$ & $1,77228 \mathrm{E}-07$ & $9,46537 \mathrm{E}-08$ & $1,35025 \mathrm{E}-07$ & $1,09618 \mathrm{E}-07$ & $2,99189 \mathrm{E}-08$ \\
\hline Transportes & $3,50533 \mathrm{E}-08$ & $2,01149 \mathrm{E}-08$ & $2,76795 \mathrm{E}-08$ & $3,10442 \mathrm{E}-08$ & $2,64819 \mathrm{E}-08$ & $3,85388 \mathrm{E}-08$ & $2,10285 \mathrm{E}-08$ & $2,42622 \mathrm{E}-08$ & $1,30325 \mathrm{E}-08$ & $1,06494 \mathrm{E}-08$ \\
\hline Informação & $1,79299 \mathrm{E}-09$ & 7,97434E-10 & $2,00568 \mathrm{E}-09$ & 2,88336E-09 & $2,46075 \mathrm{E}-09$ & $4,24228 \mathrm{E}-09$ & $1,29945 \mathrm{E}-09$ & 1,60393E-09 & $4,35707 \mathrm{E}-10$ & $1,51725 \mathrm{E}-09$ \\
\hline Financeiro & $9,76252 \mathrm{E}-10$ & $5,7514 \mathrm{E}-10$ & $1,24376 \mathrm{E}-09$ & $8,68648 \mathrm{E}-10$ & $8,88591 \mathrm{E}-10$ & $1,53065 \mathrm{E}-09$ & $6,17739 \mathrm{E}-10$ & $8,53166 \mathrm{E}-10$ & $3,65597 \mathrm{E}-10$ & $3,2876 \mathrm{E}-10$ \\
\hline Imobiliário & $8,39584 \mathrm{E}-10$ & $7,12438 \mathrm{E}-10$ & $1,11014 \mathrm{E}-09$ & 1,1904E-09 & $8,80699 \mathrm{E}-10$ & $1,17758 \mathrm{E}-09$ & $1,03595 \mathrm{E}-09$ & $7,7496 \mathrm{E}-10$ & $6,75664 \mathrm{E}-10$ & $6,07937 \mathrm{E}-10$ \\
\hline Alojamento & $1,71195 \mathrm{E}-09$ & $6,52511 \mathrm{E}-10$ & $9,4262 \mathrm{E}-10$ & $1,36311 \mathrm{E}-09$ & $2,02267 \mathrm{E}-09$ & 1,36194E-09 & $5,86112 \mathrm{E}-10$ & $1,8084 \mathrm{E}-09$ & $1,21801 \mathrm{E}-09$ & $5,00613 \mathrm{E}-10$ \\
\hline Serviços às Empresas & $1,84291 \mathrm{E}-08$ & $1,79589 \mathrm{E}-08$ & $2,15237 \mathrm{E}-08$ & $9,62805 \mathrm{E}-08$ & $3,06913 \mathrm{E}-08$ & 6,78607E-08 & $2,46468 \mathrm{E}-08$ & $4,12199 \mathrm{E}-08$ & $1,41803 \mathrm{E}-08$ & $5,23478 \mathrm{E}-08$ \\
\hline Educação e Saúde mercantis & $3,578 \mathrm{E}-10$ & $3,61528 \mathrm{E}-10$ & $5,3088 \mathrm{E}-10$ & $7,39714 \mathrm{E}-10$ & $4,54804 \mathrm{E}-10$ & $6,79444 \mathrm{E}-10$ & $4,52321 \mathrm{E}-10$ & $4,58571 \mathrm{E}-10$ & $4,15093 \mathrm{E}-10$ & $2,84661 \mathrm{E}-10$ \\
\hline Outros Serviços & $2,79615 \mathrm{E}-09$ & $2,54425 \mathrm{E}-09$ & 3,73629E-09 & 7,33963E-09 & $5,33398 \mathrm{E}-09$ & $6,76818 \mathrm{E}-09$ & $3,03572 \mathrm{E}-09$ & $3,95235 \mathrm{E}-09$ & 3,11654E-09 & 2,97317E-09 \\
\hline APU & $6,44916 \mathrm{E}-11$ & $4,4341 \mathrm{E}-11$ & $5,21689 \mathrm{E}-11$ & $1,34061 \mathrm{E}-10$ & $5,80404 \mathrm{E}-11$ & $1,06504 \mathrm{E}-10$ & $5,16406 \mathrm{E}-11$ & 7,19887E-11 & $3,33106 \mathrm{E}-11$ & $1,19664 \mathrm{E}-10$ \\
\hline
\end{tabular}

Tabela B6 - Matriz Geração de Emprego para o Grau de Instrução G(5), Distrito Federal - 2008.

(3)

\begin{tabular}{|c|c|c|c|c|c|c|c|c|c|c|c|}
\hline Setores & Construçãa & Comércio & Transportes & Informação & Financeiro & Imobiliário & Alojamento & $\begin{array}{c}\text { Serviços às } \\
\text { Empresas }\end{array}$ & $\begin{array}{l}\text { Educação e } \\
\text { Saúde } \\
\text { mercantis }\end{array}$ & $\begin{array}{c}\text { Outros } \\
\text { Serviços }\end{array}$ & APU \\
\hline Agricultura & $2,10564 \mathrm{E}-11$ & $6,53287 \mathrm{E}-11$ & $4,9417 \mathrm{E}-11$ & $2,99758 \mathrm{E}-11$ & $1,941 \mathrm{E}-11$ & $4,1138 \mathrm{E}-12$ & $6,57216 \mathrm{E}-09$ & $2,97624 \mathrm{E}-11$ & $1,56683 \mathrm{E}-10$ & $6,76854 \mathrm{E}-10$ & $8,36509 \mathrm{E}-11$ \\
\hline Pecuária & $7,28696 \mathrm{E}-12$ & $2,14154 \mathrm{E}-11$ & $1,90672 \mathrm{E}-11$ & $9,43757 \mathrm{E}-12$ & $7,22501 \mathrm{E}-12$ & $1,22176 \mathrm{E}-12$ & 2,82034E-09 & $9,4374 \mathrm{E}-12$ & $6,27712 \mathrm{E}-11$ & $3,06453 \mathrm{E}-10$ & $2,93978 \mathrm{E}-11$ \\
\hline Extrativa & $4,81855 \mathrm{E}-11$ & $2,51184 \mathrm{E}-11$ & $1,54799 \mathrm{E}-11$ & $2,90884 \mathrm{E}-11$ & $8,68109 \mathrm{E}-12$ & $4,80696 \mathrm{E}-12$ & $2,28393 \mathrm{E}-11$ & $2,32111 \mathrm{E}-11$ & $2,28381 \mathrm{E}-11$ & $2,15516 \mathrm{E}-11$ & $2,36652 \mathrm{E}-11$ \\
\hline Alimentos & $3,58618 \mathrm{E}-10$ & $1,11432 \mathrm{E}-09$ & $9,8425 \mathrm{E}-10$ & $3,90033 \mathrm{E}-10$ & $3,20679 \mathrm{E}-10$ & $5,40384 \mathrm{E}-11$ & $1,40379 \mathrm{E}-07$ & $3,74104 \mathrm{E}-10$ & 2,2787E-09 & $5,22113 \mathrm{E}-09$ & $1,04082 \mathrm{E}-09$ \\
\hline Vestuário & 7,98917E-11 & $1,79042 \mathrm{E}-10$ & $3,75398 \mathrm{E}-10$ & $1,7481 \mathrm{E}-10$ & $1,43054 \mathrm{E}-10$ & $1,89289 \mathrm{E}-11$ & $2,07707 \mathrm{E}-10$ & $5,119 \mathrm{E}-10$ & $3,30007 \mathrm{E}-10$ & $7,38049 \mathrm{E}-10$ & $1,43776 \mathrm{E}-10$ \\
\hline Madeira & $1,61627 \mathrm{E}-10$ & $5,73478 \mathrm{E}-11$ & $3,84668 \mathrm{E}-11$ & $7,61132 \mathrm{E}-11$ & $4,30329 \mathrm{E}-11$ & $5,62101 \mathrm{E}-11$ & $4,69304 \mathrm{E}-11$ & $6,33017 \mathrm{E}-11$ & $8,40528 \mathrm{E}-11$ & $8,87107 \mathrm{E}-11$ & $1,26883 \mathrm{E}-10$ \\
\hline
\end{tabular}




\begin{tabular}{|c|c|c|c|c|c|c|c|c|c|c|c|}
\hline Celulose & $2,81745 \mathrm{E}-11$ & $1,12998 \mathrm{E}-10$ & $7,14295 \mathrm{E}-11$ & $1,4381 \mathrm{E}-10$ & $4,8701 \mathrm{E}-11$ & $1,89543 \mathrm{E}-11$ & $7,07662 \mathrm{E}-11$ & $1,88085 \mathrm{E}-10$ & $1,00673 \mathrm{E}-10$ & $9,50034 \mathrm{E}-11$ & $9,46484 \mathrm{E}-11$ \\
\hline Revistas & $5,35572 \mathrm{E}-10$ & $1,92806 \mathrm{E}-09$ & $1,62492 \mathrm{E}-09$ & 4,50292E-09 & 2,3316E-09 & $5,06765 \mathrm{E}-10$ & $5,33561 \mathrm{E}-10$ & $1,43127 \mathrm{E}-08$ & 2,33645E-09 & 2,47359E-09 & 1,35952E-09 \\
\hline Químicos & 2,91191E-11 & $1,54137 \mathrm{E}-11$ & $1,08871 \mathrm{E}-11$ & $2,8362 \mathrm{E}-11$ & $6,47887 \mathrm{E}-12$ & $4,2219 \mathrm{E}-12$ & $2,11473 \mathrm{E}-10$ & $1,76285 \mathrm{E}-11$ & $2,02496 \mathrm{E}-10$ & $3,97139 \mathrm{E}-11$ & $3,06168 \mathrm{E}-11$ \\
\hline Borracha & $5,94956 \mathrm{E}-10$ & $2,37203 \mathrm{E}-10$ & $1,99566 \mathrm{E}-10$ & $4,87344 \mathrm{E}-10$ & 7,79573E-11 & $4,4487 \mathrm{E}-11$ & $3,23682 \mathrm{E}-10$ & $7,06257 \mathrm{E}-10$ & $6,16852 \mathrm{E}-10$ & $1,96821 \mathrm{E}-10$ & $9,36756 \mathrm{E}-11$ \\
\hline Cimento & 7,61086E-09 & $2,72432 \mathrm{E}-11$ & $1,17031 \mathrm{E}-11$ & $3,37176 \mathrm{E}-11$ & $3,15266 \mathrm{E}-11$ & $6,7309 \mathrm{E}-11$ & $5,31085 \mathrm{E}-11$ & $2,53316 \mathrm{E}-11$ & $2,5123 \mathrm{E}-10$ & $1,32452 \mathrm{E}-10$ & $1,2576 \mathrm{E}-10$ \\
\hline Aço & $1,24452 \mathrm{E}-10$ & $1,82467 \mathrm{E}-11$ & $1,4294 \mathrm{E}-11$ & $2,50193 \mathrm{E}-11$ & $7,17624 \mathrm{E}-12$ & $6,7162 \mathrm{E}-12$ & $3,3782 \mathrm{E}-11$ & $1,75067 \mathrm{E}-11$ & $2,11437 \mathrm{E}-11$ & $2,36486 \mathrm{E}-11$ & $1,69306 \mathrm{E}-11$ \\
\hline Metal & 2,24935E-09 & $2,17158 \mathrm{E}-10$ & $5,09604 \mathrm{E}-11$ & $1,18489 \mathrm{E}-10$ & $3,47486 \mathrm{E}-11$ & $8,49665 \mathrm{E}-11$ & $9,60842 \mathrm{E}-10$ & $6,04632 \mathrm{E}-11$ & $2,27823 \mathrm{E}-10$ & $1,44852 \mathrm{E}-10$ & $1,51175 \mathrm{E}-10$ \\
\hline Eletrodomésticos & $7,23188 \mathrm{E}-11$ & $6,92377 \mathrm{E}-11$ & $4,71163 \mathrm{E}-11$ & $8,72803 \mathrm{E}-11$ & $2,42653 \mathrm{E}-11$ & $1,82257 \mathrm{E}-11$ & $5,56236 \mathrm{E}-11$ & $6,82786 \mathrm{E}-11$ & $6,47165 \mathrm{E}-11$ & $6,54531 \mathrm{E}-11$ & $6,62805 \mathrm{E}-11$ \\
\hline Informática & 7,58733E-13 & $6,30622 \mathrm{E}-13$ & $3,2727 \mathrm{E}-13$ & $1,21121 \mathrm{E}-12$ & $4,0798 \mathrm{E}-13$ & $5,60071 \mathrm{E}-13$ & $3,35137 \mathrm{E}-13$ & $7,22602 \mathrm{E}-13$ & $8,88861 \mathrm{E}-13$ & $7,18295 \mathrm{E}-13$ & $1,2485 \mathrm{E}-12$ \\
\hline Máquinas & $5,35494 \mathrm{E}-10$ & $1,12939 \mathrm{E}-10$ & $3,32389 \mathrm{E}-10$ & $4,84449 \mathrm{E}-10$ & $6,04476 \mathrm{E}-11$ & $1,3135 \mathrm{E}-10$ & $8,96393 \mathrm{E}-11$ & $1,68648 \mathrm{E}-10$ & $1,50103 \mathrm{E}-10$ & $5,34397 \mathrm{E}-10$ & $9,51533 \mathrm{E}-11$ \\
\hline Eletrônicos & $3,60721 \mathrm{E}-12$ & $2,38932 \mathrm{E}-12$ & $2,97518 \mathrm{E}-12$ & $5,06028 \mathrm{E}-12$ & $1,11842 \mathrm{E}-12$ & $1,38783 \mathrm{E}-12$ & $1,73835 \mathrm{E}-12$ & $3,39723 \mathrm{E}-12$ & $2,32989 \mathrm{E}-12$ & $4,24892 \mathrm{E}-12$ & $2,21221 \mathrm{E}-12$ \\
\hline Instrumento hospitalar & $3,83125 \mathrm{E}-11$ & $2,31534 \mathrm{E}-11$ & $7,34294 \mathrm{E}-12$ & $9,54703 \mathrm{E}-12$ & $5,38005 \mathrm{E}-12$ & $4,3645 \mathrm{E}-11$ & $4,67097 \mathrm{E}-12$ & $6,21277 \mathrm{E}-11$ & $6,44909 \mathrm{E}-11$ & 4,91336E-11 & $1,33628 \mathrm{E}-11$ \\
\hline Veículos & $4,78942 \mathrm{E}-11$ & $2,65433 \mathrm{E}-11$ & $2,32476 \mathrm{E}-11$ & $4,02334 \mathrm{E}-11$ & $1,05209 \mathrm{E}-11$ & $1,01078 \mathrm{E}-11$ & $2,48539 \mathrm{E}-11$ & $2,70531 \mathrm{E}-11$ & $2,63117 \mathrm{E}-11$ & $3,51713 \mathrm{E}-11$ & $2,6389 \mathrm{E}-11$ \\
\hline Indústria Diversa & $4,60238 \mathrm{E}-10$ & $6,2721 \mathrm{E}-11$ & $3,94438 \mathrm{E}-10$ & 7,73983E-11 & $6,97068 \mathrm{E}-10$ & $1,74294 \mathrm{E}-10$ & $7,69929 \mathrm{E}-11$ & $2,54966 \mathrm{E}-10$ & $2,52623 \mathrm{E}-10$ & $1,27461 \mathrm{E}-09$ & $2,78464 \mathrm{E}-10$ \\
\hline SIUP & $3,42177 \mathrm{E}-10$ & 1,17243E-09 & $9,72227 \mathrm{E}-10$ & $9,13643 \mathrm{E}-10$ & $5,51341 \mathrm{E}-10$ & $1,16132 \mathrm{E}-10$ & $1,18519 \mathrm{E}-09$ & $1,02892 \mathrm{E}-09$ & $1,51495 \mathrm{E}-09$ & 3,40857E-09 & $1,30485 \mathrm{E}-09$ \\
\hline Construção & $6,09821 \mathrm{E}-07$ & $6,97865 \mathrm{E}-10$ & $5,42485 \mathrm{E}-10$ & $2,2223 \mathrm{E}-09$ & $2,19869 \mathrm{E}-09$ & $5,25652 \mathrm{E}-09$ & $3,73495 \mathrm{E}-10$ & $1,56603 \mathrm{E}-09$ & 4,69411E-09 & $4,05225 \mathrm{E}-09$ & $9,16661 \mathrm{E}-09$ \\
\hline Comércio & $9,81804 \mathrm{E}-08$ & $1,84412 \mathrm{E}-06$ & $8,17665 \mathrm{E}-08$ & $4,06291 \mathrm{E}-08$ & $2,42899 \mathrm{E}-08$ & $1,07198 \mathrm{E}-08$ & $1,88224 \mathrm{E}-07$ & 7,04341E-08 & $6,2676 \mathrm{E}-08$ & $6,77683 \mathrm{E}-08$ & $3,59165 \mathrm{E}-08$ \\
\hline Transportes & $9,97185 \mathrm{E}-09$ & $2,62366 \mathrm{E}-08$ & $8,01352 \mathrm{E}-07$ & $1,77978 \mathrm{E}-08$ & 7,48393E-09 & $1,33115 \mathrm{E}-09$ & $1,20094 \mathrm{E}-08$ & $1,41391 \mathrm{E}-08$ & $1,27051 \mathrm{E}-08$ & $1,87798 \mathrm{E}-08$ & 6,82107E-09 \\
\hline Informação & $4,96597 \mathrm{E}-10$ & $1,56518 \mathrm{E}-09$ & $1,63638 \mathrm{E}-09$ & $1,17164 \mathrm{E}-07$ & 4,77419E-09 & $3,22785 \mathrm{E}-10$ & $7,81878 \mathrm{E}-10$ & $1,26904 \mathrm{E}-08$ & $4,36408 \mathrm{E}-09$ & $2,85783 \mathrm{E}-09$ & $5,29112 \mathrm{E}-09$ \\
\hline Financeiro & $2,6472 \mathrm{E}-10$ & $5,25418 \mathrm{E}-10$ & $7,26528 \mathrm{E}-10$ & $7,39596 \mathrm{E}-10$ & $2,09787 \mathrm{E}-08$ & $1,06883 \mathrm{E}-10$ & $2,73268 \mathrm{E}-10$ & $6,99987 \mathrm{E}-10$ & $3,0905 \mathrm{E}-10$ & $1,72013 \mathrm{E}-10$ & $1,63696 \mathrm{E}-09$ \\
\hline Imobiliário & $5,00516 \mathrm{E}-10$ & 2,51969E-09 & 4,49038E-09 & $4,06805 \mathrm{E}-09$ & $1,29035 \mathrm{E}-09$ & $1,19637 \mathrm{E}-07$ & $1,55049 \mathrm{E}-09$ & $2,93658 \mathrm{E}-09$ & $3,05474 \mathrm{E}-09$ & 2,189E-09 & 2,31044E-09 \\
\hline Alojamento & $1,71031 \mathrm{E}-09$ & 2,37676E-09 & 4,6277E-09 & $3,1208 \mathrm{E}-09$ & $3,00142 \mathrm{E}-09$ & $3,31177 \mathrm{E}-10$ & $1,83589 \mathrm{E}-06$ & $2,69245 \mathrm{E}-09$ & $1,42733 \mathrm{E}-08$ & $1,62894 \mathrm{E}-08$ & $8,82266 \mathrm{E}-09$ \\
\hline Serviços às Empresas & $2,12526 \mathrm{E}-08$ & $5,92788 \mathrm{E}-08$ & $6,81176 \mathrm{E}-08$ & $9,70849 \mathrm{E}-08$ & $7,3428 \mathrm{E}-08$ & $1,14751 \mathrm{E}-08$ & $1,87744 \mathrm{E}-08$ & $1,17163 \mathrm{E}-06$ & $9,7731 \mathrm{E}-08$ & $6,21906 \mathrm{E}-08$ & $6,90604 \mathrm{E}-08$ \\
\hline Educação e Saúde mercantis & $3,18142 \mathrm{E}-10$ & $1,13364 \mathrm{E}-09$ & $7,51285 \mathrm{E}-10$ & $1,26584 \mathrm{E}-09$ & $1,30538 \mathrm{E}-09$ & $1,63486 \mathrm{E}-10$ & $9,03821 \mathrm{E}-10$ & $1,07762 \mathrm{E}-09$ & $5,7093 \mathrm{E}-07$ & $8,63772 \mathrm{E}-10$ & 1,78193E-09 \\
\hline Outros Serviços & 2,78126E-09 & 7,35334E-09 & $4,59745 \mathrm{E}-09$ & $8,19457 \mathrm{E}-09$ & 4,20997E-09 & $8,21029 \mathrm{E}-10$ & $8,01869 \mathrm{E}-09$ & $9,79058 \mathrm{E}-09$ & $7,24517 \mathrm{E}-09$ & $1,0312 \mathrm{E}-06$ & $5,19086 \mathrm{E}-09$ \\
\hline APU & $3,42046 \mathrm{E}-11$ & $9,19711 \mathrm{E}-11$ & $9,64841 \mathrm{E}-11$ & $1,24109 \mathrm{E}-10$ & $8,88447 \mathrm{E}-11$ & $1,47077 \mathrm{E}-11$ & 4,35394E-11 & $1,10454 \mathrm{E}-10$ & $1,21228 \mathrm{E}-10$ & $9,36857 \mathrm{E}-11$ & $3,00989 \mathrm{E}-08$ \\
\hline
\end{tabular}


Tabela B7 - Matriz Geração de Emprego para o Grau de Instrução G(6), Distrito Federal - 2008.

(1)

\begin{tabular}{|c|c|c|c|c|c|c|c|c|c|c|c|}
\hline Setores & Agricultura & Pecuária & Extrativa & Alimentos & Vestuário & Madeira & Celulose & Revistas & Químicos & Borracha & Cimento \\
\hline Agricultura & $1,05868 \mathrm{E}-06$ & $6,94586 \mathrm{E}-08$ & $1,15527 \mathrm{E}-10$ & $8,52949 \mathrm{E}-08$ & 1,06701E-09 & $1,67728 \mathrm{E}-09$ & 4,8439E-09 & $4,72503 \mathrm{E}-11$ & $2,12714 \mathrm{E}-10$ & 3,60492E-09 & $8,26855 \mathrm{E}-11$ \\
\hline Pecuária & $5,71719 \mathrm{E}-09$ & $1,46228 \mathrm{E}-06$ & $4,2983 \mathrm{E}-11$ & $5,78436 \mathrm{E}-08$ & $1,20763 \mathrm{E}-09$ & $1,01392 \mathrm{E}-10$ & $3,33127 \mathrm{E}-10$ & $1,6236 \mathrm{E}-11$ & $1,05449 \mathrm{E}-10$ & $4,9209 \mathrm{E}-10$ & $4,01259 \mathrm{E}-11$ \\
\hline Extrativa & $3,11353 \mathrm{E}-10$ & $7,38074 \mathrm{E}-10$ & $4,28952 \mathrm{E}-06$ & $1,75593 \mathrm{E}-10$ & $1,61371 \mathrm{E}-10$ & $2,22164 \mathrm{E}-10$ & $1,71818 \mathrm{E}-09$ & $4,1121 \mathrm{E}-11$ & 2,61143E-09 & $5,55517 \mathrm{E}-10$ & $1,94078 \mathrm{E}-09$ \\
\hline Alimentos & $3,11941 \mathrm{E}-08$ & $4,73695 \mathrm{E}-07$ & $1,63631 \mathrm{E}-09$ & $2,85592 \mathrm{E}-06$ & $2,15487 \mathrm{E}-08$ & 2,23117E-09 & $6,97453 \mathrm{E}-09$ & $6,04929 \mathrm{E}-10$ & 2,6351E-09 & $8,82091 \mathrm{E}-10$ & $1,60018 \mathrm{E}-09$ \\
\hline Vestuário & $1,72378 \mathrm{E}-10$ & $1,5255 \mathrm{E}-10$ & $5,08614 \mathrm{E}-09$ & $2,22337 \mathrm{E}-10$ & $9,12508 \mathrm{E}-06$ & $2,06762 \mathrm{E}-10$ & $7,3032 \mathrm{E}-09$ & $2,34023 \mathrm{E}-10$ & $4,66374 \mathrm{E}-10$ & $1,36667 \mathrm{E}-09$ & $3,2323 \mathrm{E}-10$ \\
\hline Madeira & $6,39632 \mathrm{E}-10$ & $1,25385 \mathrm{E}-10$ & $3,48708 \mathrm{E}-10$ & $1,49627 \mathrm{E}-10$ & $6,22689 \mathrm{E}-10$ & $1,07442 \mathrm{E}-05$ & $6,48222 \mathrm{E}-08$ & $1,07413 \mathrm{E}-10$ & $1,96477 \mathrm{E}-09$ & $5,33379 \mathrm{E}-10$ & $6,06091 \mathrm{E}-10$ \\
\hline Celulose & $1,82503 \mathrm{E}-10$ & $1,99663 \mathrm{E}-10$ & 4,77554E-09 & $2,33258 \mathrm{E}-10$ & $1,10983 \mathrm{E}-08$ & $1,8273 \mathrm{E}-08$ & $7,45794 \mathrm{E}-06$ & $1,16506 \mathrm{E}-09$ & $3,04495 \mathrm{E}-09$ & $8,82068 \mathrm{E}-09$ & $1,54944 \mathrm{E}-10$ \\
\hline Revistas & $1,89484 \mathrm{E}-09$ & $2,11255 \mathrm{E}-09$ & 4,88435E-09 & 3,48651E-09 & $1,839 \mathrm{E}-09$ & $1,1323 \mathrm{E}-09$ & $2,10275 \mathrm{E}-08$ & 4,56682E-06 & $2,9973 \mathrm{E}-08$ & $1,17837 \mathrm{E}-08$ & $4,01412 \mathrm{E}-09$ \\
\hline Químicos & $5,7934 \mathrm{E}-08$ & $4,02951 \mathrm{E}-08$ & $1,34626 \mathrm{E}-08$ & $7,5384 \mathrm{E}-09$ & 4,14373E-09 & $7,68124 \mathrm{E}-09$ & $3,49342 \mathrm{E}-08$ & $2,3292 \mathrm{E}-10$ & $1,49927 \mathrm{E}-06$ & $2,03622 \mathrm{E}-08$ & $1,90694 \mathrm{E}-09$ \\
\hline Borracha & $3,6024 \mathrm{E}-09$ & $2,30852 \mathrm{E}-09$ & $2,9647 \mathrm{E}-08$ & $6,39805 \mathrm{E}-09$ & $8,41999 \mathrm{E}-09$ & $1,56687 \mathrm{E}-08$ & $3,90759 \mathrm{E}-08$ & $4,92458 \mathrm{E}-09$ & $1,16007 \mathrm{E}-08$ & $3,29088 \mathrm{E}-06$ & $3,94356 \mathrm{E}-10$ \\
\hline Cimento & $6,57576 \mathrm{E}-10$ & $3,35718 \mathrm{E}-10$ & $7,75773 \mathrm{E}-10$ & $1,1236 \mathrm{E}-09$ & $2,95703 \mathrm{E}-10$ & $1,28433 \mathrm{E}-10$ & $1,00473 \mathrm{E}-09$ & $1,0536 \mathrm{E}-10$ & 4,13321E-09 & $3,07729 \mathrm{E}-10$ & $6,53883 \mathrm{E}-07$ \\
\hline Aço & $1,17783 \mathrm{E}-09$ & $5,67623 \mathrm{E}-10$ & $6,15826 \mathrm{E}-09$ & $6,47699 \mathrm{E}-10$ & $3,57549 \mathrm{E}-10$ & 3,14337E-09 & $6,22152 \mathrm{E}-09$ & $5,37276 \mathrm{E}-11$ & 1,63736E-09 & $9,03874 \mathrm{E}-09$ & $6,30222 \mathrm{E}-10$ \\
\hline Metal & $9,18016 \mathrm{E}-09$ & $6,4687 \mathrm{E}-09$ & $2,97464 \mathrm{E}-08$ & $1,59678 \mathrm{E}-08$ & 2,56493E-09 & $1,55072 \mathrm{E}-08$ & $2,77217 \mathrm{E}-08$ & $1,72042 \mathrm{E}-10$ & $1,34809 \mathrm{E}-08$ & $1,53197 \mathrm{E}-08$ & $2,4212 \mathrm{E}-09$ \\
\hline Eletrodomésticos & $6,18938 \mathrm{E}-10$ & $4,2233 \mathrm{E}-10$ & $2,5172 \mathrm{E}-08$ & $7,09989 \mathrm{E}-10$ & 6,48017E-09 & $1,11671 \mathrm{E}-08$ & $4,77887 \mathrm{E}-08$ & $1,90726 \mathrm{E}-10$ & $3,55908 \mathrm{E}-09$ & 4,82027E-09 & $3,73032 \mathrm{E}-10$ \\
\hline Informática & $5,1172 \mathrm{E}-12$ & $4,07127 \mathrm{E}-12$ & $3,45265 \mathrm{E}-11$ & $5,60443 \mathrm{E}-12$ & $2,90108 \mathrm{E}-11$ & $1,52941 \mathrm{E}-11$ & $1,67586 \mathrm{E}-10$ & $2,10372 \mathrm{E}-11$ & $7,42801 \mathrm{E}-11$ & $7,88468 \mathrm{E}-11$ & $4,12326 \mathrm{E}-12$ \\
\hline Máquinas & $3,16338 \mathrm{E}-10$ & $5,74918 \mathrm{E}-10$ & $9,53675 \mathrm{E}-09$ & $1,06945 \mathrm{E}-09$ & $1,06675 \mathrm{E}-09$ & 2,23744E-09 & $2,22275 \mathrm{E}-09$ & $1,38898 \mathrm{E}-10$ & $2,68487 \mathrm{E}-09$ & $8,05461 \mathrm{E}-09$ & $1,99058 \mathrm{E}-09$ \\
\hline Eletrônicos & $7,06411 \mathrm{E}-11$ & $8,01378 \mathrm{E}-11$ & $8,07101 \mathrm{E}-09$ & $1,60604 \mathrm{E}-10$ & $1,61749 \mathrm{E}-10$ & $2,64411 \mathrm{E}-10$ & $5,38764 \mathrm{E}-10$ & $9,27903 \mathrm{E}-11$ & $3,35845 \mathrm{E}-10$ & $6,60204 \mathrm{E}-10$ & $1,79869 \mathrm{E}-10$ \\
\hline Instrumento hospitalar & $2,16443 \mathrm{E}-11$ & $2,38468 \mathrm{E}-11$ & $1,06891 \mathrm{E}-10$ & $3,15248 \mathrm{E}-11$ & 4,19247E-11 & $4,48216 \mathrm{E}-11$ & $2,45884 \mathrm{E}-10$ & $4,79327 \mathrm{E}-11$ & $2,60325 \mathrm{E}-10$ & $5,00754 \mathrm{E}-10$ & 3,84924E-11 \\
\hline Veículos & $1,6853 \mathrm{E}-10$ & $1,37909 \mathrm{E}-10$ & $9,98084 \mathrm{E}-10$ & $3,20225 \mathrm{E}-10$ & $1,72124 \mathrm{E}-10$ & $4,15145 \mathrm{E}-10$ & $8,10048 \mathrm{E}-10$ & $5,29058 \mathrm{E}-11$ & $3,81716 \mathrm{E}-10$ & $8,38806 \mathrm{E}-10$ & $1,51309 \mathrm{E}-10$ \\
\hline Indústria Diversa & $1,16333 \mathrm{E}-10$ & $1,07837 \mathrm{E}-09$ & $3,14024 \mathrm{E}-10$ & $7,3071 \mathrm{E}-10$ & $1,14791 \mathrm{E}-08$ & $3,38575 \mathrm{E}-10$ & $6,21975 \mathrm{E}-09$ & $1,35348 \mathrm{E}-10$ & 3,0917E-10 & $2,20925 \mathrm{E}-09$ & $2,95457 \mathrm{E}-10$ \\
\hline SIUP & $4,13535 \mathrm{E}-09$ & $6,3827 \mathrm{E}-09$ & $1,65944 \mathrm{E}-08$ & $1,02218 \mathrm{E}-08$ & $8,36476 \mathrm{E}-09$ & $8,6895 \mathrm{E}-09$ & $2,56607 \mathrm{E}-08$ & 6,80801E-09 & $1,23956 \mathrm{E}-08$ & $1,28182 \mathrm{E}-08$ & $3,38047 \mathrm{E}-08$ \\
\hline Construção & $3,26839 \mathrm{E}-10$ & $4,64292 \mathrm{E}-10$ & $8,40151 \mathrm{E}-10$ & $1,07805 \mathrm{E}-09$ & $9,68445 \mathrm{E}-10$ & $8,55474 \mathrm{E}-10$ & $1,54019 \mathrm{E}-09$ & $1,21916 \mathrm{E}-09$ & $1,72556 \mathrm{E}-09$ & 2,80244E-09 & $3,82201 \mathrm{E}-09$ \\
\hline Comércio & $4,00404 \mathrm{E}-07$ & $5,90854 \mathrm{E}-07$ & $3,52152 \mathrm{E}-07$ & $6,33554 \mathrm{E}-07$ & $6,65483 \mathrm{E}-07$ & $2,7178 \mathrm{E}-07$ & $3,47691 \mathrm{E}-07$ & $3,60063 \mathrm{E}-07$ & 4,94101E-07 & $3,85084 \mathrm{E}-07$ & $6,17919 \mathrm{E}-07$ \\
\hline Transportes & $6,21083 \mathrm{E}-08$ & $5,65115 \mathrm{E}-08$ & $1,66015 \mathrm{E}-07$ & $1,0593 \mathrm{E}-07$ & $4,92346 \mathrm{E}-08$ & $5,33064 \mathrm{E}-08$ & $9,0304 \mathrm{E}-08$ & 5,19161E-08 & 9,81979E-08 & $6,42127 \mathrm{E}-08$ & $1,99029 \mathrm{E}-07$ \\
\hline Informação & 4,38325E-09 & 6,79513E-09 & $1,99968 \mathrm{E}-08$ & $8,53945 \mathrm{E}-09$ & 4,89319E-09 & 3,61992E-09 & $8,35723 \mathrm{E}-09$ & $2,01075 \mathrm{E}-08$ & $2,5891 \mathrm{E}-08$ & $1,15463 \mathrm{E}-08$ & $1,5669 \mathrm{E}-08$ \\
\hline
\end{tabular}




\begin{tabular}{|c|c|c|c|c|c|c|c|c|c|c|c|}
\hline Financeiro & $5,95464 \mathrm{E}-09$ & 6,60281E-09 & $1,33429 \mathrm{E}-08$ & $1,13629 \mathrm{E}-08$ & $9,08581 \mathrm{E}-09$ & $8,42272 \mathrm{E}-09$ & $1,83709 \mathrm{E}-08$ & $1,04197 \mathrm{E}-08$ & $1,80903 \mathrm{E}-08$ & $1,31398 \mathrm{E}-08$ & $2,11295 \mathrm{E}-08$ \\
\hline Imobiliário & 1,33917E-09 & $1,71502 \mathrm{E}-09$ & 4,06291E-09 & 3,42733E-09 & 3,81849E-09 & $1,52825 \mathrm{E}-09$ & 3,37642E-09 & 5,32007E-09 & 4,55452E-09 & 2,83971E-09 & 4,94832E-09 \\
\hline Alojamento & $9,53274 \mathrm{E}-10$ & $1,34458 \mathrm{E}-09$ & 8,69076E-09 & 2,36544E-09 & $1,37922 \mathrm{E}-09$ & 2,76664E-09 & 2,81952E-09 & 3,73764E-09 & $3,13258 \mathrm{E}-09$ & 2,78261E-09 & $1,5295 \mathrm{E}-08$ \\
\hline Serviços às Empresas & $3,50098 \mathrm{E}-08$ & $5,03315 \mathrm{E}-08$ & $9,70456 \mathrm{E}-08$ & $1,18437 \mathrm{E}-07$ & $7,77063 \mathrm{E}-08$ & $4,13198 \mathrm{E}-08$ & $1,00209 \mathrm{E}-07$ & 2,73071E-07 & $3,08807 \mathrm{E}-07$ & $8,35644 \mathrm{E}-08$ & $1,93972 \mathrm{E}-07$ \\
\hline Educação e Saúde mercantis & 2,11943E-09 & $2,93035 \mathrm{E}-09$ & 4,31237E-09 & $4,41702 \mathrm{E}-09$ & $5,39275 \mathrm{E}-09$ & $1,98026 \mathrm{E}-09$ & 3,87687E-09 & $4,72687 \mathrm{E}-09$ & $4,74905 \mathrm{E}-09$ & $3,39889 \mathrm{E}-09$ & 4,89682E-09 \\
\hline Outros Serviços & $5,48668 \mathrm{E}-09$ & 7,95144E-09 & $8,28391 \mathrm{E}-09$ & $1,04895 \mathrm{E}-08$ & $1,12762 \mathrm{E}-08$ & $4,15722 \mathrm{E}-09$ & 6,89322E-09 & $8,10308 \mathrm{E}-09$ & $1,11741 \mathrm{E}-08$ & $8,15909 \mathrm{E}-09$ & $1,3015 \mathrm{E}-08$ \\
\hline APU & $1,50061 \mathrm{E}-09$ & $1,7904 \mathrm{E}-09$ & $3,59441 \mathrm{E}-09$ & $3,31934 \mathrm{E}-09$ & 2,09197E-09 & $1,41165 \mathrm{E}-09$ & $3,42723 \mathrm{E}-09$ & $6,34297 \mathrm{E}-09$ & $5,73765 \mathrm{E}-09$ & $2,434 \mathrm{E}-09$ & $5,48112 \mathrm{E}-09$ \\
\hline
\end{tabular}

Tabela B7 - Matriz Geração de Emprego para o Grau de Instrução G(6), Distrito Federal - 2008.

(2)

\begin{tabular}{|c|c|c|c|c|c|c|c|c|c|c|}
\hline Setores & Aço & Metal & Eletrodomésticos & Informática & Máquinas & Eletrônicos & $\begin{array}{l}\text { Instrumento } \\
\text { hospitalar }\end{array}$ & Veículos & $\begin{array}{l}\text { Indústria } \\
\text { Diversa }\end{array}$ & SIUP \\
\hline Agricultura & $6,22941 \mathrm{E}-11$ & $3,43463 \mathrm{E}-11$ & $1,23323 \mathrm{E}-10$ & $1,17482 \mathrm{E}-10$ & $7,00643 \mathrm{E}-11$ & $1,60397 \mathrm{E}-10$ & $4,26176 \mathrm{E}-11$ & $2,44695 \mathrm{E}-10$ & $9,57481 \mathrm{E}-11$ & $1,73552 \mathrm{E}-11$ \\
\hline Pecuária & $2,20598 \mathrm{E}-11$ & $1,0897 \mathrm{E}-11$ & $2,69347 \mathrm{E}-11$ & $2,91343 \mathrm{E}-11$ & $2,31052 \mathrm{E}-11$ & $3,02309 \mathrm{E}-11$ & $1,24587 \mathrm{E}-11$ & $4,82238 \mathrm{E}-11$ & $2,58318 \mathrm{E}-10$ & $7,08521 \mathrm{E}-12$ \\
\hline Extrativa & 7,22643E-08 & $4,26939 \mathrm{E}-09$ & $1,35493 \mathrm{E}-08$ & $1,03272 \mathrm{E}-09$ & 4,10869E-09 & 2,30903E-09 & $3,84732 \mathrm{E}-10$ & 7,72854E-09 & 2,36911E-09 & $3,62672 \mathrm{E}-11$ \\
\hline Alimentos & $7,17103 \mathrm{E}-10$ & $3,37146 \mathrm{E}-10$ & $6,97939 \mathrm{E}-10$ & $7,80802 \mathrm{E}-10$ & $7,03182 \mathrm{E}-10$ & $7,63805 \mathrm{E}-10$ & $3,7029 \mathrm{E}-10$ & $9,44336 \mathrm{E}-10$ & $6,7179 \mathrm{E}-10$ & $2,25102 \mathrm{E}-10$ \\
\hline Vestuário & $4,29406 \mathrm{E}-10$ & $6,57117 \mathrm{E}-10$ & 3,60662E-09 & $5,01601 \mathrm{E}-10$ & $4,21284 \mathrm{E}-10$ & $5,71116 \mathrm{E}-10$ & $6,3574 \mathrm{E}-10$ & 3,0937E-09 & $4,3425 \mathrm{E}-10$ & $4,34765 \mathrm{E}-10$ \\
\hline Madeira & $4,87639 \mathrm{E}-10$ & $7,20257 \mathrm{E}-10$ & $1,43708 \mathrm{E}-08$ & $1,32208 \mathrm{E}-08$ & $6,35505 \mathrm{E}-10$ & $5,88 \mathrm{E}-08$ & $1,73924 \mathrm{E}-10$ & $9,00792 \mathrm{E}-09$ & $1,94183 \mathrm{E}-08$ & 2,3537E-11 \\
\hline Celulose & $1,25589 \mathrm{E}-09$ & $3,03465 \mathrm{E}-10$ & $2,31589 \mathrm{E}-08$ & $1,25222 \mathrm{E}-08$ & $2,2598 \mathrm{E}-09$ & $2,47228 \mathrm{E}-08$ & $5,28802 \mathrm{E}-10$ & $1,26653 \mathrm{E}-08$ & 1,21849E-09 & $1,06339 \mathrm{E}-10$ \\
\hline Revistas & $5,7516 \mathrm{E}-09$ & $5,65992 \mathrm{E}-09$ & $3,46638 \mathrm{E}-09$ & $6,54229 \mathrm{E}-09$ & $2,95346 \mathrm{E}-09$ & 5,49291E-09 & $2,71431 \mathrm{E}-08$ & $6,4576 \mathrm{E}-09$ & 1,92955E-09 & $8,0908 \mathrm{E}-09$ \\
\hline Químicos & $1,79513 \mathrm{E}-08$ & 3,1295E-09 & $1,65706 \mathrm{E}-08$ & $1,18889 \mathrm{E}-09$ & $5,21509 \mathrm{E}-09$ & 2,09632E-09 & 3,95501E-09 & $1,0909 \mathrm{E}-08$ & $1,94085 \mathrm{E}-09$ & $1,3126 \mathrm{E}-09$ \\
\hline Borracha & $2,02481 \mathrm{E}-08$ & $1,16068 \mathrm{E}-08$ & $5,53664 \mathrm{E}-08$ & 4,93307E-08 & $2,54485 \mathrm{E}-08$ & $5,72541 \mathrm{E}-08$ & $1,5953 \mathrm{E}-08$ & $1,32637 \mathrm{E}-07$ & 2,0992E-08 & $5,02226 \mathrm{E}-10$ \\
\hline Cimento & 5,76881E-09 & $1,72169 \mathrm{E}-09$ & $2,23765 \mathrm{E}-09$ & $1,17836 \mathrm{E}-09$ & $5,5435 \mathrm{E}-09$ & 4,31993E-09 & $2,03066 \mathrm{E}-09$ & 4,99042E-09 & $1,16029 \mathrm{E}-08$ & $5,59016 \mathrm{E}-11$ \\
\hline Aço & $1,53729 \mathrm{E}-06$ & $1,25462 \mathrm{E}-08$ & $2,29751 \mathrm{E}-07$ & $1,66377 \mathrm{E}-08$ & 4,52929E-08 & $4,00204 \mathrm{E}-08$ & 4,57677E-09 & $1,2648 \mathrm{E}-07$ & 4,66624E-09 & $1,45457 \mathrm{E}-10$ \\
\hline Metal & 7,31703E-08 & $1,87839 \mathrm{E}-06$ & $1,1779 \mathrm{E}-07$ & $4,41833 \mathrm{E}-08$ & $8,18577 \mathrm{E}-08$ & 7,28933E-08 & $5,01744 \mathrm{E}-08$ & $5,25538 \mathrm{E}-08$ & $4,03986 \mathrm{E}-08$ & $2,05404 \mathrm{E}-10$ \\
\hline Eletrodomésticos & $2,56626 \mathrm{E}-08$ & 2,94901E-09 & $9,86212 \mathrm{E}-06$ & 2,73395E-08 & $1,2618 \mathrm{E}-08$ & $1,84482 \mathrm{E}-08$ & $5,49545 \mathrm{E}-09$ & $1,15578 \mathrm{E}-07$ & 1,9131E-09 & $3,09205 \mathrm{E}-10$ \\
\hline Informática & $2,25763 \mathrm{E}-11$ & $1,21689 \mathrm{E}-11$ & $1,16681 \mathrm{E}-10$ & 4,94242E-06 & $7,23762 \mathrm{E}-11$ & 2,47561E-09 & $1,57048 \mathrm{E}-11$ & $1,5251 \mathrm{E}-10$ & $1,2375 \mathrm{E}-11$ & $2,45664 \mathrm{E}-12$ \\
\hline Máquinas & 3,43448E-09 & $9,39045 \mathrm{E}-10$ & $7,09159 \mathrm{E}-08$ & $1,69712 \mathrm{E}-07$ & $2,77561 \mathrm{E}-06$ & 3,11877E-07 & $2,06865 \mathrm{E}-08$ & 4,6371E-08 & 6,92895E-09 & $5,26696 \mathrm{E}-09$ \\
\hline
\end{tabular}




\begin{tabular}{|c|c|c|c|c|c|c|c|c|c|c|}
\hline Eletrônicos & $7,66661 \mathrm{E}-10$ & $4,5975 \mathrm{E}-10$ & $1,9351 \mathrm{E}-08$ & $2,26379 \mathrm{E}-06$ & $1,88736 \mathrm{E}-08$ & $1,11573 \mathrm{E}-05$ & 2,23895E-09 & $1,79963 \mathrm{E}-08$ & $9,37465 \mathrm{E}-10$ & $3,63902 \mathrm{E}-10$ \\
\hline Instrumento hospitalar & 7,63734E-11 & 4,19861E-11 & $1,15817 \mathrm{E}-08$ & $1,51419 \mathrm{E}-09$ & 4,4974E-09 & $2,11268 \mathrm{E}-09$ & 3,63339E-06 & $1,93322 \mathrm{E}-09$ & $1,98713 \mathrm{E}-10$ & 4,38976E-11 \\
\hline Veículos & $2,28772 \mathrm{E}-09$ & $1,44529 \mathrm{E}-09$ & $1,03189 \mathrm{E}-08$ & $7,28969 \mathrm{E}-09$ & $8,32783 \mathrm{E}-09$ & $1,32281 \mathrm{E}-08$ & $1,75313 \mathrm{E}-09$ & $3,6465 \mathrm{E}-06$ & $1,0432 \mathrm{E}-09$ & $2,22489 \mathrm{E}-10$ \\
\hline Indústria Diversa & $1,47666 \mathrm{E}-08$ & $1,088 \mathrm{E}-09$ & 3,43202E-09 & $6,49542 \mathrm{E}-10$ & 1,99279E-09 & $1,05697 \mathrm{E}-09$ & $2,8162 \mathrm{E}-10$ & $1,77298 \mathrm{E}-09$ & 3,70011E-06 & $9,22496 \mathrm{E}-11$ \\
\hline SIUP & $3,00358 \mathrm{E}-08$ & $1,46469 \mathrm{E}-08$ & $1,45797 \mathrm{E}-08$ & $9,76258 \mathrm{E}-09$ & $1,71167 \mathrm{E}-08$ & $1,19288 \mathrm{E}-08$ & $1,2475 \mathrm{E}-08$ & $1,27815 \mathrm{E}-08$ & $9,10112 \mathrm{E}-09$ & $1,35987 \mathrm{E}-06$ \\
\hline Construção & 1,19073E-09 & $8,0015 \mathrm{E}-10$ & 1,61849E-09 & 2,38263E-09 & $3,29088 \mathrm{E}-09$ & 4,97272E-09 & $7,54442 \mathrm{E}-10$ & $5,2738 \mathrm{E}-09$ & $9,66947 \mathrm{E}-10$ & $7,47443 \mathrm{E}-10$ \\
\hline Comércio & $3,2921 \mathrm{E}-07$ & $2,88334 \mathrm{E}-07$ & $4,84388 \mathrm{E}-07$ & $1,09041 \mathrm{E}-06$ & 4,31844E-07 & $8,14458 \mathrm{E}-07$ & 4,34986E-07 & $6,20513 \mathrm{E}-07$ & $5,03756 \mathrm{E}-07$ & $1,37494 \mathrm{E}-07$ \\
\hline Transportes & $1,33512 \mathrm{E}-07$ & $7,66141 \mathrm{E}-08$ & $1,05426 \mathrm{E}-07$ & $1,18242 \mathrm{E}-07$ & $1,00865 \mathrm{E}-07$ & $1,46788 \mathrm{E}-07$ & $8,00936 \mathrm{E}-08$ & $9,24104 \mathrm{E}-08$ & $4,96385 \mathrm{E}-08$ & $4,05615 \mathrm{E}-08$ \\
\hline Informação & $2,04401 \mathrm{E}-08$ & $9,09075 \mathrm{E}-09$ & $2,28648 \mathrm{E}-08$ & $3,28703 \mathrm{E}-08$ & $2,80526 \mathrm{E}-08$ & $4,8362 \mathrm{E}-08$ & $1,48138 \mathrm{E}-08$ & $1,82849 \mathrm{E}-08$ & 4,96706E-09 & $1,72966 \mathrm{E}-08$ \\
\hline Financeiro & 2,30184E-08 & $1,35609 \mathrm{E}-08$ & $2,93258 \mathrm{E}-08$ & $2,04813 \mathrm{E}-08$ & $2,09516 \mathrm{E}-08$ & $3,60903 \mathrm{E}-08$ & $1,45653 \mathrm{E}-08$ & 2,01163E-08 & $8,62019 \mathrm{E}-09$ & $7,75163 \mathrm{E}-09$ \\
\hline Imobiliário & 3,20862E-09 & $2,72271 \mathrm{E}-09$ & $4,2426 \mathrm{E}-09$ & 4,54932E-09 & 3,36575E-09 & 4,50034E-09 & 3,95907E-09 & $2,96165 \mathrm{E}-09$ & 2,58217E-09 & $2,32334 \mathrm{E}-09$ \\
\hline Alojamento & 4,04996E-09 & $1,54364 \mathrm{E}-09$ & 2,22995E-09 & $3,22469 \mathrm{E}-09$ & 4,78501E-09 & 3,22194E-09 & $1,38656 \mathrm{E}-09$ & $4,27812 \mathrm{E}-09$ & 2,88144E-09 & $1,1843 \mathrm{E}-09$ \\
\hline Serviços às Empresas & $8,11961 \mathrm{E}-08$ & $7,91242 \mathrm{E}-08$ & 9,48303E-08 & 4,24199E-07 & $1,35221 \mathrm{E}-07$ & $2,98985 \mathrm{E}-07$ & $1,0859 \mathrm{E}-07$ & $1,81609 \mathrm{E}-07$ & $6,24765 \mathrm{E}-08$ & 2,30637E-07 \\
\hline Educação e Saúde mercantis & 3,21839E-09 & $3,25192 \mathrm{E}-09$ & 4,77523E-09 & 6,65369E-09 & 4,09094E-09 & $6,11156 \mathrm{E}-09$ & 4,0686E-09 & $4,12482 \mathrm{E}-09$ & 3,73374E-09 & $2,56051 \mathrm{E}-09$ \\
\hline Outros Serviços & 7,695E-09 & 7,00178E-09 & $1,02823 \mathrm{E}-08$ & $2,01987 \mathrm{E}-08$ & $1,46791 \mathrm{E}-08$ & $1,8626 \mathrm{E}-08$ & $8,35431 \mathrm{E}-09$ & $1,08769 \mathrm{E}-08$ & $8,57672 \mathrm{E}-09$ & $8,18216 \mathrm{E}-09$ \\
\hline APU & 3,48992E-09 & 2,39948E-09 & $2,82308 \mathrm{E}-09$ & 7,25461E-09 & 3,14081E-09 & 5,76337E-09 & 2,79449E-09 & 3,89562E-09 & $1,80258 \mathrm{E}-09$ & $6,47551 \mathrm{E}-09$ \\
\hline
\end{tabular}

Tabela B7 - Matriz Geração de Emprego para o Grau de Instrução G(6), Distrito Federal - 2008.

(3)

\begin{tabular}{|c|c|c|c|c|c|c|c|c|c|c|c|}
\hline Setores & Construção & Comércio & Transportes & Informação & Financeiro & Imobiliário & Alojamento & $\begin{array}{l}\text { Serviços às } \\
\text { Empresas }\end{array}$ & $\begin{array}{l}\text { Educação e } \\
\text { Saúde } \\
\text { mercantis }\end{array}$ & $\begin{array}{c}\text { Outros } \\
\text { Serviços }\end{array}$ & APU \\
\hline Agricultura & $4,97971 \mathrm{E}-11$ & $1,54499 \mathrm{E}-10$ & $1,16868 \mathrm{E}-10$ & 7,08911E-11 & $4,59036 \mathrm{E}-11$ & $9,72891 \mathrm{E}-12$ & $1,55428 \mathrm{E}-08$ & $7,03864 \mathrm{E}-11$ & $3,70546 \mathrm{E}-10$ & $1,60072 \mathrm{E}-09$ & $1,97829 \mathrm{E}-10$ \\
\hline Pecuária & $2,13004 \mathrm{E}-11$ & $6,25988 \mathrm{E}-11$ & $5,57349 \mathrm{E}-11$ & $2,75867 \mathrm{E}-11$ & $2,11193 \mathrm{E}-11$ & $3,57129 \mathrm{E}-12$ & $8,24407 \mathrm{E}-09$ & $2,75862 \mathrm{E}-11$ & $1,83485 \mathrm{E}-10$ & $8,95786 \mathrm{E}-10$ & $8,59319 \mathrm{E}-11$ \\
\hline Extrativa & $1,88612 \mathrm{E}-10$ & $9,83206 \mathrm{E}-11$ & $6,05927 \mathrm{E}-11$ & $1,1386 \mathrm{E}-10$ & $3,39803 \mathrm{E}-11$ & $1,88158 \mathrm{E}-11$ & $8,93995 \mathrm{E}-11$ & $9,0855 \mathrm{E}-11$ & $8,9395 \mathrm{E}-11$ & $8,43591 \mathrm{E}-11$ & $9,26325 \mathrm{E}-11$ \\
\hline Alimentos & $8,8218 \mathrm{E}-10$ & 2,74116E-09 & $2,4212 \mathrm{E}-09$ & $9,59457 \mathrm{E}-10$ & 7,88851E-10 & $1,32931 \mathrm{E}-10$ & $3,45324 \mathrm{E}-07$ & $9,20273 \mathrm{E}-10$ & $5,60545 \mathrm{E}-09$ & $1,28437 \mathrm{E}-08$ & $2,56035 \mathrm{E}-09$ \\
\hline Vestuário & $2,69883 \mathrm{E}-10$ & $6,04824 \mathrm{E}-10$ & $1,26813 \mathrm{E}-09$ & $5,90528 \mathrm{E}-10$ & $4,83252 \mathrm{E}-10$ & $6,3944 \mathrm{E}-11$ & $7,01657 \mathrm{E}-10$ & $1,72926 \mathrm{E}-09$ & $1,1148 \mathrm{E}-09$ & 2,49321E-09 & $4,85692 \mathrm{E}-10$ \\
\hline Madeira & $2,20716 \mathrm{E}-10$ & 7,83137E-11 & $5,253 \mathrm{E}-11$ & $1,0394 \mathrm{E}-10$ & $5,87654 \mathrm{E}-11$ & 7,676E-11 & $6,40877 \mathrm{E}-11$ & $8,64443 \mathrm{E}-11$ & $1,14782 \mathrm{E}-10$ & $1,21143 \mathrm{E}-10$ & $1,73271 \mathrm{E}-10$ \\
\hline
\end{tabular}




\begin{tabular}{|c|c|c|c|c|c|c|c|c|c|c|c|}
\hline Celulose & 7,70104E-11 & $3,08861 \mathrm{E}-10$ & $1,95241 \mathrm{E}-10$ & $3,93079 \mathrm{E}-10$ & $1,33116 \mathrm{E}-10$ & $5,18084 \mathrm{E}-11$ & $1,93428 \mathrm{E}-10$ & $5,14099 \mathrm{E}-10$ & $2,75172 \mathrm{E}-10$ & $2,59676 \mathrm{E}-10$ & $2,58706 \mathrm{E}-10$ \\
\hline Revistas & $2,15115 \mathrm{E}-09$ & 7,74413E-09 & 6,52656E-09 & $1,80862 \mathrm{E}-08$ & 9,36497E-09 & $2,03545 \mathrm{E}-09$ & 2,14307E-09 & $5,74875 \mathrm{E}-08$ & $9,38448 \mathrm{E}-09$ & $9,93528 \mathrm{E}-09$ & $5,46058 \mathrm{E}-09$ \\
\hline Químicos &, $77664 \mathrm{E}-10$ & $9,40428 \mathrm{E}-11$ & $6,64251 \mathrm{E}-11$ & $1,73044 \mathrm{E}-10$ & $3,95293 \mathrm{E}-11$ & $2,57589 \mathrm{E}-11$ & $1,29025 \mathrm{E}-09$ & $1,07556 \mathrm{E}-10$ & $1,23548 \mathrm{E}-09$ & $2,42305 \mathrm{E}-10$ & $1,86801 \mathrm{E}-10$ \\
\hline Borracha & 2,08234E-09 & $8,30212 \mathrm{E}-10$ & $6,98481 \mathrm{E}-10$ & 1,7057E-09 & $2,7285 \mathrm{E}-10$ & $1,55705 \mathrm{E}-10$ & $1,13289 \mathrm{E}-09$ & $2,4719 \mathrm{E}-09$ & 2,15898E-09 & $6,88873 \mathrm{E}-10$ & $3,27865 \mathrm{E}-10$ \\
\hline Cimento & $2,35245 \mathrm{E}-08$ & $8,42064 \mathrm{E}-11$ & $3,61732 \mathrm{E}-11$ & $1,04218 \mathrm{E}-10$ & $9,74459 \mathrm{E}-11$ & $2,08046 \mathrm{E}-10$ & $1,64154 \mathrm{E}-10$ & 7,82976E-11 & $7,76529 \mathrm{E}-10$ & 4,09399E-10 & $3,88713 \mathrm{E}-10$ \\
\hline Aço & $4,27603 \mathrm{E}-10$ & $6,26936 \mathrm{E}-11$ & $4,91127 \mathrm{E}-11$ & $8,59636 \mathrm{E}-11$ & $2,46568 \mathrm{E}-11$ & $2,30762 \mathrm{E}-11$ & $1,16071 \mathrm{E}-10$ & $6,01512 \mathrm{E}-11$ & $7,26476 \mathrm{E}-11$ & $8,12542 \mathrm{E}-11$ & $5,81718 \mathrm{E}-11$ \\
\hline Metal & $5,04908 \mathrm{E}-09$ & $4,8745 \mathrm{E}-10$ & $1,1439 \mathrm{E}-10$ & $2,6597 \mathrm{E}-10$ & 7,79994E-11 & $1,90723 \mathrm{E}-10$ & $2,15678 \mathrm{E}-09$ & $1,35721 \mathrm{E}-10$ & $5,1139 \mathrm{E}-10$ & $3,25147 \mathrm{E}-10$ & $3,39339 \mathrm{E}-10$ \\
\hline Eletrodomésticos & $3,83657 \mathrm{E}-10$ & $3,67312 \mathrm{E}-10$ & $2,49956 \mathrm{E}-10$ & $4,6303 \mathrm{E}-10$ & $1,28729 \mathrm{E}-10$ & $9,6689 \mathrm{E}-11$ & $2,95088 \mathrm{E}-10$ & $3,62224 \mathrm{E}-10$ & $3,43327 \mathrm{E}-10$ & $3,47234 \mathrm{E}-10$ & $3,51624 \mathrm{E}-10$ \\
\hline Informática & $9,86353 \mathrm{E}-12$ & $8,19809 \mathrm{E}-12$ & $4,25451 \mathrm{E}-12$ & $1,57457 \mathrm{E}-11$ & $5,30374 \mathrm{E}-12$ & $7,28092 \mathrm{E}-12$ & $4,35678 \mathrm{E}-12$ & $9,39382 \mathrm{E}-12$ & $1,15552 \mathrm{E}-11$ & $9,33784 \mathrm{E}-12$ & $1,62305 \mathrm{E}-11$ \\
\hline Máquinas & $1,44583 \mathrm{E}-09$ & $3,04935 \mathrm{E}-10$ & $8,97449 \mathrm{E}-10$ & $1,30801 \mathrm{E}-09$ & $1,63208 \mathrm{E}-10$ & $3,54644 \mathrm{E}-10$ & $2,42026 \mathrm{E}-10$ & $4,55349 \mathrm{E}-10$ & $4,05278 \mathrm{E}-10$ & $1,44287 \mathrm{E}-09$ & $2,56914 \mathrm{E}-10$ \\
\hline Eletrônicos & $1,33467 \mathrm{E}-10$ & $8,8405 \mathrm{E}-11$ & $1,10082 \mathrm{E}-10$ & $1,8723 \mathrm{E}-10$ & $4,13816 \mathrm{E}-11$ & $5,13497 \mathrm{E}-11$ & $6,43189 \mathrm{E}-11$ & $1,25697 \mathrm{E}-10$ & $8,62059 \mathrm{E}-11$ & $1,5721 \mathrm{E}-10$ & $8,18516 \mathrm{E}-11$ \\
\hline Instrumento hospitalar & $2,46007 \mathrm{E}-10$ & $1,48669 \mathrm{E}-10$ & $4,71494 \mathrm{E}-11$ & $6,1302 \mathrm{E}-11$ & $3,45456 \mathrm{E}-11$ & $2,80247 \mathrm{E}-10$ & 2,99926E-11 & $3,98925 \mathrm{E}-10$ & $4,141 \mathrm{E}-10$ & $3,15489 \mathrm{E}-10$ & $8,58035 \mathrm{E}-11$ \\
\hline Veículos & $1,77893 \mathrm{E}-10$ & $9,85894 \mathrm{E}-11$ & $8,63483 \mathrm{E}-11$ & $1,49438 \mathrm{E}-10$ & $3,90775 \mathrm{E}-11$ & $3,75432 \mathrm{E}-11$ & $9,23145 \mathrm{E}-11$ & $1,00483 \mathrm{E}-10$ & $9,77292 \mathrm{E}-11$ & $1,30636 \mathrm{E}-10$ & $9,80164 \mathrm{E}-11$ \\
\hline Indústria Diversa & $1,21707 \mathrm{E}-09$ & $1,65862 \mathrm{E}-10$ & $1,04307 \mathrm{E}-09$ & $2,04676 \mathrm{E}-10$ & $1,84336 \mathrm{E}-09$ & $4,60911 \mathrm{E}-10$ & $2,03603 \mathrm{E}-10$ & $6,74243 \mathrm{E}-10$ & $6,68049 \mathrm{E}-10$ & 3,37064E-09 & $7,36382 \mathrm{E}-10$ \\
\hline SIUP & 2,97161E-09 & $1,01819 \mathrm{E}-08$ & $8,44324 \mathrm{E}-09$ & 7,93446E-09 & $4,78808 \mathrm{E}-09$ & $1,00854 \mathrm{E}-09$ & $1,02927 \mathrm{E}-08$ & $8,93556 \mathrm{E}-09$ & $1,31565 \mathrm{E}-08$ & $2,96015 \mathrm{E}-08$ & $1,13319 \mathrm{E}-08$ \\
\hline Construção & $1,78281 \mathrm{E}-06$ & $2,0402 \mathrm{E}-09$ & $1,58595 \mathrm{E}-09$ & $6,49688 \mathrm{E}-09$ & $6,42785 \mathrm{E}-09$ & $1,53674 \mathrm{E}-08$ & $1,09191 \mathrm{E}-09$ & $4,57827 \mathrm{E}-09$ & $1,37232 \mathrm{E}-08$ & $1,18467 \mathrm{E}-08$ & $2,67985 \mathrm{E}-08$ \\
\hline Comércio & 4,51193E-07 & $8,47473 \mathrm{E}-06$ & $3,75762 \mathrm{E}-07$ & $1,86713 \mathrm{E}-07$ & $1,11626 \mathrm{E}-07$ & $4,92635 \mathrm{E}-08$ & 8,64994E-07 & $3,23684 \mathrm{E}-07$ & 2,88031E-07 & $3,11433 \mathrm{E}-07$ & $1,65056 \mathrm{E}-07$ \\
\hline Transportes & $3,7981 \mathrm{E}-08$ & $9,99306 \mathrm{E}-08$ & $3,0522 \mathrm{E}-06$ & $6,77887 \mathrm{E}-08$ & $2,85049 \mathrm{E}-08$ & $5,07012 \mathrm{E}-09$ & $4,57417 \mathrm{E}-08$ & $5,38532 \mathrm{E}-08$ & 4,83916E-08 & $7,15289 \mathrm{E}-08$ & $2,59802 \mathrm{E}-08$ \\
\hline Informação & $5,66121 \mathrm{E}-09$ & $1,7843 \mathrm{E}-08$ & $1,86548 \mathrm{E}-08$ & $1,33567 \mathrm{E}-06$ & $5,44257 \mathrm{E}-08$ & 3,67974E-09 & $8,91341 \mathrm{E}-09$ & $1,4467 \mathrm{E}-07$ & $4,97505 \mathrm{E}-08$ & $3,25792 \mathrm{E}-08$ & $6,03188 \mathrm{E}-08$ \\
\hline Financeiro & $6,24166 \mathrm{E}-09$ & $1,23885 \mathrm{E}-08$ & $1,71304 \mathrm{E}-08$ & $1,74385 \mathrm{E}-08$ & $4,94644 \mathrm{E}-07$ & $2,52012 \mathrm{E}-09$ & $6,44323 \mathrm{E}-09$ & $1,65046 \mathrm{E}-08$ & $7,28691 \mathrm{E}-09$ & $4,0558 \mathrm{E}-09$ & $3,85969 \mathrm{E}-08$ \\
\hline Imobiliário & $1,91281 \mathrm{E}-09$ & 9,62944E-09 & $1,71608 \mathrm{E}-08$ & $1,55468 \mathrm{E}-08$ & $4,93131 \mathrm{E}-09$ & $4,57213 \mathrm{E}-07$ & $5,92546 \mathrm{E}-09$ & $1,12227 \mathrm{E}-08$ & $1,16742 \mathrm{E}-08$ & $8,36567 \mathrm{E}-09$ & 8,82977E-09 \\
\hline Alojamento & 4,04607E-09 & $5,62269 \mathrm{E}-09$ & $1,09477 \mathrm{E}-08$ & $7,38286 \mathrm{E}-09$ & $7,10044 \mathrm{E}-09$ & $7,83463 \mathrm{E}-10$ & $4,34315 \mathrm{E}-06$ & $6,3695 \mathrm{E}-09$ & $3,37662 \mathrm{E}-08$ & $3,85357 \mathrm{E}-08$ & $2,08717 \mathrm{E}-08$ \\
\hline Serviços às Empresas & $9,36361 \mathrm{E}-08$ & $2,61174 \mathrm{E}-07$ & $3,00117 \mathrm{E}-07$ & $4,27743 \mathrm{E}-07$ & $3,23514 \mathrm{E}-07$ & $5,05576 \mathrm{E}-08$ & $8,27175 \mathrm{E}-08$ & $5,16205 \mathrm{E}-06$ & $4,30589 \mathrm{E}-07$ & $2,74003 \mathrm{E}-07$ & $3,0427 \mathrm{E}-07$ \\
\hline Educação e Saúde mercantis & 2,86167E-09 & $1,0197 \mathrm{E}-08$ & $6,75776 \mathrm{E}-09$ & $1,13861 \mathrm{E}-08$ & $1,17418 \mathrm{E}-08$ & $1,47055 \mathrm{E}-09$ & $8,12981 \mathrm{E}-09$ & $9,69309 \mathrm{E}-09$ & $5,13548 \mathrm{E}-06$ & $7,76958 \mathrm{E}-09$ & $1,60284 \mathrm{E}-08$ \\
\hline Outros Serviços & 7,65402E-09 & $2,02364 \mathrm{E}-08$ & $1,26522 \mathrm{E}-08$ & $2,25515 \mathrm{E}-08$ & $1,15858 \mathrm{E}-08$ & 2,25947E-09 & $2,20674 \mathrm{E}-08$ & $2,69437 \mathrm{E}-08$ & $1,99387 \mathrm{E}-08$ & $2,83787 \mathrm{E}-06$ & $1,42852 \mathrm{E}-08$ \\
\hline APU & $1,85095 \mathrm{E}-09$ & 4,97695E-09 & $5,22116 \mathrm{E}-09$ & $6,71608 \mathrm{E}-09$ & 4,80777E-09 & 7,95897E-10 & 2,3561E-09 & $5,97711 \mathrm{E}-09$ & 6,56018E-09 & $5,06973 \mathrm{E}-09$ & $1,62878 \mathrm{E}-06$ \\
\hline
\end{tabular}


Tabela B8 - Matriz Geração de Emprego para o Grau de Instrução G(7), Distrito Federal - 2008.

(1)

\begin{tabular}{|c|c|c|c|c|c|c|c|c|c|c|c|}
\hline Setores & Agricultura & Pecuária & Extrativa & Alimentos & Vestuário & Madeira & Celulose & Revistas & Químicos & Borracha & Cimento \\
\hline Agricultura & $1,11914 \mathrm{E}-07$ & $7,34252 \mathrm{E}-09$ & $1,22124 \mathrm{E}-11$ & $9,0166 \mathrm{E}-09$ & $1,12794 \mathrm{E}-10$ & $1,77306 \mathrm{E}-10$ & $5,12052 \mathrm{E}-10$ & $4,99487 \mathrm{E}-12$ & $2,24862 \mathrm{E}-11$ & $3,81079 \mathrm{E}-10$ & $8,74076 \mathrm{E}-12$ \\
\hline Pecuária & $3,61086 \mathrm{E}-10$ & $9,23543 \mathrm{E}-08$ & $2,71471 \mathrm{E}-12$ & $3,65328 \mathrm{E}-09$ & $7,62711 \mathrm{E}-11$ & $6,40369 \mathrm{E}-12$ & $2,10396 \mathrm{E}-11$ & $1,02543 \mathrm{E}-12$ & $6,65997 \mathrm{E}-12$ & $3,10794 \mathrm{E}-11$ & $2,53427 \mathrm{E}-12$ \\
\hline Extrativa & $4,31803 \mathrm{E}-11$ & $1,02361 \mathrm{E}-10$ & $5,94897 \mathrm{E}-07$ & $2,43524 \mathrm{E}-11$ & $2,23799 \mathrm{E}-11$ & $3,08111 \mathrm{E}-11$ & $2,38288 \mathrm{E}-10$ & $5,70291 \mathrm{E}-12$ & $3,6217 \mathrm{E}-10$ & $7,70425 \mathrm{E}-11$ & $2,69159 \mathrm{E}-10$ \\
\hline Alimentos & 2,11974E-09 & $3,21892 \mathrm{E}-08$ & $1,11193 \mathrm{E}-10$ & $1,9407 \mathrm{E}-07$ & $1,4643 \mathrm{E}-09$ & $1,51615 \mathrm{E}-10$ & $4,73943 \mathrm{E}-10$ & $4,1107 \mathrm{E}-11$ & $1,79064 \mathrm{E}-10$ & $5,9941 \mathrm{E}-11$ & $1,08737 \mathrm{E}-10$ \\
\hline Vestuário & $8,63162 \mathrm{E}-12$ & $7,63874 \mathrm{E}-12$ & $2,54682 \mathrm{E}-10$ & $1,11332 \mathrm{E}-11$ & 4,56926E-07 & $1,03533 \mathrm{E}-11$ & $3,65698 \mathrm{E}-10$ & $1,17184 \mathrm{E}-11$ & $2,3353 \mathrm{E}-11$ & $6,84341 \mathrm{E}-11$ & $1,61853 \mathrm{E}-11$ \\
\hline Madeira & $5,03647 \mathrm{E}-11$ & $9,8728 \mathrm{E}-12$ & $2,74573 \mathrm{E}-11$ & $1,17816 \mathrm{E}-11$ & $4,90307 \mathrm{E}-11$ & $8,46 \mathrm{E}-07$ & 5,10411E-09 & $8,45775 \mathrm{E}-12$ & $1,54706 \mathrm{E}-10$ & $4,19983 \mathrm{E}-11$ & 4,77237E-11 \\
\hline Celulose & $1,78052 \mathrm{E}-11$ & $1,94793 \mathrm{E}-11$ & $4,65906 \mathrm{E}-10$ & $2,27569 \mathrm{E}-11$ & $1,08276 \mathrm{E}-09$ & $1,78273 \mathrm{E}-09$ & 7,27604E-07 & $1,13665 \mathrm{E}-10$ & $2,97068 \mathrm{E}-10$ & $8,60554 \mathrm{E}-10$ & $1,51165 \mathrm{E}-11$ \\
\hline Revistas & $2,93315 \mathrm{E}-10$ & $3,27016 \mathrm{E}-10$ & $7,56083 \mathrm{E}-10$ & $5,39701 \mathrm{E}-10$ & $2,84672 \mathrm{E}-10$ & $1,75276 \mathrm{E}-10$ & $3,255 \mathrm{E}-09$ & $7,0693 \mathrm{E}-07$ & 4,63974E-09 & $1,82409 \mathrm{E}-09$ & $6,21373 \mathrm{E}-10$ \\
\hline Químicos & $2,17553 \mathrm{E}-08$ & $1,51316 \mathrm{E}-08$ & $5,05547 \mathrm{E}-09$ & $2,83081 \mathrm{E}-09$ & $1,55605 \mathrm{E}-09$ & $2,88445 \mathrm{E}-09$ & $1,31184 \mathrm{E}-08$ & $8,74657 \mathrm{E}-11$ & $5,63002 \mathrm{E}-07$ & $7,64639 \mathrm{E}-09$ & $7,16093 \mathrm{E}-10$ \\
\hline Borracha & $2,05851 \mathrm{E}-10$ & $1,31916 \mathrm{E}-10$ & $1,69411 \mathrm{E}-09$ & $3,65603 \mathrm{E}-10$ & $4,81143 \mathrm{E}-10$ & $8,95354 \mathrm{E}-10$ & 2,23291E-09 & $2,81405 \mathrm{E}-10$ & $6,62899 \mathrm{E}-10$ & $1,88051 \mathrm{E}-07$ & $2,25346 \mathrm{E}-11$ \\
\hline Cimento & $5,80214 \mathrm{E}-11$ & $2,96222 \mathrm{E}-11$ & $6,84505 \mathrm{E}-11$ & $9,91412 \mathrm{E}-11$ & $2,60914 \mathrm{E}-11$ & $1,13323 \mathrm{E}-11$ & $8,86529 \mathrm{E}-11$ & $9,29649 \mathrm{E}-12$ & $3,64695 \mathrm{E}-10$ & $2,71525 \mathrm{E}-11$ & $5,76955 \mathrm{E}-08$ \\
\hline Aço & $8,78978 \mathrm{E}-11$ & $4,23599 \mathrm{E}-11$ & $4,59572 \mathrm{E}-10$ & $4,83358 \mathrm{E}-11$ & $2,66828 \mathrm{E}-11$ & $2,3458 \mathrm{E}-10$ & $4,64292 \mathrm{E}-10$ & $4,00952 \mathrm{E}-12$ & $1,22191 \mathrm{E}-10$ & $6,74533 \mathrm{E}-10$ & $4,70315 \mathrm{E}-11$ \\
\hline Metal & $5,22094 \mathrm{E}-10$ & $3,67888 \mathrm{E}-10$ & $1,69174 \mathrm{E}-09$ & $9,08121 \mathrm{E}-10$ & $1,45873 \mathrm{E}-10$ & $8,81924 \mathrm{E}-10$ & $1,57659 \mathrm{E}-09$ & $9,78438 \mathrm{E}-12$ & $7,66687 \mathrm{E}-10$ & $8,7126 \mathrm{E}-10$ & $1,37699 \mathrm{E}-10$ \\
\hline Eletrodomésticos & $8,10749 \mathrm{E}-11$ & $5,53212 \mathrm{E}-11$ & 3,29729E-09 & $9,30017 \mathrm{E}-11$ & $8,48841 \mathrm{E}-10$ & $1,46278 \mathrm{E}-09$ & $6,25987 \mathrm{E}-09$ & $2,49832 \mathrm{E}-11$ & $4,66205 \mathrm{E}-10$ & $6,31409 \mathrm{E}-10$ & $4,88636 \mathrm{E}-11$ \\
\hline Informática & $2,88662 \mathrm{E}-12$ & $2,29661 \mathrm{E}-12$ & $1,94765 \mathrm{E}-11$ & $3,16147 \mathrm{E}-12$ & $1,63651 \mathrm{E}-11$ & $8,62742 \mathrm{E}-12$ & $9,45356 \mathrm{E}-11$ & $1,18671 \mathrm{E}-11$ & $4,19016 \mathrm{E}-11$ & $4,44777 \mathrm{E}-11$ & $2,32594 \mathrm{E}-12$ \\
\hline Máquinas & $3,51487 \mathrm{E}-11$ & $6,38797 \mathrm{E}-11$ & $1,05964 \mathrm{E}-09$ & $1,18827 \mathrm{E}-10$ & $1,18527 \mathrm{E}-10$ & $2,48604 \mathrm{E}-10$ & $2,46972 \mathrm{E}-10$ & $1,54331 \mathrm{E}-11$ & $2,98318 \mathrm{E}-10$ & $8,94957 \mathrm{E}-10$ & $2,21176 \mathrm{E}-10$ \\
\hline Eletrônicos & $2,29106 \mathrm{E}-12$ & $2,59906 \mathrm{E}-12$ & $2,61763 \mathrm{E}-10$ & $5,20878 \mathrm{E}-12$ & $5,24592 \mathrm{E}-12$ & $8,5755 \mathrm{E}-12$ & $1,74734 \mathrm{E}-11$ & $3,00941 \mathrm{E}-12$ & $1,08923 \mathrm{E}-11$ & $2,1412 \mathrm{E}-11$ & $5,83359 \mathrm{E}-12$ \\
\hline Instrumento hospitalar & $2,57247 \mathrm{E}-12$ & $2,83425 \mathrm{E}-12$ & $1,27043 \mathrm{E}-11$ & $3,7468 \mathrm{E}-12$ & $4,98285 \mathrm{E}-12$ & $5,32716 \mathrm{E}-12$ & $2,92239 \mathrm{E}-11$ & $5,69692 \mathrm{E}-12$ & $3,09403 \mathrm{E}-11$ & $5,95158 \mathrm{E}-11$ & $4,57491 \mathrm{E}-12$ \\
\hline Veículos & 2,37671E-11 & $1,94487 \mathrm{E}-11$ & $1,40755 \mathrm{E}-10$ & $4,51599 \mathrm{E}-11$ & $2,42738 \mathrm{E}-11$ & $5,85461 \mathrm{E}-11$ & $1,14238 \mathrm{E}-10$ & $7,46107 \mathrm{E}-12$ & $5,38317 \mathrm{E}-11$ & $1,18293 \mathrm{E}-10$ & $2,13384 \mathrm{E}-11$ \\
\hline Indústria Diversa & $4,2362 \mathrm{E}-12$ & $3,92683 \mathrm{E}-11$ & $1,1435 \mathrm{E}-11$ & $2,66085 \mathrm{E}-11$ & $4,18007 \mathrm{E}-10$ & $1,23291 \mathrm{E}-11$ & $2,26489 \mathrm{E}-10$ & $4,92862 \mathrm{E}-12$ & $1,12583 \mathrm{E}-11$ & $8,0449 \mathrm{E}-11$ & $1,07589 \mathrm{E}-11$ \\
\hline SIUP & $4,33246 \mathrm{E}-10$ & $6,68693 \mathrm{E}-10$ & $1,73853 \mathrm{E}-09$ & $1,0709 \mathrm{E}-09$ & $8,76346 \mathrm{E}-10$ & $9,10367 \mathrm{E}-10$ & $2,68838 \mathrm{E}-09$ & $7,13251 \mathrm{E}-10$ & $1,29865 \mathrm{E}-09$ & $1,34291 \mathrm{E}-09$ & $3,5416 \mathrm{E}-09$ \\
\hline Construção & $2,36589 \mathrm{E}-11$ & $3,36088 \mathrm{E}-11$ & $6,08162 \mathrm{E}-11$ & 7,80373E-11 & $7,0103 \mathrm{E}-11$ & $6,19253 \mathrm{E}-11$ & $1,1149 \mathrm{E}-10$ & $8,82516 \mathrm{E}-11$ & $1,24908 \mathrm{E}-10$ & $2,02861 \mathrm{E}-10$ & $2,76665 \mathrm{E}-10$ \\
\hline Comércio & $2,63726 \mathrm{E}-08$ & $3,89167 \mathrm{E}-08$ & $2,31945 \mathrm{E}-08$ & $4,17291 \mathrm{E}-08$ & 4,38321E-08 & $1,79008 \mathrm{E}-08$ & $2,29007 \mathrm{E}-08$ & $2,37156 \mathrm{E}-08$ & $3,2544 \mathrm{E}-08$ & $2,53636 \mathrm{E}-08$ & $4,06993 \mathrm{E}-08$ \\
\hline Transportes & $5,60019 \mathrm{E}-09$ & $5,09553 \mathrm{E}-09$ & $1,49693 \mathrm{E}-08$ & $9,55147 \mathrm{E}-09$ & 4,4394E-09 & 4,80654E-09 & $8,14254 \mathrm{E}-09$ & $4,68118 \mathrm{E}-09$ & $8,85433 \mathrm{E}-09$ & 5,78994E-09 & $1,79461 \mathrm{E}-08$ \\
\hline Informação & $2,04067 \mathrm{E}-09$ & 3,16354E-09 & $9,30971 \mathrm{E}-09$ & 3,97563E-09 & 2,27807E-09 & $1,68529 \mathrm{E}-09$ & 3,89079E-09 & $9,36126 \mathrm{E}-09$ & $1,20538 \mathrm{E}-08$ & $5,37547 \mathrm{E}-09$ & $7,29485 \mathrm{E}-09$ \\
\hline
\end{tabular}




\begin{tabular}{|c|c|c|c|c|c|c|c|c|c|c|c|}
\hline Financeiro & 4,38392E-09 & 4,86112E-09 & 9,82332E-09 & $8,36557 \mathrm{E}-09$ & 6,68916E-09 & 6,20098E-09 & $1,3525 \mathrm{E}-08$ & 7,67123E-09 & $1,33184 \mathrm{E}-08$ & $9,67382 \mathrm{E}-09$ & $1,5556 \mathrm{E}-08$ \\
\hline Imobiliário & $1,79291 \mathrm{E}-10$ & 2,29611E-10 & $5,43952 \mathrm{E}-10$ & $4,58858 \mathrm{E}-10$ & $5,11228 \mathrm{E}-10$ & $2,04606 \mathrm{E}-10$ & $4,52043 \mathrm{E}-10$ & $7,12263 \mathrm{E}-10$ & $6,0977 \mathrm{E}-10$ & $3,80186 \mathrm{E}-10$ & $6,62492 \mathrm{E}-10$ \\
\hline Alojamento & $2,81678 \mathrm{E}-11$ & $3,97302 \mathrm{E}-11$ & 2,56799E-10 & $6,98952 \mathrm{E}-11$ & $4,07539 \mathrm{E}-11$ & $8,17499 \mathrm{E}-11$ & $8,33126 \mathrm{E}-11$ & $1,10442 \mathrm{E}-10$ & $9,2563 \mathrm{E}-11$ & $8,22217 \mathrm{E}-11$ & $4,51943 \mathrm{E}-10$ \\
\hline Serviços às Empresas & $6,11319 \mathrm{E}-09$ & $8,78857 \mathrm{E}-09$ & $1,69455 \mathrm{E}-08$ & $2,06807 \mathrm{E}-08$ & $1,35686 \mathrm{E}-08$ & $7,215 \mathrm{E}-09$ & $1,74978 \mathrm{E}-08$ & $4,7682 \mathrm{E}-08$ & $5,3922 \mathrm{E}-08$ & $1,45915 \mathrm{E}-08$ & $3,38701 \mathrm{E}-08$ \\
\hline Educação e Saúde mercantis & $3,0011 \mathrm{E}-10$ & $4,14936 \mathrm{E}-10$ & $6,1063 \mathrm{E}-10$ & $6,25448 \mathrm{E}-10$ & $7,63612 \mathrm{E}-10$ & $2,80404 \mathrm{E}-10$ & $5,48964 \mathrm{E}-10$ & $6,69323 \mathrm{E}-10$ & $6,72464 \mathrm{E}-10$ & $4,81282 \mathrm{E}-10$ & $6,93388 \mathrm{E}-10$ \\
\hline Outros Serviços & $1,00837 \mathrm{E}-09$ & $1,46136 \mathrm{E}-09$ & $1,52246 \mathrm{E}-09$ & 1,92783E-09 & $2,0724 \mathrm{E}-09$ & $7,64037 \mathrm{E}-10$ & $1,26687 \mathrm{E}-09$ & $1,48923 \mathrm{E}-09$ & $2,05364 \mathrm{E}-09$ & $1,49952 \mathrm{E}-09$ & 2,39197E-09 \\
\hline $\mathrm{APU}$ & $1,13796 \mathrm{E}-10$ & $1,35772 \mathrm{E}-10$ & $2,72575 \mathrm{E}-10$ & $2,51715 \mathrm{E}-10$ & $1,5864 \mathrm{E}-10$ & $1,07049 \mathrm{E}-10$ & $2,59897 \mathrm{E}-10$ & $4,81006 \mathrm{E}-10$ & $4,35103 \mathrm{E}-10$ & $1,84578 \mathrm{E}-10$ & $4,15649 \mathrm{E}-10$ \\
\hline
\end{tabular}

Tabela B8 - Matriz Geração de Emprego para o Grau de Instrução G(7), Distrito Federal - 2008.

(2)

\begin{tabular}{|c|c|c|c|c|c|c|c|c|c|c|}
\hline Setores & Aço & Metal & Eletrodomésticos & Informática & Máquinas & Eletrônicos & $\begin{array}{l}\text { Instrumento } \\
\text { hospitalar }\end{array}$ & Veículos & $\begin{array}{c}\text { Indústria } \\
\text { Diversa }\end{array}$ & SIUP \\
\hline Agricultura & $6,58516 \mathrm{E}-12$ & $3,63078 \mathrm{E}-12$ & $1,30366 \mathrm{E}-11$ & $1,24191 \mathrm{E}-11$ & $7,40655 \mathrm{E}-12$ & $1,69557 \mathrm{E}-11$ & $4,50515 \mathrm{E}-12$ & $2,58669 \mathrm{E}-11$ & $1,01216 \mathrm{E}-11$ & $1,83463 \mathrm{E}-12$ \\
\hline Pecuária & $1,39325 \mathrm{E}-12$ & $6,88234 \mathrm{E}-13$ & $1,70114 \mathrm{E}-12$ & $1,84006 \mathrm{E}-12$ & $1,45928 \mathrm{E}-12$ & $1,90932 \mathrm{E}-12$ & $7,86865 \mathrm{E}-13$ & $3,04572 \mathrm{E}-12$ & $1,63148 \mathrm{E}-11$ & $4,47487 \mathrm{E}-13$ \\
\hline Extrativa & $1,00221 \mathrm{E}-08$ & $5,92105 \mathrm{E}-10$ & $1,87911 \mathrm{E}-09$ & $1,43225 \mathrm{E}-10$ & $5,69819 \mathrm{E}-10$ & $3,2023 \mathrm{E}-10$ & $5,33571 \mathrm{E}-11$ & $1,07184 \mathrm{E}-09$ & $3,28563 \mathrm{E}-10$ & $5,02975 \mathrm{E}-12$ \\
\hline Alimentos & $4,87295 \mathrm{E}-11$ & $2,29102 \mathrm{E}-11$ & $4,74273 \mathrm{E}-11$ & $5,30581 \mathrm{E}-11$ & $4,77836 \mathrm{E}-11$ & $5,19031 \mathrm{E}-11$ & $2,51624 \mathrm{E}-11$ & $6,41708 \mathrm{E}-11$ & $4,56504 \mathrm{E}-11$ & $1,52964 \mathrm{E}-11$ \\
\hline Vestuário & $2,15019 \mathrm{E}-11$ & $3,29042 \mathrm{E}-11$ & $1,80596 \mathrm{E}-10$ & $2,5117 \mathrm{E}-11$ & $2,10952 \mathrm{E}-11$ & $2,85979 \mathrm{E}-11$ & $3,18338 \mathrm{E}-11$ & $1,54913 \mathrm{E}-10$ & $2,17445 \mathrm{E}-11$ & $2,17703 \mathrm{E}-11$ \\
\hline Madeira & $3,83968 \mathrm{E}-11$ & $5,67131 \mathrm{E}-11$ & $1,13156 \mathrm{E}-09$ & $1,04101 \mathrm{E}-09$ & $5,00397 \mathrm{E}-11$ & 4,62992E-09 & $1,36948 \mathrm{E}-11$ & $7,09285 \mathrm{E}-10$ & 1,529E-09 & $1,85331 \mathrm{E}-12$ \\
\hline Celulose & $1,22526 \mathrm{E}-10$ & $2,96064 \mathrm{E}-11$ & 2,25941E-09 & $1,22168 \mathrm{E}-09$ & 2,20469E-10 & 2,41198E-09 & $5,15905 \mathrm{E}-11$ & $1,23563 \mathrm{E}-09$ & $1,18877 \mathrm{E}-10$ & $1,03746 \mathrm{E}-11$ \\
\hline Revistas & $8,9033 \mathrm{E}-10$ & $8,76138 \mathrm{E}-10$ & $5,36586 \mathrm{E}-10$ & $1,01273 \mathrm{E}-09$ & $4,57187 \mathrm{E}-10$ & $8,50286 \mathrm{E}-10$ & 4,20166E-09 & $9,99617 \mathrm{E}-10$ & $2,98688 \mathrm{E}-10$ & $1,25243 \mathrm{E}-09$ \\
\hline Químicos & $6,74106 \mathrm{E}-09$ & $1,17518 \mathrm{E}-09$ & $6,22258 \mathrm{E}-09$ & $4,46452 \mathrm{E}-10$ & $1,95836 \mathrm{E}-09$ & $7,87207 \mathrm{E}-10$ & $1,48518 \mathrm{E}-09$ & 4,09655E-09 & $7,28826 \mathrm{E}-10$ & $4,92907 \mathrm{E}-10$ \\
\hline Borracha & $1,15703 \mathrm{E}-09$ & $6,63245 \mathrm{E}-10$ & $3,1638 \mathrm{E}-09$ & 2,8189E-09 & 1,4542E-09 & $3,27166 \mathrm{E}-09$ & $9,116 \mathrm{E}-10$ & 7,57929E-09 & 1,19954E-09 & $2,86986 \mathrm{E}-11$ \\
\hline Cimento & $5,09013 \mathrm{E}-10$ & $1,51914 \mathrm{E}-10$ & $1,9744 \mathrm{E}-10$ & $1,03973 \mathrm{E}-10$ & $4,89132 \mathrm{E}-10$ & $3,8117 \mathrm{E}-10$ & $1,79176 \mathrm{E}-10$ & $4,40331 \mathrm{E}-10$ & $1,02379 \mathrm{E}-09$ & $4,93249 \mathrm{E}-12$ \\
\hline Aço & $1,14723 \mathrm{E}-07$ & $9,36283 \mathrm{E}-10$ & $1,71456 \mathrm{E}-08$ & $1,24162 \mathrm{E}-09$ & $3,38006 \mathrm{E}-09$ & 2,9866E-09 & $3,4155 \mathrm{E}-10$ & $9,4388 \mathrm{E}-09$ & $3,48227 \mathrm{E}-10$ & $1,0855 \mathrm{E}-11$ \\
\hline Metal & 4,16134E-09 & $1,06828 \mathrm{E}-07$ & 6,69898E-09 & $2,5128 \mathrm{E}-09$ & 4,65542E-09 & 4,14559E-09 & 2,85352E-09 & 2,98884E-09 & 2,29755E-09 & $1,16818 \mathrm{E}-11$ \\
\hline Eletrodomésticos & 3,36156E-09 & $3,86292 \mathrm{E}-10$ & $1,29184 \mathrm{E}-06$ & 3,58121E-09 & $1,65283 \mathrm{E}-09$ & 2,41653E-09 & $7,19852 \mathrm{E}-10$ & $1,51396 \mathrm{E}-08$ & $2,50598 \mathrm{E}-10$ & $4,05028 \mathrm{E}-11$ \\
\hline Informática & $1,27353 \mathrm{E}-11$ & $6,86451 \mathrm{E}-12$ & $6,58198 \mathrm{E}-11$ & 2,78803E-06 & $4,08276 \mathrm{E}-11$ & $1,3965 \mathrm{E}-09$ & $8,8591 \mathrm{E}-12$ & $8,6031 \mathrm{E}-11$ & $6,98078 \mathrm{E}-12$ & $1,3858 \mathrm{E}-12$ \\
\hline Máquinas & $3,81609 \mathrm{E}-10$ & $1,04338 \mathrm{E}-10$ & 7,87955E-09 & $1,88568 \mathrm{E}-08$ & $3,08401 \mathrm{E}-07$ & $3,4653 \mathrm{E}-08$ & $2,2985 \mathrm{E}-09$ & $5,15233 \mathrm{E}-09$ & $7,69883 \mathrm{E}-10$ & $5,85218 \mathrm{E}-10$ \\
\hline
\end{tabular}




\begin{tabular}{|c|c|c|c|c|c|c|c|c|c|c|}
\hline Eletrônicos & $2,48647 \mathrm{E}-11$ & $1,49108 \mathrm{E}-11$ & $6,276 \mathrm{E}-10$ & $7,34202 \mathrm{E}-08$ & $6,12118 \mathrm{E}-10$ & $3,61859 \mathrm{E}-07$ & $7,26144 \mathrm{E}-11$ & $5,83664 \mathrm{E}-10$ & $3,04043 \mathrm{E}-11$ & $1,18022 \mathrm{E}-11$ \\
\hline Instrumento hospitalar & $9,07717 \mathrm{E}-12$ & $4,99015 \mathrm{E}-12$ & $1,37651 \mathrm{E}-09$ & $1,79966 \mathrm{E}-10$ & $5,34527 \mathrm{E}-10$ & $2,51098 \mathrm{E}-10$ & $4,31837 \mathrm{E}-07$ & $2,29768 \mathrm{E}-10$ & $2,36175 \mathrm{E}-11$ & $5,21734 \mathrm{E}-12$ \\
\hline Veículos & $3,22628 \mathrm{E}-10$ & $2,03823 \mathrm{E}-10$ & $1,45523 \mathrm{E}-09$ & $1,02803 \mathrm{E}-09$ & $1,17444 \mathrm{E}-09$ & $1,8655 \mathrm{E}-09$ & $2,47236 \mathrm{E}-10$ & $5,1425 \mathrm{E}-07$ & $1,47118 \mathrm{E}-10$ & 3,13767E-11 \\
\hline Indústria Diversa & $5,37719 \mathrm{E}-10$ & $3,96192 \mathrm{E}-11$ & $1,24976 \mathrm{E}-10$ & $2,36528 \mathrm{E}-11$ & $7,25668 \mathrm{E}-11$ & $3,84893 \mathrm{E}-11$ & $1,02551 \mathrm{E}-11$ & $6,45621 \mathrm{E}-11$ & $1,34738 \mathrm{E}-07$ & $3,35923 \mathrm{E}-12$ \\
\hline SIUP & $3,14674 \mathrm{E}-09$ & $1,53451 \mathrm{E}-09$ & $1,52746 \mathrm{E}-09$ & $1,02279 \mathrm{E}-09$ & $1,79326 \mathrm{E}-09$ & $1,24973 \mathrm{E}-09$ & $1,30696 \mathrm{E}-09$ & $1,33908 \mathrm{E}-09$ & $9,53492 \mathrm{E}-10$ & $1,42469 \mathrm{E}-07$ \\
\hline Construção & $8,61939 \mathrm{E}-11$ & $5,79206 \mathrm{E}-11$ & $1,17158 \mathrm{E}-10$ & $1,72472 \mathrm{E}-10$ & $2,38218 \mathrm{E}-10$ & $3,59961 \mathrm{E}-10$ & $5,46119 \mathrm{E}-11$ & $3,81756 \mathrm{E}-10$ & $6,99945 \mathrm{E}-11$ & $5,41053 \mathrm{E}-11$ \\
\hline Comércio & $2,16834 \mathrm{E}-08$ & $1,89911 \mathrm{E}-08$ & $3,19043 \mathrm{E}-08$ & 7,18197E-08 & $2,84434 \mathrm{E}-08$ & $5,36444 \mathrm{E}-08$ & $2,86504 \mathrm{E}-08$ & $4,08701 \mathrm{E}-08$ & $3,318 \mathrm{E}-08$ & $9,05606 \mathrm{E}-09$ \\
\hline Informação & $9,5161 \mathrm{E}-09$ & $4,23229 \mathrm{E}-09$ & $1,06449 \mathrm{E}-08$ & $1,53031 \mathrm{E}-08$ & $1,30601 \mathrm{E}-08$ & $2,25154 \mathrm{E}-08$ & 6,8967E-09 & $8,51269 \mathrm{E}-09$ & 2,31246E-09 & $8,05261 \mathrm{E}-09$ \\
\hline Financeiro & $1,69466 \mathrm{E}-08$ & 9,98379E-09 & $2,15902 \mathrm{E}-08$ & $1,50788 \mathrm{E}-08$ & $1,5425 \mathrm{E}-08$ & $2,65704 \mathrm{E}-08$ & $1,07233 \mathrm{E}-08$ & $1,481 \mathrm{E}-08$ & 6,34636E-09 & $5,7069 \mathrm{E}-09$ \\
\hline Imobiliário & $4,29577 \mathrm{E}-10$ & $3,64523 \mathrm{E}-10$ & $5,68008 \mathrm{E}-10$ & $6,09073 \mathrm{E}-10$ & $4,50614 \mathrm{E}-10$ & $6,02516 \mathrm{E}-10$ & $5,30049 \mathrm{E}-10$ & $3,96512 \mathrm{E}-10$ & $3,45707 \mathrm{E}-10$ & $3,11054 \mathrm{E}-10$ \\
\hline Alojamento & $1,1967 \mathrm{E}-10$ & $4,56122 \mathrm{E}-11$ & $6,58916 \mathrm{E}-11$ & $9,52848 \mathrm{E}-11$ & $1,4139 \mathrm{E}-10$ & $9,52034 \mathrm{E}-11$ & $4,09708 \mathrm{E}-11$ & $1,26412 \mathrm{E}-10$ & $8,51422 \mathrm{E}-11$ & 3,49941E-11 \\
\hline Serviços às Empresas & $1,4178 \mathrm{E}-08$ & $1,38162 \mathrm{E}-08$ & $1,65587 \mathrm{E}-08$ & $7,4071 \mathrm{E}-08$ & $2,36115 \mathrm{E}-08$ & $5,22069 \mathrm{E}-08$ & $1,89614 \mathrm{E}-08$ & $3,17115 \mathrm{E}-08$ & $1,09093 \mathrm{E}-08$ & $4,02725 \mathrm{E}-08$ \\
\hline Educação e Saúde mercantis & $4,55723 \mathrm{E}-10$ & $4,60471 \mathrm{E}-10$ & $6,76171 \mathrm{E}-10$ & $9,4216 \mathrm{E}-10$ & $5,79275 \mathrm{E}-10$ & $8,65394 \mathrm{E}-10$ & $5,76113 \mathrm{E}-10$ & $5,84074 \mathrm{E}-10$ & $5,28696 \mathrm{E}-10$ & $3,62567 \mathrm{E}-10$ \\
\hline APU & $2,64651 \mathrm{E}-10$ & $1,8196 \mathrm{E}-10$ & $2,14082 \mathrm{E}-10$ & $5,50139 \mathrm{E}-10$ & $2,38177 \mathrm{E}-10$ & $4,37053 \mathrm{E}-10$ & $2,11914 \mathrm{E}-10$ & $2,95416 \mathrm{E}-10$ & $1,36695 \mathrm{E}-10$ & $4,91057 \mathrm{E}-10$ \\
\hline
\end{tabular}

Tabela B8 - Matriz Geração de Emprego para o Grau de Instrução G(7), Distrito Federal - 2008.

(3)

\begin{tabular}{|c|c|c|c|c|c|c|c|c|c|c|c|}
\hline Setores & Construção & Comércio & Transportes & Informação & Financeiro & Imobiliário & Alojamento & $\begin{array}{c}\text { Serviços às } \\
\text { Empresas }\end{array}$ & $\begin{array}{l}\text { Educação e } \\
\text { Saúde } \\
\text { mercantis }\end{array}$ & $\begin{array}{c}\text { Outros } \\
\text { Serviços }\end{array}$ & APU \\
\hline Agricultura & $5,26409 \mathrm{E}-12$ & $1,63322 \mathrm{E}-11$ & $1,23542 \mathrm{E}-11$ & $7,49396 \mathrm{E}-12$ & $4,85251 \mathrm{E}-12$ & $1,02845 \mathrm{E}-12$ & 1,64304E-09 & $7,4406 \mathrm{E}-12$ & $3,91707 \mathrm{E}-11$ & $1,69214 \mathrm{E}-10$ & $2,09127 \mathrm{E}-11$ \\
\hline Pecuária & $1,34529 \mathrm{E}-12$ & $3,95361 \mathrm{E}-12$ & $3,5201 \mathrm{E}-12$ & $1,74232 \mathrm{E}-12$ & $1,33385 \mathrm{E}-12$ & $2,25555 \mathrm{E}-13$ & $5,20678 \mathrm{E}-10$ & $1,74229 \mathrm{E}-12$ & $1,15885 \mathrm{E}-11$ & $5,6576 \mathrm{E}-11$ & $5,42728 \mathrm{E}-12$ \\
\hline Extrativa & $2,61578 \mathrm{E}-11$ & $1,36357 \mathrm{E}-11$ & $8,40337 \mathrm{E}-12$ & $1,57908 \mathrm{E}-11$ & $4,71259 \mathrm{E}-12$ & $2,60949 \mathrm{E}-12$ & $1,23985 \mathrm{E}-11$ & $1,26003 \mathrm{E}-11$ & $1,23978 \mathrm{E}-11$ & $1,16994 \mathrm{E}-11$ & $1,28468 \mathrm{E}-11$ \\
\hline Alimentos & $5,99471 \mathrm{E}-11$ & $1,86271 \mathrm{E}-10$ & $1,64529 \mathrm{E}-10$ & 6,51983E-11 & 5,36051E-11 & $9,03313 \mathrm{E}-12$ & $2,34659 \mathrm{E}-08$ & $6,25357 \mathrm{E}-11$ & $3,80909 \mathrm{E}-10$ & $8,7277 \mathrm{E}-10$ & $1,73984 \mathrm{E}-10$ \\
\hline Vestuário & $1,3514 \mathrm{E}-11$ & $3,02857 \mathrm{E}-11$ & $6,35001 \mathrm{E}-11$ & $2,95699 \mathrm{E}-11$ & $2,41982 \mathrm{E}-11$ & $3,20191 \mathrm{E}-12$ & $3,51345 \mathrm{E}-11$ & $8,65901 \mathrm{E}-11$ & $5,5822 \mathrm{E}-11$ & $1,24844 \mathrm{E}-10$ & $2,43204 \mathrm{E}-11$ \\
\hline Madeira & $1,73792 \mathrm{E}-11$ & $6,16643 \mathrm{E}-12$ & $4,13622 \mathrm{E}-12$ & $8,18422 \mathrm{E}-12$ & $4,62719 \mathrm{E}-12$ & $6,0441 \mathrm{E}-12$ & $5,04627 \mathrm{E}-12$ & $6,80664 \mathrm{E}-12$ & $9,03793 \mathrm{E}-12$ & $9,53878 \mathrm{E}-12$ & $1,36434 \mathrm{E}-11$ \\
\hline
\end{tabular}




\begin{tabular}{|c|c|c|c|c|c|c|c|c|c|c|c|}
\hline Celulose & 7,51321E-12 & $3,01328 \mathrm{E}-11$ & 1,90479E-11 & $3,83492 \mathrm{E}-11$ & $1,29869 \mathrm{E}-11$ & $5,05448 \mathrm{E}-12$ & $1,8871 \mathrm{E}-11$ & $5,0156 \mathrm{E}-11$ & $2,68461 \mathrm{E}-11$ & $2,53342 \mathrm{E}-11$ & $2,52396 \mathrm{E}-11$ \\
\hline Revistas & 3,32991E-10 & 1,19877E-09 & $1,01029 \mathrm{E}-09$ & 2,79969E-09 & 1,44967E-09 & $3,15081 \mathrm{E}-10$ & $3,31741 \mathrm{E}-10$ & $8,89889 \mathrm{E}-09$ & $1,45269 \mathrm{E}-09$ & 1,53795E-09 & $8,45281 \mathrm{E}-10$ \\
\hline Químicos & $6,6716 \mathrm{E}-11$ & $3,53148 \mathrm{E}-11$ & 2,49439E-11 & $6,49814 \mathrm{E}-11$ & $1,4844 \mathrm{E}-11$ & $9,67296 \mathrm{E}-12$ & $4,84514 \mathrm{E}-10$ & $4,03894 \mathrm{E}-11$ & $4,63947 \mathrm{E}-10$ & $9,099 \mathrm{E}-11$ & 7,01474E-11 \\
\hline Borracha & $1,18991 \mathrm{E}-10$ & $4,74407 \mathrm{E}-11$ & 3,99132E-11 & $9,74688 \mathrm{E}-11$ & $1,55915 \mathrm{E}-11$ & $8,8974 \mathrm{E}-12$ & $6,47363 \mathrm{E}-11$ & $1,41251 \mathrm{E}-10$ & $1,2337 \mathrm{E}-10$ & $3,93642 \mathrm{E}-11$ & $1,87351 \mathrm{E}-11$ \\
\hline Cimento & 2,07569E-09 & $7,42998 \mathrm{E}-12$ & 3,19176E-12 & $9,19571 \mathrm{E}-12$ & $8,59816 \mathrm{E}-12$ & $1,8357 \mathrm{E}-11$ & $1,44841 \mathrm{E}-11$ & $6,90861 \mathrm{E}-12$ & $6,85172 \mathrm{E}-11$ & $3,61234 \mathrm{E}-11$ & $3,42982 \mathrm{E}-11$ \\
\hline Aço & 3,19107E-11 & $4,67863 \mathrm{E}-12$ & $3,66513 \mathrm{E}-12$ & $6,41519 \mathrm{E}-12$ & $1,84006 \mathrm{E}-12$ & $1,7221 \mathrm{E}-12$ & $8,66204 \mathrm{E}-12$ & $4,48889 \mathrm{E}-12$ & $5,42146 \mathrm{E}-12$ & $6,06375 \mathrm{E}-12$ & $4,34118 \mathrm{E}-12$ \\
\hline Metal & $2,87151 \mathrm{E}-10$ & $2,77222 \mathrm{E}-11$ & $6,50559 \mathrm{E}-12$ & $1,51263 \mathrm{E}-11$ & $4,43599 \mathrm{E}-12$ & $1,08468 \mathrm{E}-11$ & $1,22661 \mathrm{E}-10$ & $7,71871 \mathrm{E}-12$ & $2,90838 \mathrm{E}-11$ & $1,84917 \mathrm{E}-11$ & $1,92989 \mathrm{E}-11$ \\
\hline Eletrodomésticos & $5,02554 \mathrm{E}-11$ & $4,81143 \mathrm{E}-11$ & $3,27418 \mathrm{E}-11$ & $6,06524 \mathrm{E}-11$ & $1,68623 \mathrm{E}-11$ & $1,26653 \mathrm{E}-11$ & 3,86537E-11 & $4,74478 \mathrm{E}-11$ & $4,49725 \mathrm{E}-11$ & $4,54843 \mathrm{E}-11$ & 4,60594E-11 \\
\hline Informática & $5,56404 \mathrm{E}-12$ & $4,62456 \mathrm{E}-12$ & 2,39998E-12 & $8,88218 \mathrm{E}-12$ & $2,99186 \mathrm{E}-12$ & 4,10719E-12 & $2,45767 \mathrm{E}-12$ & $5,29908 \mathrm{E}-12$ & $6,51832 \mathrm{E}-12$ & $5,2675 \mathrm{E}-12$ & $9,15564 \mathrm{E}-12$ \\
\hline Máquinas & $1,60648 \mathrm{E}-10$ & $3,38817 \mathrm{E}-11$ & $9,97166 \mathrm{E}-11$ & $1,45335 \mathrm{E}-10$ & $1,81343 \mathrm{E}-11$ & $3,94049 \mathrm{E}-11$ & $2,68918 \mathrm{E}-11$ & $5,05943 \mathrm{E}-11$ & $4,50309 \mathrm{E}-11$ & $1,60319 \mathrm{E}-10$ & $2,8546 \mathrm{E}-11$ \\
\hline Eletrônicos & $4,32865 \mathrm{E}-12$ & $2,86719 \mathrm{E}-12$ & $3,57022 \mathrm{E}-12$ & $6,07234 \mathrm{E}-12$ & $1,3421 \mathrm{E}-12$ & $1,66539 \mathrm{E}-12$ & $2,08602 \mathrm{E}-12$ & $4,07667 \mathrm{E}-12$ & 2,79587E-12 & $5,0987 \mathrm{E}-12$ & $2,65465 \mathrm{E}-12$ \\
\hline Instrumento hospitalar & $2,92385 \mathrm{E}-11$ & $1,76697 \mathrm{E}-11$ & $5,60382 \mathrm{E}-12$ & $7,28589 \mathrm{E}-12$ & $4,10583 \mathrm{E}-12$ & $3,3308 \mathrm{E}-11$ & $3,56469 \mathrm{E}-12$ & $4,74133 \mathrm{E}-11$ & $4,92168 \mathrm{E}-11$ & $3,74967 \mathrm{E}-11$ & $1,0198 \mathrm{E}-11$ \\
\hline Veículos & $2,50874 \mathrm{E}-11$ & $1,39036 \mathrm{E}-11$ & $1,21773 \mathrm{E}-11$ & $2,10747 \mathrm{E}-11$ & $5,51093 \mathrm{E}-12$ & $5,29455 \mathrm{E}-12$ & $1,30187 \mathrm{E}-11$ & $1,41707 \mathrm{E}-11$ & $1,37823 \mathrm{E}-11$ & $1,8423 \mathrm{E}-11$ & $1,38228 \mathrm{E}-11$ \\
\hline Indústria Diversa & 4,43192E-11 & $6,0398 \mathrm{E}-12$ & 3,79829E-11 & $7,45317 \mathrm{E}-12$ & $6,71251 \mathrm{E}-11$ & $1,67839 \mathrm{E}-11$ & $7,41413 \mathrm{E}-12$ & $2,45523 \mathrm{E}-11$ & $2,43267 \mathrm{E}-11$ & $1,2274 \mathrm{E}-10$ & $2,6815 \mathrm{E}-11$ \\
\hline SIUP & $3,11325 \mathrm{E}-10$ & $1,06672 \mathrm{E}-09$ & $8,84567 \mathrm{E}-10$ & $8,31265 \mathrm{E}-10$ & $5,0163 \mathrm{E}-10$ & $1,05661 \mathrm{E}-10$ & $1,07833 \mathrm{E}-09$ & $9,36147 \mathrm{E}-10$ & $1,37836 \mathrm{E}-09$ & 3,10124E-09 & $1,1872 \mathrm{E}-09$ \\
\hline Construção & $1,29052 \mathrm{E}-07$ & $1,47685 \mathrm{E}-10$ & $1,14803 \mathrm{E}-10$ & $4,70291 \mathrm{E}-10$ & $4,65294 \mathrm{E}-10$ & 1,1124E-09 & 7,90403E-11 & $3,31408 \mathrm{E}-10$ & $9,93382 \mathrm{E}-10$ & $8,57551 \mathrm{E}-10$ & $1,93987 \mathrm{E}-09$ \\
\hline Comércio & 2,97179E-08 & $5,58189 \mathrm{E}-07$ & 2,47496E-08 & $1,22979 \mathrm{E}-08$ & 7,35223E-09 & 3,24474E-09 & $5,69729 \mathrm{E}-08$ & $2,13195 \mathrm{E}-08$ & $1,89712 \mathrm{E}-08$ & $2,05126 \mathrm{E}-08$ & $1,08714 \mathrm{E}-08$ \\
\hline Transportes & $3,42468 \mathrm{E}-09$ & $9,01056 \mathrm{E}-09$ & 2,75212E-07 & $6,11238 \mathrm{E}-09$ & $2,57024 \mathrm{E}-09$ & $4,57163 \mathrm{E}-10$ & 4,12444E-09 & 4,85584E-09 & 4,36338E-09 & 6,44963E-09 & 2,34259E-09 \\
\hline Informação & 2,63563E-09 & 8,307E-09 & $8,68491 \mathrm{E}-09$ & $6,21833 \mathrm{E}-07$ & $2,53384 \mathrm{E}-08$ & $1,71314 \mathrm{E}-09$ & 4,14973E-09 & $6,73528 \mathrm{E}-08$ & $2,31618 \mathrm{E}-08$ & $1,51676 \mathrm{E}-08$ & $2,8082 \mathrm{E}-08$ \\
\hline Financeiro & 4,59524E-09 & $9,12067 \mathrm{E}-09$ & $1,26117 \mathrm{E}-08$ & $1,28386 \mathrm{E}-08$ & $3,64167 \mathrm{E}-07$ & $1,85537 \mathrm{E}-09$ & 4,74363E-09 & $1,2151 \mathrm{E}-08$ & $5,36477 \mathrm{E}-09$ & 2,98596E-09 & $2,84158 \mathrm{E}-08$ \\
\hline Imobiliário & $2,56091 \mathrm{E}-10$ & $1,28921 \mathrm{E}-09$ & 2,29752E-09 & 2,08144E-09 & $6,60216 \mathrm{E}-10$ & $6,12127 \mathrm{E}-08$ & $7,93314 \mathrm{E}-10$ & $1,50251 \mathrm{E}-09$ & $1,56297 \mathrm{E}-09$ & $1,12001 \mathrm{E}-09$ & $1,18215 \mathrm{E}-09$ \\
\hline Alojamento & $1,19555 \mathrm{E}-10$ & $1,66142 \mathrm{E}-10$ & $3,23488 \mathrm{E}-10$ & $2,18152 \mathrm{E}-10$ & $2,09807 \mathrm{E}-10$ & $2,31501 \mathrm{E}-11$ & $1,28333 \mathrm{E}-07$ & $1,88209 \mathrm{E}-10$ & $9,97741 \mathrm{E}-10$ & 1,13867E-09 & $6,16727 \mathrm{E}-10$ \\
\hline Serviços às Empresas & $1,63502 \mathrm{E}-08$ & $4,56046 \mathrm{E}-08$ & $5,24045 \mathrm{E}-08$ & 7,46897E-08 & $5,64899 \mathrm{E}-08$ & $8,82805 \mathrm{E}-09$ & $1,44436 \mathrm{E}-08$ & $9,01365 \mathrm{E}-07$ & $7,51868 \mathrm{E}-08$ & $4,78448 \mathrm{E}-08$ & $5,31298 \mathrm{E}-08$ \\
\hline Educação e Saúde mercantis & $4,05212 \mathrm{E}-10$ & 1,4439E-09 & $9,56896 \mathrm{E}-10$ & $1,61227 \mathrm{E}-09$ & $1,66264 \mathrm{E}-09$ & $2,08229 \mathrm{E}-10$ & $1,15118 \mathrm{E}-09$ & $1,37254 \mathrm{E}-09$ & $7,27182 \mathrm{E}-07$ & 1,10017E-09 & $2,26961 \mathrm{E}-09$ \\
\hline Outros Serviços & $1,4067 \mathrm{E}-09$ & 3,71916Е-09 & 2,32529E-09 & 4,14463E-09 & $2,12931 \mathrm{E}-09$ & $4,15258 \mathrm{E}-10$ & 4,05568E-09 & 4,95186E-09 & $3,66445 \mathrm{E}-09$ & $5,2156 \mathrm{E}-07$ & $2,62542 \mathrm{E}-09$ \\
\hline APU & $1,40363 \mathrm{E}-10$ & $3,77417 \mathrm{E}-10$ & $3,95936 \mathrm{E}-10$ & $5,093 \mathrm{E}-10$ & $3,64587 \mathrm{E}-10$ & $6,03552 \mathrm{E}-11$ & $1,7867 \mathrm{E}-10$ & $4,53262 \mathrm{E}-10$ & $4,97478 \mathrm{E}-10$ & 3,84453E-10 & $1,23515 \mathrm{E}-07$ \\
\hline
\end{tabular}


Tabela B9 - Matriz Geração de Emprego para o Grau de Instrução G(8), Distrito Federal - 2008.

(1)

\begin{tabular}{|c|c|c|c|c|c|c|c|c|c|c|c|}
\hline Setores & Agricultura & Pecuária & Extrativa & Alimentos & Vestuário & Madeira & Celulose & Revistas & Químicos & Borracha & Cimento \\
\hline Agricultura & $2,25114 \mathrm{E}-07$ & $1,47694 \mathrm{E}-08$ & $2,45653 \mathrm{E}-11$ & $1,81368 \mathrm{E}-08$ & $2,26885 \mathrm{E}-10$ & $3,56651 \mathrm{E}-10$ & 1,02999E-09 & $1,00472 \mathrm{E}-11$ & $4,52308 \mathrm{E}-11$ & $7,66539 \mathrm{E}-10$ & $1,7582 \mathrm{E}-11$ \\
\hline Pecuária & $8,12443 \mathrm{E}-10$ & $2,07797 \mathrm{E}-07$ & $6,10811 \mathrm{E}-12$ & $8,21988 \mathrm{E}-09$ & $1,7161 \mathrm{E}-10$ & $1,44083 \mathrm{E}-11$ & $4,73391 \mathrm{E}-11$ & $2,30722 \mathrm{E}-12$ & $1,49849 \mathrm{E}-11$ & $6,99286 \mathrm{E}-11$ & $5,70211 \mathrm{E}-12$ \\
\hline Extrativa & $2,06811 \mathrm{E}-10$ & $4,90254 \mathrm{E}-10$ & 2,84924E-06 & $1,16635 \mathrm{E}-10$ & $1,07188 \mathrm{E}-10$ & $1,47569 \mathrm{E}-10$ & $1,14127 \mathrm{E}-09$ & $2,73139 \mathrm{E}-11$ & $1,7346 \mathrm{E}-09$ & $3,68993 \mathrm{E}-10$ & $1,28913 \mathrm{E}-09$ \\
\hline Alimentos & 2,36433E-09 & $3,59033 \mathrm{E}-08$ & $1,24023 \mathrm{E}-10$ & 2,16462E-07 & $1,63326 \mathrm{E}-09$ & $1,69109 \mathrm{E}-10$ & $5,28628 \mathrm{E}-10$ & $4,58501 \mathrm{E}-11$ & $1,99725 \mathrm{E}-10$ & $6,68573 \mathrm{E}-11$ & $1,21284 \mathrm{E}-10$ \\
\hline Vestuário & $8,88549 \mathrm{E}-12$ & $7,86341 \mathrm{E}-12$ & $2,62172 \mathrm{E}-10$ & $1,14607 \mathrm{E}-11$ & $4,70365 \mathrm{E}-07$ & $1,06578 \mathrm{E}-11$ & $3,76453 \mathrm{E}-10$ & $1,2063 \mathrm{E}-11$ & $2,40399 \mathrm{E}-11$ & $7,04468 \mathrm{E}-11$ & $1,66613 \mathrm{E}-11$ \\
\hline Madeira & $4,02918 \mathrm{E}-11$ & $7,89824 \mathrm{E}-12$ & $2,19658 \mathrm{E}-11$ & $9,42531 \mathrm{E}-12$ & $3,92245 \mathrm{E}-11$ & $6,768 \mathrm{E}-07$ & 4,08329E-09 & $6,7662 \mathrm{E}-12$ & $1,23765 \mathrm{E}-10$ & $3,35987 \mathrm{E}-11$ & $3,8179 \mathrm{E}-11$ \\
\hline Celulose & $2,81915 \mathrm{E}-11$ & $3,08422 \mathrm{E}-11$ & $7,37685 \mathrm{E}-10$ & 3,60317E-11 & 1,71437E-09 & $2,82266 \mathrm{E}-09$ & $1,15204 \mathrm{E}-06$ & $1,79969 \mathrm{E}-10$ & $4,70358 \mathrm{E}-10$ & $1,36254 \mathrm{E}-09$ & $2,39344 \mathrm{E}-11$ \\
\hline Revistas & $9,01136 \mathrm{E}-10$ & $1,00467 \mathrm{E}-09$ & 2,32287E-09 & $1,65809 \mathrm{E}-09$ & $8,74583 \mathrm{E}-10$ & $5,38492 \mathrm{E}-10$ & $1,00001 \mathrm{E}-08$ & $2,17186 \mathrm{E}-06$ & $1,42544 \mathrm{E}-08$ & 5,60404E-09 & $1,90901 \mathrm{E}-09$ \\
\hline Químicos & 4,71164E-08 & $3,27711 \mathrm{E}-08$ & $1,09489 \mathrm{E}-08$ & $6,13081 \mathrm{E}-09$ & 3,37E-09 & $6,24698 \mathrm{E}-09$ & $2,84112 \mathrm{E}-08$ & $1,89428 \mathrm{E}-10$ & $1,21932 \mathrm{E}-06$ & $1,65601 \mathrm{E}-08$ & $1,55088 \mathrm{E}-09$ \\
\hline Borracha & $1,2008 \mathrm{E}-10$ & $7,69508 \mathrm{E}-11$ & $9,88234 \mathrm{E}-10$ & $2,13268 \mathrm{E}-10$ & $2,80666 \mathrm{E}-10$ & $5,2229 \mathrm{E}-10$ & $1,30253 \mathrm{E}-09$ & $1,64153 \mathrm{E}-10$ & 3,86691E-10 & $1,09696 \mathrm{E}-07$ & $1,31452 \mathrm{E}-11$ \\
\hline Cimento & $1,14285 \mathrm{E}-10$ & $5,83467 \mathrm{E}-11$ & $1,34827 \mathrm{E}-10$ & $1,95278 \mathrm{E}-10$ & $5,13922 \mathrm{E}-11$ & $2,23212 \mathrm{E}-11$ & $1,74619 \mathrm{E}-10$ & $1,83113 \mathrm{E}-11$ & $7,18338 \mathrm{E}-10$ & $5,34823 \mathrm{E}-11$ & $1,13643 \mathrm{E}-07$ \\
\hline Aço & $1,49426 \mathrm{E}-10$ & $7,20119 \mathrm{E}-11$ & $7,81272 \mathrm{E}-10$ & $8,21708 \mathrm{E}-11$ & $4,53607 \mathrm{E}-11$ & $3,98786 \mathrm{E}-10$ & 7,89297E-10 & $6,81619 \mathrm{E}-12$ & $2,07725 \mathrm{E}-10$ & 1,14671E-09 & $7,99535 \mathrm{E}-11$ \\
\hline Metal & $6,52618 \mathrm{E}-10$ & $4,59861 \mathrm{E}-10$ & 2,11467E-09 & $1,13515 \mathrm{E}-09$ & $1,82341 \mathrm{E}-10$ & 1,1024E-09 & $1,97073 \mathrm{E}-09$ & $1,22305 \mathrm{E}-11$ & $9,58359 \mathrm{E}-10$ & $1,08908 \mathrm{E}-09$ & $1,72123 \mathrm{E}-10$ \\
\hline Eletrodomésticos & $9,68944 \mathrm{E}-11$ & $6,61156 \mathrm{E}-11$ & 3,94066E-09 & $1,11148 \mathrm{E}-10$ & $1,01447 \mathrm{E}-09$ & $1,7482 \mathrm{E}-09$ & 7,4813E-09 & $2,9858 \mathrm{E}-11$ & $5,57172 \mathrm{E}-10$ & $7,5461 \mathrm{E}-10$ & $5,8398 \mathrm{E}-11$ \\
\hline Informática & $1,83694 \mathrm{E}-12$ & $1,46148 \mathrm{E}-12$ & $1,23941 \mathrm{E}-11$ & $2,01185 \mathrm{E}-12$ & $1,04141 \mathrm{E}-11$ & $5,49017 \mathrm{E}-12$ & $6,0159 \mathrm{E}-11$ & $7,55181 \mathrm{E}-12$ & $2,66646 \mathrm{E}-11$ & $2,8304 \mathrm{E}-11$ & $1,48014 \mathrm{E}-12$ \\
\hline Máquinas & $2,84537 \mathrm{E}-11$ & $5,17122 \mathrm{E}-11$ & $8,57803 \mathrm{E}-10$ & $9,61936 \mathrm{E}-11$ & $9,59507 \mathrm{E}-11$ & $2,01251 \mathrm{E}-10$ & $1,9993 \mathrm{E}-10$ & $1,24935 \mathrm{E}-11$ & $2,41496 \mathrm{E}-10$ & $7,24489 \mathrm{E}-10$ & $1,79047 \mathrm{E}-10$ \\
\hline Eletrônicos & $9,54609 \mathrm{E}-12$ & $1,08294 \mathrm{E}-11$ & $1,09068 \mathrm{E}-09$ & $2,17033 \mathrm{E}-11$ & $2,1858 \mathrm{E}-11$ & $3,57312 \mathrm{E}-11$ & $7,2806 \mathrm{E}-11$ & $1,25392 \mathrm{E}-11$ & $4,53845 \mathrm{E}-11$ & $8,92167 \mathrm{E}-11$ & $2,43066 \mathrm{E}-11$ \\
\hline Instrumento hospitalar & $8,60448 \mathrm{E}-12$ & $9,48007 \mathrm{E}-12$ & $4,24937 \mathrm{E}-11$ & $1,25324 \mathrm{E}-11$ & $1,66668 \mathrm{E}-11$ & $1,78184 \mathrm{E}-11$ & $9,77488 \mathrm{E}-11$ & $1,90552 \mathrm{E}-11$ & $1,0349 \mathrm{E}-10$ & $1,9907 \mathrm{E}-10$ & $1,53023 \mathrm{E}-11$ \\
\hline Veículos & $1,98779 \mathrm{E}-10$ & $1,62662 \mathrm{E}-10$ & $1,17723 \mathrm{E}-09$ & $3,77701 \mathrm{E}-10$ & $2,03018 \mathrm{E}-10$ & $4,89658 \mathrm{E}-10$ & $9,55442 \mathrm{E}-10$ & $6,24017 \mathrm{E}-11$ & $4,50229 \mathrm{E}-10$ & $9,89361 \mathrm{E}-10$ & $1,78466 \mathrm{E}-10$ \\
\hline Indústria Diversa & $4,88793 \mathrm{E}-12$ & 4,53096E-11 & $1,31943 \mathrm{E}-11$ & $3,07021 \mathrm{E}-11$ & $4,82316 \mathrm{E}-10$ & $1,42258 \mathrm{E}-11$ & $2,61334 \mathrm{E}-10$ & $5,68687 \mathrm{E}-12$ & $1,29903 \mathrm{E}-11$ & $9,28257 \mathrm{E}-11$ & $1,24141 \mathrm{E}-11$ \\
\hline SIUP & 3,81139E-09 & $5,88269 \mathrm{E}-09$ & $1,52944 \mathrm{E}-08$ & 9,42104E-09 & 7,70948E-09 & $8,00877 \mathrm{E}-09$ & 2,36504E-08 & $6,27468 \mathrm{E}-09$ & $1,14246 \mathrm{E}-08$ & $1,1814 \mathrm{E}-08$ & $3,11565 \mathrm{E}-08$ \\
\hline Construção & $6,91674 \mathrm{E}-11$ & $9,82561 \mathrm{E}-11$ & $1,77798 \mathrm{E}-10$ & $2,28144 \mathrm{E}-10$ & $2,04948 \mathrm{E}-10$ & $1,8104 \mathrm{E}-10$ & $3,25943 \mathrm{E}-10$ & $2,58006 \mathrm{E}-10$ & $3,65172 \mathrm{E}-10$ & $5,93068 \mathrm{E}-10$ & $8,08835 \mathrm{E}-10$ \\
\hline Comércio & $2,58661 \mathrm{E}-08$ & 3,81693E-08 & 2,27491E-08 & 4,09276E-08 & 4,29903E-08 & $1,7557 \mathrm{E}-08$ & $2,24609 \mathrm{E}-08$ & $2,32601 \mathrm{E}-08$ & $3,1919 \mathrm{E}-08$ & $2,48765 \mathrm{E}-08$ & 3,99177E-08 \\
\hline Transportes & 2,13241E-08 & $1,94025 \mathrm{E}-08$ & 5,69993E-08 & $3,63696 \mathrm{E}-08$ & $1,69041 \mathrm{E}-08$ & $1,83021 \mathrm{E}-08$ & 3,10047E-08 & $1,78248 \mathrm{E}-08$ & $3,3715 \mathrm{E}-08$ & 2,20466E-08 & $6,83341 \mathrm{E}-08$ \\
\hline Informação & $4,95251 \mathrm{E}-09$ & $7,67762 \mathrm{E}-09$ & $2,25938 \mathrm{E}-08$ & 9,64848E-09 & $5,52867 \mathrm{E}-09$ & 4,09005E-09 & $9,44259 \mathrm{E}-09$ & 2,27189E-08 & $2,92535 \mathrm{E}-08$ & $1,30458 \mathrm{E}-08$ & $1,77039 \mathrm{E}-08$ \\
\hline
\end{tabular}




\begin{tabular}{|c|c|c|c|c|c|c|c|c|c|c|c|}
\hline Financeiro & $2,00647 \mathrm{E}-08$ & $2,22487 \mathrm{E}-08$ & $4,49601 \mathrm{E}-08$ & $3,82882 \mathrm{E}-08$ & $3,06154 \mathrm{E}-08$ & $2,83811 \mathrm{E}-08$ & $6,19024 \mathrm{E}-08$ & $3,51103 \mathrm{E}-08$ & $6,09567 \mathrm{E}-08$ & $4,42759 \mathrm{E}-08$ & 7,11978E-08 \\
\hline Imobiliário & $2,45044 \mathrm{E}-10$ & $3,13819 \mathrm{E}-10$ & $7,43442 \mathrm{E}-10$ & $6,27141 \mathrm{E}-10$ & $6,98718 \mathrm{E}-10$ & $2,79644 \mathrm{E}-10$ & $6,17826 \mathrm{E}-10$ & $9,7348 \mathrm{E}-10$ & $8,33398 \mathrm{E}-10$ & $5,19617 \mathrm{E}-10$ & $9,05456 \mathrm{E}-10$ \\
\hline Alojamento & 3,7979E-11 & $5,35688 \mathrm{E}-11$ & $3,46245 \mathrm{E}-10$ & $9,42407 \mathrm{E}-11$ & $5,49491 \mathrm{E}-11$ & $1,10225 \mathrm{E}-10$ & $1,12332 \mathrm{E}-10$ & $1,4891 \mathrm{E}-10$ & $1,24804 \mathrm{E}-10$ & $1,10861 \mathrm{E}-10$ & $6,09362 \mathrm{E}-10$ \\
\hline Serviços às Empresas & 7,97359E-09 & $1,14632 \mathrm{E}-08$ & $2,21024 \mathrm{E}-08$ & $2,69743 \mathrm{E}-08$ & $1,76979 \mathrm{E}-08$ & $9,4107 \mathrm{E}-09$ & $2,28229 \mathrm{E}-08$ & $6,21928 \mathrm{E}-08$ & $7,03318 \mathrm{E}-08$ & $1,9032 \mathrm{E}-08$ & $4,41776 \mathrm{E}-08$ \\
\hline Educação e Saúde mercantis & $1,59673 \mathrm{E}-09$ & $2,20765 \mathrm{E}-09$ & 3,24884E-09 & $3,32767 \mathrm{E}-09$ & $4,06277 \mathrm{E}-09$ & $1,49188 \mathrm{E}-09$ & 2,92074E-09 & $3,56111 \mathrm{E}-09$ & $3,57782 \mathrm{E}-09$ & $2,56065 \mathrm{E}-09$ & $3,68915 \mathrm{E}-09$ \\
\hline Outros Serviços & 2,99747E-09 & 4,34402E-09 & $4,52565 \mathrm{E}-09$ & $5,73062 \mathrm{E}-09$ & $6,16038 \mathrm{E}-09$ & 2,27116E-09 & $3,76589 \mathrm{E}-09$ & 4,42686E-09 & $6,1046 \mathrm{E}-09$ & 4,45746E-09 & 7,11033E-09 \\
\hline APU & $1,58933 \mathrm{E}-09$ & $1,89626 \mathrm{E}-09$ & $3,80693 \mathrm{E}-09$ & $3,5156 \mathrm{E}-09$ & $2,21566 \mathrm{E}-09$ & $1,49511 \mathrm{E}-09$ & $3,62987 \mathrm{E}-09$ & $6,718 \mathrm{E}-09$ & $6,07689 \mathrm{E}-09$ & $2,57792 \mathrm{E}-09$ & $5,80519 \mathrm{E}-09$ \\
\hline
\end{tabular}

Tabela B9 - Matriz Geração de Emprego para o Grau de Instrução G(8), Distrito Federal - 2008.

(2)

\begin{tabular}{|c|c|c|c|c|c|c|c|c|c|c|}
\hline Setores & Aço & Metal & Eletrodomésticos & Informática & Máquinas & Eletrônicos & $\begin{array}{l}\text { Instrumento } \\
\text { hospitalar }\end{array}$ & Veículos & $\begin{array}{l}\text { Indústria } \\
\text { Diversa }\end{array}$ & SIUP \\
\hline Agricultura & $1,3246 \mathrm{E}-11$ & $7,30329 \mathrm{E}-12$ & $2,6223 \mathrm{E}-11$ & $2,49809 \mathrm{E}-11$ & $1,48982 \mathrm{E}-11$ & $3,41063 \mathrm{E}-11$ & $9,06207 \mathrm{E}-12$ & $5,20311 \mathrm{E}-11$ & $2,03596 \mathrm{E}-11$ & $3,69035 \mathrm{E}-12$ \\
\hline Pecuária & $3,13481 \mathrm{E}-12$ & $1,54853 \mathrm{E}-12$ & $3,82756 \mathrm{E}-12$ & $4,14014 \mathrm{E}-12$ & $3,28337 \mathrm{E}-12$ & $4,29597 \mathrm{E}-12$ & $1,77045 \mathrm{E}-12$ & $6,85286 \mathrm{E}-12$ & $3,67083 \mathrm{E}-11$ & $1,00685 \mathrm{E}-12$ \\
\hline Extrativa & 4,80004E-08 & 2,83587E-09 & 8,99993E-09 & $6,8597 \mathrm{E}-10$ & 2,72913E-09 & $1,53373 \mathrm{E}-09$ & $2,55552 \mathrm{E}-10$ & $5,13356 \mathrm{E}-09$ & $1,57364 \mathrm{E}-09$ & $2,40899 \mathrm{E}-11$ \\
\hline Alimentos & $5,43522 \mathrm{E}-11$ & $2,55537 \mathrm{E}-11$ & $5,28997 \mathrm{E}-11$ & $5,91802 \mathrm{E}-11$ & $5,3297 \mathrm{E}-11$ & $5,7892 \mathrm{E}-11$ & $2,80658 \mathrm{E}-11$ & $7,15751 \mathrm{E}-11$ & $5,09178 \mathrm{E}-11$ & $1,70614 \mathrm{E}-11$ \\
\hline Vestuário & $2,21343 \mathrm{E}-11$ & $3,3872 \mathrm{E}-11$ & $1,85908 \mathrm{E}-10$ & $2,58557 \mathrm{E}-11$ & $2,17157 \mathrm{E}-11$ & $2,9439 \mathrm{E}-11$ & $3,27701 \mathrm{E}-11$ & $1,59469 \mathrm{E}-10$ & $2,2384 \mathrm{E}-11$ & $2,24106 \mathrm{E}-11$ \\
\hline Madeira & $3,07174 \mathrm{E}-11$ & $4,53705 \mathrm{E}-11$ & $9,05245 \mathrm{E}-10$ & $8,32805 \mathrm{E}-10$ & $4,00318 \mathrm{E}-11$ & 3,70394E-09 & $1,09558 \mathrm{E}-11$ & $5,67428 \mathrm{E}-10$ & $1,2232 \mathrm{E}-09$ & $1,48264 \mathrm{E}-12$ \\
\hline Celulose & $1,94 \mathrm{E}-10$ & $4,68768 \mathrm{E}-11$ & 3,5774E-09 & $1,93432 \mathrm{E}-09$ & $3,49075 \mathrm{E}-10$ & 3,81897E-09 & $8,16849 \mathrm{E}-11$ & $1,95642 \mathrm{E}-09$ & $1,88222 \mathrm{E}-10$ & $1,64264 \mathrm{E}-11$ \\
\hline Revistas & 2,73531E-09 & 2,69171E-09 & $1,64852 \mathrm{E}-09$ & $3,11134 \mathrm{E}-09$ & $1,40459 \mathrm{E}-09$ & 2,61229E-09 & $1,29085 \mathrm{E}-08$ & $3,07107 \mathrm{E}-09$ & $9,17642 \mathrm{E}-10$ & $3,84777 \mathrm{E}-09$ \\
\hline Químicos & $1,45994 \mathrm{E}-08$ & $2,54515 \mathrm{E}-09$ & $1,34765 \mathrm{E}-08$ & $9,66901 \mathrm{E}-10$ & 4,24132E-09 & $1,70489 \mathrm{E}-09$ & 3,21653E-09 & $8,87209 \mathrm{E}-09$ & $1,57845 \mathrm{E}-09$ & $1,06751 \mathrm{E}-09$ \\
\hline Borracha & $6,74936 \mathrm{E}-10$ & $3,86893 \mathrm{E}-10$ & $1,84555 \mathrm{E}-09$ & $1,64436 \mathrm{E}-09$ & $8,48285 \mathrm{E}-10$ & $1,90847 \mathrm{E}-09$ & $5,31767 \mathrm{E}-10$ & $4,42125 \mathrm{E}-09$ & $6,99734 \mathrm{E}-10$ & $1,67409 \mathrm{E}-11$ \\
\hline Cimento & $1,0026 \mathrm{E}-09$ & $2,99224 \mathrm{E}-10$ & $3,88897 \mathrm{E}-10$ & $2,04796 \mathrm{E}-10$ & $9,63442 \mathrm{E}-10$ & $7,5079 \mathrm{E}-10$ & $3,52923 \mathrm{E}-10$ & $8,67319 \mathrm{E}-10$ & $2,01655 \mathrm{E}-09$ & $9,71552 \mathrm{E}-12$ \\
\hline Aço & $1,9503 \mathrm{E}-07$ & $1,59168 \mathrm{E}-09$ & $2,91475 \mathrm{E}-08$ & $2,11075 \mathrm{E}-09$ & $5,74611 \mathrm{E}-09$ & $5,07722 \mathrm{E}-09$ & $5,80635 \mathrm{E}-10$ & $1,6046 \mathrm{E}-08$ & $5,91986 \mathrm{E}-10$ & $1,84535 \mathrm{E}-11$ \\
\hline Metal & $5,20168 \mathrm{E}-09$ & $1,33535 \mathrm{E}-07$ & 8,37373E-09 & $3,141 \mathrm{E}-09$ & $5,81927 \mathrm{E}-09$ & $5,18199 \mathrm{E}-09$ & 3,5669E-09 & $3,73605 \mathrm{E}-09$ & 2,87194E-09 & $1,46022 \mathrm{E}-11$ \\
\hline Eletrodomésticos & 4,01747E-09 & $4,61666 \mathrm{E}-10$ & $1,54391 \mathrm{E}-06$ & 4,27998E-09 & $1,97534 \mathrm{E}-09$ & $2,88805 \mathrm{E}-09$ & $8,6031 \mathrm{E}-10$ & $1,80936 \mathrm{E}-08$ & 2,99496E-10 & $4,84058 \mathrm{E}-11$ \\
\hline Informática & $8,1043 \mathrm{E}-12$ & $4,36832 \mathrm{E}-12$ & $4,18854 \mathrm{E}-11$ & $1,7742 \mathrm{E}-06$ & $2,59812 \mathrm{E}-11$ & $8,88681 \mathrm{E}-10$ & $5,63761 \mathrm{E}-12$ & $5,4747 \mathrm{E}-11$ & $4,44231 \mathrm{E}-12$ & $8,8187 \mathrm{E}-13$ \\
\hline Máquinas & $3,08922 \mathrm{E}-10$ & $8,44643 \mathrm{E}-11$ & $6,37868 \mathrm{E}-09$ & $1,52651 \mathrm{E}-08$ & $2,49658 \mathrm{E}-07$ & $2,80524 \mathrm{E}-08$ & $1,86069 \mathrm{E}-09$ & 4,17093E-09 & $6,23238 \mathrm{E}-10$ & $4,73748 \mathrm{E}-10$ \\
\hline
\end{tabular}




\begin{tabular}{|c|c|c|c|c|c|c|c|c|c|c|}
\hline Eletrônicos & $1,03603 \mathrm{E}-10$ & $6,21284 \mathrm{E}-11$ & 2,615E-09 & $3,05918 \mathrm{E}-07$ & 2,55049E-09 & $1,50775 \mathrm{E}-06$ & $3,0256 \mathrm{E}-10$ & 2,43193E-09 & $1,26685 \mathrm{E}-10$ & 4,91759E-11 \\
\hline Instrumento hospitalar & $3,03616 \mathrm{E}-11$ & $1,66912 \mathrm{E}-11$ & 4,60419E-09 & $6,01954 \mathrm{E}-10$ & $1,7879 \mathrm{E}-09$ & $8,39878 \mathrm{E}-10$ & $1,44442 \mathrm{E}-06$ & $7,68535 \mathrm{E}-10$ & $7,89965 \mathrm{E}-11$ & $1,74511 \mathrm{E}-11$ \\
\hline Veículos & 2,69834E-09 & $1,70471 \mathrm{E}-09$ & 1,2171E-08 & 8,5981E-09 & $9,82257 \mathrm{E}-09$ & $1,56023 \mathrm{E}-08$ & 2,0678E-09 & $4,301 \mathrm{E}-06$ & 1,23044E-09 & $2,62423 \mathrm{E}-10$ \\
\hline Indústria Diversa & $6,20445 \mathrm{E}-10$ & $4,57145 \mathrm{E}-11$ & $1,44203 \mathrm{E}-10$ & $2,72917 \mathrm{E}-11$ & $8,37309 \mathrm{E}-11$ & $4,44107 \mathrm{E}-11$ & $1,18328 \mathrm{E}-11$ & $7,44948 \mathrm{E}-11$ & $1,55467 \mathrm{E}-07$ & $3,87603 \mathrm{E}-12$ \\
\hline SIUP & $2,76828 \mathrm{E}-08$ & $1,34995 \mathrm{E}-08$ & $1,34375 \mathrm{E}-08$ & $8,99779 \mathrm{E}-09$ & $1,57758 \mathrm{E}-08$ & $1,09943 \mathrm{E}-08$ & $1,14977 \mathrm{E}-08$ & $1,17803 \mathrm{E}-08$ & $8,38815 \mathrm{E}-09$ & $1,25334 \mathrm{E}-06$ \\
\hline Construção & $2,5199 \mathrm{E}-10$ & $1,69332 \mathrm{E}-10$ & $3,42514 \mathrm{E}-10$ & $5,04225 \mathrm{E}-10$ & $6,96434 \mathrm{E}-10$ & $1,05235 \mathrm{E}-09$ & $1,59659 \mathrm{E}-10$ & $1,11607 \mathrm{E}-09$ & $2,04631 \mathrm{E}-10$ & $1,58178 \mathrm{E}-10$ \\
\hline Comércio & $2,1267 \mathrm{E}-08$ & $1,86264 \mathrm{E}-08$ & $3,12915 \mathrm{E}-08$ & $7,04404 \mathrm{E}-08$ & 2,78972E-08 & $5,26141 \mathrm{E}-08$ & $2,81001 \mathrm{E}-08$ & $4,00852 \mathrm{E}-08$ & $3,25427 \mathrm{E}-08$ & $8,88213 \mathrm{E}-09$ \\
\hline Informação & $2,30947 \mathrm{E}-08$ & $1,02714 \mathrm{E}-08$ & $2,58343 \mathrm{E}-08$ & $3,71392 \mathrm{E}-08$ & $3,16958 \mathrm{E}-08$ & $5,46428 \mathrm{E}-08$ & $1,67377 \mathrm{E}-08$ & $2,06595 \mathrm{E}-08$ & $5,61214 \mathrm{E}-09$ & $1,95429 \mathrm{E}-08$ \\
\hline Financeiro & $7,75627 \mathrm{E}-08$ & $4,56946 \mathrm{E}-08$ & $9,88157 \mathrm{E}-08$ & $6,90136 \mathrm{E}-08$ & 7,05981E-08 & $1,21609 \mathrm{E}-07$ & $4,9079 \mathrm{E}-08$ & $6,77836 \mathrm{E}-08$ & $2,90465 \mathrm{E}-08$ & 2,61198E-08 \\
\hline Imobiliário & $5,87122 \mathrm{E}-10$ & $4,98209 \mathrm{E}-10$ & $7,76321 \mathrm{E}-10$ & $8,32446 \mathrm{E}-10$ & $6,15874 \mathrm{E}-10$ & $8,23485 \mathrm{E}-10$ & $7,24441 \mathrm{E}-10$ & $5,4193 \mathrm{E}-10$ & $4,72492 \mathrm{E}-10$ & $4,25131 \mathrm{E}-10$ \\
\hline Alojamento & $1,61353 \mathrm{E}-10$ & $6,14996 \mathrm{E}-11$ & $8,88426 \mathrm{E}-11$ & $1,28474 \mathrm{E}-10$ & $1,90638 \mathrm{E}-10$ & $1,28364 \mathrm{E}-10$ & $5,52415 \mathrm{E}-11$ & $1,70443 \mathrm{E}-10$ & $1,14798 \mathrm{E}-10$ & $4,71831 \mathrm{E}-11$ \\
\hline Serviços às Empresas & $1,84927 \mathrm{E}-08$ & $1,80208 \mathrm{E}-08$ & $2,15979 \mathrm{E}-08$ & $9,66126 \mathrm{E}-08$ & $3,07971 \mathrm{E}-08$ & $6,80947 \mathrm{E}-08$ & 2,47318E-08 & $4,13621 \mathrm{E}-08$ & $1,42292 \mathrm{E}-08$ & $5,25284 \mathrm{E}-08$ \\
\hline Educação e Saúde mercantis & $2,42466 \mathrm{E}-09$ & 2,44992E-09 & $3,59755 \mathrm{E}-09$ & $5,01273 \mathrm{E}-09$ & $3,08202 \mathrm{E}-09$ & $4,6043 \mathrm{E}-09$ & $3,06519 \mathrm{E}-09$ & $3,10754 \mathrm{E}-09$ & 2,81291E-09 & $1,92903 \mathrm{E}-09$ \\
\hline APU & $3,69626 \mathrm{E}-09$ & $2,54135 \mathrm{E}-09$ & 2,98999E-09 & $7,68354 \mathrm{E}-09$ & $3,32651 \mathrm{E}-09$ & $6,10413 \mathrm{E}-09$ & 2,95971E-09 & $4,12595 \mathrm{E}-09$ & $1,90916 \mathrm{E}-09$ & $6,85838 \mathrm{E}-09$ \\
\hline
\end{tabular}

Tabela B9 - Matriz Geração de Emprego para o Grau de Instrução G(8), Distrito Federal - 2008.

(3)

\begin{tabular}{|c|c|c|c|c|c|c|c|c|c|c|c|}
\hline Setores & Construção & Comércio & Transportes & Informação & Financeiro & Imobiliário & Alojamento & $\begin{array}{c}\text { Serviços às } \\
\text { Empresas }\end{array}$ & $\begin{array}{l}\text { Educação e } \\
\text { Saúde } \\
\text { mercantis }\end{array}$ & $\begin{array}{c}\text { Outros } \\
\text { Serviços }\end{array}$ & APU \\
\hline Agricultura & $1,05887 \mathrm{E}-11$ & $3,28521 \mathrm{E}-11$ & $2,48505 \mathrm{E}-11$ & $1,50741 \mathrm{E}-11$ & $9,76079 \mathrm{E}-12$ & $2,06872 \mathrm{E}-12$ & 3,30497E-09 & $1,49667 \mathrm{E}-11$ & $7,87916 \mathrm{E}-11$ & $3,40372 \mathrm{E}-10$ & $4,20658 \mathrm{E}-11$ \\
\hline Pecuária & $3,02689 \mathrm{E}-12$ & $8,89563 \mathrm{E}-12$ & $7,92022 \mathrm{E}-12$ & $3,92022 \mathrm{E}-12$ & $3,00116 \mathrm{E}-12$ & $5,07499 \mathrm{E}-13$ & $1,17153 \mathrm{E}-09$ & $3,92015 \mathrm{E}-12$ & $2,60742 \mathrm{E}-11$ & $1,27296 \mathrm{E}-10$ & $1,22114 \mathrm{E}-11$ \\
\hline Extrativa & $1,25282 \mathrm{E}-10$ & $6,53079 \mathrm{E}-11$ & $4,02477 \mathrm{E}-11$ & $7,56297 \mathrm{E}-11$ & $2,25708 \mathrm{E}-11$ & $1,24981 \mathrm{E}-11$ & $5,93822 \mathrm{E}-11$ & $6,03489 \mathrm{E}-11$ & $5,93791 \mathrm{E}-11$ & $5,60342 \mathrm{E}-11$ & $6,15296 \mathrm{E}-11$ \\
\hline Alimentos & $6,6864 \mathrm{E}-11$ & $2,07764 \mathrm{E}-10$ & $1,83513 \mathrm{E}-10$ & $7,27212 \mathrm{E}-11$ & $5,97902 \mathrm{E}-11$ & $1,00754 \mathrm{E}-11$ & $2,61735 \mathrm{E}-08$ & $6,97513 \mathrm{E}-11$ & $4,24861 \mathrm{E}-10$ & $9,73474 \mathrm{E}-10$ & $1,9406 \mathrm{E}-10$ \\
\hline Vestuário & $1,39115 \mathrm{E}-11$ & $3,11765 \mathrm{E}-11$ & $6,53678 \mathrm{E}-11$ & $3,04396 \mathrm{E}-11$ & $2,49099 \mathrm{E}-11$ & $3,29609 \mathrm{E}-12$ & $3,61679 \mathrm{E}-11$ & $8,91369 \mathrm{E}-11$ & $5,74638 \mathrm{E}-11$ & $1,28516 \mathrm{E}-10$ & $2,50357 \mathrm{E}-11$ \\
\hline Madeira & $1,39034 \mathrm{E}-11$ & $4,93315 \mathrm{E}-12$ & $3,30897 \mathrm{E}-12$ & $6,54737 \mathrm{E}-12$ & $3,70175 \mathrm{E}-12$ & $4,83528 \mathrm{E}-12$ & $4,03702 \mathrm{E}-12$ & $5,44531 \mathrm{E}-12$ & $7,23035 \mathrm{E}-12$ & $7,63102 \mathrm{E}-12$ & $1,09147 \mathrm{E}-11$ \\
\hline
\end{tabular}




\begin{tabular}{|c|c|c|c|c|c|c|c|c|c|c|c|}
\hline Celulose & $1,18959 \mathrm{E}-11$ & $4,77103 \mathrm{E}-11$ & $3,01591 \mathrm{E}-11$ & $6,07196 \mathrm{E}-11$ & $2,05626 \mathrm{E}-11$ & $8,00293 \mathrm{E}-12$ & $2,98791 \mathrm{E}-11$ & 7,94136E-11 & $4,25063 \mathrm{E}-11$ & $4,01126 \mathrm{E}-11$ & $3,99626 \mathrm{E}-11$ \\
\hline Revistas & $1,02303 \mathrm{E}-09$ & 3,68291E-09 & $3,10386 \mathrm{E}-09$ & 8,60133E-09 & 4,45374E-09 & $9,68005 \mathrm{E}-10$ & $1,01919 \mathrm{E}-09$ & $2,73396 \mathrm{E}-08$ & 4,46301E-09 & $4,72496 \mathrm{E}-09$ & 2,59691E-09 \\
\hline Químicos & $1,4449 \mathrm{E}-10$ & $7,64829 \mathrm{E}-11$ & $5,40221 \mathrm{E}-11$ & $1,40733 \mathrm{E}-10$ & $3,21483 \mathrm{E}-11$ & 2,09492E-11 & $1,04933 \mathrm{E}-09$ & $8,74731 \mathrm{E}-11$ & $1,00479 \mathrm{E}-09$ & $1,97061 \mathrm{E}-10$ & $1,51921 \mathrm{E}-10$ \\
\hline Borracha & $6,94115 \mathrm{E}-11$ & $2,76737 \mathrm{E}-11$ & $2,32827 \mathrm{E}-11$ & $5,68568 \mathrm{E}-11$ & $9,09502 \mathrm{E}-12$ & $5,19015 \mathrm{E}-12$ & $3,77629 \mathrm{E}-11$ & $8,23966 \mathrm{E}-11$ & $7,1966 \mathrm{E}-11$ & $2,29624 \mathrm{E}-11$ & $1,09288 \mathrm{E}-11$ \\
\hline Cimento & 4,08848E-09 & $1,46348 \mathrm{E}-11$ & $6,28679 \mathrm{E}-12$ & $1,81128 \mathrm{E}-11$ & $1,69358 \mathrm{E}-11$ & 3,61577E-11 & $2,85294 \mathrm{E}-11$ & 1,36079E-11 & $1,34958 \mathrm{E}-10$ & $7,11522 \mathrm{E}-11$ & 6,75571E-11 \\
\hline Aço & $5,42482 \mathrm{E}-11$ & $7,95367 \mathrm{E}-12$ & $6,23071 \mathrm{E}-12$ & $1,09058 \mathrm{E}-11$ & $3,12811 \mathrm{E}-12$ & $2,92757 \mathrm{E}-12$ & $1,47255 \mathrm{E}-11$ & $7,63112 \mathrm{E}-12$ & $9,21649 \mathrm{E}-12$ & $1,03084 \mathrm{E}-11$ & $7,38 \mathrm{E}-12$ \\
\hline Metal & $3,58939 \mathrm{E}-10$ & $3,46528 \mathrm{E}-11$ & $8,13198 \mathrm{E}-12$ & $1,89079 \mathrm{E}-11$ & $5,54498 \mathrm{E}-12$ & $1,35585 \mathrm{E}-11$ & $1,53326 \mathrm{E}-10$ & $9,64839 \mathrm{E}-12$ & $3,63548 \mathrm{E}-11$ & $2,31147 \mathrm{E}-11$ & $2,41236 \mathrm{E}-11$ \\
\hline Eletrodomésticos & $6,00614 \mathrm{E}-11$ & $5,75025 \mathrm{E}-11$ & $3,91305 \mathrm{E}-11$ & $7,24871 \mathrm{E}-11$ & $2,01525 \mathrm{E}-11$ & $1,51366 \mathrm{E}-11$ & 4,61959E-11 & $5,67059 \mathrm{E}-11$ & $5,37476 \mathrm{E}-11$ & $5,43593 \mathrm{E}-11$ & $5,50466 \mathrm{E}-11$ \\
\hline Informática & $3,54075 \mathrm{E}-12$ & $2,9429 \mathrm{E}-12$ & $1,52726 \mathrm{E}-12$ & $5,65229 \mathrm{E}-12$ & $1,90391 \mathrm{E}-12$ & $2,61366 \mathrm{E}-12$ & $1,56397 \mathrm{E}-12$ & $3,37214 \mathrm{E}-12$ & $4,14802 \mathrm{E}-12$ & $3,35205 \mathrm{E}-12$ & $5,82632 \mathrm{E}-12$ \\
\hline Máquinas & $1,30049 \mathrm{E}-10$ & $2,74281 \mathrm{E}-11$ & $8,0723 \mathrm{E}-11$ & $1,17652 \mathrm{E}-10$ & $1,46801 \mathrm{E}-11$ & $3,18992 \mathrm{E}-11$ & $2,17695 \mathrm{E}-11$ & 4,09573E-11 & $3,64536 \mathrm{E}-11$ & $1,29782 \mathrm{E}-10$ & $2,31087 \mathrm{E}-11$ \\
\hline Eletrônicos & $1,80361 \mathrm{E}-11$ & $1,19466 \mathrm{E}-11$ & $1,48759 \mathrm{E}-11$ & $2,53014 \mathrm{E}-11$ & $5,5921 \mathrm{E}-12$ & $6,93914 \mathrm{E}-12$ & $8,69175 \mathrm{E}-12$ & $1,69861 \mathrm{E}-11$ & $1,16495 \mathrm{E}-11$ & $2,12446 \mathrm{E}-11$ & $1,1061 \mathrm{E}-11$ \\
\hline Instrumento hospitalar & $9,77978 \mathrm{E}-11$ & $5,91022 \mathrm{E}-11$ & $1,87438 \mathrm{E}-11$ & $2,43701 \mathrm{E}-11$ & $1,37333 \mathrm{E}-11$ & $1,1141 \mathrm{E}-10$ & $1,19233 \mathrm{E}-11$ & $1,58589 \mathrm{E}-10$ & $1,64622 \mathrm{E}-10$ & $1,2542 \mathrm{E}-10$ & $3,41104 \mathrm{E}-11$ \\
\hline Veículos & $2,09822 \mathrm{E}-10$ & $1,16285 \mathrm{E}-10$ & $1,01847 \mathrm{E}-10$ & $1,76261 \mathrm{E}-10$ & $4,60915 \mathrm{E}-11$ & $4,42817 \mathrm{E}-11$ & $1,08884 \mathrm{E}-10$ & $1,18518 \mathrm{E}-10$ & $1,1527 \mathrm{E}-10$ & $1,54084 \mathrm{E}-10$ & $1,15609 \mathrm{E}-10$ \\
\hline Indústria Diversa & $5,11376 \mathrm{E}-11$ & $6,969 \mathrm{E}-12$ & $4,38264 \mathrm{E}-11$ & $8,59981 \mathrm{E}-12$ & $7,7452 \mathrm{E}-11$ & $1,9366 \mathrm{E}-11$ & $8,55476 \mathrm{E}-12$ & $2,83295 \mathrm{E}-11$ & $2,80693 \mathrm{E}-11$ & $1,41624 \mathrm{E}-10$ & $3,09404 \mathrm{E}-11$ \\
\hline SIUP & $2,73882 \mathrm{E}-09$ & $9,38423 \mathrm{E}-09$ & $7,7818 \mathrm{E}-09$ & 7,31289E-09 & 4,41299E-09 & $9,29536 \mathrm{E}-10$ & $9,48636 \mathrm{E}-09$ & $8,23556 \mathrm{E}-09$ & $1,21258 \mathrm{E}-08$ & $2,72825 \mathrm{E}-08$ & $1,04442 \mathrm{E}-08$ \\
\hline Construção & $3,77287 \mathrm{E}-07$ & $4,31759 \mathrm{E}-10$ & $3,35628 \mathrm{E}-10$ & 1,37491E-09 & $1,3603 \mathrm{E}-09$ & $3,25213 \mathrm{E}-09$ & $2,31076 \mathrm{E}-10$ & $9,68878 \mathrm{E}-10$ & 2,90418E-09 & 2,50707E-09 & $5,67125 \mathrm{E}-09$ \\
\hline Comércio & $2,91471 \mathrm{E}-08$ & $5,47469 \mathrm{E}-07$ & $2,42743 \mathrm{E}-08$ & 1,20617E-08 & 7,21102E-09 & $3,18242 \mathrm{E}-09$ & $5,58787 \mathrm{E}-08$ & $2,091 \mathrm{E}-08$ & $1,86068 \mathrm{E}-08$ & $2,01186 \mathrm{E}-08$ & $1,06626 \mathrm{E}-08$ \\
\hline Transportes & $1,30403 \mathrm{E}-08$ & $3,43099 \mathrm{E}-08$ & $1,04794 \mathrm{E}-06$ & 2,32744E-08 & $9,78682 \mathrm{E}-09$ & $1,74076 \mathrm{E}-09$ & $1,57048 \mathrm{E}-08$ & $1,84898 \mathrm{E}-08$ & $1,66147 \mathrm{E}-08$ & $2,45585 \mathrm{E}-08$ & $8,92 \mathrm{E}-09$ \\
\hline Informação & $6,39644 \mathrm{E}-09$ & $2,01603 \mathrm{E}-08$ & $2,10775 \mathrm{E}-08$ & 1,50913E-06 & $6,14941 \mathrm{E}-08$ & 4,15764E-09 & $1,0071 \mathrm{E}-08$ & $1,63459 \mathrm{E}-07$ & $5,62117 \mathrm{E}-08$ & 3,68103E-08 & $6,81525 \mathrm{E}-08$ \\
\hline Financeiro & $2,10318 \mathrm{E}-08$ & $4,17442 \mathrm{E}-08$ & $5,77223 \mathrm{E}-08$ & $5,87605 \mathrm{E}-08$ & $1,66675 \mathrm{E}-06$ & $8,49178 \mathrm{E}-09$ & $2,1711 \mathrm{E}-08$ & $5,56136 \mathrm{E}-08$ & $2,45539 \mathrm{E}-08$ & $1,36664 \mathrm{E}-08$ & $1,30056 \mathrm{E}-07$ \\
\hline Imobiliário & $3,50011 \mathrm{E}-10$ & $1,76202 \mathrm{E}-09$ & 3,14012E-09 & 2,84479E-09 & $9,02345 \mathrm{E}-10$ & $8,36619 \mathrm{E}-08$ & $1,08426 \mathrm{E}-09$ & $2,05355 \mathrm{E}-09$ & $2,13618 \mathrm{E}-09$ & $1,53077 \mathrm{E}-09$ & 1,61569E-09 \\
\hline Alojamento & $1,61198 \mathrm{E}-10$ & $2,24012 \mathrm{E}-10$ & $4,36164 \mathrm{E}-10$ & $2,94138 \mathrm{E}-10$ & $2,82886 \mathrm{E}-10$ & $3,12137 \mathrm{E}-11$ & $1,73034 \mathrm{E}-07$ & $2,53765 \mathrm{E}-10$ & $1,34527 \mathrm{E}-09$ & $1,53529 \mathrm{E}-09$ & $8,31542 \mathrm{E}-10$ \\
\hline Serviços às Empresas & $2,13259 \mathrm{E}-08$ & $5,94832 \mathrm{E}-08$ & $6,83526 \mathrm{E}-08$ & $9,74197 \mathrm{E}-08$ & $7,36812 \mathrm{E}-08$ & $1,15146 \mathrm{E}-08$ & $1,88392 \mathrm{E}-08$ & $1,17567 \mathrm{E}-06$ & $9,8068 \mathrm{E}-08$ & $6,24051 \mathrm{E}-08$ & $6,92985 \mathrm{E}-08$ \\
\hline Educação e Saúde mercantis & $2,15592 \mathrm{E}-09$ & $7,68221 \mathrm{E}-09$ & 5,09113E-09 & $8,57805 \mathrm{E}-09$ & $8,84601 \mathrm{E}-09$ & $1,10787 \mathrm{E}-09$ & $6,12481 \mathrm{E}-09$ & 7,30254E-09 & $3,86895 \mathrm{E}-06$ & $5,85342 \mathrm{E}-09$ & $1,20754 \mathrm{E}-08$ \\
\hline Outros Serviços & 4,18153E-09 & $1,10555 \mathrm{E}-08$ & 6,91212E-09 & $1,23203 \mathrm{E}-08$ & $6,32955 \mathrm{E}-09$ & $1,23439 \mathrm{E}-09$ & $1,20558 \mathrm{E}-08$ & $1,47198 \mathrm{E}-08$ & $1,08929 \mathrm{E}-08$ & $1,55038 \mathrm{E}-06$ & $7,80428 \mathrm{E}-09$ \\
\hline APU & $1,96039 \mathrm{E}-09$ & $5,27121 \mathrm{E}-09$ & $5,52986 \mathrm{E}-09$ & 7,11317E-09 & $5,09203 \mathrm{E}-09$ & $8,42955 \mathrm{E}-10$ & 2,49541E-09 & 6,33051E-09 & $6,94806 \mathrm{E}-09$ & $5,36948 \mathrm{E}-09$ & $1,72508 \mathrm{E}-06$ \\
\hline
\end{tabular}


Tabela B10 - Matriz Geração de Emprego para o Grau de Instrução G(9), Distrito Federal - 2008.

(1)

\begin{tabular}{|c|c|c|c|c|c|c|c|c|c|c|c|}
\hline Setores & Agricultura & Pecuária & Extrativa & Alimentos & Vestuário & Madeira & Celulose & Revistas & Químicos & Borracha & Cimento \\
\hline Agricultura & $1,02909 \mathrm{E}-08$ & $6,75174 \mathrm{E}-10$ & $1,12298 \mathrm{E}-12$ & $8,29112 \mathrm{E}-10$ & $1,03719 \mathrm{E}-11$ & $1,6304 \mathrm{E}-11$ & $4,70853 \mathrm{E}-11$ & $4,59299 \mathrm{E}-13$ & $2,06769 \mathrm{E}-12$ & $3,50418 \mathrm{E}-11$ & $8,03748 \mathrm{E}-13$ \\
\hline Pecuária & 0 & 0 & 0 & 0 & 0 & 0 & 0 & 0 & 0 & 0 & 0 \\
\hline Extrativa & $2,27265 \mathrm{E}-12$ & $5,3874 \mathrm{E}-12$ & $3,13104 \mathrm{E}-08$ & $1,2817 \mathrm{E}-12$ & $1,17789 \mathrm{E}-12$ & $1,62164 \mathrm{E}-12$ & $1,25415 \mathrm{E}-11$ & $3,00153 \mathrm{E}-13$ & $1,90616 \mathrm{E}-11$ & $4,05487 \mathrm{E}-12$ & $1,41662 \mathrm{E}-11$ \\
\hline Alimentos & $1,25428 \mathrm{E}-11$ & $1,90469 \mathrm{E}-10$ & $6,57946 \mathrm{E}-13$ & $1,14834 \mathrm{E}-09$ & $8,66452 \mathrm{E}-12$ & $8,97132 \mathrm{E}-13$ & $2,80439 \mathrm{E}-12$ & $2,43237 \mathrm{E}-13$ & $1,05955 \mathrm{E}-12$ & $3,54681 \mathrm{E}-13$ & $6,43417 \mathrm{E}-13$ \\
\hline Vestuário & 0 & 0 & 0 & 0 & 0 & 0 & 0 & 0 & 0 & 0 & 0 \\
\hline Madeira & 0 & 0 & 0 & 0 & 0 & 0 & 0 & 0 & 0 & 0 & 0 \\
\hline Celulose & 0 & 0 & 0 & 0 & 0 & 0 & 0 & 0 & 0 & 0 & 0 \\
\hline Revistas & 0 & 0 & 0 & 0 & 0 & 0 & 0 & 0 & 0 & 0 & 0 \\
\hline Químicos & $8,41365 \mathrm{E}-10$ & $5,85199 \mathrm{E}-10$ & $1,95515 \mathrm{E}-10$ & $1,09479 \mathrm{E}-10$ & $6,01786 \mathrm{E}-11$ & $1,11553 \mathrm{E}-10$ & $5,07343 \mathrm{E}-10$ & $3,38265 \mathrm{E}-12$ & $2,17736 \mathrm{E}-08$ & $2,95717 \mathrm{E}-10$ & $2,76942 \mathrm{E}-11$ \\
\hline Borracha & 0 & 0 & 0 & 0 & 0 & 0 & 0 & 0 & 0 & 0 & 0 \\
\hline Cimento & 0 & 0 & 0 & 0 & 0 & 0 & 0 & 0 & 0 & 0 & 0 \\
\hline Aço & 0 & 0 & 0 & 0 & 0 & 0 & 0 & 0 & 0 & 0 & 0 \\
\hline Metal & 0 & 0 & 0 & 0 & 0 & 0 & 0 & 0 & 0 & 0 & 0 \\
\hline Eletrodomésticos & 0 & 0 & 0 & 0 & 0 & 0 & 0 & 0 & 0 & 0 & 0 \\
\hline Informática & 0 & 0 & 0 & 0 & 0 & 0 & 0 & 0 & 0 & 0 & 0 \\
\hline Máquinas & 0 & 0 & 0 & 0 & 0 & 0 & 0 & 0 & 0 & 0 & 0 \\
\hline Eletrônicos & 0 & 0 & 0 & 0 & 0 & 0 & 0 & 0 & 0 & 0 & 0 \\
\hline Instrumento hospitalar & $8,8706 \mathrm{E}-14$ & $9,77327 \mathrm{E}-14$ & $4,3808 \mathrm{E}-13$ & $1,292 \mathrm{E}-13$ & $1,71822 \mathrm{E}-13$ & $1,83695 \mathrm{E}-13$ & $1,00772 \mathrm{E}-12$ & $1,96446 \mathrm{E}-13$ & $1,06691 \mathrm{E}-12$ & $2,05227 \mathrm{E}-12$ & $1,57756 \mathrm{E}-13$ \\
\hline Veículos & $1,51245 \mathrm{E}-11$ & $1,23765 \mathrm{E}-11$ & $8,95717 \mathrm{E}-11$ & $2,87381 \mathrm{E}-11$ & $1,5447 \mathrm{E}-11$ & $3,72566 \mathrm{E}-11$ & $7,26966 \mathrm{E}-11$ & $4,74795 \mathrm{E}-12$ & $3,42565 \mathrm{E}-11$ & $7,52775 \mathrm{E}-11$ & $1,3579 \mathrm{E}-11$ \\
\hline Indústria Diversa & 0 & 0 & 0 & 0 & 0 & 0 & 0 & 0 & 0 & 0 & 0 \\
\hline SIUP & $1,71737 \mathrm{E}-10$ & $2,65067 \mathrm{E}-10$ & $6,89147 \mathrm{E}-10$ & $4,24501 \mathrm{E}-10$ & $3,4738 \mathrm{E}-10$ & $3,60866 \mathrm{E}-10$ & $1,06566 \mathrm{E}-09$ & $2,8273 \mathrm{E}-10$ & $5,14778 \mathrm{E}-10$ & $5,32326 \mathrm{E}-10$ & $1,40388 \mathrm{E}-09$ \\
\hline Construção & $6,30539 \mathrm{E}-13$ & $8,95716 \mathrm{E}-13$ & $1,62083 \mathrm{E}-12$ & $2,07979 \mathrm{E}-12$ & $1,86833 \mathrm{E}-12$ & $1,65039 \mathrm{E}-12$ & $2,97134 \mathrm{E}-12$ & $2,35201 \mathrm{E}-12$ & $3,32896 \mathrm{E}-12$ & $5,40649 \mathrm{E}-12$ & $7,37345 \mathrm{E}-12$ \\
\hline Comércio & $1,62278 \mathrm{E}-10$ & $2,39465 \mathrm{E}-10$ & $1,42722 \mathrm{E}-10$ & $2,5677 \mathrm{E}-10$ & $2,69711 \mathrm{E}-10$ & $1,10148 \mathrm{E}-10$ & $1,40914 \mathrm{E}-10$ & $1,45928 \mathrm{E}-10$ & $2,00252 \mathrm{E}-10$ & $1,56069 \mathrm{E}-10$ & $2,50434 \mathrm{E}-10$ \\
\hline Transportes & $6,8295 \mathrm{E}-11$ & $6,21407 \mathrm{E}-11$ & $1,82552 \mathrm{E}-10$ & $1,16481 \mathrm{E}-10$ & $5,4139 \mathrm{E}-11$ & $5,86163 \mathrm{E}-11$ & $9,92993 \mathrm{E}-11$ & $5,70876 \mathrm{E}-11$ & $1,0798 \mathrm{E}-10$ & 7,06091E-11 & $2,18854 \mathrm{E}-10$ \\
\hline Informação & $6,76093 \mathrm{E}-11$ & $1,04811 \mathrm{E}-10$ & $3,0844 \mathrm{E}-10$ & $1,31716 \mathrm{E}-10$ & $7,54748 \mathrm{E}-11$ & $5,58354 \mathrm{E}-11$ & $1,28906 \mathrm{E}-10$ & $3,10148 \mathrm{E}-10$ & $3,99355 \mathrm{E}-10$ & $1,78095 \mathrm{E}-10$ & $2,41686 \mathrm{E}-10$ \\
\hline
\end{tabular}




\begin{tabular}{|c|c|c|c|c|c|c|c|c|c|c|c|}
\hline Financeiro & $3,32622 \mathrm{E}-10$ & $3,68828 \mathrm{E}-10$ & $7,45326 \mathrm{E}-10$ & $6,34722 \mathrm{E}-10$ & $5,07527 \mathrm{E}-10$ & $4,70488 \mathrm{E}-10$ & $1,02619 \mathrm{E}-09$ & $5,8204 \mathrm{E}-10$ & $1,01051 \mathrm{E}-09$ & $7,33983 \mathrm{E}-10$ & $1,18028 \mathrm{E}-09$ \\
\hline Imobiliário & $4,90088 \mathrm{E}-12$ & $6,27638 \mathrm{E}-12$ & $1,48688 \mathrm{E}-11$ & $1,25428 \mathrm{E}-11$ & $1,39744 \mathrm{E}-11$ & $5,59288 \mathrm{E}-12$ & $1,23565 \mathrm{E}-11$ & $1,94696 \mathrm{E}-11$ & $1,6668 \mathrm{E}-11$ & $1,03923 \mathrm{E}-11$ & $1,81091 \mathrm{E}-11$ \\
\hline Alojamento & $1,26597 \mathrm{E}-13$ & $1,78563 \mathrm{E}-13$ & $1,15415 \mathrm{E}-12$ & $3,14136 \mathrm{E}-13$ & $1,83164 \mathrm{E}-13$ & $3,67415 \mathrm{E}-13$ & $3,74439 \mathrm{E}-13$ & $4,96367 \mathrm{E}-13$ & $4,16013 \mathrm{E}-13$ & $3,69536 \mathrm{E}-13$ & $2,03121 \mathrm{E}-12$ \\
\hline Serviços às Empresas & $4,67517 \mathrm{E}-10$ & $6,72122 \mathrm{E}-10$ & 1,29594E-09 & $1,58159 \mathrm{E}-09$ & $1,03768 \mathrm{E}-09$ & $5,5178 \mathrm{E}-10$ & $1,33818 \mathrm{E}-09$ & $3,64656 \mathrm{E}-09$ & $4,12378 \mathrm{E}-09$ & 1,11591E-09 & $2,59028 \mathrm{E}-09$ \\
\hline Educação e Saúde mercantis & $1,16109 \mathrm{E}-10$ & $1,60533 \mathrm{E}-10$ & $2,36244 \mathrm{E}-10$ & $2,41977 \mathrm{E}-10$ & $2,95431 \mathrm{E}-10$ & $1,08484 \mathrm{E}-10$ & $2,12386 \mathrm{E}-10$ & $2,58952 \mathrm{E}-10$ & $2,60167 \mathrm{E}-10$ & $1,86202 \mathrm{E}-10$ & $2,68262 \mathrm{E}-10$ \\
\hline Outros Serviços & $3,61525 \mathrm{E}-11$ & $5,23932 \mathrm{E}-11$ & $5,45839 \mathrm{E}-11$ & 6,91171E-11 & 7,43004E-11 & $2,73925 \mathrm{E}-11$ & $4,54204 \mathrm{E}-11$ & $5,33924 \mathrm{E}-11$ & 7,36277E-11 & $5,37615 \mathrm{E}-11$ & $8,57578 \mathrm{E}-11$ \\
\hline APU & $2,30318 \mathrm{E}-11$ & 2,74797E-11 & $5,51682 \mathrm{E}-11$ & $5,09463 \mathrm{E}-11$ & $3,21082 \mathrm{E}-11$ & $2,16664 \mathrm{E}-11$ & $5,26022 \mathrm{E}-11$ & $9,73538 \mathrm{E}-11$ & $8,80633 \mathrm{E}-11$ & $3,73579 \mathrm{E}-11$ & $8,41259 \mathrm{E}-11$ \\
\hline
\end{tabular}

Tabela B10 - Matriz Geração de Emprego para o Grau de Instrução G(9), Distrito Federal - 2008.

(2)

\begin{tabular}{|c|c|c|c|c|c|c|c|c|c|c|}
\hline Setores & Aço & Metal & Eletrodomésticos & Informática & Máquinas & Eletrônicos & $\begin{array}{l}\text { Instrumento } \\
\text { hospitalar }\end{array}$ & Veículos & $\begin{array}{c}\text { Indústria } \\
\text { Diversa }\end{array}$ & SIUP \\
\hline Agricultura & $6,05532 \mathrm{E}-13$ & $3,33865 \mathrm{E}-13$ & $1,19877 \mathrm{E}-12$ & $1,14198 \mathrm{E}-12$ & $6,81062 \mathrm{E}-13$ & $1,55915 \mathrm{E}-12$ & $4,14266 \mathrm{E}-13$ & $2,37857 \mathrm{E}-12$ & $9,30722 \mathrm{E}-13$ & $1,68702 \mathrm{E}-13$ \\
\hline Pecuária & 0 & 0 & 0 & 0 & 0 & 0 & 0 & 0 & 0 & 0 \\
\hline Extrativa & $5,27477 \mathrm{E}-10$ & $3,11634 \mathrm{E}-11$ & $9,89003 \mathrm{E}-11$ & $7,53814 \mathrm{E}-12$ & $2,99904 \mathrm{E}-11$ & $1,68542 \mathrm{E}-11$ & $2,80827 \mathrm{E}-12$ & $5,64127 \mathrm{E}-11$ & $1,72928 \mathrm{E}-11$ & $2,64724 \mathrm{E}-13$ \\
\hline Alimentos & $2,88341 \mathrm{E}-13$ & $1,35563 \mathrm{E}-13$ & $2,80635 \mathrm{E}-13$ & 3,13953E-13 & $2,82743 \mathrm{E}-13$ & $3,07119 \mathrm{E}-13$ & $1,4889 \mathrm{E}-13$ & $3,79709 \mathrm{E}-13$ & $2,70121 \mathrm{E}-13$ & $9,05115 \mathrm{E}-14$ \\
\hline Vestuário & 0 & 0 & 0 & 0 & 0 & 0 & 0 & 0 & 0 & 0 \\
\hline Madeira & 0 & 0 & 0 & 0 & 0 & 0 & 0 & 0 & 0 & 0 \\
\hline Celulose & 0 & 0 & 0 & 0 & 0 & 0 & 0 & 0 & 0 & 0 \\
\hline Revistas & 0 & 0 & 0 & 0 & 0 & 0 & 0 & 0 & 0 & 0 \\
\hline Químicos & $2,60704 \mathrm{E}-10$ & $4,54491 \mathrm{E}-11$ & $2,40652 \mathrm{E}-10$ & $1,72661 \mathrm{E}-11$ & $7,57378 \mathrm{E}-11$ & $3,04445 \mathrm{E}-11$ & $5,7438 \mathrm{E}-11$ & $1,5843 \mathrm{E}-10$ & $2,81866 \mathrm{E}-11$ & $1,90627 \mathrm{E}-11$ \\
\hline Borracha & 0 & 0 & 0 & 0 & 0 & 0 & 0 & 0 & 0 & 0 \\
\hline Cimento & 0 & 0 & 0 & 0 & 0 & 0 & 0 & 0 & 0 & 0 \\
\hline Aço & 0 & 0 & 0 & 0 & 0 & 0 & 0 & 0 & 0 & 0 \\
\hline Metal & 0 & 0 & 0 & 0 & 0 & 0 & 0 & 0 & 0 & 0 \\
\hline Eletrodomésticos & 0 & 0 & 0 & 0 & 0 & 0 & 0 & 0 & 0 & 0 \\
\hline Informática & 0 & 0 & 0 & 0 & 0 & 0 & 0 & 0 & 0 & 0 \\
\hline Máquinas & 0 & 0 & 0 & 0 & 0 & 0 & 0 & 0 & 0 & 0 \\
\hline
\end{tabular}




\begin{tabular}{|c|c|c|c|c|c|c|c|c|c|c|}
\hline Eletrônicos & 0 & 0 & 0 & 0 & 0 & 0 & 0 & 0 & 0 & 0 \\
\hline Instrumento hospitalar & $3,13006 \mathrm{E}-13$ & $1,72074 \mathrm{E}-13$ & $4,74659 \mathrm{E}-11$ & $6,20572 \mathrm{E}-12$ & $1,8432 \mathrm{E}-11$ & $8,65854 \mathrm{E}-12$ & $1,48909 \mathrm{E}-08$ & 7,92304E-12 & $8,14397 \mathrm{E}-13$ & $1,79908 \mathrm{E}-13$ \\
\hline Veículos & $2,05308 \mathrm{E}-10$ & $1,29706 \mathrm{E}-10$ & $9,26054 \mathrm{E}-10$ & $6,54203 \mathrm{E}-10$ & $7,47369 \mathrm{E}-10$ & $1,18713 \mathrm{E}-09$ & $1,57332 \mathrm{E}-10$ & $3,2725 \mathrm{E}-07$ & $9,36208 \mathrm{E}-11$ & $1,9967 \mathrm{E}-11$ \\
\hline Indústria Diversa & 0 & 0 & 0 & 0 & 0 & 0 & 0 & 0 & 0 & 0 \\
\hline SIUP & $1,24736 \mathrm{E}-09$ & $6,08273 \mathrm{E}-10$ & $6,05481 \mathrm{E}-10$ & $4,0543 \mathrm{E}-10$ & $7,10842 \mathrm{E}-10$ & $4,9539 \mathrm{E}-10$ & $5,18076 \mathrm{E}-10$ & $5,30805 \mathrm{E}-10$ & $3,77961 \mathrm{E}-10$ & $5,6474 \mathrm{E}-08$ \\
\hline Construção & $2,29717 \mathrm{E}-12$ & $1,54366 \mathrm{E}-12$ & $3,1224 \mathrm{E}-12$ & $4,59658 \mathrm{E}-12$ & $6,34879 \mathrm{E}-12$ & $9,59341 \mathrm{E}-12$ & $1,45547 \mathrm{E}-12$ & $1,01743 \mathrm{E}-11$ & $1,86544 \mathrm{E}-12$ & $1,44197 \mathrm{E}-12$ \\
\hline Comércio & $1,33424 \mathrm{E}-10$ & $1,16858 \mathrm{E}-10$ & $1,96316 \mathrm{E}-10$ & $4,41926 \mathrm{E}-10$ & $1,7502 \mathrm{E}-10$ & $3,30088 \mathrm{E}-10$ & $1,76294 \mathrm{E}-10$ & $2,51485 \mathrm{E}-10$ & $2,04165 \mathrm{E}-10$ & $5,57244 \mathrm{E}-11$ \\
\hline Transportes & $1,46811 \mathrm{E}-10$ & $8,42458 \mathrm{E}-11$ & $1,15928 \mathrm{E}-10$ & $1,3002 \mathrm{E}-10$ & $1,10912 \mathrm{E}-10$ & $1,61409 \mathrm{E}-10$ & $8,80719 \mathrm{E}-11$ & $1,01616 \mathrm{E}-10$ & $5,45831 \mathrm{E}-11$ & $4,46019 \mathrm{E}-11$ \\
\hline Informação & $3,15278 \mathrm{E}-10$ & $1,4022 \mathrm{E}-10$ & $3,52677 \mathrm{E}-10$ & $5,07007 \mathrm{E}-10$ & $4,32696 \mathrm{E}-10$ & $7,45958 \mathrm{E}-10$ & $2,28495 \mathrm{E}-10$ & $2,82034 \mathrm{E}-10$ & $7,66143 \mathrm{E}-11$ & $2,66791 \mathrm{E}-10$ \\
\hline Financeiro & $1,28579 \mathrm{E}-09$ & $7,57502 \mathrm{E}-10$ & $1,63812 \mathrm{E}-09$ & 1,14407E-09 & $1,17034 \mathrm{E}-09$ & $2,01598 \mathrm{E}-09$ & $8,13607 \mathrm{E}-10$ & $1,12368 \mathrm{E}-09$ & $4,81518 \mathrm{E}-10$ & $4,33001 \mathrm{E}-10$ \\
\hline Imobiliário & $1,17424 \mathrm{E}-11$ & $9,96417 \mathrm{E}-12$ & $1,55264 \mathrm{E}-11$ & $1,66489 \mathrm{E}-11$ & $1,23175 \mathrm{E}-11$ & $1,64697 \mathrm{E}-11$ & $1,44888 \mathrm{E}-11$ & $1,08386 \mathrm{E}-11$ & $9,44985 \mathrm{E}-12$ & $8,50262 \mathrm{E}-12$ \\
\hline Alojamento & $5,37843 \mathrm{E}-13$ & $2,04999 \mathrm{E}-13$ & $2,96142 \mathrm{E}-13$ & $4,28246 \mathrm{E}-13$ & $6,35459 \mathrm{E}-13$ & $4,2788 \mathrm{E}-13$ & $1,84138 \mathrm{E}-13$ & $5,68143 \mathrm{E}-13$ & $3,82662 \mathrm{E}-13$ & $1,57277 \mathrm{E}-13$ \\
\hline Serviços às Empresas & $1,08428 \mathrm{E}-09$ & $1,05662 \mathrm{E}-09$ & $1,26635 \mathrm{E}-09$ & $5,66471 \mathrm{E}-09$ & $1,80573 \mathrm{E}-09$ & 3,99261E-09 & $1,45011 \mathrm{E}-09$ & $2,42519 \mathrm{E}-09$ & $8,34305 \mathrm{E}-10$ & $3,07991 \mathrm{E}-09$ \\
\hline Educação e Saúde mercantis & $1,76313 \mathrm{E}-10$ & $1,7815 \mathrm{E}-10$ & $2,61601 \mathrm{E}-10$ & $3,64509 \mathrm{E}-10$ & $2,24114 \mathrm{E}-10$ & $3,34809 \mathrm{E}-10$ & $2,2289 \mathrm{E}-10$ & $2,2597 \mathrm{E}-10$ & $2,04545 \mathrm{E}-10$ & $1,40272 \mathrm{E}-10$ \\
\hline Outros Serviços & $5,07035 \mathrm{E}-11$ & $4,61358 \mathrm{E}-11$ & $6,77515 \mathrm{E}-11$ & $1,33092 \mathrm{E}-10$ & $9,67228 \mathrm{E}-11$ & $1,2273 \mathrm{E}-10$ & $5,50478 \mathrm{E}-11$ & $7,16693 \mathrm{E}-11$ & $5,65133 \mathrm{E}-11$ & $5,39135 \mathrm{E}-11$ \\
\hline APU & $5,35643 \mathrm{E}-11$ & $3,6828 \mathrm{E}-11$ & $4,33295 \mathrm{E}-11$ & $1,11346 \mathrm{E}-10$ & $4,82062 \mathrm{E}-11$ & $8,8458 \mathrm{E}-11$ & $4,28907 \mathrm{E}-11$ & $5,97911 \mathrm{E}-11$ & $2,76666 \mathrm{E}-11$ & $9,93882 \mathrm{E}-11$ \\
\hline
\end{tabular}

Tabela B10 - Matriz Geração de Emprego para o Grau de Instrução G(9), Distrito Federal - 2008.

(3)

\begin{tabular}{|c|c|c|c|c|c|c|c|c|c|c|c|}
\hline Setores & Construção & Comércio & Transportes & Informação & Financeiro & Imobiliário & Alojamento & $\begin{array}{c}\text { Serviços às } \\
\text { Empresas }\end{array}$ & $\begin{array}{l}\text { Educação e } \\
\text { Saúde } \\
\text { mercantis }\end{array}$ & $\begin{array}{c}\text { Outros } \\
\text { Serviços }\end{array}$ & APU \\
\hline Agricultura & $4,84054 \mathrm{E}-13$ & $1,50181 \mathrm{E}-12$ & $1,13602 \mathrm{E}-12$ & $6,891 \mathrm{E}-13$ & $4,46207 \mathrm{E}-13$ & $9,45702 \mathrm{E}-14$ & $1,51084 \mathrm{E}-10$ & $6,84193 \mathrm{E}-13$ & $3,6019 \mathrm{E}-12$ & $1,55599 \mathrm{E}-11$ & $1,92301 \mathrm{E}-12$ \\
\hline Pecuária & 0 & 0 & 0 & 0 & 0 & 0 & 0 & 0 & 0 & 0 & 0 \\
\hline Extrativa & $1,37673 \mathrm{E}-12$ & $7,17669 \mathrm{E}-13$ & $4,42282 \mathrm{E}-13$ & $8,31096 \mathrm{E}-13$ & $2,48031 \mathrm{E}-13$ & $1,37342 \mathrm{E}-13$ & $6,52551 \mathrm{E}-13$ & $6,63175 \mathrm{E}-13$ & $6,52518 \mathrm{E}-13$ & $6,1576 \mathrm{E}-13$ & $6,7615 \mathrm{E}-13$ \\
\hline Alimentos & $3,54716 \mathrm{E}-13$ & $1,10219 \mathrm{E}-12$ & $9,73541 \mathrm{E}-13$ & $3,85789 \mathrm{E}-13$ & $3,1719 \mathrm{E}-13$ & $5,34505 \mathrm{E}-14$ & $1,38852 \mathrm{E}-10$ & $3,70033 \mathrm{E}-13$ & $2,2539 \mathrm{E}-12$ & $5,16432 \mathrm{E}-12$ & $1,02949 \mathrm{E}-12$ \\
\hline Vestuário & 0 & 0 & 0 & 0 & 0 & 0 & 0 & 0 & 0 & 0 & 0 \\
\hline Madeira & 0 & 0 & 0 & 0 & 0 & 0 & 0 & 0 & 0 & 0 & 0 \\
\hline
\end{tabular}




\begin{tabular}{|c|c|c|c|c|c|c|c|c|c|c|c|}
\hline Celulose & 0 & 0 & 0 & 0 & 0 & 0 & 0 & 0 & 0 & 0 & 0 \\
\hline Revistas & 0 & 0 & 0 & 0 & 0 & 0 & 0 & 0 & 0 & 0 & 0 \\
\hline Químicos & $2,58018 \mathrm{E}-12$ & $1,36577 \mathrm{E}-12$ & $9,6468 \mathrm{E}-13$ & $2,51309 \mathrm{E}-12$ & $5,74077 \mathrm{E}-13$ & $3,74092 \mathrm{E}-13$ & $1,87381 \mathrm{E}-11$ & $1,56202 \mathrm{E}-12$ & $1,79427 \mathrm{E}-11$ & $3,51895 \mathrm{E}-12$ & $2,71288 \mathrm{E}-12$ \\
\hline Borracha & 0 & 0 & 0 & 0 & 0 & 0 & 0 & 0 & 0 & 0 & 0 \\
\hline Cimento & 0 & 0 & 0 & 0 & 0 & 0 & 0 & 0 & 0 & 0 & 0 \\
\hline Aço & 0 & 0 & 0 & 0 & 0 & 0 & 0 & 0 & 0 & 0 & 0 \\
\hline Metal & 0 & 0 & 0 & 0 & 0 & 0 & 0 & 0 & 0 & 0 & 0 \\
\hline Eletrodomésticos & 0 & 0 & 0 & 0 & 0 & 0 & 0 & 0 & 0 & 0 & 0 \\
\hline Informática & 0 & 0 & 0 & 0 & 0 & 0 & 0 & 0 & 0 & 0 & 0 \\
\hline Máquinas & 0 & 0 & 0 & 0 & 0 & 0 & 0 & 0 & 0 & 0 & 0 \\
\hline Eletrônicos & 0 & 0 & 0 & 0 & 0 & 0 & 0 & 0 & 0 & 0 & 0 \\
\hline Instrumento hospitalar & $1,00822 \mathrm{E}-12$ & $6,09301 \mathrm{E}-13$ & $1,93235 \mathrm{E}-13$ & $2,51238 \mathrm{E}-13$ & $1,4158 \mathrm{E}-13$ & $1,14855 \mathrm{E}-12$ & $1,2292 \mathrm{E}-13$ & $1,63494 \mathrm{E}-12$ & $1,69713 \mathrm{E}-12$ & $1,29299 \mathrm{E}-12$ & $3,51654 \mathrm{E}-13$ \\
\hline Veículos & $1,59647 \mathrm{E}-11$ & $8,84777 \mathrm{E}-12$ & $7,7492 \mathrm{E}-12$ & $1,34111 \mathrm{E}-11$ & $3,50696 \mathrm{E}-12$ & $3,36926 \mathrm{E}-12$ & $8,28464 \mathrm{E}-12$ & $9,01771 \mathrm{E}-12$ & $8,77057 \mathrm{E}-12$ & $1,17238 \mathrm{E}-11$ & $8,79635 \mathrm{E}-12$ \\
\hline Indústria Diversa & 0 & 0 & 0 & 0 & 0 & 0 & 0 & 0 & 0 & 0 & 0 \\
\hline SIUP & $1,23408 \mathrm{E}-10$ & $4,22843 \mathrm{E}-10$ & $3,50639 \mathrm{E}-10$ & $3,2951 \mathrm{E}-10$ & $1,98844 \mathrm{E}-10$ & $4,18838 \mathrm{E}-11$ & $4,27445 \mathrm{E}-10$ & $3,71085 \mathrm{E}-10$ & $5,46375 \mathrm{E}-10$ & $1,22932 \mathrm{E}-09$ & $4,70603 \mathrm{E}-10$ \\
\hline Construção & 3,4394E-09 & $3,93597 \mathrm{E}-12$ & $3,05963 \mathrm{E}-12$ & $1,25338 \mathrm{E}-11$ & $1,24006 \mathrm{E}-11$ & $2,96469 \mathrm{E}-11$ & $2,10652 \mathrm{E}-12$ & $8,83242 \mathrm{E}-12$ & $2,64748 \mathrm{E}-11$ & $2,28548 \mathrm{E}-11$ & $5,16999 \mathrm{E}-11$ \\
\hline Comércio & $1,82862 \mathrm{E}-10$ & $3,43469 \mathrm{E}-09$ & $1,52291 \mathrm{E}-10$ & $7,56723 \mathrm{E}-11$ & $4,52402 \mathrm{E}-11$ & $1,99658 \mathrm{E}-11$ & $3,5057 \mathrm{E}-10$ & $1,31184 \mathrm{E}-10$ & $1,16735 \mathrm{E}-10$ & $1,26219 \mathrm{E}-10$ & $6,68949 \mathrm{E}-11$ \\
\hline Transportes & $4,17643 \mathrm{E}-11$ & $1,09885 \mathrm{E}-10$ & 3,35624E-09 & $7,45412 \mathrm{E}-11$ & $3,13444 \mathrm{E}-11$ & $5,57516 \mathrm{E}-12$ & $5,02981 \mathrm{E}-11$ & $5,92176 \mathrm{E}-11$ & $5,3212 \mathrm{E}-11$ & $7,8654 \mathrm{E}-11$ & $2,85682 \mathrm{E}-11$ \\
\hline Informação & $8,73211 \mathrm{E}-11$ & $2,75219 \mathrm{E}-10$ & $2,8774 \mathrm{E}-10$ & $2,0602 \mathrm{E}-08$ & $8,39488 \mathrm{E}-10$ & $5,67581 \mathrm{E}-11$ & $1,37485 \mathrm{E}-10$ & 2,23147E-09 & $7,67375 \mathrm{E}-10$ & $5,02517 \mathrm{E}-10$ & $9,30386 \mathrm{E}-10$ \\
\hline Financeiro & $3,48655 \mathrm{E}-10$ & $6,92014 \mathrm{E}-10$ & $9,56891 \mathrm{E}-10$ & $9,74102 \mathrm{E}-10$ & $2,76305 \mathrm{E}-08$ & $1,40772 \mathrm{E}-10$ & $3,59914 \mathrm{E}-10$ & $9,21934 \mathrm{E}-10$ & $4,07042 \mathrm{E}-10$ & $2,26554 \mathrm{E}-10$ & $2,156 \mathrm{E}-09$ \\
\hline Imobiliário & $7,00022 \mathrm{E}-12$ & $3,52404 \mathrm{E}-11$ & $6,28025 \mathrm{E}-11$ & $5,68958 \mathrm{E}-11$ & $1,80469 \mathrm{E}-11$ & $1,67324 \mathrm{E}-09$ & $2,16851 \mathrm{E}-11$ & $4,1071 \mathrm{E}-11$ & $4,27236 \mathrm{E}-11$ & $3,06154 \mathrm{E}-11$ & $3,23139 \mathrm{E}-11$ \\
\hline Alojamento & $5,37327 \mathrm{E}-13$ & $7,46705 \mathrm{E}-13$ & $1,45388 \mathrm{E}-12$ & $9,8046 \mathrm{E}-13$ & $9,42954 \mathrm{E}-13$ & $1,04046 \mathrm{E}-13$ & $5,76779 \mathrm{E}-10$ & $8,45883 \mathrm{E}-13$ & $4,48423 \mathrm{E}-12$ & $5,11762 \mathrm{E}-12$ & $2,77181 \mathrm{E}-12$ \\
\hline Serviços às Empresas & $1,25041 \mathrm{E}-09$ & $3,48769 \mathrm{E}-09$ & 4,00773E-09 & $5,71203 \mathrm{E}-09$ & 4,32017E-09 & $6,75141 \mathrm{E}-10$ & $1,1046 \mathrm{E}-09$ & $6,89335 \mathrm{E}-08$ & $5,75005 \mathrm{E}-09$ & $3,65902 \mathrm{E}-09$ & $4,0632 \mathrm{E}-09$ \\
\hline Educação e Saúde mercantis & $1,56771 \mathrm{E}-10$ & $5,58625 \mathrm{E}-10$ & $3,7021 \mathrm{E}-10$ & $6,23767 \mathrm{E}-10$ & $6,43252 \mathrm{E}-10$ & $8,05609 \mathrm{E}-11$ & $4,45375 \mathrm{E}-10$ & $5,31016 \mathrm{E}-10$ & $2,81337 \mathrm{E}-07$ & $4,25641 \mathrm{E}-10$ & $8,78081 \mathrm{E}-10$ \\
\hline Outros Serviços & $5,04335 \mathrm{E}-11$ & $1,33341 \mathrm{E}-10$ & $8,33671 \mathrm{E}-11$ & $1,48595 \mathrm{E}-10$ & $7,63407 \mathrm{E}-11$ & $1,4888 \mathrm{E}-11$ & $1,45406 \mathrm{E}-10$ & $1,77536 \mathrm{E}-10$ & $1,31379 \mathrm{E}-10$ & $1,86992 \mathrm{E}-08$ & $9,41275 \mathrm{E}-11$ \\
\hline APU & $2,8409 \mathrm{E}-11$ & 7,63877E-11 & $8,0136 \mathrm{E}-11$ & $1,0308 \mathrm{E}-10$ & 7,37911E-11 & $1,22157 \mathrm{E}-11$ & $3,61622 \mathrm{E}-11$ & $9,17386 \mathrm{E}-11$ & $1,00688 \mathrm{E}-10$ & $7,78118 \mathrm{E}-11$ & $2,4999 \mathrm{E}-08$ \\
\hline
\end{tabular}


Tabela B11 - Matriz Geração de Emprego para o Grau de Instrução G(10), Distrito Federal - 2008.

(1)

\begin{tabular}{|c|c|c|c|c|c|c|c|c|c|c|c|}
\hline Setores & Agricultura & Pecuária & Extrativa & Alimentos & Vestuário & Madeira & Celulose & Revistas & Químicos & Borracha & Cimento \\
\hline Agricultura & $3,8591 \mathrm{E}-09$ & $2,5319 \mathrm{E}-10$ & $4,21119 \mathrm{E}-13$ & $3,10917 \mathrm{E}-10$ & $3,88946 \mathrm{E}-12$ & $6,11401 \mathrm{E}-12$ & $1,7657 \mathrm{E}-11$ & $1,72237 \mathrm{E}-13$ & $7,75385 \mathrm{E}-13$ & $1,31407 \mathrm{E}-11$ & $3,01405 \mathrm{E}-13$ \\
\hline Pecuária & 0 & 0 & 0 & 0 & 0 & 0 & 0 & 0 & 0 & 0 & 0 \\
\hline Extrativa & 0 & 0 & 0 & 0 & 0 & 0 & 0 & 0 & 0 & 0 & 0 \\
\hline Alimentos & 0 & 0 & 0 & 0 & 0 & 0 & 0 & 0 & 0 & 0 & 0 \\
\hline Vestuário & $2,53871 \mathrm{E}-13$ & $2,24669 \mathrm{E}-13$ & 7,49063E-12 & $3,27448 \mathrm{E}-13$ & $1,3439 \mathrm{E}-08$ & $3,04509 \mathrm{E}-13$ & $1,07558 \mathrm{E}-11$ & $3,44658 \mathrm{E}-13$ & $6,86854 \mathrm{E}-13$ & $2,01277 \mathrm{E}-12$ & $4,76038 \mathrm{E}-13$ \\
\hline Madeira & 0 & 0 & 0 & 0 & 0 & 0 & 0 & 0 & 0 & 0 & 0 \\
\hline Celulose & 0 & 0 & 0 & 0 & 0 & 0 & 0 & 0 & 0 & 0 & 0 \\
\hline Revistas & 0 & 0 & 0 & 0 & 0 & 0 & 0 & 0 & 0 & 0 & 0 \\
\hline Químicos & $1,20195 \mathrm{E}-10$ & $8,35998 \mathrm{E}-11$ & $2,79308 \mathrm{E}-11$ & $1,56398 \mathrm{E}-11$ & $8,59694 \mathrm{E}-12$ & $1,59362 \mathrm{E}-11$ & $7,24775 \mathrm{E}-11$ & $4,83236 \mathrm{E}-13$ & $3,11051 \mathrm{E}-09$ & $4,22453 \mathrm{E}-11$ & $3,95632 \mathrm{E}-12$ \\
\hline Borracha & 0 & 0 & 0 & 0 & 0 & 0 & 0 & 0 & 0 & 0 & 0 \\
\hline Cimento & $1,75822 \mathrm{E}-12$ & $8,97642 \mathrm{E}-13$ & $2,07426 \mathrm{E}-12$ & $3,00428 \mathrm{E}-12$ & $7,90649 \mathrm{E}-13$ & $3,43403 \mathrm{E}-13$ & $2,68645 \mathrm{E}-12$ & $2,81712 \mathrm{E}-13$ & $1,10514 \mathrm{E}-11$ & $8,22804 \mathrm{E}-13$ & $1,74835 \mathrm{E}-09$ \\
\hline Aço & 0 & 0 & 0 & 0 & 0 & 0 & 0 & 0 & 0 & 0 & 0 \\
\hline Metal & 0 & 0 & 0 & 0 & 0 & 0 & 0 & 0 & 0 & 0 & 0 \\
\hline Eletrodomésticos & $7,90975 \mathrm{E}-12$ & $5,39719 \mathrm{E}-12$ & $3,21686 \mathrm{E}-10$ & $9,07334 \mathrm{E}-12$ & $8,28137 \mathrm{E}-11$ & $1,4271 \mathrm{E}-10$ & $6,10719 \mathrm{E}-10$ & $2,43739 \mathrm{E}-12$ & $4,54835 \mathrm{E}-11$ & $6,16009 \mathrm{E}-11$ & $4,76718 \mathrm{E}-12$ \\
\hline Informática & 0 & 0 & 0 & 0 & 0 & 0 & 0 & 0 & 0 & 0 & 0 \\
\hline Máquinas & 0 & 0 & 0 & 0 & 0 & 0 & 0 & 0 & 0 & 0 & 0 \\
\hline Eletrônicos & 0 & 0 & 0 & 0 & 0 & 0 & 0 & 0 & 0 & 0 & 0 \\
\hline Instrumento hospitalar & $8,8706 \mathrm{E}-14$ & $9,77327 \mathrm{E}-14$ & $4,3808 \mathrm{E}-13$ & $1,292 \mathrm{E}-13$ & $1,71822 \mathrm{E}-13$ & $1,83695 \mathrm{E}-13$ & $1,00772 \mathrm{E}-12$ & $1,96446 \mathrm{E}-13$ & $1,06691 \mathrm{E}-12$ & $2,05227 \mathrm{E}-12$ & $1,57756 \mathrm{E}-13$ \\
\hline Veículos & 0 & 0 & 0 & 0 & 0 & 0 & 0 & 0 & 0 & 0 & 0 \\
\hline Indústria Diversa & 0 & 0 & 0 & 0 & 0 & 0 & 0 & 0 & 0 & 0 & 0 \\
\hline SIUP & $1,36609 \mathrm{E}-11$ & $2,10849 \mathrm{E}-11$ & $5,48185 \mathrm{E}-11$ & $3,37672 \mathrm{E}-11$ & $2,76325 \mathrm{E}-11$ & $2,87053 \mathrm{E}-11$ & $8,47686 \mathrm{E}-11$ & $2,24899 \mathrm{E}-11$ & $4,09483 \mathrm{E}-11$ & $4,23441 \mathrm{E}-11$ & $1,11672 \mathrm{E}-10$ \\
\hline Construção & $7,12784 \mathrm{E}-13$ & $1,01255 \mathrm{E}-12$ & $1,83224 \mathrm{E}-12$ & $2,35107 \mathrm{E}-12$ & $2,11203 \mathrm{E}-12$ & $1,86565 \mathrm{E}-12$ & $3,35891 \mathrm{E}-12$ & $2,6588 \mathrm{E}-12$ & $3,76317 \mathrm{E}-12$ & $6,11168 \mathrm{E}-12$ & $8,3352 \mathrm{E}-12$ \\
\hline Comércio & $8,85153 \mathrm{E}-11$ & $1,30617 \mathrm{E}-10$ & $7,78485 \mathrm{E}-11$ & $1,40057 \mathrm{E}-10$ & $1,47115 \mathrm{E}-10$ & $6,0081 \mathrm{E}-11$ & $7,68624 \mathrm{E}-11$ & $7,95972 \mathrm{E}-11$ & $1,09229 \mathrm{E}-10$ & $8,51285 \mathrm{E}-11$ & $1,366 \mathrm{E}-10$ \\
\hline Transportes & $2,41041 \mathrm{E}-11$ & $2,1932 \mathrm{E}-11$ & $6,44303 \mathrm{E}-11$ & $4,11111 \mathrm{E}-11$ & $1,91079 \mathrm{E}-11$ & $2,06881 \mathrm{E}-11$ & $3,50468 \mathrm{E}-11$ & $2,01486 \mathrm{E}-11$ & $3,81104 \mathrm{E}-11$ & $2,49208 \mathrm{E}-11$ & $7,72427 \mathrm{E}-11$ \\
\hline Informação & $6,70932 \mathrm{E}-12$ & $1,04011 \mathrm{E}-11$ & $3,06086 \mathrm{E}-11$ & $1,30711 \mathrm{E}-11$ & $7,48987 \mathrm{E}-12$ & $5,54092 \mathrm{E}-12$ & $1,27922 \mathrm{E}-11$ & $3,07781 \mathrm{E}-11$ & $3,96307 \mathrm{E}-11$ & $1,76735 \mathrm{E}-11$ & $2,39841 \mathrm{E}-11$ \\
\hline
\end{tabular}




\begin{tabular}{|c|c|c|c|c|c|c|c|c|c|c|c|}
\hline Financeiro & $6,07167 \mathrm{E}-11$ & $6,73258 \mathrm{E}-11$ & $1,36052 \mathrm{E}-10$ & $1,15862 \mathrm{E}-10$ & $9,26439 \mathrm{E}-11$ & $8,58827 \mathrm{E}-11$ & $1,8732 \mathrm{E}-10$ & $1,06245 \mathrm{E}-10$ & $1,84458 \mathrm{E}-10$ & $1,33981 \mathrm{E}-10$ & $2,15448 \mathrm{E}-10$ \\
\hline Imobiliário & 0 & 0 & 0 & 0 & 0 & 0 & 0 & 0 & 0 & 0 & 0 \\
\hline Alojamento & $6,32984 \mathrm{E}-14$ & $8,92814 \mathrm{E}-14$ & $5,77076 \mathrm{E}-13$ & $1,57068 \mathrm{E}-13$ & $9,15818 \mathrm{E}-14$ & $1,83708 \mathrm{E}-13$ & $1,87219 \mathrm{E}-13$ & $2,48184 \mathrm{E}-13$ & $2,08007 \mathrm{E}-13$ & $1,84768 \mathrm{E}-13$ & $1,0156 \mathrm{E}-12$ \\
\hline Serviços às Empresas & 3,57892E-10 & $5,14521 \mathrm{E}-10$ & $9,92063 \mathrm{E}-10$ & $1,21073 \mathrm{E}-09$ & 7,94364E-10 & 4,22397E-10 & $1,0244 \mathrm{E}-09$ & 2,79151E-09 & 3,15683E-09 & $8,54249 \mathrm{E}-10$ & $1,9829 \mathrm{E}-09$ \\
\hline Educação e Saúde mercantis & 3,57781E-11 & $4,94673 \mathrm{E}-11$ & $7,27973 \mathrm{E}-11$ & $7,45638 \mathrm{E}-11$ & $9,10353 \mathrm{E}-11$ & $3,34288 \mathrm{E}-11$ & $6,54456 \mathrm{E}-11$ & 7,97944E-11 & $8,01689 \mathrm{E}-11$ & $5,73768 \mathrm{E}-11$ & $8,26634 \mathrm{E}-11$ \\
\hline Outros Serviços & 7,79761E-12 & $1,13005 \mathrm{E}-11$ & $1,1773 \mathrm{E}-11$ & $1,49076 \mathrm{E}-11$ & $1,60256 \mathrm{E}-11$ & $5,90819 \mathrm{E}-12$ & $9,79657 \mathrm{E}-12$ & $1,1516 \mathrm{E}-11$ & $1,58805 \mathrm{E}-11$ & $1,15956 \mathrm{E}-11$ & $1,84968 \mathrm{E}-11$ \\
\hline APU & 2,91331E-12 & $3,47592 \mathrm{E}-12$ & $6,97826 \mathrm{E}-12$ & $6,44423 \mathrm{E}-12$ & $4,06138 \mathrm{E}-12$ & $2,7406 \mathrm{E}-12$ & $6,65369 \mathrm{E}-12$ & $1,23143 \mathrm{E}-11$ & $1,11392 \mathrm{E}-11$ & $4,72542 \mathrm{E}-12$ & $1,06411 \mathrm{E}-11$ \\
\hline
\end{tabular}

Tabela B11 - Matriz Geração de Emprego para o Grau de Instrução G(10), Distrito Federal - 2008.

(2)

\begin{tabular}{|c|c|c|c|c|c|c|c|c|c|c|}
\hline Setores & Aço & Metal & Eletrodomésticos & Informática & Máquinas & Eletrônicos & $\begin{array}{l}\text { Instrumento } \\
\text { hospitalar }\end{array}$ & Veículos & $\begin{array}{c}\text { Indústria } \\
\text { Diversa }\end{array}$ & SIUP \\
\hline Agricultura & $2,27075 \mathrm{E}-13$ & $1,25199 \mathrm{E}-13$ & $4,49538 \mathrm{E}-13$ & $4,28244 \mathrm{E}-13$ & $2,55398 \mathrm{E}-13$ & $5,8468 \mathrm{E}-13$ & $1,5535 \mathrm{E}-13$ & $8,91962 \mathrm{E}-13$ & $3,49021 \mathrm{E}-13$ & $6,32631 \mathrm{E}-14$ \\
\hline Pecuária & 0 & 0 & 0 & 0 & 0 & 0 & 0 & 0 & 0 & 0 \\
\hline Extrativa & 0 & 0 & 0 & 0 & 0 & 0 & 0 & 0 & 0 & 0 \\
\hline Alimentos & 0 & 0 & 0 & 0 & 0 & 0 & 0 & 0 & 0 & 0 \\
\hline Vestuário & $6,32409 \mathrm{E}-13$ & $9,67771 \mathrm{E}-13$ & $5,31166 \mathrm{E}-12$ & 7,38734E-13 & $6,20448 \mathrm{E}-13$ & $8,41114 \mathrm{E}-13$ & $9,36289 \mathrm{E}-13$ & $4,55626 \mathrm{E}-12$ & $6,39544 \mathrm{E}-13$ & $6,40302 \mathrm{E}-13$ \\
\hline Madeira & 0 & 0 & 0 & 0 & 0 & 0 & 0 & 0 & 0 & 0 \\
\hline Celulose & 0 & 0 & 0 & 0 & 0 & 0 & 0 & 0 & 0 & 0 \\
\hline Revistas & 0 & 0 & 0 & 0 & 0 & 0 & 0 & 0 & 0 & 0 \\
\hline Químicos & $3,72434 \mathrm{E}-11$ & $6,49273 \mathrm{E}-12$ & $3,43789 \mathrm{E}-11$ & $2,46659 \mathrm{E}-12$ & $1,08197 \mathrm{E}-11$ & $4,34921 \mathrm{E}-12$ & $8,20542 \mathrm{E}-12$ & $2,26329 \mathrm{E}-11$ & $4,02666 \mathrm{E}-12$ & $2,72324 \mathrm{E}-12$ \\
\hline Borracha & 0 & 0 & 0 & 0 & 0 & 0 & 0 & 0 & 0 & 0 \\
\hline Cimento & $1,54246 \mathrm{E}-11$ & $4,60345 \mathrm{E}-12$ & $5,98303 \mathrm{E}-12$ & $3,1507 \mathrm{E}-12$ & $1,48222 \mathrm{E}-11$ & $1,15506 \mathrm{E}-11$ & $5,42958 \mathrm{E}-12$ & $1,33434 \mathrm{E}-11$ & $3,10239 \mathrm{E}-11$ & $1,49469 \mathrm{E}-13$ \\
\hline Aço & 0 & 0 & 0 & 0 & 0 & 0 & 0 & 0 & 0 & 0 \\
\hline Metal & 0 & 0 & 0 & 0 & 0 & 0 & 0 & 0 & 0 & 0 \\
\hline Eletrodomésticos & $3,27957 \mathrm{E}-10$ & $3,7687 \mathrm{E}-11$ & $1,26034 \mathrm{E}-07$ & $3,49386 \mathrm{E}-10$ & $1,61252 \mathrm{E}-10$ & $2,35759 \mathrm{E}-10$ & $7,02294 \mathrm{E}-11$ & 1,47703E-09 & $2,44486 \mathrm{E}-11$ & $3,9515 \mathrm{E}-12$ \\
\hline Informática & 0 & 0 & 0 & 0 & 0 & 0 & 0 & 0 & 0 & 0 \\
\hline Máquinas & 0 & 0 & 0 & 0 & 0 & 0 & 0 & 0 & 0 & 0 \\
\hline
\end{tabular}




\begin{tabular}{|c|c|c|c|c|c|c|c|c|c|c|}
\hline Eletrônicos & 0 & 0 & 0 & 0 & 0 & 0 & 0 & 0 & 0 & 0 \\
\hline Instrumento hospitalar & $3,13006 \mathrm{E}-13$ & $1,72074 \mathrm{E}-13$ & $4,74659 \mathrm{E}-11$ & $6,20572 \mathrm{E}-12$ & $1,8432 \mathrm{E}-11$ & $8,65854 \mathrm{E}-12$ & $1,48909 \mathrm{E}-08$ & $7,92304 \mathrm{E}-12$ & $8,14397 \mathrm{E}-13$ & $1,79908 \mathrm{E}-13$ \\
\hline Veículos & 0 & 0 & 0 & 0 & 0 & 0 & 0 & 0 & 0 & 0 \\
\hline Indústria Diversa & 0 & 0 & 0 & 0 & 0 & 0 & 0 & 0 & 0 & 0 \\
\hline SIUP & 9,92216E-11 & $4,83854 \mathrm{E}-11$ & $4,81633 \mathrm{E}-11$ & $3,22501 \mathrm{E}-11$ & $5,65442 \mathrm{E}-11$ & $3,94061 \mathrm{E}-11$ & $4,12106 \mathrm{E}-11$ & $4,22231 \mathrm{E}-11$ & $3,00651 \mathrm{E}-11$ & 4,49225E-09 \\
\hline Construção & $2,5968 \mathrm{E}-12$ & $1,745 \mathrm{E}-12$ & $3,52967 \mathrm{E}-12$ & $5,19613 \mathrm{E}-12$ & $7,17689 \mathrm{E}-12$ & $1,08447 \mathrm{E}-11$ & $1,64532 \mathrm{E}-12$ & $1,15013 \mathrm{E}-11$ & $2,10876 \mathrm{E}-12$ & $1,63005 \mathrm{E}-12$ \\
\hline Comércio & $7,27767 \mathrm{E}-11$ & $6,37405 \mathrm{E}-11$ & $1,07081 \mathrm{E}-10$ & $2,41051 \mathrm{E}-10$ & $9,54656 \mathrm{E}-11$ & $1,80048 \mathrm{E}-10$ & $9,61602 \mathrm{E}-11$ & $1,37174 \mathrm{E}-10$ & $1,11363 \mathrm{E}-10$ & $3,03951 \mathrm{E}-11$ \\
\hline Transportes & $5,18156 \mathrm{E}-11$ & $2,97338 \mathrm{E}-11$ & $4,09157 \mathrm{E}-11$ & $4,58894 \mathrm{E}-11$ & $3,91454 \mathrm{E}-11$ & $5,6968 \mathrm{E}-11$ & $3,10842 \mathrm{E}-11$ & $3,58643 \mathrm{E}-11$ & $1,92646 \mathrm{E}-11$ & $1,57418 \mathrm{E}-11$ \\
\hline Informação & $3,12871 \mathrm{E}-11$ & $1,3915 \mathrm{E}-11$ & $3,49985 \mathrm{E}-11$ & $5,03136 \mathrm{E}-11$ & 4,29393E-11 & 7,40264E-11 & $2,2675 \mathrm{E}-11$ & $2,79881 \mathrm{E}-11$ & 7,60294E-12 & $2,64754 \mathrm{E}-11$ \\
\hline Financeiro & $2,34709 \mathrm{E}-10$ & $1,38274 \mathrm{E}-10$ & $2,99021 \mathrm{E}-10$ & $2,08839 \mathrm{E}-10$ & $2,13633 \mathrm{E}-10$ & $3,67996 \mathrm{E}-10$ & $1,48516 \mathrm{E}-10$ & $2,05117 \mathrm{E}-10$ & $8,78961 \mathrm{E}-11$ & 7,90398E-11 \\
\hline Imobiliário & 0 & 0 & 0 & 0 & 0 & 0 & 0 & 0 & 0 & 0 \\
\hline Alojamento & $2,68921 \mathrm{E}-13$ & $1,02499 \mathrm{E}-13$ & $1,48071 \mathrm{E}-13$ & $2,14123 \mathrm{E}-13$ & $3,1773 \mathrm{E}-13$ & $2,1394 \mathrm{E}-13$ & $9,20692 \mathrm{E}-14$ & $2,84072 \mathrm{E}-13$ & $1,91331 \mathrm{E}-13$ & $7,86385 \mathrm{E}-14$ \\
\hline Serviços às Empresas & $8,30038 \mathrm{E}-10$ & $8,08859 \mathrm{E}-10$ & $9,69417 \mathrm{E}-10$ & 4,33643E-09 & $1,38232 \mathrm{E}-09$ & $3,05642 \mathrm{E}-09$ & $1,11008 \mathrm{E}-09$ & $1,85653 \mathrm{E}-09$ & $6,38675 \mathrm{E}-10$ & $2,35772 \mathrm{E}-09$ \\
\hline Educação e Saúde mercantis & $5,43297 \mathrm{E}-11$ & $5,48958 \mathrm{E}-11$ & $8,06108 \mathrm{E}-11$ & $1,12321 \mathrm{E}-10$ & $6,90592 \mathrm{E}-11$ & $1,03169 \mathrm{E}-10$ & $6,86822 \mathrm{E}-11$ & $6,96312 \mathrm{E}-11$ & $6,30293 \mathrm{E}-11$ & $4,3224 \mathrm{E}-11$ \\
\hline Outros Serviços & $1,0936 \mathrm{E}-11$ & $9,95085 \mathrm{E}-12$ & $1,46131 \mathrm{E}-11$ & $2,87061 \mathrm{E}-11$ & $2,08618 \mathrm{E}-11$ & $2,64711 \mathrm{E}-11$ & $1,18731 \mathrm{E}-11$ & $1,54581 \mathrm{E}-11$ & $1,21891 \mathrm{E}-11$ & $1,16284 \mathrm{E}-11$ \\
\hline APU & $6,77538 \mathrm{E}-12$ & $4,6584 \mathrm{E}-12$ & $5,48078 \mathrm{E}-12$ & $1,40842 \mathrm{E}-11$ & $6,09763 \mathrm{E}-12$ & $1,11891 \mathrm{E}-11$ & $5,42527 \mathrm{E}-12$ & $7,56302 \mathrm{E}-12$ & 3,49956E-12 & $1,25717 \mathrm{E}-11$ \\
\hline
\end{tabular}

Tabela B11 - Matriz Geração de Emprego para o Grau de Instrução G(10), Distrito Federal - 2008.

(3)

\begin{tabular}{|c|c|c|c|c|c|c|c|c|c|c|c|}
\hline Setores & Construção & Comércio & Transportes & Informação & Financeiro & Imobiliário & Alojamento & $\begin{array}{l}\text { Serviços às } \\
\text { Empresas }\end{array}$ & $\begin{array}{l}\text { Educação e } \\
\text { Saúde } \\
\text { mercantis }\end{array}$ & $\begin{array}{c}\text { Outros } \\
\text { Serviços }\end{array}$ & APU \\
\hline Agricultura & $1,8152 \mathrm{E}-13$ & $5,63178 \mathrm{E}-13$ & $4,26008 \mathrm{E}-13$ & $2,58412 \mathrm{E}-13$ & $1,67328 \mathrm{E}-13$ & $3,54638 \mathrm{E}-14$ & $5,66566 \mathrm{E}-11$ & $2,56573 \mathrm{E}-13$ & $1,35071 \mathrm{E}-12$ & $5,83495 \mathrm{E}-12$ & $7,21128 \mathrm{E}-13$ \\
\hline Pecuária & 0 & 0 & 0 & 0 & 0 & 0 & 0 & 0 & 0 & 0 & 0 \\
\hline Extrativa & 0 & 0 & 0 & 0 & 0 & 0 & 0 & 0 & 0 & 0 & 0 \\
\hline Alimentos & 0 & 0 & 0 & 0 & 0 & 0 & 0 & 0 & 0 & 0 & 0 \\
\hline Vestuário & 3,97471E-13 & $8,90757 \mathrm{E}-13$ & $1,86765 \mathrm{E}-12$ & $8,69702 \mathrm{E}-13$ & $7,11711 \mathrm{E}-13$ & $9,41739 \mathrm{E}-14$ & $1,03337 \mathrm{E}-12$ & $2,54677 \mathrm{E}-12$ & $1,64182 \mathrm{E}-12$ & $3,67189 \mathrm{E}-12$ & $7,15305 \mathrm{E}-13$ \\
\hline Madeira & 0 & 0 & 0 & 0 & 0 & 0 & 0 & 0 & 0 & 0 & 0 \\
\hline
\end{tabular}




\begin{tabular}{|c|c|c|c|c|c|c|c|c|c|c|c|}
\hline Celulose & 0 & 0 & 0 & 0 & 0 & 0 & 0 & 0 & 0 & 0 & 0 \\
\hline Revistas & 0 & 0 & 0 & 0 & 0 & 0 & 0 & 0 & 0 & 0 & 0 \\
\hline Químicos & $3,68597 \mathrm{E}-13$ & $1,9511 \mathrm{E}-13$ & $1,37811 \mathrm{E}-13$ & $3,59013 \mathrm{E}-13$ & $8,2011 \mathrm{E}-14$ & $5,34417 \mathrm{E}-14$ & $2,67687 \mathrm{E}-12$ & $2,23146 \mathrm{E}-13$ & $2,56324 \mathrm{E}-12$ & $5,02707 \mathrm{E}-13$ & $3,87555 \mathrm{E}-13$ \\
\hline Borracha & 0 & 0 & 0 & 0 & 0 & 0 & 0 & 0 & 0 & 0 & 0 \\
\hline Cimento & $6,28996 \mathrm{E}-11$ & $2,25151 \mathrm{E}-13$ & $9,67199 \mathrm{E}-14$ & $2,78658 \mathrm{E}-13$ & $2,6055 \mathrm{E}-13$ & $5,56273 \mathrm{E}-13$ & 4,38913E-13 & $2,09352 \mathrm{E}-13$ & $2,07628 \mathrm{E}-12$ & $1,09465 \mathrm{E}-12$ & $1,03934 \mathrm{E}-12$ \\
\hline Aço & 0 & 0 & 0 & 0 & 0 & 0 & 0 & 0 & 0 & 0 & 0 \\
\hline Metal & 0 & 0 & 0 & 0 & 0 & 0 & 0 & 0 & 0 & 0 & 0 \\
\hline Eletrodomésticos & $4,90297 \mathrm{E}-12$ & $4,69408 \mathrm{E}-12$ & $3,19433 \mathrm{E}-12$ & $5,91731 \mathrm{E}-12$ & $1,6451 \mathrm{E}-12$ & $1,23564 \mathrm{E}-12$ & $3,77109 \mathrm{E}-12$ & $4,62905 \mathrm{E}-12$ & $4,38756 \mathrm{E}-12$ & $4,4375 \mathrm{E}-12$ & $4,4936 \mathrm{E}-12$ \\
\hline Informática & 0 & 0 & 0 & 0 & 0 & 0 & 0 & 0 & 0 & 0 & 0 \\
\hline Máquinas & 0 & 0 & 0 & 0 & 0 & 0 & 0 & 0 & 0 & 0 & 0 \\
\hline Eletrônicos & 0 & 0 & 0 & 0 & 0 & 0 & 0 & 0 & 0 & 0 & 0 \\
\hline Instrumento hospitalar & $1,00822 \mathrm{E}-12$ & $6,09301 \mathrm{E}-13$ & $1,93235 \mathrm{E}-13$ & $2,51238 \mathrm{E}-13$ & $1,4158 \mathrm{E}-13$ & $1,14855 \mathrm{E}-12$ & $1,2292 \mathrm{E}-13$ & $1,63494 \mathrm{E}-12$ & $1,69713 \mathrm{E}-12$ & $1,29299 \mathrm{E}-12$ & $3,51654 \mathrm{E}-13$ \\
\hline Veículos & 0 & 0 & 0 & 0 & 0 & 0 & 0 & 0 & 0 & 0 & 0 \\
\hline Indústria Diversa & 0 & 0 & 0 & 0 & 0 & 0 & 0 & 0 & 0 & 0 & 0 \\
\hline SIUP & $9,81655 \mathrm{E}-12$ & $3,36352 \mathrm{E}-11$ & $2,78918 \mathrm{E}-11$ & $2,62111 \mathrm{E}-11$ & $1,58172 \mathrm{E}-11$ & $3,33167 \mathrm{E}-12$ & $3,40013 \mathrm{E}-11$ & $2,95181 \mathrm{E}-11$ & $4,34616 \mathrm{E}-11$ & $9,77869 \mathrm{E}-11$ & $3,74343 \mathrm{E}-11$ \\
\hline Construção & $3,88802 \mathrm{E}-09$ & $4,44936 \mathrm{E}-12$ & $3,45871 \mathrm{E}-12$ & $1,41687 \mathrm{E}-11$ & $1,40181 \mathrm{E}-11$ & $3,35139 \mathrm{E}-11$ & $2,38128 \mathrm{E}-12$ & $9,98447 \mathrm{E}-12$ & $2,99281 \mathrm{E}-11$ & $2,58358 \mathrm{E}-11$ & $5,84433 \mathrm{E}-11$ \\
\hline Comércio & $9,9743 \mathrm{E}-11$ & $1,87347 \mathrm{E}-09$ & $8,30679 \mathrm{E}-11$ & $4,12758 \mathrm{E}-11$ & $2,46765 \mathrm{E}-11$ & $1,08904 \mathrm{E}-11$ & $1,9122 \mathrm{E}-10$ & $7,15552 \mathrm{E}-11$ & $6,36736 \mathrm{E}-11$ & $6,88469 \mathrm{E}-11$ & $3,64881 \mathrm{E}-11$ \\
\hline Transportes & $1,47404 \mathrm{E}-11$ & $3,87829 \mathrm{E}-11$ & $1,18456 \mathrm{E}-09$ & $2,63087 \mathrm{E}-11$ & $1,10627 \mathrm{E}-11$ & $1,9677 \mathrm{E}-12$ & $1,77523 \mathrm{E}-11$ & $2,09003 \mathrm{E}-11$ & $1,87807 \mathrm{E}-11$ & $2,77602 \mathrm{E}-11$ & $1,00829 \mathrm{E}-11$ \\
\hline Informação & $8,66546 \mathrm{E}-12$ & $2,73118 \mathrm{E}-11$ & $2,85543 \mathrm{E}-11$ & $2,04447 \mathrm{E}-09$ & $8,3308 \mathrm{E}-11$ & $5,63248 \mathrm{E}-12$ & $1,36435 \mathrm{E}-11$ & $2,21443 \mathrm{E}-10$ & $7,61518 \mathrm{E}-11$ & $4,98681 \mathrm{E}-11$ & $9,23283 \mathrm{E}-11$ \\
\hline Financeiro & $6,36434 \mathrm{E}-11$ & $1,2632 \mathrm{E}-10$ & $1,74671 \mathrm{E}-10$ & $1,77812 \mathrm{E}-10$ & $5,04366 \mathrm{E}-09$ & $2,56966 \mathrm{E}-11$ & $6,56987 \mathrm{E}-11$ & $1,68289 \mathrm{E}-10$ & $7,43013 \mathrm{E}-11$ & $4,13551 \mathrm{E}-11$ & $3,93555 \mathrm{E}-10$ \\
\hline Imobiliário & 0 & 0 & 0 & 0 & 0 & 0 & 0 & 0 & 0 & 0 & 0 \\
\hline Alojamento & $2,68664 \mathrm{E}-13$ & $3,73353 \mathrm{E}-13$ & $7,26939 \mathrm{E}-13$ & $4,9023 \mathrm{E}-13$ & $4,71477 \mathrm{E}-13$ & $5,20228 \mathrm{E}-14$ & $2,8839 \mathrm{E}-10$ & $4,22942 \mathrm{E}-13$ & $2,24211 \mathrm{E}-12$ & $2,55881 \mathrm{E}-12$ & $1,3859 \mathrm{E}-12$ \\
\hline Serviços às Empresas & $9,57208 \mathrm{E}-10$ & $2,66989 \mathrm{E}-09$ & 3,06799E-09 & $4,37266 \mathrm{E}-09$ & 3,30716E-09 & $5,16832 \mathrm{E}-10$ & $8,45592 \mathrm{E}-10$ & $5,27698 \mathrm{E}-08$ & 4,40176E-09 & 2,80104E-09 & $3,11045 \mathrm{E}-09$ \\
\hline Educação e Saúde mercantis & $4,8308 \mathrm{E}-11$ & $1,72137 \mathrm{E}-10$ & $1,14078 \mathrm{E}-10$ & $1,9221 \mathrm{E}-10$ & $1,98214 \mathrm{E}-10$ & $2,48243 \mathrm{E}-11$ & $1,3724 \mathrm{E}-10$ & $1,63629 \mathrm{E}-10$ & $8,66922 \mathrm{E}-08$ & $1,31159 \mathrm{E}-10$ & $2,70575 \mathrm{E}-10$ \\
\hline Outros Serviços & $1,08778 \mathrm{E}-11$ & $2,87597 \mathrm{E}-11$ & $1,79811 \mathrm{E}-11$ & $3,20499 \mathrm{E}-11$ & $1,64656 \mathrm{E}-11$ & $3,21114 \mathrm{E}-12$ & $3,1362 \mathrm{E}-11$ & $3,82921 \mathrm{E}-11$ & $2,83367 \mathrm{E}-11$ & 4,03315E-09 & $2,0302 \mathrm{E}-11$ \\
\hline APU & $3,59348 \mathrm{E}-12$ & $9,66233 \mathrm{E}-12$ & $1,01365 \mathrm{E}-11$ & $1,30387 \mathrm{E}-11$ & $9,33388 \mathrm{E}-12$ & $1,54517 \mathrm{E}-12$ & $4,57418 \mathrm{E}-12$ & $1,16041 \mathrm{E}-11$ & $1,27361 \mathrm{E}-11$ & $9,84247 \mathrm{E}-12$ & $3,16214 \mathrm{E}-09$ \\
\hline
\end{tabular}




\section{APÊNDICE “C” - Matrizes de Geração de Renda}

Tabela C1 - Matriz Geração de Renda para o Grau de Instrução G(0), Distrito Federal - 2008.

(1)

\begin{tabular}{|c|c|c|c|c|c|c|c|c|c|c|c|}
\hline Setores & Agricultura & Pecuária & Extrativa & Alimentos & Vestuário & Madeira & Celulose & Revistas & Químicos & Borracha & Cimento \\
\hline Agricultura & $8,38632 \mathrm{E}-06$ & $5,50215 \mathrm{E}-07$ & $9,15145 \mathrm{E}-10$ & $6,75662 \mathrm{E}-07$ & $8,4523 \mathrm{E}-09$ & $1,32865 \mathrm{E}-08$ & $3,83708 \mathrm{E}-08$ & $3,74293 \mathrm{E}-10$ & $1,68501 \mathrm{E}-09$ & $2,85563 \mathrm{E}-08$ & $6,54992 \mathrm{E}-10$ \\
\hline Pecuária & $1,00448 \mathrm{E}-07$ & 2,56914E-05 & $7,55187 \mathrm{E}-10$ & $1,01628 \mathrm{E}-06$ & $2,12173 \mathrm{E}-08$ & $1,7814 \mathrm{E}-09$ & $5,85285 \mathrm{E}-09$ & $2,85258 \mathrm{E}-10$ & $1,85269 \mathrm{E}-09$ & 8,64575E-09 & $7,0499 \mathrm{E}-10$ \\
\hline Extrativa & $1,80458 \mathrm{E}-08$ & $4,27783 \mathrm{E}-08$ & 0,000248618 & $1,01773 \mathrm{E}-08$ & 9,35294E-09 & $1,28765 \mathrm{E}-08$ & $9,95847 \mathrm{E}-08$ & 2,38334E-09 & $1,51357 \mathrm{E}-07$ & $3,21974 \mathrm{E}-08$ & $1,12486 \mathrm{E}-07$ \\
\hline Alimentos & $5,01967 \mathrm{E}-08$ & $7,62259 \mathrm{E}-07$ & $2,63311 \mathrm{E}-09$ & $4,59568 \mathrm{E}-06$ & $3,46756 \mathrm{E}-08$ & 3,59034E-09 & $1,12232 \mathrm{E}-08$ & $9,73437 \mathrm{E}-10$ & 4,24033E-09 & $1,41944 \mathrm{E}-09$ & $2,57497 \mathrm{E}-09$ \\
\hline Vestuário & 3,41978E-09 & $3,02641 \mathrm{E}-09$ & $1,00903 \mathrm{E}-07$ & $4,4109 \mathrm{E}-09$ & 0,00018103 & 4,1019E-09 & $1,44886 \mathrm{E}-07$ & 4,64272E-09 & $9,25228 \mathrm{E}-09$ & $2,7113 \mathrm{E}-08$ & $6,41249 \mathrm{E}-09$ \\
\hline Madeira & $3,11484 \mathrm{E}-08$ & $6,10589 \mathrm{E}-09$ & $1,69811 \mathrm{E}-08$ & $7,28642 \mathrm{E}-09$ & $3,03233 \mathrm{E}-08$ & 0,000523214 & $3,15667 \mathrm{E}-06$ & $5,23075 \mathrm{E}-09$ & $9,56788 \mathrm{E}-08$ & $2,59741 \mathrm{E}-08$ & $2,9515 \mathrm{E}-08$ \\
\hline Celulose & 0 & 0 & 0 & 0 & 0 & 0 & 0 & 0 & 0 & 0 & 0 \\
\hline Revistas & 7,39623E-09 & $8,24604 \mathrm{E}-09$ & $1,90654 \mathrm{E}-08$ & $1,36091 \mathrm{E}-08$ & $7,17829 \mathrm{E}-09$ & 4,41976E-09 & $8,20779 \mathrm{E}-08$ & $1,78259 \mathrm{E}-05$ & $1,16995 \mathrm{E}-07$ & 4,59961E-08 & $1,56685 \mathrm{E}-08$ \\
\hline Químicos & 1,319E-06 & $9,17411 \mathrm{E}-07$ & $3,06508 \mathrm{E}-07$ & $1,71629 \mathrm{E}-07$ & $9,43415 \mathrm{E}-08$ & $1,74881 \mathrm{E}-07$ & 7,95357E-07 & $5,30295 \mathrm{E}-09$ & 3,41343E-05 & 4,63593E-07 & $4,3416 \mathrm{E}-08$ \\
\hline Borracha & $1,43033 \mathrm{E}-07$ & $9,16599 \mathrm{E}-08$ & $1,17713 \mathrm{E}-06$ & $2,54034 \mathrm{E}-07$ & $3,34316 \mathrm{E}-07$ & $6,22126 \mathrm{E}-07$ & $1,55151 \mathrm{E}-06$ & $1,95531 \mathrm{E}-07$ & 4,60607E-07 & 0,000130665 & $1,56579 \mathrm{E}-08$ \\
\hline Cimento & $5,92096 \mathrm{E}-09$ & $3,02288 \mathrm{E}-09$ & 6,98523E-09 & $1,01171 \mathrm{E}-08$ & $2,66258 \mathrm{E}-09$ & $1,15644 \mathrm{E}-09$ & $9,04684 \mathrm{E}-09$ & $9,48687 \mathrm{E}-10$ & 3,72163E-08 & $2,77086 \mathrm{E}-09$ & $5,88771 \mathrm{E}-06$ \\
\hline Aço & 0 & 0 & 0 & 0 & 0 & 0 & 0 & 0 & 0 & 0 & 0 \\
\hline Metal & $1,09945 \mathrm{E}-07$ & 7,74713E-08 & $3,56253 \mathrm{E}-07$ & $1,91235 \mathrm{E}-07$ & $3,07184 \mathrm{E}-08$ & $1,85719 \mathrm{E}-07$ & 3,32003E-07 & $2,06043 \mathrm{E}-09$ & $1,61452 \mathrm{E}-07$ & $1,83473 \mathrm{E}-07$ & 2,89971E-08 \\
\hline Eletrodomésticos & 0 & 0 & 0 & 0 & 0 & 0 & 0 & 0 & 0 & 0 & 0 \\
\hline Informática & 0 & 0 & 0 & 0 & 0 & 0 & 0 & 0 & 0 & 0 & 0 \\
\hline Máquinas & 0 & 0 & 0 & 0 & 0 & 0 & 0 & 0 & 0 & 0 & 0 \\
\hline Eletrônicos & 0 & 0 & 0 & 0 & 0 & 0 & 0 & 0 & 0 & 0 & 0 \\
\hline Instrumento hospitalar & 0 & 0 & 0 & 0 & 0 & 0 & 0 & 0 & 0 & 0 & 0 \\
\hline Veículos & $1,56589 \mathrm{E}-08$ & $1,28138 \mathrm{E}-08$ & $9,27364 \mathrm{E}-08$ & $2,97535 \mathrm{E}-08$ & $1,59928 \mathrm{E}-08$ & $3,85729 \mathrm{E}-08$ & $7,52651 \mathrm{E}-08$ & 4,9157E-09 & $3,54669 \mathrm{E}-08$ & 7,79371E-08 & $1,40587 \mathrm{E}-08$ \\
\hline Indústria Diversa & $1,4118 \mathrm{E}-09$ & $1,30869 \mathrm{E}-08$ & $3,81095 \mathrm{E}-09$ & $8,86778 \mathrm{E}-09$ & $1,39309 \mathrm{E}-07$ & 4,10889E-09 & $7,5482 \mathrm{E}-08$ & $1,64256 \mathrm{E}-09$ & 3,75204E-09 & $2,68112 \mathrm{E}-08$ & $3,58562 \mathrm{E}-09$ \\
\hline SIUP & $1,29186 \mathrm{E}-08$ & $1,99392 \mathrm{E}-08$ & $5,18399 \mathrm{E}-08$ & 3,19323E-08 & $2,61311 \mathrm{E}-08$ & $2,71455 \mathrm{E}-08$ & $8,01625 \mathrm{E}-08$ & $2,12679 \mathrm{E}-08$ & $3,87233 \mathrm{E}-08$ & $4,00432 \mathrm{E}-08$ & $1,05604 \mathrm{E}-07$ \\
\hline Construção & $2,4864 \mathrm{E}-10$ & $3,53207 \mathrm{E}-10$ & $6,39139 \mathrm{E}-10$ & $8,20123 \mathrm{E}-10$ & $7,36738 \mathrm{E}-10$ & $6,50796 \mathrm{E}-10$ & $1,17169 \mathrm{E}-09$ & $9,27468 \mathrm{E}-10$ & $1,31271 \mathrm{E}-09$ & 2,13194E-09 & 2,90757E-09 \\
\hline
\end{tabular}




\begin{tabular}{|c|c|c|c|c|c|c|c|c|c|c|c|}
\hline Comércio & $3,45585 \mathrm{E}-08$ & $5,09962 \mathrm{E}-08$ & $3,03939 \mathrm{E}-08$ & $5,46815 \mathrm{E}-08$ & $5,74373 \mathrm{E}-08$ & $2,34571 \mathrm{E}-08$ & $3,0009 \mathrm{E}-08$ & $3,10767 \mathrm{E}-08$ & $4,26455 \mathrm{E}-08$ & $3,32363 \mathrm{E}-08$ & $5,33321 \mathrm{E}-08$ \\
\hline Transportes & $3,52092 \mathrm{E}-08$ & $3,20363 \mathrm{E}-08$ & $9,41141 \mathrm{E}-08$ & $6,00514 \mathrm{E}-08$ & $2,79111 \mathrm{E}-08$ & $3,02194 \mathrm{E}-08$ & $5,11933 \mathrm{E}-08$ & $2,94312 \mathrm{E}-08$ & $5,56684 \mathrm{E}-08$ & $3,64022 \mathrm{E}-08$ & $1,12829 \mathrm{E}-07$ \\
\hline Informação & 4,45274E-09 & $6,90285 \mathrm{E}-09$ & $2,03138 \mathrm{E}-08$ & 8,67483E-09 & 4,97076E-09 & $3,67731 \mathrm{E}-09$ & $8,48972 \mathrm{E}-09$ & $2,04263 \mathrm{E}-08$ & $2,63015 \mathrm{E}-08$ & $1,17293 \mathrm{E}-08$ & $1,59174 \mathrm{E}-08$ \\
\hline Financeiro & 4,55344E-09 & $5,04908 \mathrm{E}-09$ & $1,02032 \mathrm{E}-08$ & 8,68904E-09 & 6,94781E-09 & $6,44075 \mathrm{E}-09$ & $1,4048 \mathrm{E}-08$ & 7,96785E-09 & $1,38334 \mathrm{E}-08$ & $1,00479 \mathrm{E}-08$ & $1,61575 \mathrm{E}-08$ \\
\hline Imobiliário & 3,11754E-09 & 3,99252E-09 & 9,45834E-09 & 7,97872E-09 & $8,88934 \mathrm{E}-09$ & $3,55773 \mathrm{E}-09$ & 7,86021E-09 & $1,2385 \mathrm{E}-08$ & $1,06028 \mathrm{E}-08$ & 6,61076E-09 & $1,15195 \mathrm{E}-08$ \\
\hline Alojamento & $4,14813 \mathrm{E}-10$ & $5,85088 \mathrm{E}-10$ & 3,78175E-09 & $1,02931 \mathrm{E}-09$ & $6,00163 \mathrm{E}-10$ & $1,20389 \mathrm{E}-09$ & $1,2269 \mathrm{E}-09$ & $1,62642 \mathrm{E}-09$ & $1,36313 \mathrm{E}-09$ & $1,21084 \mathrm{E}-09$ & 6,65555E-09 \\
\hline Serviços às Empresas & $5,81709 \mathrm{E}-09$ & $8,36289 \mathrm{E}-09$ & $1,61247 \mathrm{E}-08$ & $1,9679 \mathrm{E}-08$ & $1,29114 \mathrm{E}-08$ & $6,86553 \mathrm{E}-09$ & $1,66503 \mathrm{E}-08$ & 4,53724E-08 & $5,13102 \mathrm{E}-08$ & $1,38847 \mathrm{E}-08$ & $3,22296 \mathrm{E}-08$ \\
\hline Educação e Saúde mercantis & $7,19851 \mathrm{E}-10$ & $9,95274 \mathrm{E}-10$ & 1,46467E-09 & $1,50021 \mathrm{E}-09$ & $1,83162 \mathrm{E}-09$ & $6,72582 \mathrm{E}-10$ & 1,31676E-09 & $1,60545 \mathrm{E}-09$ & $1,61299 \mathrm{E}-09$ & $1,15441 \mathrm{E}-09$ & $1,66318 \mathrm{E}-09$ \\
\hline Outros Serviços & 2,90859E-09 & $4,21521 \mathrm{E}-09$ & 4,39146E-09 & 5,5607E-09 & 5,97771E-09 & 2,20382E-09 & 3,65423E-09 & 4,29559E-09 & $5,92359 \mathrm{E}-09$ & 4,32529E-09 & $6,8995 \mathrm{E}-09$ \\
\hline APU & $2,32093 \mathrm{E}-12$ & $2,76915 \mathrm{E}-12$ & $5,55935 \mathrm{E}-12$ & $5,1339 \mathrm{E}-12$ & $3,23557 \mathrm{E}-12$ & $2,18334 \mathrm{E}-12$ & $5,30077 \mathrm{E}-12$ & $9,81043 \mathrm{E}-12$ & $8,87421 \mathrm{E}-12$ & $3,76458 \mathrm{E}-12$ & $8,47744 \mathrm{E}-12$ \\
\hline
\end{tabular}

Tabela C1 - Matriz Geração de Renda para o Grau de Instrução G(0), Distrito Federal - 2008.

(2)

\begin{tabular}{|c|c|c|c|c|c|c|c|c|c|c|}
\hline Setores & Aço & Metal & Eletrodomésticos & Informática & Máquinas & Eletrônicos & $\begin{array}{l}\text { Instrumento } \\
\text { hospitalar }\end{array}$ & Veículos & $\begin{array}{l}\text { Indústria } \\
\text { Diversa }\end{array}$ & SIUP \\
\hline Agricultura & $4,93462 \mathrm{E}-10$ & $2,72074 \mathrm{E}-10$ & $9,76903 \mathrm{E}-10$ & $9,30629 \mathrm{E}-10$ & $5,55013 \mathrm{E}-10$ & $1,27058 \mathrm{E}-09$ & $3,37595 \mathrm{E}-10$ & $1,93835 \mathrm{E}-09$ & $7,58467 \mathrm{E}-10$ & $1,37479 \mathrm{E}-10$ \\
\hline Pecuária & $3,87578 \mathrm{E}-10$ & $1,91455 \mathrm{E}-10$ & $4,73227 \mathrm{E}-10$ & $5,11874 \mathrm{E}-10$ & $4,05946 \mathrm{E}-10$ & $5,3114 \mathrm{E}-10$ & $2,18892 \mathrm{E}-10$ & $8,47266 \mathrm{E}-10$ & 4,5385E-09 & $1,24483 \mathrm{E}-10$ \\
\hline Extrativa & $4,18839 \mathrm{E}-06$ & $2,47451 \mathrm{E}-07$ & $7,85311 \mathrm{E}-07$ & $5,9856 \mathrm{E}-08$ & $2,38137 \mathrm{E}-07$ & $1,3383 \mathrm{E}-07$ & $2,22988 \mathrm{E}-08$ & 4,47941E-07 & $1,37312 \mathrm{E}-07$ & $2,10202 \mathrm{E}-09$ \\
\hline Alimentos & $1,15394 \mathrm{E}-09$ & $5,42527 \mathrm{E}-10$ & $1,12311 \mathrm{E}-09$ & $1,25645 \mathrm{E}-09$ & $1,13154 \mathrm{E}-09$ & 1,2291E-09 & $5,95861 \mathrm{E}-10$ & $1,5196 \mathrm{E}-09$ & $1,08103 \mathrm{E}-09$ & $3,62229 \mathrm{E}-10$ \\
\hline Vestuário & $8,51889 \mathrm{E}-09$ & $1,30364 \mathrm{E}-08$ & $7,15509 \mathrm{E}-08$ & $9,95114 \mathrm{E}-09$ & $8,35776 \mathrm{E}-09$ & $1,13302 \mathrm{E}-08$ & $1,26123 \mathrm{E}-08$ & $6,13753 \mathrm{E}-08$ & $8,61499 \mathrm{E}-09$ & $8,6252 \mathrm{E}-09$ \\
\hline Madeira & $2,37467 \mathrm{E}-08$ & $3,50746 \mathrm{E}-08$ & $6,99817 \mathrm{E}-07$ & $6,43816 \mathrm{E}-07$ & $3,09474 \mathrm{E}-08$ & $2,8634 \mathrm{E}-06$ & $8,46964 \mathrm{E}-09$ & $4,38662 \mathrm{E}-07$ & $9,45618 \mathrm{E}-07$ & $1,14619 \mathrm{E}-09$ \\
\hline Celulose & 0 & 0 & 0 & 0 & 0 & 0 & 0 & 0 & 0 & 0 \\
\hline Revistas & $2,24505 \mathrm{E}-08$ & $2,20927 \mathrm{E}-08$ & $1,35305 \mathrm{E}-08$ & $2,55369 \mathrm{E}-08$ & $1,15284 \mathrm{E}-08$ & $2,14408 \mathrm{E}-08$ & $1,05949 \mathrm{E}-07$ & $2,52063 \mathrm{E}-08$ & 7,53171E-09 & $3,15813 \mathrm{E}-08$ \\
\hline Químicos & $4,08703 \mathrm{E}-07$ & $7,12502 \mathrm{E}-08$ & $3,77269 \mathrm{E}-07$ & $2,70679 \mathrm{E}-08$ & $1,18734 \mathrm{E}-07$ & $4,77275 \mathrm{E}-08$ & $9,0045 \mathrm{E}-08$ & 2,4837E-07 & $4,41879 \mathrm{E}-08$ & $2,98844 \mathrm{E}-08$ \\
\hline Borracha & $8,03951 \mathrm{E}-07$ & $4,60847 \mathrm{E}-07$ & 2,19832E-06 & $1,95867 \mathrm{E}-06$ & $1,01043 \mathrm{E}-06$ & $2,27327 \mathrm{E}-06$ & $6,33414 \mathrm{E}-07$ & $5,26637 \mathrm{E}-06$ & $8,33488 \mathrm{E}-07$ & $1,99409 \mathrm{E}-08$ \\
\hline Cimento & 5,19437E-08 & $1,55025 \mathrm{E}-08$ & $2,01483 \mathrm{E}-08$ & $1,06102 \mathrm{E}-08$ & $4,99149 \mathrm{E}-08$ & $3,88976 \mathrm{E}-08$ & $1,82846 \mathrm{E}-08$ & 4,49349E-08 & $1,04475 \mathrm{E}-07$ & $5,0335 \mathrm{E}-10$ \\
\hline Aço & 0 & 0 & 0 & 0 & 0 & 0 & 0 & 0 & 0 & 0 \\
\hline Metal & $8,76311 \mathrm{E}-07$ & $2,24962 \mathrm{E}-05$ & $1,4107 \mathrm{E}-06$ & $5,29154 \mathrm{E}-07$ & $9,80354 \mathrm{E}-07$ & $8,72993 \mathrm{E}-07$ & $6,00905 \mathrm{E}-07$ & $6,29401 \mathrm{E}-07$ & $4,83827 \mathrm{E}-07$ & $2,45999 \mathrm{E}-09$ \\
\hline
\end{tabular}




\begin{tabular}{|c|c|c|c|c|c|c|c|c|c|c|}
\hline Eletrodomésticos & 0 & 0 & 0 & 0 & 0 & 0 & 0 & 0 & 0 & 0 \\
\hline Informática & 0 & 0 & 0 & 0 & 0 & 0 & 0 & 0 & 0 & 0 \\
\hline Máquinas & 0 & 0 & 0 & 0 & 0 & 0 & 0 & 0 & 0 & 0 \\
\hline Eletrônicos & 0 & 0 & 0 & 0 & 0 & 0 & 0 & 0 & 0 & 0 \\
\hline Instrumento hospitalar & 0 & 0 & 0 & 0 & 0 & 0 & 0 & 0 & 0 & 0 \\
\hline Veículos & $2,12562 \mathrm{E}-07$ & $1,34289 \mathrm{E}-07$ & $9,58773 \mathrm{E}-07$ & $6,77317 \mathrm{E}-07$ & 7,73775E-07 & $1,22908 \mathrm{E}-06$ & $1,62891 \mathrm{E}-07$ & 0,000338812 & $9,69286 \mathrm{E}-08$ & $2,06725 \mathrm{E}-08$ \\
\hline Indústria Diversa & $1,79205 \mathrm{E}-07$ & $1,32039 \mathrm{E}-08$ & $4,16505 \mathrm{E}-08$ & 7,88274E-09 & $2,41843 \mathrm{E}-08$ & $1,28273 \mathrm{E}-08$ & $3,41769 \mathrm{E}-09$ & $2,15166 \mathrm{E}-08$ & 4,4904E-05 & $1,11953 \mathrm{E}-09$ \\
\hline SIUP & $9,38302 \mathrm{E}-08$ & $4,57562 \mathrm{E}-08$ & $4,55462 \mathrm{E}-08$ & $3,04978 \mathrm{E}-08$ & $5,34718 \mathrm{E}-08$ & $3,72648 \mathrm{E}-08$ & 3,89713E-08 & $3,99288 \mathrm{E}-08$ & $2,84314 \mathrm{E}-08$ & 4,24816E-06 \\
\hline Construção & $9,05843 \mathrm{E}-10$ & $6,08709 \mathrm{E}-10$ & $1,23125 \mathrm{E}-09$ & $1,81257 \mathrm{E}-09$ & 2,50351E-09 & $3,78296 \mathrm{E}-09$ & $5,73937 \mathrm{E}-10$ & 4,01201E-09 & $7,35598 \mathrm{E}-10$ & $5,68612 \mathrm{E}-10$ \\
\hline Comércio & $2,84138 \mathrm{E}-08$ & $2,48858 \mathrm{E}-08$ & $4,18071 \mathrm{E}-08$ & $9,41121 \mathrm{E}-08$ & $3,72721 \mathrm{E}-08$ & $7,02952 \mathrm{E}-08$ & $3,75433 \mathrm{E}-08$ & $5,35559 \mathrm{E}-08$ & $4,34788 \mathrm{E}-08$ & $1,1867 \mathrm{E}-08$ \\
\hline Transportes & 7,56877E-08 & $4,34325 \mathrm{E}-08$ & $5,9766 \mathrm{E}-08$ & $6,70312 \mathrm{E}-08$ & $5,71802 \mathrm{E}-08$ & $8,32138 \mathrm{E}-08$ & $4,54051 \mathrm{E}-08$ & $5,23874 \mathrm{E}-08$ & 2,81401E-08 & 2,29943E-08 \\
\hline Informação & $2,07642 \mathrm{E}-08$ & $9,23487 \mathrm{E}-09$ & $2,32272 \mathrm{E}-08$ & $3,33914 \mathrm{E}-08$ & 2,84973E-08 & $4,91287 \mathrm{E}-08$ & $1,50486 \mathrm{E}-08$ & $1,85747 \mathrm{E}-08$ & $5,0458 \mathrm{E}-09$ & $1,75708 \mathrm{E}-08$ \\
\hline Financeiro & $1,76019 \mathrm{E}-08$ & $1,03698 \mathrm{E}-08$ & $2,2425 \mathrm{E}-08$ & $1,56618 \mathrm{E}-08$ & $1,60214 \mathrm{E}-08$ & $2,75978 \mathrm{E}-08$ & $1,11379 \mathrm{E}-08$ & $1,53827 \mathrm{E}-08$ & 6,59175E-09 & $5,92757 \mathrm{E}-09$ \\
\hline Imobiliário & $7,46958 \mathrm{E}-09$ & $6,33839 \mathrm{E}-09$ & $9,87664 \mathrm{E}-09$ & $1,05907 \mathrm{E}-08$ & 7,83537E-09 & $1,04767 \mathrm{E}-08$ & $9,2166 \mathrm{E}-09$ & 6,89464E-09 & $6,01122 \mathrm{E}-09$ & 5,40867E-09 \\
\hline Alojamento & $1,76232 \mathrm{E}-09$ & $6,71709 \mathrm{E}-10$ & $9,70354 \mathrm{E}-10$ & $1,40321 \mathrm{E}-09$ & $2,08218 \mathrm{E}-09$ & $1,40201 \mathrm{E}-09$ & $6,03357 \mathrm{E}-10$ & $1,86161 \mathrm{E}-09$ & $1,25385 \mathrm{E}-09$ & $5,15342 \mathrm{E}-10$ \\
\hline Serviços às Empresas & $1,34912 \mathrm{E}-08$ & $1,3147 \mathrm{E}-08$ & $1,57566 \mathrm{E}-08$ & $7,04832 \mathrm{E}-08$ & $2,24679 \mathrm{E}-08$ & $4,96782 \mathrm{E}-08$ & $1,8043 \mathrm{E}-08$ & $3,01755 \mathrm{E}-08$ & $1,03809 \mathrm{E}-08$ & $3,83218 \mathrm{E}-08$ \\
\hline Educação e Saúde mercantis & 1,09311E-09 & $1,1045 \mathrm{E}-09$ & $1,62188 \mathrm{E}-09$ & $2,25988 \mathrm{E}-09$ & 1,38946E-09 & $2,07575 \mathrm{E}-09$ & $1,38188 \mathrm{E}-09$ & 1,40097E-09 & $1,26814 \mathrm{E}-09$ & $8,69661 \mathrm{E}-10$ \\
\hline Outros Serviços & 4,07926E-09 & $3,71178 \mathrm{E}-09$ & $5,45083 \mathrm{E}-09$ & $1,07077 \mathrm{E}-08$ & 7,78167E-09 & $9,87401 \mathrm{E}-09$ & $4,42878 \mathrm{E}-09$ & 5,76603E-09 & $4,54668 \mathrm{E}-09$ & 4,33752E-09 \\
\hline APU & $5,39772 \mathrm{E}-12$ & $3,71119 \mathrm{E}-12$ & $4,36635 \mathrm{E}-12$ & $1,12204 \mathrm{E}-11$ & $4,85778 \mathrm{E}-12$ & $8,91399 \mathrm{E}-12$ & $4,32213 \mathrm{E}-12$ & $6,02521 \mathrm{E}-12$ & $2,78798 \mathrm{E}-12$ & $1,00154 \mathrm{E}-11$ \\
\hline
\end{tabular}

Tabela C1 - Matriz Geração de Renda para o Grau de Instrução G(0), Distrito Federal - 2008.

(3)

\begin{tabular}{|c|c|c|c|c|c|c|c|c|c|c|c|}
\hline Setores & Construção & Comércio & Transportes & Informação & Financeiro & Imobiliário & Alojamento & $\begin{array}{c}\text { Serviços às } \\
\text { Empresas }\end{array}$ & $\begin{array}{l}\text { Educação e } \\
\text { Saúde } \\
\text { mercantis }\end{array}$ & $\begin{array}{c}\text { Outros } \\
\text { Serviços }\end{array}$ & APU \\
\hline Agricultura & $3,94467 \mathrm{E}-10$ & $1,22386 \mathrm{E}-09$ & $9,2577 \mathrm{E}-10$ & $5,61563 \mathrm{E}-10$ & $3,63624 \mathrm{E}-10$ & 7,70674E-11 & $1,23122 \mathrm{E}-07$ & $5,57565 \mathrm{E}-10$ & $2,93527 \mathrm{E}-09$ & $1,26801 \mathrm{E}-08$ & $1,5671 \mathrm{E}-09$ \\
\hline Pecuária & $3,74235 \mathrm{E}-10$ & $1,09983 \mathrm{E}-09$ & $9,79231 \mathrm{E}-10$ & $4,84684 \mathrm{E}-10$ & $3,71054 \mathrm{E}-10$ & $6,27456 \mathrm{E}-11$ & $1,44844 \mathrm{E}-07$ & $4,84675 \mathrm{E}-10$ & $3,22373 \mathrm{E}-09$ & $1,57385 \mathrm{E}-08$ & $1,50978 \mathrm{E}-09$ \\
\hline Extrativa & $1,09318 \mathrm{E}-08$ & $5,6986 \mathrm{E}-09$ & 3,51191E-09 & 6,59926E-09 & $1,96947 \mathrm{E}-09$ & $1,09055 \mathrm{E}-09$ & 5,18154E-09 & $5,26589 \mathrm{E}-09$ & $5,18127 \mathrm{E}-09$ & $4,8894 \mathrm{E}-09$ & $5,36892 \mathrm{E}-09$ \\
\hline
\end{tabular}




\begin{tabular}{|c|c|c|c|c|c|c|c|c|c|c|c|}
\hline Alimentos & $1,41958 \mathrm{E}-09$ & $4,41101 \mathrm{E}-09$ & 3,89613E-09 & $1,54394 \mathrm{E}-09$ & $1,2694 \mathrm{E}-09$ & $2,1391 \mathrm{E}-10$ & $5,55687 \mathrm{E}-07$ & $1,48088 \mathrm{E}-09$ & $9,02016 \mathrm{E}-09$ & $2,06677 \mathrm{E}-08$ & 4,12006E-09 \\
\hline Vestuário & $5,35415 \mathrm{E}-09$ & $1,1999 \mathrm{E}-08$ & 2,51582E-08 & $1,17153 \mathrm{E}-08$ & 9,58713E-09 & $1,26857 \mathrm{E}-09$ & $1,392 \mathrm{E}-08$ & $3,43063 \mathrm{E}-08$ & $2,21162 \mathrm{E}-08$ & 4,94623E-08 & 9,63553E-09 \\
\hline Madeira & $1,07483 \mathrm{E}-08$ & 3,81367E-09 & 2,55807E-09 & $5,06158 \mathrm{E}-09$ & 2,86172E-09 & 3,73801E-09 & $3,1209 \mathrm{E}-09$ & 4,20961E-09 & 5,58956E-09 & 5,89932E-09 & 8,43783E-09 \\
\hline Celulose & 0 & 0 & 0 & 0 & 0 & 0 & 0 & 0 & 0 & 0 & 0 \\
\hline Revistas & 8,3967E-09 & $3,02281 \mathrm{E}-08$ & $2,54755 \mathrm{E}-08$ & $7,05969 \mathrm{E}-08$ & $3,65548 \mathrm{E}-08$ & 7,94507E-09 & $8,36517 \mathrm{E}-09$ & $2,24394 \mathrm{E}-07$ & $3,6631 \mathrm{E}-08$ & $3,87809 \mathrm{E}-08$ & $2,13146 \mathrm{E}-08$ \\
\hline Químicos & 4,04492E-09 & $2,1411 \mathrm{E}-09$ & $1,51232 \mathrm{E}-09$ & 3,93975E-09 & $8,99976 \mathrm{E}-10$ & $5,86461 \mathrm{E}-10$ & $2,93756 \mathrm{E}-08$ & $2,44876 \mathrm{E}-09$ & $2,81286 \mathrm{E}-08$ & 5,51663E-09 & 4,25296E-09 \\
\hline Borracha & $8,26795 \mathrm{E}-08$ & $3,29636 \mathrm{E}-08$ & 2,77332E-08 & $6,7725 \mathrm{E}-08$ & $1,08335 \mathrm{E}-08$ & $6,18225 \mathrm{E}-09$ & 4,49812E-08 & $9,81467 \mathrm{E}-08$ & $8,57223 \mathrm{E}-08$ & 2,73517E-08 & $1,30179 \mathrm{E}-08$ \\
\hline Cimento & $2,1182 \mathrm{E}-07$ & $7,58213 \mathrm{E}-10$ & $3,25712 \mathrm{E}-10$ & $9,38403 \mathrm{E}-10$ & $8,77424 \mathrm{E}-10$ & $1,87329 \mathrm{E}-09$ & $1,47808 \mathrm{E}-09$ & $7,05009 \mathrm{E}-10$ & 6,99204E-09 & 3,68632E-09 & $3,50006 \mathrm{E}-09$ \\
\hline Aço & 0 & 0 & 0 & 0 & 0 & 0 & 0 & 0 & 0 & 0 & 0 \\
\hline Metal & 6,04694E-08 & $5,83785 \mathrm{E}-09$ & 1,36997E-09 & $3,18535 \mathrm{E}-09$ & $9,34146 \mathrm{E}-10$ & 2,28416E-09 & $2,58303 \mathrm{E}-08$ & $1,62543 \mathrm{E}-09$ & $6,12457 \mathrm{E}-09$ & 3,89406E-09 & 4,06403E-09 \\
\hline Eletrodomésticos & 0 & 0 & 0 & 0 & 0 & 0 & 0 & 0 & 0 & 0 & 0 \\
\hline Informática & 0 & 0 & 0 & 0 & 0 & 0 & 0 & 0 & 0 & 0 & 0 \\
\hline Máquinas & 0 & 0 & 0 & 0 & 0 & 0 & 0 & 0 & 0 & 0 & 0 \\
\hline Eletrônicos & 0 & 0 & 0 & 0 & 0 & 0 & 0 & 0 & 0 & 0 & 0 \\
\hline Instrumento hospitalar & 0 & 0 & 0 & 0 & 0 & 0 & 0 & 0 & 0 & 0 & 0 \\
\hline Veículos & $1,65288 \mathrm{E}-08$ & $9,16037 \mathrm{E}-09$ & $8,02299 \mathrm{E}-09$ & $1,3885 \mathrm{E}-08$ & 3,63086E-09 & $3,4883 \mathrm{E}-09$ & $8,57734 \mathrm{E}-09$ & $9,33632 \mathrm{E}-09$ & $9,08044 \mathrm{E}-09$ & $1,2138 \mathrm{E}-08$ & 9,10713E-09 \\
\hline Indústria Diversa & $1,47702 \mathrm{E}-08$ & $2,01288 \mathrm{E}-09$ & $1,26585 \mathrm{E}-08$ & 2,48391E-09 & $2,23707 \mathrm{E}-08$ & $5,59355 \mathrm{E}-09$ & $2,4709 \mathrm{E}-09$ & $8,18252 \mathrm{E}-09$ & $8,10734 \mathrm{E}-09$ & 4,09056E-08 & $8,93662 \mathrm{E}-09$ \\
\hline SIUP & $9,28315 \mathrm{E}-09$ & $3,18076 \mathrm{E}-08$ & $2,63762 \mathrm{E}-08$ & $2,47868 \mathrm{E}-08$ & $1,49577 \mathrm{E}-08$ & $3,15064 \mathrm{E}-09$ & $3,21538 \mathrm{E}-08$ & $2,79142 \mathrm{E}-08$ & $4,11001 \mathrm{E}-08$ & $9,24734 \mathrm{E}-08$ & $3,54003 \mathrm{E}-08$ \\
\hline Construção & $1,35626 \mathrm{E}-06$ & $1,55207 \mathrm{E}-09$ & $1,2065 \mathrm{E}-09$ & $4,94246 \mathrm{E}-09$ & 4,88994E-09 & $1,16906 \mathrm{E}-08$ & $8,30663 \mathrm{E}-10$ & $3,48288 \mathrm{E}-09$ & $1,04398 \mathrm{E}-08$ & $9,01232 \mathrm{E}-09$ & $2,03868 \mathrm{E}-08$ \\
\hline Comércio & 3,89421E-08 & $7,31447 \mathrm{E}-07$ & $3,24317 \mathrm{E}-08$ & $1,61151 \mathrm{E}-08$ & 9,63431E-09 & $4,25189 \mathrm{E}-09$ & $7,46569 \mathrm{E}-08$ & $2,79369 \mathrm{E}-08$ & $2,48597 \mathrm{E}-08$ & $2,68795 \mathrm{E}-08$ & $1,42459 \mathrm{E}-08$ \\
\hline Transportes & $2,15314 \mathrm{E}-08$ & $5,66506 \mathrm{E}-08$ & $1,73029 \mathrm{E}-06$ & $3,84294 \mathrm{E}-08$ & $1,61594 \mathrm{E}-08$ & $2,87425 \mathrm{E}-09$ & $2,59309 \mathrm{E}-08$ & $3,05293 \mathrm{E}-08$ & $2,74332 \mathrm{E}-08$ & 4,05497E-08 & $1,47282 \mathrm{E}-08$ \\
\hline Informação & $5,75096 \mathrm{E}-09$ & $1,81259 \mathrm{E}-08$ & $1,89505 \mathrm{E}-08$ & $1,35684 \mathrm{E}-06$ & $5,52885 \mathrm{E}-08$ & $3,73808 \mathrm{E}-09$ & $9,05472 \mathrm{E}-09$ & $1,46964 \mathrm{E}-07$ & $5,05392 \mathrm{E}-08$ & 3,30957E-08 & $6,12751 \mathrm{E}-08$ \\
\hline Financeiro & 4,77292E-09 & 9,47335E-09 & $1,30994 \mathrm{E}-08$ & $1,3335 \mathrm{E}-08$ & $3,78248 \mathrm{E}-07$ & 1,92711E-09 & 4,92706E-09 & $1,26208 \mathrm{E}-08$ & $5,57221 \mathrm{E}-09$ & 3,10142E-09 & $2,95146 \mathrm{E}-08$ \\
\hline Imobiliário & 4,45297E-09 & $2,24171 \mathrm{E}-08$ & $3,99498 \mathrm{E}-08$ & $3,61925 \mathrm{E}-08$ & $1,148 \mathrm{E}-08$ & $1,06438 \mathrm{E}-06$ & $1,37943 \mathrm{E}-08$ & $2,6126 \mathrm{E}-08$ & $2,71773 \mathrm{E}-08$ & $1,9475 \mathrm{E}-08$ & $2,05555 \mathrm{E}-08$ \\
\hline Alojamento & 1,76063E-09 & 2,44669E-09 & 4,76385E-09 & $3,21262 \mathrm{E}-09$ & 3,08973E-09 & $3,40921 \mathrm{E}-10$ & $1,8899 \mathrm{E}-06$ & $2,77166 \mathrm{E}-09$ & $1,46932 \mathrm{E}-08$ & $1,67687 \mathrm{E}-08$ & $9,08224 \mathrm{E}-09$ \\
\hline Serviços às Empresas & $1,55582 \mathrm{E}-08$ & $4,33957 \mathrm{E}-08$ & 4,98663E-08 & $7,10721 \mathrm{E}-08$ & $5,37538 \mathrm{E}-08$ & $8,40045 \mathrm{E}-09$ & $1,3744 \mathrm{E}-08$ & $8,57707 \mathrm{E}-07$ & $7,15451 \mathrm{E}-08$ & 4,55274E-08 & $5,05564 \mathrm{E}-08$ \\
\hline Educação e Saúde mercantis & $9,71949 \mathrm{E}-10$ & $3,46337 \mathrm{E}-09$ & 2,29523E-09 & $3,86723 \mathrm{E}-09$ & 3,98804E-09 & $4,99462 \mathrm{E}-10$ & $2,76124 \mathrm{E}-09$ & $3,2922 \mathrm{E}-09$ & $1,74423 \mathrm{E}-06$ & $2,63889 \mathrm{E}-09$ & $5,44394 \mathrm{E}-09$ \\
\hline Outros Serviços & 4,05754E-09 & $1,07277 \mathrm{E}-08$ & 6,70716E-09 & $1,1955 \mathrm{E}-08$ & 6,14187E-09 & 1,19779E-09 & $1,16984 \mathrm{E}-08$ & $1,42834 \mathrm{E}-08$ & $1,05699 \mathrm{E}-08$ & $1,50441 \mathrm{E}-06$ & 7,57287E-09 \\
\hline APU & $2,8628 \mathrm{E}-12$ & $7,69766 \mathrm{E}-12$ & $8,07538 \mathrm{E}-12$ & $1,03875 \mathrm{E}-11$ & $7,43599 \mathrm{E}-12$ & $1,23098 \mathrm{E}-12$ & $3,64409 \mathrm{E}-12$ & $9,24458 \mathrm{E}-12$ & $1,01464 \mathrm{E}-11$ & $7,84116 \mathrm{E}-12$ & $2,51917 \mathrm{E}-09$ \\
\hline
\end{tabular}


Tabela C2 - Matriz Geração de Renda para o Grau de Instrução G(1), Distrito Federal - 2008.

(1)

\begin{tabular}{|c|c|c|c|c|c|c|c|c|c|c|c|}
\hline Setores & Agricultura & Pecuária & Extrativa & Alimentos & Vestuário & Madeira & Celulose & Revistas & Químicos & Borracha & Cimento \\
\hline Agricultura & $2,68403 \mathrm{E}-05$ & $1,76095 \mathrm{E}-06$ & 2,92891E-09 & $2,16245 \mathrm{E}-06$ & $2,70515 \mathrm{E}-08$ & $4,25234 \mathrm{E}-08$ & $1,22805 \mathrm{E}-07$ & 1,19792E-09 & $5,39285 \mathrm{E}-09$ & $9,13941 \mathrm{E}-08$ & $2,09629 \mathrm{E}-09$ \\
\hline Pecuária & $1,07498 \mathrm{E}-07$ & $2,74945 \mathrm{E}-05$ & $8,0819 \mathrm{E}-10$ & $1,08761 \mathrm{E}-06$ & $2,27065 \mathrm{E}-08$ & $1,90642 \mathrm{E}-09$ & $6,26363 \mathrm{E}-09$ & $3,05279 \mathrm{E}-10$ & $1,98272 \mathrm{E}-09$ & $9,25255 \mathrm{E}-09$ & $7,5447 \mathrm{E}-10$ \\
\hline Extrativa & $2,66642 \mathrm{E}-08$ & $6,32087 \mathrm{E}-08$ & 0,000367355 & $1,50378 \mathrm{E}-08$ & $1,38198 \mathrm{E}-08$ & $1,90261 \mathrm{E}-08$ & $1,47145 \mathrm{E}-07$ & $3,5216 \mathrm{E}-09$ & $2,23643 \mathrm{E}-07$ & 4,75744E-08 & $1,66208 \mathrm{E}-07$ \\
\hline Alimentos & $1,15285 \mathrm{E}-07$ & $1,75066 \mathrm{E}-06$ & $6,04739 \mathrm{E}-09$ & $1,05548 \mathrm{E}-05$ & 7,96384E-08 & $8,24583 \mathrm{E}-09$ & $2,57761 \mathrm{E}-08$ & 2,23567E-09 & $9,73865 \mathrm{E}-09$ & $3,25999 \mathrm{E}-09$ & 5,91385E-09 \\
\hline Vestuário & $3,75 \mathrm{E}-09$ & $3,31864 \mathrm{E}-09$ & $1,10646 \mathrm{E}-07$ & 4,83682E-09 & 0,000198511 & 4,49799E-09 & $1,58877 \mathrm{E}-07$ & $5,09103 \mathrm{E}-09$ & $1,01457 \mathrm{E}-08$ & $2,97311 \mathrm{E}-08$ & 7,03169E-09 \\
\hline Madeira & $5,66632 \mathrm{E}-08$ & $1,11075 \mathrm{E}-08$ & $3,08911 \mathrm{E}-08$ & $1,3255 \mathrm{E}-08$ & $5,51623 \mathrm{E}-08$ & 0,000951799 & $5,74242 \mathrm{E}-06$ & $9,51546 \mathrm{E}-09$ & $1,74053 \mathrm{E}-07$ & $4,72506 \mathrm{E}-08$ & $5,3692 \mathrm{E}-08$ \\
\hline Celulose & $1,44303 \mathrm{E}-08$ & $1,57871 \mathrm{E}-08$ & $3,77596 \mathrm{E}-07$ & $1,84434 \mathrm{E}-08$ & $8,7753 \mathrm{E}-07$ & $1,44483 \mathrm{E}-06$ & 0,00058969 & $9,21202 \mathrm{E}-08$ & $2,40761 \mathrm{E}-07$ & 6,97441E-07 & $1,22512 \mathrm{E}-08$ \\
\hline Revistas & $1,39246 \mathrm{E}-08$ & $1,55245 \mathrm{E}-08$ & $3,58935 \mathrm{E}-08$ & $2,56212 \mathrm{E}-08$ & $1,35142 \mathrm{E}-08$ & $8,3209 \mathrm{E}-09$ & $1,54524 \mathrm{E}-07$ & $3,35601 \mathrm{E}-05$ & $2,20262 \mathrm{E}-07$ & 8,65949E-08 & $2,94985 \mathrm{E}-08$ \\
\hline Químicos & 3,72461E-06 & $2,5906 \mathrm{E}-06$ & $8,6552 \mathrm{E}-07$ & $4,84648 \mathrm{E}-07$ & $2,66403 \mathrm{E}-07$ & 4,93831E-07 & $2,24594 \mathrm{E}-06$ & $1,49745 \mathrm{E}-08$ & $9,63887 \mathrm{E}-05$ & $1,3091 \mathrm{E}-06$ & $1,22599 \mathrm{E}-07$ \\
\hline Borracha & $1,56402 \mathrm{E}-07$ & $1,00227 \mathrm{E}-07$ & $1,28715 \mathrm{E}-06$ & $2,77778 \mathrm{E}-07$ & $3,65562 \mathrm{E}-07$ & $6,80272 \mathrm{E}-07$ & $1,69652 \mathrm{E}-06$ & $2,13806 \mathrm{E}-07$ & $5,03657 \mathrm{E}-07$ & 0,000142877 & $1,71214 \mathrm{E}-08$ \\
\hline Cimento & $9,14544 \mathrm{E}-09$ & 4,6691E-09 & $1,07893 \mathrm{E}-08$ & $1,56268 \mathrm{E}-08$ & 4,11258E-09 & $1,78622 \mathrm{E}-09$ & $1,39736 \mathrm{E}-08$ & $1,46533 \mathrm{E}-09$ & $5,74839 \mathrm{E}-08$ & 4,27984E-09 & $9,09408 \mathrm{E}-06$ \\
\hline Aço & $1,06116 \mathrm{E}-07$ & $5,11399 \mathrm{E}-08$ & $5,54827 \mathrm{E}-07$ & $5,83543 \mathrm{E}-08$ & $3,22133 \mathrm{E}-08$ & $2,83201 \mathrm{E}-07$ & $5,60526 \mathrm{E}-07$ & 4,84057E-09 & $1,47518 \mathrm{E}-07$ & $8,14343 \mathrm{E}-07$ & 5,67797E-08 \\
\hline Metal & $1,70875 \mathrm{E}-07$ & $1,20405 \mathrm{E}-07$ & $5,53685 \mathrm{E}-07$ & $2,97217 \mathrm{E}-07$ & $4,77424 \mathrm{E}-08$ & $2,88643 \mathrm{E}-07$ & $5,15997 \mathrm{E}-07$ & $3,20231 \mathrm{E}-09$ & $2,50927 \mathrm{E}-07$ & $2,85153 \mathrm{E}-07$ & $4,50671 \mathrm{E}-08$ \\
\hline Eletrodomésticos & 3,91477E-08 & $2,67123 \mathrm{E}-08$ & $1,59212 \mathrm{E}-06$ & 4,49067E-08 & 4,0987E-07 & 7,06317E-07 & $3,02263 \mathrm{E}-06$ & $1,20634 \mathrm{E}-08$ & $2,25112 \mathrm{E}-07$ & $3,04881 \mathrm{E}-07$ & $2,35942 \mathrm{E}-08$ \\
\hline Informática & 0 & 0 & 0 & 0 & 0 & 0 & 0 & 0 & 0 & 0 & 0 \\
\hline Máquinas & $1,18 \mathrm{E}-08$ & $2,14455 \mathrm{E}-08$ & $3,55738 \mathrm{E}-07$ & $3,98923 \mathrm{E}-08$ & $3,97916 \mathrm{E}-08$ & $8,34607 \mathrm{E}-08$ & $8,29126 \mathrm{E}-08$ & $5,18115 \mathrm{E}-09$ & $1,0015 \mathrm{E}-07$ & $3,00452 \mathrm{E}-07$ & $7,42523 \mathrm{E}-08$ \\
\hline Eletrônicos & 0 & 0 & 0 & 0 & 0 & 0 & 0 & 0 & 0 & 0 & 0 \\
\hline Instrumento hospitalar & $5,56141 \mathrm{E}-10$ & $6,12734 \mathrm{E}-10$ & $2,74654 \mathrm{E}-09$ & $8,10019 \mathrm{E}-10$ & $1,07724 \mathrm{E}-09$ & $1,15167 \mathrm{E}-09$ & $6,31789 \mathrm{E}-09$ & $1,23161 \mathrm{E}-09$ & 6,68896E-09 & $1,28667 \mathrm{E}-08$ & $9,89047 \mathrm{E}-10$ \\
\hline Veículos & $1,91944 \mathrm{E}-08$ & $1,57069 \mathrm{E}-08$ & $1,13675 \mathrm{E}-07$ & $3,64713 \mathrm{E}-08$ & $1,96036 \mathrm{E}-08$ & $4,7282 \mathrm{E}-08$ & $9,22587 \mathrm{E}-08$ & $6,02559 \mathrm{E}-09$ & $4,34747 \mathrm{E}-08$ & $9,5534 \mathrm{E}-08$ & $1,7233 \mathrm{E}-08$ \\
\hline Indústria Diversa & $1,27583 \mathrm{E}-09$ & $1,18266 \mathrm{E}-08$ & 3,44394E-09 & $8,01378 \mathrm{E}-09$ & $1,25893 \mathrm{E}-07$ & 3,71319E-09 & $6,82127 \mathrm{E}-08$ & $1,48437 \mathrm{E}-09$ & 3,3907E-09 & $2,42291 \mathrm{E}-08$ & 3,24031E-09 \\
\hline SIUP & $1,80372 \mathrm{E}-08$ & $2,78395 \mathrm{E}-08$ & $7,23797 \mathrm{E}-08$ & $4,45845 \mathrm{E}-08$ & $3,64847 \mathrm{E}-08$ & 3,79011E-08 & $1,11924 \mathrm{E}-07$ & $2,96946 \mathrm{E}-08$ & $5,40661 \mathrm{E}-08$ & 5,59091E-08 & $1,47446 \mathrm{E}-07$ \\
\hline Construção & $2,82344 \mathrm{E}-10$ & $4,01085 \mathrm{E}-10$ & $7,25777 \mathrm{E}-10$ & $9,31293 \mathrm{E}-10$ & $8,36605 \mathrm{E}-10$ & 7,39013E-10 & $1,33051 \mathrm{E}-09$ & $1,05319 \mathrm{E}-09$ & $1,49065 \mathrm{E}-09$ & 2,42093E-09 & 3,3017E-09 \\
\hline Comércio & $4,50909 \mathrm{E}-08$ & $6,65382 \mathrm{E}-08$ & $3,9657 \mathrm{E}-08$ & 7,13467E-08 & $7,49424 \mathrm{E}-08$ & $3,06061 \mathrm{E}-08$ & $3,91547 \mathrm{E}-08$ & $4,05479 \mathrm{E}-08$ & $5,56425 \mathrm{E}-08$ & 4,33656E-08 & $6,9586 \mathrm{E}-08$ \\
\hline Transportes & 4,77073E-08 & $4,34083 \mathrm{E}-08$ & $1,27522 \mathrm{E}-07$ & $8,13678 \mathrm{E}-08$ & $3,78187 \mathrm{E}-08$ & $4,09463 \mathrm{E}-08$ & $6,93654 \mathrm{E}-08$ & $3,98784 \mathrm{E}-08$ & $7,5429 \mathrm{E}-08$ & $4,93238 \mathrm{E}-08$ & $1,5288 \mathrm{E}-07$ \\
\hline Informação & $6,5339 \mathrm{E}-09$ & $1,01292 \mathrm{E}-08$ & $2,98083 \mathrm{E}-08$ & $1,27293 \mathrm{E}-08$ & $7,29404 \mathrm{E}-09$ & 5,39604E-09 & $1,24577 \mathrm{E}-08$ & $2,99733 \mathrm{E}-08$ & $3,85945 \mathrm{E}-08$ & $1,72114 \mathrm{E}-08$ & $2,3357 \mathrm{E}-08$ \\
\hline
\end{tabular}




\begin{tabular}{|c|c|c|c|c|c|c|c|c|c|c|c|}
\hline Financeiro & $1,22486 \mathrm{E}-08$ & $1,35819 \mathrm{E}-08$ & 2,74462E-08 & $2,33732 \mathrm{E}-08$ & $1,86894 \mathrm{E}-08$ & $1,73254 \mathrm{E}-08$ & 3,77886E-08 & $2,14333 \mathrm{E}-08$ & $3,72114 \mathrm{E}-08$ & $2,70285 \mathrm{E}-08$ & $4,34631 \mathrm{E}-08$ \\
\hline Imobiliário & $5,25549 \mathrm{E}-09$ & 6,73052E-09 & $1,59447 \mathrm{E}-08$ & $1,34504 \mathrm{E}-08$ & $1,49855 \mathrm{E}-08$ & $5,99756 \mathrm{E}-09$ & $1,32506 \mathrm{E}-08$ & $2,08784 \mathrm{E}-08$ & $1,7874 \mathrm{E}-08$ & $1,11443 \mathrm{E}-08$ & $1,94194 \mathrm{E}-08$ \\
\hline Alojamento & $5,30901 \mathrm{E}-10$ & 7,48828E-10 & 4,84009E-09 & $1,31737 \mathrm{E}-09$ & $7,68122 \mathrm{E}-10$ & $1,54081 \mathrm{E}-09$ & $1,57026 \mathrm{E}-09$ & $2,08158 \mathrm{E}-09$ & $1,74461 \mathrm{E}-09$ & $1,5497 \mathrm{E}-09$ & $8,51814 \mathrm{E}-09$ \\
\hline Serviços às Empresas & 6,64366E-09 & $9,5512 \mathrm{E}-09$ & $1,84159 \mathrm{E}-08$ & $2,24752 \mathrm{E}-08$ & $1,4746 \mathrm{E}-08$ & $7,84108 \mathrm{E}-09$ & $1,90162 \mathrm{E}-08$ & $5,18196 \mathrm{E}-08$ & $5,86011 \mathrm{E}-08$ & $1,58577 \mathrm{E}-08$ & $3,68092 \mathrm{E}-08$ \\
\hline Educação e Saúde mercantis & $9,50538 \mathrm{E}-10$ & $1,31422 \mathrm{E}-09$ & $1,93405 \mathrm{E}-09$ & $1,98098 \mathrm{E}-09$ & $2,41859 \mathrm{E}-09$ & $8,88122 \mathrm{E}-10$ & 1,73873E-09 & 2,11994E-09 & $2,12989 \mathrm{E}-09$ & $1,52436 \mathrm{E}-09$ & 2,19617E-09 \\
\hline Outros Serviços & $3,24587 \mathrm{E}-09$ & 4,704E-09 & $4,90068 \mathrm{E}-09$ & 6,20551E-09 & $6,67088 \mathrm{E}-09$ & 2,45937E-09 & 4,07796E-09 & 4,7937E-09 & $6,61048 \mathrm{E}-09$ & $4,82684 \mathrm{E}-09$ & 7,69955E-09 \\
\hline $\mathrm{APU}$ & $2,76848 \mathrm{E}-10$ & $3,30312 \mathrm{E}-10$ & $6,63135 \mathrm{E}-10$ & $6,12387 \mathrm{E}-10$ & $3,85948 \mathrm{E}-10$ & $2,60435 \mathrm{E}-10$ & $6,32291 \mathrm{E}-10$ & $1,17022 \mathrm{E}-09$ & $1,05854 \mathrm{E}-09$ & $4,4905 \mathrm{E}-10$ & $1,01121 \mathrm{E}-09$ \\
\hline
\end{tabular}

Tabela C2 - Matriz Geração de Renda para o Grau de Instrução G(1), Distrito Federal - 2008.

(2)

\begin{tabular}{|c|c|c|c|c|c|c|c|c|c|c|}
\hline Setores & Aço & Metal & Eletrodomésticos & Informática & Máquinas & Eletrônicos & $\begin{array}{l}\text { Instrumento } \\
\text { hospitalar }\end{array}$ & Veículos & $\begin{array}{l}\text { Indústria } \\
\text { Diversa }\end{array}$ & SIUP \\
\hline Agricultura & $1,57932 \mathrm{E}-09$ & $8,70769 \mathrm{E}-10$ & $3,12656 \mathrm{E}-09$ & 2,97847E-09 & $1,77631 \mathrm{E}-09$ & 4,06649E-09 & 1,08047E-09 & $6,20365 \mathrm{E}-09$ & 2,42746E-09 & 4,39999E-10 \\
\hline Pecuária & $4,1478 \mathrm{E}-10$ & $2,04892 \mathrm{E}-10$ & $5,0644 \mathrm{E}-10$ & $5,47799 \mathrm{E}-10$ & $4,34437 \mathrm{E}-10$ & $5,68418 \mathrm{E}-10$ & $2,34255 \mathrm{E}-10$ & $9,06731 \mathrm{E}-10$ & 4,85703E-09 & $1,3322 \mathrm{E}-10$ \\
\hline Extrativa & $6,18871 \mathrm{E}-06$ & $3,65631 \mathrm{E}-07$ & $1,16037 \mathrm{E}-06$ & $8,84425 \mathrm{E}-08$ & $3,51868 \mathrm{E}-07$ & $1,97745 \mathrm{E}-07$ & $3,29485 \mathrm{E}-08$ & $6,61872 \mathrm{E}-07$ & $2,02891 \mathrm{E}-07$ & 3,10592E-09 \\
\hline Alimentos & 2,65023E-09 & $1,24601 \mathrm{E}-09$ & 2,57941E-09 & $2,88565 \mathrm{E}-09$ & 2,59878E-09 & $2,82283 \mathrm{E}-09$ & $1,3685 \mathrm{E}-09$ & 3,49003E-09 & 2,48277E-09 & $8,31921 \mathrm{E}-10$ \\
\hline Vestuário & $9,34148 \mathrm{E}-09$ & $1,42952 \mathrm{E}-08$ & $7,84599 \mathrm{E}-08$ & $1,0912 \mathrm{E}-08$ & $9,1648 \mathrm{E}-09$ & $1,24243 \mathrm{E}-08$ & $1,38302 \mathrm{E}-08$ & $6,73018 \mathrm{E}-08$ & 9,44687E-09 & $9,45806 \mathrm{E}-09$ \\
\hline Madeira & 4,31986E-08 & $6,38056 \mathrm{E}-08$ & $1,27307 \mathrm{E}-06$ & $1,17119 \mathrm{E}-06$ & $5,62976 \mathrm{E}-08$ & $5,20893 \mathrm{E}-06$ & $1,54075 \mathrm{E}-08$ & 7,97987E-07 & $1,72021 \mathrm{E}-06$ & $2,08508 \mathrm{E}-09$ \\
\hline Celulose & $9,93019 \mathrm{E}-08$ & $2,39946 \mathrm{E}-08$ & $1,83115 \mathrm{E}-06$ & $9,90115 \mathrm{E}-07$ & $1,7868 \mathrm{E}-07$ & $1,9548 \mathrm{E}-06$ & $4,18117 \mathrm{E}-08$ & $1,00143 \mathrm{E}-06$ & $9,63445 \mathrm{E}-08$ & $8,40812 \mathrm{E}-09$ \\
\hline Revistas & $4,22666 \mathrm{E}-08$ & $4,15929 \mathrm{E}-08$ & $2,54733 \mathrm{E}-08$ & $4,80772 \mathrm{E}-08$ & 2,1704E-08 & $4,03656 \mathrm{E}-08$ & $1,99466 \mathrm{E}-07$ & $4,74548 \mathrm{E}-08$ & $1,41796 \mathrm{E}-08$ & $5,94566 \mathrm{E}-08$ \\
\hline Químicos & $1,1541 \mathrm{E}-06$ & $2,01197 \mathrm{E}-07$ & $1,06534 \mathrm{E}-06$ & 7,64347E-08 & $3,35281 \mathrm{E}-07$ & $1,34774 \mathrm{E}-07$ & $2,5427 \mathrm{E}-07$ & 7,01349E-07 & $1,24778 \mathrm{E}-07$ & $8,43879 \mathrm{E}-08$ \\
\hline Borracha & 8,79091E-07 & $5,0392 \mathrm{E}-07$ & 2,40379E-06 & $2,14174 \mathrm{E}-06$ & $1,10487 \mathrm{E}-06$ & $2,48574 \mathrm{E}-06$ & $6,92615 \mathrm{E}-07$ & $5,75859 \mathrm{E}-06$ & $9,11389 \mathrm{E}-07$ & $2,18046 \mathrm{E}-08$ \\
\hline Cimento & $8,02316 \mathrm{E}-08$ & 2,39449E-08 & $3,11209 \mathrm{E}-08$ & $1,63885 \mathrm{E}-08$ & 7,70979E-08 & $6,00808 \mathrm{E}-08$ & $2,82421 \mathrm{E}-08$ & $6,94059 \mathrm{E}-08$ & $1,61372 \mathrm{E}-07$ & $7,77469 \mathrm{E}-10$ \\
\hline Aço & 0,000138502 & $1,13035 \mathrm{E}-06$ & $2,06994 \mathrm{E}-05$ & 1,49897E-06 & $4,08065 \mathrm{E}-06$ & $3,60563 \mathrm{E}-06$ & $4,12343 \mathrm{E}-07$ & $1,13952 \mathrm{E}-05$ & 4,20404E-07 & $1,31049 \mathrm{E}-08$ \\
\hline Metal & $1,36196 \mathrm{E}-06$ & $3,49635 \mathrm{E}-05$ & $2,19249 \mathrm{E}-06$ & $8,22407 \mathrm{E}-07$ & $1,52366 \mathrm{E}-06$ & $1,3568 \mathrm{E}-06$ & $9,33922 \mathrm{E}-07$ & $9,78211 \mathrm{E}-07$ & 7,5196E-07 & 3,8233E-09 \\
\hline Eletrodomésticos & $1,62316 \mathrm{E}-06$ & $1,86525 \mathrm{E}-07$ & 0,000623778 & $1,72922 \mathrm{E}-06$ & $7,98085 \mathrm{E}-07$ & $1,16684 \mathrm{E}-06$ & 3,47587E-07 & $7,31028 \mathrm{E}-06$ & $1,21004 \mathrm{E}-07$ & $1,95572 \mathrm{E}-08$ \\
\hline Informática & 0 & 0 & 0 & 0 & 0 & 0 & 0 & 0 & 0 & 0 \\
\hline Máquinas & $1,28113 \mathrm{E}-07$ & 3,50281E-08 & $2,6453 \mathrm{E}-06$ & $6,33056 \mathrm{E}-06$ & 0,000103535 & $1,16336 \mathrm{E}-05$ & $7,71645 \mathrm{E}-07$ & $1,72972 \mathrm{E}-06$ & $2,58462 \mathrm{E}-07$ & $1,96467 \mathrm{E}-07$ \\
\hline
\end{tabular}




\begin{tabular}{|c|c|c|c|c|c|c|c|c|c|c|}
\hline Eletrônicos & 0 & 0 & 0 & 0 & 0 & 0 & 0 & 0 & 0 & 0 \\
\hline Instrumento hospitalar & 1,96239E-09 & $1,07882 \mathrm{E}-09$ & 2,97587E-07 & $3,89067 \mathrm{E}-08$ & $1,15559 \mathrm{E}-07$ & $5,42846 \mathrm{E}-08$ & $9,33586 \mathrm{E}-05$ & 4,96734E-08 & $5,10585 \mathrm{E}-09$ & $1,12793 \mathrm{E}-09$ \\
\hline Veículos & $2,60555 \mathrm{E}-07$ & $1,64609 \mathrm{E}-07$ & $1,17525 \mathrm{E}-06$ & $8,30243 \mathrm{E}-07$ & $9,4848 \mathrm{E}-07$ & $1,50658 \mathrm{E}-06$ & $1,99669 \mathrm{E}-07$ & 0,00041531 & $1,18813 \mathrm{E}-07$ & $2,53399 \mathrm{E}-08$ \\
\hline Indústria Diversa & $1,61947 \mathrm{E}-07$ & $1,19323 \mathrm{E}-08$ & $3,76394 \mathrm{E}-08$ & $7,1236 \mathrm{E}-09$ & $2,18552 \mathrm{E}-08$ & $1,1592 \mathrm{E}-08$ & $3,08855 \mathrm{E}-09$ & $1,94444 \mathrm{E}-08$ & $4,05795 \mathrm{E}-05$ & $1,01171 \mathrm{E}-09$ \\
\hline SIUP & $1,31007 \mathrm{E}-07$ & $6,38857 \mathrm{E}-08$ & 6,35924E-08 & $4,25815 \mathrm{E}-08$ & 7,46583E-08 & $5,20298 \mathrm{E}-08$ & $5,44124 \mathrm{E}-08$ & $5,57494 \mathrm{E}-08$ & 3,96964E-08 & $5,93135 \mathrm{E}-06$ \\
\hline Construção & $1,02863 \mathrm{E}-09$ & $6,91221 \mathrm{E}-10$ & $1,39815 \mathrm{E}-09$ & $2,05827 \mathrm{E}-09$ & 2,84287E-09 & 4,29576E-09 & $6,51735 \mathrm{E}-10$ & $4,55585 \mathrm{E}-09$ & $8,35311 \mathrm{E}-10$ & $6,45689 \mathrm{E}-10$ \\
\hline Comércio & 3,70734E-08 & 3,24703E-08 & $5,45486 \mathrm{E}-08$ & $1,22794 \mathrm{E}-07$ & 4,86314E-08 & $9,1719 \mathrm{E}-08$ & 4,89853E-08 & 6,98781E-08 & $5,67297 \mathrm{E}-08$ & $1,54837 \mathrm{E}-08$ \\
\hline Transportes & $1,02555 \mathrm{E}-07$ & $5,88497 \mathrm{E}-08$ & $8,09812 \mathrm{E}-08$ & $9,08252 \mathrm{E}-08$ & 7,74775E-08 & $1,12752 \mathrm{E}-07$ & $6,15225 \mathrm{E}-08$ & 7,09834E-08 & $3,81289 \mathrm{E}-08$ & $3,11566 \mathrm{E}-08$ \\
\hline Informação & 3,04691E-08 & $1,35511 \mathrm{E}-08$ & 3,40834E-08 & $4,89981 \mathrm{E}-08$ & 4,18166E-08 & 7,20909E-08 & $2,20822 \mathrm{E}-08$ & $2,72563 \mathrm{E}-08$ & 7,40415E-09 & $2,57832 \mathrm{E}-08$ \\
\hline Financeiro & $4,73486 \mathrm{E}-08$ & $2,78945 \mathrm{E}-08$ & $6,03226 \mathrm{E}-08$ & $4,21298 \mathrm{E}-08$ & 4,3097E-08 & 7,42371E-08 & $2,99606 \mathrm{E}-08$ & 4,13789E-08 & $1,77316 \mathrm{E}-08$ & $1,5945 \mathrm{E}-08$ \\
\hline Imobiliário & $1,25921 \mathrm{E}-08$ & $1,06851 \mathrm{E}-08$ & $1,66499 \mathrm{E}-08$ & $1,78536 \mathrm{E}-08$ & $1,32087 \mathrm{E}-08$ & $1,76614 \mathrm{E}-08$ & $1,55372 \mathrm{E}-08$ & $1,16229 \mathrm{E}-08$ & $1,01336 \mathrm{E}-08$ & $9,11784 \mathrm{E}-09$ \\
\hline Alojamento & $2,25552 \mathrm{E}-09$ & $8,59691 \mathrm{E}-10$ & $1,24191 \mathrm{E}-09$ & $1,79591 \mathrm{E}-09$ & 2,66489E-09 & $1,79438 \mathrm{E}-09$ & $7,7221 \mathrm{E}-10$ & 2,38259E-09 & $1,60474 \mathrm{E}-09$ & $6,59563 \mathrm{E}-10$ \\
\hline Serviços às Empresas & $1,54082 \mathrm{E}-08$ & $1,50151 \mathrm{E}-08$ & $1,79956 \mathrm{E}-08$ & $8,04985 \mathrm{E}-08$ & 2,56604E-08 & $5,67371 \mathrm{E}-08$ & $2,06068 \mathrm{E}-08$ & $3,44633 \mathrm{E}-08$ & $1,18559 \mathrm{E}-08$ & $4,37671 \mathrm{E}-08$ \\
\hline Educação e Saúde mercantis & 1,44341E-09 & $1,45845 \mathrm{E}-09$ & 2,14163E-09 & $2,9841 \mathrm{E}-09$ & $1,83474 \mathrm{E}-09$ & 2,74096E-09 & $1,82472 \mathrm{E}-09$ & $1,84993 \mathrm{E}-09$ & 1,67454E-09 & $1,14836 \mathrm{E}-09$ \\
\hline Outros Serviços & 4,55229E-09 & $4,14219 \mathrm{E}-09$ & $6,0829 \mathrm{E}-09$ & $1,19493 \mathrm{E}-08$ & $8,68402 \mathrm{E}-09$ & $1,1019 \mathrm{E}-08$ & 4,94233E-09 & $6,43465 \mathrm{E}-09$ & $5,07391 \mathrm{E}-09$ & $4,84049 \mathrm{E}-09$ \\
\hline APU & $6,43856 \mathrm{E}-10$ & $4,42681 \mathrm{E}-10$ & $5,20831 \mathrm{E}-10$ & $1,33841 \mathrm{E}-09$ & $5,7945 \mathrm{E}-10$ & $1,06329 \mathrm{E}-09$ & $5,15556 \mathrm{E}-10$ & $7,18704 \mathrm{E}-10$ & $3,32559 \mathrm{E}-10$ & $1,19467 \mathrm{E}-09$ \\
\hline
\end{tabular}

Tabela C2 - Matriz Geração de Renda para o Grau de Instrução G(1), Distrito Federal - 2008.

(3)

\begin{tabular}{|c|c|c|c|c|c|c|c|c|c|c|c|}
\hline Setores & Construção & Comércio & Transportes & Informação & Financeiro & Imobiliário & Alojamento & $\begin{array}{l}\text { Serviços às } \\
\text { Empresas }\end{array}$ & $\begin{array}{l}\text { Educação e } \\
\text { Saúde } \\
\text { mercantis }\end{array}$ & $\begin{array}{l}\text { Outros } \\
\text { Serviços }\end{array}$ & APU \\
\hline Agricultura & $1,26249 \mathrm{E}-09$ & $3,91694 \mathrm{E}-09$ & 2,96292E-09 & $1,79727 \mathrm{E}-09$ & $1,16378 \mathrm{E}-09$ & $2,46653 \mathrm{E}-10$ & $3,9405 \mathrm{E}-07$ & $1,78448 \mathrm{E}-09$ & 9,3943E-09 & $4,05824 \mathrm{E}-08$ & $5,01549 \mathrm{E}-09$ \\
\hline Pecuária & $4,00501 \mathrm{E}-10$ & $1,17702 \mathrm{E}-09$ & $1,04796 \mathrm{E}-09$ & $5,18701 \mathrm{E}-10$ & $3,97096 \mathrm{E}-10$ & $6,71494 \mathrm{E}-11$ & $1,5501 \mathrm{E}-07$ & $5,18692 \mathrm{E}-10$ & $3,44998 \mathrm{E}-09$ & $1,68431 \mathrm{E}-08$ & $1,61574 \mathrm{E}-09$ \\
\hline Extrativa & $1,61527 \mathrm{E}-08$ & $8,42018 \mathrm{E}-09$ & 5,18916E-09 & $9,75098 \mathrm{E}-09$ & $2,91007 \mathrm{E}-09$ & $1,61139 \mathrm{E}-09$ & $7,65618 \mathrm{E}-09$ & 7,78082E-09 & $7,65579 \mathrm{E}-09$ & $7,22452 \mathrm{E}-09$ & $7,93305 \mathrm{E}-09$ \\
\hline Alimentos & 3,26031E-09 & $1,01306 \mathrm{E}-08$ & 8,94814E-09 & $3,54591 \mathrm{E}-09$ & 2,91539E-09 & $4,91281 \mathrm{E}-10$ & $1,27623 \mathrm{E}-06$ & $3,4011 \mathrm{E}-09$ & $2,07163 \mathrm{E}-08$ & 4,74669E-08 & $9,46241 \mathrm{E}-09$ \\
\hline Vestuário & $5,87115 \mathrm{E}-09$ & $1,31576 \mathrm{E}-08$ & $2,75876 \mathrm{E}-08$ & $1,28466 \mathrm{E}-08$ & $1,05129 \mathrm{E}-08$ & $1,39107 \mathrm{E}-09$ & $1,52642 \mathrm{E}-08$ & $3,7619 \mathrm{E}-08$ & $2,42518 \mathrm{E}-08$ & $5,42384 \mathrm{E}-08$ & $1,0566 \mathrm{E}-08$ \\
\hline Madeira & $1,95527 \mathrm{E}-08$ & $6,9376 \mathrm{E}-09$ & $4,65348 \mathrm{E}-09$ & $9,20772 \mathrm{E}-09$ & $5,20586 \mathrm{E}-09$ & 6,79996E-09 & $5,67735 \mathrm{E}-09$ & 7,65786E-09 & $1,01682 \mathrm{E}-08$ & $1,07317 \mathrm{E}-08$ & $1,53496 \mathrm{E}-08$ \\
\hline
\end{tabular}




\begin{tabular}{|c|c|c|c|c|c|c|c|c|c|c|c|}
\hline Celulose & 6,08912E-09 & 2,44213E-08 & $1,54374 \mathrm{E}-08$ & $3,10803 \mathrm{E}-08$ & $1,05253 \mathrm{E}-08$ & 4,09643E-09 & $1,52941 \mathrm{E}-08$ & $4,06492 \mathrm{E}-08$ & $2,17575 \mathrm{E}-08$ & $2,05323 \mathrm{E}-08$ & $2,04555 \mathrm{E}-08$ \\
\hline Revistas & $1,58081 \mathrm{E}-08$ & 5,69091E-08 & 4,79615E-08 & $1,3291 \mathrm{E}-07$ & $6,88201 \mathrm{E}-08$ & $1,49578 \mathrm{E}-08$ & $1,57487 \mathrm{E}-08$ & 4,22457E-07 & $6,89635 \mathrm{E}-08$ & 7,30112E-08 & $4,0128 \mathrm{E}-08$ \\
\hline Químicos & $1,14221 \mathrm{E}-08$ & $6,04606 \mathrm{E}-09$ & 4,27051E-09 & $1,11251 \mathrm{E}-08$ & $2,54136 \mathrm{E}-09$ & $1,65606 \mathrm{E}-09$ & $8,29511 \mathrm{E}-08$ & $6,91485 \mathrm{E}-09$ & 7,943E-08 & $1,55779 \mathrm{E}-08$ & $1,20096 \mathrm{E}-08$ \\
\hline Borracha & $9,04071 \mathrm{E}-08$ & $3,60445 \mathrm{E}-08$ & $3,03252 \mathrm{E}-08$ & $7,40549 \mathrm{E}-08$ & $1,18461 \mathrm{E}-08$ & 6,76007E-09 & $4,91854 \mathrm{E}-08$ & $1,0732 \mathrm{E}-07$ & $9,37343 \mathrm{E}-08$ & $2,99081 \mathrm{E}-08$ & $1,42346 \mathrm{E}-08$ \\
\hline Cimento & $3,27174 \mathrm{E}-07$ & 1,17113E-09 & $5,03091 \mathrm{E}-10$ & $1,44945 \mathrm{E}-09$ & $1,35526 \mathrm{E}-09$ & 2,89347E-09 & 2,28302E-09 & $1,08895 \mathrm{E}-09$ & $1,07998 \mathrm{E}-08$ & $5,69384 \mathrm{E}-09$ & 5,40615E-09 \\
\hline Aço & $3,85248 \mathrm{E}-08$ & $5,64837 \mathrm{E}-09$ & 4,4248E-09 & 7,74487E-09 & 2,22145E-09 & 2,07904E-09 & $1,04574 \mathrm{E}-08$ & $5,4193 \mathrm{E}-09$ & $6,54517 \mathrm{E}-09$ & 7,32058E-09 & 5,24097E-09 \\
\hline Metal & $9,3981 \mathrm{E}-08$ & $9,07315 \mathrm{E}-09$ & 2,1292E-09 & $4,95064 \mathrm{E}-09$ & $1,45184 \mathrm{E}-09$ & $3,55002 \mathrm{E}-09$ & $4,01453 \mathrm{E}-08$ & $2,52624 \mathrm{E}-09$ & $9,51877 \mathrm{E}-09$ & $6,05212 \mathrm{E}-09$ & $6,31629 \mathrm{E}-09$ \\
\hline Eletrodomésticos & 2,42663E-08 & 2,32324E-08 & $1,58097 \mathrm{E}-08$ & $2,92866 \mathrm{E}-08$ & $8,14212 \mathrm{E}-09$ & 6,11557E-09 & $1,86643 \mathrm{E}-08$ & 2,29106E-08 & $2,17154 \mathrm{E}-08$ & $2,19625 \mathrm{E}-08$ & $2,22402 \mathrm{E}-08$ \\
\hline Informática & 0 & 0 & 0 & 0 & 0 & 0 & 0 & 0 & 0 & 0 & 0 \\
\hline Máquinas & 5,39323E-08 & $1,13747 \mathrm{E}-08$ & $3,34765 \mathrm{E}-08$ & 4,87913E-08 & 6,08798E-09 & $1,32289 \mathrm{E}-08$ & $9,02802 \mathrm{E}-09$ & $1,69854 \mathrm{E}-08$ & $1,51176 \mathrm{E}-08$ & $5,38218 \mathrm{E}-08$ & 9,58337E-09 \\
\hline Eletrônicos & 0 & 0 & 0 & 0 & 0 & 0 & 0 & 0 & 0 & 0 & 0 \\
\hline Instrumento hospitalar & $6,32105 \mathrm{E}-09$ & $3,82001 \mathrm{E}-09$ & $1,21149 \mathrm{E}-09$ & $1,57513 \mathrm{E}-09$ & $8,87636 \mathrm{E}-10$ & $7,20084 \mathrm{E}-09$ & $7,70648 \mathrm{E}-10$ & $1,02502 \mathrm{E}-08$ & $1,06401 \mathrm{E}-08$ & $8,10638 \mathrm{E}-09$ & 2,20469E-09 \\
\hline Veículos & $2,02607 \mathrm{E}-08$ & $1,12286 \mathrm{E}-08$ & $9,83445 \mathrm{E}-09$ & $1,702 \mathrm{E}-08$ & 4,45065E-09 & $4,2759 \mathrm{E}-09$ & $1,0514 \mathrm{E}-08$ & $1,14443 \mathrm{E}-08$ & $1,11307 \mathrm{E}-08$ & $1,48785 \mathrm{E}-08$ & $1,11634 \mathrm{E}-08$ \\
\hline Indústria Diversa & $1,33478 \mathrm{E}-08$ & $1,81903 \mathrm{E}-09$ & $1,14395 \mathrm{E}-08$ & $2,2447 \mathrm{E}-09$ & $2,02163 \mathrm{E}-08$ & $5,05487 \mathrm{E}-09$ & 2,23294E-09 & 7,3945E-09 & 7,32657E-09 & $3,69662 \mathrm{E}-08$ & $8,07598 \mathrm{E}-09$ \\
\hline SIUP & $1,29613 \mathrm{E}-08$ & 4,44103E-08 & $3,68269 \mathrm{E}-08$ & $3,46078 \mathrm{E}-08$ & $2,08842 \mathrm{E}-08$ & 4,39897E-09 & 4,48937E-08 & $3,89743 \mathrm{E}-08$ & $5,73846 \mathrm{E}-08$ & $1,29113 \mathrm{E}-07$ & $4,94265 \mathrm{E}-08$ \\
\hline Construção & $1,5401 \mathrm{E}-06$ & $1,76246 \mathrm{E}-09$ & $1,37005 \mathrm{E}-09$ & $5,61242 \mathrm{E}-09$ & $5,55279 \mathrm{E}-09$ & $1,32753 \mathrm{E}-08$ & $9,43262 \mathrm{E}-10$ & $3,955 \mathrm{E}-09$ & $1,1855 \mathrm{E}-08$ & $1,0234 \mathrm{E}-08$ & $2,31503 \mathrm{E}-08$ \\
\hline Comércio & $5,08104 \mathrm{E}-08$ & $9,54369 \mathrm{E}-07$ & 4,23159E-08 & $2,10264 \mathrm{E}-08$ & $1,25705 \mathrm{E}-08$ & $5,54773 \mathrm{E}-09$ & 9,741E-08 & $3,64511 \mathrm{E}-08$ & $3,24362 \mathrm{E}-08$ & $3,50715 \mathrm{E}-08$ & $1,85875 \mathrm{E}-08$ \\
\hline Transportes & 2,91744E-08 & 7,67599E-08 & $2,3445 \mathrm{E}-06$ & $5,20706 \mathrm{E}-08$ & $2,18956 \mathrm{E}-08$ & 3,89452E-09 & $3,51356 \mathrm{E}-08$ & $4,13663 \mathrm{E}-08$ & $3,71711 \mathrm{E}-08$ & $5,49436 \mathrm{E}-08$ & $1,99563 \mathrm{E}-08$ \\
\hline Informação & $8,43889 \mathrm{E}-09$ & $2,65977 \mathrm{E}-08$ & $2,78077 \mathrm{E}-08$ & $1,99101 \mathrm{E}-06$ & $8,11298 \mathrm{E}-08$ & $5,48521 \mathrm{E}-09$ & $1,32868 \mathrm{E}-08$ & $2,15653 \mathrm{E}-07$ & $7,41607 \mathrm{E}-08$ & $4,85642 \mathrm{E}-08$ & $8,99143 \mathrm{E}-08$ \\
\hline Financeiro & $1,2839 \mathrm{E}-08$ & $2,5483 \mathrm{E}-08$ & $3,52369 \mathrm{E}-08$ & $3,58707 \mathrm{E}-08$ & $1,01747 \mathrm{E}-06$ & $5,18386 \mathrm{E}-09$ & $1,32536 \mathrm{E}-08$ & $3,39496 \mathrm{E}-08$ & $1,49891 \mathrm{E}-08$ & $8,34271 \mathrm{E}-09$ & 7,93933E-08 \\
\hline Imobiliário & 7,50673E-09 & 3,77903E-08 & $6,73467 \mathrm{E}-08$ & $6,10126 \mathrm{E}-08$ & $1,93527 \mathrm{E}-08$ & $1,79431 \mathrm{E}-06$ & $2,32542 \mathrm{E}-08$ & $4,40428 \mathrm{E}-08$ & $4,58149 \mathrm{E}-08$ & $3,28307 \mathrm{E}-08$ & $3,4652 \mathrm{E}-08$ \\
\hline Alojamento & $2,25336 \mathrm{E}-09$ & $3,13141 \mathrm{E}-09$ & $6,09704 \mathrm{E}-09$ & $4,11169 \mathrm{E}-09$ & $3,95441 \mathrm{E}-09$ & $4,3633 \mathrm{E}-10$ & $2,4188 \mathrm{E}-06$ & $3,54733 \mathrm{E}-09$ & $1,88052 \mathrm{E}-08$ & $2,14615 \mathrm{E}-08$ & $1,1624 \mathrm{E}-08$ \\
\hline Serviços às Empresas & $1,77689 \mathrm{E}-08$ & $4,95619 \mathrm{E}-08$ & $5,69519 \mathrm{E}-08$ & $8,11709 \mathrm{E}-08$ & $6,13918 \mathrm{E}-08$ & $9,5941 \mathrm{E}-09$ & $1,5697 \mathrm{E}-08$ & $9,79581 \mathrm{E}-07$ & $8,17111 \mathrm{E}-08$ & $5,19965 \mathrm{E}-08$ & $5,77401 \mathrm{E}-08$ \\
\hline Educação e Saúde mercantis & $1,28343 \mathrm{E}-09$ & 4,57325E-09 & $3,03077 \mathrm{E}-09$ & $5,10655 \mathrm{E}-09$ & $5,26607 \mathrm{E}-09$ & $6,59523 \mathrm{E}-10$ & $3,64612 \mathrm{E}-09$ & $4,34723 \mathrm{E}-09$ & $2,3032 \mathrm{E}-06$ & $3,48456 \mathrm{E}-09$ & $7,18853 \mathrm{E}-09$ \\
\hline Outros Serviços & $4,52805 \mathrm{E}-09$ & 1,19717E-08 & $7,48491 \mathrm{E}-09$ & $1,33412 \mathrm{E}-08$ & $6,85407 \mathrm{E}-09$ & $1,33668 \mathrm{E}-09$ & $1,30549 \mathrm{E}-08$ & $1,59396 \mathrm{E}-08$ & $1,17955 \mathrm{E}-08$ & $1,67886 \mathrm{E}-06$ & $8,45101 \mathrm{E}-09$ \\
\hline APU & 3,41483E-10 & 9,18199E-10 & $9,63254 \mathrm{E}-10$ & $1,23905 \mathrm{E}-09$ & $8,86987 \mathrm{E}-10$ & $1,46835 \mathrm{E}-10$ & $4,34678 \mathrm{E}-10$ & $1,10272 \mathrm{E}-09$ & $1,21029 \mathrm{E}-09$ & $9,35317 \mathrm{E}-10$ & $3,00494 \mathrm{E}-07$ \\
\hline
\end{tabular}


Tabela C3 - Matriz Geração de Renda para o Grau de Instrução G(2), Distrito Federal - 2008.

(1)

\begin{tabular}{|c|c|c|c|c|c|c|c|c|c|c|c|}
\hline Setores & Agricultura & Pecuária & Extrativa & Alimentos & Vestuário & Madeira & Celulose & Revistas & Químicos & Borracha & Cimento \\
\hline Agricultura & $1,89705 \mathrm{E}-05$ & $1,24462 \mathrm{E}-06$ & $2,07012 \mathrm{E}-09$ & $1,5284 \mathrm{E}-06$ & 1,91197E-08 & $3,00551 \mathrm{E}-08$ & 8,67976E-08 & $8,46677 \mathrm{E}-10$ & 3,81161E-09 & 6,45964E-08 & $1,48164 \mathrm{E}-09$ \\
\hline Pecuária & $1,05668 \mathrm{E}-07$ & $2,70264 \mathrm{E}-05$ & $7,94431 \mathrm{E}-10$ & $1,06909 \mathrm{E}-06$ & $2,23199 \mathrm{E}-08$ & $1,87397 \mathrm{E}-09$ & $6,157 \mathrm{E}-09$ & $3,00081 \mathrm{E}-10$ & $1,94896 \mathrm{E}-09$ & $9,09502 \mathrm{E}-09$ & $7,41625 \mathrm{E}-10$ \\
\hline Extrativa & $3,27559 \mathrm{E}-08$ & $7,76492 \mathrm{E}-08$ & 0,00045128 & $1,84733 \mathrm{E}-08$ & $1,6977 \mathrm{E}-08$ & $2,33728 \mathrm{E}-08$ & $1,80761 \mathrm{E}-07$ & 4,32614E-09 & $2,74736 \mathrm{E}-07$ & $5,84432 \mathrm{E}-08$ & $2,0418 \mathrm{E}-07$ \\
\hline Alimentos & $5,23136 \mathrm{E}-08$ & 7,94405E-07 & $2,74416 \mathrm{E}-09$ & 4,78949E-06 & 3,61379E-08 & 3,74175E-09 & $1,16966 \mathrm{E}-08$ & $1,01449 \mathrm{E}-09$ & 4,41916E-09 & $1,4793 \mathrm{E}-09$ & $2,68356 \mathrm{E}-09$ \\
\hline Vestuário & 3,68018E-09 & $3,25685 \mathrm{E}-09$ & $1,08586 \mathrm{E}-07$ & 4,74677E-09 & 0,000194815 & 4,41424E-09 & $1,55919 \mathrm{E}-07$ & 4,99624E-09 & $9,9568 \mathrm{E}-09$ & $2,91775 \mathrm{E}-08$ & 6,90077E-09 \\
\hline Madeira & $4,7634 \mathrm{E}-08$ & $9,33752 \mathrm{E}-09$ & $2,59686 \mathrm{E}-08$ & $1,11429 \mathrm{E}-08$ & $4,63723 \mathrm{E}-08$ & 0,000800131 & 4,82737E-06 & 7,99919E-09 & $1,46318 \mathrm{E}-07$ & $3,97213 \mathrm{E}-08$ & $4,51362 \mathrm{E}-08$ \\
\hline Celulose & $2,24669 \mathrm{E}-08$ & $2,45793 \mathrm{E}-08$ & $5,87889 \mathrm{E}-07$ & $2,8715 \mathrm{E}-08$ & $1,36625 \mathrm{E}-06$ & $2,24948 \mathrm{E}-06$ & 0,000918103 & $1,43424 \mathrm{E}-07$ & $3,74846 \mathrm{E}-07$ & $1,08586 \mathrm{E}-06$ & $1,90742 \mathrm{E}-08$ \\
\hline Revistas & $1,4615 \mathrm{E}-08$ & $1,62942 \mathrm{E}-08$ & $3,76732 \mathrm{E}-08$ & 2,68916E-08 & $1,41843 \mathrm{E}-08$ & $8,73346 \mathrm{E}-09$ & $1,62186 \mathrm{E}-07$ & $3,5224 \mathrm{E}-05$ & $2,31183 \mathrm{E}-07$ & $9,08883 \mathrm{E}-08$ & $3,0961 \mathrm{E}-08$ \\
\hline Químicos & $3,5611 \mathrm{E}-06$ & $2,47687 \mathrm{E}-06$ & $8,27525 \mathrm{E}-07$ & 4,63373E-07 & $2,54708 \mathrm{E}-07$ & $4,72153 \mathrm{E}-07$ & $2,14734 \mathrm{E}-06$ & $1,43172 \mathrm{E}-08$ & $9,21573 \mathrm{E}-05$ & $1,25163 \mathrm{E}-06$ & $1,17217 \mathrm{E}-07$ \\
\hline Borracha & $1,52308 \mathrm{E}-07$ & $9,76033 \mathrm{E}-08$ & $1,25346 \mathrm{E}-06$ & $2,70506 \mathrm{E}-07$ & 3,55993E-07 & $6,62465 \mathrm{E}-07$ & $1,65211 \mathrm{E}-06$ & $2,08209 \mathrm{E}-07$ & 4,90473E-07 & 0,000139137 & $1,66732 \mathrm{E}-08$ \\
\hline Cimento & $8,52905 \mathrm{E}-09$ & 4,35441E-09 & $1,00621 \mathrm{E}-08$ & $1,45736 \mathrm{E}-08$ & 3,8354E-09 & $1,66583 \mathrm{E}-09$ & $1,30318 \mathrm{E}-08$ & $1,36657 \mathrm{E}-09$ & $5,36095 \mathrm{E}-08$ & 3,99138E-09 & $8,48114 \mathrm{E}-06$ \\
\hline Aço & $7,22954 \mathrm{E}-08$ & $3,48408 \mathrm{E}-08$ & $3,77995 \mathrm{E}-07$ & $3,97559 \mathrm{E}-08$ & $2,19464 \mathrm{E}-08$ & $1,92941 \mathrm{E}-07$ & $3,81878 \mathrm{E}-07$ & 3,29781E-09 & $1,00502 \mathrm{E}-07$ & $5,54799 \mathrm{E}-07$ & $3,86831 \mathrm{E}-08$ \\
\hline Metal & $1,38855 \mathrm{E}-07$ & $9,78426 \mathrm{E}-08$ & 4,4993E-07 & $2,41521 \mathrm{E}-07$ & $3,8796 \mathrm{E}-08$ & $2,34554 \mathrm{E}-07$ & $4,19305 \mathrm{E}-07$ & 2,60223E-09 & $2,03906 \mathrm{E}-07$ & $2,31718 \mathrm{E}-07$ & $3,6622 \mathrm{E}-08$ \\
\hline Eletrodomésticos & $3,52137 \mathrm{E}-08$ & $2,4028 \mathrm{E}-08$ & $1,43213 \mathrm{E}-06$ & $4,03939 \mathrm{E}-08$ & $3,68682 \mathrm{E}-07$ & 6,35337E-07 & $2,71888 \mathrm{E}-06$ & $1,08511 \mathrm{E}-08$ & $2,0249 \mathrm{E}-07$ & $2,74243 \mathrm{E}-07$ & $2,12232 \mathrm{E}-08$ \\
\hline Informática & 0 & 0 & 0 & 0 & 0 & 0 & 0 & 0 & 0 & 0 & 0 \\
\hline Máquinas & $2,36006 \mathrm{E}-08$ & $4,28921 \mathrm{E}-08$ & $7,11496 \mathrm{E}-07$ & $7,97868 \mathrm{E}-08$ & $7,95853 \mathrm{E}-08$ & $1,66926 \mathrm{E}-07$ & $1,6583 \mathrm{E}-07$ & $1,03626 \mathrm{E}-08$ & $2,00306 \mathrm{E}-07$ & $6,0092 \mathrm{E}-07$ & $1,48509 \mathrm{E}-07$ \\
\hline Eletrônicos & $2,49158 \mathrm{E}-09$ & 2,82653E-09 & $2,84672 \mathrm{E}-07$ & $5,66465 \mathrm{E}-09$ & 5,70504E-09 & $9,32603 \mathrm{E}-09$ & $1,90027 \mathrm{E}-08$ & $3,2728 \mathrm{E}-09$ & $1,18456 \mathrm{E}-08$ & $2,3286 \mathrm{E}-08$ & $6,34415 \mathrm{E}-09$ \\
\hline Instrumento hospitalar & $5,14505 \mathrm{E}-10$ & $5,66861 \mathrm{E}-10$ & $2,54092 \mathrm{E}-09$ & $7,49376 \mathrm{E}-10$ & $9,9659 \mathrm{E}-10$ & $1,06545 \mathrm{E}-09$ & $5,8449 \mathrm{E}-09$ & 1,13941E-09 & $6,18819 \mathrm{E}-09$ & $1,19034 \mathrm{E}-08$ & $9,15001 \mathrm{E}-10$ \\
\hline Veículos & $1,2878 \mathrm{E}-08$ & $1,05382 \mathrm{E}-08$ & $7,62675 \mathrm{E}-08$ & $2,44696 \mathrm{E}-08$ & $1,31526 \mathrm{E}-08$ & $3,17228 \mathrm{E}-08$ & $6,18989 \mathrm{E}-08$ & 4,04273E-09 & $2,91684 \mathrm{E}-08$ & 6,40964E-08 & $1,15621 \mathrm{E}-08$ \\
\hline Indústria Diversa & $1,6078 \mathrm{E}-09$ & $1,49039 \mathrm{E}-08$ & 4,34004E-09 & $1,00989 \mathrm{E}-08$ & $1,5865 \mathrm{E}-07$ & 4,67936E-09 & $8,59615 \mathrm{E}-08$ & $1,8706 \mathrm{E}-09$ & 4,27296E-09 & $3,05335 \mathrm{E}-08$ & 4,08343E-09 \\
\hline SIUP & $1,81312 \mathrm{E}-08$ & $2,79846 \mathrm{E}-08$ & $7,27569 \mathrm{E}-08$ & $4,48168 \mathrm{E}-08$ & $3,66748 \mathrm{E}-08$ & $3,80985 \mathrm{E}-08$ & $1,12508 \mathrm{E}-07$ & $2,98493 \mathrm{E}-08$ & $5,43479 \mathrm{E}-08$ & $5,62004 \mathrm{E}-08$ & $1,48215 \mathrm{E}-07$ \\
\hline Construção & $3,1681 \mathrm{E}-10$ & $4,50046 \mathrm{E}-10$ & $8,14373 \mathrm{E}-10$ & $1,04498 \mathrm{E}-09$ & $9,38731 \mathrm{E}-10$ & $8,29225 \mathrm{E}-10$ & $1,49293 \mathrm{E}-09$ & $1,18175 \mathrm{E}-09$ & $1,67261 \mathrm{E}-09$ & 2,71645E-09 & $3,70474 \mathrm{E}-09$ \\
\hline Comércio & $4,41289 \mathrm{E}-08$ & $6,51186 \mathrm{E}-08$ & $3,8811 \mathrm{E}-08$ & $6,98245 \mathrm{E}-08$ & $7,33435 \mathrm{E}-08$ & $2,99531 \mathrm{E}-08$ & 3,83194E-08 & $3,96828 \mathrm{E}-08$ & $5,44553 \mathrm{E}-08$ & 4,24404E-08 & $6,81014 \mathrm{E}-08$ \\
\hline Transportes & $4,86929 \mathrm{E}-08$ & $4,4305 \mathrm{E}-08$ & $1,30156 \mathrm{E}-07$ & $8,30488 \mathrm{E}-08$ & $3,86 \mathrm{E}-08$ & $4,17922 \mathrm{E}-08$ & $7,07984 \mathrm{E}-08$ & $4,07023 \mathrm{E}-08$ & 7,69872E-08 & $5,03428 \mathrm{E}-08$ & $1,56039 \mathrm{E}-07$ \\
\hline Informação & $5,98998 \mathrm{E}-09$ & $9,28596 \mathrm{E}-09$ & $2,73269 \mathrm{E}-08$ & $1,16697 \mathrm{E}-08$ & 6,68684E-09 & 4,94685E-09 & $1,14207 \mathrm{E}-08$ & $2,74782 \mathrm{E}-08$ & $3,53817 \mathrm{E}-08$ & $1,57787 \mathrm{E}-08$ & $2,14126 \mathrm{E}-08$ \\
\hline
\end{tabular}




\begin{tabular}{|c|c|c|c|c|c|c|c|c|c|c|c|}
\hline Financeiro & $1,37627 \mathrm{E}-08$ & $1,52608 \mathrm{E}-08$ & $3,0839 \mathrm{E}-08$ & $2,62626 \mathrm{E}-08$ & $2,09997 \mathrm{E}-08$ & $1,94671 \mathrm{E}-08$ & $4,246 \mathrm{E}-08$ & $2,40828 \mathrm{E}-08$ & 4,18114E-08 & $3,03697 \mathrm{E}-08$ & $4,88359 \mathrm{E}-08$ \\
\hline Imobiliário & $3,6832 \mathrm{E}-09$ & 4,71694E-09 & $1,11745 \mathrm{E}-08$ & $9,42641 \mathrm{E}-09$ & $1,05023 \mathrm{E}-08$ & 4,20326E-09 & $9,28639 \mathrm{E}-09$ & $1,46322 \mathrm{E}-08$ & $1,25266 \mathrm{E}-08$ & $7,81024 \mathrm{E}-09$ & $1,36097 \mathrm{E}-08$ \\
\hline Alojamento & $5,13081 \mathrm{E}-10$ & $7,23694 \mathrm{E}-10$ & 4,67764E-09 & $1,27315 \mathrm{E}-09$ & $7,4234 \mathrm{E}-10$ & $1,48909 \mathrm{E}-09$ & $1,51756 \mathrm{E}-09$ & 2,01172E-09 & $1,68605 \mathrm{E}-09$ & $1,49768 \mathrm{E}-09$ & $8,23223 \mathrm{E}-09$ \\
\hline Serviços às Empresas & 7,47417E-09 & $1,07452 \mathrm{E}-08$ & $2,07181 \mathrm{E}-08$ & $2,52848 \mathrm{E}-08$ & $1,65894 \mathrm{E}-08$ & $8,82128 \mathrm{E}-09$ & 2,13934E-08 & $5,82974 \mathrm{E}-08$ & $6,59267 \mathrm{E}-08$ & $1,784 \mathrm{E}-08$ & $4,14106 \mathrm{E}-08$ \\
\hline Educação e Saúde mercantis & $9,34674 \mathrm{E}-10$ & $1,29229 \mathrm{E}-09$ & 1,90177E-09 & $1,94792 \mathrm{E}-09$ & $2,37822 \mathrm{E}-09$ & $8,73299 \mathrm{E}-10$ & 1,70971E-09 & 2,08456E-09 & 2,09434E-09 & $1,49892 \mathrm{E}-09$ & 2,15951E-09 \\
\hline Outros Serviços & 3,28994E-09 & 4,76787E-09 & 4,96722E-09 & 6,28976E-09 & $6,76145 \mathrm{E}-09$ & 2,49276E-09 & 4,13333E-09 & $4,85879 \mathrm{E}-09$ & 6,70024E-09 & 4,89238E-09 & $7,80409 \mathrm{E}-09$ \\
\hline APU & $8,93257 \mathrm{E}-11$ & $1,06576 \mathrm{E}-10$ & $2,13962 \mathrm{E}-10$ & $1,97588 \mathrm{E}-10$ & $1,24527 \mathrm{E}-10$ & $8,40303 \mathrm{E}-11$ & $2,04011 \mathrm{E}-10$ & $3,77574 \mathrm{E}-10$ & $3,41541 \mathrm{E}-10$ & $1,44887 \mathrm{E}-10$ & $3,26271 \mathrm{E}-10$ \\
\hline
\end{tabular}

Tabela C3 - Matriz Geração de Renda para o Grau de Instrução G(2), Distrito Federal - 2008.

(2)

\begin{tabular}{|c|c|c|c|c|c|c|c|c|c|c|}
\hline Setores & Aço & Metal & Eletrodomésticos & Informática & Máquinas & Eletrônicos & $\begin{array}{l}\text { Instrumento } \\
\text { hospitalar }\end{array}$ & Veículos & $\begin{array}{l}\text { Indústria } \\
\text { Diversa }\end{array}$ & SIUP \\
\hline Agricultura & $1,11625 \mathrm{E}-09$ & $6,1545 \mathrm{E}-10$ & 2,20982E-09 & $2,10515 \mathrm{E}-09$ & $1,25548 \mathrm{E}-09$ & $2,87415 \mathrm{E}-09$ & $7,63664 \mathrm{E}-10$ & $4,38468 \mathrm{E}-09$ & 1,71571E-09 & 3,10987E-10 \\
\hline Pecuária & $4,07718 \mathrm{E}-10$ & $2,01404 \mathrm{E}-10$ & $4,97819 \mathrm{E}-10$ & $5,38473 \mathrm{E}-10$ & $4,27041 \mathrm{E}-10$ & $5,58741 \mathrm{E}-10$ & $2,30267 \mathrm{E}-10$ & $8,91294 \mathrm{E}-10$ & 4,77434E-09 & $1,30952 \mathrm{E}-10$ \\
\hline Extrativa & $7,60257 \mathrm{E}-06$ & $4,49162 \mathrm{E}-07$ & $1,42546 \mathrm{E}-06$ & $1,08648 \mathrm{E}-07$ & $4,32255 \mathrm{E}-07$ & $2,42921 \mathrm{E}-07$ & $4,04758 \mathrm{E}-08$ & $8,13082 \mathrm{E}-07$ & 2,49243E-07 & 3,81549E-09 \\
\hline Alimentos & $1,20261 \mathrm{E}-09$ & $5,65407 \mathrm{E}-10$ & $1,17047 \mathrm{E}-09$ & 1,30944E-09 & $1,17926 \mathrm{E}-09$ & $1,28093 \mathrm{E}-09$ & $6,2099 \mathrm{E}-10$ & $1,58369 \mathrm{E}-09$ & $1,12662 \mathrm{E}-09$ & $3,77505 \mathrm{E}-10$ \\
\hline Vestuário & $9,16756 \mathrm{E}-09$ & $1,4029 \mathrm{E}-08$ & 7,69991E-08 & $1,07089 \mathrm{E}-08$ & 8,99416E-09 & $1,2193 \mathrm{E}-08$ & $1,35727 \mathrm{E}-08$ & $6,60487 \mathrm{E}-08$ & $9,27098 \mathrm{E}-09$ & $9,28197 \mathrm{E}-09$ \\
\hline Madeira & $3,6315 \mathrm{E}-08$ & $5,36383 \mathrm{E}-08$ & $1,07021 \mathrm{E}-06$ & $9,84565 \mathrm{E}-07$ & $4,73267 \mathrm{E}-08$ & 4,3789E-06 & $1,29523 \mathrm{E}-08$ & $6,70829 \mathrm{E}-07$ & 1,4461E-06 & $1,75282 \mathrm{E}-09$ \\
\hline Celulose & $1,54606 \mathrm{E}-07$ & $3,73579 \mathrm{E}-08$ & $2,85096 \mathrm{E}-06$ & $1,54153 \mathrm{E}-06$ & $2,78191 \mathrm{E}-07$ & $3,04348 \mathrm{E}-06$ & $6,50977 \mathrm{E}-08$ & $1,55915 \mathrm{E}-06$ & $1,50001 \mathrm{E}-07$ & $1,30908 \mathrm{E}-08$ \\
\hline Revistas & $4,43623 \mathrm{E}-08$ & $4,36551 \mathrm{E}-08$ & $2,67363 \mathrm{E}-08$ & $5,04609 \mathrm{E}-08$ & $2,27801 \mathrm{E}-08$ & 4,2367E-08 & $2,09355 \mathrm{E}-07$ & 4,98077E-08 & $1,48827 \mathrm{E}-08$ & $6,24046 \mathrm{E}-08$ \\
\hline Químicos & $1,10344 \mathrm{E}-06$ & $1,92365 \mathrm{E}-07$ & $1,01857 \mathrm{E}-06$ & 7,30793E-08 & 3,20563E-07 & $1,28857 \mathrm{E}-07$ & $2,43108 \mathrm{E}-07$ & $6,70561 \mathrm{E}-07$ & 1,19301E-07 & $8,06834 \mathrm{E}-08$ \\
\hline Borracha & $8,5608 \mathrm{E}-07$ & 4,90729E-07 & 2,34087E-06 & $2,08568 \mathrm{E}-06$ & $1,07595 \mathrm{E}-06$ & $2,42068 \mathrm{E}-06$ & $6,74485 \mathrm{E}-07$ & $5,60785 \mathrm{E}-06$ & $8,87532 \mathrm{E}-07$ & $2,12339 \mathrm{E}-08$ \\
\hline Cimento & $7,4824 \mathrm{E}-08$ & $2,23311 \mathrm{E}-08$ & $2,90234 \mathrm{E}-08$ & $1,52839 \mathrm{E}-08$ & 7,19016E-08 & $5,60314 \mathrm{E}-08$ & $2,63386 \mathrm{E}-08$ & $6,47279 \mathrm{E}-08$ & $1,50495 \mathrm{E}-07$ & $7,25068 \mathrm{E}-10$ \\
\hline Aço & $9,43593 \mathrm{E}-05$ & 7,70087E-07 & $1,41022 \mathrm{E}-05$ & $1,02122 \mathrm{E}-06$ & $2,78008 \mathrm{E}-06$ & $2,45646 \mathrm{E}-06$ & $2,80923 \mathrm{E}-07$ & 7,76336E-06 & 2,86414E-07 & $8,92815 \mathrm{E}-09$ \\
\hline Metal & $1,10674 \mathrm{E}-06$ & $2,84117 \mathrm{E}-05$ & $1,78164 \mathrm{E}-06$ & $6,68296 \mathrm{E}-07$ & $1,23814 \mathrm{E}-06$ & $1,10255 \mathrm{E}-06$ & $7,58915 \mathrm{E}-07$ & 7,94904E-07 & $6,11051 \mathrm{E}-07$ & $3,10685 \mathrm{E}-09$ \\
\hline Eletrodomésticos & $1,46004 \mathrm{E}-06$ & $1,6778 \mathrm{E}-07$ & 0,000561093 & $1,55545 \mathrm{E}-06$ & 7,17884E-07 & $1,04959 \mathrm{E}-06$ & $3,12657 \mathrm{E}-07$ & $6,57565 \mathrm{E}-06$ & $1,08844 \mathrm{E}-07$ & $1,75918 \mathrm{E}-08$ \\
\hline Informática & 0 & 0 & 0 & 0 & 0 & 0 & 0 & 0 & 0 & 0 \\
\hline Máquinas & $2,56232 \mathrm{E}-07$ & 7,00581E-08 & $5,29073 \mathrm{E}-06$ & $1,26615 \mathrm{E}-05$ & 0,000207076 & $2,32678 \mathrm{E}-05$ & $1,54333 \mathrm{E}-06$ & 3,45954E-06 & $5,16939 \mathrm{E}-07$ & $3,92945 \mathrm{E}-07$ \\
\hline
\end{tabular}




\begin{tabular}{|c|c|c|c|c|c|c|c|c|c|c|}
\hline Eletrônicos & $2,70408 \mathrm{E}-08$ & $1,62158 \mathrm{E}-08$ & $6,82528 \mathrm{E}-07$ & $7,9846 \mathrm{E}-05$ & $6,6569 \mathrm{E}-07$ & 0,000393529 & 7,89697E-08 & $6,34746 \mathrm{E}-07$ & $3,30653 \mathrm{E}-08$ & $1,28351 \mathrm{E}-08$ \\
\hline Instrumento hospitalar & $1,81547 \mathrm{E}-09$ & $9,9805 \mathrm{E}-10$ & $2,75308 \mathrm{E}-07$ & $3,59939 \mathrm{E}-08$ & $1,06908 \mathrm{E}-07$ & $5,02206 \mathrm{E}-08$ & $8,63692 \mathrm{E}-05$ & $4,59546 \mathrm{E}-08$ & $4,7236 \mathrm{E}-09$ & $1,04349 \mathrm{E}-09$ \\
\hline Veículos & $1,74814 \mathrm{E}-07$ & $1,1044 \mathrm{E}-07$ & $7,88506 \mathrm{E}-07$ & $5,57033 \mathrm{E}-07$ & 6,36361E-07 & $1,01081 \mathrm{E}-06$ & $1,33963 \mathrm{E}-07$ & 0,000278643 & $7,97152 \mathrm{E}-08$ & $1,70013 \mathrm{E}-08$ \\
\hline Indústria Diversa & $2,04085 \mathrm{E}-07$ & $1,5037 \mathrm{E}-08$ & 4,74331E-08 & $8,97715 \mathrm{E}-09$ & $2,75419 \mathrm{E}-08$ & $1,46082 \mathrm{E}-08$ & 3,89219E-09 & $2,45038 \mathrm{E}-08$ & $5,11382 \mathrm{E}-05$ & $1,27496 \mathrm{E}-09$ \\
\hline SIUP & $1,3169 \mathrm{E}-07$ & $6,42186 \mathrm{E}-08$ & $6,39238 \mathrm{E}-08$ & $4,28034 \mathrm{E}-08$ & 7,50473E-08 & $5,2301 \mathrm{E}-08$ & $5,4696 \mathrm{E}-08$ & $5,60399 \mathrm{E}-08$ & 3,99033E-08 & $5,96226 \mathrm{E}-06$ \\
\hline Construção & $1,1542 \mathrm{E}-09$ & $7,756 \mathrm{E}-10$ & $1,56883 \mathrm{E}-09$ & 2,30952E-09 & 3,18991E-09 & 4,82014E-09 & $7,31294 \mathrm{E}-10$ & $5,11199 \mathrm{E}-09$ & $9,37278 \mathrm{E}-10$ & $7,24509 \mathrm{E}-10$ \\
\hline Comércio & $3,62825 \mathrm{E}-08$ & $3,17775 \mathrm{E}-08$ & $5,33848 \mathrm{E}-08$ & $1,20175 \mathrm{E}-07$ & $4,75939 \mathrm{E}-08$ & $8,97622 \mathrm{E}-08$ & $4,79402 \mathrm{E}-08$ & 6,83872E-08 & $5,55194 \mathrm{E}-08$ & $1,51533 \mathrm{E}-08$ \\
\hline Transportes & $1,04673 \mathrm{E}-07$ & $6,00655 \mathrm{E}-08$ & $8,26542 \mathrm{E}-08$ & $9,27015 \mathrm{E}-08$ & $7,9078 \mathrm{E}-08$ & $1,15082 \mathrm{E}-07$ & $6,27935 \mathrm{E}-08$ & $7,24498 \mathrm{E}-08$ & $3,89166 \mathrm{E}-08$ & $3,18002 \mathrm{E}-08$ \\
\hline Informação & 2,79327E-08 & $1,24231 \mathrm{E}-08$ & $3,12461 \mathrm{E}-08$ & 4,49193E-08 & 3,83356E-08 & $6,60896 \mathrm{E}-08$ & $2,02439 \mathrm{E}-08$ & $2,49874 \mathrm{E}-08$ & $6,7878 \mathrm{E}-09$ & $2,36369 \mathrm{E}-08$ \\
\hline Financeiro & $5,32017 \mathrm{E}-08$ & $3,13428 \mathrm{E}-08$ & 6,77796E-08 & $4,73378 \mathrm{E}-08$ & $4,84246 \mathrm{E}-08$ & $8,34141 \mathrm{E}-08$ & $3,36643 \mathrm{E}-08$ & 4,64941E-08 & $1,99235 \mathrm{E}-08$ & $1,79161 \mathrm{E}-08$ \\
\hline Imobiliário & $8,82489 \mathrm{E}-09$ & $7,48846 \mathrm{E}-09$ & $1,16687 \mathrm{E}-08$ & $1,25123 \mathrm{E}-08$ & $9,25705 \mathrm{E}-09$ & $1,23776 \mathrm{E}-08$ & $1,08889 \mathrm{E}-08$ & $8,14563 \mathrm{E}-09$ & 7,10192E-09 & $6,39004 \mathrm{E}-09$ \\
\hline Alojamento & 2,17981E-09 & $8,30835 \mathrm{E}-10$ & 1,20023E-09 & $1,73563 \mathrm{E}-09$ & 2,57544E-09 & $1,73415 \mathrm{E}-09$ & $7,46291 \mathrm{E}-10$ & $2,30262 \mathrm{E}-09$ & $1,55088 \mathrm{E}-09$ & $6,37425 \mathrm{E}-10$ \\
\hline Serviços às Empresas & $1,73344 \mathrm{E}-08$ & $1,68921 \mathrm{E}-08$ & $2,02452 \mathrm{E}-08$ & $9,05614 \mathrm{E}-08$ & $2,88682 \mathrm{E}-08$ & $6,38297 \mathrm{E}-08$ & $2,31828 \mathrm{E}-08$ & 3,87715E-08 & $1,3338 \mathrm{E}-08$ & $4,92383 \mathrm{E}-08$ \\
\hline Educação e Saúde mercantis & $1,41932 \mathrm{E}-09$ & $1,43411 \mathrm{E}-09$ & $2,10589 \mathrm{E}-09$ & 2,93429E-09 & $1,80412 \mathrm{E}-09$ & 2,69521E-09 & $1,79426 \mathrm{E}-09$ & $1,81906 \mathrm{E}-09$ & $1,64659 \mathrm{E}-09$ & $1,12919 \mathrm{E}-09$ \\
\hline Outros Serviços & 4,61409E-09 & 4,19843E-09 & 6,16549E-09 & $1,21116 \mathrm{E}-08$ & 8,80193E-09 & $1,11686 \mathrm{E}-08$ & 5,00944E-09 & $6,52202 \mathrm{E}-09$ & $5,1428 \mathrm{E}-09$ & $4,90621 \mathrm{E}-09$ \\
\hline APU & $2,07742 \mathrm{E}-10$ & $1,42832 \mathrm{E}-10$ & $1,68048 \mathrm{E}-10$ & $4,31841 \mathrm{E}-10$ & $1,86961 \mathrm{E}-10$ & 3,43072E-10 & $1,66346 \mathrm{E}-10$ & $2,31892 \mathrm{E}-10$ & $1,07301 \mathrm{E}-10$ & $3,85464 \mathrm{E}-10$ \\
\hline
\end{tabular}

Tabela C3 - Matriz Geração de Renda para o Grau de Instrução G(2), Distrito Federal - 2008.

(3)

\begin{tabular}{|c|c|c|c|c|c|c|c|c|c|c|c|}
\hline Setores & Construção & Comércio & Transportes & Informação & Financeiro & Imobiliário & Alojamento & $\begin{array}{c}\text { Serviços às } \\
\text { Empresas }\end{array}$ & $\begin{array}{l}\text { Educação e } \\
\text { Saúde } \\
\text { mercantis }\end{array}$ & $\begin{array}{c}\text { Outros } \\
\text { Serviços }\end{array}$ & APU \\
\hline Agricultura & $8,92312 \mathrm{E}-10$ & 2,76845E-09 & 2,09416E-09 & $1,2703 \mathrm{E}-09$ & $8,22544 \mathrm{E}-10$ & $1,74332 \mathrm{E}-10$ & $2,7851 \mathrm{E}-07$ & $1,26125 \mathrm{E}-09$ & $6,63979 \mathrm{E}-09$ & $2,86833 \mathrm{E}-08$ & $3,5449 \mathrm{E}-09$ \\
\hline Pecuária & $3,93683 \mathrm{E}-10$ & $1,15698 \mathrm{E}-09$ & $1,03012 \mathrm{E}-09$ & $5,09871 \mathrm{E}-10$ & $3,90335 \mathrm{E}-10$ & $6,60062 \mathrm{E}-11$ & $1,52371 \mathrm{E}-07$ & $5,09861 \mathrm{E}-10$ & $3,39125 \mathrm{E}-09$ & $1,65563 \mathrm{E}-08$ & $1,58823 \mathrm{E}-09$ \\
\hline Extrativa & $1,98429 \mathrm{E}-08$ & $1,03438 \mathrm{E}-08$ & 6,37466E-09 & $1,19787 \mathrm{E}-08$ & $3,5749 \mathrm{E}-09$ & $1,97952 \mathrm{E}-09$ & $9,40529 \mathrm{E}-09$ & $9,55841 \mathrm{E}-09$ & $9,40481 \mathrm{E}-09$ & $8,87501 \mathrm{E}-09$ & $9,74541 \mathrm{E}-09$ \\
\hline Alimentos & $1,47945 \mathrm{E}-09$ & 4,59703E-09 & 4,06044E-09 & $1,60905 \mathrm{E}-09$ & $1,32293 \mathrm{E}-09$ & $2,22931 \mathrm{E}-10$ & $5,79121 \mathrm{E}-07$ & $1,54333 \mathrm{E}-09$ & $9,40056 \mathrm{E}-09$ & $2,15393 \mathrm{E}-08$ & 4,29381E-09 \\
\hline Vestuário & 5,76184E-09 & $1,29126 \mathrm{E}-08$ & $2,70739 \mathrm{E}-08$ & $1,26074 \mathrm{E}-08$ & $1,03171 \mathrm{E}-08$ & $1,36517 \mathrm{E}-09$ & $1,498 \mathrm{E}-08$ & $3,69186 \mathrm{E}-08$ & $2,38003 \mathrm{E}-08$ & $5,32286 \mathrm{E}-08$ & $1,03692 \mathrm{E}-08$ \\
\hline Madeira & $1,6437 \mathrm{E}-08$ & 5,8321E-09 & $3,91196 \mathrm{E}-09$ & $7,74049 \mathrm{E}-09$ & $4,37632 \mathrm{E}-09$ & $5,7164 \mathrm{E}-09$ & $4,77268 \mathrm{E}-09$ & $6,4376 \mathrm{E}-09$ & 8,54791E-09 & $9,02161 \mathrm{E}-09$ & $1,29037 \mathrm{E}-08$ \\
\hline
\end{tabular}




\begin{tabular}{|c|c|c|c|c|c|c|c|c|c|c|c|}
\hline Celulose & $9,4803 \mathrm{E}-09$ & $3,80221 \mathrm{E}-08$ & $2,40349 \mathrm{E}-08$ & 4,83897E-08 & $1,63871 \mathrm{E}-08$ & 6,37783E-09 & $2,38117 \mathrm{E}-08$ & $6,32877 \mathrm{E}-08$ & $3,38748 \mathrm{E}-08$ & $3,19672 \mathrm{E}-08$ & $3,18477 \mathrm{E}-08$ \\
\hline Revistas & $1,65919 \mathrm{E}-08$ & $5,97307 \mathrm{E}-08$ & $5,03395 \mathrm{E}-08$ & $1,39499 \mathrm{E}-07$ & $7,22323 \mathrm{E}-08$ & $1,56995 \mathrm{E}-08$ & $1,65296 \mathrm{E}-08$ & 4,43403E-07 & $7,23828 \mathrm{E}-08$ & 7,66311E-08 & 4,21176E-08 \\
\hline Químicos & $1,09207 \mathrm{E}-08$ & $5,78065 \mathrm{E}-09$ & 4,08304E-09 & $1,06367 \mathrm{E}-08$ & $2,4298 \mathrm{E}-09$ & $1,58336 \mathrm{E}-09$ & 7,93097E-08 & 6,6113E-09 & $7,59431 \mathrm{E}-08$ & $1,48941 \mathrm{E}-08$ & $1,14824 \mathrm{E}-08$ \\
\hline Borracha & $8,80405 \mathrm{E}-08$ & 3,5101E-08 & 2,95314E-08 & $7,21164 \mathrm{E}-08$ & $1,1536 \mathrm{E}-08$ & 6,58311E-09 & $4,78979 \mathrm{E}-08$ & $1,04511 \mathrm{E}-07$ & $9,12807 \mathrm{E}-08$ & $2,91252 \mathrm{E}-08$ & $1,3862 \mathrm{E}-08$ \\
\hline Cimento & $3,05123 \mathrm{E}-07$ & 1,09219E-09 & $4,69183 \mathrm{E}-10$ & $1,35175 \mathrm{E}-09$ & $1,26392 \mathrm{E}-09$ & 2,69845E-09 & 2,12914E-09 & $1,01555 \mathrm{E}-09$ & $1,00719 \mathrm{E}-08$ & $5,31008 \mathrm{E}-09$ & $5,04178 \mathrm{E}-09$ \\
\hline Aço & $2,62464 \mathrm{E}-08$ & $3,84815 \mathrm{E}-09$ & $3,01454 \mathrm{E}-09$ & $5,27646 \mathrm{E}-09$ & $1,51344 \mathrm{E}-09$ & $1,41642 \mathrm{E}-09$ & $7,12448 \mathrm{E}-09$ & $3,69209 \mathrm{E}-09$ & 4,45912E-09 & 4,9874E-09 & 3,57059E-09 \\
\hline Metal & 7,637E-08 & 7,37293E-09 & $1,73021 \mathrm{E}-09$ & 4,02294E-09 & 1,17978E-09 & $2,88478 \mathrm{E}-09$ & $3,26225 \mathrm{E}-08$ & $2,05285 \mathrm{E}-09$ & 7,73505E-09 & 4,91801E-09 & $5,13269 \mathrm{E}-09$ \\
\hline Eletrodomésticos & $2,18277 \mathrm{E}-08$ & $2,08978 \mathrm{E}-08$ & $1,42209 \mathrm{E}-08$ & $2,63435 \mathrm{E}-08$ & 7,3239E-09 & $5,501 \mathrm{E}-09$ & $1,67887 \mathrm{E}-08$ & $2,06083 \mathrm{E}-08$ & $1,95331 \mathrm{E}-08$ & $1,97555 \mathrm{E}-08$ & $2,00052 \mathrm{E}-08$ \\
\hline Informática & 0 & 0 & 0 & 0 & 0 & 0 & 0 & 0 & 0 & 0 & 0 \\
\hline Máquinas & $1,07867 \mathrm{E}-07$ & 2,27499E-08 & 6,69549E-08 & $9,75853 \mathrm{E}-08$ & $1,21763 \mathrm{E}-08$ & $2,64584 \mathrm{E}-08$ & $1,80565 \mathrm{E}-08$ & 3,39716E-08 & $3,02361 \mathrm{E}-08$ & $1,07646 \mathrm{E}-07$ & $1,91673 \mathrm{E}-08$ \\
\hline Eletrônicos & 4,7075E-09 & $3,11812 \mathrm{E}-09$ & $3,88269 \mathrm{E}-09$ & 6,60379E-09 & $1,45957 \mathrm{E}-09$ & $1,81115 \mathrm{E}-09$ & $2,26859 \mathrm{E}-09$ & 4,43346E-09 & $3,04056 \mathrm{E}-09$ & $5,54494 \mathrm{E}-09$ & 2,88698E-09 \\
\hline Instrumento hospitalar & $5,84782 \mathrm{E}-09$ & 3,53402E-09 & $1,12079 \mathrm{E}-09$ & $1,45721 \mathrm{E}-09$ & $8,21183 \mathrm{E}-10$ & 6,66174E-09 & $7,12953 \mathrm{E}-10$ & $9,48285 \mathrm{E}-09$ & $9,84355 \mathrm{E}-09$ & 7,49949E-09 & 2,03963E-09 \\
\hline Veículos & $1,35935 \mathrm{E}-08$ & 7,5336E-09 & $6,5982 \mathrm{E}-09$ & $1,14192 \mathrm{E}-08$ & 2,98607E-09 & 2,86882E-09 & $7,05411 \mathrm{E}-09$ & $7,6783 \mathrm{E}-09$ & 7,46786E-09 & $9,98241 \mathrm{E}-09$ & 7,48981E-09 \\
\hline Indústria Diversa & $1,68209 \mathrm{E}-08$ & 2,29234E-09 & $1,4416 \mathrm{E}-08$ & 2,82877E-09 & $2,54766 \mathrm{E}-08$ & 6,37014E-09 & 2,81395E-09 & $9,31854 \mathrm{E}-09$ & $9,23293 \mathrm{E}-09$ & $4,65848 \mathrm{E}-08$ & $1,01773 \mathrm{E}-08$ \\
\hline SIUP & $1,30288 \mathrm{E}-08$ & 4,46417E-08 & $3,70188 \mathrm{E}-08$ & $3,47881 \mathrm{E}-08$ & $2,0993 \mathrm{E}-08$ & $4,4219 \mathrm{E}-09$ & $4,51276 \mathrm{E}-08$ & 3,91774E-08 & $5,76837 \mathrm{E}-08$ & $1,29786 \mathrm{E}-07$ & $4,9684 \mathrm{E}-08$ \\
\hline Construção & $1,7281 \mathrm{E}-06$ & 1,9776E-09 & $1,53729 \mathrm{E}-09$ & $6,29754 \mathrm{E}-09$ & $6,23062 \mathrm{E}-09$ & $1,48959 \mathrm{E}-08$ & $1,05841 \mathrm{E}-09$ & 4,43779E-09 & $1,33021 \mathrm{E}-08$ & $1,14832 \mathrm{E}-08$ & $2,59763 \mathrm{E}-08$ \\
\hline Comércio & 4,97264E-08 & $9,34008 \mathrm{E}-07$ & 4,14131E-08 & $2,05778 \mathrm{E}-08$ & $1,23023 \mathrm{E}-08$ & 5,42937E-09 & $9,53317 \mathrm{E}-08$ & $3,56735 \mathrm{E}-08$ & $3,17442 \mathrm{E}-08$ & $3,43233 \mathrm{E}-08$ & $1,8191 \mathrm{E}-08$ \\
\hline Transportes & 2,97771E-08 & $7,83456 \mathrm{E}-08$ & 2,39293E-06 & $5,31464 \mathrm{E}-08$ & $2,23479 \mathrm{E}-08$ & 3,97498E-09 & $3,58615 \mathrm{E}-08$ & $4,22209 \mathrm{E}-08$ & 3,7939E-08 & $5,60787 \mathrm{E}-08$ & $2,03685 \mathrm{E}-08$ \\
\hline Informação & 7,73639E-09 & $2,43836 \mathrm{E}-08$ & $2,54929 \mathrm{E}-08$ & $1,82527 \mathrm{E}-06$ & $7,43761 \mathrm{E}-08$ & $5,0286 \mathrm{E}-09$ & $1,21807 \mathrm{E}-08$ & $1,97701 \mathrm{E}-07$ & $6,79872 \mathrm{E}-08$ & $4,45215 \mathrm{E}-08$ & $8,24294 \mathrm{E}-08$ \\
\hline Financeiro & $1,44261 \mathrm{E}-08$ & $2,86332 \mathrm{E}-08$ & $3,95928 \mathrm{E}-08$ & $4,0305 \mathrm{E}-08$ & $1,14325 \mathrm{E}-06$ & $5,82468 \mathrm{E}-09$ & $1,4892 \mathrm{E}-08$ & $3,81464 \mathrm{E}-08$ & $1,6842 \mathrm{E}-08$ & $9,37402 \mathrm{E}-09$ & $8,92078 \mathrm{E}-08$ \\
\hline Imobiliário & $5,26093 \mathrm{E}-09$ & $2,64845 \mathrm{E}-08$ & $4,71985 \mathrm{E}-08$ & $4,27594 \mathrm{E}-08$ & $1,35629 \mathrm{E}-08$ & $1,2575 \mathrm{E}-06$ & $1,62972 \mathrm{E}-08$ & $3,08664 \mathrm{E}-08$ & $3,21084 \mathrm{E}-08$ & $2,30087 \mathrm{E}-08$ & $2,42851 \mathrm{E}-08$ \\
\hline Alojamento & $2,17772 \mathrm{E}-09$ & 3,02631E-09 & $5,8924 \mathrm{E}-09$ & $3,97368 \mathrm{E}-09$ & $3,82168 \mathrm{E}-09$ & $4,21684 \mathrm{E}-10$ & $2,33762 \mathrm{E}-06$ & $3,42826 \mathrm{E}-09$ & $1,8174 \mathrm{E}-08$ & $2,07411 \mathrm{E}-08$ & $1,12338 \mathrm{E}-08$ \\
\hline Serviços às Empresas & $1,99902 \mathrm{E}-08$ & $5,57576 \mathrm{E}-08$ & $6,40714 \mathrm{E}-08$ & $9,1318 \mathrm{E}-08$ & $6,90663 \mathrm{E}-08$ & $1,07934 \mathrm{E}-08$ & $1,76592 \mathrm{E}-08$ & $1,10204 \mathrm{E}-06$ & $9,19257 \mathrm{E}-08$ & $5,84965 \mathrm{E}-08$ & 6,49581E-08 \\
\hline Educação e Saúde mercantis & $1,26201 \mathrm{E}-09$ & 4,49693E-09 & 2,98019E-09 & $5,02132 \mathrm{E}-09$ & $5,17818 \mathrm{E}-09$ & $6,48515 \mathrm{E}-10$ & $3,58527 \mathrm{E}-09$ & $4,27468 \mathrm{E}-09$ & $2,26476 \mathrm{E}-06$ & $3,42641 \mathrm{E}-09$ & $7,06856 \mathrm{E}-09$ \\
\hline Outros Serviços & 4,58953E-09 & $1,21342 \mathrm{E}-08$ & 7,58654E-09 & $1,35224 \mathrm{E}-08$ & $6,94713 \mathrm{E}-09$ & $1,35483 \mathrm{E}-09$ & $1,32321 \mathrm{E}-08$ & $1,6156 \mathrm{E}-08$ & $1,19557 \mathrm{E}-08$ & $1,70165 \mathrm{E}-06$ & $8,56575 \mathrm{E}-09$ \\
\hline APU & $1,10181 \mathrm{E}-10$ & $2,9626 \mathrm{E}-10$ & $3,10797 \mathrm{E}-10$ & $3,99784 \mathrm{E}-10$ & $2,86189 \mathrm{E}-10$ & $4,73769 \mathrm{E}-11$ & $1,4025 \mathrm{E}-10$ & $3,55796 \mathrm{E}-10$ & $3,90504 \mathrm{E}-10$ & $3,01783 \mathrm{E}-10$ & $9,69554 \mathrm{E}-08$ \\
\hline
\end{tabular}


Tabela C4 - Matriz Geração de Renda para o Grau de Instrução G(3), Distrito Federal - 2008.

(1)

\begin{tabular}{|c|c|c|c|c|c|c|c|c|c|c|c|}
\hline Setores & Agricultura & Pecuária & Extrativa & Alimentos & Vestuário & Madeira & Celulose & Revistas & Químicos & Borracha & Cimento \\
\hline Agricultura & $1,74968 \mathrm{E}-05$ & $1,14794 \mathrm{E}-06$ & $1,90931 \mathrm{E}-09$ & $1,40967 \mathrm{E}-06$ & $1,76345 \mathrm{E}-08$ & $2,77204 \mathrm{E}-08$ & $8,00551 \mathrm{E}-08$ & $7,80906 \mathrm{E}-10$ & $3,51552 \mathrm{E}-09$ & $5,95785 \mathrm{E}-08$ & $1,36654 \mathrm{E}-09$ \\
\hline Pecuária & $1,11846 \mathrm{E}-07$ & $2,86068 \mathrm{E}-05$ & $8,40884 \mathrm{E}-10$ & $1,1316 \mathrm{E}-06$ & $2,3625 \mathrm{E}-08$ & $1,98354 \mathrm{E}-09$ & $6,51702 \mathrm{E}-09$ & $3,17628 \mathrm{E}-10$ & $2,06293 \mathrm{E}-09$ & $9,62684 \mathrm{E}-09$ & 7,84991E-10 \\
\hline Extrativa & $3,49478 \mathrm{E}-08$ & $8,28452 \mathrm{E}-08$ & 0,000481478 & $1,97095 \mathrm{E}-08$ & $1,81131 \mathrm{E}-08$ & $2,49368 \mathrm{E}-08$ & $1,92857 \mathrm{E}-07$ & 4,61562E-09 & $2,9312 \mathrm{E}-07$ & $6,2354 \mathrm{E}-08$ & $2,17842 \mathrm{E}-07$ \\
\hline Alimentos & $1,07384 \mathrm{E}-07$ & $1,63067 \mathrm{E}-06$ & $5,6329 \mathrm{E}-09$ & $9,83134 \mathrm{E}-06$ & 7,41799E-08 & 7,68065E-09 & $2,40094 \mathrm{E}-08$ & $2,08243 \mathrm{E}-09$ & 9,07116E-09 & $3,03654 \mathrm{E}-09$ & 5,50851E-09 \\
\hline Vestuário & $5,3969 \mathrm{E}-09$ & 4,7761E-09 & $1,59239 \mathrm{E}-07$ & 6,96103E-09 & 0,000285692 & 6,47339E-09 & $2,28652 \mathrm{E}-07$ & $7,32689 \mathrm{E}-09$ & $1,46014 \mathrm{E}-08$ & $4,27883 \mathrm{E}-08$ & $1,01198 \mathrm{E}-08$ \\
\hline Madeira & 4,62616E-08 & $9,06848 \mathrm{E}-09$ & $2,52204 \mathrm{E}-08$ & $1,08218 \mathrm{E}-08$ & $4,50362 \mathrm{E}-08$ & 0,000777078 & 4,68829E-06 & $7,76872 \mathrm{E}-09$ & $1,42102 \mathrm{E}-07$ & $3,85768 \mathrm{E}-08$ & $4,38358 \mathrm{E}-08$ \\
\hline Celulose & $1,57388 \mathrm{E}-08$ & $1,72186 \mathrm{E}-08$ & $4,11835 \mathrm{E}-07$ & $2,01158 \mathrm{E}-08$ & $9,571 \mathrm{E}-07$ & $1,57584 \mathrm{E}-06$ & 0,000643161 & 1,00473E-07 & $2,62592 \mathrm{E}-07$ & 7,60681E-07 & $1,33621 \mathrm{E}-08$ \\
\hline Revistas & $1,56629 \mathrm{E}-08$ & $1,74625 \mathrm{E}-08$ & $4,03744 \mathrm{E}-08$ & 2,88197E-08 & $1,52013 \mathrm{E}-08$ & $9,35966 \mathrm{E}-09$ & $1,73815 \mathrm{E}-07$ & 3,77497E-05 & $2,47759 \mathrm{E}-07$ & $9,74052 \mathrm{E}-08$ & $3,3181 \mathrm{E}-08$ \\
\hline Químicos & $3,24553 \mathrm{E}-06$ & $2,25738 \mathrm{E}-06$ & $7,54192 \mathrm{E}-07$ & $4,2231 \mathrm{E}-07$ & $2,32136 \mathrm{E}-07$ & $4,30312 \mathrm{E}-07$ & $1,95705 \mathrm{E}-06$ & $1,30484 \mathrm{E}-08$ & $8,39906 \mathrm{E}-05$ & $1,14071 \mathrm{E}-06$ & $1,06829 \mathrm{E}-07$ \\
\hline Borracha & $1,76618 \mathrm{E}-07$ & $1,13182 \mathrm{E}-07$ & $1,45353 \mathrm{E}-06$ & $3,13682 \mathrm{E}-07$ & $4,12814 \mathrm{E}-07$ & $7,68202 \mathrm{E}-07$ & $1,9158 \mathrm{E}-06$ & $2,41442 \mathrm{E}-07$ & $5,68758 \mathrm{E}-07$ & 0,000161345 & $1,93344 \mathrm{E}-08$ \\
\hline Cimento & $9,49034 \mathrm{E}-09$ & 4,84519E-09 & $1,11962 \mathrm{E}-08$ & $1,62161 \mathrm{E}-08$ & 4,26768E-09 & $1,85358 \mathrm{E}-09$ & $1,45006 \mathrm{E}-08$ & $1,52059 \mathrm{E}-09$ & $5,96517 \mathrm{E}-08$ & 4,44124E-09 & $9,43704 \mathrm{E}-06$ \\
\hline Aço & $1,51666 \mathrm{E}-07$ & 7,30912E-08 & $7,92982 \mathrm{E}-07$ & $8,34023 \mathrm{E}-08$ & 4,60406E-08 & $4,04763 \mathrm{E}-07$ & $8,01127 \mathrm{E}-07$ & $6,91835 \mathrm{E}-09$ & $2,10839 \mathrm{E}-07$ & $1,16389 \mathrm{E}-06$ & $8,11518 \mathrm{E}-08$ \\
\hline Metal & $1,35279 \mathrm{E}-07$ & $9,5323 \mathrm{E}-08$ & $4,38344 \mathrm{E}-07$ & $2,35302 \mathrm{E}-07$ & $3,77969 \mathrm{E}-08$ & $2,28514 \mathrm{E}-07$ & $4,08507 \mathrm{E}-07$ & $2,53522 \mathrm{E}-09$ & $1,98655 \mathrm{E}-07$ & $2,25751 \mathrm{E}-07$ & $3,56789 \mathrm{E}-08$ \\
\hline Eletrodomésticos & $2,94882 \mathrm{E}-08$ & $2,01212 \mathrm{E}-08$ & $1,19927 \mathrm{E}-06$ & $3,38261 \mathrm{E}-08$ & $3,08736 \mathrm{E}-07$ & $5,32036 \mathrm{E}-07$ & $2,27681 \mathrm{E}-06$ & $9,08678 \mathrm{E}-09$ & $1,69566 \mathrm{E}-07$ & $2,29653 \mathrm{E}-07$ & $1,77724 \mathrm{E}-08$ \\
\hline Informática & $1,49727 \mathrm{E}-09$ & $1,19123 \mathrm{E}-09$ & $1,01023 \mathrm{E}-08$ & $1,63983 \mathrm{E}-09$ & $8,48842 \mathrm{E}-09$ & 4,47497E-09 & $4,90348 \mathrm{E}-08$ & $6,15538 \mathrm{E}-09$ & $2,1734 \mathrm{E}-08$ & $2,30702 \mathrm{E}-08$ & $1,20645 \mathrm{E}-09$ \\
\hline Máquinas & $1,56376 \mathrm{E}-08$ & $2,84199 \mathrm{E}-08$ & 4,71431E-07 & $5,2866 \mathrm{E}-08$ & $5,27325 \mathrm{E}-08$ & $1,10604 \mathrm{E}-07$ & $1,09877 \mathrm{E}-07$ & $6,86614 \mathrm{E}-09$ & $1,32721 \mathrm{E}-07$ & 3,98164E-07 & $9,84005 \mathrm{E}-08$ \\
\hline Eletrônicos & $3,17062 \mathrm{E}-09$ & 3,59686E-09 & $3,62255 \mathrm{E}-07$ & 7,20847E-09 & $7,25986 \mathrm{E}-09$ & $1,18677 \mathrm{E}-08$ & $2,41816 \mathrm{E}-08$ & 4,16475E-09 & $1,50739 \mathrm{E}-08$ & $2,96322 \mathrm{E}-08$ & $8,07315 \mathrm{E}-09$ \\
\hline Instrumento hospitalar & $6,53315 \mathrm{E}-10$ & $7,19796 \mathrm{E}-10$ & $3,22644 \mathrm{E}-09$ & $9,51552 \mathrm{E}-10$ & $1,26546 \mathrm{E}-09$ & $1,35291 \mathrm{E}-09$ & $7,42181 \mathrm{E}-09$ & $1,44681 \mathrm{E}-09$ & 7,85772E-09 & $1,51149 \mathrm{E}-08$ & $1,16186 \mathrm{E}-09$ \\
\hline Veículos & $3,25253 \mathrm{E}-08$ & $2,66156 \mathrm{E}-08$ & $1,92624 \mathrm{E}-07$ & $6,18015 \mathrm{E}-08$ & $3,32188 \mathrm{E}-08$ & $8,01204 \mathrm{E}-08$ & $1,56334 \mathrm{E}-07$ & $1,02105 \mathrm{E}-08$ & $7,36688 \mathrm{E}-08$ & $1,61884 \mathrm{E}-07$ & $2,92016 \mathrm{E}-08$ \\
\hline Indústria Diversa & $1,34708 \mathrm{E}-09$ & $1,2487 \mathrm{E}-08$ & $3,63626 \mathrm{E}-09$ & $8,4613 \mathrm{E}-09$ & $1,32923 \mathrm{E}-07$ & $3,92055 \mathrm{E}-09$ & $7,2022 \mathrm{E}-08$ & $1,56727 \mathrm{E}-09$ & 3,58006E-09 & $2,55822 \mathrm{E}-08$ & $3,42126 \mathrm{E}-09$ \\
\hline SIUP & $5,30025 \mathrm{E}-08$ & $8,18067 \mathrm{E}-08$ & $2,12689 \mathrm{E}-07$ & $1,31012 \mathrm{E}-07$ & $1,07211 \mathrm{E}-07$ & $1,11373 \mathrm{E}-07$ & $3,28891 \mathrm{E}-07$ & $8,72578 \mathrm{E}-08$ & $1,58874 \mathrm{E}-07$ & $1,64289 \mathrm{E}-07$ & 4,33273E-07 \\
\hline Construção & $3,09231 \mathrm{E}-10$ & $4,39279 \mathrm{E}-10$ & $7,9489 \mathrm{E}-10$ & $1,01998 \mathrm{E}-09$ & $9,16272 \mathrm{E}-10$ & $8,09386 \mathrm{E}-10$ & $1,45721 \mathrm{E}-09$ & $1,15348 \mathrm{E}-09$ & $1,6326 \mathrm{E}-09$ & 2,65146E-09 & $3,6161 \mathrm{E}-09$ \\
\hline Comércio & $4,32978 \mathrm{E}-08$ & $6,38923 \mathrm{E}-08$ & $3,80801 \mathrm{E}-08$ & $6,85096 \mathrm{E}-08$ & $7,19623 \mathrm{E}-08$ & $2,9389 \mathrm{E}-08$ & $3,75978 \mathrm{E}-08$ & $3,89355 \mathrm{E}-08$ & $5,34299 \mathrm{E}-08$ & $4,16412 \mathrm{E}-08$ & $6,6819 \mathrm{E}-08$ \\
\hline Transportes & $4,62878 \mathrm{E}-08$ & $4,21166 \mathrm{E}-08$ & $1,23727 \mathrm{E}-07$ & 7,89467E-08 & $3,66934 \mathrm{E}-08$ & $3,97279 \mathrm{E}-08$ & $6,73013 \mathrm{E}-08$ & $3,86918 \mathrm{E}-08$ & $7,31845 \mathrm{E}-08$ & $4,78562 \mathrm{E}-08$ & $1,48331 \mathrm{E}-07$ \\
\hline Informação & $6,33061 \mathrm{E}-09$ & 9,81403E-09 & $2,88809 \mathrm{E}-08$ & $1,23333 \mathrm{E}-08$ & $7,0671 \mathrm{E}-09$ & $5,22816 \mathrm{E}-09$ & $1,20701 \mathrm{E}-08$ & $2,90408 \mathrm{E}-08$ & 3,73937E-08 & $1,6676 \mathrm{E}-08$ & $2,26303 \mathrm{E}-08$ \\
\hline
\end{tabular}




\begin{tabular}{|c|c|c|c|c|c|c|c|c|c|c|c|}
\hline Financeiro & $3,11975 \mathrm{E}-08$ & 3,45934E-08 & 6,99061E-08 & $5,95322 \mathrm{E}-08$ & $4,76023 \mathrm{E}-08$ & $4,41283 \mathrm{E}-08$ & $9,62487 \mathrm{E}-08$ & $5,45911 \mathrm{E}-08$ & $9,47784 \mathrm{E}-08$ & $6,88422 \mathrm{E}-08$ & $1,10702 \mathrm{E}-07$ \\
\hline Imobiliário & $5,02846 \mathrm{E}-09$ & 6,43977E-09 & $1,52559 \mathrm{E}-08$ & $1,28693 \mathrm{E}-08$ & $1,43381 \mathrm{E}-08$ & 5,73847E-09 & $1,26782 \mathrm{E}-08$ & $1,99764 \mathrm{E}-08$ & $1,71019 \mathrm{E}-08$ & $1,06629 \mathrm{E}-08$ & $1,85805 \mathrm{E}-08$ \\
\hline Alojamento & $5,12134 \mathrm{E}-10$ & 7,22357E-10 & 4,669E-09 & $1,2708 \mathrm{E}-09$ & $7,40969 \mathrm{E}-10$ & $1,48634 \mathrm{E}-09$ & $1,51475 \mathrm{E}-09$ & $2,008 \mathrm{E}-09$ & $1,68294 \mathrm{E}-09$ & 1,49492E-09 & $8,21703 \mathrm{E}-09$ \\
\hline Serviços às Empresas & 6,89169E-09 & $9,90778 \mathrm{E}-09$ & $1,91035 \mathrm{E}-08$ & $2,33143 \mathrm{E}-08$ & $1,52965 \mathrm{E}-08$ & $8,13382 \mathrm{E}-09$ & $1,97262 \mathrm{E}-08$ & $5,37542 \mathrm{E}-08$ & $6,07889 \mathrm{E}-08$ & $1,64497 \mathrm{E}-08$ & 3,81834E-08 \\
\hline Educação e Saúde mercantis & $8,94193 \mathrm{E}-10$ & $1,23632 \mathrm{E}-09$ & 1,8194E-09 & $1,86355 \mathrm{E}-09$ & $2,27522 \mathrm{E}-09$ & $8,35477 \mathrm{E}-10$ & $1,63566 \mathrm{E}-09$ & $1,99428 \mathrm{E}-09$ & $2,00364 \mathrm{E}-09$ & $1,434 \mathrm{E}-09$ & 2,06598E-09 \\
\hline Outros Serviços & 3,19589E-09 & 4,63157E-09 & $4,82522 \mathrm{E}-09$ & 6,10996E-09 & $6,56816 \mathrm{E}-09$ & 2,4215E-09 & 4,01517E-09 & 4,71989E-09 & $6,5087 \mathrm{E}-09$ & $4,75252 \mathrm{E}-09$ & 7,58099E-09 \\
\hline APU & $2,35132 \mathrm{E}-10$ & $2,8054 \mathrm{E}-10$ & $5,63212 \mathrm{E}-10$ & $5,20111 \mathrm{E}-10$ & $3,27792 \mathrm{E}-10$ & 2,21193E-10 & $5,37016 \mathrm{E}-10$ & $9,93886 \mathrm{E}-10$ & $8,99038 \mathrm{E}-10$ & 3,81387E-10 & $8,58842 \mathrm{E}-10$ \\
\hline
\end{tabular}

Tabela C4 - Matriz Geração de Renda para o Grau de Instrução G(3), Distrito Federal - 2008.

(2)

\begin{tabular}{|c|c|c|c|c|c|c|c|c|c|c|}
\hline Setores & Aço & Metal & Eletrodomésticos & Informática & Máquinas & Eletrônicos & $\begin{array}{l}\text { Instrumento } \\
\text { hospitalar }\end{array}$ & Veículos & $\begin{array}{l}\text { Indústria } \\
\text { Diversa }\end{array}$ & SIUP \\
\hline Agricultura & $1,02953 \mathrm{E}-09$ & $5,67642 \mathrm{E}-10$ & 2,03816E-09 & 1,94162E-09 & $1,15795 \mathrm{E}-09$ & $2,65088 \mathrm{E}-09$ & $7,04342 \mathrm{E}-10$ & 4,04407E-09 & 1,58243E-09 & $2,86829 \mathrm{E}-10$ \\
\hline Pecuária & $4,31559 \mathrm{E}-10$ & $2,13181 \mathrm{E}-10$ & $5,26928 \mathrm{E}-10$ & $5,6996 \mathrm{E}-10$ & $4,52012 \mathrm{E}-10$ & $5,91412 \mathrm{E}-10$ & $2,43732 \mathrm{E}-10$ & $9,43412 \mathrm{E}-10$ & $5,05351 \mathrm{E}-09$ & $1,38609 \mathrm{E}-10$ \\
\hline Extrativa & $8,11131 \mathrm{E}-06$ & $4,79218 \mathrm{E}-07$ & $1,52085 \mathrm{E}-06$ & $1,15918 \mathrm{E}-07$ & $4,6118 \mathrm{E}-07$ & 2,59177E-07 & 4,31843E-08 & 8,6749E-07 & 2,65921E-07 & 4,07081E-09 \\
\hline Alimentos & $2,46858 \mathrm{E}-09$ & $1,1606 \mathrm{E}-09$ & 2,40261E-09 & $2,68786 \mathrm{E}-09$ & $2,42066 \mathrm{E}-09$ & $2,62935 \mathrm{E}-09$ & $1,2747 \mathrm{E}-09$ & $3,25082 \mathrm{E}-09$ & $2,3126 \mathrm{E}-09$ & $7,749 \mathrm{E}-10$ \\
\hline Vestuário & $1,3444 \mathrm{E}-08$ & $2,05733 \mathrm{E}-08$ & $1,12918 \mathrm{E}-07$ & $1,57043 \mathrm{E}-08$ & $1,31898 \mathrm{E}-08$ & $1,78808 \mathrm{E}-08$ & $1,9904 \mathrm{E}-08$ & $9,6859 \mathrm{E}-08$ & $1,35957 \mathrm{E}-08$ & $1,36118 \mathrm{E}-08$ \\
\hline Madeira & $3,52687 \mathrm{E}-08$ & $5,20928 \mathrm{E}-08$ & $1,03937 \mathrm{E}-06$ & $9,56197 \mathrm{E}-07$ & $4,59631 \mathrm{E}-08$ & $4,25273 \mathrm{E}-06$ & $1,25791 \mathrm{E}-08$ & $6,51501 \mathrm{E}-07$ & $1,40443 \mathrm{E}-06$ & $1,70232 \mathrm{E}-09$ \\
\hline Celulose & $1,08306 \mathrm{E}-07$ & $2,61704 \mathrm{E}-08$ & 1,99719E-06 & $1,07989 \mathrm{E}-06$ & $1,94882 \mathrm{E}-07$ & $2,13205 \mathrm{E}-06$ & $4,5603 \mathrm{E}-08$ & $1,09223 \mathrm{E}-06$ & $1,05081 \mathrm{E}-07$ & $9,17053 \mathrm{E}-09$ \\
\hline Revistas & $4,75431 \mathrm{E}-08$ & $4,67852 \mathrm{E}-08$ & $2,86534 \mathrm{E}-08$ & $5,4079 \mathrm{E}-08$ & $2,44135 \mathrm{E}-08$ & $4,54048 \mathrm{E}-08$ & $2,24366 \mathrm{E}-07$ & $5,3379 \mathrm{E}-08$ & $1,59498 \mathrm{E}-08$ & 6,68791E-08 \\
\hline Químicos & $1,00565 \mathrm{E}-06$ & $1,75318 \mathrm{E}-07$ & $9,28306 \mathrm{E}-07$ & $6,66032 \mathrm{E}-08$ & $2,92155 \mathrm{E}-07$ & $1,17438 \mathrm{E}-07$ & 2,21564E-07 & $6,11137 \mathrm{E}-07$ & $1,08729 \mathrm{E}-07$ & $7,35334 \mathrm{E}-08$ \\
\hline Borracha & $9,9272 \mathrm{E}-07$ & $5,69055 \mathrm{E}-07$ & $2,7145 \mathrm{E}-06$ & $2,41857 \mathrm{E}-06$ & $1,24769 \mathrm{E}-06$ & $2,80704 \mathrm{E}-06$ & 7,82141E-07 & $6,50293 \mathrm{E}-06$ & $1,02919 \mathrm{E}-06$ & $2,4623 \mathrm{E}-08$ \\
\hline Cimento & $8,32573 \mathrm{E}-08$ & $2,4848 \mathrm{E}-08$ & $3,22945 \mathrm{E}-08$ & $1,70065 \mathrm{E}-08$ & $8,00055 \mathrm{E}-08$ & $6,23466 \mathrm{E}-08$ & 2,93072E-08 & 7,20233E-08 & $1,67457 \mathrm{E}-07$ & $8,06789 \mathrm{E}-10$ \\
\hline Aço & 0,000197953 & $1,61554 \mathrm{E}-06$ & 2,95844E-05 & 2,14239E-06 & $5,83223 \mathrm{E}-06$ & $5,15331 \mathrm{E}-06$ & $5,89337 \mathrm{E}-07$ & $1,62865 \mathrm{E}-05$ & $6,00858 \mathrm{E}-07$ & $1,873 \mathrm{E}-08$ \\
\hline Metal & $1,07824 \mathrm{E}-06$ & $2,768 \mathrm{E}-05$ & $1,73576 \mathrm{E}-06$ & $6,51087 \mathrm{E}-07$ & $1,20626 \mathrm{E}-06$ & $1,07416 \mathrm{E}-06$ & 7,39371E-07 & 7,74434E-07 & $5,95315 \mathrm{E}-07$ & $3,02684 \mathrm{E}-09$ \\
\hline Eletrodomésticos & $1,22265 \mathrm{E}-06$ & $1,405 \mathrm{E}-07$ & 0,000469863 & $1,30254 \mathrm{E}-06$ & $6,01161 \mathrm{E}-07$ & 8,7893E-07 & $2,61821 \mathrm{E}-07$ & $5,50649 \mathrm{E}-06$ & $9,11465 \mathrm{E}-08$ & $1,47315 \mathrm{E}-08$ \\
\hline Informática & 6,60571E-09 & $3,56056 \mathrm{E}-09$ & $3,41402 \mathrm{E}-08$ & 0,001446129 & $2,11769 \mathrm{E}-08$ & $7,24352 \mathrm{E}-07$ & 4,59514E-09 & $4,46236 \mathrm{E}-08$ & $3,62087 \mathrm{E}-09$ & $7,18801 \mathrm{E}-10$ \\
\hline Máquinas & $1,69777 \mathrm{E}-07$ & $4,64199 \mathrm{E}-08$ & 3,50559E-06 & 8,38937E-06 & 0,000137207 & $1,5417 \mathrm{E}-05$ & $1,0226 \mathrm{E}-06$ & 2,29226E-06 & $3,42519 \mathrm{E}-07$ & $2,60362 \mathrm{E}-07$ \\
\hline
\end{tabular}




\begin{tabular}{|c|c|c|c|c|c|c|c|c|c|c|}
\hline Eletrônicos & 3,44104E-08 & $2,06352 \mathrm{E}-08$ & $8,6854 \mathrm{E}-07$ & 0,000101607 & $8,47114 \mathrm{E}-07$ & 0,00050078 & $1,00492 \mathrm{E}-07$ & $8,07736 \mathrm{E}-07$ & $4,20767 \mathrm{E}-08$ & $1,63332 \mathrm{E}-08$ \\
\hline Instrumento hospitalar & $2,30527 \mathrm{E}-09$ & $1,26732 \mathrm{E}-09$ & $3,49584 \mathrm{E}-07$ & $4,57048 \mathrm{E}-08$ & $1,3575 \mathrm{E}-07$ & $6,37697 \mathrm{E}-08$ & 0,000109671 & $5,83528 \mathrm{E}-08$ & $5,99799 \mathrm{E}-09$ & $1,32502 \mathrm{E}-09$ \\
\hline Veículos & $4,41516 \mathrm{E}-07$ & 2,78933E-07 & $1,99148 \mathrm{E}-06$ & $1,40687 \mathrm{E}-06$ & $1,60722 \mathrm{E}-06$ & $2,55294 \mathrm{E}-06$ & 3,38343E-07 & 0,000703752 & $2,01332 \mathrm{E}-07$ & $4,29391 \mathrm{E}-08$ \\
\hline Indústria Diversa & 1,70991E-07 & $1,25986 \mathrm{E}-08$ & 3,97413E-08 & 7,52141E-09 & $2,30757 \mathrm{E}-08$ & $1,22393 \mathrm{E}-08$ & 3,26103E-09 & $2,05303 \mathrm{E}-08$ & $4,28457 \mathrm{E}-05$ & $1,06821 \mathrm{E}-09$ \\
\hline SIUP & 3,84967E-07 & $1,87729 \mathrm{E}-07$ & $1,86867 \mathrm{E}-07$ & $1,25126 \mathrm{E}-07$ & 2,19384E-07 & $1,5289 \mathrm{E}-07$ & $1,59892 \mathrm{E}-07$ & $1,6382 \mathrm{E}-07$ & $1,16648 \mathrm{E}-07$ & $1,74294 \mathrm{E}-05$ \\
\hline Construção & $1,12659 \mathrm{E}-09$ & $7,57044 \mathrm{E}-10$ & $1,5313 \mathrm{E}-09$ & 2,25427E-09 & 3,11359E-09 & $4,70482 \mathrm{E}-09$ & $7,13798 \mathrm{E}-10$ & 4,98969E-09 & $9,14854 \mathrm{E}-10$ & $7,07175 \mathrm{E}-10$ \\
\hline Comércio & $3,55992 \mathrm{E}-08$ & $3,11791 \mathrm{E}-08$ & $5,23795 \mathrm{E}-08$ & $1,17912 \mathrm{E}-07$ & 4,66976E-08 & $8,80718 \mathrm{E}-08$ & 4,70374E-08 & 6,70994E-08 & $5,44739 \mathrm{E}-08$ & $1,4868 \mathrm{E}-08$ \\
\hline Transportes & $9,95029 \mathrm{E}-08$ & $5,70986 \mathrm{E}-08$ & 7,85715E-08 & $8,81226 \mathrm{E}-08$ & $7,5172 \mathrm{E}-08$ & $1,09397 \mathrm{E}-07$ & $5,96918 \mathrm{E}-08$ & 6,88712E-08 & 3,69944E-08 & $3,02295 \mathrm{E}-08$ \\
\hline Informação & $2,95211 \mathrm{E}-08$ & $1,31295 \mathrm{E}-08$ & $3,3023 \mathrm{E}-08$ & $4,74737 \mathrm{E}-08$ & $4,05156 \mathrm{E}-08$ & $6,9848 \mathrm{E}-08$ & $2,13952 \mathrm{E}-08$ & $2,64083 \mathrm{E}-08$ & $7,1738 \mathrm{E}-09$ & $2,4981 \mathrm{E}-08$ \\
\hline Financeiro & $1,20598 \mathrm{E}-07$ & $7,10481 \mathrm{E}-08$ & $1,53643 \mathrm{E}-07$ & $1,07306 \mathrm{E}-07$ & $1,09769 \mathrm{E}-07$ & $1,89084 \mathrm{E}-07$ & 7,63104E-08 & $1,05393 \mathrm{E}-07$ & $4,51628 \mathrm{E}-08$ & $4,06123 \mathrm{E}-08$ \\
\hline Imobiliário & $1,20481 \mathrm{E}-08$ & $1,02236 \mathrm{E}-08$ & $1,59306 \mathrm{E}-08$ & $1,70823 \mathrm{E}-08$ & $1,26381 \mathrm{E}-08$ & $1,68984 \mathrm{E}-08$ & $1,4866 \mathrm{E}-08$ & $1,11208 \mathrm{E}-08$ & 9,69584E-09 & $8,72396 \mathrm{E}-09$ \\
\hline Alojamento & $2,17579 \mathrm{E}-09$ & $8,29301 \mathrm{E}-10$ & 1,19801E-09 & $1,73243 \mathrm{E}-09$ & $2,57068 \mathrm{E}-09$ & $1,73095 \mathrm{E}-09$ & $7,44912 \mathrm{E}-10$ & $2,29836 \mathrm{E}-09$ & $1,54802 \mathrm{E}-09$ & $6,36248 \mathrm{E}-10$ \\
\hline Serviços às Empresas & $1,59835 \mathrm{E}-08$ & $1,55756 \mathrm{E}-08$ & $1,86674 \mathrm{E}-08$ & $8,35038 \mathrm{E}-08$ & $2,66184 \mathrm{E}-08$ & $5,88553 \mathrm{E}-08$ & $2,13761 \mathrm{E}-08$ & 3,57499E-08 & $1,22985 \mathrm{E}-08$ & $4,54011 \mathrm{E}-08$ \\
\hline Educação e Saúde mercantis & $1,35785 \mathrm{E}-09$ & $1,372 \mathrm{E}-09$ & $2,01469 \mathrm{E}-09$ & 2,80721E-09 & $1,72598 \mathrm{E}-09$ & $2,57848 \mathrm{E}-09$ & $1,71656 \mathrm{E}-09$ & $1,74028 \mathrm{E}-09$ & $1,57528 \mathrm{E}-09$ & $1,08029 \mathrm{E}-09$ \\
\hline Outros Serviços & 4,48219E-09 & 4,07841E-09 & 5,98924E-09 & $1,17653 \mathrm{E}-08$ & $8,55031 \mathrm{E}-09$ & $1,08493 \mathrm{E}-08$ & 4,86623E-09 & $6,33557 \mathrm{E}-09$ & 4,99578E-09 & $4,76596 \mathrm{E}-09$ \\
\hline APU & $5,46838 \mathrm{E}-10$ & 3,75977E-10 & $4,42351 \mathrm{E}-10$ & 1,13673E-09 & $4,92137 \mathrm{E}-10$ & $9,03068 \mathrm{E}-10$ & $4,37871 \mathrm{E}-10$ & $6,10408 \mathrm{E}-10$ & $2,82448 \mathrm{E}-10$ & $1,01465 \mathrm{E}-09$ \\
\hline
\end{tabular}

Tabela C4 - Matriz Geração de Renda para o Grau de Instrução G(3), Distrito Federal - 2008.

(3)

\begin{tabular}{|c|c|c|c|c|c|c|c|c|c|c|c|}
\hline Setores & Construção & Comércio & Transportes & Informação & Financeiro & Imobiliário & Alojamento & $\begin{array}{c}\text { Serviços às } \\
\text { Empresas }\end{array}$ & $\begin{array}{l}\text { Educação e } \\
\text { Saúde } \\
\text { mercantis }\end{array}$ & $\begin{array}{c}\text { Outros } \\
\text { Serviços }\end{array}$ & APU \\
\hline Agricultura & $8,22996 \mathrm{E}-10$ & 2,5534E-09 & $1,93148 \mathrm{E}-09$ & $1,17162 \mathrm{E}-09$ & $7,58649 \mathrm{E}-10$ & $1,6079 \mathrm{E}-10$ & $2,56876 \mathrm{E}-07$ & $1,16328 \mathrm{E}-09$ & $6,12401 \mathrm{E}-09$ & $2,64551 \mathrm{E}-08$ & $3,26953 \mathrm{E}-09$ \\
\hline Pecuária & $4,16703 \mathrm{E}-10$ & $1,22463 \mathrm{E}-09$ & $1,09035 \mathrm{E}-09$ & $5,39685 \mathrm{E}-10$ & $4,1316 \mathrm{E}-10$ & $6,98658 \mathrm{E}-11$ & $1,6128 \mathrm{E}-07$ & $5,39675 \mathrm{E}-10$ & $3,58955 \mathrm{E}-09$ & $1,75244 \mathrm{E}-08$ & $1,6811 \mathrm{E}-09$ \\
\hline Extrativa & $2,11707 \mathrm{E}-08$ & $1,1036 \mathrm{E}-08$ & 6,80123E-09 & $1,27802 \mathrm{E}-08$ & 3,81412E-09 & 2,11198E-09 & $1,00347 \mathrm{E}-08$ & $1,0198 \mathrm{E}-08$ & $1,00341 \mathrm{E}-08$ & $9,46889 \mathrm{E}-09$ & $1,03975 \mathrm{E}-08$ \\
\hline Alimentos & $3,03685 \mathrm{E}-09$ & $9,43627 \mathrm{E}-09$ & 8,33482E-09 & $3,30287 \mathrm{E}-09$ & $2,71557 \mathrm{E}-09$ & $4,57608 \mathrm{E}-10$ & $1,18876 \mathrm{E}-06$ & 3,16798E-09 & $1,92964 \mathrm{E}-08$ & $4,42135 \mathrm{E}-08$ & $8,81385 \mathrm{E}-09$ \\
\hline Vestuário & $8,44962 \mathrm{E}-09$ & $1,89361 \mathrm{E}-08$ & 3,97033E-08 & $1,84885 \mathrm{E}-08$ & $1,51299 \mathrm{E}-08$ & $2,00199 \mathrm{E}-09$ & $2,19678 \mathrm{E}-08$ & $5,41403 \mathrm{E}-08$ & $3,49026 \mathrm{E}-08$ & $7,80586 \mathrm{E}-08$ & $1,52063 \mathrm{E}-08$ \\
\hline Madeira & $1,59634 \mathrm{E}-08$ & $5,66407 \mathrm{E}-09$ & $3,79925 \mathrm{E}-09$ & 7,51747E-09 & $4,25023 \mathrm{E}-09$ & 5,5517E-09 & $4,63516 \mathrm{E}-09$ & $6,25211 \mathrm{E}-09$ & 8,30163E-09 & $8,76167 \mathrm{E}-09$ & $1,25319 \mathrm{E}-08$ \\
\hline
\end{tabular}




\begin{tabular}{|c|c|c|c|c|c|c|c|c|c|c|c|}
\hline Celulose & $6,64125 \mathrm{E}-09$ & $2,66357 \mathrm{E}-08$ & $1,68372 \mathrm{E}-08$ & $3,38985 \mathrm{E}-08$ & $1,14797 \mathrm{E}-08$ & 4,46787E-09 & $1,66809 \mathrm{E}-08$ & $4,4335 \mathrm{E}-08$ & $2,37304 \mathrm{E}-08$ & $2,2394 \mathrm{E}-08$ & $2,23103 \mathrm{E}-08$ \\
\hline Revistas & $1,77816 \mathrm{E}-08$ & $6,40135 \mathrm{E}-08$ & $5,3949 \mathrm{E}-08$ & $1,49502 \mathrm{E}-07$ & $7,74115 \mathrm{E}-08$ & $1,68251 \mathrm{E}-08$ & $1,77148 \mathrm{E}-08$ & 4,75196E-07 & 7,75727E-08 & $8,21257 \mathrm{E}-08$ & $4,51375 \mathrm{E}-08$ \\
\hline Químicos & $9,95291 \mathrm{E}-09$ & $5,26838 \mathrm{E}-09$ & $3,72121 \mathrm{E}-09$ & $9,69414 \mathrm{E}-09$ & 2,21448E-09 & 1,44304E-09 & $7,22815 \mathrm{E}-08$ & $6,02542 \mathrm{E}-09$ & $6,92132 \mathrm{E}-08$ & $1,35742 \mathrm{E}-08$ & $1,04648 \mathrm{E}-08$ \\
\hline Borracha & $1,02093 \mathrm{E}-07$ & $4,07035 \mathrm{E}-08$ & $3,4245 \mathrm{E}-08$ & $8,36269 \mathrm{E}-08$ & $1,33773 \mathrm{E}-08$ & 7,63385E-09 & $5,55429 \mathrm{E}-08$ & $1,21192 \mathrm{E}-07$ & $1,0585 \mathrm{E}-07$ & 3,37739E-08 & $1,60745 \mathrm{E}-08$ \\
\hline Cimento & $3,39512 \mathrm{E}-07$ & $1,21529 \mathrm{E}-09$ & $5,22064 \mathrm{E}-10$ & $1,50411 \mathrm{E}-09$ & $1,40637 \mathrm{E}-09$ & $3,00259 \mathrm{E}-09$ & 2,36912E-09 & $1,13001 \mathrm{E}-09$ & $1,12071 \mathrm{E}-08$ & $5,90857 \mathrm{E}-09$ & $5,61003 \mathrm{E}-09$ \\
\hline Aço & $5,50612 \mathrm{E}-08$ & $8,07288 \mathrm{E}-09$ & $6,3241 \mathrm{E}-09$ & $1,10693 \mathrm{E}-08$ & 3,17499E-09 & 2,97145E-09 & $1,49462 \mathrm{E}-08$ & 7,74549E-09 & $9,35462 \mathrm{E}-09$ & $1,04629 \mathrm{E}-08$ & 7,49061E-09 \\
\hline Metal & 7,44033E-08 & 7,18307E-09 & $1,68565 \mathrm{E}-09$ & 3,91935E-09 & $1,1494 \mathrm{E}-09$ & 2,81049E-09 & $3,17824 \mathrm{E}-08$ & $1,99998 \mathrm{E}-09$ & 7,53586E-09 & 4,79137E-09 & 5,00051E-09 \\
\hline Eletrodomésticos & $1,82787 \mathrm{E}-08$ & 1,74999E-08 & $1,19087 \mathrm{E}-08$ & $2,20602 \mathrm{E}-08$ & 6,13308E-09 & 4,60657E-09 & $1,40589 \mathrm{E}-08$ & $1,72575 \mathrm{E}-08$ & $1,63572 \mathrm{E}-08$ & $1,65434 \mathrm{E}-08$ & $1,67525 \mathrm{E}-08$ \\
\hline Informática & 2,88602E-09 & 2,39872E-09 & $1,24485 \mathrm{E}-09$ & 4,60711E-09 & $1,55185 \mathrm{E}-09$ & 2,13036E-09 & $1,27477 \mathrm{E}-09$ & $2,74859 \mathrm{E}-09$ & 3,381E-09 & $2,73221 \mathrm{E}-09$ & 4,74896E-09 \\
\hline Máquinas & 7,1472E-08 & $1,50739 \mathrm{E}-08$ & 4,43637E-08 & $6,46591 \mathrm{E}-08$ & $8,06789 \mathrm{E}-09$ & $1,75311 \mathrm{E}-08$ & $1,19641 \mathrm{E}-08$ & $2,25093 \mathrm{E}-08$ & $2,00341 \mathrm{E}-08$ & $7,13255 \mathrm{E}-08$ & $1,27 \mathrm{E}-08$ \\
\hline Eletrônicos & $5,99045 \mathrm{E}-09$ & 3,96792E-09 & $4,94085 \mathrm{E}-09$ & $8,40355 \mathrm{E}-09$ & $1,85735 \mathrm{E}-09$ & 2,30475E-09 & $2,88686 \mathrm{E}-09$ & $5,64173 \mathrm{E}-09$ & $3,86922 \mathrm{E}-09$ & $7,05613 \mathrm{E}-09$ & $3,67378 \mathrm{E}-09$ \\
\hline Instrumento hospitalar & $7,42552 \mathrm{E}-09$ & 4,48747E-09 & $1,42317 \mathrm{E}-09$ & $1,85035 \mathrm{E}-09$ & $1,04273 \mathrm{E}-09$ & 8,45903E-09 & $9,05302 \mathrm{E}-10$ & $1,20413 \mathrm{E}-08$ & $1,24993 \mathrm{E}-08$ & $9,5228 \mathrm{E}-09$ & 2,58991E-09 \\
\hline Veículos & $3,43322 \mathrm{E}-08$ & $1,90272 \mathrm{E}-08$ & $1,66647 \mathrm{E}-08$ & $2,88407 \mathrm{E}-08$ & 7,54172E-09 & 7,24561E-09 & $1,78161 \mathrm{E}-08$ & $1,93926 \mathrm{E}-08$ & $1,88611 \mathrm{E}-08$ & $2,5212 \mathrm{E}-08$ & $1,89166 \mathrm{E}-08$ \\
\hline Indústria Diversa & $1,40932 \mathrm{E}-08$ & $1,92061 \mathrm{E}-09$ & $1,20783 \mathrm{E}-08$ & 2,37005E-09 & $2,13453 \mathrm{E}-08$ & $5,33715 \mathrm{E}-09$ & 2,35764E-09 & 7,80744E-09 & 7,73571E-09 & $3,90306 \mathrm{E}-08$ & $8,52698 \mathrm{E}-09$ \\
\hline SIUP & $3,80869 \mathrm{E}-08$ & $1,305 \mathrm{E}-07$ & $1,08216 \mathrm{E}-07$ & $1,01695 \mathrm{E}-07$ & $6,13685 \mathrm{E}-08$ & $1,29264 \mathrm{E}-08$ & $1,31921 \mathrm{E}-07$ & $1,14527 \mathrm{E}-07$ & $1,68625 \mathrm{E}-07$ & 3,794E-07 & $1,4524 \mathrm{E}-07$ \\
\hline Construção & $1,68676 \mathrm{E}-06$ & $1,93029 \mathrm{E}-09$ & $1,50051 \mathrm{E}-09$ & $6,14687 \mathrm{E}-09$ & $6,08156 \mathrm{E}-09$ & $1,45395 \mathrm{E}-08$ & $1,03309 \mathrm{E}-09$ & $4,33162 \mathrm{E}-09$ & $1,29839 \mathrm{E}-08$ & $1,12085 \mathrm{E}-08$ & $2,53548 \mathrm{E}-08$ \\
\hline Comércio & 4,879E-08 & $9,16419 \mathrm{E}-07$ & $4,06332 \mathrm{E}-08$ & $2,01903 \mathrm{E}-08$ & $1,20707 \mathrm{E}-08$ & $5,32713 \mathrm{E}-09$ & $9,35365 \mathrm{E}-08$ & $3,50017 \mathrm{E}-08$ & $3,11464 \mathrm{E}-08$ & $3,36769 \mathrm{E}-08$ & $1,78484 \mathrm{E}-08$ \\
\hline Transportes & 2,83063E-08 & $7,44758 \mathrm{E}-08$ & $2,27473 \mathrm{E}-06$ & $5,05212 \mathrm{E}-08$ & $2,1244 \mathrm{E}-08$ & $3,77864 \mathrm{E}-09$ & $3,40901 \mathrm{E}-08$ & 4,01354E-08 & $3,60651 \mathrm{E}-08$ & $5,33087 \mathrm{E}-08$ & $1,93624 \mathrm{E}-08$ \\
\hline Informação & $8,17634 \mathrm{E}-09$ & $2,57702 \mathrm{E}-08$ & $2,69426 \mathrm{E}-08$ & $1,92907 \mathrm{E}-06$ & $7,86057 \mathrm{E}-08$ & $5,31456 \mathrm{E}-09$ & $1,28734 \mathrm{E}-08$ & $2,08944 \mathrm{E}-07$ & $7,18534 \mathrm{E}-08$ & $4,70533 \mathrm{E}-08$ & $8,71169 \mathrm{E}-08$ \\
\hline Financeiro & 3,27013E-08 & $6,49058 \mathrm{E}-08$ & $8,97493 \mathrm{E}-08$ & $9,13635 \mathrm{E}-08$ & $2,59153 \mathrm{E}-06$ & $1,32034 \mathrm{E}-08$ & $3,37573 \mathrm{E}-08$ & $8,64706 \mathrm{E}-08$ & $3,81775 \mathrm{E}-08$ & $2,12491 \mathrm{E}-08$ & $2,02217 \mathrm{E}-07$ \\
\hline Imobiliário & $7,18245 \mathrm{E}-09$ & $3,61578 \mathrm{E}-08$ & $6,44373 \mathrm{E}-08$ & $5,83769 \mathrm{E}-08$ & $1,85167 \mathrm{E}-08$ & $1,7168 \mathrm{E}-06$ & $2,22496 \mathrm{E}-08$ & $4,21402 \mathrm{E}-08$ & $4,38358 \mathrm{E}-08$ & $3,14124 \mathrm{E}-08$ & $3,31551 \mathrm{E}-08$ \\
\hline Alojamento & 2,1737E-09 & 3,02072E-09 & $5,88151 \mathrm{E}-09$ & $3,96635 \mathrm{E}-09$ & $3,81462 \mathrm{E}-09$ & $4,20905 \mathrm{E}-10$ & 2,3333E-06 & $3,42193 \mathrm{E}-09$ & $1,81405 \mathrm{E}-08$ & $2,07028 \mathrm{E}-08$ & $1,12131 \mathrm{E}-08$ \\
\hline Serviços às Empresas & $1,84323 \mathrm{E}-08$ & $5,14123 \mathrm{E}-08$ & $5,90782 \mathrm{E}-08$ & $8,42014 \mathrm{E}-08$ & $6,36838 \mathrm{E}-08$ & $9,95229 \mathrm{E}-09$ & $1,6283 \mathrm{E}-08$ & $1,01615 \mathrm{E}-06$ & $8,47617 \mathrm{E}-08$ & $5,39377 \mathrm{E}-08$ & $5,98958 \mathrm{E}-08$ \\
\hline Educação e Saúde mercantis & $1,20735 \mathrm{E}-09$ & 4,30217E-09 & 2,85112E-09 & $4,80385 \mathrm{E}-09$ & 4,95391E-09 & $6,20428 \mathrm{E}-10$ & $3,42999 \mathrm{E}-09$ & 4,08954E-09 & $2,16667 \mathrm{E}-06$ & $3,27801 \mathrm{E}-09$ & $6,76242 \mathrm{E}-09$ \\
\hline Outros Serviços & 4,45832E-09 & $1,17873 \mathrm{E}-08$ & 7,36966E-09 & $1,31358 \mathrm{E}-08$ & $6,74853 \mathrm{E}-09$ & $1,3161 \mathrm{E}-09$ & $1,28539 \mathrm{E}-08$ & $1,56942 \mathrm{E}-08$ & $1,16139 \mathrm{E}-08$ & $1,65301 \mathrm{E}-06$ & $8,32088 \mathrm{E}-09$ \\
\hline APU & $2,90028 \mathrm{E}-10$ & 7,79843E-10 & $8,18109 \mathrm{E}-10$ & $1,05235 \mathrm{E}-09$ & $7,53334 \mathrm{E}-10$ & $1,2471 \mathrm{E}-10$ & $3,6918 \mathrm{E}-10$ & $9,36559 \mathrm{E}-10$ & $1,02792 \mathrm{E}-09$ & $7,94381 \mathrm{E}-10$ & $2,55215 \mathrm{E}-07$ \\
\hline
\end{tabular}


Tabela C5 - Matriz Geração de Renda para o Grau de Instrução G(4), Distrito Federal - 2008.

(1)

\begin{tabular}{|c|c|c|c|c|c|c|c|c|c|c|c|}
\hline Setores & Agricultura & Pecuária & Extrativa & Alimentos & Vestuário & Madeira & Celulose & Revistas & Químicos & Borracha & Cimento \\
\hline Agricultura & $1,42637 \mathrm{E}-05$ & $9,35819 \mathrm{E}-07$ & $1,5565 \mathrm{E}-09$ & $1,14918 \mathrm{E}-06$ & $1,43759 \mathrm{E}-08$ & $2,25981 \mathrm{E}-08$ & $6,52621 \mathrm{E}-08$ & $6,36607 \mathrm{E}-10$ & 2,86591E-09 & 4,85693E-08 & $1,11403 \mathrm{E}-09$ \\
\hline Pecuária & $1,09718 \mathrm{E}-07$ & $2,80623 \mathrm{E}-05$ & $8,24879 \mathrm{E}-10$ & $1,11007 \mathrm{E}-06$ & $2,31754 \mathrm{E}-08$ & $1,94579 \mathrm{E}-09$ & $6,39298 \mathrm{E}-09$ & $3,11583 \mathrm{E}-10$ & $2,02366 \mathrm{E}-09$ & $9,44362 \mathrm{E}-09$ & $7,7005 \mathrm{E}-10$ \\
\hline Extrativa & $2,33235 \mathrm{E}-08$ & $5,52893 \mathrm{E}-08$ & 0,000321329 & $1,31537 \mathrm{E}-08$ & $1,20883 \mathrm{E}-08$ & $1,66423 \mathrm{E}-08$ & $1,28709 \mathrm{E}-07$ & $3,08038 \mathrm{E}-09$ & $1,95623 \mathrm{E}-07$ & $4,16138 \mathrm{E}-08$ & $1,45384 \mathrm{E}-07$ \\
\hline Alimentos & $4,84141 \mathrm{E}-08$ & 7,3519E-07 & $2,5396 \mathrm{E}-09$ & $4,43248 \mathrm{E}-06$ & $3,34442 \mathrm{E}-08$ & $3,46284 \mathrm{E}-09$ & $1,08247 \mathrm{E}-08$ & $9,38869 \mathrm{E}-10$ & 4,08975E-09 & $1,36903 \mathrm{E}-09$ & 2,48352E-09 \\
\hline Vestuário & 5,35803E-09 & $4,74171 \mathrm{E}-09$ & $1,58092 \mathrm{E}-07$ & $6,9109 \mathrm{E}-09$ & 0,000283634 & 6,42677E-09 & $2,27005 \mathrm{E}-07$ & $7,27412 \mathrm{E}-09$ & $1,44963 \mathrm{E}-08$ & $4,24801 \mathrm{E}-08$ & $1,00469 \mathrm{E}-08$ \\
\hline Madeira & $5,05251 \mathrm{E}-08$ & $9,90424 \mathrm{E}-09$ & $2,75448 \mathrm{E}-08$ & $1,18192 \mathrm{E}-08$ & $4,91868 \mathrm{E}-08$ & 0,000848694 & $5,12036 \mathrm{E}-06$ & $8,48469 \mathrm{E}-09$ & $1,55199 \mathrm{E}-07$ & $4,21321 \mathrm{E}-08$ & 4,78757E-08 \\
\hline Celulose & $1,96856 \mathrm{E}-08$ & $2,15366 \mathrm{E}-08$ & $5,15113 \mathrm{E}-07$ & $2,51603 \mathrm{E}-08$ & 1,19712E-06 & $1,97102 \mathrm{E}-06$ & 0,000804449 & $1,25669 \mathrm{E}-07$ & $3,28443 \mathrm{E}-07$ & $9,51441 \mathrm{E}-07$ & $1,6713 \mathrm{E}-08$ \\
\hline Revistas & $1,42968 \mathrm{E}-08$ & $1,59395 \mathrm{E}-08$ & $3,6853 \mathrm{E}-08$ & $2,63061 \mathrm{E}-08$ & $1,38755 \mathrm{E}-08$ & $8,54333 \mathrm{E}-09$ & $1,58655 \mathrm{E}-07$ & $3,44572 \mathrm{E}-05$ & $2,2615 \mathrm{E}-07$ & $8,89097 \mathrm{E}-08$ & $3,0287 \mathrm{E}-08$ \\
\hline Químicos & 2,67691E-06 & $1,86189 \mathrm{E}-06$ & $6,22058 \mathrm{E}-07$ & $3,48321 \mathrm{E}-07$ & $1,91466 \mathrm{E}-07$ & $3,54921 \mathrm{E}-07$ & $1,61418 \mathrm{E}-06$ & $1,07623 \mathrm{E}-08$ & $6,92754 \mathrm{E}-05$ & $9,40861 \mathrm{E}-07$ & $8,81127 \mathrm{E}-08$ \\
\hline Borracha & $1,55886 \mathrm{E}-07$ & $9,98961 \mathrm{E}-08$ & $1,28291 \mathrm{E}-06$ & $2,76861 \mathrm{E}-07$ & $3,64356 \mathrm{E}-07$ & $6,78027 \mathrm{E}-07$ & $1,69092 \mathrm{E}-06$ & $2,131 \mathrm{E}-07$ & $5,01995 \mathrm{E}-07$ & 0,000142406 & $1,70649 \mathrm{E}-08$ \\
\hline Cimento & $1,00042 \mathrm{E}-08$ & $5,10755 \mathrm{E}-09$ & $1,18025 \mathrm{E}-08$ & $1,70942 \mathrm{E}-08$ & 4,49877E-09 & $1,95395 \mathrm{E}-09$ & $1,52858 \mathrm{E}-08$ & $1,60293 \mathrm{E}-09$ & $6,28819 \mathrm{E}-08$ & 4,68173E-09 & $9,94805 \mathrm{E}-06$ \\
\hline Aço & $9,06413 \mathrm{E}-08$ & 4,36821E-08 & 4,73916E-07 & $4,98445 \mathrm{E}-08$ & $2,75156 \mathrm{E}-08$ & $2,41902 \mathrm{E}-07$ & $4,78784 \mathrm{E}-07$ & 4,13467E-09 & $1,26005 \mathrm{E}-07$ & $6,95587 \mathrm{E}-07$ & 4,84995E-08 \\
\hline Metal & $1,56464 \mathrm{E}-07$ & $1,1025 \mathrm{E}-07$ & $5,06988 \mathrm{E}-07$ & $2,7215 \mathrm{E}-07$ & $4,37158 \mathrm{E}-08$ & $2,64299 \mathrm{E}-07$ & $4,72479 \mathrm{E}-07$ & 2,93223E-09 & $2,29764 \mathrm{E}-07$ & $2,61103 \mathrm{E}-07$ & $4,12662 \mathrm{E}-08$ \\
\hline Eletrodomésticos & $2,07545 \mathrm{E}-08$ & $1,41617 \mathrm{E}-08$ & $8,44076 \mathrm{E}-07$ & $2,38076 \mathrm{E}-08$ & $2,17296 \mathrm{E}-07$ & $3,74459 \mathrm{E}-07$ & $1,60247 \mathrm{E}-06$ & $6,39549 \mathrm{E}-09$ & $1,19345 \mathrm{E}-07$ & $1,61635 \mathrm{E}-07$ & $1,25087 \mathrm{E}-08$ \\
\hline Informática & $9,47323 \mathrm{E}-10$ & $7,53695 \mathrm{E}-10$ & $6,39172 \mathrm{E}-09$ & $1,03752 \mathrm{E}-09$ & $5,37063 \mathrm{E}-09$ & 2,83132E-09 & $3,10244 \mathrm{E}-08$ & $3,89452 \mathrm{E}-09$ & $1,37511 \mathrm{E}-08$ & $1,45965 \mathrm{E}-08$ & 7,63319E-10 \\
\hline Máquinas & $1,37851 \mathrm{E}-08$ & $2,50532 \mathrm{E}-08$ & $4,15583 \mathrm{E}-07$ & $4,66033 \mathrm{E}-08$ & $4,64856 \mathrm{E}-08$ & $9,7501 \mathrm{E}-08$ & $9,68607 \mathrm{E}-08$ & $6,05275 \mathrm{E}-09$ & $1,16998 \mathrm{E}-07$ & 3,50996E-07 & $8,67436 \mathrm{E}-08$ \\
\hline Eletrônicos & $3,68348 \mathrm{E}-09$ & 4,17867E-09 & $4,20851 \mathrm{E}-07$ & 8,37447E-09 & $8,43418 \mathrm{E}-09$ & $1,37873 \mathrm{E}-08$ & $2,80931 \mathrm{E}-08$ & 4,83842E-09 & $1,75122 \mathrm{E}-08$ & $3,44254 \mathrm{E}-08$ & 9,37902E-09 \\
\hline Instrumento hospitalar & $8,47129 \mathrm{E}-10$ & $9,33332 \mathrm{E}-10$ & $4,1836 \mathrm{E}-09$ & $1,23384 \mathrm{E}-09$ & $1,64088 \mathrm{E}-09$ & $1,75426 \mathrm{E}-09$ & $9,62357 \mathrm{E}-09$ & $1,87603 \mathrm{E}-09$ & $1,01888 \mathrm{E}-08$ & $1,95989 \mathrm{E}-08$ & $1,50654 \mathrm{E}-09$ \\
\hline Veículos & 4,16196E-08 & $3,40576 \mathrm{E}-08$ & $2,46483 \mathrm{E}-07$ & 7,90816E-08 & $4,2507 \mathrm{E}-08$ & $1,02523 \mathrm{E}-07$ & $2,00047 \mathrm{E}-07$ & $1,30654 \mathrm{E}-08$ & $9,42671 \mathrm{E}-08$ & $2,07148 \mathrm{E}-07$ & $3,73666 \mathrm{E}-08$ \\
\hline Indústria Diversa & $1,40232 \mathrm{E}-09$ & $1,2999 \mathrm{E}-08$ & $3,78536 \mathrm{E}-09$ & $8,80823 \mathrm{E}-09$ & $1,38373 \mathrm{E}-07$ & 4,0813E-09 & 7,49751E-08 & $1,63153 \mathrm{E}-09$ & $3,72685 \mathrm{E}-09$ & $2,66311 \mathrm{E}-08$ & 3,56154E-09 \\
\hline SIUP & 5,18191E-08 & $7,99802 \mathrm{E}-08$ & $2,0794 \mathrm{E}-07$ & $1,28087 \mathrm{E}-07$ & $1,04817 \mathrm{E}-07$ & $1,08886 \mathrm{E}-07$ & $3,21548 \mathrm{E}-07$ & $8,53096 \mathrm{E}-08$ & $1,55327 \mathrm{E}-07$ & $1,60621 \mathrm{E}-07$ & 4,23599E-07 \\
\hline Construção & $3,28447 \mathrm{E}-10$ & $4,66576 \mathrm{E}-10$ & $8,44285 \mathrm{E}-10$ & $1,08336 \mathrm{E}-09$ & $9,7321 \mathrm{E}-10$ & $8,59682 \mathrm{E}-10$ & $1,54777 \mathrm{E}-09$ & $1,22516 \mathrm{E}-09$ & $1,73405 \mathrm{E}-09$ & $2,81623 \mathrm{E}-09$ & $3,84081 \mathrm{E}-09$ \\
\hline Comércio & $4,22621 \mathrm{E}-08$ & $6,23639 \mathrm{E}-08$ & $3,71691 \mathrm{E}-08$ & 6,68707E-08 & $7,02408 \mathrm{E}-08$ & $2,8686 \mathrm{E}-08$ & $3,66983 \mathrm{E}-08$ & $3,80041 \mathrm{E}-08$ & $5,21517 \mathrm{E}-08$ & $4,0645 \mathrm{E}-08$ & $6,52205 \mathrm{E}-08$ \\
\hline Transportes & 4,39172E-08 & $3,99596 \mathrm{E}-08$ & $1,17391 \mathrm{E}-07$ & $7,49035 \mathrm{E}-08$ & $3,48141 \mathrm{E}-08$ & $3,76933 \mathrm{E}-08$ & $6,38545 \mathrm{E}-08$ & $3,67102 \mathrm{E}-08$ & $6,94364 \mathrm{E}-08$ & $4,54052 \mathrm{E}-08$ & $1,40735 \mathrm{E}-07$ \\
\hline Informação & $6,08326 \mathrm{E}-09$ & 9,43057E-09 & $2,77524 \mathrm{E}-08$ & $1,18514 \mathrm{E}-08$ & $6,79098 \mathrm{E}-09$ & $5,02389 \mathrm{E}-09$ & $1,15985 \mathrm{E}-08$ & $2,79061 \mathrm{E}-08$ & $3,59327 \mathrm{E}-08$ & $1,60244 \mathrm{E}-08$ & $2,17461 \mathrm{E}-08$ \\
\hline
\end{tabular}




\begin{tabular}{|c|c|c|c|c|c|c|c|c|c|c|c|}
\hline Financeiro & $3,14662 \mathrm{E}-08$ & $3,48914 \mathrm{E}-08$ & 7,05083E-08 & $6,00451 \mathrm{E}-08$ & $4,80124 \mathrm{E}-08$ & $4,45084 \mathrm{E}-08$ & $9,70778 \mathrm{E}-08$ & 5,50613E-08 & $9,55948 \mathrm{E}-08$ & $6,94352 \mathrm{E}-08$ & $1,11655 \mathrm{E}-07$ \\
\hline Imobiliário & 4,48294E-09 & $5,74113 \mathrm{E}-09$ & $1,36008 \mathrm{E}-08$ & $1,14732 \mathrm{E}-08$ & $1,27826 \mathrm{E}-08$ & $5,11592 \mathrm{E}-09$ & $1,13028 \mathrm{E}-08$ & $1,78092 \mathrm{E}-08$ & $1,52465 \mathrm{E}-08$ & $9,50608 \mathrm{E}-09$ & $1,65648 \mathrm{E}-08$ \\
\hline Alojamento & $4,79681 \mathrm{E}-10$ & $6,76583 \mathrm{E}-10$ & 4,37314E-09 & $1,19028 \mathrm{E}-09$ & $6,94016 \mathrm{E}-10$ & $1,39216 \mathrm{E}-09$ & $1,41877 \mathrm{E}-09$ & 1,88076E-09 & $1,5763 \mathrm{E}-09$ & $1,40019 \mathrm{E}-09$ & $7,69634 \mathrm{E}-09$ \\
\hline Serviços às Empresas & 7,74464E-09 & $1,1134 \mathrm{E}-08$ & $2,14678 \mathrm{E}-08$ & 2,61998E-08 & $1,71897 \mathrm{E}-08$ & $9,14049 \mathrm{E}-09$ & 2,21676E-08 & $6,0407 \mathrm{E}-08$ & $6,83124 \mathrm{E}-08$ & $1,84856 \mathrm{E}-08$ & 4,29091E-08 \\
\hline Educação e Saúde mercantis & $8,07186 \mathrm{E}-10$ & $1,11602 \mathrm{E}-09$ & $1,64237 \mathrm{E}-09$ & $1,68222 \mathrm{E}-09$ & $2,05384 \mathrm{E}-09$ & $7,54183 \mathrm{E}-10$ & $1,47651 \mathrm{E}-09$ & $1,80023 \mathrm{E}-09$ & $1,80868 \mathrm{E}-09$ & $1,29447 \mathrm{E}-09$ & $1,86496 \mathrm{E}-09$ \\
\hline Outros Serviços & 3,37676E-09 & 4,89369E-09 & $5,0983 \mathrm{E}-09$ & $6,45575 \mathrm{E}-09$ & $6,93988 \mathrm{E}-09$ & 2,55855E-09 & $4,24241 \mathrm{E}-09$ & 4,98701E-09 & $6,87705 \mathrm{E}-09$ & $5,02149 \mathrm{E}-09$ & $8,01003 \mathrm{E}-09$ \\
\hline APU & $2,11767 \mathrm{E}-10$ & $2,52663 \mathrm{E}-10$ & $5,07247 \mathrm{E}-10$ & $4,68428 \mathrm{E}-10$ & $2,9522 \mathrm{E}-10$ & $1,99213 \mathrm{E}-10$ & $4,83653 \mathrm{E}-10$ & $8,95125 \mathrm{E}-10$ & $8,09702 \mathrm{E}-10$ & $3,43489 \mathrm{E}-10$ & $7,735 \mathrm{E}-10$ \\
\hline
\end{tabular}

Tabela C5 - Matriz Geração de Renda para o Grau de Instrução G(4), Distrito Federal - 2008.

(2)

\begin{tabular}{|c|c|c|c|c|c|c|c|c|c|c|}
\hline Setores & Aço & Metal & Eletrodomésticos & Informática & Máquinas & Eletrônicos & $\begin{array}{l}\text { Instrumento } \\
\text { hospitalar }\end{array}$ & Veículos & $\begin{array}{l}\text { Indústria } \\
\text { Diversa }\end{array}$ & SIUP \\
\hline Agricultura & $8,39292 \mathrm{E}-10$ & $4,6275 \mathrm{E}-10$ & 1,66154E-09 & $1,58284 \mathrm{E}-09$ & $9,4398 \mathrm{E}-10$ & 2,16104E-09 & $5,7419 \mathrm{E}-10$ & 3,29679E-09 & $1,29002 \mathrm{E}-09$ & $2,33827 \mathrm{E}-10$ \\
\hline Pecuária & $4,23345 \mathrm{E}-10$ & 2,09123E-10 & $5,16899 \mathrm{E}-10$ & $5,59112 \mathrm{E}-10$ & $4,43409 \mathrm{E}-10$ & $5,80156 \mathrm{E}-10$ & $2,39093 \mathrm{E}-10$ & $9,25456 \mathrm{E}-10$ & 4,95733E-09 & $1,35971 \mathrm{E}-10$ \\
\hline Extrativa & $5,41333 \mathrm{E}-06$ & 3,19821E-07 & $1,01498 \mathrm{E}-06$ & $7,73616 \mathrm{E}-08$ & 3,07783E-07 & 1,7297E-07 & $2,88204 \mathrm{E}-08$ & $5,78946 \mathrm{E}-07$ & $1,77471 \mathrm{E}-07$ & $2,71678 \mathrm{E}-09$ \\
\hline Alimentos & 1,11297E-09 & $5,23261 \mathrm{E}-10$ & $1,08322 \mathrm{E}-09$ & $1,21183 \mathrm{E}-09$ & $1,09136 \mathrm{E}-09$ & $1,18545 \mathrm{E}-09$ & $5,74701 \mathrm{E}-10$ & 1,46564E-09 & $1,04264 \mathrm{E}-09$ & $3,49365 \mathrm{E}-10$ \\
\hline Vestuário & $1,33472 \mathrm{E}-08$ & $2,04251 \mathrm{E}-08$ & $1,12104 \mathrm{E}-07$ & $1,55912 \mathrm{E}-08$ & $1,30948 \mathrm{E}-08$ & $1,7752 \mathrm{E}-08$ & $1,97607 \mathrm{E}-08$ & $9,61615 \mathrm{E}-08$ & $1,34978 \mathrm{E}-08$ & $1,35138 \mathrm{E}-08$ \\
\hline Madeira & $3,85191 \mathrm{E}-08$ & $5,68938 \mathrm{E}-08$ & $1,13516 \mathrm{E}-06$ & $1,04432 \mathrm{E}-06$ & $5,01991 \mathrm{E}-08$ & $4,64467 \mathrm{E}-06$ & $1,37384 \mathrm{E}-08$ & 7,11544E-07 & $1,53387 \mathrm{E}-06$ & $1,85921 \mathrm{E}-09$ \\
\hline Celulose & $1,35467 \mathrm{E}-07$ & $3,27332 \mathrm{E}-08$ & 2,49803E-06 & 1,3507E-06 & $2,43753 \mathrm{E}-07$ & $2,66672 \mathrm{E}-06$ & 5,70391E-08 & $1,36614 \mathrm{E}-06$ & $1,31432 \mathrm{E}-07$ & $1,14703 \mathrm{E}-08$ \\
\hline Revistas & $4,33965 \mathrm{E}-08$ & $4,27047 \mathrm{E}-08$ & 2,61543E-08 & $4,93624 \mathrm{E}-08$ & $2,22842 \mathrm{E}-08$ & $4,14447 \mathrm{E}-08$ & $2,04798 \mathrm{E}-07$ & $4,87234 \mathrm{E}-08$ & $1,45587 \mathrm{E}-08$ & $6,1046 \mathrm{E}-08$ \\
\hline Químicos & $8,29463 \mathrm{E}-07$ & $1,44602 \mathrm{E}-07$ & 7,65667E-07 & $5,49343 \mathrm{E}-08$ & 2,4097E-07 & $9,6863 \mathrm{E}-08$ & $1,82746 \mathrm{E}-07$ & $5,04066 \mathrm{E}-07$ & $8,96794 \mathrm{E}-08$ & $6,06504 \mathrm{E}-08$ \\
\hline Borracha & $8,7619 \mathrm{E}-07$ & $5,02257 \mathrm{E}-07$ & 2,39586E-06 & $2,13467 \mathrm{E}-06$ & $1,10123 \mathrm{E}-06$ & $2,47754 \mathrm{E}-06$ & $6,9033 \mathrm{E}-07$ & $5,73958 \mathrm{E}-06$ & $9,08381 \mathrm{E}-07$ & $2,17327 \mathrm{E}-08$ \\
\hline Cimento & $8,77656 \mathrm{E}-08$ & 2,61935E-08 & $3,40433 \mathrm{E}-08$ & $1,79274 \mathrm{E}-08$ & $8,43378 \mathrm{E}-08$ & $6,57227 \mathrm{E}-08$ & $3,08942 \mathrm{E}-08$ & 7,59234E-08 & $1,76525 \mathrm{E}-07$ & $8,50477 \mathrm{E}-10$ \\
\hline Aço & 0,000118304 & $9,65507 \mathrm{E}-07$ & $1,76808 \mathrm{E}-05$ & $1,28037 \mathrm{E}-06$ & $3,48557 \mathrm{E}-06$ & $3,07982 \mathrm{E}-06$ & $3,52211 \mathrm{E}-07$ & $9,73341 \mathrm{E}-06$ & $3,59096 \mathrm{E}-07$ & $1,11938 \mathrm{E}-08$ \\
\hline Metal & $1,24709 \mathrm{E}-06$ & $3,20147 \mathrm{E}-05$ & $2,00758 \mathrm{E}-06$ & $7,53046 \mathrm{E}-07$ & $1,39516 \mathrm{E}-06$ & $1,24237 \mathrm{E}-06$ & $8,55156 \mathrm{E}-07$ & $8,9571 \mathrm{E}-07$ & $6,88541 \mathrm{E}-07$ & $3,50084 \mathrm{E}-09$ \\
\hline Eletrodomésticos & $8,60529 \mathrm{E}-07$ & $9,88874 \mathrm{E}-08$ & 0,000330701 & $9,16758 \mathrm{E}-07$ & $4,23111 \mathrm{E}-07$ & $6,18611 \mathrm{E}-07$ & $1,84276 \mathrm{E}-07$ & $3,8756 \mathrm{E}-06$ & $6,4151 \mathrm{E}-08$ & $1,03684 \mathrm{E}-08$ \\
\hline Informática & 4,17944E-09 & $2,25277 \mathrm{E}-09$ & $2,16005 \mathrm{E}-08$ & 0,000914967 & $1,33987 \mathrm{E}-08$ & $4,58298 \mathrm{E}-07$ & $2,90735 \mathrm{E}-09$ & $2,82334 \mathrm{E}-08$ & 2,29093E-09 & $4,54786 \mathrm{E}-10$ \\
\hline Máquinas & $1,49665 \mathrm{E}-07$ & $4,09208 \mathrm{E}-08$ & 3,09031E-06 & 7,39553E-06 & 0,000120953 & $1,35907 \mathrm{E}-05$ & $9,01457 \mathrm{E}-07$ & $2,02071 \mathrm{E}-06$ & 3,01943E-07 & $2,29518 \mathrm{E}-07$ \\
\hline
\end{tabular}




\begin{tabular}{|c|c|c|c|c|c|c|c|c|c|c|}
\hline Eletrônicos & 3,99764E-08 & 2,3973E-08 & $1,00903 \mathrm{E}-06$ & 0,000118042 & $9,84139 \mathrm{E}-07$ & 0,000581783 & $1,16747 \mathrm{E}-07$ & 9,38391E-07 & $4,88828 \mathrm{E}-08$ & $1,89751 \mathrm{E}-08$ \\
\hline Instrumento hospitalar & $2,98916 \mathrm{E}-09$ & $1,64328 \mathrm{E}-09$ & $4,53292 \mathrm{E}-07$ & $5,92637 \mathrm{E}-08$ & $1,76022 \mathrm{E}-07$ & $8,26878 \mathrm{E}-08$ & 0,000142206 & $7,56639 \mathrm{E}-08$ & 7,77737E-09 & $1,7181 \mathrm{E}-09$ \\
\hline Veículos & $5,64967 \mathrm{E}-07$ & $3,56924 \mathrm{E}-07$ & $2,54831 \mathrm{E}-06$ & $1,80023 \mathrm{E}-06$ & $2,05661 \mathrm{E}-06$ & $3,26676 \mathrm{E}-06$ & 4,32947E-07 & 0,000900526 & $2,57626 \mathrm{E}-07$ & $5,49451 \mathrm{E}-08$ \\
\hline Indústria Diversa & $1,78002 \mathrm{E}-07$ & $1,31152 \mathrm{E}-08$ & $4,13708 \mathrm{E}-08$ & 7,82981E-09 & $2,40219 \mathrm{E}-08$ & $1,27411 \mathrm{E}-08$ & 3,39474E-09 & $2,13721 \mathrm{E}-08$ & $4,46024 \mathrm{E}-05$ & $1,11201 \mathrm{E}-09$ \\
\hline SIUP & 3,76371E-07 & $1,83537 \mathrm{E}-07$ & $1,82695 \mathrm{E}-07$ & $1,22333 \mathrm{E}-07$ & $2,14486 \mathrm{E}-07$ & $1,49477 \mathrm{E}-07$ & $1,56322 \mathrm{E}-07$ & $1,60163 \mathrm{E}-07$ & $1,14044 \mathrm{E}-07$ & $1,70402 \mathrm{E}-05$ \\
\hline Construção & $1,19659 \mathrm{E}-09$ & $8,04087 \mathrm{E}-10$ & $1,62645 \mathrm{E}-09$ & 2,39435E-09 & 3,30707E-09 & 4,99718E-09 & $7,58153 \mathrm{E}-10$ & $5,29975 \mathrm{E}-09$ & $9,71704 \mathrm{E}-10$ & $7,5112 \mathrm{E}-10$ \\
\hline Comércio & $3,47476 \mathrm{E}-08$ & $3,04332 \mathrm{E}-08$ & $5,11265 \mathrm{E}-08$ & $1,15091 \mathrm{E}-07$ & $4,55805 \mathrm{E}-08$ & $8,59649 \mathrm{E}-08$ & $4,59122 \mathrm{E}-08$ & $6,54942 \mathrm{E}-08$ & $5,31708 \mathrm{E}-08$ & $1,45123 \mathrm{E}-08$ \\
\hline Transportes & $9,4407 \mathrm{E}-08$ & $5,41743 \mathrm{E}-08$ & $7,45475 \mathrm{E}-08$ & $8,36095 \mathrm{E}-08$ & $7,13222 \mathrm{E}-08$ & $1,03794 \mathrm{E}-07$ & $5,66347 \mathrm{E}-08$ & 6,5344E-08 & 3,50997E-08 & $2,86813 \mathrm{E}-08$ \\
\hline Informação & $2,83677 \mathrm{E}-08$ & $1,26165 \mathrm{E}-08$ & $3,17327 \mathrm{E}-08$ & $4,56188 \mathrm{E}-08$ & $3,89325 \mathrm{E}-08$ & $6,71188 \mathrm{E}-08$ & $2,05592 \mathrm{E}-08$ & $2,53765 \mathrm{E}-08$ & $6,8935 \mathrm{E}-09$ & $2,4005 \mathrm{E}-08$ \\
\hline Financeiro & $1,21637 \mathrm{E}-07$ & $7,16601 \mathrm{E}-08$ & $1,54967 \mathrm{E}-07$ & $1,0823 \mathrm{E}-07$ & $1,10715 \mathrm{E}-07$ & $1,90713 \mathrm{E}-07$ & 7,69677E-08 & $1,06301 \mathrm{E}-07$ & $4,55519 \mathrm{E}-08$ & $4,09621 \mathrm{E}-08$ \\
\hline Imobiliário & $1,0741 \mathrm{E}-08$ & $9,11443 \mathrm{E}-09$ & $1,42023 \mathrm{E}-08$ & $1,52291 \mathrm{E}-08$ & $1,1267 \mathrm{E}-08$ & $1,50652 \mathrm{E}-08$ & $1,32532 \mathrm{E}-08$ & $9,91429 \mathrm{E}-09$ & 8,64397E-09 & $7,77752 \mathrm{E}-09$ \\
\hline Alojamento & 2,03791E-09 & $7,7675 \mathrm{E}-10$ & $1,1221 \mathrm{E}-09$ & $1,62265 \mathrm{E}-09$ & 2,40779E-09 & $1,62126 \mathrm{E}-09$ & $6,97709 \mathrm{E}-10$ & $2,15272 \mathrm{E}-09$ & 1,44992E-09 & $5,9593 \mathrm{E}-10$ \\
\hline Serviços às Empresas & $1,79617 \mathrm{E}-08$ & $1,75034 \mathrm{E}-08$ & $2,09778 \mathrm{E}-08$ & $9,38385 \mathrm{E}-08$ & $2,99128 \mathrm{E}-08$ & 6,61395E-08 & $2,40217 \mathrm{E}-08$ & $4,01745 \mathrm{E}-08$ & $1,38207 \mathrm{E}-08$ & $5,10201 \mathrm{E}-08$ \\
\hline Educação e Saúde mercantis & $1,22573 \mathrm{E}-09$ & $1,2385 \mathrm{E}-09$ & $1,81865 \mathrm{E}-09$ & 2,53406E-09 & $1,55804 \mathrm{E}-09$ & $2,32759 \mathrm{E}-09$ & $1,54953 \mathrm{E}-09$ & $1,57094 \mathrm{E}-09$ & $1,422 \mathrm{E}-09$ & $9,75172 \mathrm{E}-10$ \\
\hline Outros Serviços & 4,73586E-09 & $4,30922 \mathrm{E}-09$ & 6,32819E-09 & $1,24312 \mathrm{E}-08$ & $9,0342 \mathrm{E}-09$ & $1,14633 \mathrm{E}-08$ & $5,14163 \mathrm{E}-09$ & 6,69413E-09 & 5,27851E-09 & $5,03568 \mathrm{E}-09$ \\
\hline APU & $4,925 \mathrm{E}-10$ & $3,38617 \mathrm{E}-10$ & $3,98395 \mathrm{E}-10$ & $1,02378 \mathrm{E}-09$ & $4,43234 \mathrm{E}-10$ & $8,13332 \mathrm{E}-10$ & $3,94361 \mathrm{E}-10$ & $5,49753 \mathrm{E}-10$ & $2,54381 \mathrm{E}-10$ & $9,1383 \mathrm{E}-10$ \\
\hline
\end{tabular}

Tabela C5 - Matriz Geração de Renda para o Grau de Instrução G(4), Distrito Federal - 2008.

(3)

\begin{tabular}{|c|c|c|c|c|c|c|c|c|c|c|c|}
\hline Setores & Construção & Comércio & Transportes & Informação & Financeiro & Imobiliário & Alojamento & $\begin{array}{l}\text { Serviços às } \\
\text { Empresas }\end{array}$ & $\begin{array}{l}\text { Educação e } \\
\text { Saúde } \\
\text { mercantis }\end{array}$ & $\begin{array}{c}\text { Outros } \\
\text { Serviços }\end{array}$ & APU \\
\hline Agricultura & $6,70919 \mathrm{E}-10$ & $2,08157 \mathrm{E}-09$ & $1,57457 \mathrm{E}-09$ & $9,55121 \mathrm{E}-10$ & $6,18462 \mathrm{E}-10$ & $1,31078 \mathrm{E}-10$ & $2,09409 \mathrm{E}-07$ & $9,4832 \mathrm{E}-10$ & 4,99239E-09 & $2,15666 \mathrm{E}-08$ & $2,66537 \mathrm{E}-09$ \\
\hline Pecuária & $4,08772 \mathrm{E}-10$ & $1,20132 \mathrm{E}-09$ & $1,0696 \mathrm{E}-09$ & $5,29413 \mathrm{E}-10$ & $4,05296 \mathrm{E}-10$ & $6,85361 \mathrm{E}-11$ & $1,58211 \mathrm{E}-07$ & $5,29403 \mathrm{E}-10$ & $3,52123 \mathrm{E}-09$ & 1,71909E-08 & $1,64911 \mathrm{E}-09$ \\
\hline Extrativa & $1,41289 \mathrm{E}-08$ & 7,36521E-09 & 4,53901E-09 & $8,52928 \mathrm{E}-09$ & $2,54547 \mathrm{E}-09$ & $1,40949 \mathrm{E}-09$ & 6,69693E-09 & 6,80596E-09 & 6,69659E-09 & 6,31936E-09 & 6,93911E-09 \\
\hline Alimentos & 1,36917E-09 & $4,25436 \mathrm{E}-09$ & 3,75777E-09 & $1,48911 \mathrm{E}-09$ & $1,22432 \mathrm{E}-09$ & $2,06313 \mathrm{E}-10$ & $5,35953 \mathrm{E}-07$ & $1,42829 \mathrm{E}-09$ & $8,69984 \mathrm{E}-09$ & $1,99338 \mathrm{E}-08$ & $3,97374 \mathrm{E}-09$ \\
\hline Vestuário & 8,38876E-09 & $1,87997 \mathrm{E}-08$ & 3,94174E-08 & $1,83553 \mathrm{E}-08$ & $1,50209 \mathrm{E}-08$ & $1,98757 \mathrm{E}-09$ & $2,18096 \mathrm{E}-08$ & $5,37504 \mathrm{E}-08$ & $3,46512 \mathrm{E}-08$ & 7,74964E-08 & $1,50967 \mathrm{E}-08$ \\
\hline Madeira & $1,74346 \mathrm{E}-08$ & 6,18607E-09 & 4,14939E-09 & $8,21028 \mathrm{E}-09$ & 4,64193E-09 & $6,06335 \mathrm{E}-09$ & $5,06235 \mathrm{E}-09$ & $6,82832 \mathrm{E}-09$ & $9,06672 \mathrm{E}-09$ & 9,56916E-09 & $1,36868 \mathrm{E}-08$ \\
\hline
\end{tabular}




\begin{tabular}{|c|c|c|c|c|c|c|c|c|c|c|c|}
\hline Celulose & $8,30671 \mathrm{E}-09$ & 3,33153E-08 & $2,10596 \mathrm{E}-08$ & $4,23994 \mathrm{E}-08$ & $1,43585 \mathrm{E}-08$ & 5,5883E-09 & $2,0864 \mathrm{E}-08$ & $5,54532 \mathrm{E}-08$ & $2,96814 \mathrm{E}-08$ & $2,80099 \mathrm{E}-08$ & $2,79052 \mathrm{E}-08$ \\
\hline Revistas & $1,62307 \mathrm{E}-08$ & $5,84304 \mathrm{E}-08$ & 4,92436E-08 & $1,36463 \mathrm{E}-07$ & $7,06598 \mathrm{E}-08$ & $1,53577 \mathrm{E}-08$ & $1,61697 \mathrm{E}-08$ & $4,3375 \mathrm{E}-07$ & 7,0807E-08 & 7,49629E-08 & $4,12007 \mathrm{E}-08$ \\
\hline Químicos & ,20916E-09 & 4,34536E-09 & $3,06925 \mathrm{E}-09$ & 7,99572E-09 & $1,8265 \mathrm{E}-09$ & 1,19022E-09 & $5,96177 \mathrm{E}-08$ & 4,96976E-09 & $5,70871 \mathrm{E}-08$ & $1,1196 \mathrm{E}-08$ & $8,63138 \mathrm{E}-09$ \\
\hline Borracha & $9,01087 \mathrm{E}-08$ & $3,59255 \mathrm{E}-08$ & $3,02252 \mathrm{E}-08$ & $7,38105 \mathrm{E}-08$ & $1,1807 \mathrm{E}-08$ & 6,73776E-09 & $4,9023 \mathrm{E}-08$ & $1,06966 \mathrm{E}-07$ & $9,34249 \mathrm{E}-08$ & $2,98094 \mathrm{E}-08$ & $1,41876 \mathrm{E}-08$ \\
\hline Cimento & 3,57897E-07 & $1,2811 \mathrm{E}-09$ & $5,50333 \mathrm{E}-10$ & $1,58556 \mathrm{E}-09$ & $1,48252 \mathrm{E}-09$ & $3,16518 \mathrm{E}-09$ & 2,4974E-09 & $1,19121 \mathrm{E}-09$ & $1,1814 \mathrm{E}-08$ & $6,22852 \mathrm{E}-09$ & $5,91382 \mathrm{E}-09$ \\
\hline Aço & 3,29067E-08 & 4,82466E-09 & 3,77952E-09 & 6,61543E-09 & $1,8975 \mathrm{E}-09$ & $1,77585 \mathrm{E}-09$ & $8,93241 \mathrm{E}-09$ & 4,629E-09 & $5,59068 \mathrm{E}-09$ & $6,25301 \mathrm{E}-09$ & 4,47668E-09 \\
\hline Metal & $8,60548 \mathrm{E}-08$ & 8,30793E-09 & $1,94962 \mathrm{E}-09$ & 4,53311E-09 & 1,3294E-09 & $3,25061 \mathrm{E}-09$ & $3,67595 \mathrm{E}-08$ & $2,31318 \mathrm{E}-09$ & $8,71597 \mathrm{E}-09$ & $5,54169 \mathrm{E}-09$ & $5,78358 \mathrm{E}-09$ \\
\hline Eletrodomésticos & $1,28649 \mathrm{E}-08$ & $1,23168 \mathrm{E}-08$ & 8,38162E-09 & $1,55265 \mathrm{E}-08$ & 4,3166E-09 & $3,24221 \mathrm{E}-09$ & 9,89501E-09 & $1,21462 \mathrm{E}-08$ & $1,15126 \mathrm{E}-08$ & $1,16436 \mathrm{E}-08$ & $1,17908 \mathrm{E}-08$ \\
\hline Informática & $1,82599 \mathrm{E}-09$ & $1,51767 \mathrm{E}-09$ & 7,87617E-10 & 2,91492E-09 & $9,81858 \mathrm{E}-10$ & $1,34788 \mathrm{E}-09$ & $8,0655 \mathrm{E}-10$ & $1,73903 \mathrm{E}-09$ & 2,13916E-09 & $1,72867 \mathrm{E}-09$ & 3,00467E-09 \\
\hline Máquinas & $6,30051 \mathrm{E}-08$ & $1,32882 \mathrm{E}-08$ & $3,91082 \mathrm{E}-08$ & $5,69993 \mathrm{E}-08$ & $7,11214 \mathrm{E}-09$ & $1,54543 \mathrm{E}-08$ & $1,05468 \mathrm{E}-08$ & $1,98428 \mathrm{E}-08$ & $1,76608 \mathrm{E}-08$ & $6,2876 \mathrm{E}-08$ & $1,11956 \mathrm{E}-08$ \\
\hline Eletrônicos & $6,95944 \mathrm{E}-09$ & 4,60975E-09 & $5,74006 \mathrm{E}-09$ & $9,76286 \mathrm{E}-09$ & $2,15778 \mathrm{E}-09$ & $2,67755 \mathrm{E}-09$ & $3,35382 \mathrm{E}-09$ & $6,55431 \mathrm{E}-09$ & $4,49508 \mathrm{E}-09$ & $8,19749 \mathrm{E}-09$ & $4,26804 \mathrm{E}-09$ \\
\hline Instrumento hospitalar & $9,62839 \mathrm{E}-09$ & $5,81873 \mathrm{E}-09$ & $1,84537 \mathrm{E}-09$ & 2,39928E-09 & $1,35207 \mathrm{E}-09$ & $1,09685 \mathrm{E}-08$ & $1,17387 \mathrm{E}-09$ & $1,56134 \mathrm{E}-08$ & $1,62073 \mathrm{E}-08$ & $1,23478 \mathrm{E}-08$ & $3,35824 \mathrm{E}-09$ \\
\hline Veículos & 4,39317E-08 & $2,43473 \mathrm{E}-08$ & $2,13242 \mathrm{E}-08$ & $3,69048 \mathrm{E}-08$ & $9,65044 \mathrm{E}-09$ & $9,27153 \mathrm{E}-09$ & $2,27976 \mathrm{E}-08$ & $2,48149 \mathrm{E}-08$ & $2,41348 \mathrm{E}-08$ & $3,22614 \mathrm{E}-08$ & $2,42058 \mathrm{E}-08$ \\
\hline Indústria Diversa & $1,4671 \mathrm{E}-08$ & $1,99936 \mathrm{E}-09$ & $1,25735 \mathrm{E}-08$ & 2,46723E-09 & $2,22205 \mathrm{E}-08$ & $5,55599 \mathrm{E}-09$ & 2,45431E-09 & $8,12757 \mathrm{E}-09$ & $8,0529 \mathrm{E}-09$ & 4,06309E-08 & $8,87661 \mathrm{E}-09$ \\
\hline SIUP & $3,72366 \mathrm{E}-08$ & $1,27587 \mathrm{E}-07$ & $1,058 \mathrm{E}-07$ & $9,94249 \mathrm{E}-08$ & 5,99983E-08 & $1,26378 \mathrm{E}-08$ & $1,28975 \mathrm{E}-07$ & $1,11969 \mathrm{E}-07$ & $1,64861 \mathrm{E}-07$ & 3,70929E-07 & $1,41998 \mathrm{E}-07$ \\
\hline Construção & $1,79158 \mathrm{E}-06$ & $2,05024 \mathrm{E}-09$ & $1,59375 \mathrm{E}-09$ & $6,52884 \mathrm{E}-09$ & $6,45947 \mathrm{E}-09$ & $1,5443 \mathrm{E}-08$ & $1,09728 \mathrm{E}-09$ & $4,60079 \mathrm{E}-09$ & $1,37907 \mathrm{E}-08$ & $1,1905 \mathrm{E}-08$ & 2,69304E-08 \\
\hline Comércio & $4,76228 \mathrm{E}-08$ & $8,94496 \mathrm{E}-07$ & $3,96612 \mathrm{E}-08$ & $1,97073 \mathrm{E}-08$ & $1,17819 \mathrm{E}-08$ & 5,19969E-09 & $9,12989 \mathrm{E}-08$ & $3,41644 \mathrm{E}-08$ & $3,04013 \mathrm{E}-08$ & $3,28713 \mathrm{E}-08$ & $1,74214 \mathrm{E}-08$ \\
\hline Transportes & $2,68566 \mathrm{E}-08$ & $7,06616 \mathrm{E}-08$ & $2,15823 \mathrm{E}-06$ & $4,79338 \mathrm{E}-08$ & $2,0156 \mathrm{E}-08$ & $3,58512 \mathrm{E}-09$ & $3,23442 \mathrm{E}-08$ & 3,80799E-08 & $3,4218 \mathrm{E}-08$ & $5,05785 \mathrm{E}-08$ & $1,83708 \mathrm{E}-08$ \\
\hline Informação & 7,85687E-09 & $2,47633 \mathrm{E}-08$ & $2,58899 \mathrm{E}-08$ & $1,8537 \mathrm{E}-06$ & $7,55344 \mathrm{E}-08$ & 5,10691E-09 & $1,23704 \mathrm{E}-08$ & $2,0078 \mathrm{E}-07$ & $6,90459 \mathrm{E}-08$ & $4,52148 \mathrm{E}-08$ & $8,3713 \mathrm{E}-08$ \\
\hline Financeiro & $3,2983 \mathrm{E}-08$ & $6,5465 \mathrm{E}-08$ & $9,05224 \mathrm{E}-08$ & $9,21506 \mathrm{E}-08$ & $2,61386 \mathrm{E}-06$ & $1,33172 \mathrm{E}-08$ & $3,40481 \mathrm{E}-08$ & $8,72155 \mathrm{E}-08$ & $3,85064 \mathrm{E}-08$ & $2,14321 \mathrm{E}-08$ & $2,03959 \mathrm{E}-07$ \\
\hline Imobiliário & $6,40324 \mathrm{E}-09$ & $3,22351 \mathrm{E}-08$ & $5,74467 \mathrm{E}-08$ & $5,20438 \mathrm{E}-08$ & $1,65079 \mathrm{E}-08$ & $1,53055 \mathrm{E}-06$ & $1,98358 \mathrm{E}-08$ & $3,75685 \mathrm{E}-08$ & $3,90801 \mathrm{E}-08$ & $2,80045 \mathrm{E}-08$ & $2,95582 \mathrm{E}-08$ \\
\hline Alojamento & $2,03596 \mathrm{E}-09$ & 2,8293E-09 & $5,50882 \mathrm{E}-09$ & $3,71501 \mathrm{E}-09$ & $3,5729 \mathrm{E}-09$ & $3,94234 \mathrm{E}-10$ & $2,18545 \mathrm{E}-06$ & $3,20509 \mathrm{E}-09$ & $1,6991 \mathrm{E}-08$ & $1,93909 \mathrm{E}-08$ & $1,05025 \mathrm{E}-08$ \\
\hline Serviços às Empresas & $2,07136 \mathrm{E}-08$ & $5,77753 \mathrm{E}-08$ & $6,63899 \mathrm{E}-08$ & $9,46225 \mathrm{E}-08$ & $7,15656 \mathrm{E}-08$ & $1,1184 \mathrm{E}-08$ & $1,82982 \mathrm{E}-08$ & $1,14192 \mathrm{E}-06$ & $9,52522 \mathrm{E}-08$ & $6,06133 \mathrm{E}-08$ & $6,73088 \mathrm{E}-08$ \\
\hline Educação e Saúde mercantis & $1,08987 \mathrm{E}-09$ & $3,88356 \mathrm{E}-09$ & 2,5737E-09 & $4,33642 \mathrm{E}-09$ & $4,47188 \mathrm{E}-09$ & $5,60059 \mathrm{E}-10$ & $3,09625 \mathrm{E}-09$ & $3,69162 \mathrm{E}-09$ & $1,95585 \mathrm{E}-06$ & $2,95905 \mathrm{E}-09$ & $6,10442 \mathrm{E}-09$ \\
\hline Outros Serviços & 4,71064E-09 & $1,24544 \mathrm{E}-08$ & $7,78674 \mathrm{E}-09$ & $1,38792 \mathrm{E}-08$ & $7,13046 \mathrm{E}-09$ & $1,39058 \mathrm{E}-09$ & $1,35813 \mathrm{E}-08$ & $1,65824 \mathrm{E}-08$ & $1,22712 \mathrm{E}-08$ & $1,74656 \mathrm{E}-06$ & $8,7918 \mathrm{E}-09$ \\
\hline APU & $2,61208 \mathrm{E}-10$ & $7,02351 \mathrm{E}-10$ & $7,36815 \mathrm{E}-10$ & $9,47779 \mathrm{E}-10$ & 6,78476E-10 & $1,12318 \mathrm{E}-10$ & $3,32495 \mathrm{E}-10$ & $8,43495 \mathrm{E}-10$ & $9,25778 \mathrm{E}-10$ & $7,15445 \mathrm{E}-10$ & $2,29855 \mathrm{E}-07$ \\
\hline
\end{tabular}


Tabela C6 - Matriz Geração de Renda para o Grau de Instrução G(5), Distrito Federal - 2008.

(1)

\begin{tabular}{|c|c|c|c|c|c|c|c|c|c|c|c|}
\hline Setores & Agricultura & Pecuária & Extrativa & Alimentos & Vestuário & Madeira & Celulose & Revistas & Químicos & Borracha & Cimento \\
\hline Agricultura & $2,32451 \mathrm{E}-05$ & $1,52508 \mathrm{E}-06$ & $2,53658 \mathrm{E}-09$ & $1,87279 \mathrm{E}-06$ & $2,34279 \mathrm{E}-08$ & $3,68274 \mathrm{E}-08$ & $1,06356 \mathrm{E}-07$ & $1,03746 \mathrm{E}-09$ & 4,67048E-09 & 7,91519E-08 & $1,8155 \mathrm{E}-09$ \\
\hline Pecuária & $1,12262 \mathrm{E}-07$ & $2,8713 \mathrm{E}-05$ & $8,44007 \mathrm{E}-10$ & $1,13581 \mathrm{E}-06$ & $2,37128 \mathrm{E}-08$ & 1,99091E-09 & $6,54122 \mathrm{E}-09$ & $3,18808 \mathrm{E}-10$ & $2,07059 \mathrm{E}-09$ & $9,6626 \mathrm{E}-09$ & $7,87906 \mathrm{E}-10$ \\
\hline Extrativa & $4,7502 \mathrm{E}-08$ & $1,12606 \mathrm{E}-07$ & 0,000654438 & $2,67897 \mathrm{E}-08$ & $2,46198 \mathrm{E}-08$ & $3,38948 \mathrm{E}-08$ & $2,62137 \mathrm{E}-07$ & $6,27369 \mathrm{E}-09$ & $3,98418 \mathrm{E}-07$ & $8,47533 \mathrm{E}-08$ & $2,96098 \mathrm{E}-07$ \\
\hline Alimentos & $1,49675 \mathrm{E}-07$ & $2,27288 \mathrm{E}-06$ & $7,85133 \mathrm{E}-09$ & $1,37033 \mathrm{E}-05$ & $1,03395 \mathrm{E}-07$ & $1,07056 \mathrm{E}-08$ & $3,34651 \mathrm{E}-08$ & 2,90257E-09 & $1,26437 \mathrm{E}-08$ & 4,23244E-09 & 7,67796E-09 \\
\hline Vestuário & $5,07087 \mathrm{E}-09$ & $4,48758 \mathrm{E}-09$ & $1,49619 \mathrm{E}-07$ & 6,54051E-09 & 0,000268433 & $6,08233 \mathrm{E}-09$ & $2,14839 \mathrm{E}-07$ & $6,88426 \mathrm{E}-09$ & $1,37193 \mathrm{E}-08$ & $4,02034 \mathrm{E}-08$ & $9,50848 \mathrm{E}-09$ \\
\hline Madeira & $4,36569 \mathrm{E}-08$ & $8,55789 \mathrm{E}-09$ & $2,38004 \mathrm{E}-08$ & $1,02125 \mathrm{E}-08$ & $4,25005 \mathrm{E}-08$ & 0,000733325 & $4,42432 \mathrm{E}-06$ & 7,33131E-09 & $1,34101 \mathrm{E}-07$ & $3,64048 \mathrm{E}-08$ & $4,13676 \mathrm{E}-08$ \\
\hline Celulose & $1,82046 \mathrm{E}-08$ & $1,99163 \mathrm{E}-08$ & $4,76359 \mathrm{E}-07$ & $2,32674 \mathrm{E}-08$ & $1,10705 \mathrm{E}-06$ & $1,82273 \mathrm{E}-06$ & 0,000743928 & $1,16215 \mathrm{E}-07$ & $3,03733 \mathrm{E}-07$ & $8,79862 \mathrm{E}-07$ & $1,54556 \mathrm{E}-08$ \\
\hline Revistas & $1,30071 \mathrm{E}-08$ & $1,45016 \mathrm{E}-08$ & $3,35286 \mathrm{E}-08$ & $2,39331 \mathrm{E}-08$ & $1,26238 \mathrm{E}-08$ & 7,77266E-09 & $1,44343 \mathrm{E}-07$ & $3,13489 \mathrm{E}-05$ & $2,0575 \mathrm{E}-07$ & $8,08893 \mathrm{E}-08$ & $2,75549 \mathrm{E}-08$ \\
\hline Químicos & 3,19929E-06 & $2,22522 \mathrm{E}-06$ & $7,43449 \mathrm{E}-07$ & $4,16294 \mathrm{E}-07$ & $2,2883 \mathrm{E}-07$ & $4,24182 \mathrm{E}-07$ & $1,92917 \mathrm{E}-06$ & $1,28625 \mathrm{E}-08$ & $8,27942 \mathrm{E}-05$ & $1,12447 \mathrm{E}-06$ & $1,05307 \mathrm{E}-07$ \\
\hline Borracha & $1,4902 \mathrm{E}-07$ & $9,54962 \mathrm{E}-08$ & $1,2264 \mathrm{E}-06$ & $2,64667 \mathrm{E}-07$ & $3,48308 \mathrm{E}-07$ & $6,48164 \mathrm{E}-07$ & $1,61644 \mathrm{E}-06$ & 2,03714E-07 & $4,79885 \mathrm{E}-07$ & 0,000136133 & $1,63133 \mathrm{E}-08$ \\
\hline Cimento & $1,01483 \mathrm{E}-08$ & 5,18111E-09 & $1,19724 \mathrm{E}-08$ & $1,73404 \mathrm{E}-08$ & 4,56356E-09 & $1,98209 \mathrm{E}-09$ & $1,5506 \mathrm{E}-08$ & $1,62601 \mathrm{E}-09$ & $6,37874 \mathrm{E}-08$ & 4,74915E-09 & $1,00913 \mathrm{E}-05$ \\
\hline Aço & $9,44386 \mathrm{E}-08$ & $4,55121 \mathrm{E}-08$ & $4,9377 \mathrm{E}-07$ & $5,19326 \mathrm{E}-08$ & $2,86684 \mathrm{E}-08$ & $2,52036 \mathrm{E}-07$ & $4,98842 \mathrm{E}-07$ & 4,30789E-09 & $1,31284 \mathrm{E}-07$ & $7,24727 \mathrm{E}-07$ & $5,05313 \mathrm{E}-08$ \\
\hline Metal & $1,47057 \mathrm{E}-07$ & $1,03623 \mathrm{E}-07$ & $4,7651 \mathrm{E}-07$ & $2,55789 \mathrm{E}-07$ & $4,10878 \mathrm{E}-08$ & $2,4841 \mathrm{E}-07$ & $4,44075 \mathrm{E}-07$ & $2,75595 \mathrm{E}-09$ & $2,15951 \mathrm{E}-07$ & $2,45406 \mathrm{E}-07$ & $3,87854 \mathrm{E}-08$ \\
\hline Eletrodomésticos & $2,94202 \mathrm{E}-08$ & $2,00748 \mathrm{E}-08$ & $1,19651 \mathrm{E}-06$ & $3,37482 \mathrm{E}-08$ & $3,08025 \mathrm{E}-07$ & $5,3081 \mathrm{E}-07$ & $2,27156 \mathrm{E}-06$ & $9,06584 \mathrm{E}-09$ & $1,69175 \mathrm{E}-07$ & $2,29124 \mathrm{E}-07$ & $1,77315 \mathrm{E}-08$ \\
\hline Informática & $3,49135 \mathrm{E}-10$ & $2,77773 \mathrm{E}-10$ & $2,35566 \mathrm{E}-09$ & $3,82377 \mathrm{E}-10$ & 1,97934E-09 & $1,04348 \mathrm{E}-09$ & $1,1434 \mathrm{E}-08$ & $1,43532 \mathrm{E}-09$ & 5,06796E-09 & 5,37953E-09 & $2,8132 \mathrm{E}-10$ \\
\hline Máquinas & $1,6529 \mathrm{E}-08$ & $3,00401 \mathrm{E}-08$ & 4,98306E-07 & $5,58798 \mathrm{E}-08$ & $5,57387 \mathrm{E}-08$ & $1,16909 \mathrm{E}-07$ & $1,16141 \mathrm{E}-07$ & 7,25757E-09 & $1,40287 \mathrm{E}-07$ & $4,20863 \mathrm{E}-07$ & $1,0401 \mathrm{E}-07$ \\
\hline Eletrônicos & $2,57724 \mathrm{E}-09$ & 2,92372E-09 & $2,9446 \mathrm{E}-07$ & $5,85942 \mathrm{E}-09$ & $5,9012 \mathrm{E}-09$ & $9,64668 \mathrm{E}-09$ & $1,96561 \mathrm{E}-08$ & $3,38533 \mathrm{E}-09$ & $1,22529 \mathrm{E}-08$ & $2,40866 \mathrm{E}-08$ & $6,56228 \mathrm{E}-09$ \\
\hline Instrumento hospitalar & $5,7146 \mathrm{E}-10$ & $6,29611 \mathrm{E}-10$ & $2,82219 \mathrm{E}-09$ & $8,3233 \mathrm{E}-10$ & 1,10691E-09 & $1,1834 \mathrm{E}-09$ & 6,49191E-09 & $1,26554 \mathrm{E}-09$ & $6,87321 \mathrm{E}-09$ & $1,32211 \mathrm{E}-08$ & $1,01629 \mathrm{E}-09$ \\
\hline Veículos & $3,43089 \mathrm{E}-08$ & $2,80752 \mathrm{E}-08$ & $2,03187 \mathrm{E}-07$ & $6,51906 \mathrm{E}-08$ & $3,50405 \mathrm{E}-08$ & $8,45142 \mathrm{E}-08$ & $1,64908 \mathrm{E}-07$ & $1,07704 \mathrm{E}-08$ & 7,77087E-08 & $1,70762 \mathrm{E}-07$ & $3,0803 \mathrm{E}-08$ \\
\hline Indústria Diversa & $1,37154 \mathrm{E}-09$ & $1,27138 \mathrm{E}-08$ & $3,70228 \mathrm{E}-09$ & $8,61492 \mathrm{E}-09$ & $1,35336 \mathrm{E}-07$ & 3,99173E-09 & $7,33296 \mathrm{E}-08$ & $1,59572 \mathrm{E}-09$ & $3,64506 \mathrm{E}-09$ & $2,60467 \mathrm{E}-08$ & $3,48338 \mathrm{E}-09$ \\
\hline SIUP & $4,43046 \mathrm{E}-08$ & $6,83818 \mathrm{E}-08$ & $1,77786 \mathrm{E}-07$ & $1,09512 \mathrm{E}-07$ & $8,96169 \mathrm{E}-08$ & $9,30959 \mathrm{E}-08$ & $2,74919 \mathrm{E}-07$ & $7,29384 \mathrm{E}-08$ & $1,32802 \mathrm{E}-07$ & $1,37329 \mathrm{E}-07$ & $3,62171 \mathrm{E}-07$ \\
\hline Construção & $3,07242 \mathrm{E}-10$ & $4,36453 \mathrm{E}-10$ & $7,89776 \mathrm{E}-10$ & $1,01341 \mathrm{E}-09$ & $9,10378 \mathrm{E}-10$ & $8,0418 \mathrm{E}-10$ & $1,44784 \mathrm{E}-09$ & $1,14606 \mathrm{E}-09$ & $1,62209 \mathrm{E}-09$ & 2,63441E-09 & $3,59284 \mathrm{E}-09$ \\
\hline Comércio & $4,29745 \mathrm{E}-08$ & $6,34151 \mathrm{E}-08$ & $3,77957 \mathrm{E}-08$ & 6,79979E-08 & $7,14249 \mathrm{E}-08$ & $2,91695 \mathrm{E}-08$ & $3,73169 \mathrm{E}-08$ & $3,86447 \mathrm{E}-08$ & $5,30308 \mathrm{E}-08$ & $4,13302 \mathrm{E}-08$ & $6,63199 \mathrm{E}-08$ \\
\hline Transportes & $3,99683 \mathrm{E}-08$ & $3,63666 \mathrm{E}-08$ & $1,06835 \mathrm{E}-07$ & $6,81684 \mathrm{E}-08$ & $3,16838 \mathrm{E}-08$ & $3,43041 \mathrm{E}-08$ & $5,8113 \mathrm{E}-08$ & $3,34094 \mathrm{E}-08$ & $6,3193 \mathrm{E}-08$ & $4,13226 \mathrm{E}-08$ & $1,2808 \mathrm{E}-07$ \\
\hline Informação & $6,85662 \mathrm{E}-09$ & $1,06295 \mathrm{E}-08$ & $3,12806 \mathrm{E}-08$ & $1,33581 \mathrm{E}-08$ & 7,65431E-09 & 5,66257E-09 & $1,3073 \mathrm{E}-08$ & $3,14538 \mathrm{E}-08$ & $4,05008 \mathrm{E}-08$ & $1,80616 \mathrm{E}-08$ & $2,45107 \mathrm{E}-08$ \\
\hline
\end{tabular}




\begin{tabular}{|c|c|c|c|c|c|c|c|c|c|c|c|}
\hline Financeiro & $2,63604 \mathrm{E}-08$ & $2,92297 \mathrm{E}-08$ & $5,90673 \mathrm{E}-08$ & $5,03019 \mathrm{E}-08$ & $4,02217 \mathrm{E}-08$ & $3,72863 \mathrm{E}-08$ & $8,13255 \mathrm{E}-08$ & $4,61268 \mathrm{E}-08$ & $8,00832 \mathrm{E}-08$ & $5,81684 \mathrm{E}-08$ & $9,35376 \mathrm{E}-08$ \\
\hline Imobiliário & 4,75988E-09 & 6,09581E-09 & $1,44411 \mathrm{E}-08$ & $1,2182 \mathrm{E}-08$ & $1,35723 \mathrm{E}-08$ & $5,43197 \mathrm{E}-09$ & $1,2001 \mathrm{E}-08$ & $1,89095 \mathrm{E}-08$ & $1,61884 \mathrm{E}-08$ & $1,00933 \mathrm{E}-08$ & $1,75881 \mathrm{E}-08$ \\
\hline Alojamento & $4,47167 \mathrm{E}-10$ & $6,30722 \mathrm{E}-10$ & $4,07671 \mathrm{E}-09$ & $1,1096 \mathrm{E}-09$ & $6,46973 \mathrm{E}-10$ & $1,29779 \mathrm{E}-09$ & $1,3226 \mathrm{E}-09$ & $1,75328 \mathrm{E}-09$ & $1,46945 \mathrm{E}-09$ & $1,30528 \mathrm{E}-09$ & $7,17465 \mathrm{E}-09$ \\
\hline Serviços às Empresas & 7,30386E-09 & $1,05003 \mathrm{E}-08$ & $2,0246 \mathrm{E}-08$ & $2,47086 \mathrm{E}-08$ & $1,62114 \mathrm{E}-08$ & $8,62027 \mathrm{E}-09$ & 2,09059E-08 & $5,6969 \mathrm{E}-08$ & $6,44244 \mathrm{E}-08$ & $1,74335 \mathrm{E}-08$ & $4,0467 \mathrm{E}-08$ \\
\hline Educação e Saúde mercantis & $7,83842 \mathrm{E}-10$ & $1,08375 \mathrm{E}-09$ & $1,59487 \mathrm{E}-09$ & $1,63357 \mathrm{E}-09$ & $1,99444 \mathrm{E}-09$ & $7,32372 \mathrm{E}-10$ & 1,43381E-09 & $1,74817 \mathrm{E}-09$ & $1,75637 \mathrm{E}-09$ & $1,25704 \mathrm{E}-09$ & $1,81102 \mathrm{E}-09$ \\
\hline Outros Serviços & 2,78112E-09 & 4,03047E-09 & 4,19899E-09 & $5,317 \mathrm{E}-09$ & 5,71573E-09 & 2,10724E-09 & 3,49407E-09 & 4,10733E-09 & $5,66398 \mathrm{E}-09$ & 4,13573E-09 & 6,59712E-09 \\
\hline APU & $1,68368 \mathrm{E}-10$ & $2,00883 \mathrm{E}-10$ & $4,03292 \mathrm{E}-10$ & $3,72429 \mathrm{E}-10$ & $2,34718 \mathrm{E}-10$ & $1,58386 \mathrm{E}-10$ & $3,84534 \mathrm{E}-10$ & $7,11678 \mathrm{E}-10$ & $6,43762 \mathrm{E}-10$ & $2,73094 \mathrm{E}-10$ & $6,14979 \mathrm{E}-10$ \\
\hline
\end{tabular}

Tabela C6 - Matriz Geração de Renda para o Grau de Instrução G(5), Distrito Federal - 2008.

(2)

\begin{tabular}{|c|c|c|c|c|c|c|c|c|c|c|}
\hline Setores & Aço & Metal & Eletrodomésticos & Informática & Máquinas & Eletrônicos & $\begin{array}{l}\text { Instrumento } \\
\text { hospitalar }\end{array}$ & Veículos & $\begin{array}{l}\text { Indústria } \\
\text { Diversa }\end{array}$ & SIUP \\
\hline Agricultura & $1,36777 \mathrm{E}-09$ & 7,5413E-10 & 2,70776E-09 & $2,5795 \mathrm{E}-09$ & $1,53838 \mathrm{E}-09$ & $3,52178 \mathrm{E}-09$ & $9,3574 \mathrm{E}-10$ & $5,37268 \mathrm{E}-09$ & 2,10231E-09 & $3,81061 \mathrm{E}-10$ \\
\hline Pecuária & $4,33162 \mathrm{E}-10$ & 2,13973E-10 & $5,28885 \mathrm{E}-10$ & $5,72076 \mathrm{E}-10$ & $4,5369 \mathrm{E}-10$ & $5,93609 \mathrm{E}-10$ & $2,44637 \mathrm{E}-10$ & $9,46916 \mathrm{E}-10$ & $5,07228 \mathrm{E}-09$ & $1,39124 \mathrm{E}-10$ \\
\hline Extrativa & $1,10251 \mathrm{E}-05$ & 6,51366E-07 & $2,06718 \mathrm{E}-06$ & $1,57559 \mathrm{E}-07$ & $6,26849 \mathrm{E}-07$ & $3,5228 \mathrm{E}-07$ & $5,86973 \mathrm{E}-08$ & $1,17912 \mathrm{E}-06$ & $3,61447 \mathrm{E}-07$ & $5,53316 \mathrm{E}-09$ \\
\hline Alimentos & 3,4408E-09 & $1,61769 \mathrm{E}-09$ & 3,34884E-09 & 3,74644E-09 & 3,374E-09 & $3,66489 \mathrm{E}-09$ & $1,77672 \mathrm{E}-09$ & 4,53111E-09 & 3,22338E-09 & $1,08008 \mathrm{E}-09$ \\
\hline Vestuário & $1,26319 \mathrm{E}-08$ & $1,93304 \mathrm{E}-08$ & $1,06096 \mathrm{E}-07$ & $1,47556 \mathrm{E}-08$ & $1,23929 \mathrm{E}-08$ & $1,68006 \mathrm{E}-08$ & $1,87016 \mathrm{E}-08$ & $9,10077 \mathrm{E}-08$ & $1,27744 \mathrm{E}-08$ & $1,27895 \mathrm{E}-08$ \\
\hline Madeira & $3,32829 \mathrm{E}-08$ & $4,91598 \mathrm{E}-08$ & $9,80849 \mathrm{E}-07$ & $9,0236 \mathrm{E}-07$ & $4,33752 \mathrm{E}-08$ & $4,01328 \mathrm{E}-06$ & $1,18709 \mathrm{E}-08$ & $6,14819 \mathrm{E}-07$ & $1,32536 \mathrm{E}-06$ & $1,60647 \mathrm{E}-09$ \\
\hline Celulose & $1,25275 \mathrm{E}-07$ & $3,02706 \mathrm{E}-08$ & 2,3101E-06 & $1,24909 \mathrm{E}-06$ & $2,25415 \mathrm{E}-07$ & $2,46609 \mathrm{E}-06$ & $5,27479 \mathrm{E}-08$ & $1,26336 \mathrm{E}-06$ & $1,21544 \mathrm{E}-07$ & $1,06073 \mathrm{E}-08$ \\
\hline Revistas & $3,94818 \mathrm{E}-08$ & $3,88524 \mathrm{E}-08$ & $2,3795 \mathrm{E}-08$ & 4,49095E-08 & $2,0274 \mathrm{E}-08$ & $3,77061 \mathrm{E}-08$ & $1,86323 \mathrm{E}-07$ & $4,43281 \mathrm{E}-08$ & $1,32454 \mathrm{E}-08$ & $5,55392 \mathrm{E}-08$ \\
\hline Químicos & $9,91328 \mathrm{E}-07$ & $1,72821 \mathrm{E}-07$ & $9,15082 \mathrm{E}-07$ & 6,56544E-08 & 2,87994E-07 & $1,15765 \mathrm{E}-07$ & $2,18408 \mathrm{E}-07$ & $6,02432 \mathrm{E}-07$ & $1,0718 \mathrm{E}-07$ & $7,2486 \mathrm{E}-08$ \\
\hline Borracha & $8,37599 \mathrm{E}-07$ & $4,80135 \mathrm{E}-07$ & 2,29033E-06 & $2,04065 \mathrm{E}-06$ & $1,05273 \mathrm{E}-06$ & $2,36842 \mathrm{E}-06$ & $6,59925 \mathrm{E}-07$ & $5,48679 \mathrm{E}-06$ & $8,68373 \mathrm{E}-07$ & $2,07755 \mathrm{E}-08$ \\
\hline Cimento & $8,90295 \mathrm{E}-08$ & 2,65707E-08 & $3,45335 \mathrm{E}-08$ & $1,81856 \mathrm{E}-08$ & $8,55523 \mathrm{E}-08$ & 6,66691E-08 & 3,13391E-08 & 7,70167E-08 & 1,79067E-07 & $8,62724 \mathrm{E}-10$ \\
\hline Aço & 0,00012326 & $1,00596 \mathrm{E}-06$ & $1,84215 \mathrm{E}-05$ & $1,33401 \mathrm{E}-06$ & $3,63159 \mathrm{E}-06$ & $3,20884 \mathrm{E}-06$ & $3,66966 \mathrm{E}-07$ & $1,01412 \mathrm{E}-05$ & 3,7414E-07 & $1,16627 \mathrm{E}-08$ \\
\hline Metal & $1,17212 \mathrm{E}-06$ & $3,00901 \mathrm{E}-05$ & $1,88689 \mathrm{E}-06$ & $7,07775 \mathrm{E}-07$ & $1,31128 \mathrm{E}-06$ & $1,16768 \mathrm{E}-06$ & $8,03747 \mathrm{E}-07$ & $8,41863 \mathrm{E}-07$ & $6,47148 \mathrm{E}-07$ & $3,29038 \mathrm{E}-09$ \\
\hline Eletrodomésticos & $1,21983 \mathrm{E}-06$ & $1,40177 \mathrm{E}-07$ & 0,000468781 & $1,29954 \mathrm{E}-06$ & 5,99775E-07 & $8,76905 \mathrm{E}-07$ & $2,61218 \mathrm{E}-07$ & $5,49381 \mathrm{E}-06$ & $9,09364 \mathrm{E}-08$ & $1,46976 \mathrm{E}-08$ \\
\hline Informática & $1,54033 \mathrm{E}-09$ & $8,30256 \mathrm{E}-10$ & $7,96085 \mathrm{E}-09$ & 0,00033721 & 4,93806E-09 & $1,68905 \mathrm{E}-07$ & $1,0715 \mathrm{E}-09$ & $1,04054 \mathrm{E}-08$ & $8,44319 \mathrm{E}-10$ & $1,67611 \mathrm{E}-10$ \\
\hline Máquinas & $1,79456 \mathrm{E}-07$ & $4,90662 \mathrm{E}-08$ & 3,70544E-06 & 8,86763E-06 & 0,000145029 & $1,62959 \mathrm{E}-05$ & $1,08089 \mathrm{E}-06$ & 2,42294E-06 & $3,62045 \mathrm{E}-07$ & $2,75205 \mathrm{E}-07$ \\
\hline
\end{tabular}




\begin{tabular}{|c|c|c|c|c|c|c|c|c|c|c|}
\hline Eletrônicos & $2,79706 \mathrm{E}-08$ & $1,67734 \mathrm{E}-08$ & 7,05995E-07 & $8,25913 \mathrm{E}-05$ & $6,88579 \mathrm{E}-07$ & 0,00040706 & $8,16848 \mathrm{E}-08$ & $6,5657 \mathrm{E}-07$ & $3,42021 \mathrm{E}-08$ & $1,32764 \mathrm{E}-08$ \\
\hline Instrumento hospitalar & $2,01644 \mathrm{E}-09$ & $1,10853 \mathrm{E}-09$ & $3,05784 \mathrm{E}-07$ & 3,99783E-08 & $1,18742 \mathrm{E}-07$ & $5,57799 \mathrm{E}-08$ & $9,59301 \mathrm{E}-05$ & $5,10417 \mathrm{E}-08$ & $5,24649 \mathrm{E}-09$ & $1,159 \mathrm{E}-09$ \\
\hline Veículos & $4,65729 \mathrm{E}-07$ & $2,94229 \mathrm{E}-07$ & $2,10069 \mathrm{E}-06$ & $1,48402 \mathrm{E}-06$ & $1,69536 \mathrm{E}-06$ & 2,69294E-06 & $3,56898 \mathrm{E}-07$ & 0,000742345 & 2,12373E-07 & 4,52938E-08 \\
\hline Indústria Diversa & $1,74095 \mathrm{E}-07$ & $1,28274 \mathrm{E}-08$ & $4,04629 \mathrm{E}-08$ & 7,65797E-09 & $2,34947 \mathrm{E}-08$ & $1,24615 \mathrm{E}-08$ & 3,32024E-09 & $2,0903 \mathrm{E}-08$ & $4,36236 \mathrm{E}-05$ & $1,0876 \mathrm{E}-09$ \\
\hline SIUP & $3,21792 \mathrm{E}-07$ & $1,56922 \mathrm{E}-07$ & $1,56201 \mathrm{E}-07$ & $1,04592 \mathrm{E}-07$ & $1,83382 \mathrm{E}-07$ & $1,278 \mathrm{E}-07$ & $1,33653 \mathrm{E}-07$ & $1,36937 \mathrm{E}-07$ & $9,75059 \mathrm{E}-08$ & $1,45691 \mathrm{E}-05$ \\
\hline Construção & 1,11934E-09 & $7,52174 \mathrm{E}-10$ & $1,52144 \mathrm{E}-09$ & 2,23977E-09 & $3,09356 \mathrm{E}-09$ & 4,67456E-09 & $7,09206 \mathrm{E}-10$ & $4,95759 \mathrm{E}-09$ & $9,08969 \mathrm{E}-10$ & $7,02626 \mathrm{E}-10$ \\
\hline Comércio & 3,53333E-08 & $3,09462 \mathrm{E}-08$ & $5,19883 \mathrm{E}-08$ & $1,17031 \mathrm{E}-07$ & $4,63488 \mathrm{E}-08$ & $8,7414 \mathrm{E}-08$ & 4,66861E-08 & 6,65983E-08 & $5,4067 \mathrm{E}-08$ & $1,47569 \mathrm{E}-08$ \\
\hline Transportes & $8,59183 \mathrm{E}-08$ & $4,93032 \mathrm{E}-08$ & $6,78445 \mathrm{E}-08$ & 7,60917E-08 & $6,49092 \mathrm{E}-08$ & $9,44617 \mathrm{E}-08$ & $5,15424 \mathrm{E}-08$ & $5,94685 \mathrm{E}-08$ & 3,19437E-08 & $2,61024 \mathrm{E}-08$ \\
\hline Informação & 3,1974E-08 & $1,42205 \mathrm{E}-08$ & $3,57669 \mathrm{E}-08$ & $5,14183 \mathrm{E}-08$ & $4,3882 \mathrm{E}-08$ & $7,56516 \mathrm{E}-08$ & $2,31729 \mathrm{E}-08$ & $2,86026 \mathrm{E}-08$ & 7,76987E-09 & $2,70567 \mathrm{E}-08$ \\
\hline Financeiro & $1,019 \mathrm{E}-07$ & $6,00322 \mathrm{E}-08$ & $1,29821 \mathrm{E}-07$ & $9,06681 \mathrm{E}-08$ & $9,27498 \mathrm{E}-08$ & $1,59767 \mathrm{E}-07$ & $6,44786 \mathrm{E}-08$ & $8,90521 \mathrm{E}-08$ & $3,81604 \mathrm{E}-08$ & $3,43154 \mathrm{E}-08$ \\
\hline Imobiliário & $1,14046 \mathrm{E}-08$ & $9,6775 \mathrm{E}-09$ & $1,50797 \mathrm{E}-08$ & $1,61699 \mathrm{E}-08$ & $1,19631 \mathrm{E}-08$ & $1,59959 \mathrm{E}-08$ & $1,4072 \mathrm{E}-08$ & $1,05268 \mathrm{E}-08$ & 9,17798E-09 & $8,258 \mathrm{E}-09$ \\
\hline Alojamento & $1,89978 \mathrm{E}-09$ & $7,241 \mathrm{E}-10$ & $1,04604 \mathrm{E}-09$ & $1,51266 \mathrm{E}-09$ & $2,24458 \mathrm{E}-09$ & $1,51137 \mathrm{E}-09$ & $6,50416 \mathrm{E}-10$ & $2,0068 \mathrm{E}-09$ & 1,35164E-09 & $5,55536 \mathrm{E}-10$ \\
\hline Serviços às Empresas & $1,69394 \mathrm{E}-08$ & $1,65072 \mathrm{E}-08$ & $1,97838 \mathrm{E}-08$ & $8,84978 \mathrm{E}-08$ & $2,82104 \mathrm{E}-08$ & $6,23752 \mathrm{E}-08$ & $2,26545 \mathrm{E}-08$ & $3,7888 \mathrm{E}-08$ & $1,30341 \mathrm{E}-08$ & 4,81164E-08 \\
\hline Educação e Saúde mercantis & $1,19028 \mathrm{E}-09$ & $1,20268 \mathrm{E}-09$ & $1,76606 \mathrm{E}-09$ & $2,46078 \mathrm{E}-09$ & $1,51298 \mathrm{E}-09$ & $2,26028 \mathrm{E}-09$ & $1,50472 \mathrm{E}-09$ & $1,52551 \mathrm{E}-09$ & $1,38087 \mathrm{E}-09$ & $9,4697 \mathrm{E}-10$ \\
\hline Outros Serviços & $3,90048 \mathrm{E}-09$ & $3,5491 \mathrm{E}-09$ & 5,21194E-09 & $1,02384 \mathrm{E}-08$ & 7,44063E-09 & $9,44127 \mathrm{E}-09$ & $4,23468 \mathrm{E}-09$ & $5,51333 \mathrm{E}-09$ & 4,34742E-09 & $4,14742 \mathrm{E}-09$ \\
\hline APU & $3,91567 \mathrm{E}-10$ & $2,69221 \mathrm{E}-10$ & $3,16748 \mathrm{E}-10$ & $8,13964 \mathrm{E}-10$ & $3,52398 \mathrm{E}-10$ & $6,46648 \mathrm{E}-10$ & $3,13541 \mathrm{E}-10$ & $4,37087 \mathrm{E}-10$ & $2,02249 \mathrm{E}-10$ & $7,2655 \mathrm{E}-10$ \\
\hline
\end{tabular}

Tabela C6 - Matriz Geração de Renda para o Grau de Instrução G(5), Distrito Federal - 2008.

(3)

\begin{tabular}{|c|c|c|c|c|c|c|c|c|c|c|c|}
\hline Setores & Construção & Comércio & Transportes & Informação & Financeiro & Imobiliário & Alojamento & $\begin{array}{l}\text { Serviços às } \\
\text { Empresas }\end{array}$ & $\begin{array}{l}\text { Educação e } \\
\text { Saúde } \\
\text { mercantis }\end{array}$ & $\begin{array}{c}\text { Outros } \\
\text { Serviços }\end{array}$ & APU \\
\hline Agricultura & $1,09338 \mathrm{E}-09$ & 3,39227E-09 & 2,56603E-09 & $1,55653 \mathrm{E}-09$ & $1,00789 \mathrm{E}-09$ & $2,13614 \mathrm{E}-10$ & $3,41267 \mathrm{E}-07$ & $1,54545 \mathrm{E}-09$ & $8,13594 \mathrm{E}-09$ & $3,51465 \mathrm{E}-08$ & 4,34367E-09 \\
\hline Pecuária & $4,1825 \mathrm{E}-10$ & $1,22918 \mathrm{E}-09$ & $1,0944 \mathrm{E}-09$ & $5,41689 \mathrm{E}-10$ & $4,14694 \mathrm{E}-10$ & $7,01253 \mathrm{E}-11$ & $1,61879 \mathrm{E}-07$ & $5,41679 \mathrm{E}-10$ & $3,60288 \mathrm{E}-09$ & $1,75895 \mathrm{E}-08$ & $1,68735 \mathrm{E}-09$ \\
\hline Extrativa & $2,87758 \mathrm{E}-08$ & $1,50004 \mathrm{E}-08$ & $9,24442 \mathrm{E}-09$ & $1,73713 \mathrm{E}-08$ & $5,18425 \mathrm{E}-09$ & $2,87066 \mathrm{E}-09$ & $1,36394 \mathrm{E}-08$ & $1,38614 \mathrm{E}-08$ & $1,36387 \mathrm{E}-08$ & $1,28704 \mathrm{E}-08$ & $1,41326 \mathrm{E}-08$ \\
\hline Alimentos & 4,23287E-09 & $1,31526 \mathrm{E}-08$ & $1,16174 \mathrm{E}-08$ & $4,60366 \mathrm{E}-09$ & $3,78506 \mathrm{E}-09$ & $6,3783 \mathrm{E}-10$ & $1,65693 \mathrm{E}-06$ & $4,41565 \mathrm{E}-09$ & $2,68961 \mathrm{E}-08$ & $6,16264 \mathrm{E}-08$ & $1,22851 \mathrm{E}-08$ \\
\hline Vestuário & 7,93917E-09 & $1,77921 \mathrm{E}-08$ & $3,73048 \mathrm{E}-08$ & $1,73716 \mathrm{E}-08$ & $1,42159 \mathrm{E}-08$ & $1,88105 \mathrm{E}-09$ & $2,06407 \mathrm{E}-08$ & $5,08696 \mathrm{E}-08$ & $3,27941 \mathrm{E}-08$ & 7,3343E-08 & $1,42876 \mathrm{E}-08$ \\
\hline Madeira & $1,50646 \mathrm{E}-08$ & 5,34516E-09 & 3,58534E-09 & $7,0942 \mathrm{E}-09$ & $4,01092 \mathrm{E}-09$ & $5,23911 \mathrm{E}-09$ & 4,37419E-09 & $5,9001 \mathrm{E}-09$ & $7,83421 \mathrm{E}-09$ & $8,26836 \mathrm{E}-09$ & $1,18263 \mathrm{E}-08$ \\
\hline
\end{tabular}




\begin{tabular}{|c|c|c|c|c|c|c|c|c|c|c|c|}
\hline Celulose & 7,68177E-09 & $3,08089 \mathrm{E}-08$ & $1,94752 \mathrm{E}-08$ & $3,92096 \mathrm{E}-08$ & $1,32783 \mathrm{E}-08$ & $5,16788 \mathrm{E}-09$ & $1,92944 \mathrm{E}-08$ & $5,12813 \mathrm{E}-08$ & $2,74484 \mathrm{E}-08$ & $2,59026 \mathrm{E}-08$ & $2,58058 \mathrm{E}-08$ \\
\hline Revistas & $1,47666 \mathrm{E}-08$ & $5,31595 \mathrm{E}-08$ & 4,48015E-08 & $1,24153 \mathrm{E}-07$ & $6,42858 \mathrm{E}-08$ & $1,39723 \mathrm{E}-08$ & $1,47111 \mathrm{E}-08$ & $3,94622 \mathrm{E}-07$ & $6,44197 \mathrm{E}-08$ & $6,82006 \mathrm{E}-08$ & $3,74841 \mathrm{E}-08$ \\
\hline Químicos & $9,81114 \mathrm{E}-09$ & 5,19334E-09 & 3,6682E-09 & $9,55604 \mathrm{E}-09$ & 2,18293E-09 & 1,42249E-09 & $7,12518 \mathrm{E}-08$ & 5,93959E-09 & $6,82273 \mathrm{E}-08$ & $1,33808 \mathrm{E}-08$ & $1,03157 \mathrm{E}-08$ \\
\hline Borracha & $8,61399 \mathrm{E}-08$ & $3,43432 \mathrm{E}-08$ & 2,88939E-08 & $7,05595 \mathrm{E}-08$ & $1,1287 \mathrm{E}-08$ & $6,441 \mathrm{E}-09$ & $4,68639 \mathrm{E}-08$ & $1,02255 \mathrm{E}-07$ & $8,93101 \mathrm{E}-08$ & $2,84965 \mathrm{E}-08$ & $1,35627 \mathrm{E}-08$ \\
\hline Cimento & 3,63051E-07 & $1,29955 \mathrm{E}-09$ & $5,58259 \mathrm{E}-10$ & $1,60839 \mathrm{E}-09$ & $1,50387 \mathrm{E}-09$ & 3,21076E-09 & 2,53337E-09 & $1,20836 \mathrm{E}-09$ & $1,19841 \mathrm{E}-08$ & $6,31821 \mathrm{E}-09$ & $5,99898 \mathrm{E}-09$ \\
\hline Aço & $3,42853 \mathrm{E}-08$ & $5,02679 \mathrm{E}-09$ & 3,93786E-09 & 6,89257E-09 & $1,97699 \mathrm{E}-09$ & $1,85025 \mathrm{E}-09$ & $9,30662 \mathrm{E}-09$ & 4,82293E-09 & $5,82489 \mathrm{E}-09$ & 6,51497E-09 & 4,66422E-09 \\
\hline Metal & $8,08814 \mathrm{E}-08$ & $7,80848 \mathrm{E}-09$ & $1,83242 \mathrm{E}-09$ & $4,26059 \mathrm{E}-09$ & $1,24948 \mathrm{E}-09$ & $3,0552 \mathrm{E}-09$ & $3,45496 \mathrm{E}-08$ & 2,17412E-09 & 8,19199E-09 & $5,20854 \mathrm{E}-09$ & $5,43589 \mathrm{E}-09$ \\
\hline Eletrodomésticos & $1,82366 \mathrm{E}-08$ & $1,74596 \mathrm{E}-08$ & $1,18813 \mathrm{E}-08$ & 2,20094E-08 & $6,11895 \mathrm{E}-09$ & 4,59596E-09 & $1,40266 \mathrm{E}-08$ & $1,72177 \mathrm{E}-08$ & $1,63195 \mathrm{E}-08$ & $1,65052 \mathrm{E}-08$ & $1,67139 \mathrm{E}-08$ \\
\hline Informática & $6,72966 \mathrm{E}-10$ & $5,59337 \mathrm{E}-10$ & $2,90275 \mathrm{E}-10$ & $1,07429 \mathrm{E}-09$ & $3,61862 \mathrm{E}-10$ & $4,9676 \mathrm{E}-10$ & $2,97253 \mathrm{E}-10$ & $6,40919 \mathrm{E}-10$ & $7,88385 \mathrm{E}-10$ & $6,37099 \mathrm{E}-10$ & 1,10737E-09 \\
\hline Máquinas & $7,55465 \mathrm{E}-08$ & $1,59332 \mathrm{E}-08$ & $4,68928 \mathrm{E}-08$ & $6,83452 \mathrm{E}-08$ & $8,52783 \mathrm{E}-09$ & $1,85305 \mathrm{E}-08$ & $1,26461 \mathrm{E}-08$ & $2,37925 \mathrm{E}-08$ & $2,11762 \mathrm{E}-08$ & $7,53917 \mathrm{E}-08$ & $1,34241 \mathrm{E}-08$ \\
\hline Eletrônicos & 4,86935E-09 & $3,22533 \mathrm{E}-09$ & $4,01618 \mathrm{E}-09$ & $6,83085 \mathrm{E}-09$ & $1,50975 \mathrm{E}-09$ & $1,87342 \mathrm{E}-09$ & $2,34659 \mathrm{E}-09$ & $4,58589 \mathrm{E}-09$ & $3,1451 \mathrm{E}-09$ & $5,73559 \mathrm{E}-09$ & $2,98624 \mathrm{E}-09$ \\
\hline Instrumento hospitalar & $6,49516 \mathrm{E}-09$ & $3,92523 \mathrm{E}-09$ & $1,24486 \mathrm{E}-09$ & $1,61852 \mathrm{E}-09$ & $9,12086 \mathrm{E}-10$ & 7,39918E-09 & $7,91875 \mathrm{E}-10$ & $1,05326 \mathrm{E}-08$ & $1,09332 \mathrm{E}-08$ & $8,32967 \mathrm{E}-09$ & 2,26542E-09 \\
\hline Veículos & $3,62149 \mathrm{E}-08$ & $2,00706 \mathrm{E}-08$ & $1,75786 \mathrm{E}-08$ & $3,04223 \mathrm{E}-08$ & 7,95531E-09 & $7,64295 \mathrm{E}-09$ & $1,87932 \mathrm{E}-08$ & $2,04561 \mathrm{E}-08$ & $1,98955 \mathrm{E}-08$ & $2,65946 \mathrm{E}-08$ & $1,99539 \mathrm{E}-08$ \\
\hline Indústria Diversa & $1,43491 \mathrm{E}-08$ & $1,95548 \mathrm{E}-09$ & $1,22976 \mathrm{E}-08$ & $2,41308 \mathrm{E}-09$ & $2,17328 \mathrm{E}-08$ & $5,43405 \mathrm{E}-09$ & 2,40044E-09 & 7,94919E-09 & 7,87616E-09 & 3,97392E-08 & $8,6818 \mathrm{E}-09$ \\
\hline SIUP & $3,18367 \mathrm{E}-08$ & $1,09085 \mathrm{E}-07$ & $9,04576 \mathrm{E}-08$ & $8,50068 \mathrm{E}-08$ & $5,12977 \mathrm{E}-08$ & $1,08051 \mathrm{E}-08$ & $1,10272 \mathrm{E}-07$ & $9,57322 \mathrm{E}-08$ & $1,40953 \mathrm{E}-07$ & 3,17139E-07 & $1,21406 \mathrm{E}-07$ \\
\hline Construção & $1,67591 \mathrm{E}-06$ & $1,91787 \mathrm{E}-09$ & $1,49086 \mathrm{E}-09$ & $6,10733 \mathrm{E}-09$ & $6,04244 \mathrm{E}-09$ & $1,4446 \mathrm{E}-08$ & $1,02644 \mathrm{E}-09$ & $4,30375 \mathrm{E}-09$ & $1,29003 \mathrm{E}-08$ & $1,11364 \mathrm{E}-08$ & $2,51917 \mathrm{E}-08$ \\
\hline Comércio & $4,84256 \mathrm{E}-08$ & $9,09575 \mathrm{E}-07$ & 4,03297E-08 & $2,00395 \mathrm{E}-08$ & $1,19805 \mathrm{E}-08$ & $5,28734 \mathrm{E}-09$ & $9,28379 \mathrm{E}-08$ & $3,47403 \mathrm{E}-08$ & $3,09137 \mathrm{E}-08$ & $3,34254 \mathrm{E}-08$ & $1,77151 \mathrm{E}-08$ \\
\hline Transportes & $2,44418 \mathrm{E}-08$ & $6,4308 \mathrm{E}-08$ & $1,96417 \mathrm{E}-06$ & $4,36238 \mathrm{E}-08$ & $1,83437 \mathrm{E}-08$ & $3,26276 \mathrm{E}-09$ & $2,9436 \mathrm{E}-08$ & $3,46559 \mathrm{E}-08$ & $3,11413 \mathrm{E}-08$ & 4,60307E-08 & $1,6719 \mathrm{E}-08$ \\
\hline Informação & $8,85571 \mathrm{E}-09$ & $2,79115 \mathrm{E}-08$ & $2,91812 \mathrm{E}-08$ & $2,08936 \mathrm{E}-06$ & $8,5137 \mathrm{E}-08$ & $5,75615 \mathrm{E}-09$ & $1,39431 \mathrm{E}-08$ & $2,26305 \mathrm{E}-07$ & $7,78237 \mathrm{E}-08$ & $5,0963 \mathrm{E}-08$ & $9,43554 \mathrm{E}-08$ \\
\hline Financeiro & $2,7631 \mathrm{E}-08$ & $5,48423 \mathrm{E}-08$ & $7,58339 \mathrm{E}-08$ & 7,71978E-08 & $2,18972 \mathrm{E}-06$ & $1,11563 \mathrm{E}-08$ & $2,85233 \mathrm{E}-08$ & $7,30635 \mathrm{E}-08$ & $3,22582 \mathrm{E}-08$ & $1,79545 \mathrm{E}-08$ & $1,70864 \mathrm{E}-07$ \\
\hline Imobiliário & 6,79882E-09 & $3,42265 \mathrm{E}-08$ & 6,09957E-08 & $5,52589 \mathrm{E}-08$ & $1,75277 \mathrm{E}-08$ & $1,6251 \mathrm{E}-06$ & $2,10612 \mathrm{E}-08$ & $3,98894 \mathrm{E}-08$ & $4,14944 \mathrm{E}-08$ & $2,97346 \mathrm{E}-08$ & $3,13842 \mathrm{E}-08$ \\
\hline Alojamento & $1,89795 \mathrm{E}-09$ & $2,63752 \mathrm{E}-09$ & $5,13541 \mathrm{E}-09$ & $3,46319 \mathrm{E}-09$ & $3,33071 \mathrm{E}-09$ & $3,67511 \mathrm{E}-10$ & $2,03731 \mathrm{E}-06$ & $2,98784 \mathrm{E}-09$ & $1,58393 \mathrm{E}-08$ & $1,80765 \mathrm{E}-08$ & $9,79062 \mathrm{E}-09$ \\
\hline Serviços às Empresas & $1,95347 \mathrm{E}-08$ & $5,44871 \mathrm{E}-08$ & $6,26114 \mathrm{E}-08$ & $8,92371 \mathrm{E}-08$ & $6,74925 \mathrm{E}-08$ & $1,05475 \mathrm{E}-08$ & $1,72568 \mathrm{E}-08$ & $1,07692 \mathrm{E}-06$ & $8,9831 \mathrm{E}-08$ & $5,71635 \mathrm{E}-08$ & $6,34779 \mathrm{E}-08$ \\
\hline Educação e Saúde mercantis & $1,05835 \mathrm{E}-09$ & $3,77124 \mathrm{E}-09$ & 2,49927E-09 & $4,21101 \mathrm{E}-09$ & $4,34256 \mathrm{E}-09$ & $5,43862 \mathrm{E}-10$ & 3,0067E-09 & $3,58486 \mathrm{E}-09$ & $1,89929 \mathrm{E}-06$ & $2,87348 \mathrm{E}-09$ & $5,92788 \mathrm{E}-09$ \\
\hline Outros Serviços & 3,87971E-09 & $1,02575 \mathrm{E}-08$ & $6,41321 \mathrm{E}-09$ & $1,1431 \mathrm{E}-08$ & $5,87269 \mathrm{E}-09$ & $1,14529 \mathrm{E}-09$ & $1,11857 \mathrm{E}-08$ & $1,36574 \mathrm{E}-08$ & $1,01066 \mathrm{E}-08$ & $1,43848 \mathrm{E}-06$ & $7,24098 \mathrm{E}-09$ \\
\hline APU & $2,07676 \mathrm{E}-10$ & $5,58411 \mathrm{E}-10$ & $5,85812 \mathrm{E}-10$ & 7,53541E-10 & $5,39429 \mathrm{E}-10$ & 8,92993E-11 & $2,64354 \mathrm{E}-10$ & $6,70629 \mathrm{E}-10$ & $7,3605 \mathrm{E}-10$ & $5,68822 \mathrm{E}-10$ & $1,82748 \mathrm{E}-07$ \\
\hline
\end{tabular}


Tabela C7 - Matriz Geração de Renda para o Grau de Instrução G(6), Distrito Federal - 2008.

(1)

\begin{tabular}{|c|c|c|c|c|c|c|c|c|c|c|c|}
\hline Setores & Agricultura & Pecuária & Extrativa & Alimentos & Vestuário & Madeira & Celulose & Revistas & Químicos & Borracha & Cimento \\
\hline Agricultura & $2,35473 \mathrm{E}-05$ & $1,5449 \mathrm{E}-06$ & $2,56956 \mathrm{E}-09$ & $1,89714 \mathrm{E}-06$ & $2,37325 \mathrm{E}-08$ & $3,73062 \mathrm{E}-08$ & $1,07738 \mathrm{E}-07$ & $1,05095 \mathrm{E}-09$ & $4,7312 \mathrm{E}-09$ & $8,0181 \mathrm{E}-08$ & $1,8391 \mathrm{E}-09$ \\
\hline Pecuária & $1,60201 \mathrm{E}-07$ & $4,09744 \mathrm{E}-05$ & $1,20442 \mathrm{E}-09$ & $1,62083 \mathrm{E}-06$ & $3,38389 \mathrm{E}-08$ & 2,84109E-09 & $9,33453 \mathrm{E}-09$ & $4,54949 \mathrm{E}-10$ & $2,9548 \mathrm{E}-09$ & $1,37888 \mathrm{E}-08$ & $1,12437 \mathrm{E}-09$ \\
\hline Extrativa & $4,79201 \mathrm{E}-08$ & $1,13597 \mathrm{E}-07$ & 0,000660198 & $2,70255 \mathrm{E}-08$ & $2,48365 \mathrm{E}-08$ & $3,41932 \mathrm{E}-08$ & $2,64444 \mathrm{E}-07$ & 6,32891E-09 & $4,01924 \mathrm{E}-07$ & $8,54993 \mathrm{E}-08$ & $2,98704 \mathrm{E}-07$ \\
\hline Alimentos & $1,77926 \mathrm{E}-07$ & $2,70189 \mathrm{E}-06$ & $9,33327 \mathrm{E}-09$ & $1,62898 \mathrm{E}-05$ & $1,2291 \mathrm{E}-07$ & $1,27262 \mathrm{E}-08$ & $3,97817 \mathrm{E}-08$ & $3,45043 \mathrm{E}-09$ & $1,50302 \mathrm{E}-08$ & $5,03132 \mathrm{E}-09$ & $9,12717 \mathrm{E}-09$ \\
\hline Vestuário & 6,00557E-09 & $5,31476 \mathrm{E}-09$ & $1,77198 \mathrm{E}-07$ & 7,7461E-09 & 0,000317912 & 7,20347E-09 & $2,54439 \mathrm{E}-07$ & $8,15322 \mathrm{E}-09$ & $1,62482 \mathrm{E}-08$ & 4,76139E-08 & $1,12611 \mathrm{E}-08$ \\
\hline Madeira & $4,60831 \mathrm{E}-08$ & $9,03349 \mathrm{E}-09$ & $2,51231 \mathrm{E}-08$ & $1,07801 \mathrm{E}-08$ & $4,48625 \mathrm{E}-08$ & 0,00077408 & $4,6702 \mathrm{E}-06$ & 7,73874E-09 & $1,41554 \mathrm{E}-07$ & $3,8428 \mathrm{E}-08$ & $4,36666 \mathrm{E}-08$ \\
\hline Celulose & $3,21738 \mathrm{E}-08$ & $3,5199 \mathrm{E}-08$ & $8,41889 \mathrm{E}-07$ & $4,11215 \mathrm{E}-08$ & $1,95654 \mathrm{E}-06$ & $3,22139 \mathrm{E}-06$ & 0,001314775 & 2,05391E-07 & $5,368 \mathrm{E}-07$ & $1,55502 \mathrm{E}-06$ & $2,73153 \mathrm{E}-08$ \\
\hline Revistas & $1,69823 \mathrm{E}-08$ & $1,89335 \mathrm{E}-08$ & $4,37755 \mathrm{E}-08$ & $3,12475 \mathrm{E}-08$ & $1,64819 \mathrm{E}-08$ & $1,01481 \mathrm{E}-08$ & $1,88457 \mathrm{E}-07$ & 4,09296E-05 & $2,6863 \mathrm{E}-07$ & $1,0561 \mathrm{E}-07$ & $3,59761 \mathrm{E}-08$ \\
\hline Químicos & $5,04795 \mathrm{E}-06$ & $3,51102 \mathrm{E}-06$ & $1,17304 \mathrm{E}-06$ & $6,56841 \mathrm{E}-07$ & $3,61054 \mathrm{E}-07$ & 6,69287E-07 & $3,04391 \mathrm{E}-06$ & 2,02949E-08 & 0,000130635 & $1,77422 \mathrm{E}-06$ & $1,66157 \mathrm{E}-07$ \\
\hline Borracha & $1,62787 \mathrm{E}-07$ & $1,04319 \mathrm{E}-07$ & 1,33971E-06 & $2,89119 \mathrm{E}-07$ & $3,80487 \mathrm{E}-07$ & $7,08046 \mathrm{E}-07$ & $1,76578 \mathrm{E}-06$ & $2,22535 \mathrm{E}-07$ & $5,2422 \mathrm{E}-07$ & 0,00014871 & $1,78204 \mathrm{E}-08$ \\
\hline Cimento & $1,49119 \mathrm{E}-08$ & 7,61311E-09 & $1,75923 \mathrm{E}-08$ & $2,548 \mathrm{E}-08$ & 6,70569E-09 & $2,91248 \mathrm{E}-09$ & $2,27844 \mathrm{E}-08$ & 2,38926E-09 & $9,37292 \mathrm{E}-08$ & $6,9784 \mathrm{E}-09$ & $1,48282 \mathrm{E}-05$ \\
\hline Aço & $1,07274 \mathrm{E}-07$ & $5,1698 \mathrm{E}-08$ & $5,60882 \mathrm{E}-07$ & $5,89911 \mathrm{E}-08$ & $3,25649 \mathrm{E}-08$ & $2,86292 \mathrm{E}-07$ & $5,66643 \mathrm{E}-07$ & $4,8934 \mathrm{E}-09$ & $1,49128 \mathrm{E}-07$ & $8,2323 \mathrm{E}-07$ & $5,73993 \mathrm{E}-08$ \\
\hline Metal & $1,98087 \mathrm{E}-07$ & $1,3958 \mathrm{E}-07$ & $6,41859 \mathrm{E}-07$ & $3,44548 \mathrm{E}-07$ & $5,53453 \mathrm{E}-08$ & $3,34609 \mathrm{E}-07$ & $5,98169 \mathrm{E}-07$ & $3,71227 \mathrm{E}-09$ & $2,90887 \mathrm{E}-07$ & $3,30563 \mathrm{E}-07$ & $5,2244 \mathrm{E}-08$ \\
\hline Eletrodomésticos & $3,17775 \mathrm{E}-08$ & $2,16833 \mathrm{E}-08$ & $1,29238 \mathrm{E}-06$ & $3,64523 \mathrm{E}-08$ & $3,32706 \mathrm{E}-07$ & $5,73341 \mathrm{E}-07$ & $2,45357 \mathrm{E}-06$ & $9,79225 \mathrm{E}-09$ & $1,82731 \mathrm{E}-07$ & $2,47483 \mathrm{E}-07$ & $1,91522 \mathrm{E}-08$ \\
\hline Informática & $1,94124 \mathrm{E}-09$ & $1,54446 \mathrm{E}-09$ & $1,30978 \mathrm{E}-08$ & $2,12607 \mathrm{E}-09$ & $1,10054 \mathrm{E}-08$ & $5,80188 \mathrm{E}-09$ & $6,35746 \mathrm{E}-08$ & 7,98057E-09 & $2,81786 \mathrm{E}-08$ & $2,99109 \mathrm{E}-08$ & $1,56418 \mathrm{E}-09$ \\
\hline Máquinas & $1,82223 \mathrm{E}-08$ & $3,31174 \mathrm{E}-08$ & $5,49353 \mathrm{E}-07$ & $6,16041 \mathrm{E}-08$ & $6,14486 \mathrm{E}-08$ & $1,28885 \mathrm{E}-07$ & $1,28039 \mathrm{E}-07$ & $8,00104 \mathrm{E}-09$ & $1,54658 \mathrm{E}-07$ & 4,63976E-07 & $1,14665 \mathrm{E}-07$ \\
\hline Eletrônicos & $2,55653 \mathrm{E}-09$ & 2,90022E-09 & $2,92093 \mathrm{E}-07$ & $5,81233 \mathrm{E}-09$ & 5,85377E-09 & $9,56915 \mathrm{E}-09$ & $1,94981 \mathrm{E}-08$ & 3,35812E-09 & $1,21544 \mathrm{E}-08$ & $2,38931 \mathrm{E}-08$ & 6,50954E-09 \\
\hline Instrumento hospitalar & $1,07562 \mathrm{E}-09$ & $1,18507 \mathrm{E}-09$ & $5,31201 \mathrm{E}-09$ & $1,56664 \mathrm{E}-09$ & $2,08346 \mathrm{E}-09$ & $2,22743 \mathrm{E}-09$ & $1,22193 \mathrm{E}-08$ & 2,38203E-09 & $1,2937 \mathrm{E}-08$ & $2,48851 \mathrm{E}-08$ & $1,91289 \mathrm{E}-09$ \\
\hline Veículos & $5,9493 \mathrm{E}-08$ & $4,86835 \mathrm{E}-08$ & $3,52335 \mathrm{E}-07$ & $1,13043 \mathrm{E}-07$ & $6,07615 \mathrm{E}-08$ & $1,46551 \mathrm{E}-07$ & $2,85956 \mathrm{E}-07$ & $1,86763 \mathrm{E}-08$ & $1,3475 \mathrm{E}-07$ & $2,96108 \mathrm{E}-07$ & $5,34136 \mathrm{E}-08$ \\
\hline Indústria Diversa & $1,4989 \mathrm{E}-09$ & $1,38943 \mathrm{E}-08$ & 4,04606E-09 & $9,41487 \mathrm{E}-09$ & $1,47903 \mathrm{E}-07$ & $4,36239 \mathrm{E}-09$ & $8,01387 \mathrm{E}-08$ & $1,7439 \mathrm{E}-09$ & 3,98352E-09 & $2,84653 \mathrm{E}-08$ & 3,80683E-09 \\
\hline SIUP & $9,18078 \mathrm{E}-08$ & $1,41701 \mathrm{E}-07$ & $3,68407 \mathrm{E}-07$ & $2,26931 \mathrm{E}-07$ & $1,85704 \mathrm{E}-07$ & $1,92913 \mathrm{E}-07$ & $5,69686 \mathrm{E}-07$ & $1,51143 \mathrm{E}-07$ & $2,75192 \mathrm{E}-07$ & $2,84573 \mathrm{E}-07$ & $7,5049 \mathrm{E}-07$ \\
\hline Construção & $3,9696 \mathrm{E}-10$ & $5,63903 \mathrm{E}-10$ & $1,0204 \mathrm{E}-09$ & $1,30934 \mathrm{E}-09$ & $1,17622 \mathrm{E}-09$ & $1,03901 \mathrm{E}-09$ & $1,87062 \mathrm{E}-09$ & 1,48072E-09 & 2,09576E-09 & $3,40368 \mathrm{E}-09$ & 4,64199E-09 \\
\hline Comércio & $4,93928 \mathrm{E}-08$ & $7,28862 \mathrm{E}-08$ & $4,34405 \mathrm{E}-08$ & $7,81535 \mathrm{E}-08$ & $8,20923 \mathrm{E}-08$ & $3,3526 \mathrm{E}-08$ & 4,28903E-08 & 4,44164E-08 & $6,0951 \mathrm{E}-08$ & $4,75029 \mathrm{E}-08$ & $7,62249 \mathrm{E}-08$ \\
\hline Transportes & $5,8621 \mathrm{E}-08$ & $5,33384 \mathrm{E}-08$ & $1,56694 \mathrm{E}-07$ & $9,99817 \mathrm{E}-08$ & $4,64702 \mathrm{E}-08$ & $5,03133 \mathrm{E}-08$ & $8,52335 \mathrm{E}-08$ & $4,90011 \mathrm{E}-08$ & $9,26842 \mathrm{E}-08$ & $6,06073 \mathrm{E}-08$ & $1,87854 \mathrm{E}-07$ \\
\hline Informação & $9,02476 \mathrm{E}-09$ & $1,39906 \mathrm{E}-08$ & $4,11718 \mathrm{E}-08$ & $1,7582 \mathrm{E}-08$ & $1,00747 \mathrm{E}-08$ & 7,45313E-09 & $1,72069 \mathrm{E}-08$ & $4,13998 \mathrm{E}-08$ & $5,33075 \mathrm{E}-08$ & $2,37728 \mathrm{E}-08$ & $3,22612 \mathrm{E}-08$ \\
\hline
\end{tabular}




\begin{tabular}{|c|c|c|c|c|c|c|c|c|c|c|c|}
\hline Financeiro & $3,19888 \mathrm{E}-08$ & $3,54708 \mathrm{E}-08$ & 7,16791E-08 & $6,10422 \mathrm{E}-08$ & 4,88097E-08 & $4,52475 \mathrm{E}-08$ & $9,86898 \mathrm{E}-08$ & $5,59757 \mathrm{E}-08$ & $9,71822 \mathrm{E}-08$ & $7,05882 \mathrm{E}-08$ & $1,13509 \mathrm{E}-07$ \\
\hline Imobiliário & $6,34588 \mathrm{E}-09$ & $8,12694 \mathrm{E}-09$ & $1,92528 \mathrm{E}-08$ & $1,6241 \mathrm{E}-08$ & $1,80946 \mathrm{E}-08$ & 7,24191E-09 & $1,59998 \mathrm{E}-08$ & $2,52101 \mathrm{E}-08$ & $2,15824 \mathrm{E}-08$ & $1,34565 \mathrm{E}-08$ & $2,34485 \mathrm{E}-08$ \\
\hline Alojamento & $4,95995 \mathrm{E}-10$ & 6,99593E-10 & 4,52186E-09 & $1,23076 \mathrm{E}-09$ & $7,17618 \mathrm{E}-10$ & $1,4395 \mathrm{E}-09$ & $1,46702 \mathrm{E}-09$ & $1,94472 \mathrm{E}-09$ & $1,6299 \mathrm{E}-09$ & $1,44781 \mathrm{E}-09$ & $7,95808 \mathrm{E}-09$ \\
\hline Serviços às Empresas & $9,94848 \mathrm{E}-09$ & $1,43023 \mathrm{E}-08$ & $2,75768 \mathrm{E}-08$ & $3,36553 \mathrm{E}-08$ & $2,20812 \mathrm{E}-08$ & $1,17415 \mathrm{E}-08$ & $2,84756 \mathrm{E}-08$ & $7,75966 \mathrm{E}-08$ & $8,77515 \mathrm{E}-08$ & $2,37459 \mathrm{E}-08$ & $5,51195 \mathrm{E}-08$ \\
\hline Educação e Saúde mercantis & $9,2336 \mathrm{E}-10$ & $1,27665 \mathrm{E}-09$ & $1,87875 \mathrm{E}-09$ & $1,92434 \mathrm{E}-09$ & 2,34943E-09 & $8,62729 \mathrm{E}-10$ & $1,68902 \mathrm{E}-09$ & 2,05933E-09 & $2,06899 \mathrm{E}-09$ & $1,48078 \mathrm{E}-09$ & 2,13337E-09 \\
\hline Outros Serviços & 4,33307E-09 & 6,27961E-09 & $6,54217 \mathrm{E}-09$ & $8,28405 \mathrm{E}-09$ & $8,9053 \mathrm{E}-09$ & $3,28314 \mathrm{E}-09$ & $5,44388 \mathrm{E}-09$ & 6,39936E-09 & $8,82467 \mathrm{E}-09$ & $6,4436 \mathrm{E}-09$ & $1,02785 \mathrm{E}-08$ \\
\hline APU & $3,60628 \mathrm{E}-10$ & $4,30272 \mathrm{E}-10$ & $8,63814 \mathrm{E}-10$ & $7,97709 \mathrm{E}-10$ & $5,02744 \mathrm{E}-10$ & $3,39249 \mathrm{E}-10$ & $8,23636 \mathrm{E}-10$ & $1,52435 \mathrm{E}-09$ & $1,37888 \mathrm{E}-09$ & $5,84943 \mathrm{E}-10$ & $1,31723 \mathrm{E}-09$ \\
\hline
\end{tabular}

Tabela C7 - Matriz Geração de Renda para o Grau de Instrução G(6), Distrito Federal - 2008.

(2)

\begin{tabular}{|c|c|c|c|c|c|c|c|c|c|c|}
\hline Setores & Aço & Metal & Eletrodomésticos & Informática & Máquinas & Eletrônicos & $\begin{array}{l}\text { Instrumento } \\
\text { hospitalar }\end{array}$ & Veículos & $\begin{array}{l}\text { Indústria } \\
\text { Diversa }\end{array}$ & SIUP \\
\hline Agricultura & $1,38555 \mathrm{E}-09$ & $7,63935 \mathrm{E}-10$ & 2,74297E-09 & 2,61304E-09 & $1,55838 \mathrm{E}-09$ & $3,56757 \mathrm{E}-09$ & $9,47906 \mathrm{E}-10$ & $5,44253 \mathrm{E}-09$ & 2,12964E-09 & $3,86015 \mathrm{E}-10$ \\
\hline Pecuária & $6,18136 \mathrm{E}-10$ & 3,05346E-10 & $7,54736 \mathrm{E}-10$ & $8,16371 \mathrm{E}-10$ & $6,47431 \mathrm{E}-10$ & $8,47098 \mathrm{E}-10$ & $3,49105 \mathrm{E}-10$ & $1,35128 \mathrm{E}-09$ & $7,23831 \mathrm{E}-09$ & $1,98534 \mathrm{E}-10$ \\
\hline Extrativa & $1,11222 \mathrm{E}-05$ & $6,571 \mathrm{E}-07$ & $2,08537 \mathrm{E}-06$ & $1,58946 \mathrm{E}-07$ & 6,32367E-07 & $3,55381 \mathrm{E}-07$ & $5,9214 \mathrm{E}-08$ & $1,1895 \mathrm{E}-06$ & $3,64629 \mathrm{E}-07$ & $5,58186 \mathrm{E}-09$ \\
\hline Alimentos & 4,09025E-09 & 1,92303E-09 & 3,98094E-09 & $4,45358 \mathrm{E}-09$ & 4,01084E-09 & 4,35663E-09 & $2,11208 \mathrm{E}-09$ & 5,38635E-09 & 3,83179E-09 & $1,28395 \mathrm{E}-09$ \\
\hline Vestuário & $1,49603 \mathrm{E}-08$ & $2,28936 \mathrm{E}-08$ & $1,25652 \mathrm{E}-07$ & $1,74755 \mathrm{E}-08$ & $1,46773 \mathrm{E}-08$ & $1,98974 \mathrm{E}-08$ & $2,21488 \mathrm{E}-08$ & $1,07783 \mathrm{E}-07$ & $1,5129 \mathrm{E}-08$ & $1,5147 \mathrm{E}-08$ \\
\hline Madeira & $3,51326 \mathrm{E}-08$ & $5,18918 \mathrm{E}-08$ & $1,03536 \mathrm{E}-06$ & $9,52508 \mathrm{E}-07$ & $4,57858 \mathrm{E}-08$ & $4,23632 \mathrm{E}-06$ & $1,25306 \mathrm{E}-08$ & 6,48988E-07 & $1,39901 \mathrm{E}-06$ & $1,69575 \mathrm{E}-09$ \\
\hline Celulose & 2,21404E-07 & $5,34985 \mathrm{E}-08$ & $4,08274 \mathrm{E}-06$ & $2,20756 \mathrm{E}-06$ & $3,98385 \mathrm{E}-07$ & $4,35843 \mathrm{E}-06$ & $9,32236 \mathrm{E}-08$ & $2,23278 \mathrm{E}-06$ & $2,1481 \mathrm{E}-07$ & $1,87468 \mathrm{E}-08$ \\
\hline Revistas & $5,15481 \mathrm{E}-08$ & $5,07264 \mathrm{E}-08$ & $3,10671 \mathrm{E}-08$ & $5,86346 \mathrm{E}-08$ & 2,64701E-08 & $4,92296 \mathrm{E}-08$ & $2,43267 \mathrm{E}-07$ & $5,78755 \mathrm{E}-08$ & $1,72934 \mathrm{E}-08$ & $7,25129 \mathrm{E}-08$ \\
\hline Químicos & $1,56415 \mathrm{E}-06$ & $2,72682 \mathrm{E}-07$ & $1,44385 \mathrm{E}-06$ & $1,03592 \mathrm{E}-07$ & $4,54405 \mathrm{E}-07$ & $1,82658 \mathrm{E}-07$ & 3,44611E-07 & $9,50535 \mathrm{E}-07$ & $1,69112 \mathrm{E}-07$ & $1,14371 \mathrm{E}-07$ \\
\hline Borracha & $9,14982 \mathrm{E}-07$ & $5,24494 \mathrm{E}-07$ & $2,50193 \mathrm{E}-06$ & $2,22918 \mathrm{E}-06$ & $1,14998 \mathrm{E}-06$ & $2,58723 \mathrm{E}-06$ & $7,20893 \mathrm{E}-07$ & 5,9937E-06 & $9,48599 \mathrm{E}-07$ & $2,26949 \mathrm{E}-08$ \\
\hline Cimento & $1,3082 \mathrm{E}-07$ & $3,90429 \mathrm{E}-08$ & $5,07435 \mathrm{E}-08$ & $2,67219 \mathrm{E}-08$ & $1,2571 \mathrm{E}-07$ & $9,79636 \mathrm{E}-08$ & 4,60496E-08 & $1,13168 \mathrm{E}-07$ & $2,63121 \mathrm{E}-07$ & $1,26769 \mathrm{E}-09$ \\
\hline Aço & 0,000140014 & $1,14268 \mathrm{E}-06$ & $2,09253 \mathrm{E}-05$ & $1,51533 \mathrm{E}-06$ & $4,12518 \mathrm{E}-06$ & $3,64498 \mathrm{E}-06$ & $4,16843 \mathrm{E}-07$ & $1,15195 \mathrm{E}-05$ & 4,24992E-07 & $1,32479 \mathrm{E}-08$ \\
\hline Metal & $1,57885 \mathrm{E}-06$ & $4,05314 \mathrm{E}-05$ & $2,54165 \mathrm{E}-06$ & $9,53375 \mathrm{E}-07$ & $1,7663 \mathrm{E}-06$ & $1,57287 \mathrm{E}-06$ & $1,08265 \mathrm{E}-06$ & $1,13399 \mathrm{E}-06$ & $8,71709 \mathrm{E}-07$ & $4,43215 \mathrm{E}-09$ \\
\hline Eletrodomésticos & $1,31757 \mathrm{E}-06$ & $1,51408 \mathrm{E}-07$ & 0,000506342 & 1,40367E-06 & $6,47832 \mathrm{E}-07$ & $9,47167 \mathrm{E}-07$ & $2,82148 \mathrm{E}-07$ & $5,934 \mathrm{E}-06$ & $9,82227 \mathrm{E}-08$ & $1,58752 \mathrm{E}-08$ \\
\hline Informática & $8,56442 \mathrm{E}-09$ & 4,61634E-09 & $4,42634 \mathrm{E}-08$ & 0,001874933 & $2,74563 \mathrm{E}-08$ & $9,39136 \mathrm{E}-07$ & $5,95769 \mathrm{E}-09$ & $5,78553 \mathrm{E}-08$ & 4,69453E-09 & $9,31939 \mathrm{E}-10$ \\
\hline Máquinas & $1,97839 \mathrm{E}-07$ & $5,40925 \mathrm{E}-08$ & $4,08502 \mathrm{E}-06$ & $9,77603 \mathrm{E}-06$ & 0,000159885 & $1,79653 \mathrm{E}-05$ & $1,19162 \mathrm{E}-06$ & $2,67114 \mathrm{E}-06$ & 3,99133E-07 & $3,03397 \mathrm{E}-07$ \\
\hline
\end{tabular}




\begin{tabular}{|c|c|c|c|c|c|c|c|c|c|c|}
\hline Eletrônicos & $2,77458 \mathrm{E}-08$ & $1,66386 \mathrm{E}-08$ & 7,00321E-07 & $8,19275 \mathrm{E}-05$ & $6,83045 \mathrm{E}-07$ & 0,000403789 & $8,10284 \mathrm{E}-08$ & $6,51294 \mathrm{E}-07$ & 3,39273E-08 & $1,31698 \mathrm{E}-08$ \\
\hline Instrumento hospitalar & 3,7954E-09 & 2,08651E-09 & $5,75555 \mathrm{E}-07$ & $7,52484 \mathrm{E}-08$ & 2,235E-07 & $1,04991 \mathrm{E}-07$ & 0,000180562 & $9,60721 \mathrm{E}-08$ & 9,8751E-09 & $2,18151 \mathrm{E}-09$ \\
\hline Veículos & $8,07591 \mathrm{E}-07$ & $5,10204 \mathrm{E}-07$ & $3,64268 \mathrm{E}-06$ & $2,57334 \mathrm{E}-06$ & 2,93981E-06 & $4,66965 \mathrm{E}-06$ & 6,18874E-07 & 0,001287254 & $3,68262 \mathrm{E}-07$ & $7,85412 \mathrm{E}-08$ \\
\hline Indústria Diversa & $1,90261 \mathrm{E}-07$ & $1,40185 \mathrm{E}-08$ & $4,42201 \mathrm{E}-08$ & $8,36906 \mathrm{E}-09$ & $2,56763 \mathrm{E}-08$ & $1,36187 \mathrm{E}-08$ & $3,62855 \mathrm{E}-09$ & $2,2844 \mathrm{E}-08$ & $4,76743 \mathrm{E}-05$ & $1,1886 \mathrm{E}-09$ \\
\hline SIUP & 6,66816E-07 & 3,25173E-07 & $3,2368 \mathrm{E}-07$ & $2,16736 \mathrm{E}-07$ & 3,80004E-07 & $2,64828 \mathrm{E}-07$ & $2,76955 \mathrm{E}-07$ & 2,8376E-07 & $2,02052 \mathrm{E}-07$ & $3,01901 \mathrm{E}-05$ \\
\hline Construção & $1,4462 \mathrm{E}-09$ & $9,71817 \mathrm{E}-10$ & $1,96572 \mathrm{E}-09$ & $2,8938 \mathrm{E}-09$ & 3,99692E-09 & 6,03958E-09 & $9,16302 \mathrm{E}-10$ & $6,40526 \mathrm{E}-09$ & $1,1744 \mathrm{E}-09$ & $9,07801 \mathrm{E}-10$ \\
\hline Comércio & 4,06104E-08 & $3,55681 \mathrm{E}-08$ & $5,97528 \mathrm{E}-08$ & $1,3451 \mathrm{E}-07$ & $5,32711 \mathrm{E}-08$ & $1,00469 \mathrm{E}-07$ & $5,36587 \mathrm{E}-08$ & $7,65448 \mathrm{E}-08$ & $6,2142 \mathrm{E}-08$ & $1,69609 \mathrm{E}-08$ \\
\hline Transportes & $1,26015 \mathrm{E}-07$ & $7,23123 \mathrm{E}-08$ & $9,95066 \mathrm{E}-08$ & $1,11603 \mathrm{E}-07$ & 9,52013E-08 & $1,38546 \mathrm{E}-07$ & $7,55965 \mathrm{E}-08$ & $8,72217 \mathrm{E}-08$ & $4,68514 \mathrm{E}-08$ & $3,8284 \mathrm{E}-08$ \\
\hline Informação & $4,20845 \mathrm{E}-08$ & $1,87171 \mathrm{E}-08$ & 4,70767E-08 & $6,76772 \mathrm{E}-08$ & $5,7758 \mathrm{E}-08$ & $9,95734 \mathrm{E}-08$ & $3,05004 \mathrm{E}-08$ & $3,7647 \mathrm{E}-08$ & $1,02268 \mathrm{E}-08$ & $3,56123 \mathrm{E}-08$ \\
\hline Financeiro & $1,23657 \mathrm{E}-07$ & $7,28501 \mathrm{E}-08$ & $1,5754 \mathrm{E}-07$ & $1,10027 \mathrm{E}-07$ & $1,12553 \mathrm{E}-07$ & $1,9388 \mathrm{E}-07$ & $7,82458 \mathrm{E}-08$ & $1,08066 \mathrm{E}-07$ & 4,63083E-08 & $4,16423 \mathrm{E}-08$ \\
\hline Imobiliário & $1,52046 \mathrm{E}-08$ & $1,29021 \mathrm{E}-08$ & 2,01043E-08 & $2,15578 \mathrm{E}-08$ & $1,59492 \mathrm{E}-08$ & $2,13257 \mathrm{E}-08$ & $1,87608 \mathrm{E}-08$ & $1,40343 \mathrm{E}-08$ & $1,22361 \mathrm{E}-08$ & $1,10096 \mathrm{E}-08$ \\
\hline Alojamento & $2,10722 \mathrm{E}-09$ & $8,03167 \mathrm{E}-10$ & $1,16026 \mathrm{E}-09$ & $1,67783 \mathrm{E}-09$ & $2,48967 \mathrm{E}-09$ & $1,6764 \mathrm{E}-09$ & $7,21437 \mathrm{E}-10$ & $2,22593 \mathrm{E}-09$ & $1,49923 \mathrm{E}-09$ & $6,16197 \mathrm{E}-10$ \\
\hline Serviços às Empresas & $2,30729 \mathrm{E}-08$ & $2,24842 \mathrm{E}-08$ & 2,69472E-08 & $1,20542 \mathrm{E}-07$ & $3,84249 \mathrm{E}-08$ & $8,49604 \mathrm{E}-08$ & $3,08574 \mathrm{E}-08$ & $5,16066 \mathrm{E}-08$ & $1,77535 \mathrm{E}-08$ & $6,55385 \mathrm{E}-08$ \\
\hline Educação e Saúde mercantis & $1,40214 \mathrm{E}-09$ & $1,41675 \mathrm{E}-09$ & $2,0804 \mathrm{E}-09$ & 2,89878E-09 & $1,78228 \mathrm{E}-09$ & $2,66259 \mathrm{E}-09$ & $1,77255 \mathrm{E}-09$ & $1,79704 \mathrm{E}-09$ & $1,62666 \mathrm{E}-09$ & $1,11552 \mathrm{E}-09$ \\
\hline Outros Serviços & $6,07708 \mathrm{E}-09$ & $5,52962 \mathrm{E}-09$ & 8,12037E-09 & $1,59518 \mathrm{E}-08$ & $1,15927 \mathrm{E}-08$ & $1,47098 \mathrm{E}-08$ & 6,59777E-09 & $8,58995 \mathrm{E}-09$ & $6,77342 \mathrm{E}-09$ & $6,46182 \mathrm{E}-09$ \\
\hline APU & $8,38701 \mathrm{E}-10$ & $5,76647 \mathrm{E}-10$ & $6,78446 \mathrm{E}-10$ & 1,74344E-09 & 7,54804E-10 & $1,38506 \mathrm{E}-09$ & $6,71575 \mathrm{E}-10$ & $9,362 \mathrm{E}-10$ & $4,33198 \mathrm{E}-10$ & $1,5562 \mathrm{E}-09$ \\
\hline
\end{tabular}

Tabela C7 - Matriz Geração de Renda para o Grau de Instrução G(6), Distrito Federal - 2008.

(3)

\begin{tabular}{|c|c|c|c|c|c|c|c|c|c|c|c|}
\hline Setores & Construção & Comércio & Transportes & Informação & Financeiro & Imobiliário & Alojamento & $\begin{array}{l}\text { Serviços às } \\
\text { Empresas }\end{array}$ & $\begin{array}{l}\text { Educação e } \\
\text { Saúde } \\
\text { mercantis }\end{array}$ & $\begin{array}{c}\text { Outros } \\
\text { Serviços }\end{array}$ & APU \\
\hline Agricultura & $1,10759 \mathrm{E}-09$ & $3,43637 \mathrm{E}-09$ & 2,5994E-09 & $1,57677 \mathrm{E}-09$ & $1,02099 \mathrm{E}-09$ & $2,16391 \mathrm{E}-10$ & $3,45704 \mathrm{E}-07$ & $1,56554 \mathrm{E}-09$ & $8,24172 \mathrm{E}-09$ & $3,56034 \mathrm{E}-08$ & 4,40014E-09 \\
\hline Pecuária & $5,96857 \mathrm{E}-10$ & $1,75408 \mathrm{E}-09$ & $1,56174 \mathrm{E}-09$ & $7,73008 \mathrm{E}-10$ & $5,91782 \mathrm{E}-10$ & $1,00071 \mathrm{E}-10$ & $2,31007 \mathrm{E}-07$ & $7,72993 \mathrm{E}-10$ & 5,14143E-09 & $2,51008 \mathrm{E}-08$ & 2,4079E-09 \\
\hline Extrativa & 2,90291E-08 & $1,51325 \mathrm{E}-08$ & $9,32579 \mathrm{E}-09$ & $1,75242 \mathrm{E}-08$ & $5,22988 \mathrm{E}-09$ & 2,89593E-09 & $1,37594 \mathrm{E}-08$ & $1,39834 \mathrm{E}-08$ & $1,37587 \mathrm{E}-08$ & $1,29837 \mathrm{E}-08$ & $1,4257 \mathrm{E}-08$ \\
\hline Alimentos & $5,03182 \mathrm{E}-09$ & $1,56352 \mathrm{E}-08$ & $1,38102 \mathrm{E}-08$ & $5,4726 \mathrm{E}-09$ & 4,49949E-09 & $7,5822 \mathrm{E}-10$ & $1,96968 \mathrm{E}-06$ & 5,2491E-09 & $3,19727 \mathrm{E}-08$ & 7,32584E-08 & $1,46039 \mathrm{E}-08$ \\
\hline Vestuário & 9,40257E-09 & $2,10717 \mathrm{E}-08$ & $4,41811 \mathrm{E}-08$ & $2,05736 \mathrm{E}-08$ & $1,68362 \mathrm{E}-08$ & 2,22777E-09 & $2,44453 \mathrm{E}-08$ & $6,02463 \mathrm{E}-08$ & $3,88389 \mathrm{E}-08$ & $8,68621 \mathrm{E}-08$ & $1,69212 \mathrm{E}-08$ \\
\hline Madeira & $1,59018 \mathrm{E}-08$ & $5,64221 \mathrm{E}-09$ & $3,78459 \mathrm{E}-09$ & 7,48846E-09 & 4,23383E-09 & $5,53028 \mathrm{E}-09$ & $4,61728 \mathrm{E}-09$ & 6,22799E-09 & $8,2696 \mathrm{E}-09$ & 8,72787E-09 & $1,24835 \mathrm{E}-08$ \\
\hline
\end{tabular}




\begin{tabular}{|c|c|c|c|c|c|c|c|c|c|c|c|}
\hline Celulose & $1,35763 \mathrm{E}-08$ & $5,44498 \mathrm{E}-08$ & $3,44194 \mathrm{E}-08$ & $6,92968 \mathrm{E}-08$ & $2,34673 \mathrm{E}-08$ & $9,13341 \mathrm{E}-09$ & $3,40997 \mathrm{E}-08$ & $9,06315 \mathrm{E}-08$ & $4,85106 \mathrm{E}-08$ & $4,57788 \mathrm{E}-08$ & $4,56077 \mathrm{E}-08$ \\
\hline Revistas & $1,92794 \mathrm{E}-08$ & $6,94059 \mathrm{E}-08$ & $5,84935 \mathrm{E}-08$ & $1,62096 \mathrm{E}-07$ & 8,39325E-08 & $1,82425 \mathrm{E}-08$ & $1,9207 \mathrm{E}-08$ & $5,15225 \mathrm{E}-07$ & $8,41074 \mathrm{E}-08$ & $8,90439 \mathrm{E}-08$ & 4,89399E-08 \\
\hline Químicos &, $54803 \mathrm{E}-08$ & $8,19421 \mathrm{E}-09$ & $5,7878 \mathrm{E}-09$ & $1,50778 \mathrm{E}-08$ & 3,4443E-09 & 2,24445E-09 & $1,12423 \mathrm{E}-07$ & $9,37166 \mathrm{E}-09$ & $1,07651 \mathrm{E}-07$ & $2,11127 \mathrm{E}-08$ & $1,62765 \mathrm{E}-08$ \\
\hline Borracha & $9,40982 \mathrm{E}-08$ & $3,75161 \mathrm{E}-08$ & $3,15634 \mathrm{E}-08$ & 7,70783E-08 & $1,23297 \mathrm{E}-08$ & 7,03607E-09 & $5,11935 \mathrm{E}-08$ & $1,11702 \mathrm{E}-07$ & $9,75612 \mathrm{E}-08$ & $3,11292 \mathrm{E}-08$ & $1,48157 \mathrm{E}-08$ \\
\hline Cimento & $5,33467 \mathrm{E}-07$ & $1,90956 \mathrm{E}-09$ & $8,20305 \mathrm{E}-10$ & 2,36336E-09 & 2,20979E-09 & 4,71788E-09 & $3,72253 \mathrm{E}-09$ & $1,77556 \mathrm{E}-09$ & $1,76094 \mathrm{E}-08$ & $9,28398 \mathrm{E}-09$ & $8,8149 \mathrm{E}-09$ \\
\hline Aço & $3,89452 \mathrm{E}-08$ & $5,71001 \mathrm{E}-09$ & 4,47308E-09 & 7,82939E-09 & 2,24569E-09 & 2,10173E-09 & $1,05715 \mathrm{E}-08$ & $5,47845 \mathrm{E}-09$ & $6,6166 \mathrm{E}-09$ & 7,40047E-09 & 5,29817E-09 \\
\hline Metal & $1,08947 \mathrm{E}-07$ & $1,0518 \mathrm{E}-08$ & 2,46827E-09 & $5,73903 \mathrm{E}-09$ & $1,68305 \mathrm{E}-09$ & $4,11535 \mathrm{E}-09$ & 4,65384E-08 & 2,92854E-09 & $1,10346 \mathrm{E}-08$ & 7,01591E-09 & $7,32216 \mathrm{E}-09$ \\
\hline Eletrodomésticos & $1,96978 \mathrm{E}-08$ & $1,88586 \mathrm{E}-08$ & $1,28333 \mathrm{E}-08$ & $2,37729 \mathrm{E}-08$ & 6,60923E-09 & 4,96421E-09 & $1,51504 \mathrm{E}-08$ & $1,85973 \mathrm{E}-08$ & $1,76271 \mathrm{E}-08$ & $1,78277 \mathrm{E}-08$ & $1,80531 \mathrm{E}-08$ \\
\hline Informática & $3,74178 \mathrm{E}-09$ & 3,10999E-09 & 1,61397E-09 & $5,97321 \mathrm{E}-09$ & $2,012 \mathrm{E}-09$ & 2,76206E-09 & $1,65277 \mathrm{E}-09$ & 3,5636E-09 & 4,38353E-09 & $3,54236 \mathrm{E}-09$ & 6,15711E-09 \\
\hline Máquinas & $8,32854 \mathrm{E}-08$ & $1,75654 \mathrm{E}-08$ & $5,16965 \mathrm{E}-08$ & $7,53465 \mathrm{E}-08$ & $9,40142 \mathrm{E}-09$ & $2,04288 \mathrm{E}-08$ & $1,39416 \mathrm{E}-08$ & $2,62298 \mathrm{E}-08$ & $2,33455 \mathrm{E}-08$ & $8,31148 \mathrm{E}-08$ & $1,47992 \mathrm{E}-08$ \\
\hline Eletrônicos & $4,83022 \mathrm{E}-09$ & 3,19941E-09 & 3,98391E-09 & $6,77595 \mathrm{E}-09$ & $1,49762 \mathrm{E}-09$ & $1,85837 \mathrm{E}-09$ & 2,32773E-09 & 4,54904E-09 & $3,11983 \mathrm{E}-09$ & $5,6895 \mathrm{E}-09$ & $2,96225 \mathrm{E}-09$ \\
\hline Instrumento hospitalar & $1,22254 \mathrm{E}-08$ & 7,38817E-09 & 2,34311E-09 & $3,04642 \mathrm{E}-09$ & $1,71675 \mathrm{E}-09$ & $1,3927 \mathrm{E}-08$ & 1,49049E-09 & $1,98247 \mathrm{E}-08$ & $2,05788 \mathrm{E}-08$ & $1,56783 \mathrm{E}-08$ & 4,26403E-09 \\
\hline Veículos & $6,2798 \mathrm{E}-08$ & $3,48031 \mathrm{E}-08$ & $3,04819 \mathrm{E}-08$ & $5,27534 \mathrm{E}-08$ & $1,37948 \mathrm{E}-08$ & $1,32532 \mathrm{E}-08$ & $3,2588 \mathrm{E}-08$ & $3,54716 \mathrm{E}-08$ & $3,44995 \mathrm{E}-08$ & $4,6116 \mathrm{E}-08$ & $3,46009 \mathrm{E}-08$ \\
\hline Indústria Diversa & $1,56815 \mathrm{E}-08$ & $2,13706 \mathrm{E}-09$ & $1,34395 \mathrm{E}-08$ & 2,63716E-09 & $2,37509 \mathrm{E}-08$ & $5,93864 \mathrm{E}-09$ & $2,62334 \mathrm{E}-09$ & $8,68733 \mathrm{E}-09$ & $8,60752 \mathrm{E}-09$ & 4,34293E-08 & $9,48796 \mathrm{E}-09$ \\
\hline SIUP & 6,59719E-08 & $2,26045 \mathrm{E}-07$ & $1,87446 \mathrm{E}-07$ & $1,76151 \mathrm{E}-07$ & $1,06299 \mathrm{E}-07$ & 2,23904E-08 & $2,28505 \mathrm{E}-07$ & $1,98376 \mathrm{E}-07$ & 2,92083E-07 & $6,57175 \mathrm{E}-07$ & $2,51577 \mathrm{E}-07$ \\
\hline Construção & $2,16529 \mathrm{E}-06$ & 2,47791E-09 & $1,92621 \mathrm{E}-09$ & 7,89074E-09 & $7,8069 \mathrm{E}-09$ & $1,86644 \mathrm{E}-08$ & $1,32617 \mathrm{E}-09$ & $5,5605 \mathrm{E}-09$ & $1,66674 \mathrm{E}-08$ & $1,43884 \mathrm{E}-08$ & $3,25479 \mathrm{E}-08$ \\
\hline Comércio & $5,5658 \mathrm{E}-08$ & $1,04542 \mathrm{E}-06$ & $4,6353 \mathrm{E}-08$ & $2,30325 \mathrm{E}-08$ & $1,37698 \mathrm{E}-08$ & 6,07701E-09 & $1,06703 \mathrm{E}-07$ & $3,99288 \mathrm{E}-08$ & $3,55307 \mathrm{E}-08$ & $3,84175 \mathrm{E}-08$ & $2,03609 \mathrm{E}-08$ \\
\hline Transportes & $3,58484 \mathrm{E}-08$ & $9,43196 \mathrm{E}-08$ & $2,88083 \mathrm{E}-06$ & $6,39824 \mathrm{E}-08$ & $2,69044 \mathrm{E}-08$ & 4,78544E-09 & $4,31733 \mathrm{E}-08$ & $5,08294 \mathrm{E}-08$ & $4,56745 \mathrm{E}-08$ & $6,75126 \mathrm{E}-08$ & $2,45215 \mathrm{E}-08$ \\
\hline Informação & $1,1656 \mathrm{E}-08$ & $3,67374 \mathrm{E}-08$ & $3,84086 \mathrm{E}-08$ & $2,75003 \mathrm{E}-06$ & $1,12058 \mathrm{E}-07$ & $7,5763 \mathrm{E}-09$ & $1,8352 \mathrm{E}-08$ & $2,97865 \mathrm{E}-07$ & $1,02432 \mathrm{E}-07$ & $6,7078 \mathrm{E}-08$ & $1,24192 \mathrm{E}-07$ \\
\hline Financeiro & $3,35307 \mathrm{E}-08$ & $6,6552 \mathrm{E}-08$ & $9,20256 \mathrm{E}-08$ & $9,36808 \mathrm{E}-08$ & $2,65726 \mathrm{E}-06$ & $1,35383 \mathrm{E}-08$ & $3,46135 \mathrm{E}-08$ & $8,86637 \mathrm{E}-08$ & $3,91458 \mathrm{E}-08$ & $2,1788 \mathrm{E}-08$ & $2,07346 \mathrm{E}-07$ \\
\hline Imobiliário & $9,0642 \mathrm{E}-09$ & $4,56309 \mathrm{E}-08$ & $8,13195 \mathrm{E}-08$ & 7,36713E-08 & $2,33679 \mathrm{E}-08$ & $2,16658 \mathrm{E}-06$ & $2,80789 \mathrm{E}-08$ & $5,31806 \mathrm{E}-08$ & $5,53204 \mathrm{E}-08$ & $3,96422 \mathrm{E}-08$ & $4,18415 \mathrm{E}-08$ \\
\hline Alojamento & $2,1052 \mathrm{E}-09$ & $2,92552 \mathrm{E}-09$ & $5,69617 \mathrm{E}-09$ & $3,84135 \mathrm{E}-09$ & $3,69441 \mathrm{E}-09$ & $4,07641 \mathrm{E}-10$ & $2,25977 \mathrm{E}-06$ & $3,31409 \mathrm{E}-09$ & $1,75688 \mathrm{E}-08$ & $2,00504 \mathrm{E}-08$ & $1,08597 \mathrm{E}-08$ \\
\hline Serviços às Empresas & $2,66079 \mathrm{E}-08$ & $7,4216 \mathrm{E}-08$ & $8,5282 \mathrm{E}-08$ & $1,21548 \mathrm{E}-07$ & $9,19305 \mathrm{E}-08$ & $1,43666 \mathrm{E}-08$ & $2,35052 \mathrm{E}-08$ & $1,46686 \mathrm{E}-06$ & $1,22357 \mathrm{E}-07$ & $7,78616 \mathrm{E}-08$ & $8,64623 \mathrm{E}-08$ \\
\hline Educação e Saúde mercantis & $1,24673 \mathrm{E}-09$ & $4,4425 \mathrm{E}-09$ & $2,94412 \mathrm{E}-09$ & $4,96054 \mathrm{E}-09$ & $5,1155 \mathrm{E}-09$ & $6,40665 \mathrm{E}-10$ & $3,54187 \mathrm{E}-09$ & $4,22294 \mathrm{E}-09$ & $2,23735 \mathrm{E}-06$ & $3,38493 \mathrm{E}-09$ & $6,983 \mathrm{E}-09$ \\
\hline Outros Serviços & $6,04472 \mathrm{E}-09$ & $1,59816 \mathrm{E}-08$ & 9,99199E-09 & $1,78099 \mathrm{E}-08$ & $9,14984 \mathrm{E}-09$ & $1,7844 \mathrm{E}-09$ & $1,74276 \mathrm{E}-08$ & $2,12786 \mathrm{E}-08$ & $1,57465 \mathrm{E}-08$ & $2,24119 \mathrm{E}-06$ & $1,12817 \mathrm{E}-08$ \\
\hline APU & $4,44824 \mathrm{E}-10$ & $1,19607 \mathrm{E}-09$ & $1,25476 \mathrm{E}-09$ & $1,61402 \mathrm{E}-09$ & $1,15541 \mathrm{E}-09$ & $1,91271 \mathrm{E}-10$ & $5,66221 \mathrm{E}-10$ & $1,43643 \mathrm{E}-09$ & $1,57655 \mathrm{E}-09$ & $1,21836 \mathrm{E}-09$ & $3,91431 \mathrm{E}-07$ \\
\hline
\end{tabular}


Tabela C8 - Matriz Geração de Renda para o Grau de Instrução G(7), Distrito Federal - 2008.

(1)

\begin{tabular}{|c|c|c|c|c|c|c|c|c|c|c|c|}
\hline Setores & Agricultura & Pecuária & Extrativa & Alimentos & Vestuário & Madeira & Celulose & Revistas & Químicos & Borracha & Cimento \\
\hline Agricultura & 4,64799E-05 & $3,04948 \mathrm{E}-06$ & $5,07204 \mathrm{E}-09$ & $3,74475 \mathrm{E}-06$ & $4,68455 \mathrm{E}-08$ & $7,36385 \mathrm{E}-08$ & $2,12664 \mathrm{E}-07$ & 2,07446E-09 & $9,3389 \mathrm{E}-09$ & $1,58269 \mathrm{E}-07$ & 3,63019E-09 \\
\hline Pecuária & $2,62659 \mathrm{E}-07$ & $6,71798 \mathrm{E}-05$ & $1,97472 \mathrm{E}-09$ & 2,65744E-06 & $5,54807 \mathrm{E}-08$ & 4,65813E-09 & $1,53045 \mathrm{E}-08$ & $7,45914 \mathrm{E}-10$ & 4,84455E-09 & $2,26076 \mathrm{E}-08$ & $1,84346 \mathrm{E}-09$ \\
\hline Extrativa & $1,31395 \mathrm{E}-07$ & $3,11477 \mathrm{E}-07$ & 0,001810235 & $7,41027 \mathrm{E}-08$ & $6,81006 \mathrm{E}-08$ & $9,37562 \mathrm{E}-08$ & $7,25095 \mathrm{E}-07$ & $1,73536 \mathrm{E}-08$ & $1,10206 \mathrm{E}-06$ & $2,34435 \mathrm{E}-07$ & $8,19033 \mathrm{E}-07$ \\
\hline Alimentos & $3,51328 \mathrm{E}-07$ & $5,33507 \mathrm{E}-06$ & $1,84292 \mathrm{E}-08$ & $3,21653 \mathrm{E}-05$ & $2,42695 \mathrm{E}-07$ & $2,51289 \mathrm{E}-08$ & 7,85517E-08 & 6,81311E-09 & $2,96782 \mathrm{E}-08$ & $9,93468 \mathrm{E}-09$ & $1,80222 \mathrm{E}-08$ \\
\hline Vestuário & 8,86638E-09 & $7,8465 \mathrm{E}-09$ & $2,61608 \mathrm{E}-07$ & $1,1436 \mathrm{E}-08$ & 0,000469353 & $1,06349 \mathrm{E}-08$ & $3,75644 \mathrm{E}-07$ & $1,20371 \mathrm{E}-08$ & $2,39882 \mathrm{E}-08$ & $7,02953 \mathrm{E}-08$ & $1,66255 \mathrm{E}-08$ \\
\hline Madeira & $3,55728 \mathrm{E}-08$ & $6,9732 \mathrm{E}-09$ & $1,93932 \mathrm{E}-08$ & $8,32142 \mathrm{E}-09$ & $3,46306 \mathrm{E}-08$ & 0,000597533 & $3,60505 \mathrm{E}-06$ & $5,97375 \mathrm{E}-09$ & $1,09269 \mathrm{E}-07$ & $2,96636 \mathrm{E}-08$ & $3,37075 \mathrm{E}-08$ \\
\hline Celulose & $5,37137 \mathrm{E}-08$ & $5,87642 \mathrm{E}-08$ & $1,40552 \mathrm{E}-06$ & $6,86518 \mathrm{E}-08$ & $3,26642 \mathrm{E}-06$ & $5,37806 \mathrm{E}-06$ & 0,002194999 & $3,42898 \mathrm{E}-07$ & $8,96181 \mathrm{E}-07$ & $2,59608 \mathrm{E}-06$ & $4,56026 \mathrm{E}-08$ \\
\hline Revistas & $2,91866 \mathrm{E}-08$ & $3,254 \mathrm{E}-08$ & $7,52346 \mathrm{E}-08$ & $5,37034 \mathrm{E}-08$ & $2,83265 \mathrm{E}-08$ & $1,7441 \mathrm{E}-08$ & $3,23891 \mathrm{E}-07$ & $7,03436 \mathrm{E}-05$ & 4,61681E-07 & $1,81507 \mathrm{E}-07$ & $6,18303 \mathrm{E}-08$ \\
\hline Químicos & $8,32213 \mathrm{E}-06$ & $5,78833 \mathrm{E}-06$ & 1,93389E-06 & $1,08288 \mathrm{E}-06$ & $5,9524 \mathrm{E}-07$ & $1,1034 \mathrm{E}-06$ & $5,01824 \mathrm{E}-06$ & $3,34586 \mathrm{E}-08$ & 0,000215367 & $2,925 \mathrm{E}-06$ & $2,7393 \mathrm{E}-07$ \\
\hline Borracha & $3,35069 \mathrm{E}-07$ & $2,14722 \mathrm{E}-07$ & $2,75755 \mathrm{E}-06$ & $5,951 \mathrm{E}-07$ & $7,83166 \mathrm{E}-07$ & $1,45739 \mathrm{E}-06$ & $3,63455 \mathrm{E}-06$ & $4,58049 \mathrm{E}-07$ & $1,07902 \mathrm{E}-06$ & 0,000306094 & $3,66801 \mathrm{E}-08$ \\
\hline Cimento & $2,05961 \mathrm{E}-08$ & $1,05151 \mathrm{E}-08$ & $2,42982 \mathrm{E}-08$ & $3,51925 \mathrm{E}-08$ & $9,26178 \mathrm{E}-09$ & 4,02267E-09 & $3,14695 \mathrm{E}-08$ & 3,30001E-09 & $1,29457 \mathrm{E}-07$ & $9,63845 \mathrm{E}-09$ & $2,04804 \mathrm{E}-05$ \\
\hline Aço & $1,19097 \mathrm{E}-07$ & $5,73956 \mathrm{E}-08$ & $6,22697 \mathrm{E}-07$ & $6,54926 \mathrm{E}-08$ & $3,61539 \mathrm{E}-08$ & $3,17844 \mathrm{E}-07$ & $6,29094 \mathrm{E}-07$ & $5,43271 \mathrm{E}-09$ & $1,65563 \mathrm{E}-07$ & $9,13959 \mathrm{E}-07$ & $6,37253 \mathrm{E}-08$ \\
\hline Metal & $2,87014 \mathrm{E}-07$ & $2,02242 \mathrm{E}-07$ & $9,30011 \mathrm{E}-07$ & 4,99227E-07 & $8,01917 \mathrm{E}-08$ & $4,84826 \mathrm{E}-07$ & $8,66708 \mathrm{E}-07$ & $5,37883 \mathrm{E}-09$ & $4,21476 \mathrm{E}-07$ & 4,78964E-07 & $7,5698 \mathrm{E}-08$ \\
\hline Eletrodomésticos & 4,48576E-08 & $3,06085 \mathrm{E}-08$ & $1,82434 \mathrm{E}-06$ & $5,14566 \mathrm{E}-08$ & 4,69652E-07 & $8,09336 \mathrm{E}-07$ & $3,4635 \mathrm{E}-06$ & $1,38229 \mathrm{E}-08$ & $2,57945 \mathrm{E}-07$ & $3,4935 \mathrm{E}-07$ & $2,70356 \mathrm{E}-08$ \\
\hline Informática & $2,41652 \mathrm{E}-09$ & $1,92259 \mathrm{E}-09$ & $1,63046 \mathrm{E}-08$ & $2,6466 \mathrm{E}-09$ & $1,36999 \mathrm{E}-08$ & $7,22238 \mathrm{E}-09$ & $7,91398 \mathrm{E}-08$ & $9,93448 \mathrm{E}-09$ & 3,50776E-08 & $3,72342 \mathrm{E}-08$ & $1,94714 \mathrm{E}-09$ \\
\hline Máquinas & $4,05802 \mathrm{E}-08$ & $7,37511 \mathrm{E}-08$ & $1,22339 \mathrm{E}-06$ & $1,3719 \mathrm{E}-07$ & $1,36843 \mathrm{E}-07$ & $2,87022 \mathrm{E}-07$ & $2,85137 \mathrm{E}-07$ & $1,7818 \mathrm{E}-08$ & $3,44418 \mathrm{E}-07$ & $1,03325 \mathrm{E}-06$ & $2,55354 \mathrm{E}-07$ \\
\hline Eletrônicos & $6,26958 \mathrm{E}-09$ & 7,11244E-09 & 7,16324E-07 & $1,4254 \mathrm{E}-08$ & $1,43557 \mathrm{E}-08$ & $2,34672 \mathrm{E}-08$ & $4,78168 \mathrm{E}-08$ & $8,23538 \mathrm{E}-09$ & $2,98072 \mathrm{E}-08$ & $5,85948 \mathrm{E}-08$ & $1,59639 \mathrm{E}-08$ \\
\hline Instrumento hospitalar & $1,32217 \mathrm{E}-09$ & $1,45672 \mathrm{E}-09$ & $6,52964 \mathrm{E}-09$ & $1,92575 \mathrm{E}-09$ & 2,56104E-09 & $2,738 \mathrm{E}-09$ & $1,50202 \mathrm{E}-08$ & $2,92805 \mathrm{E}-09$ & $1,59024 \mathrm{E}-08$ & $3,05894 \mathrm{E}-08$ & 2,35137E-09 \\
\hline Veículos & $1,8409 \mathrm{E}-07$ & $1,50642 \mathrm{E}-07$ & $1,09023 \mathrm{E}-06$ & $3,4979 \mathrm{E}-07$ & $1,88015 \mathrm{E}-07$ & 4,53473E-07 & $8,84836 \mathrm{E}-07$ & $5,77903 \mathrm{E}-08$ & $4,16958 \mathrm{E}-07$ & $9,16248 \mathrm{E}-07$ & $1,65278 \mathrm{E}-07$ \\
\hline Indústria Diversa & $3,02269 \mathrm{E}-09$ & 2,80194E-08 & $8,15932 \mathrm{E}-09$ & $1,89861 \mathrm{E}-08$ & $2,98263 \mathrm{E}-07$ & $8,79723 \mathrm{E}-09$ & $1,61608 \mathrm{E}-07$ & $3,51675 \mathrm{E}-09$ & $8,03321 \mathrm{E}-09$ & $5,74033 \mathrm{E}-08$ & 7,67689E-09 \\
\hline SIUP & $9,41319 \mathrm{E}-08$ & $1,45288 \mathrm{E}-07$ & 3,77733E-07 & $2,32676 \mathrm{E}-07$ & $1,90405 \mathrm{E}-07$ & $1,97797 \mathrm{E}-07$ & $5,84107 \mathrm{E}-07$ & $1,54969 \mathrm{E}-07$ & $2,82158 \mathrm{E}-07$ & 2,91776E-07 & $7,69488 \mathrm{E}-07$ \\
\hline Construção & $5,77784 \mathrm{E}-10$ & $8,20774 \mathrm{E}-10$ & $1,48522 \mathrm{E}-09$ & $1,90578 \mathrm{E}-09$ & $1,71201 \mathrm{E}-09$ & $1,5123 \mathrm{E}-09$ & $2,72274 \mathrm{E}-09$ & 2,15523E-09 & 3,05043E-09 & 4,95414E-09 & $6,75654 \mathrm{E}-09$ \\
\hline Comércio & $8,7676 \mathrm{E}-08$ & $1,29379 \mathrm{E}-07$ & $7,71103 \mathrm{E}-08$ & $1,38729 \mathrm{E}-07$ & $1,4572 \mathrm{E}-07$ & $5,95113 \mathrm{E}-08$ & $7,61336 \mathrm{E}-08$ & 7,88425E-08 & $1,08193 \mathrm{E}-07$ & $8,43214 \mathrm{E}-08$ & $1,35305 \mathrm{E}-07$ \\
\hline Transportes & $8,98523 \mathrm{E}-08$ & $8,17554 \mathrm{E}-08$ & $2,40175 \mathrm{E}-07$ & $1,53249 \mathrm{E}-07$ & $7,1228 \mathrm{E}-08$ & 7,71186E-08 & $1,30643 \mathrm{E}-07$ & $7,51073 \mathrm{E}-08$ & $1,42063 \mathrm{E}-07$ & $9,28969 \mathrm{E}-08$ & 2,87936E-07 \\
\hline Informação & $1,22386 \mathrm{E}-08$ & $1,89729 \mathrm{E}-08$ & $5,58338 \mathrm{E}-08$ & $2,38433 \mathrm{E}-08$ & $1,36624 \mathrm{E}-08$ & $1,01073 \mathrm{E}-08$ & $2,33345 \mathrm{E}-08$ & $5,6143 \mathrm{E}-08$ & $7,22912 \mathrm{E}-08$ & $3,22387 \mathrm{E}-08$ & 4,37499E-08 \\
\hline
\end{tabular}




\begin{tabular}{|c|c|c|c|c|c|c|c|c|c|c|c|}
\hline Financeiro & $3,0099 \mathrm{E}-08$ & 3,33753E-08 & $6,74446 \mathrm{E}-08$ & $5,74361 \mathrm{E}-08$ & $4,59262 \mathrm{E}-08$ & $4,25745 \mathrm{E}-08$ & $9,28596 \mathrm{E}-08$ & $5,26689 \mathrm{E}-08$ & 9,14411E-08 & $6,64182 \mathrm{E}-08$ & $1,06804 \mathrm{E}-07$ \\
\hline Imobiliário & $1,02283 \mathrm{E}-08$ & $1,3099 \mathrm{E}-08$ & 3,10317E-08 & $2,61772 \mathrm{E}-08$ & $2,91648 \mathrm{E}-08$ & $1,16725 \mathrm{E}-08$ & 2,57884E-08 & $4,06336 \mathrm{E}-08$ & $3,47865 \mathrm{E}-08$ & $2,16891 \mathrm{E}-08$ & $3,77942 \mathrm{E}-08$ \\
\hline Alojamento & 7,91494E-10 & 1,11639E-09 & 7,21586E-09 & $1,96401 \mathrm{E}-09$ & $1,14516 \mathrm{E}-09$ & 2,29711E-09 & 2,34102E-09 & 3,10333E-09 & 2,60095E-09 & 2,31037E-09 & $1,26993 \mathrm{E}-08$ \\
\hline Serviços às Empresas & $1,30279 \mathrm{E}-08$ & $1,87295 \mathrm{E}-08$ & 3,61129E-08 & 4,4073E-08 & 2,89163E-08 & $1,5376 \mathrm{E}-08$ & $3,729 \mathrm{E}-08$ & $1,01616 \mathrm{E}-07$ & $1,14914 \mathrm{E}-07$ & $3,10962 \mathrm{E}-08$ & $7,21813 \mathrm{E}-08$ \\
\hline Educação e Saúde mercantis & 1,31821E-09 & $1,82257 \mathrm{E}-09$ & 2,68215E-09 & 2,74723E-09 & $3,35411 \mathrm{E}-09$ & $1,23165 \mathrm{E}-09$ & 2,41128E-09 & 2,93995E-09 & $2,95374 \mathrm{E}-09$ & 2,114E-09 & 3,04565E-09 \\
\hline Outros Serviços & 6,95931E-09 & $1,00856 \mathrm{E}-08$ & $1,05073 \mathrm{E}-08$ & $1,33049 \mathrm{E}-08$ & $1,43027 \mathrm{E}-08$ & $5,27302 \mathrm{E}-09$ & 8,74337E-09 & $1,02779 \mathrm{E}-08$ & $1,41732 \mathrm{E}-08$ & $1,0349 \mathrm{E}-08$ & $1,65082 \mathrm{E}-08$ \\
\hline APU & $2,55507 \mathrm{E}-10$ & $3,0485 \mathrm{E}-10$ & $6,12017 \mathrm{E}-10$ & $5,65181 \mathrm{E}-10$ & $3,56197 \mathrm{E}-10$ & $2,4036 \mathrm{E}-10$ & $5,83551 \mathrm{E}-10$ & $1,08001 \mathrm{E}-09$ & $9,76943 \mathrm{E}-10$ & $4,14435 \mathrm{E}-10$ & $9,33264 \mathrm{E}-10$ \\
\hline
\end{tabular}

Tabela C8 - Matriz Geração de Renda para o Grau de Instrução G(7), Distrito Federal - 2008.

(2)

\begin{tabular}{|c|c|c|c|c|c|c|c|c|c|c|}
\hline Setores & Aço & Metal & Eletrodomésticos & Informática & Máquinas & Eletrônicos & $\begin{array}{l}\text { Instrumento } \\
\text { hospitalar }\end{array}$ & Veículos & $\begin{array}{l}\text { Indústria } \\
\text { Diversa }\end{array}$ & SIUP \\
\hline Agricultura & 2,73493E-09 & $1,50793 \mathrm{E}-09$ & $5,41433 \mathrm{E}-09$ & $5,15786 \mathrm{E}-09$ & 3,07607E-09 & 7,04201E-09 & 1,87107E-09 & $1,0743 \mathrm{E}-08$ & $4,20368 \mathrm{E}-09$ & 7,61954E-10 \\
\hline Pecuária & $1,01347 \mathrm{E}-09$ & $5,00631 \mathrm{E}-10$ & $1,23743 \mathrm{E}-09$ & 1,33849E-09 & $1,0615 \mathrm{E}-09$ & $1,38886 \mathrm{E}-09$ & $5,72376 \mathrm{E}-10$ & 2,2155E-09 & $1,18676 \mathrm{E}-08$ & $3,25508 \mathrm{E}-10$ \\
\hline Extrativa & $3,04965 \mathrm{E}-05$ & $1,80174 \mathrm{E}-06$ & $5,718 \mathrm{E}-06$ & $4,35824 \mathrm{E}-07$ & $1,73392 \mathrm{E}-06$ & $9,7444 \mathrm{E}-07$ & $1,62362 \mathrm{E}-07$ & $3,26155 \mathrm{E}-06$ & 9,99797E-07 & $1,53052 \mathrm{E}-08$ \\
\hline Alimentos & $8,07648 \mathrm{E}-09$ & 3,79716E-09 & 7,86064E-09 & 8,7939E-09 & 7,91969E-09 & $8,60247 \mathrm{E}-09$ & 4,17044E-09 & $1,06357 \mathrm{E}-08$ & 7,56614E-09 & $2,53525 \mathrm{E}-09$ \\
\hline Vestuário & 2,20867E-08 & $3,37992 \mathrm{E}-08$ & $1,85508 \mathrm{E}-07$ & $2,58001 \mathrm{E}-08$ & $2,1669 \mathrm{E}-08$ & $2,93757 \mathrm{E}-08$ & 3,26996E-08 & $1,59126 \mathrm{E}-07$ & 2,23359E-08 & 2,23624E-08 \\
\hline Madeira & $2,71198 \mathrm{E}-08$ & $4,00567 \mathrm{E}-08$ & $7,99222 \mathrm{E}-07$ & 7,35267E-07 & 3,53433E-08 & $3,27013 \mathrm{E}-06$ & $9,6727 \mathrm{E}-09$ & $5,00971 \mathrm{E}-07$ & $1,07994 \mathrm{E}-06$ & $1,309 \mathrm{E}-09$ \\
\hline Celulose & 3,69631E-07 & $8,93151 \mathrm{E}-08$ & $6,81607 \mathrm{E}-06$ & 3,6855E-06 & $6,65099 \mathrm{E}-07$ & $7,27633 \mathrm{E}-06$ & $1,55636 \mathrm{E}-07$ & $3,7276 \mathrm{E}-06$ & $3,58622 \mathrm{E}-07$ & $3,12975 \mathrm{E}-08$ \\
\hline Revistas & 8,8593E-08 & $8,71808 \mathrm{E}-08$ & $5,33934 \mathrm{E}-08$ & $1,00772 \mathrm{E}-07$ & $4,54928 \mathrm{E}-08$ & $8,46084 \mathrm{E}-08$ & $4,1809 \mathrm{E}-07$ & $9,94677 \mathrm{E}-08$ & $2,97212 \mathrm{E}-08$ & $1,24624 \mathrm{E}-07$ \\
\hline Químicos & $2,57868 \mathrm{E}-06$ & $4,49547 \mathrm{E}-07$ & $2,38035 \mathrm{E}-06$ & $1,70783 \mathrm{E}-07$ & 7,4914E-07 & $3,01133 \mathrm{E}-07$ & $5,68132 \mathrm{E}-07$ & $1,56707 \mathrm{E}-06$ & $2,788 \mathrm{E}-07$ & $1,88553 \mathrm{E}-07$ \\
\hline Borracha & $1,88333 \mathrm{E}-06$ & $1,07958 \mathrm{E}-06$ & $5,14978 \mathrm{E}-06$ & $4,58838 \mathrm{E}-06$ & 2,36704E-06 & $5,32536 \mathrm{E}-06$ & $1,48383 \mathrm{E}-06$ & $1,2337 \mathrm{E}-05$ & $1,95252 \mathrm{E}-06$ & 4,67134E-08 \\
\hline Cimento & $1,80686 \mathrm{E}-07$ & $5,39254 \mathrm{E}-08$ & $7,00861 \mathrm{E}-08$ & $3,69078 \mathrm{E}-08$ & $1,73629 \mathrm{E}-07$ & $1,35306 \mathrm{E}-07$ & $6,36029 \mathrm{E}-08$ & $1,56306 \mathrm{E}-07$ & $3,63418 \mathrm{E}-07$ & $1,75091 \mathrm{E}-09$ \\
\hline Aço & 0,000155445 & $1,26862 \mathrm{E}-06$ & $2,32315 \mathrm{E}-05$ & $1,68233 \mathrm{E}-06$ & 4,57982E-06 & $4,04669 \mathrm{E}-06$ & 4,62784E-07 & $1,27891 \mathrm{E}-05$ & 4,7183E-07 & $1,4708 \mathrm{E}-08$ \\
\hline Metal & $2,28764 \mathrm{E}-06$ & $5,87273 \mathrm{E}-05$ & $3,68267 \mathrm{E}-06$ & $1,38138 \mathrm{E}-06$ & $2,55925 \mathrm{E}-06$ & $2,27898 \mathrm{E}-06$ & $1,56869 \mathrm{E}-06$ & $1,64308 \mathrm{E}-06$ & $1,26305 \mathrm{E}-06$ & $6,42189 \mathrm{E}-09$ \\
\hline Eletrodomésticos & $1,8599 \mathrm{E}-06$ & $2,1373 \mathrm{E}-07$ & 0,000714759 & $1,98143 \mathrm{E}-06$ & $9,1449 \mathrm{E}-07$ & $1,33703 \mathrm{E}-06$ & 3,98284E-07 & $8,37652 \mathrm{E}-06$ & $1,38653 \mathrm{E}-07$ & 2,24097E-08 \\
\hline Informática & $1,06613 \mathrm{E}-08$ & $5,74658 \mathrm{E}-09$ & $5,51006 \mathrm{E}-08$ & 0,002333981 & $3,41785 \mathrm{E}-08$ & $1,16907 \mathrm{E}-06$ & 7,41634E-09 & $7,20203 \mathrm{E}-08$ & $5,84391 \mathrm{E}-09$ & $1,16011 \mathrm{E}-09$ \\
\hline Máquinas & 4,4058E-07 & $1,20462 \mathrm{E}-07$ & $9,09718 \mathrm{E}-06$ & $2,17708 \mathrm{E}-05$ & 0,000356058 & $4,00079 \mathrm{E}-05$ & $2,65369 \mathrm{E}-06$ & $5,94852 \mathrm{E}-06$ & $8,88854 \mathrm{E}-07$ & $6,75652 \mathrm{E}-07$ \\
\hline
\end{tabular}




\begin{tabular}{|c|c|c|c|c|c|c|c|c|c|c|}
\hline Eletrônicos & $6,80432 \mathrm{E}-08$ & $4,0804 \mathrm{E}-08$ & $1,71745 \mathrm{E}-06$ & 0,000200917 & $1,67509 \mathrm{E}-06$ & 0,000990243 & $1,98712 \mathrm{E}-07$ & $1,59722 \mathrm{E}-06$ & $8,32025 \mathrm{E}-08$ & 3,22972E-08 \\
\hline Instrumento hospitalar & 4,6654E-09 & $2,56479 \mathrm{E}-09$ & $7,07486 \mathrm{E}-07$ & 9,24971E-08 & 2,74731E-07 & $1,29057 \mathrm{E}-07$ & 0,000221952 & $1,18094 \mathrm{E}-07$ & $1,21387 \mathrm{E}-08$ & 2,68156E-09 \\
\hline Veículos & 2,49894E-06 & $1,57873 \mathrm{E}-06$ & $1,12716 \mathrm{E}-05$ & 7,96271E-06 & $9,09669 \mathrm{E}-06$ & $1,44494 \mathrm{E}-05$ & $1,91499 \mathrm{E}-06$ & 0,003983162 & $1,13952 \mathrm{E}-06$ & 2,43031E-07 \\
\hline Indústria Diversa & 3,83682E-07 & $2,82698 \mathrm{E}-08$ & $8,91746 \mathrm{E}-08$ & $1,68771 \mathrm{E}-08$ & $5,1779 \mathrm{E}-08$ & $2,74635 \mathrm{E}-08$ & 7,31735E-09 & 4,60674E-08 & $9,61404 \mathrm{E}-05$ & 2,39693E-09 \\
\hline SIUP & 6,83696E-07 & 3,33404E-07 & $3,31874 \mathrm{E}-07$ & $2,22223 \mathrm{E}-07$ & $3,89624 \mathrm{E}-07$ & $2,71531 \mathrm{E}-07$ & $2,83966 \mathrm{E}-07$ & 2,90943E-07 & 2,07166E-07 & 3,09543E-05 \\
\hline Construção & $2,10498 \mathrm{E}-09$ & $1,4145 \mathrm{E}-09$ & 2,86116E-09 & $4,212 \mathrm{E}-09$ & $5,81761 \mathrm{E}-09$ & 8,79076E-09 & $1,3337 \mathrm{E}-09$ & $9,32301 \mathrm{E}-09$ & $1,70937 \mathrm{E}-09$ & 1,32133E-09 \\
\hline Comércio & 7,20867E-08 & $6,31361 \mathrm{E}-08$ & $1,06066 \mathrm{E}-07$ & $2,38765 \mathrm{E}-07$ & $9,45604 \mathrm{E}-08$ & $1,78341 \mathrm{E}-07$ & $9,52484 \mathrm{E}-08$ & $1,35873 \mathrm{E}-07$ & $1,10307 \mathrm{E}-07$ & $3,01069 \mathrm{E}-08$ \\
\hline Transportes & $1,93152 \mathrm{E}-07$ & $1,10838 \mathrm{E}-07$ & $1,52521 \mathrm{E}-07$ & $1,71061 \mathrm{E}-07$ & $1,45922 \mathrm{E}-07$ & $2,12358 \mathrm{E}-07$ & $1,15872 \mathrm{E}-07$ & $1,33691 \mathrm{E}-07$ & $7,18123 \mathrm{E}-08$ & $5,86805 \mathrm{E}-08$ \\
\hline Informação & $5,70716 \mathrm{E}-08$ & $2,53826 \mathrm{E}-08$ & $6,38415 \mathrm{E}-08$ & $9,17782 \mathrm{E}-08$ & $7,83265 \mathrm{E}-08$ & $1,35033 \mathrm{E}-07$ & $4,13621 \mathrm{E}-08$ & $5,10538 \mathrm{E}-08$ & $1,38687 \mathrm{E}-08$ & $4,82945 \mathrm{E}-08$ \\
\hline Financeiro & $1,16352 \mathrm{E}-07$ & $6,85464 \mathrm{E}-08$ & $1,48233 \mathrm{E}-07$ & $1,03527 \mathrm{E}-07$ & $1,05904 \mathrm{E}-07$ & $1,82426 \mathrm{E}-07$ & $7,36234 \mathrm{E}-08$ & $1,01682 \mathrm{E}-07$ & $4,35726 \mathrm{E}-08$ & 3,91823E-08 \\
\hline Imobiliário & $2,45068 \mathrm{E}-08$ & $2,07955 \mathrm{E}-08$ & $3,24041 \mathrm{E}-08$ & $3,47467 \mathrm{E}-08$ & $2,57069 \mathrm{E}-08$ & $3,43727 \mathrm{E}-08$ & $3,02385 \mathrm{E}-08$ & $2,26205 \mathrm{E}-08$ & $1,97221 \mathrm{E}-08$ & $1,77452 \mathrm{E}-08$ \\
\hline Alojamento & 3,36264E-09 & $1,28167 \mathrm{E}-09$ & $1,85151 \mathrm{E}-09$ & 2,67743E-09 & 3,97295E-09 & $2,67515 \mathrm{E}-09$ & $1,15125 \mathrm{E}-09$ & $3,55208 \mathrm{E}-09$ & 2,39243E-09 & $9,8331 \mathrm{E}-10$ \\
\hline Serviços às Empresas & $3,02149 \mathrm{E}-08$ & 2,9444E-08 & $3,52886 \mathrm{E}-08$ & $1,57854 \mathrm{E}-07$ & $5,0319 \mathrm{E}-08$ & $1,11259 \mathrm{E}-07$ & $4,0409 \mathrm{E}-08$ & 6,7581E-08 & $2,3249 \mathrm{E}-08$ & $8,58255 \mathrm{E}-08$ \\
\hline Educação e Saúde mercantis & $2,00173 \mathrm{E}-09$ & $2,02258 \mathrm{E}-09$ & 2,97003E-09 & 4,13836E-09 & $2,54442 \mathrm{E}-09$ & $3,80118 \mathrm{E}-09$ & 2,53053E-09 & 2,5655E-09 & 2,32226E-09 & $1,59255 \mathrm{E}-09$ \\
\hline Outros Serviços & $9,76034 \mathrm{E}-09$ & 8,88106E-09 & $1,30421 \mathrm{E}-08$ & $2,562 \mathrm{E}-08$ & $1,8619 \mathrm{E}-08$ & $2,36253 \mathrm{E}-08$ & $1,05966 \mathrm{E}-08$ & $1,37962 \mathrm{E}-08$ & $1,08787 \mathrm{E}-08$ & $1,03783 \mathrm{E}-08$ \\
\hline APU & $5,94224 \mathrm{E}-10$ & $4,08557 \mathrm{E}-10$ & $4,80683 \mathrm{E}-10$ & 1,23523E-09 & $5,34783 \mathrm{E}-10$ & $9,81323 \mathrm{E}-10$ & $4,75815 \mathrm{E}-10$ & 6,63302E-10 & $3,06923 \mathrm{E}-10$ & $1,10258 \mathrm{E}-09$ \\
\hline
\end{tabular}

Tabela C8 - Matriz Geração de Renda para o Grau de Instrução G(7), Distrito Federal - 2008.

(3)

\begin{tabular}{|c|c|c|c|c|c|c|c|c|c|c|c|}
\hline Setores & Construção & Comércio & Transportes & Informação & Financeiro & Imobiliário & Alojamento & $\begin{array}{l}\text { Serviços às } \\
\text { Empresas }\end{array}$ & $\begin{array}{c}\text { Educação e } \\
\text { Saúde } \\
\text { mercantis }\end{array}$ & $\begin{array}{c}\text { Outros } \\
\text { Serviços }\end{array}$ & APU \\
\hline Agricultura & $2,18627 \mathrm{E}-09$ & 6,78304E-09 & $5,13093 \mathrm{E}-09$ & $3,11237 \mathrm{E}-09$ & $2,01533 \mathrm{E}-09$ & $4,27134 \mathrm{E}-10$ & $6,82384 \mathrm{E}-07$ & 3,09021E-09 & $1,62683 \mathrm{E}-08$ & 7,02774E-08 & $8,68542 \mathrm{E}-09$ \\
\hline Pecuária & $9,78579 \mathrm{E}-10$ & 2,87591E-09 & 2,56057E-09 & 1,26739E-09 & $9,70259 \mathrm{E}-10$ & $1,64072 \mathrm{E}-10$ & $3,78749 \mathrm{E}-07$ & $1,26736 \mathrm{E}-09$ & $8,42965 \mathrm{E}-09$ & $4,11541 \mathrm{E}-08$ & $3,94788 \mathrm{E}-09$ \\
\hline Extrativa & $7,95966 \mathrm{E}-08$ & $4,14926 \mathrm{E}-08$ & $2,55709 \mathrm{E}-08$ & $4,80505 \mathrm{E}-08$ & $1,43401 \mathrm{E}-08$ & $7,94052 \mathrm{E}-09$ & $3,77278 \mathrm{E}-08$ & $3,8342 \mathrm{E}-08$ & $3,77259 \mathrm{E}-08$ & $3,56007 \mathrm{E}-08$ & $3,90921 \mathrm{E}-08$ \\
\hline Alimentos & $9,93568 \mathrm{E}-09$ & $3,08727 \mathrm{E}-08$ & $2,72691 \mathrm{E}-08$ & $1,0806 \mathrm{E}-08$ & $8,88455 \mathrm{E}-09$ & 1,49716E-09 & $3,88926 \mathrm{E}-06$ & $1,03647 \mathrm{E}-08$ & $6,31323 \mathrm{E}-08$ & $1,44654 \mathrm{E}-07$ & $2,88363 \mathrm{E}-08$ \\
\hline Vestuário & $1,38816 \mathrm{E}-08$ & $3,11094 \mathrm{E}-08$ & $6,52272 \mathrm{E}-08$ & $3,03741 \mathrm{E}-08$ & $2,48563 \mathrm{E}-08$ & $3,289 \mathrm{E}-09$ & $3,60901 \mathrm{E}-08$ & $8,89452 \mathrm{E}-08$ & $5,73403 \mathrm{E}-08$ & $1,2824 \mathrm{E}-07$ & $2,49818 \mathrm{E}-08$ \\
\hline Madeira & $1,2275 \mathrm{E}-08$ & $4,35538 \mathrm{E}-09$ & $2,92143 \mathrm{E}-09$ & $5,78055 \mathrm{E}-09$ & $3,26821 \mathrm{E}-09$ & 4,26897E-09 & $3,5642 \mathrm{E}-09$ & 4,80756E-09 & 6,38353E-09 & $6,73728 \mathrm{E}-09$ & $9,63637 \mathrm{E}-09$ \\
\hline
\end{tabular}




\begin{tabular}{|c|c|c|c|c|c|c|c|c|c|c|c|}
\hline Celulose & $2,26655 \mathrm{E}-08$ & $9,09032 \mathrm{E}-08$ & $5,74627 \mathrm{E}-08$ & $1,1569 \mathrm{E}-07$ & $3,91783 \mathrm{E}-08$ & $1,52481 \mathrm{E}-08$ & $5,6929 \mathrm{E}-08$ & $1,51308 \mathrm{E}-07$ & $8,09879 \mathrm{E}-08$ & 7,64271E-08 & $7,61415 \mathrm{E}-08$ \\
\hline Revistas & $3,31346 \mathrm{E}-08$ & $1,19284 \mathrm{E}-07$ & $1,0053 \mathrm{E}-07$ & $2,78585 \mathrm{E}-07$ & $1,4425 \mathrm{E}-07$ & $3,13524 \mathrm{E}-08$ & $3,30102 \mathrm{E}-08$ & $8,85491 \mathrm{E}-07$ & $1,44551 \mathrm{E}-07$ & $1,53035 \mathrm{E}-07$ & $8,41104 \mathrm{E}-08$ \\
\hline Químicos & ,55211E-08 & $1,35091 \mathrm{E}-08$ & $9,54187 \mathrm{E}-09$ & $2,48576 \mathrm{E}-08$ & $5,67832 \mathrm{E}-09$ & 3,70023E-09 & $1,85343 \mathrm{E}-07$ & $1,54503 \mathrm{E}-08$ & $1,77475 \mathrm{E}-07$ & $3,48067 \mathrm{E}-08$ & 2,68337E-08 \\
\hline Borracha & $1,93685 \mathrm{E}-07$ & 7,72203E-08 & 6,49676E-08 & $1,58652 \mathrm{E}-07$ & $2,53786 \mathrm{E}-08$ & $1,44825 \mathrm{E}-08$ & $1,05373 \mathrm{E}-07$ & $2,29918 \mathrm{E}-07$ & $2,00813 \mathrm{E}-07$ & $6,40739 \mathrm{E}-08$ & $3,04956 \mathrm{E}-08$ \\
\hline Cimento & $7,36815 \mathrm{E}-07$ & 2,63745E-09 & 1,13299E-09 & $3,26424 \mathrm{E}-09$ & $3,05212 \mathrm{E}-09$ & 6,51626E-09 & $5,14149 \mathrm{E}-09$ & $2,45238 \mathrm{E}-09$ & $2,43218 \mathrm{E}-08$ & $1,28229 \mathrm{E}-08$ & $1,2175 \mathrm{E}-08$ \\
\hline Aço & 4,32374E-08 & 6,33931E-09 & 4,96606E-09 & 8,69227E-09 & 2,49319E-09 & 2,33337E-09 & $1,17366 \mathrm{E}-08$ & $6,08223 \mathrm{E}-09$ & $7,34582 \mathrm{E}-09$ & $8,21608 \mathrm{E}-09$ & 5,88208E-09 \\
\hline Metal & $1,57858 \mathrm{E}-07$ & $1,52399 \mathrm{E}-08$ & 3,57636E-09 & $8,31547 \mathrm{E}-09$ & 2,43862E-09 & $5,96288 \mathrm{E}-09$ & $6,74311 \mathrm{E}-08$ & 4,24326E-09 & $1,59884 \mathrm{E}-08$ & $1,01656 \mathrm{E}-08$ & $1,06093 \mathrm{E}-08$ \\
\hline Eletrodomésticos & $2,78056 \mathrm{E}-08$ & $2,6621 \mathrm{E}-08$ & $1,81156 \mathrm{E}-08$ & $3,35582 \mathrm{E}-08$ & $9,32968 \mathrm{E}-09$ & 7,00755E-09 & $2,13866 \mathrm{E}-08$ & $2,62522 \mathrm{E}-08$ & $2,48827 \mathrm{E}-08$ & $2,51659 \mathrm{E}-08$ & $2,5484 \mathrm{E}-08$ \\
\hline Informática & 4,6579E-09 & $3,87142 \mathrm{E}-09$ & 2,00913E-09 & 7,43565E-09 & 2,50461E-09 & $3,4383 \mathrm{E}-09$ & $2,05742 \mathrm{E}-09$ & 4,43609E-09 & $5,45676 \mathrm{E}-09$ & 4,40965E-09 & 7,66458E-09 \\
\hline Máquinas & $1,85473 \mathrm{E}-07$ & $3,91175 \mathrm{E}-08$ & $1,15126 \mathrm{E}-07$ & $1,67794 \mathrm{E}-07$ & $2,09366 \mathrm{E}-08$ & 4,54941E-08 & $3,10474 \mathrm{E}-08$ & $5,84127 \mathrm{E}-08$ & $5,19896 \mathrm{E}-08$ & $1,85093 \mathrm{E}-07$ & 3,29572E-08 \\
\hline Eletrônicos & $1,18455 \mathrm{E}-08$ & 7,84617E-09 & $9,77005 \mathrm{E}-09$ & $1,66172 \mathrm{E}-08$ & $3,67272 \mathrm{E}-09$ & $4,55742 \mathrm{E}-09$ & $5,70848 \mathrm{E}-09$ & $1,1156 \mathrm{E}-08$ & 7,651E-09 & $1,39528 \mathrm{E}-08$ & $7,26455 \mathrm{E}-09$ \\
\hline Instrumento hospitalar & $1,50277 \mathrm{E}-08$ & $9,08171 \mathrm{E}-09$ & $2,8802 \mathrm{E}-09$ & 3,74473E-09 & 2,11027E-09 & $1,71193 \mathrm{E}-08$ & $1,83215 \mathrm{E}-09$ & $2,4369 \mathrm{E}-08$ & $2,5296 \mathrm{E}-08$ & $1,92722 \mathrm{E}-08$ & $5,24145 \mathrm{E}-09$ \\
\hline Veículos & $1,94317 \mathrm{E}-07$ & $1,07692 \mathrm{E}-07$ & $9,43204 \mathrm{E}-08$ & $1,63235 \mathrm{E}-07$ & $4,26854 \mathrm{E}-08$ & 4,10094E-08 & $1,00837 \mathrm{E}-07$ & $1,0976 \mathrm{E}-07$ & $1,06752 \mathrm{E}-07$ & $1,42697 \mathrm{E}-07$ & $1,07066 \mathrm{E}-07$ \\
\hline Indústria Diversa & $3,16234 \mathrm{E}-08$ & 4,30962E-09 & $2,71022 \mathrm{E}-08$ & $5,31811 \mathrm{E}-09$ & $4,78962 \mathrm{E}-08$ & $1,19759 \mathrm{E}-08$ & $5,29025 \mathrm{E}-09$ & $1,75189 \mathrm{E}-08$ & $1,7358 \mathrm{E}-08$ & $8,75798 \mathrm{E}-08$ & $1,91335 \mathrm{E}-08$ \\
\hline SIUP & 6,76419E-08 & $2,31767 \mathrm{E}-07$ & $1,92191 \mathrm{E}-07$ & $1,8061 \mathrm{E}-07$ & $1,0899 \mathrm{E}-07$ & 2,29572E-08 & $2,34289 \mathrm{E}-07$ & $2,03398 \mathrm{E}-07$ & 2,99477E-07 & $6,7381 \mathrm{E}-07$ & $2,57945 \mathrm{E}-07$ \\
\hline Construção & $3,15164 \mathrm{E}-06$ & $3,60666 \mathrm{E}-09$ & $2,80364 \mathrm{E}-09$ & $1,14852 \mathrm{E}-08$ & $1,13631 \mathrm{E}-08$ & $2,71664 \mathrm{E}-08$ & $1,93028 \mathrm{E}-09$ & $8,09344 \mathrm{E}-09$ & $2,42598 \mathrm{E}-08$ & $2,09426 \mathrm{E}-08$ & $4,73743 \mathrm{E}-08$ \\
\hline Comércio & 9,87973E-08 & $1,8557 \mathrm{E}-06$ & $8,22802 \mathrm{E}-08$ & $4,08844 \mathrm{E}-08$ & $2,44425 \mathrm{E}-08$ & $1,07872 \mathrm{E}-08$ & $1,89407 \mathrm{E}-07$ & $7,08767 \mathrm{E}-08$ & $6,30699 \mathrm{E}-08$ & $6,81941 \mathrm{E}-08$ & $3,61421 \mathrm{E}-08$ \\
\hline Transportes & 5,49473E-08 & $1,4457 \mathrm{E}-07$ & $4,41564 \mathrm{E}-06$ & $9,80702 \mathrm{E}-08$ & $4,12382 \mathrm{E}-08$ & 7,33497E-09 & $6,61747 \mathrm{E}-08$ & 7,79096E-08 & $7,00084 \mathrm{E}-08$ & $1,03481 \mathrm{E}-07$ & $3,75857 \mathrm{E}-08$ \\
\hline Informação & $1,58069 \mathrm{E}-08$ & $4,98202 \mathrm{E}-08$ & $5,20866 \mathrm{E}-08$ & $3,72936 \mathrm{E}-06$ & $1,51964 \mathrm{E}-07$ & $1,02743 \mathrm{E}-08$ & $2,48874 \mathrm{E}-08$ & $4,0394 \mathrm{E}-07$ & $1,3891 \mathrm{E}-07$ & $9,09656 \mathrm{E}-08$ & $1,68418 \mathrm{E}-07$ \\
\hline Financeiro & $3,15498 \mathrm{E}-08$ & $6,26204 \mathrm{E}-08$ & $8,65891 \mathrm{E}-08$ & $8,81465 \mathrm{E}-08$ & $2,50028 \mathrm{E}-06$ & $1,27385 \mathrm{E}-08$ & $3,25687 \mathrm{E}-08$ & $8,34259 \mathrm{E}-08$ & $3,68332 \mathrm{E}-08$ & $2,05009 \mathrm{E}-08$ & $1,95097 \mathrm{E}-07$ \\
\hline Imobiliário & $1,46096 \mathrm{E}-08$ & $7,35477 \mathrm{E}-08$ & $1,3107 \mathrm{E}-07$ & $1,18743 \mathrm{E}-07$ & $3,76644 \mathrm{E}-08$ & $3,49209 \mathrm{E}-06$ & $4,52574 \mathrm{E}-08$ & $8,57163 \mathrm{E}-08$ & $8,91653 \mathrm{E}-08$ & $6,38952 \mathrm{E}-08$ & $6,744 \mathrm{E}-08$ \\
\hline Alojamento & $3,35942 \mathrm{E}-09$ & $4,66847 \mathrm{E}-09$ & $9,08978 \mathrm{E}-09$ & $6,12992 \mathrm{E}-09$ & $5,89543 \mathrm{E}-09$ & $6,50502 \mathrm{E}-10$ & $3,60608 \mathrm{E}-06$ & $5,28854 \mathrm{E}-09$ & $2,80358 \mathrm{E}-08$ & $3,19958 \mathrm{E}-08$ & $1,73296 \mathrm{E}-08$ \\
\hline Serviços às Empresas & $3,48442 \mathrm{E}-08$ & $9,71889 \mathrm{E}-08$ & $1,1168 \mathrm{E}-07$ & $1,59173 \mathrm{E}-07$ & $1,20387 \mathrm{E}-07$ & $1,88136 \mathrm{E}-08$ & $3,07811 \mathrm{E}-08$ & $1,92092 \mathrm{E}-06$ & $1,60232 \mathrm{E}-07$ & $1,01963 \mathrm{E}-07$ & $1,13226 \mathrm{E}-07$ \\
\hline Educação e Saúde mercantis & $1,77986 \mathrm{E}-09$ & $6,34221 \mathrm{E}-09$ & 4,20309E-09 & $7,08179 \mathrm{E}-09$ & 7,30301E-09 & $9,14629 \mathrm{E}-10$ & $5,05646 \mathrm{E}-09$ & $6,02876 \mathrm{E}-09$ & $3,19409 \mathrm{E}-06$ & 4,83241E-09 & $9,96909 \mathrm{E}-09$ \\
\hline Outros Serviços & $9,70836 \mathrm{E}-09$ & $2,56679 \mathrm{E}-08$ & $1,6048 \mathrm{E}-08$ & $2,86043 \mathrm{E}-08$ & $1,46955 \mathrm{E}-08$ & 2,86592E-09 & $2,79904 \mathrm{E}-08$ & $3,41754 \mathrm{E}-08$ & $2,52903 \mathrm{E}-08$ & $3,59956 \mathrm{E}-06$ & $1,81194 \mathrm{E}-08$ \\
\hline APU & $3,1516 \mathrm{E}-10$ & $8,47419 \mathrm{E}-10$ & $8,89001 \mathrm{E}-10$ & $1,14354 \mathrm{E}-09$ & $8,18613 \mathrm{E}-10$ & $1,35517 \mathrm{E}-10$ & $4,01171 \mathrm{E}-10$ & $1,01772 \mathrm{E}-09$ & $1,117 \mathrm{E}-09$ & $8,63217 \mathrm{E}-10$ & $2,77331 \mathrm{E}-07$ \\
\hline
\end{tabular}


Tabela C9 - Matriz Geração de Renda para o Grau de Instrução G(8), Distrito Federal - 2008.

(1)

\begin{tabular}{|c|c|c|c|c|c|c|c|c|c|c|c|}
\hline Setores & Agricultura & Pecuária & Extrativa & Alimentos & Vestuário & Madeira & Celulose & Revistas & Químicos & Borracha & Cimento \\
\hline Agricultura & $7,69608 \mathrm{E}-05$ & $5,04929 \mathrm{E}-06$ & 8,39823E-09 & $6,20052 \mathrm{E}-06$ & $7,75663 \mathrm{E}-08$ & $1,2193 \mathrm{E}-07$ & $3,52127 \mathrm{E}-07$ & 3,43486E-09 & $1,54632 \mathrm{E}-08$ & $2,6206 \mathrm{E}-07$ & 6,01083E-09 \\
\hline Pecuária & $6,01507 \mathrm{E}-07$ & 0,000153846 & $4,52225 \mathrm{E}-09$ & $6,08574 \mathrm{E}-06$ & $1,27055 \mathrm{E}-07$ & $1,06674 \mathrm{E}-08$ & $3,50483 \mathrm{E}-08$ & 1,7082E-09 & $1,10944 \mathrm{E}-08$ & $5,17729 \mathrm{E}-08$ & $4,22166 \mathrm{E}-09$ \\
\hline Extrativa & $2,54806 \mathrm{E}-07$ & $6,04028 \mathrm{E}-07$ & 0,003510476 & $1,43703 \mathrm{E}-07$ & $1,32063 \mathrm{E}-07$ & $1,81816 \mathrm{E}-07$ & $1,40613 \mathrm{E}-06$ & $3,36527 \mathrm{E}-08$ & $2,13716 \mathrm{E}-06$ & $4,54626 \mathrm{E}-07$ & $1,5883 \mathrm{E}-06$ \\
\hline Alimentos & $8,54653 \mathrm{E}-07$ & $1,29783 \mathrm{E}-05$ & $4,48315 \mathrm{E}-08$ & 7,82464E-05 & $5,90388 \mathrm{E}-07$ & $6,11293 \mathrm{E}-08$ & $1,91088 \mathrm{E}-07$ & $1,65738 \mathrm{E}-08$ & $7,21962 \mathrm{E}-08$ & $2,41675 \mathrm{E}-08$ & $4,38415 \mathrm{E}-08$ \\
\hline Vestuário & $1,50883 \mathrm{E}-08$ & $1,33527 \mathrm{E}-08$ & 4,4519E-07 & $1,94612 \mathrm{E}-08$ & 0,000798718 & $1,80979 \mathrm{E}-08$ & $6,39249 \mathrm{E}-07$ & $2,0484 \mathrm{E}-08$ & $4,08217 \mathrm{E}-08$ & $1,19625 \mathrm{E}-07$ & $2,82923 \mathrm{E}-08$ \\
\hline Madeira & $1,96015 \mathrm{E}-07$ & $3,84241 \mathrm{E}-08$ & $1,06861 \mathrm{E}-07$ & $4,58531 \mathrm{E}-08$ & $1,90823 \mathrm{E}-07$ & 0,003292558 & $1,98647 \mathrm{E}-05$ & $3,29168 \mathrm{E}-08$ & $6,02102 \mathrm{E}-07$ & $1,63454 \mathrm{E}-07$ & $1,85737 \mathrm{E}-07$ \\
\hline Celulose & 7,57871E-08 & $8,2913 \mathrm{E}-08$ & $1,98311 \mathrm{E}-06$ & $9,68638 \mathrm{E}-08$ & $4,60874 \mathrm{E}-06$ & 7,58814E-06 & 0,003097021 & 4,8381E-07 & $1,26446 \mathrm{E}-06$ & 3,66292E-06 & $6,43427 \mathrm{E}-08$ \\
\hline Revistas & 7,01196E-08 & $7,81761 \mathrm{E}-08$ & $1,80748 \mathrm{E}-07$ & $1,2902 \mathrm{E}-07$ & $6,80534 \mathrm{E}-08$ & 4,19014E-08 & $7,78135 \mathrm{E}-07$ & 0,000168998 & $1,10917 \mathrm{E}-06$ & 4,36064E-07 & $1,48545 \mathrm{E}-07$ \\
\hline Químicos & $1,08222 \mathrm{E}-05$ & $7,52725 \mathrm{E}-06$ & 2,51486E-06 & $1,4082 \mathrm{E}-06$ & $7,74061 \mathrm{E}-07$ & $1,43488 \mathrm{E}-06$ & $6,52581 \mathrm{E}-06$ & $4,35101 \mathrm{E}-08$ & 0,000280068 & 3,80373E-06 & $3,56223 \mathrm{E}-07$ \\
\hline Borracha & $8,44833 \mathrm{E}-07$ & $5,41394 \mathrm{E}-07$ & $6,9528 \mathrm{E}-06$ & $1,50047 \mathrm{E}-06$ & $1,97465 \mathrm{E}-06$ & $3,67462 \mathrm{E}-06$ & $9,16405 \mathrm{E}-06$ & $1,15491 \mathrm{E}-06$ & $2,7206 \mathrm{E}-06$ & 0,000771777 & $9,24842 \mathrm{E}-08$ \\
\hline Cimento & $6,44321 \mathrm{E}-08$ & 3,28951E-08 & 7,60135E-08 & $1,10095 \mathrm{E}-07$ & $2,89742 \mathrm{E}-08$ & $1,25844 \mathrm{E}-08$ & $9,8448 \mathrm{E}-08$ & $1,03236 \mathrm{E}-08$ & $4,04989 \mathrm{E}-07$ & $3,01526 \mathrm{E}-08$ & $6,40702 \mathrm{E}-05$ \\
\hline Aço & $5,09384 \mathrm{E}-07$ & $2,45484 \mathrm{E}-07$ & $2,66331 \mathrm{E}-06$ & $2,80115 \mathrm{E}-07$ & $1,54632 \mathrm{E}-07$ & $1,35943 \mathrm{E}-06$ & $2,69066 \mathrm{E}-06$ & $2,32359 \mathrm{E}-08$ & $7,08122 \mathrm{E}-07$ & $3,90904 \mathrm{E}-06$ & $2,72556 \mathrm{E}-07$ \\
\hline Metal & $5,00724 \mathrm{E}-07$ & $3,5283 \mathrm{E}-07$ & $1,62249 \mathrm{E}-06$ & $8,7095 \mathrm{E}-07$ & $1,39902 \mathrm{E}-07$ & $8,45825 \mathrm{E}-07$ & $1,51205 \mathrm{E}-06$ & $9,38389 \mathrm{E}-09$ & $7,35305 \mathrm{E}-07$ & $8,35598 \mathrm{E}-07$ & $1,32062 \mathrm{E}-07$ \\
\hline Eletrodomésticos & $1,59723 \mathrm{E}-07$ & $1,08986 \mathrm{E}-07$ & $6,49586 \mathrm{E}-06$ & $1,83219 \mathrm{E}-07$ & $1,67227 \mathrm{E}-06$ & $2,88177 \mathrm{E}-06$ & $1,23323 \mathrm{E}-05$ & $4,92185 \mathrm{E}-08$ & $9,18454 \mathrm{E}-07$ & $1,24392 \mathrm{E}-06$ & $9,62644 \mathrm{E}-08$ \\
\hline Informática & $4,78258 \mathrm{E}-09$ & $3,80505 \mathrm{E}-09$ & $3,22688 \mathrm{E}-08$ & $5,23795 \mathrm{E}-09$ & $2,71138 \mathrm{E}-08$ & $1,4294 \mathrm{E}-08$ & $1,56627 \mathrm{E}-07$ & $1,96616 \mathrm{E}-08$ & $6,94229 \mathrm{E}-08$ & 7,3691E-08 & 3,85364E-09 \\
\hline Máquinas & 3,43993E-08 & $6,25178 \mathrm{E}-08$ & $1,03705 \mathrm{E}-06$ & $1,16294 \mathrm{E}-07$ & $1,16 \mathrm{E}-07$ & $2,43304 \mathrm{E}-07$ & $2,41706 \mathrm{E}-07$ & $1,51041 \mathrm{E}-08$ & $2,91958 \mathrm{E}-07$ & $8,75876 \mathrm{E}-07$ & $2,1646 \mathrm{E}-07$ \\
\hline Eletrônicos & $2,35746 \mathrm{E}-08$ & $2,67439 \mathrm{E}-08$ & 2,69349E-06 & $5,35974 \mathrm{E}-08$ & $5,39796 \mathrm{E}-08$ & $8,82403 \mathrm{E}-08$ & 1,79799E-07 & 3,09663E-08 & $1,1208 \mathrm{E}-07$ & 2,20326E-07 & $6,00267 \mathrm{E}-08$ \\
\hline Instrumento hospitalar & 2,7673E-09 & $3,0489 \mathrm{E}-09$ & $1,36665 \mathrm{E}-08$ & 4,03057E-09 & $5,36022 \mathrm{E}-09$ & $5,73061 \mathrm{E}-09$ & $3,14371 \mathrm{E}-08$ & $6,12838 \mathrm{E}-09$ & $3,32836 \mathrm{E}-08$ & $6,40232 \mathrm{E}-08$ & 4,92139E-09 \\
\hline Veículos & $5,12872 \mathrm{E}-07$ & $4,19687 \mathrm{E}-07$ & $3,03738 \mathrm{E}-06$ & $9,74512 \mathrm{E}-07$ & $5,23808 \mathrm{E}-07$ & $1,26337 \mathrm{E}-06$ & $2,46515 \mathrm{E}-06$ & $1,61003 \mathrm{E}-07$ & $1,16164 \mathrm{E}-06$ & $2,55266 \mathrm{E}-06$ & $4,60464 \mathrm{E}-07$ \\
\hline Indústria Diversa & $3,6135 \mathrm{E}-09$ & 3,34961E-08 & 9,75414E-09 & 2,26971E-08 & $3,56561 \mathrm{E}-07$ & $1,05167 \mathrm{E}-08$ & $1,93196 \mathrm{E}-07$ & 4,20414E-09 & $9,60337 \mathrm{E}-09$ & $6,86233 \mathrm{E}-08$ & $9,17741 \mathrm{E}-09$ \\
\hline SIUP & 2,20214E-07 & 3,39889E-07 & $8,83676 \mathrm{E}-07$ & $5,44327 \mathrm{E}-07$ & $4,45437 \mathrm{E}-07$ & $4,6273 \mathrm{E}-07$ & $1,36647 \mathrm{E}-06$ & 3,62537E-07 & 6,60087E-07 & $6,82588 \mathrm{E}-07$ & $1,80016 \mathrm{E}-06$ \\
\hline Construção & $1,84165 \mathrm{E}-09$ & 2,61617E-09 & 4,73404E-09 & $6,07456 \mathrm{E}-09$ & 5,45694E-09 & 4,82037E-09 & $8,67856 \mathrm{E}-09$ & $6,86966 \mathrm{E}-09$ & $9,72307 \mathrm{E}-09$ & $1,5791 \mathrm{E}-08$ & $2,1536 \mathrm{E}-08$ \\
\hline Comércio & $1,56219 \mathrm{E}-07$ & $2,30524 \mathrm{E}-07$ & $1,37393 \mathrm{E}-07$ & $2,47183 \mathrm{E}-07$ & $2,59641 \mathrm{E}-07$ & $1,06036 \mathrm{E}-07$ & $1,35653 \mathrm{E}-07$ & $1,4048 \mathrm{E}-07$ & $1,92775 \mathrm{E}-07$ & $1,50242 \mathrm{E}-07$ & $2,41083 \mathrm{E}-07$ \\
\hline Transportes & $2,50364 \mathrm{E}-07$ & $2,27803 \mathrm{E}-07$ & $6,69223 \mathrm{E}-07$ & $4,27011 \mathrm{E}-07$ & $1,98469 \mathrm{E}-07$ & $2,14883 \mathrm{E}-07$ & $3,64023 \mathrm{E}-07$ & $2,09279 \mathrm{E}-07$ & $3,95845 \mathrm{E}-07$ & 2,58847E-07 & $8,02303 \mathrm{E}-07$ \\
\hline Informação & $3,01779 \mathrm{E}-08$ & $4,67832 \mathrm{E}-08$ & $1,37674 \mathrm{E}-07$ & $5,87926 \mathrm{E}-08$ & $3,36887 \mathrm{E}-08$ & $2,49225 \mathrm{E}-08$ & $5,7538 \mathrm{E}-08$ & $1,38437 \mathrm{E}-07$ & $1,78255 \mathrm{E}-07$ & 7,94939E-08 & $1,07878 \mathrm{E}-07$ \\
\hline
\end{tabular}




\begin{tabular}{|c|c|c|c|c|c|c|c|c|c|c|c|}
\hline Financeiro & $6,90831 \mathrm{E}-08$ & $7,66029 \mathrm{E}-08$ & $1,54799 \mathrm{E}-07$ & $1,31827 \mathrm{E}-07$ & $1,0541 \mathrm{E}-07$ & $9,77168 \mathrm{E}-08$ & 2,13131E-07 & $1,20885 \mathrm{E}-07$ & $2,09875 \mathrm{E}-07$ & $1,52443 \mathrm{E}-07$ & $2,45136 \mathrm{E}-07$ \\
\hline Imobiliário & $3,24734 \mathrm{E}-08$ & $4,15875 \mathrm{E}-08$ & 9,85214E-08 & $8,31091 \mathrm{E}-08$ & $9,25945 \mathrm{E}-08$ & 3,70586E-08 & $8,18746 \mathrm{E}-08$ & $1,29006 \mathrm{E}-07$ & $1,10442 \mathrm{E}-07$ & $6,88599 \mathrm{E}-08$ & $1,19992 \mathrm{E}-07$ \\
\hline Alojamento & $1,608 \mathrm{E}-09$ & 2,26806E-09 & $1,46597 \mathrm{E}-08$ & 3,99007E-09 & $2,3265 \mathrm{E}-09$ & 4,66682E-09 & 4,75603E-09 & 6,30473E-09 & $5,28409 \mathrm{E}-09$ & 4,69375E-09 & 2,57999E-08 \\
\hline Serviços às Empresas & $3,20757 \mathrm{E}-08$ & 4,61134E-08 & 8,89125E-08 & $1,08511 \mathrm{E}-07$ & $7,1194 \mathrm{E}-08$ & $3,78569 \mathrm{E}-08$ & $9,18106 \mathrm{E}-08$ & $2,50186 \mathrm{E}-07$ & $2,82927 \mathrm{E}-07$ & 7,65611E-08 & $1,77715 \mathrm{E}-07$ \\
\hline Educação e Saúde mercantis & 2,82812E-09 & 3,9102E-09 & 5,75434E-09 & $5,89398 \mathrm{E}-09$ & 7,19599E-09 & 2,64242E-09 & $5,17322 \mathrm{E}-09$ & 6,30744E-09 & 6,33704E-09 & 4,53542E-09 & 6,53422E-09 \\
\hline Outros Serviços & $1,50915 \mathrm{E}-08$ & $2,1871 \mathrm{E}-08$ & 2,27855E-08 & $2,88523 \mathrm{E}-08$ & $3,1016 \mathrm{E}-08$ & $1,14347 \mathrm{E}-08$ & $1,89603 \mathrm{E}-08$ & $2,22881 \mathrm{E}-08$ & $3,07352 \mathrm{E}-08$ & $2,24422 \mathrm{E}-08$ & 3,57987E-08 \\
\hline APU & $7,78809 \mathrm{E}-10$ & $9,29213 \mathrm{E}-10$ & $1,86549 \mathrm{E}-09$ & $1,72273 \mathrm{E}-09$ & $1,08572 \mathrm{E}-09$ & $7,3264 \mathrm{E}-10$ & $1,77872 \mathrm{E}-09$ & 3,29198E-09 & 2,97782E-09 & $1,26324 \mathrm{E}-09$ & $2,84468 \mathrm{E}-09$ \\
\hline
\end{tabular}

Tabela C9 - Matriz Geração de Renda para o Grau de Instrução G(8), Distrito Federal - 2008.

(2)

\begin{tabular}{|c|c|c|c|c|c|c|c|c|c|c|}
\hline Setores & Aço & Metal & Eletrodomésticos & Informática & Máquinas & Eletrônicos & $\begin{array}{l}\text { Instrumento } \\
\text { hospitalar }\end{array}$ & Veículos & $\begin{array}{l}\text { Indústria } \\
\text { Diversa }\end{array}$ & SIUP \\
\hline Agricultura & 4,52847E-09 & 2,49681E-09 & 8,96498E-09 & 8,54033E-09 & $5,09332 \mathrm{E}-09$ & $1,16601 \mathrm{E}-08$ & 3,09809E-09 & $1,77881 \mathrm{E}-08$ & 6,96041E-09 & 1,26163E-09 \\
\hline Pecuária & 2,32091E-09 & $1,14648 \mathrm{E}-09$ & 2,8338E-09 & $3,06523 \mathrm{E}-09$ & 2,43091E-09 & $3,1806 \mathrm{E}-09$ & 1,31078E-09 & 5,07364E-09 & 2,71777E-08 & 7,45437E-10 \\
\hline Extrativa & 5,91399E-05 & 3,494E-06 & $1,10886 \mathrm{E}-05$ & $8,45165 \mathrm{E}-07$ & $3,36249 \mathrm{E}-06$ & $1,88967 \mathrm{E}-06$ & $3,14859 \mathrm{E}-07$ & $6,32492 \mathrm{E}-06$ & $1,93884 \mathrm{E}-06$ & $2,96805 \mathrm{E}-08$ \\
\hline Alimentos & $1,96471 \mathrm{E}-08$ & $9,2371 \mathrm{E}-09$ & $1,91221 \mathrm{E}-08$ & 2,13924E-08 & $1,92657 \mathrm{E}-08$ & $2,09267 \mathrm{E}-08$ & $1,01452 \mathrm{E}-08$ & $2,58728 \mathrm{E}-08$ & $1,84057 \mathrm{E}-08$ & $6,16733 \mathrm{E}-09$ \\
\hline Vestuário & $3,75859 \mathrm{E}-08$ & $5,75174 \mathrm{E}-08$ & $3,15687 \mathrm{E}-07$ & $4,39051 \mathrm{E}-08$ & $3,6875 \mathrm{E}-08$ & 4,99898E-08 & $5,56464 \mathrm{E}-08$ & 2,70792E-07 & $3,80099 \mathrm{E}-08$ & $3,8055 \mathrm{E}-08$ \\
\hline Madeira & $1,49437 \mathrm{E}-07$ & $2,20723 \mathrm{E}-07$ & 4,40392E-06 & $4,05151 \mathrm{E}-06$ & $1,9475 \mathrm{E}-07$ & $1,80193 \mathrm{E}-05$ & $5,3299 \mathrm{E}-08$ & $2,76048 \mathrm{E}-06$ & $5,95073 \mathrm{E}-06$ & $7,2129 \mathrm{E}-09$ \\
\hline Celulose & $5,21528 \mathrm{E}-07$ & $1,26019 \mathrm{E}-07$ & 9,6171E-06 & $5,20003 \mathrm{E}-06$ & $9,38417 \mathrm{E}-07$ & $1,02665 \mathrm{E}-05$ & $2,19593 \mathrm{E}-07$ & $5,25944 \mathrm{E}-06$ & $5,05996 \mathrm{E}-07$ & $4,4159 \mathrm{E}-08$ \\
\hline Revistas & $2,12841 \mathrm{E}-07$ & $2,09448 \mathrm{E}-07$ & $1,28275 \mathrm{E}-07$ & $2,42101 \mathrm{E}-07$ & $1,09295 \mathrm{E}-07$ & $2,03268 \mathrm{E}-07$ & $1,00444 \mathrm{E}-06$ & 2,38967E-07 & $7,1404 \mathrm{E}-08$ & 2,99404E-07 \\
\hline Químicos & $3,35336 \mathrm{E}-06$ & $5,846 \mathrm{E}-07$ & $3,09545 \mathrm{E}-06$ & $2,22089 \mathrm{E}-07$ & $9,74195 \mathrm{E}-07$ & $3,91599 \mathrm{E}-07$ & 7,38809E-07 & $2,03784 \mathrm{E}-06$ & $3,62557 \mathrm{E}-07$ & $2,45198 \mathrm{E}-07$ \\
\hline Borracha & $4,74857 \mathrm{E}-06$ & $2,72202 \mathrm{E}-06$ & $1,29845 \mathrm{E}-05$ & $1,1569 \mathrm{E}-05$ & $5,96818 \mathrm{E}-06$ & $1,34272 \mathrm{E}-05$ & $3,74129 \mathrm{E}-06$ & $3,11061 \mathrm{E}-05$ & 4,92304E-06 & $1,17782 \mathrm{E}-07$ \\
\hline Cimento & $5,65252 \mathrm{E}-07$ & $1,68698 \mathrm{E}-07$ & $2,19255 \mathrm{E}-07$ & $1,15461 \mathrm{E}-07$ & $5,43175 \mathrm{E}-07$ & $4,23285 \mathrm{E}-07$ & 1,98973E-07 & 4,88983E-07 & $1,13691 \mathrm{E}-06$ & $5,47748 \mathrm{E}-09$ \\
\hline Aço & 0,000664844 & $5,42594 \mathrm{E}-06$ & $9,9362 \mathrm{E}-05$ & $7,19541 \mathrm{E}-06$ & $1,95881 \mathrm{E}-05$ & $1,73079 \mathrm{E}-05$ & $1,97935 \mathrm{E}-06$ & $5,46996 \mathrm{E}-05$ & $2,01804 \mathrm{E}-06$ & $6,29066 \mathrm{E}-08$ \\
\hline Metal & 3,99101E-06 & 0,000102455 & $6,42478 \mathrm{E}-06$ & 2,40994E-06 & 4,46486E-06 & $3,9759 \mathrm{E}-06$ & 2,73672E-06 & $2,86651 \mathrm{E}-06$ & $2,20351 \mathrm{E}-06$ & $1,12036 \mathrm{E}-08$ \\
\hline Eletrodomésticos & $6,62248 \mathrm{E}-06$ & 7,6102E-07 & 0,002545014 & $7,05521 \mathrm{E}-06$ & $3,25618 \mathrm{E}-06$ & $4,76072 \mathrm{E}-06$ & $1,41815 \mathrm{E}-06$ & 2,98259E-05 & 4,93694E-07 & 7,97932E-08 \\
\hline Informática & $2,11 \mathrm{E}-08$ & $1,13732 \mathrm{E}-08$ & $1,09051 \mathrm{E}-07$ & 0,004619234 & $6,76435 \mathrm{E}-08$ & 2,31373E-06 & $1,46778 \mathrm{E}-08$ & $1,42537 \mathrm{E}-07$ & $1,15658 \mathrm{E}-08$ & 2,296E-09 \\
\hline Máquinas & $3,73474 \mathrm{E}-07$ & $1,02114 \mathrm{E}-07$ & $7,71155 \mathrm{E}-06$ & $1,84548 \mathrm{E}-05$ & 0,000301826 & 3,39142E-05 & $2,2495 \mathrm{E}-06$ & $5,04248 \mathrm{E}-06$ & $7,53469 \mathrm{E}-07$ & 5,72741E-07 \\
\hline
\end{tabular}




\begin{tabular}{|c|c|c|c|c|c|c|c|c|c|c|}
\hline Eletrônicos & 2,55853E-07 & $1,5343 \mathrm{E}-07$ & $6,45789 \mathrm{E}-06$ & 0,000755481 & $6,29858 \mathrm{E}-06$ & 0,00372347 & $7,4719 \mathrm{E}-07$ & $6,0058 \mathrm{E}-06$ & $3,12855 \mathrm{E}-07$ & $1,21443 \mathrm{E}-07$ \\
\hline Instrumento hospitalar & 9,76462E-09 & $5,36808 \mathrm{E}-09$ & $1,48076 \mathrm{E}-06$ & $1,93595 \mathrm{E}-07$ & $5,75009 \mathrm{E}-07$ & 2,70114E-07 & 0,000464542 & $2,4717 \mathrm{E}-07$ & $2,54062 \mathrm{E}-08$ & $5,61248 \mathrm{E}-09$ \\
\hline Veículos & 6,96202E-06 & 4,39833E-06 & $3,14025 \mathrm{E}-05$ & $2,21841 \mathrm{E}-05$ & $2,53433 \mathrm{E}-05$ & $4,02558 \mathrm{E}-05$ & $5,33514 \mathrm{E}-06$ & 0,011097063 & $3,17469 \mathrm{E}-06$ & $6,77082 \mathrm{E}-07$ \\
\hline Indústria Diversa & $4,58676 \mathrm{E}-07$ & 3,37953E-08 & $1,06605 \mathrm{E}-07$ & $2,01759 \mathrm{E}-08$ & 6,18997E-08 & $3,28315 \mathrm{E}-08$ & $8,7476 \mathrm{E}-09$ & $5,50717 \mathrm{E}-08$ & 0,000114932 & 2,86544E-09 \\
\hline SIUP & $1,59945 \mathrm{E}-06$ & 7,79973E-07 & 7,76393E-07 & $5,19873 \mathrm{E}-07$ & 9,11494E-07 & $6,35227 \mathrm{E}-07$ & $6,64315 \mathrm{E}-07$ & $6,80638 \mathrm{E}-07$ & 4,84649E-07 & $7,24152 \mathrm{E}-05$ \\
\hline Construção & 6,70948E-09 & 4,50864E-09 & 9,11977E-09 & $1,34255 \mathrm{E}-08$ & $1,85433 \mathrm{E}-08$ & $2,802 \mathrm{E}-08$ & $4,25109 \mathrm{E}-09$ & $2,97165 \mathrm{E}-08$ & $5,4485 \mathrm{E}-09$ & 4,21165E-09 \\
\hline Comércio & $1,28442 \mathrm{E}-07$ & $1,12494 \mathrm{E}-07$ & $1,88986 \mathrm{E}-07$ & $4,25426 \mathrm{E}-07$ & $1,68485 \mathrm{E}-07$ & 3,17764E-07 & $1,69711 \mathrm{E}-07$ & 2,42095E-07 & $1,96542 \mathrm{E}-07$ & $5,36438 \mathrm{E}-08$ \\
\hline Transportes & 5,38197E-07 & $3,08838 \mathrm{E}-07$ & $4,24982 \mathrm{E}-07$ & $4,76643 \mathrm{E}-07$ & 4,06595E-07 & 5,91714E-07 & $3,22865 \mathrm{E}-07$ & $3,72515 \mathrm{E}-07$ & $2,00097 \mathrm{E}-07$ & $1,63507 \mathrm{E}-07$ \\
\hline Informação & 1,40727E-07 & $6,25882 \mathrm{E}-08$ & $1,5742 \mathrm{E}-07$ & $2,26306 \mathrm{E}-07$ & $1,93137 \mathrm{E}-07$ & 3,32964E-07 & $1,0199 \mathrm{E}-07$ & $1,25888 \mathrm{E}-07$ & 3,41973E-08 & 1,19084E-07 \\
\hline Financeiro & $2,6705 \mathrm{E}-07$ & $1,57327 \mathrm{E}-07$ & $3,40225 \mathrm{E}-07$ & $2,37615 \mathrm{E}-07$ & $2,43071 \mathrm{E}-07$ & $4,18703 \mathrm{E}-07$ & $1,6898 \mathrm{E}-07$ & $2,3338 \mathrm{E}-07$ & $1,00008 \mathrm{E}-07$ & $8,9931 \mathrm{E}-08$ \\
\hline Imobiliário & 7,78057E-08 & $6,60229 \mathrm{E}-08$ & $1,02879 \mathrm{E}-07$ & $1,10316 \mathrm{E}-07$ & $8,16159 \mathrm{E}-08$ & $1,09129 \mathrm{E}-07$ & $9,60033 \mathrm{E}-08$ & $7,18169 \mathrm{E}-08$ & $6,2615 \mathrm{E}-08$ & $5,63386 \mathrm{E}-08$ \\
\hline Alojamento & 6,83154E-09 & 2,60384E-09 & 3,76152E-09 & $5,43947 \mathrm{E}-09$ & 8,07144E-09 & $5,43483 \mathrm{E}-09$ & $2,33888 \mathrm{E}-09$ & $7,21641 \mathrm{E}-09$ & 4,86047E-09 & $1,99769 \mathrm{E}-09$ \\
\hline Serviços às Empresas & 7,43913E-08 & $7,24931 \mathrm{E}-08$ & $8,68829 \mathrm{E}-08$ & $3,88648 \mathrm{E}-07$ & $1,23889 \mathrm{E}-07$ & $2,73928 \mathrm{E}-07$ & $9,94898 \mathrm{E}-08$ & $1,66389 \mathrm{E}-07$ & $5,72405 \mathrm{E}-08$ & $2,11308 \mathrm{E}-07$ \\
\hline Educação e Saúde mercantis & 4,29456E-09 & 4,3393E-09 & 6,37198E-09 & $8,87855 \mathrm{E}-09$ & $5,45887 \mathrm{E}-09$ & $8,15514 \mathrm{E}-09$ & $5,42906 \mathrm{E}-09$ & $5,50408 \mathrm{E}-09$ & 4,98223E-09 & $3,41669 \mathrm{E}-09$ \\
\hline Outros Serviços & $2,11657 \mathrm{E}-08$ & $1,92589 \mathrm{E}-08$ & $2,82822 \mathrm{E}-08$ & $5,55579 \mathrm{E}-08$ & $4,0376 \mathrm{E}-08$ & $5,12323 \mathrm{E}-08$ & $2,29792 \mathrm{E}-08$ & $2,99176 \mathrm{E}-08$ & $2,35909 \mathrm{E}-08$ & $2,25057 \mathrm{E}-08$ \\
\hline APU & $1,81125 \mathrm{E}-09$ & $1,24532 \mathrm{E}-09$ & $1,46517 \mathrm{E}-09$ & $3,76512 \mathrm{E}-09$ & $1,63007 \mathrm{E}-09$ & 2,99117E-09 & $1,45033 \mathrm{E}-09$ & $2,02181 \mathrm{E}-09$ & $9,35532 \mathrm{E}-10$ & $3,36077 \mathrm{E}-09$ \\
\hline
\end{tabular}

Tabela C9 - Matriz Geração de Renda para o Grau de Instrução G(8), Distrito Federal - 2008.

(3)

\begin{tabular}{|c|c|c|c|c|c|c|c|c|c|c|c|}
\hline Setores & Construção & Comércio & Transportes & Informação & Financeiro & Imobiliário & Alojamento & $\begin{array}{l}\text { Serviços às } \\
\text { Empresas }\end{array}$ & $\begin{array}{l}\text { Educação e } \\
\text { Saúde } \\
\text { mercantis }\end{array}$ & $\begin{array}{c}\text { Outros } \\
\text { Serviços }\end{array}$ & APU \\
\hline Agricultura & $3,62 \mathrm{E}-09$ & $1,12313 \mathrm{E}-08$ & $8,49574 \mathrm{E}-09$ & 5,15343E-09 & 3,33696E-09 & $7,07243 \mathrm{E}-10$ & $1,12988 \mathrm{E}-06$ & $5,11674 \mathrm{E}-09$ & $2,69368 \mathrm{E}-08$ & $1,16364 \mathrm{E}-07$ & $1,43812 \mathrm{E}-08$ \\
\hline Pecuária & 2,24102E-09 & 6,58604E-09 & $5,86388 \mathrm{E}-09$ & 2,90241E-09 & 2,22196E-09 & $3,75737 \mathrm{E}-10$ & $8,67361 \mathrm{E}-07$ & 2,90236E-09 & $1,93045 \mathrm{E}-08$ & $9,42459 \mathrm{E}-08$ & $9,04092 \mathrm{E}-09$ \\
\hline Extrativa & $1,54357 \mathrm{E}-07$ & $8,0464 \mathrm{E}-08$ & $4,95881 \mathrm{E}-08$ & $9,31813 \mathrm{E}-08$ & $2,78089 \mathrm{E}-08$ & $1,53986 \mathrm{E}-08$ & $7,31632 \mathrm{E}-08$ & 7,43543E-08 & 7,31594E-08 & $6,90382 \mathrm{E}-08$ & $7,58089 \mathrm{E}-08$ \\
\hline Alimentos & $2,41699 \mathrm{E}-08$ & 7,5102E-08 & $6,63358 \mathrm{E}-08$ & $2,62871 \mathrm{E}-08$ & $2,16129 \mathrm{E}-08$ & 3,64204E-09 & $9,46116 \mathrm{E}-06$ & $2,52136 \mathrm{E}-08$ & $1,53578 \mathrm{E}-07$ & $3,5189 \mathrm{E}-07$ & $7,01483 \mathrm{E}-08$ \\
\hline Vestuário & $2,36229 \mathrm{E}-08$ & $5,29402 \mathrm{E}-08$ & $1,11 \mathrm{E}-07$ & $5,16889 \mathrm{E}-08$ & 4,22991E-08 & 5,59702E-09 & 6,14161E-08 & $1,51362 \mathrm{E}-07$ & 9,75783E-08 & $2,18231 \mathrm{E}-07$ & $4,25126 \mathrm{E}-08$ \\
\hline Madeira & 6,76385E-08 & 2,39992E-08 & $1,60978 \mathrm{E}-08$ & $3,18523 \mathrm{E}-08$ & $1,80086 \mathrm{E}-08$ & 2,35231E-08 & $1,96397 \mathrm{E}-08$ & 2,64909E-08 & 3,51749E-08 & $3,71241 \mathrm{E}-08$ & $5,30989 \mathrm{E}-08$ \\
\hline
\end{tabular}




\begin{tabular}{|c|c|c|c|c|c|c|c|c|c|c|c|}
\hline Celulose & $3,19797 \mathrm{E}-08$ & $1,28259 \mathrm{E}-07$ & $8,10766 \mathrm{E}-08$ & $1,63232 \mathrm{E}-07$ & $5,52784 \mathrm{E}-08$ & $2,15142 \mathrm{E}-08$ & $8,03237 \mathrm{E}-08$ & $2,13487 \mathrm{E}-07$ & $1,14269 \mathrm{E}-07$ & $1,07834 \mathrm{E}-07$ & $1,07431 \mathrm{E}-07$ \\
\hline Revistas & $7,96045 \mathrm{E}-08$ & $2,86576 \mathrm{E}-07$ & $2,41519 \mathrm{E}-07$ & $6,6929 \mathrm{E}-07$ & $3,46556 \mathrm{E}-07$ & $7,53228 \mathrm{E}-08$ & 7,93056E-08 & $2,12736 \mathrm{E}-06$ & $3,47278 \mathrm{E}-07$ & $3,67661 \mathrm{E}-07$ & $2,02072 \mathrm{E}-07$ \\
\hline Químicos & 3,31881E-08 & $1,75675 \mathrm{E}-08$ & $1,24084 \mathrm{E}-08$ & $3,23252 \mathrm{E}-08$ & $7,3842 \mathrm{E}-09$ & $4,81185 \mathrm{E}-09$ & 2,41023E-07 & 2,00918E-08 & 2,30792E-07 & $4,52633 \mathrm{E}-08$ & $3,48951 \mathrm{E}-08$ \\
\hline Borracha & $4,8835 \mathrm{E}-07$ & $1,94701 \mathrm{E}-07$ & $1,63807 \mathrm{E}-07$ & $4,00021 \mathrm{E}-07$ & $6,39888 \mathrm{E}-08$ & $3,65158 \mathrm{E}-08$ & $2,65684 \mathrm{E}-07$ & $5,79708 \mathrm{E}-07$ & $5,06323 \mathrm{E}-07$ & $1,61554 \mathrm{E}-07$ & 7,68907E-08 \\
\hline Cimento & 2,30503E-06 & $8,2509 \mathrm{E}-09$ & 3,54441E-09 & $1,02117 \mathrm{E}-08$ & $9,54816 \mathrm{E}-09$ & $2,03852 \mathrm{E}-08$ & $1,60845 \mathrm{E}-08$ & 7,67193E-09 & $7,60876 \mathrm{E}-08$ & $4,01146 \mathrm{E}-08$ & $3,80878 \mathrm{E}-08$ \\
\hline Aço & $1,84928 \mathrm{E}-07$ & $2,71135 \mathrm{E}-08$ & $2,12401 \mathrm{E}-08$ & 3,71772E-08 & $1,06635 \mathrm{E}-08$ & 9,97991E-09 & $5,01982 \mathrm{E}-08$ & $2,6014 \mathrm{E}-08$ & $3,14184 \mathrm{E}-08$ & $3,51406 \mathrm{E}-08$ & $2,51579 \mathrm{E}-08$ \\
\hline Metal & $2,75398 \mathrm{E}-07$ & $2,65875 \mathrm{E}-08$ & 6,2393E-09 & $1,45071 \mathrm{E}-08$ & $4,25441 \mathrm{E}-09$ & $1,04028 \mathrm{E}-08$ & $1,1764 \mathrm{E}-07$ & 7,40277E-09 & $2,78934 \mathrm{E}-08$ & $1,77348 \mathrm{E}-08$ & $1,8509 \mathrm{E}-08$ \\
\hline Eletrodomésticos & $9,90063 \mathrm{E}-08$ & 9,47883E-08 & $6,45035 \mathrm{E}-08$ & $1,19489 \mathrm{E}-07$ & $3,32198 \mathrm{E}-08$ & $2,49515 \mathrm{E}-08$ & $7,61502 \mathrm{E}-08$ & $9,34752 \mathrm{E}-08$ & $8,85987 \mathrm{E}-08$ & $8,9607 \mathrm{E}-08$ & $9,07399 \mathrm{E}-08$ \\
\hline Informática & $9,21855 \mathrm{E}-09$ & 7,66202E-09 & $3,97631 \mathrm{E}-09$ & $1,47161 \mathrm{E}-08$ & 4,95693E-09 & $6,80482 \mathrm{E}-09$ & $4,07189 \mathrm{E}-09$ & 8,77956E-09 & $1,07996 \mathrm{E}-08$ & $8,72724 \mathrm{E}-09$ & $1,51691 \mathrm{E}-08$ \\
\hline Máquinas & $1,57223 \mathrm{E}-07$ & $3,31594 \mathrm{E}-08$ & $9,75906 \mathrm{E}-08$ & $1,42236 \mathrm{E}-07$ & $1,77476 \mathrm{E}-08$ & $3,85647 \mathrm{E}-08$ & $2,63185 \mathrm{E}-08$ & $4,95156 \mathrm{E}-08$ & $4,40708 \mathrm{E}-08$ & $1,56901 \mathrm{E}-07$ & 2,79374E-08 \\
\hline Eletrônicos & $4,45411 \mathrm{E}-08$ & $2,95028 \mathrm{E}-08$ & $3,67369 \mathrm{E}-08$ & $6,24833 \mathrm{E}-08$ & $1,381 \mathrm{E}-08$ & $1,71366 \mathrm{E}-08$ & $2,14648 \mathrm{E}-08$ & $4,19482 \mathrm{E}-08$ & $2,8769 \mathrm{E}-08$ & $5,24647 \mathrm{E}-08$ & $2,73159 \mathrm{E}-08$ \\
\hline Instrumento hospitalar & $3,14529 \mathrm{E}-08$ & $1,90079 \mathrm{E}-08$ & $6,02823 \mathrm{E}-09$ & 7,83769E-09 & $4,41678 \mathrm{E}-09$ & $3,58306 \mathrm{E}-08$ & $3,83466 \mathrm{E}-09$ & $5,10041 \mathrm{E}-08$ & $5,29442 \mathrm{E}-08$ & $4,03365 \mathrm{E}-08$ & $1,09703 \mathrm{E}-08$ \\
\hline Veículos & $5,41364 \mathrm{E}-07$ & $3,00028 \mathrm{E}-07$ & $2,62776 \mathrm{E}-07$ & 4,54773E-07 & $1,18921 \mathrm{E}-07$ & $1,14252 \mathrm{E}-07$ & $2,80932 \mathrm{E}-07$ & 3,05791E-07 & $2,9741 \mathrm{E}-07$ & $3,97553 \mathrm{E}-07$ & $2,98285 \mathrm{E}-07$ \\
\hline Indústria Diversa & $3,78045 \mathrm{E}-08$ & 5,15197E-09 & $3,23996 \mathrm{E}-08$ & $6,35758 \mathrm{E}-09$ & $5,72579 \mathrm{E}-08$ & $1,43167 \mathrm{E}-08$ & $6,32428 \mathrm{E}-09$ & $2,09432 \mathrm{E}-08$ & $2,07508 \mathrm{E}-08$ & $1,04698 \mathrm{E}-07$ & $2,28733 \mathrm{E}-08$ \\
\hline SIUP & $1,58243 \mathrm{E}-07$ & $5,42201 \mathrm{E}-07$ & 4,49616E-07 & $4,22523 \mathrm{E}-07$ & $2,54973 \mathrm{E}-07$ & $5,37066 \mathrm{E}-08$ & $5,48102 \mathrm{E}-07$ & 4,75833E-07 & $7,00603 \mathrm{E}-07$ & $1,57633 \mathrm{E}-06$ & $6,03443 \mathrm{E}-07$ \\
\hline Construção & $1,00457 \mathrm{E}-05$ & $1,1496 \mathrm{E}-08$ & 8,93643E-09 & $3,66083 \mathrm{E}-08$ & $3,62193 \mathrm{E}-08$ & 8,65913E-08 & 6,15263E-09 & 2,57973E-08 & $7,73266 \mathrm{E}-08$ & $6,67533 \mathrm{E}-08$ & $1,51003 \mathrm{E}-07$ \\
\hline Comércio & $1,76035 \mathrm{E}-07$ & $3,30645 \mathrm{E}-06$ & $1,46605 \mathrm{E}-07$ & $7,28469 \mathrm{E}-08$ & $4,35511 \mathrm{E}-08$ & $1,92203 \mathrm{E}-08$ & $3,37481 \mathrm{E}-07$ & $1,26286 \mathrm{E}-07$ & $1,12376 \mathrm{E}-07$ & $1,21507 \mathrm{E}-07$ & $6,43972 \mathrm{E}-08$ \\
\hline Transportes & $1,53105 \mathrm{E}-07$ & $4,02829 \mathrm{E}-07$ & $1,23037 \mathrm{E}-05$ & $2,73262 \mathrm{E}-07$ & $1,14906 \mathrm{E}-07$ & $2,04381 \mathrm{E}-08$ & $1,84389 \mathrm{E}-07$ & $2,17087 \mathrm{E}-07$ & $1,95071 \mathrm{E}-07$ & $2,88339 \mathrm{E}-07$ & $1,04729 \mathrm{E}-07$ \\
\hline Informação & $3,89764 \mathrm{E}-08$ & $1,22846 \mathrm{E}-07$ & $1,28435 \mathrm{E}-07$ & $9,19583 \mathrm{E}-06$ & $3,74711 \mathrm{E}-07$ & $2,53344 \mathrm{E}-08$ & $6,13672 \mathrm{E}-08$ & 9,9603E-07 & $3,42523 \mathrm{E}-07$ & $2,24302 \mathrm{E}-07$ & $4,15284 \mathrm{E}-07$ \\
\hline Financeiro & $7,2413 \mathrm{E}-08$ & $1,43726 \mathrm{E}-07$ & $1,98739 \mathrm{E}-07$ & $2,02314 \mathrm{E}-07$ & $5,73864 \mathrm{E}-06$ & 2,92374E-08 & $7,47515 \mathrm{E}-08$ & 1,91479E-07 & $8,45395 \mathrm{E}-08$ & $4,70536 \mathrm{E}-08$ & $4,47785 \mathrm{E}-07$ \\
\hline Imobiliário & 4,63837E-08 & $2,33504 \mathrm{E}-07$ & $4,16131 \mathrm{E}-07$ & 3,76994E-07 & $1,19579 \mathrm{E}-07$ & $1,10869 \mathrm{E}-05$ & $1,43686 \mathrm{E}-07$ & $2,72138 \mathrm{E}-07$ & $2,83088 \mathrm{E}-07$ & $2,02859 \mathrm{E}-07$ & $2,14113 \mathrm{E}-07$ \\
\hline Alojamento & 6,82499E-09 & $9,48446 \mathrm{E}-09$ & $1,84668 \mathrm{E}-08$ & $1,24535 \mathrm{E}-08$ & $1,19772 \mathrm{E}-08$ & $1,32156 \mathrm{E}-09$ & $7,3261 \mathrm{E}-06$ & $1,07442 \mathrm{E}-08$ & $5,69575 \mathrm{E}-08$ & $6,50028 \mathrm{E}-08$ & $3,52068 \mathrm{E}-08$ \\
\hline Serviços às Empresas & $8,57888 \mathrm{E}-08$ & 2,39286E-07 & $2,74965 \mathrm{E}-07$ & 3,91895E-07 & $2,96401 \mathrm{E}-07$ & $4,63205 \mathrm{E}-08$ & $7,57852 \mathrm{E}-08$ & $4,72944 \mathrm{E}-06$ & 3,94503E-07 & $2,5104 \mathrm{E}-07$ & $2,7877 \mathrm{E}-07$ \\
\hline Educação e Saúde mercantis & $3,81856 \mathrm{E}-09$ & $1,36067 \mathrm{E}-08$ & $9,01742 \mathrm{E}-09$ & $1,51934 \mathrm{E}-08$ & $1,56681 \mathrm{E}-08$ & $1,96227 \mathrm{E}-09$ & $1,08483 \mathrm{E}-08$ & $1,29343 \mathrm{E}-08$ & $6,85268 \mathrm{E}-06$ & $1,03676 \mathrm{E}-08$ & $2,13879 \mathrm{E}-08$ \\
\hline Outros Serviços & 2,1053E-08 & $5,56617 \mathrm{E}-08$ & $3,48008 \mathrm{E}-08$ & $6,20295 \mathrm{E}-08$ & $3,18677 \mathrm{E}-08$ & $6,21485 \mathrm{E}-09$ & $6,06982 \mathrm{E}-08$ & $7,41106 \mathrm{E}-08$ & $5,48429 \mathrm{E}-08$ & 7,80579E-06 & $3,92926 \mathrm{E}-08$ \\
\hline APU & $9,60638 \mathrm{E}-10$ & $2,58302 \mathrm{E}-09$ & 2,70976E-09 & $3,48562 \mathrm{E}-09$ & 2,49521E-09 & $4,13068 \mathrm{E}-10$ & $1,22281 \mathrm{E}-09$ & $3,1021 \mathrm{E}-09$ & $3,40471 \mathrm{E}-09$ & 2,63117E-09 & $8,45331 \mathrm{E}-07$ \\
\hline
\end{tabular}


Tabela C10 - Matriz Geração de Renda para o Grau de Instrução G(9), Distrito Federal - 2008.

(1)

\begin{tabular}{|c|c|c|c|c|c|c|c|c|c|c|c|}
\hline Setores & Agricultura & Pecuária & Extrativa & Alimentos & Vestuário & Madeira & Celulose & Revistas & Químicos & Borracha & Cimento \\
\hline Agricultura & 0,000104197 & 6,83624E-06 & $1,13704 \mathrm{E}-08$ & $8,39488 \mathrm{E}-06$ & $1,05017 \mathrm{E}-07$ & $1,65081 \mathrm{E}-07$ & $4,76745 \mathrm{E}-07$ & $4,65046 \mathrm{E}-09$ & $2,09357 \mathrm{E}-08$ & $3,54803 \mathrm{E}-07$ & $8,13806 \mathrm{E}-09$ \\
\hline Pecuária & 0 & 0 & 0 & 0 & 0 & 0 & 0 & 0 & 0 & 0 & 0 \\
\hline Extrativa & $1,59865 \mathrm{E}-07$ & $3,78966 \mathrm{E}-07$ & 0,002202463 & $9,01587 \mathrm{E}-08$ & $8,28561 \mathrm{E}-08$ & $1,14071 \mathrm{E}-07$ & $8,82204 \mathrm{E}-07$ & $2,11136 \mathrm{E}-08$ & $1,34085 \mathrm{E}-06$ & $2,85231 \mathrm{E}-07$ & $9,96495 \mathrm{E}-07$ \\
\hline Alimentos & $8,76341 \mathrm{E}-07$ & $1,33076 \mathrm{E}-05$ & 4,59692E-08 & $8,0232 \mathrm{E}-05$ & 6,05371E-07 & $6,26806 \mathrm{E}-08$ & $1,95937 \mathrm{E}-07$ & $1,69944 \mathrm{E}-08$ & $7,40283 \mathrm{E}-08$ & $2,47808 \mathrm{E}-08$ & 4,49541E-08 \\
\hline Vestuário & 0 & 0 & 0 & 0 & 0 & 0 & 0 & 0 & 0 & 0 & 0 \\
\hline Madeira & 0 & 0 & 0 & 0 & 0 & 0 & 0 & 0 & 0 & 0 & 0 \\
\hline Celulose & 0 & 0 & 0 & 0 & 0 & 0 & 0 & 0 & 0 & 0 & 0 \\
\hline Revistas & 0 & 0 & 0 & 0 & 0 & 0 & 0 & 0 & 0 & 0 & 0 \\
\hline Químicos & $1,13612 \mathrm{E}-05$ & 7,90214E-06 & $2,64011 \mathrm{E}-06$ & $1,47833 \mathrm{E}-06$ & $8,12612 \mathrm{E}-07$ & $1,50634 \mathrm{E}-06$ & $6,85082 \mathrm{E}-06$ & $4,56771 \mathrm{E}-08$ & 0,000294016 & $3,99317 \mathrm{E}-06$ & $3,73964 \mathrm{E}-07$ \\
\hline Borracha & 0 & 0 & 0 & 0 & 0 & 0 & 0 & 0 & 0 & 0 & 0 \\
\hline Cimento & 0 & 0 & 0 & 0 & 0 & 0 & 0 & 0 & 0 & 0 & 0 \\
\hline Aço & 0 & 0 & 0 & 0 & 0 & 0 & 0 & 0 & 0 & 0 & 0 \\
\hline Metal & 0 & 0 & 0 & 0 & 0 & 0 & 0 & 0 & 0 & 0 & 0 \\
\hline Eletrodomésticos & 0 & 0 & 0 & 0 & 0 & 0 & 0 & 0 & 0 & 0 & 0 \\
\hline Informática & 0 & 0 & 0 & 0 & 0 & 0 & 0 & 0 & 0 & 0 & 0 \\
\hline Máquinas & 0 & 0 & 0 & 0 & 0 & 0 & 0 & 0 & 0 & 0 & 0 \\
\hline Eletrônicos & 0 & 0 & 0 & 0 & 0 & 0 & 0 & 0 & 0 & 0 & 0 \\
\hline Instrumento hospitalar & 3,9758E-09 & 4,38038E-09 & $1,96347 \mathrm{E}-08$ & $5,79075 \mathrm{E}-09$ & 7,70108E-09 & $8,23322 \mathrm{E}-09$ & $4,5166 \mathrm{E}-08$ & $8,80469 \mathrm{E}-09$ & $4,78188 \mathrm{E}-08$ & $9,19828 \mathrm{E}-08$ & 7,07061E-09 \\
\hline Veículos & $2,4135 \mathrm{E}-07$ & $1,97498 \mathrm{E}-07$ & $1,42934 \mathrm{E}-06$ & $4,5859 \mathrm{E}-07$ & $2,46496 \mathrm{E}-07$ & $5,94524 \mathrm{E}-07$ & $1,16006 \mathrm{E}-06$ & 7,57657E-08 & $5,4665 \mathrm{E}-07$ & $1,20124 \mathrm{E}-06$ & $2,16687 \mathrm{E}-07$ \\
\hline Indústria Diversa & 0 & 0 & 0 & 0 & 0 & 0 & 0 & 0 & 0 & 0 & 0 \\
\hline SIUP & 2,84167E-07 & $4,38596 \mathrm{E}-07$ & $1,1403 \mathrm{E}-06$ & $7,02405 \mathrm{E}-07$ & $5,74797 \mathrm{E}-07$ & $5,97111 \mathrm{E}-07$ & $1,76331 \mathrm{E}-06$ & $4,67822 \mathrm{E}-07$ & $8,51783 \mathrm{E}-07$ & $8,80818 \mathrm{E}-07$ & $2,32294 \mathrm{E}-06$ \\
\hline Construção & $1,72181 \mathrm{E}-09$ & 2,44593E-09 & 4,42599E-09 & $5,67928 \mathrm{E}-09$ & 5,10185E-09 & 4,50671E-09 & $8,11384 \mathrm{E}-09$ & $6,42264 \mathrm{E}-09$ & $9,09038 \mathrm{E}-09$ & $1,47635 \mathrm{E}-08$ & $2,01347 \mathrm{E}-08$ \\
\hline Comércio & $2,18333 \mathrm{E}-07$ & $3,22182 \mathrm{E}-07$ & $1,92022 \mathrm{E}-07$ & $3,45465 \mathrm{E}-07$ & $3,62876 \mathrm{E}-07$ & $1,48196 \mathrm{E}-07$ & $1,8959 \mathrm{E}-07$ & $1,96335 \mathrm{E}-07$ & $2,69424 \mathrm{E}-07$ & $2,09979 \mathrm{E}-07$ & $3,3694 \mathrm{E}-07$ \\
\hline Transportes & $2,74739 \mathrm{E}-07$ & 2,49981E-07 & 7,34378E-07 & $4,68585 \mathrm{E}-07$ & $2,17792 \mathrm{E}-07$ & $2,35804 \mathrm{E}-07$ & $3,99464 \mathrm{E}-07$ & 2,29654E-07 & $4,34384 \mathrm{E}-07$ & $2,84048 \mathrm{E}-07$ & $8,80414 \mathrm{E}-07$ \\
\hline Informação & $5,52187 \mathrm{E}-08$ & $8,56027 \mathrm{E}-08$ & 2,51913E-07 & $1,07577 \mathrm{E}-07$ & $6,16427 \mathrm{E}-08$ & $4,56026 \mathrm{E}-08$ & $1,05281 \mathrm{E}-07$ & $2,53308 \mathrm{E}-07$ & $3,26166 \mathrm{E}-07$ & $1,45456 \mathrm{E}-07$ & $1,97392 \mathrm{E}-07$ \\
\hline
\end{tabular}




\begin{tabular}{|c|c|c|c|c|c|c|c|c|c|c|c|}
\hline Financeiro & $9,82631 \mathrm{E}-08$ & $1,08959 \mathrm{E}-07$ & $2,20184 \mathrm{E}-07$ & $1,87509 \mathrm{E}-07$ & 1,49934E-07 & $1,38991 \mathrm{E}-07$ & $3,03156 \mathrm{E}-07$ & $1,71946 \mathrm{E}-07$ & $2,98525 \mathrm{E}-07$ & $2,16833 \mathrm{E}-07$ & $3,48678 \mathrm{E}-07$ \\
\hline Imobiliário & 5,18103E-08 & $6,63515 \mathrm{E}-08$ & $1,57188 \mathrm{E}-07$ & $1,32598 \mathrm{E}-07$ & $1,47731 \mathrm{E}-07$ & $5,91258 \mathrm{E}-08$ & $1,30628 \mathrm{E}-07$ & $2,05825 \mathrm{E}-07$ & $1,76207 \mathrm{E}-07$ & 1,09864E-07 & $1,91443 \mathrm{E}-07$ \\
\hline Alojamento & 3,99343E-09 & $5,63268 \mathrm{E}-09$ & 3,64071E-08 & $9,90926 \mathrm{E}-09$ & $5,77781 \mathrm{E}-09$ & $1,15899 \mathrm{E}-08$ & $1,18115 \mathrm{E}-08$ & $1,56577 \mathrm{E}-08$ & $1,31229 \mathrm{E}-08$ & $1,16568 \mathrm{E}-08$ & 6,40734E-08 \\
\hline Serviços às Empresas & 6,16695E-08 & 8,86586E-08 & $1,70945 \mathrm{E}-07$ & $2,08625 \mathrm{E}-07$ & 1,36879E-07 & 7,27845E-08 & $1,76517 \mathrm{E}-07$ & 4,81013E-07 & $5,43962 \mathrm{E}-07$ & $1,47198 \mathrm{E}-07$ & $3,41679 \mathrm{E}-07$ \\
\hline Educação e Saúde mercantis & 3,68636E-09 & $5,09681 \mathrm{E}-09$ & 7,5006E-09 & $7,68261 \mathrm{E}-09$ & $9,37973 \mathrm{E}-09$ & $3,4443 \mathrm{E}-09$ & $6,74312 \mathrm{E}-09$ & $8,22154 \mathrm{E}-09$ & $8,26012 \mathrm{E}-09$ & 5,91177E-09 & $8,51714 \mathrm{E}-09$ \\
\hline Outros Serviços & 3,07093E-08 & $4,45047 \mathrm{E}-08$ & $4,63655 \mathrm{E}-08$ & $5,87105 \mathrm{E}-08$ & $6,31134 \mathrm{E}-08$ & $2,32682 \mathrm{E}-08$ & $3,85818 \mathrm{E}-08$ & $4,53534 \mathrm{E}-08$ & $6,2542 \mathrm{E}-08$ & $4,56669 \mathrm{E}-08$ & 7,28457E-08 \\
\hline APU & $6,75716 \mathrm{E}-11$ & $8,06211 \mathrm{E}-11$ & $1,61855 \mathrm{E}-10$ & $1,49468 \mathrm{E}-10$ & $9,42003 \mathrm{E}-11$ & $6,35658 \mathrm{E}-11$ & $1,54327 \mathrm{E}-10$ & $2,85621 \mathrm{E}-10$ & $2,58364 \mathrm{E}-10$ & $1,09602 \mathrm{E}-10$ & $2,46812 \mathrm{E}-10$ \\
\hline
\end{tabular}

Tabela C10 - Matriz Geração de Renda para o Grau de Instrução G(9), Distrito Federal - 2008.

(2)

\begin{tabular}{|c|c|c|c|c|c|c|c|c|c|c|}
\hline Setores & Aço & Metal & Eletrodomésticos & Informática & Máquinas & Eletrônicos & $\begin{array}{l}\text { Instrumento } \\
\text { hospitalar }\end{array}$ & Veículos & $\begin{array}{l}\text { Indústria } \\
\text { Diversa }\end{array}$ & SIUP \\
\hline Agricultura & $6,1311 \mathrm{E}-09$ & $3,38043 \mathrm{E}-09$ & $1,21377 \mathrm{E}-08$ & $1,15628 \mathrm{E}-08$ & $6,89585 \mathrm{E}-09$ & $1,57866 \mathrm{E}-08$ & 4,19451E-09 & $2,40833 \mathrm{E}-08$ & 9,4237E-09 & 1,70813E-09 \\
\hline Pecuária & 0 & 0 & 0 & 0 & 0 & 0 & 0 & 0 & 0 & 0 \\
\hline Extrativa & $3,71042 \mathrm{E}-05$ & $2,19213 \mathrm{E}-06$ & 6,95694E-06 & $5,30255 \mathrm{E}-07$ & $2,10962 \mathrm{E}-06$ & $1,18557 \mathrm{E}-06$ & $1,97542 \mathrm{E}-07$ & 3,96824E-06 & $1,21643 \mathrm{E}-06$ & $1,86215 \mathrm{E}-08$ \\
\hline Alimentos & $2,01457 \mathrm{E}-08$ & $9,47151 \mathrm{E}-09$ & $1,96073 \mathrm{E}-08$ & 2,19352E-08 & $1,97546 \mathrm{E}-08$ & $2,14577 \mathrm{E}-08$ & $1,04026 \mathrm{E}-08$ & 2,65294E-08 & $1,88727 \mathrm{E}-08$ & $6,32384 \mathrm{E}-09$ \\
\hline Vestuário & 0 & 0 & 0 & 0 & 0 & 0 & 0 & 0 & 0 & 0 \\
\hline Madeira & 0 & 0 & 0 & 0 & 0 & 0 & 0 & 0 & 0 & 0 \\
\hline Celulose & 0 & 0 & 0 & 0 & 0 & 0 & 0 & 0 & 0 & 0 \\
\hline Revistas & 0 & 0 & 0 & 0 & 0 & 0 & 0 & 0 & 0 & 0 \\
\hline Químicos & $3,52038 \mathrm{E}-06$ & $6,13715 \mathrm{E}-07$ & $3,24961 \mathrm{E}-06$ & $2,3315 \mathrm{E}-07$ & $1,02271 \mathrm{E}-06$ & $4,11102 \mathrm{E}-07$ & 7,75604E-07 & 2,13934E-06 & $3,80614 \mathrm{E}-07$ & $2,5741 \mathrm{E}-07$ \\
\hline Borracha & 0 & 0 & 0 & 0 & 0 & 0 & 0 & 0 & 0 & 0 \\
\hline Cimento & 0 & 0 & 0 & 0 & 0 & 0 & 0 & 0 & 0 & 0 \\
\hline Aço & 0 & 0 & 0 & 0 & 0 & 0 & 0 & 0 & 0 & 0 \\
\hline Metal & 0 & 0 & 0 & 0 & 0 & 0 & 0 & 0 & 0 & 0 \\
\hline Eletrodomésticos & 0 & 0 & 0 & 0 & 0 & 0 & 0 & 0 & 0 & 0 \\
\hline Informática & 0 & 0 & 0 & 0 & 0 & 0 & 0 & 0 & 0 & 0 \\
\hline Máquinas & 0 & 0 & 0 & 0 & 0 & 0 & 0 & 0 & 0 & 0 \\
\hline
\end{tabular}




\begin{tabular}{|c|c|c|c|c|c|c|c|c|c|c|}
\hline Eletrônicos & 0 & 0 & 0 & 0 & 0 & 0 & 0 & 0 & 0 & 0 \\
\hline Instrumento hospitalar & $1,40289 \mathrm{E}-08$ & 7,71236E-09 & $2,12742 \mathrm{E}-06$ & 2,7814E-07 & $8,2612 \mathrm{E}-07$ & $3,88076 \mathrm{E}-07$ & 0,000667412 & $3,55111 \mathrm{E}-07$ & $3,65013 \mathrm{E}-08$ & $8,06349 \mathrm{E}-09$ \\
\hline Veículos & $3,27622 \mathrm{E}-06$ & 2,06979E-06 & $1,47776 \mathrm{E}-05$ & $1,04395 \mathrm{E}-05$ & $1,19262 \mathrm{E}-05$ & $1,89438 \mathrm{E}-05$ & 2,51064E-06 & 0,005222106 & $1,49396 \mathrm{E}-06$ & $3,18624 \mathrm{E}-07$ \\
\hline Indústria Diversa & 0 & 0 & 0 & 0 & 0 & 0 & 0 & 0 & 0 & 0 \\
\hline SIUP & $2,06395 \mathrm{E}-06$ & $1,00649 \mathrm{E}-06$ & $1,00186 \mathrm{E}-06$ & 6,70849E-07 & $1,1762 \mathrm{E}-06$ & $8,19703 \mathrm{E}-07$ & $8,57239 \mathrm{E}-07$ & $8,78302 \mathrm{E}-07$ & $6,25396 \mathrm{E}-07$ & $9,34453 \mathrm{E}-05$ \\
\hline Construção & $6,27289 \mathrm{E}-09$ & 4,21526E-09 & $8,52634 \mathrm{E}-09$ & $1,25519 \mathrm{E}-08$ & $1,73366 \mathrm{E}-08$ & 2,61967E-08 & $3,97446 \mathrm{E}-09$ & $2,77829 \mathrm{E}-08$ & 5,09396E-09 & 3,93759E-09 \\
\hline Comércio & $1,79512 \mathrm{E}-07$ & $1,57223 \mathrm{E}-07$ & $2,64128 \mathrm{E}-07$ & $5,94579 \mathrm{E}-07$ & $2,35476 \mathrm{E}-07$ & $4,44109 \mathrm{E}-07$ & $2,3719 \mathrm{E}-07$ & $3,38354 \mathrm{E}-07$ & $2,74689 \mathrm{E}-07$ & 7,49729E-08 \\
\hline Transportes & $5,90596 \mathrm{E}-07$ & $3,38906 \mathrm{E}-07$ & $4,66358 \mathrm{E}-07$ & $5,23048 \mathrm{E}-07$ & $4,46181 \mathrm{E}-07$ & $6,49322 \mathrm{E}-07$ & $3,54298 \mathrm{E}-07$ & $4,08782 \mathrm{E}-07$ & $2,19579 \mathrm{E}-07$ & $1,79426 \mathrm{E}-07$ \\
\hline Informação & $2,57498 \mathrm{E}-07$ & $1,14522 \mathrm{E}-07$ & $2,88042 \mathrm{E}-07$ & 4,14089E-07 & $3,53397 \mathrm{E}-07$ & $6,09248 \mathrm{E}-07$ & $1,86619 \mathrm{E}-07$ & $2,30346 \mathrm{E}-07$ & $6,25733 \mathrm{E}-08$ & $2,17897 \mathrm{E}-07$ \\
\hline Financeiro & $3,79849 \mathrm{E}-07$ & 2,23781E-07 & $4,83932 \mathrm{E}-07$ & $3,37982 \mathrm{E}-07$ & $3,45742 \mathrm{E}-07$ & $5,9556 \mathrm{E}-07$ & $2,40356 \mathrm{E}-07$ & $3,31958 \mathrm{E}-07$ & $1,4225 \mathrm{E}-07$ & $1,27917 \mathrm{E}-07$ \\
\hline Imobiliário & $1,24137 \mathrm{E}-07$ & $1,05337 \mathrm{E}-07$ & $1,64139 \mathrm{E}-07$ & $1,76006 \mathrm{E}-07$ & $1,30216 \mathrm{E}-07$ & $1,74111 \mathrm{E}-07$ & $1,5317 \mathrm{E}-07$ & $1,14582 \mathrm{E}-07$ & $9,99002 \mathrm{E}-08$ & $8,98864 \mathrm{E}-08$ \\
\hline Alojamento & $1,6966 \mathrm{E}-08$ & 6,46659E-09 & $9,34166 \mathrm{E}-09$ & $1,35088 \mathrm{E}-08$ & $2,00453 \mathrm{E}-08$ & $1,34973 \mathrm{E}-08$ & $5,80856 \mathrm{E}-09$ & $1,79218 \mathrm{E}-08$ & $1,20709 \mathrm{E}-08$ & 4,96123E-09 \\
\hline Serviços às Empresas & $1,43026 \mathrm{E}-07$ & $1,39377 \mathrm{E}-07$ & $1,67043 \mathrm{E}-07$ & $7,47223 \mathrm{E}-07$ & $2,38192 \mathrm{E}-07$ & $5,2666 \mathrm{E}-07$ & $1,91281 \mathrm{E}-07$ & 3,19904E-07 & $1,10052 \mathrm{E}-07$ & $4,06266 \mathrm{E}-07$ \\
\hline Educação e Saúde mercantis & $5,59781 \mathrm{E}-09$ & $5,65614 \mathrm{E}-09$ & $8,30566 \mathrm{E}-09$ & $1,15729 \mathrm{E}-08$ & $7,11545 \mathrm{E}-09$ & $1,063 \mathrm{E}-08$ & $7,0766 \mathrm{E}-09$ & 7,17439E-09 & 6,49417E-09 & $4,45355 \mathrm{E}-09$ \\
\hline Outros Serviços & $4,30693 \mathrm{E}-08$ & $3,91894 \mathrm{E}-08$ & $5,75505 \mathrm{E}-08$ & $1,13053 \mathrm{E}-07$ & $8,21598 \mathrm{E}-08$ & $1,04251 \mathrm{E}-07$ & $4,67596 \mathrm{E}-08$ & $6,08785 \mathrm{E}-08$ & $4,80044 \mathrm{E}-08$ & $4,5796 \mathrm{E}-08$ \\
\hline APU & $1,57149 \mathrm{E}-10$ & $1,08048 \mathrm{E}-10$ & $1,27122 \mathrm{E}-10$ & $3,26672 \mathrm{E}-10$ & $1,41429 \mathrm{E}-10$ & $2,59522 \mathrm{E}-10$ & $1,25835 \mathrm{E}-10$ & $1,75418 \mathrm{E}-10$ & $8,11693 \mathrm{E}-11$ & $2,91589 \mathrm{E}-10$ \\
\hline
\end{tabular}

Tabela C10 - Matriz Geração de Renda para o Grau de Instrução G(9), Distrito Federal - 2008.

(3)

\begin{tabular}{|c|c|c|c|c|c|c|c|c|c|c|c|}
\hline Setores & Construção & Comércio & Transportes & Informação & Financeiro & Imobiliário & Alojamento & $\begin{array}{l}\text { Serviços às } \\
\text { Empresas }\end{array}$ & $\begin{array}{l}\text { Educação e } \\
\text { Saúde } \\
\text { mercantis }\end{array}$ & $\begin{array}{c}\text { Outros } \\
\text { Serviços }\end{array}$ & APU \\
\hline Agricultura & 4,90112E-09 & $1,5206 \mathrm{E}-08$ & $1,15024 \mathrm{E}-08$ & $6,97723 \mathrm{E}-09$ & 4,51792E-09 & $9,57537 \mathrm{E}-10$ & $1,52975 \mathrm{E}-06$ & 6,92756E-09 & $3,64698 \mathrm{E}-08$ & $1,57546 \mathrm{E}-07$ & $1,94707 \mathrm{E}-08$ \\
\hline Pecuária & 0 & 0 & 0 & 0 & 0 & 0 & 0 & 0 & 0 & 0 & 0 \\
\hline Extrativa & $9,6843 \mathrm{E}-08$ & $5,04829 \mathrm{E}-08$ & $3,11114 \mathrm{E}-08$ & $5,84617 \mathrm{E}-08$ & $1,74472 \mathrm{E}-08$ & $9,66101 \mathrm{E}-09$ & $4,59024 \mathrm{E}-08$ & 4,66497E-08 & $4,59 \mathrm{E}-08$ & 4,33144E-08 & $4,75623 \mathrm{E}-08$ \\
\hline Alimentos & $2,47832 \mathrm{E}-08$ & 7,70079E-08 & $6,80192 \mathrm{E}-08$ & $2,69542 \mathrm{E}-08$ & $2,21613 \mathrm{E}-08$ & 3,73446E-09 & $9,70125 \mathrm{E}-06$ & $2,58534 \mathrm{E}-08$ & $1,57475 \mathrm{E}-07$ & $3,6082 \mathrm{E}-07$ & $7,19285 \mathrm{E}-08$ \\
\hline Vestuário & 0 & 0 & 0 & 0 & 0 & 0 & 0 & 0 & 0 & 0 & 0 \\
\hline Madeira & 0 & 0 & 0 & 0 & 0 & 0 & 0 & 0 & 0 & 0 & 0 \\
\hline
\end{tabular}




\begin{tabular}{|c|c|c|c|c|c|c|c|c|c|c|c|}
\hline Celulose & 0 & 0 & 0 & 0 & 0 & 0 & 0 & 0 & 0 & 0 & 0 \\
\hline Revistas & 0 & 0 & 0 & 0 & 0 & 0 & 0 & 0 & 0 & 0 & 0 \\
\hline Químicos & $3,4841 \mathrm{E}-08$ & $1,84424 \mathrm{E}-08$ & $1,30264 \mathrm{E}-08$ & 3,39351E-08 & 7,75196E-09 & $5,0515 \mathrm{E}-09$ & $2,53027 \mathrm{E}-07$ & $2,10925 \mathrm{E}-08$ & $2,42287 \mathrm{E}-07$ & $4,75176 \mathrm{E}-08$ & $3,6633 \mathrm{E}-08$ \\
\hline Borracha & 0 & 0 & 0 & 0 & 0 & 0 & 0 & 0 & 0 & 0 & 0 \\
\hline Cimento & 0 & 0 & 0 & 0 & 0 & 0 & 0 & 0 & 0 & 0 & 0 \\
\hline Aço & 0 & 0 & 0 & 0 & 0 & 0 & 0 & 0 & 0 & 0 & 0 \\
\hline Metal & 0 & 0 & 0 & 0 & 0 & 0 & 0 & 0 & 0 & 0 & 0 \\
\hline Eletrodomésticos & 0 & 0 & 0 & 0 & 0 & 0 & 0 & 0 & 0 & 0 & 0 \\
\hline Informática & 0 & 0 & 0 & 0 & 0 & 0 & 0 & 0 & 0 & 0 & 0 \\
\hline Máquinas & 0 & 0 & 0 & 0 & 0 & 0 & 0 & 0 & 0 & 0 & 0 \\
\hline Eletrônicos & 0 & 0 & 0 & 0 & 0 & 0 & 0 & 0 & 0 & 0 & 0 \\
\hline Instrumento hospitalar & $4,51886 \mathrm{E}-08$ & $2,73089 \mathrm{E}-08$ & $8,6608 \mathrm{E}-09$ & $1,12605 \mathrm{E}-08$ & $6,34563 \mathrm{E}-09$ & $5,14781 \mathrm{E}-08$ & $5,50929 \mathrm{E}-09$ & $7,3278 \mathrm{E}-08$ & 7,60653E-08 & $5,79518 \mathrm{E}-08$ & $1,57611 \mathrm{E}-08$ \\
\hline Veículos & $2,54758 \mathrm{E}-07$ & $1,41189 \mathrm{E}-07$ & $1,23658 \mathrm{E}-07$ & $2,14009 \mathrm{E}-07$ & $5,59624 \mathrm{E}-08$ & $5,37651 \mathrm{E}-08$ & $1,32202 \mathrm{E}-07$ & $1,43901 \mathrm{E}-07$ & $1,39957 \mathrm{E}-07$ & $1,87082 \mathrm{E}-07$ & $1,40368 \mathrm{E}-07$ \\
\hline Indústria Diversa & 0 & 0 & 0 & 0 & 0 & 0 & 0 & 0 & 0 & 0 & 0 \\
\hline SIUP & $2,04198 \mathrm{E}-07$ & $6,99661 \mathrm{E}-07$ & $5,80189 \mathrm{E}-07$ & $5,45228 \mathrm{E}-07$ & $3,2902 \mathrm{E}-07$ & $6,93035 \mathrm{E}-08$ & $7,07276 \mathrm{E}-07$ & $6,1402 \mathrm{E}-07$ & $9,04065 \mathrm{E}-07$ & $2,03411 \mathrm{E}-06$ & $7,78688 \mathrm{E}-07$ \\
\hline Construção & $9,39197 \mathrm{E}-06$ & $1,0748 \mathrm{E}-08$ & $8,35493 \mathrm{E}-09$ & $3,42261 \mathrm{E}-08$ & $3,38625 \mathrm{E}-08$ & $8,09567 \mathrm{E}-08$ & $5,75228 \mathrm{E}-09$ & 2,41187E-08 & $7,22949 \mathrm{E}-08$ & $6,24096 \mathrm{E}-08$ & $1,41177 \mathrm{E}-07$ \\
\hline Comércio & $2,46027 \mathrm{E}-07$ & $4,62112 \mathrm{E}-06$ & $2,04896 \mathrm{E}-07$ & $1,01811 \mathrm{E}-07$ & $6,08673 \mathrm{E}-08$ & $2,68624 \mathrm{E}-08$ & $4,71665 \mathrm{E}-07$ & $1,76499 \mathrm{E}-07$ & $1,57058 \mathrm{E}-07$ & $1,69819 \mathrm{E}-07$ & $9,0002 \mathrm{E}-08$ \\
\hline Transportes & $1,68011 \mathrm{E}-07$ & $4,42048 \mathrm{E}-07$ & $1,35016 \mathrm{E}-05$ & 2,99867E-07 & $1,26093 \mathrm{E}-07$ & $2,24279 \mathrm{E}-08$ & $2,02341 \mathrm{E}-07$ & $2,38222 \mathrm{E}-07$ & $2,14063 \mathrm{E}-07$ & $3,16412 \mathrm{E}-07$ & $1,14925 \mathrm{E}-07$ \\
\hline Informação & $7,1318 \mathrm{E}-08$ & $2,2478 \mathrm{E}-07$ & $2,35006 \mathrm{E}-07$ & $1,68263 \mathrm{E}-05$ & 6,85637E-07 & $4,63562 \mathrm{E}-08$ & $1,12288 \mathrm{E}-07$ & $1,82251 \mathrm{E}-06$ & $6,2674 \mathrm{E}-07$ & $4,10422 \mathrm{E}-07$ & $7,59876 \mathrm{E}-07$ \\
\hline Financeiro & $1,03 \mathrm{E}-07$ & $2,04435 \mathrm{E}-07$ & $2,82684 \mathrm{E}-07$ & $2,87769 \mathrm{E}-07$ & $8,16259 \mathrm{E}-06$ & $4,1587 \mathrm{E}-08$ & $1,06326 \mathrm{E}-07$ & $2,72357 \mathrm{E}-07$ & $1,20248 \mathrm{E}-07$ & $6,69286 \mathrm{E}-08$ & $6,36925 \mathrm{E}-07$ \\
\hline Imobiliário & $7,40036 \mathrm{E}-08$ & $3,72548 \mathrm{E}-07$ & 6,63924E-07 & $6,01481 \mathrm{E}-07$ & $1,90785 \mathrm{E}-07$ & $1,76888 \mathrm{E}-05$ & 2,29247E-07 & $4,34187 \mathrm{E}-07$ & $4,51658 \mathrm{E}-07$ & $3,23655 \mathrm{E}-07$ & $3,4161 \mathrm{E}-07$ \\
\hline Alojamento & 1,69497E-08 & $2,35545 \mathrm{E}-08$ & $4,58619 \mathrm{E}-08$ & 3,09281E-08 & $2,9745 \mathrm{E}-08$ & 3,28207E-09 & $1,81942 \mathrm{E}-05$ & $2,6683 \mathrm{E}-08$ & $1,41453 \mathrm{E}-07$ & $1,61433 \mathrm{E}-07$ & $8,74353 \mathrm{E}-08$ \\
\hline Serviços às Empresas & $1,64939 \mathrm{E}-07$ & $4,60057 \mathrm{E}-07$ & $5,28654 \mathrm{E}-07$ & $7,53465 \mathrm{E}-07$ & $5,69867 \mathrm{E}-07$ & $8,90568 \mathrm{E}-08$ & $1,45706 \mathrm{E}-07$ & $9,09292 \mathrm{E}-06$ & $7,5848 \mathrm{E}-07$ & $4,82655 \mathrm{E}-07$ & $5,3597 \mathrm{E}-07$ \\
\hline Educação e Saúde mercantis & 4,97736E-09 & $1,77359 \mathrm{E}-08$ & $1,17539 \mathrm{E}-08$ & $1,98042 \mathrm{E}-08$ & $2,04228 \mathrm{E}-08$ & $2,55775 \mathrm{E}-09$ & $1,41404 \mathrm{E}-08$ & $1,68594 \mathrm{E}-08$ & $8,93224 \mathrm{E}-06$ & $1,35138 \mathrm{E}-08$ & $2,78785 \mathrm{E}-08$ \\
\hline Outros Serviços & $4,284 \mathrm{E}-08$ & $1,13264 \mathrm{E}-07$ & $7,0815 \mathrm{E}-08$ & $1,26222 \mathrm{E}-07$ & $6,48466 \mathrm{E}-08$ & $1,26464 \mathrm{E}-08$ & $1,23513 \mathrm{E}-07$ & $1,50805 \mathrm{E}-07$ & $1,11598 \mathrm{E}-07$ & $1,58837 \mathrm{E}-05$ & $7,99553 \mathrm{E}-08$ \\
\hline APU & $8,33476 \mathrm{E}-11$ & $2,2411 \mathrm{E}-10$ & $2,35106 \mathrm{E}-10$ & $3,02422 \mathrm{E}-10$ & $2,16491 \mathrm{E}-10$ & $3,58389 \mathrm{E}-11$ & $1,06094 \mathrm{E}-10$ & $2,69146 \mathrm{E}-10$ & $2,95402 \mathrm{E}-10$ & $2,28288 \mathrm{E}-10$ & $7,33432 \mathrm{E}-08$ \\
\hline
\end{tabular}


Tabela C11 - Matriz Geração de Renda para o Grau de Instrução G(10), Distrito Federal - 2008.

(1)

\begin{tabular}{|c|c|c|c|c|c|c|c|c|c|c|c|}
\hline Setores & Agricultura & Pecuária & Extrativa & Alimentos & Vestuário & Madeira & Celulose & Revistas & Químicos & Borracha & Cimento \\
\hline Agricultura & 0,000221854 & $1,45555 \mathrm{E}-05$ & $2,42095 \mathrm{E}-08$ & $1,78742 \mathrm{E}-05$ & $2,236 \mathrm{E}-07$ & $3,51486 \mathrm{E}-07$ & $1,01507 \mathrm{E}-06$ & $9,90165 \mathrm{E}-09$ & 4,45757E-08 & 7,55437E-07 & $1,73273 \mathrm{E}-08$ \\
\hline Pecuária & 0 & 0 & 0 & 0 & 0 & 0 & 0 & 0 & 0 & 0 & 0 \\
\hline Extrativa & 0 & 0 & 0 & 0 & 0 & 0 & 0 & 0 & 0 & 0 & 0 \\
\hline Alimentos & 0 & 0 & 0 & 0 & 0 & 0 & 0 & 0 & 0 & 0 & 0 \\
\hline Vestuário & $2,79753 \mathrm{E}-08$ & $2,47574 \mathrm{E}-08$ & $8,25431 \mathrm{E}-07$ & $3,60832 \mathrm{E}-08$ & 0,00148091 & $3,35554 \mathrm{E}-08$ & $1,18524 \mathrm{E}-06$ & $3,79796 \mathrm{E}-08$ & $7,56879 \mathrm{E}-08$ & 2,21797E-07 & $5,24571 \mathrm{E}-08$ \\
\hline Madeira & 0 & 0 & 0 & 0 & 0 & 0 & 0 & 0 & 0 & 0 & 0 \\
\hline Celulose & 0 & 0 & 0 & 0 & 0 & 0 & 0 & 0 & 0 & 0 & 0 \\
\hline Revistas & 0 & 0 & 0 & 0 & 0 & 0 & 0 & 0 & 0 & 0 & 0 \\
\hline Químicos & $1,13188 \mathrm{E}-05$ & $7,8726 \mathrm{E}-06$ & $2,63024 \mathrm{E}-06$ & $1,4728 \mathrm{E}-06$ & $8,09574 \mathrm{E}-07$ & $1,50071 \mathrm{E}-06$ & $6,82521 \mathrm{E}-06$ & $4,55063 \mathrm{E}-08$ & 0,000292917 & $3,97824 \mathrm{E}-06$ & $3,72566 \mathrm{E}-07$ \\
\hline Borracha & 0 & 0 & 0 & 0 & 0 & 0 & 0 & 0 & 0 & 0 & 0 \\
\hline Cimento & $1,98718 \mathrm{E}-07$ & $1,01453 \mathrm{E}-07$ & $2,34437 \mathrm{E}-07$ & $3,3955 \mathrm{E}-07$ & $8,93608 \mathrm{E}-08$ & $3,88121 \mathrm{E}-08$ & $3,03628 \mathrm{E}-07$ & $3,18396 \mathrm{E}-08$ & $1,24905 \mathrm{E}-06$ & $9,2995 \mathrm{E}-08$ & 0,000197602 \\
\hline Aço & 0 & 0 & 0 & 0 & 0 & 0 & 0 & 0 & 0 & 0 & 0 \\
\hline Metal & 0 & 0 & 0 & 0 & 0 & 0 & 0 & 0 & 0 & 0 & 0 \\
\hline Eletrodomésticos & 0 & 0 & 0 & 0 & 0 & 0 & 0 & 0 & 0 & 0 & 0 \\
\hline Informática & 0 & 0 & 0 & 0 & 0 & 0 & 0 & 0 & 0 & 0 & 0 \\
\hline Máquinas & 0 & 0 & 0 & 0 & 0 & 0 & 0 & 0 & 0 & 0 & 0 \\
\hline Eletrônicos & 0 & 0 & 0 & 0 & 0 & 0 & 0 & 0 & 0 & 0 & 0 \\
\hline Instrumento hospitalar & $2,90311 \mathrm{E}-09$ & 3,19853E-09 & $1,43372 \mathrm{E}-08$ & $4,22838 \mathrm{E}-09$ & $5,62329 \mathrm{E}-09$ & $6,01186 \mathrm{E}-09$ & $3,298 \mathrm{E}-08$ & 6,42915E-09 & 3,49171E-08 & 6,71654E-08 & $5,16292 \mathrm{E}-09$ \\
\hline Veículos & 0 & 0 & 0 & 0 & 0 & 0 & 0 & 0 & 0 & 0 & 0 \\
\hline Indústria Diversa & 0 & 0 & 0 & 0 & 0 & 0 & 0 & 0 & 0 & 0 & 0 \\
\hline SIUP & $2,08889 \mathrm{E}-07$ & $3,22409 \mathrm{E}-07$ & $8,38229 \mathrm{E}-07$ & $5,16333 \mathrm{E}-07$ & $4,22528 \mathrm{E}-07$ & $4,38932 \mathrm{E}-07$ & $1,2962 \mathrm{E}-06$ & $3,43892 \mathrm{E}-07$ & $6,26139 \mathrm{E}-07$ & $6,47482 \mathrm{E}-07$ & $1,70758 \mathrm{E}-06$ \\
\hline Construção & $5,26297 \mathrm{E}-10$ & $7,47634 \mathrm{E}-10$ & $1,35287 \mathrm{E}-09$ & $1,73596 \mathrm{E}-09$ & $1,55946 \mathrm{E}-09$ & $1,37754 \mathrm{E}-09$ & $2,48011 \mathrm{E}-09$ & 1,96317E-09 & 2,77861E-09 & $4,51268 \mathrm{E}-09$ & $6,15446 \mathrm{E}-09$ \\
\hline Comércio & $6,67232 \mathrm{E}-07$ & $9,84599 \mathrm{E}-07$ & $5,86825 \mathrm{E}-07$ & $1,05575 \mathrm{E}-06$ & $1,10896 \mathrm{E}-06$ & $4,52893 \mathrm{E}-07$ & $5,79392 \mathrm{E}-07$ & $6,00008 \mathrm{E}-07$ & $8,2337 \mathrm{E}-07$ & 6,41703E-07 & $1,0297 \mathrm{E}-06$ \\
\hline Transportes & $2,62515 \mathrm{E}-07$ & $2,38859 \mathrm{E}-07$ & $7,01702 \mathrm{E}-07$ & $4,47736 \mathrm{E}-07$ & $2,08102 \mathrm{E}-07$ & $2,25312 \mathrm{E}-07$ & $3,81691 \mathrm{E}-07$ & $2,19436 \mathrm{E}-07$ & 4,15056E-07 & $2,7141 \mathrm{E}-07$ & $8,41241 \mathrm{E}-07$ \\
\hline Informação & $4,74441 \mathrm{E}-08$ & 7,35501E-08 & $2,16444 \mathrm{E}-07$ & $9,24306 \mathrm{E}-08$ & $5,29636 \mathrm{E}-08$ & $3,91819 \mathrm{E}-08$ & $9,04582 \mathrm{E}-08$ & $2,17643 \mathrm{E}-07$ & $2,80243 \mathrm{E}-07$ & $1,24976 \mathrm{E}-07$ & $1,696 \mathrm{E}-07$ \\
\hline
\end{tabular}




\begin{tabular}{|c|c|c|c|c|c|c|c|c|c|c|c|}
\hline Financeiro & $1,13969 \mathrm{E}-07$ & $1,26374 \mathrm{E}-07$ & $2,55377 \mathrm{E}-07$ & $2,1748 \mathrm{E}-07$ & $1,73898 \mathrm{E}-07$ & $1,61207 \mathrm{E}-07$ & $3,5161 \mathrm{E}-07$ & $1,99429 \mathrm{E}-07$ & $3,46239 \mathrm{E}-07$ & $2,5149 \mathrm{E}-07$ & $4,04409 \mathrm{E}-07$ \\
\hline Imobiliário & 0 & 0 & 0 & 0 & 0 & 0 & 0 & 0 & 0 & 0 & 0 \\
\hline Alojamento & $1,26403 \mathrm{E}-09$ & 1,7829E-09 & $1,15239 \mathrm{E}-08$ & $3,13656 \mathrm{E}-09$ & $1,82884 \mathrm{E}-09$ & 3,66854E-09 & 3,73867E-09 & 4,95609E-09 & 4,15378E-09 & 3,68971E-09 & $2,0281 \mathrm{E}-08$ \\
\hline Serviços às Empresas & $1,00331 \mathrm{E}-07$ & $1,4424 \mathrm{E}-07$ & 2,78113E-07 & $3,39415 \mathrm{E}-07$ & 2,2269E-07 & $1,18414 \mathrm{E}-07$ & $2,87178 \mathrm{E}-07$ & 7,82565E-07 & 8,84979E-07 & $2,39478 \mathrm{E}-07$ & $5,55883 \mathrm{E}-07$ \\
\hline Educação e Saúde mercantis & $6,38038 \mathrm{E}-09$ & $8,82158 \mathrm{E}-09$ & $1,29821 \mathrm{E}-08$ & $1,32971 \mathrm{E}-08$ & $1,62345 \mathrm{E}-08$ & 5,96141E-09 & $1,1671 \mathrm{E}-08$ & $1,42299 \mathrm{E}-08$ & $1,42967 \mathrm{E}-08$ & $1,02321 \mathrm{E}-08$ & $1,47415 \mathrm{E}-08$ \\
\hline Outros Serviços & 3,24037E-08 & 4,69603E-08 & $4,89238 \mathrm{E}-08$ & $6,195 \mathrm{E}-08$ & 6,65958E-08 & $2,45521 \mathrm{E}-08$ & $4,07106 \mathrm{E}-08$ & $4,78558 \mathrm{E}-08$ & $6,59928 \mathrm{E}-08$ & 4,81867E-08 & $7,68651 \mathrm{E}-08$ \\
\hline APU & $4,62333 \mathrm{E}-12$ & $5,51619 \mathrm{E}-12$ & $1,10743 \mathrm{E}-11$ & $1,02268 \mathrm{E}-11$ & $6,44529 \mathrm{E}-12$ & $4,34925 \mathrm{E}-12$ & $1,05592 \mathrm{E}-11$ & $1,95425 \mathrm{E}-11$ & $1,76775 \mathrm{E}-11$ & 7,4991E-12 & $1,68872 \mathrm{E}-11$ \\
\hline
\end{tabular}

Tabela C11 - Matriz Geração de Renda para o Grau de Instrução G(10), Distrito Federal - 2008.

(2)

\begin{tabular}{|c|c|c|c|c|c|c|c|c|c|c|}
\hline Setores & Aço & Metal & Eletrodomésticos & Informática & Máquinas & Eletrônicos & $\begin{array}{l}\text { Instrumento } \\
\text { hospitalar }\end{array}$ & Veículos & $\begin{array}{l}\text { Indústria } \\
\text { Diversa }\end{array}$ & SIUP \\
\hline Agricultura & $1,30542 \mathrm{E}-08$ & 7,19752E-09 & $2,58433 \mathrm{E}-08$ & 2,46191E-08 & $1,46825 \mathrm{E}-08$ & $3,36124 \mathrm{E}-08$ & 8,93083E-09 & $5,12776 \mathrm{E}-08$ & $2,00647 \mathrm{E}-08$ & $3,6369 \mathrm{E}-09$ \\
\hline Pecuária & 0 & 0 & 0 & 0 & 0 & 0 & 0 & 0 & 0 & 0 \\
\hline Extrativa & 0 & 0 & 0 & 0 & 0 & 0 & 0 & 0 & 0 & 0 \\
\hline Alimentos & 0 & 0 & 0 & 0 & 0 & 0 & 0 & 0 & 0 & 0 \\
\hline Vestuário & $6,96884 \mathrm{E}-08$ & $1,06644 \mathrm{E}-07$ & $5,85319 \mathrm{E}-07$ & $8,14049 \mathrm{E}-08$ & $6,83703 \mathrm{E}-08$ & $9,26866 \mathrm{E}-08$ & $1,03174 \mathrm{E}-07$ & $5,02078 \mathrm{E}-07$ & $7,04745 \mathrm{E}-08$ & $7,05581 \mathrm{E}-08$ \\
\hline Madeira & 0 & 0 & 0 & 0 & 0 & 0 & 0 & 0 & 0 & 0 \\
\hline Celulose & 0 & 0 & 0 & 0 & 0 & 0 & 0 & 0 & 0 & 0 \\
\hline Revistas & 0 & 0 & 0 & 0 & 0 & 0 & 0 & 0 & 0 & 0 \\
\hline Químicos & $3,50721 \mathrm{E}-06$ & $6,11421 \mathrm{E}-07$ & $3,23746 \mathrm{E}-06$ & $2,32278 \mathrm{E}-07$ & $1,01889 \mathrm{E}-06$ & $4,09565 \mathrm{E}-07$ & $7,72705 \mathrm{E}-07$ & $2,13134 \mathrm{E}-06$ & $3,79191 \mathrm{E}-07$ & $2,56448 \mathrm{E}-07$ \\
\hline Borracha & 0 & 0 & 0 & 0 & 0 & 0 & 0 & 0 & 0 & 0 \\
\hline Cimento & $1,74332 \mathrm{E}-06$ & $5,20291 \mathrm{E}-07$ & $6,76214 \mathrm{E}-07$ & $3,56099 \mathrm{E}-07$ & $1,67523 \mathrm{E}-06$ & $1,30547 \mathrm{E}-06$ & $6,13663 \mathrm{E}-07$ & $1,50809 \mathrm{E}-06$ & $3,50638 \mathrm{E}-06$ & $1,68933 \mathrm{E}-08$ \\
\hline Aço & 0 & 0 & 0 & 0 & 0 & 0 & 0 & 0 & 0 & 0 \\
\hline Metal & 0 & 0 & 0 & 0 & 0 & 0 & 0 & 0 & 0 & 0 \\
\hline Eletrodomésticos & 0 & 0 & 0 & 0 & 0 & 0 & 0 & 0 & 0 & 0 \\
\hline Informática & 0 & 0 & 0 & 0 & 0 & 0 & 0 & 0 & 0 & 0 \\
\hline Máquinas & 0 & 0 & 0 & 0 & 0 & 0 & 0 & 0 & 0 & 0 \\
\hline
\end{tabular}




\begin{tabular}{|c|c|c|c|c|c|c|c|c|c|c|}
\hline Eletrônicos & 0 & 0 & 0 & 0 & 0 & 0 & 0 & 0 & 0 & 0 \\
\hline Instrumento hospitalar & $1,02439 \mathrm{E}-08$ & $5,63153 \mathrm{E}-09$ & $1,55343 \mathrm{E}-06$ & $2,03097 \mathrm{E}-07$ & $6,03229 \mathrm{E}-07$ & $2,83371 \mathrm{E}-07$ & 0,000487341 & $2,593 \mathrm{E}-07$ & $2,6653 \mathrm{E}-08$ & 5,88793E-09 \\
\hline Veículos & 0 & 0 & 0 & 0 & 0 & 0 & 0 & 0 & 0 & 0 \\
\hline Indústria Diversa & 0 & 0 & 0 & 0 & 0 & 0 & 0 & 0 & 0 & 0 \\
\hline SIUP & $1,51719 \mathrm{E}-06$ & 7,3986E-07 & 7,36463E-07 & $4,93136 \mathrm{E}-07$ & $8,64616 \mathrm{E}-07$ & $6,02557 \mathrm{E}-07$ & $6,3015 \mathrm{E}-07$ & $6,45633 \mathrm{E}-07$ & 4,59724E-07 & 6,86909E-05 \\
\hline Construção & $1,9174 \mathrm{E}-09$ & $1,28846 \mathrm{E}-09$ & $2,6062 \mathrm{E}-09$ & $3,83666 \mathrm{E}-09$ & $5,2992 \mathrm{E}-09$ & $8,00741 \mathrm{E}-09$ & $1,21485 \mathrm{E}-09$ & 8,49223E-09 & 1,55704E-09 & $1,20358 \mathrm{E}-09$ \\
\hline Comércio & 5,48594E-07 & $4,80479 \mathrm{E}-07$ & $8,07183 \mathrm{E}-07$ & $1,81705 \mathrm{E}-06$ & $7,19624 \mathrm{E}-07$ & $1,35721 \mathrm{E}-06$ & $7,2486 \mathrm{E}-07$ & $1,03402 \mathrm{E}-06$ & $8,39458 \mathrm{E}-07$ & 2,2912E-07 \\
\hline Transportes & $5,64318 \mathrm{E}-07$ & $3,23827 \mathrm{E}-07$ & $4,45608 \mathrm{E}-07$ & 4,99776E-07 & $4,26328 \mathrm{E}-07$ & $6,20432 \mathrm{E}-07$ & $3,38534 \mathrm{E}-07$ & $3,90594 \mathrm{E}-07$ & $2,09809 \mathrm{E}-07$ & $1,71442 \mathrm{E}-07$ \\
\hline Informação & 2,21243E-07 & $9,83978 \mathrm{E}-08$ & $2,47487 \mathrm{E}-07$ & $3,55786 \mathrm{E}-07$ & $3,03639 \mathrm{E}-07$ & $5,23468 \mathrm{E}-07$ & $1,60344 \mathrm{E}-07$ & $1,97914 \mathrm{E}-07$ & $5,37632 \mathrm{E}-08$ & $1,87218 \mathrm{E}-07$ \\
\hline Financeiro & 4,40562E-07 & $2,59549 \mathrm{E}-07$ & $5,6128 \mathrm{E}-07$ & $3,92002 \mathrm{E}-07$ & $4,01002 \mathrm{E}-07$ & $6,9075 \mathrm{E}-07$ & $2,78772 \mathrm{E}-07$ & $3,85016 \mathrm{E}-07$ & $1,64986 \mathrm{E}-07$ & $1,48362 \mathrm{E}-07$ \\
\hline Imobiliário & 0 & 0 & 0 & 0 & 0 & 0 & 0 & 0 & 0 & 0 \\
\hline Alojamento & $5,37021 \mathrm{E}-09$ & $2,04685 \mathrm{E}-09$ & 2,95689E-09 & $4,27592 \mathrm{E}-09$ & $6,34488 \mathrm{E}-09$ & 4,27227E-09 & 1,83857E-09 & $5,67275 \mathrm{E}-09$ & 3,82077E-09 & $1,57037 \mathrm{E}-09$ \\
\hline Serviços às Empresas & 2,32691E-07 & $2,26754 \mathrm{E}-07$ & $2,71764 \mathrm{E}-07$ & $1,21567 \mathrm{E}-06$ & $3,87517 \mathrm{E}-07$ & $8,56829 \mathrm{E}-07$ & $3,11198 \mathrm{E}-07$ & $5,20455 \mathrm{E}-07$ & $1,79045 \mathrm{E}-07$ & $6,60959 \mathrm{E}-07$ \\
\hline Educação e Saúde mercantis & $9,68872 \mathrm{E}-09$ & $9,78966 \mathrm{E}-09$ & $1,43755 \mathrm{E}-08$ & $2,00304 \mathrm{E}-08$ & $1,23155 \mathrm{E}-08$ & $1,83984 \mathrm{E}-08$ & $1,22482 \mathrm{E}-08$ & $1,24175 \mathrm{E}-08$ & $1,12401 \mathrm{E}-08$ & 7,70821E-09 \\
\hline Outros Serviços & 4,54457E-08 & $4,13517 \mathrm{E}-08$ & $6,0726 \mathrm{E}-08$ & $1,19291 \mathrm{E}-07$ & $8,66931 \mathrm{E}-08$ & $1,10003 \mathrm{E}-07$ & 4,93396E-08 & $6,42375 \mathrm{E}-08$ & $5,06531 \mathrm{E}-08$ & $4,83229 \mathrm{E}-08$ \\
\hline APU & $1,07523 \mathrm{E}-11$ & 7,39274E-12 & $8,69783 \mathrm{E}-12$ & $2,23513 \mathrm{E}-11$ & $9,67675 \mathrm{E}-12$ & $1,77568 \mathrm{E}-11$ & $8,60974 \mathrm{E}-12$ & $1,20023 \mathrm{E}-11$ & $5,5537 \mathrm{E}-12$ & $1,99509 \mathrm{E}-11$ \\
\hline
\end{tabular}

Tabela C11 - Matriz Geração de Renda para o Grau de Instrução G(10), Distrito Federal - 2008.

(3)

\begin{tabular}{|c|c|c|c|c|c|c|c|c|c|c|c|}
\hline Setores & Construção & Comércio & Transportes & Informação & Financeiro & Imobiliário & Alojamento & $\begin{array}{l}\text { Serviços às } \\
\text { Empresas }\end{array}$ & $\begin{array}{l}\text { Educação e } \\
\text { Saúde } \\
\text { mercantis }\end{array}$ & $\begin{array}{c}\text { Outros } \\
\text { Serviços }\end{array}$ & APU \\
\hline Agricultura & $1,04353 \mathrm{E}-08$ & $3,23763 \mathrm{E}-08$ & $2,44906 \mathrm{E}-08$ & $1,48557 \mathrm{E}-08$ & 9,61943E-09 & $2,03876 \mathrm{E}-09$ & $3,2571 \mathrm{E}-06$ & $1,475 \mathrm{E}-08$ & $7,76505 \mathrm{E}-08$ & $3,35443 \mathrm{E}-07$ & $4,14566 \mathrm{E}-08$ \\
\hline Pecuária & 0 & 0 & 0 & 0 & 0 & 0 & 0 & 0 & 0 & 0 & 0 \\
\hline Extrativa & 0 & 0 & 0 & 0 & 0 & 0 & 0 & 0 & 0 & 0 & 0 \\
\hline Alimentos & 0 & 0 & 0 & 0 & 0 & 0 & 0 & 0 & 0 & 0 & 0 \\
\hline Vestuário & 4,37994E-08 & $9,8157 \mathrm{E}-08$ & $2,05806 \mathrm{E}-07$ & $9,58368 \mathrm{E}-08$ & $7,84271 \mathrm{E}-08$ & $1,03775 \mathrm{E}-08$ & $1,13872 \mathrm{E}-07$ & $2,80641 \mathrm{E}-07$ & $1,80921 \mathrm{E}-07$ & $4,04624 \mathrm{E}-07$ & $7,8823 \mathrm{E}-08$ \\
\hline Madeira & 0 & 0 & 0 & 0 & 0 & 0 & 0 & 0 & 0 & 0 & 0 \\
\hline
\end{tabular}




\begin{tabular}{|c|c|c|c|c|c|c|c|c|c|c|c|}
\hline Celulose & 0 & 0 & 0 & 0 & 0 & 0 & 0 & 0 & 0 & 0 & 0 \\
\hline Revistas & 0 & 0 & 0 & 0 & 0 & 0 & 0 & 0 & 0 & 0 & 0 \\
\hline Químicos & $3,47107 \mathrm{E}-08$ & $1,83735 \mathrm{E}-08$ & 1,29777E-08 & 3,38083E-08 & $7,72298 \mathrm{E}-09$ & $5,03261 \mathrm{E}-09$ & $2,52081 \mathrm{E}-07$ & $2,10136 \mathrm{E}-08$ & $2,41381 \mathrm{E}-07$ & 4,73399E-08 & $3,6496 \mathrm{E}-08$ \\
\hline Borracha & 0 & 0 & 0 & 0 & 0 & 0 & 0 & 0 & 0 & 0 & 0 \\
\hline Cimento & 7,10904E-06 & $2,5447 \mathrm{E}-08$ & $1,09315 \mathrm{E}-08$ & $3,14945 \mathrm{E}-08$ & 2,94479E-08 & $6,28711 \mathrm{E}-08$ & $4,96069 \mathrm{E}-08$ & 2,36614E-08 & $2,34665 \mathrm{E}-07$ & $1,23719 \mathrm{E}-07$ & $1,17468 \mathrm{E}-07$ \\
\hline Aço & 0 & 0 & 0 & 0 & 0 & 0 & 0 & 0 & 0 & 0 & 0 \\
\hline Metal & 0 & 0 & 0 & 0 & 0 & 0 & 0 & 0 & 0 & 0 & 0 \\
\hline Eletrodomésticos & 0 & 0 & 0 & 0 & 0 & 0 & 0 & 0 & 0 & 0 & 0 \\
\hline Informática & 0 & 0 & 0 & 0 & 0 & 0 & 0 & 0 & 0 & 0 & 0 \\
\hline Máquinas & 0 & 0 & 0 & 0 & 0 & 0 & 0 & 0 & 0 & 0 & 0 \\
\hline Eletrônicos & 0 & 0 & 0 & 0 & 0 & 0 & 0 & 0 & 0 & 0 & 0 \\
\hline Instrumento hospitalar & $3,29965 \mathrm{E}-08$ & $1,99408 \mathrm{E}-08$ & $6,32408 \mathrm{E}-09$ & $8,22235 \mathrm{E}-09$ & 4,63355E-09 & $3,75891 \mathrm{E}-08$ & $4,02286 \mathrm{E}-09$ & $5,35073 \mathrm{E}-08$ & $5,55426 \mathrm{E}-08$ & 4,23161E-08 & $1,15087 \mathrm{E}-08$ \\
\hline Veículos & 0 & 0 & 0 & 0 & 0 & 0 & 0 & 0 & 0 & 0 & 0 \\
\hline Indústria Diversa & 0 & 0 & 0 & 0 & 0 & 0 & 0 & 0 & 0 & 0 & 0 \\
\hline SIUP & $1,50105 \mathrm{E}-07$ & $5,14315 \mathrm{E}-07$ & 4,26492E-07 & $4,00793 \mathrm{E}-07$ & $2,4186 \mathrm{E}-07$ & $5,09445 \mathrm{E}-08$ & 5,19913E-07 & $4,51361 \mathrm{E}-07$ & $6,64571 \mathrm{E}-07$ & $1,49526 \mathrm{E}-06$ & $5,72408 \mathrm{E}-07$ \\
\hline Construção & $2,87079 \mathrm{E}-06$ & $3,28527 \mathrm{E}-09$ & $2,5538 \mathrm{E}-09$ & $1,04617 \mathrm{E}-08$ & $1,03506 \mathrm{E}-08$ & $2,47456 \mathrm{E}-08$ & $1,75827 \mathrm{E}-09$ & 7,37223E-09 & $2,2098 \mathrm{E}-08$ & $1,90764 \mathrm{E}-08$ & $4,31528 \mathrm{E}-08$ \\
\hline Comércio & $7,51868 \mathrm{E}-07$ & $1,41223 \mathrm{E}-05$ & $6,26169 \mathrm{E}-07$ & $3,11139 \mathrm{E}-07$ & $1,86013 \mathrm{E}-07$ & $8,20925 \mathrm{E}-08$ & $1,44142 \mathrm{E}-06$ & $5,39386 \mathrm{E}-07$ & 4,79974E-07 & 5,18971E-07 & 2,75049E-07 \\
\hline Transportes & $1,60535 \mathrm{E}-07$ & $4,2238 \mathrm{E}-07$ & $1,29009 \mathrm{E}-05$ & $2,86524 \mathrm{E}-07$ & $1,20483 \mathrm{E}-07$ & $2,143 \mathrm{E}-08$ & $1,93338 \mathrm{E}-07$ & $2,27623 \mathrm{E}-07$ & $2,04538 \mathrm{E}-07$ & $3,02333 \mathrm{E}-07$ & $1,09812 \mathrm{E}-07$ \\
\hline Informação & $6,12766 \mathrm{E}-08$ & $1,93132 \mathrm{E}-07$ & $2,01918 \mathrm{E}-07$ & $1,44572 \mathrm{E}-05$ & $5,89101 \mathrm{E}-07$ & $3,98294 \mathrm{E}-08$ & $9,64783 \mathrm{E}-08$ & $1,56591 \mathrm{E}-06$ & $5,38497 \mathrm{E}-07$ & $3,52636 \mathrm{E}-07$ & $6,52888 \mathrm{E}-07$ \\
\hline Financeiro & $1,19462 \mathrm{E}-07$ & $2,3711 \mathrm{E}-07$ & $3,27867 \mathrm{E}-07$ & $3,33764 \mathrm{E}-07$ & $9,46724 \mathrm{E}-06$ & $4,82339 \mathrm{E}-08$ & $1,2332 \mathrm{E}-07$ & $3,15889 \mathrm{E}-07$ & $1,39468 \mathrm{E}-07$ & $7,76259 \mathrm{E}-08$ & 7,38726E-07 \\
\hline Imobiliário & 0 & 0 & 0 & 0 & 0 & 0 & 0 & 0 & 0 & 0 & 0 \\
\hline Alojamento & $5,36506 \mathrm{E}-09$ & $7,45564 \mathrm{E}-09$ & $1,45166 \mathrm{E}-08$ & 9,78961E-09 & $9,41513 \mathrm{E}-09$ & $1,03887 \mathrm{E}-09$ & $5,75898 \mathrm{E}-06$ & 8,44591E-09 & $4,47738 \mathrm{E}-08$ & $5,1098 \mathrm{E}-08$ & 2,76757E-08 \\
\hline Serviços às Empresas & $2,68342 \mathrm{E}-07$ & $7,48472 \mathrm{E}-07$ & 8,60073E-07 & $1,22582 \mathrm{E}-06$ & $9,27123 \mathrm{E}-07$ & $1,44888 \mathrm{E}-07$ & $2,37052 \mathrm{E}-07$ & $1,47934 \mathrm{E}-05$ & $1,23398 \mathrm{E}-06$ & $7,85238 \mathrm{E}-07$ & 8,71977E-07 \\
\hline Educação e Saúde mercantis & 8,61484E-09 & $3,06974 \mathrm{E}-08$ & $2,03437 \mathrm{E}-08$ & $3,42771 \mathrm{E}-08$ & $3,53479 \mathrm{E}-08$ & 4,42697E-09 & $2,44742 \mathrm{E}-08$ & $2,91803 \mathrm{E}-08$ & $1,546 \mathrm{E}-05$ & 2,33897E-08 & $4,82522 \mathrm{E}-08$ \\
\hline Outros Serviços & $4,52038 \mathrm{E}-08$ & $1,19514 \mathrm{E}-07$ & 7,47223E-08 & $1,33186 \mathrm{E}-07$ & $6,84245 \mathrm{E}-08$ & $1,33442 \mathrm{E}-08$ & $1,30328 \mathrm{E}-07$ & $1,59126 \mathrm{E}-07$ & $1,17756 \mathrm{E}-07$ & $1,67602 \mathrm{E}-05$ & $8,43669 \mathrm{E}-08$ \\
\hline $\mathrm{APU}$ & $5,70274 \mathrm{E}-12$ & $1,53338 \mathrm{E}-11$ & $1,60863 \mathrm{E}-11$ & $2,0692 \mathrm{E}-11$ & $1,48126 \mathrm{E}-11$ & $2,45214 \mathrm{E}-12$ & $7,25908 \mathrm{E}-12$ & $1,84153 \mathrm{E}-11$ & $2,02117 \mathrm{E}-11$ & $1,56197 \mathrm{E}-11$ & $5,01823 \mathrm{E}-09$ \\
\hline
\end{tabular}


